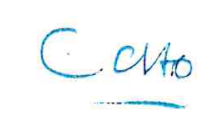

NIOZ-RAPPORT 1995 - 5

\title{
CONSUMPTION OF DISCARDS BY SEABIRDS IN THE NORTH SEA
}

C.J. Camphuysen, B. Calvo, J. Durinck, K. Ensor, A. Follestad, R.W. Furness,

S. Garthe, G. Leaper, H. Skov, M.L. Tasker \& C.J.N. Winter

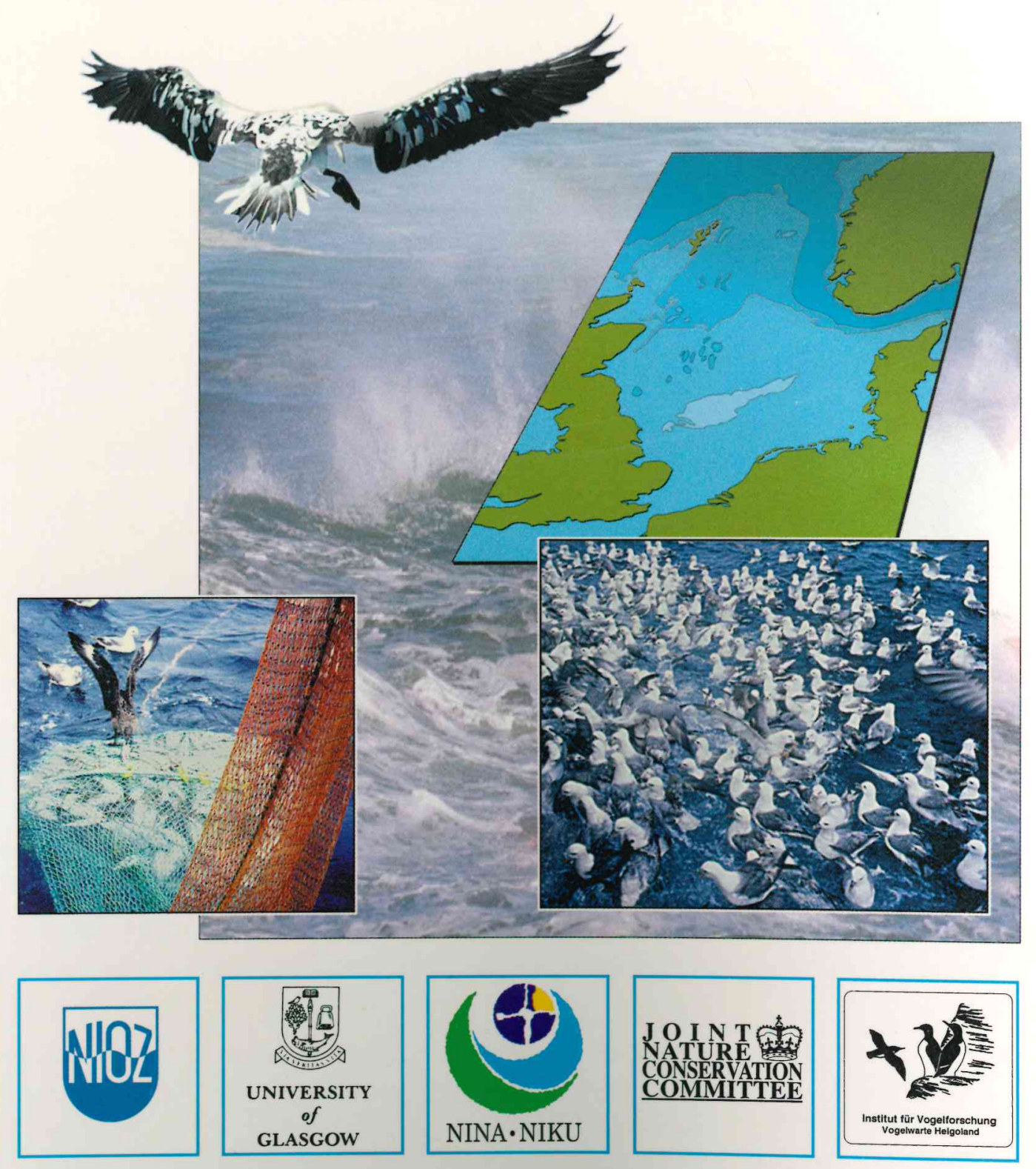




\section{(c) 1995}

This report is not to be cited without the acknowledgement of the source

Netherlands Institute for Sea Research Nederlands Instituut voor Onderzoek der Zee (NIOZ) P.O. Box 59, 1790 AB Den Burg, Texel, The Netherlands

Division of Environmental and Evolutionary Biology, Glasgow University G12 80Q, Scotland

Institute for Bird Research 'Vogelwarte Helgoland' Institut für Vogelforschung 'Voge/warte Helgoland', Postfach 1220, D-27494 Helgoland, Germany

Joint Nature Conservation Committee (JNCC),

16-17 Rubislaw Terrace, AB1 1XE Aberdeen, Scotland

Norwegian Institute for Nature Research Norsk Institutt for Naturforskning (NINA)

Tungasletta 2, N-7004 Trondheim, Norway

Ornis Consult Ltd,

140 Vesterbrogade, 1620 København V, Denmark

This report should be cited as follows: Camphuysen C.J., B. Calvo, J. Durinck, K. Ensor, A. Follestad, R.W. Furness, S. Garthe, G. Leaper, H. Skov, M.L. Tasker \& C.J.N. Winter 1995. Consumption of discards by seabirds in the North Sea. Final report EC DG XIV research NIOZ Rapport 1995 - 5, Netherlands Institute for Sea Research, Texel, 202 + LVI pp.

Front cover: design Henk Hobbelink, photographs Bob Furness

Lay out, word processing and maps: C.J. Camphuysen \& C.J.N. Winter

ISSN $0923-3210$ 


\title{
Consumption of discards by seabirds in the North Sea
}

Final report

EC DG XIV research contract BIOECO/93/10

\author{
Camphuysen C.J. ${ }^{1}$, B. Calvo ${ }^{2}$, J. Durinck ${ }^{6}$, K. Ensor ${ }^{2}$, \\ A. Follestad ${ }^{5}$, R.W. Furness ${ }^{2}$, S. Garthe ${ }^{3}$, \\ G. Leaper ${ }^{1,4}$, H. Skov ${ }^{6}$, M.L. Tasker ${ }^{4}$ \& C.J.N. Winter ${ }^{1}$
}

This study does not necessarily reflect the views of the Commission of the European Communities and in no way anticipates the Commission's future policy in this area.

Reproduction in part or in whole of the contents of this report is conditional on a specific mention of the source.

This study has been carried out with financial assistance from the Commission of the European Communities.

Ensor, A. ter 1995. research Research,
Nederlands Instituut voor Onderzoek der Zee

(NIOZ) Division of Environmental and Evolutionary Biology, Glasgow University Institut für Vogelforschung, 'Vogelwarte Helgoland' Joint Nature Conservation Committee Norsk Institutt for Naturforskning Ornis Consult Ltd
(GU)

(VWH)

(JNCC)

(NINA)

(OC) 


\section{ABSTRACT}

Fisheries research vessels engaged in the International Bottom Trawl Survey in February 1993, May, August and November 1994, were joined by ornithologists from six institutions around the North Sea. Onboard oservations were designed to assess seasonal patterns in the spatial distribution of scavenging seabirds in the North Sea and to study the attraction of fishing vessels for these birds. The selection and consumption of discards by seabirds was quantified during sessions of experimental discarding. Dominance hierarchies were studied to obtain information on the vulnerability to robbery for each species. The spatial distribution of fishing vessels in the North Sea and discard practices were investigated and the results were used to analyse the attractiveness of different fisheries for seabirds, and to calculate the total number of active boats in different regions in the North Sea.

Seabird distribution was studied by means of strip-transect counts. The attraction of fishing vessels for seabirds was investigated by means of counts of birds associated with fishing research vessels and commercial fishing vessels. Trawler numbers were assessed by systematic counts using radar equipment. Discard experiments, in which the fate of measured discarded fish was studied were designed to assess consumption rates. Discarding practices were described from direct observations, interviews with fishermen and others, and literature.

Eight species of seabirds utilised fishery waste on a large scale, at least during a part of the year. Consumption rates by seabirds, which were higher in winter than in summer, ranged from $95 \%$ for offal (entrails of gutted fish), to $80 \%$ for roundfish, $20 \%$ for flatfish and $6 \%$ for benthic invertebrates. All length classes of discards which occur normally in commercial fisheries can be consumed by seabirds. The median length of experimentally discarded roundfish consumed by seabirds ranged from $15 \mathrm{~cm}$ in a small species such as the Kittiwake to $25 \mathrm{~cm}$ in Gannets and Great Skuas. Fulmars and Kittiwakes were specialised feeders on offal. Discards size selection by different species of seabirds overlapped, leading to severe inter-specific competition. Many discards were stolen from smaller birds by larger species, with the result that success rates of the smaller birds were usually lower. Around 1500 active commercial fishing vessels were estimated to occur in the North Sea. The distribution of different types of fishing vessels are described. For none of the scavenging seabirds could the spatial distribution be fully explained by the presence or absence of commercial fishing vessels.

The data obtained can be used to provide detailed advice when the potential effects of measures to reduce fishing effort in general or discards production in particular are evaluated. The effects of different measures can be predicted, using the information on feeding success rates, vulnerability to robbery and prey selection. Anticipated scientific papers resulting from these studies include the distribution of seabirds in the North Sea, the distribution of fisheries in the North Sea, inter- and intra-specific relationships of scavenging seabirds, the analysis of inter-observer variance, and quantified information on discards utilisation by scavenging seabirds.

Key words: Marine birds, census, diets, discards, ecological balance, feeding behaviour, feeding experiments, food preferences, interspecific relationships, nature conservation, marine fisheries, fishing effort, fishing gear, fishery management, ANE, North Sea, Skagerrak, Kattegat 


\section{SUMMARY FOR NON-SPECIALISTS}

Ornithological observations were performed onboard fisheries research vessels engaged in the International Bottom Trawl Survey in February 1993, May, August and November 1994. The observations onboard were designed to assess seasonal patterns in the spatial distribution of scavenging seabirds (birds which utilise fishery waste) in the North Sea and to study the attraction of fishing vessels for these birds. The selection and consumption of discards by seabirds was quantified during sessions of experimental discarding. Dominance hierarchies were studied to obtain information on the vulnerability to robbery for each species. The spatial distribution of fishing vessels in the North Sea and discard practices were investigated and the results were used to analyse the attractiveness of different fisheries for seabirds, and to calculate the total number of active boats in different regions in the North Sea.

Seasonal fluctuations in spatial distribution patterns and the attraction to fishing vessels for eight common species of seabirds (Fulmar, Gannet, Great Skua and five species of gulls) are described. Total numbers of these seabirds in the North Sea were estimated to vary between 2 and 6.5 million individuals.

Total numbers of fishing vessels in the North Sea were estimated to vary between 800 and 1800 boats, although sampling was not very good in the coastal zone. Beamtrawlers and shrimpers were the most numerous type, followed by stern or otter trawlers, set net fishing vessels (or long liners), purse seiners, pair trawlers and anchor seiners. Up to several thousands of seabirds were observed in association with commercial fishing vessels. The highest numbers were seen associated with otter trawlers and stern trawlers, relatively small numbers of seabirds were associated with purse seiners, beamtrawlers and anchor seiners.
Seabirds consumed $95 \%$ of the offal (intestines of gutted marketable fish), $80 \%$ of roundfish, $20 \%$ of flatfish and $6 \%$ of benthic invertebrates. The competition for fishery waste increased between summer and winter and from south to north. Larger scavenging seabirds tended to consume larger discards than those selected by smaller species and many discards were stolen from smaller birds by larger species, resulting in the success rates of the smaller birds tending to be lower than those of larger species. All size classes in the discards fraction of commercial fisheries in the North Sea, except some of the larger flatfish, can be utilised by seabirds. The total amount of discards and offal in the North Sea has been estimated as $70,000 \mathrm{t}$ of offal, $120,000 \mathrm{t}$ of roundfish, $200,000 \mathrm{t}$ of flatfish and $180,000 \mathrm{t}$ of benthic invertebrates. Between 2.5 and 3.5 million seabirds are potentially supported by fishery waste in the North Sea.

A general reduction in fishing effort (and therefore of catch and discards) will probably lead to more intense competition and thus would there for lead to a decline in foraging success of species with the highest vulnerability to robbery. The effects of a reduction in discards and offal discharges would be greater under adverse conditions (prolonged storms, winter) than in summer. The development of commercial fisheries this century has provided an important extra source of food, as a result of which several species have apparently increased in numbers and spread over larger areas. If circumstances arise when discards and offal were no longer produced or discharged, and if these birds could not turn to alternative foods, these populations would be negatively affected. The results of this study may be used to help predict the possible effects of measures to reduce the amounts of discards directly or to reduce fishing effort for seabirds on a regional scale and on species level. 


\section{ENGLISH SUMMARY}

Fisheries research vessels engaged in the International Bottom Trawl Survey in February 1993, May, August and November 1994, were joined by ornithologists from six institutions based around the North Sea. Onboard observations were designed to assess seasonal patterns in the spatial distribution of scavenging seabirds in the North Sea and to study the attraction of fishing vessels for these birds. The selection and consumption of discards by seabirds was quantified during sessions of experimental discarding. Dominance hierarchies were studied to obtain information on the vulnerability to robbery for each species. The spatial distribution of fishing vessels in the North Sea and discard practices were investigated and the results were used to analyse the attractiveness of different fisheries for seabirds, and to calculate the total number of active boats in different regions in the North Sea.

Seasonal fluctuations in spatial distribution patterns and the attraction to fishing vessels for eight common species of seabirds, including Fulmar Fulmarus glacialis, Gannet Morus bassanus, Great Skua Catharacta skua, Common Gull Larus canus, Lesser Blackbacked Gull Larus fuscus, Herring Gull Larus argentatus, Great Black-backed Gull Larus marinus, and Kittiwake Rissa tridactyla are described. Total numbers of these seabirds in the North Sea were estimated to range from 1.5-4.0 million individuals in February to 3.0-6.5 million individuals in November. Most abundant were Fulmars and Kittiwakes. Fulmars, Gannets, and Kittiwakes were numerous all year round, Common Gulls, Herring Gulls, and Great Black-backed Gulls were comparatively scarce in summer, whereas Great Skuas and Lesser Black-backed Gulls were scarce in winter. Generally, the seasonal and spatial variations in relative abundance and species composition of seabirds at sea were reflected in the numbers and species composition of scavenging seabirds attracted to the fishing research vessels. A notable exception was the Kittiwake which appeared to be more readily attracted by fishing vessels in winter than in summer whereas numbers at sea peaked in summer.

Total numbers of (active, not on transit) fishing vessels in the North Sea were estimated to vary between 800 and 1800 boats. However, these numbers do not adequately assess fishing vessels working close to the coast due to poor sampling in this zone. Beamtrawlers and shrimpers were the most numerous type $(28 \%)$, followed by stern or otter trawlers (27), set net fishing vessels (or long liners; $11 \%)$, purse seiners $(7 \%)$, pair trawlers $(7 \%)$ and anchor seiners $(2 \%)$. Beamtrawlers, shrimpers, set net fishing vessels and anchor seiners predominated in the southeastern half of the North Sea and these vessels were rare in the northwest. Purse seiners, pair trawlers, stern trawlers and otter trawlers were the most common types in the central, northern and northwestern North Sea.

Maximum numbers of individual seabird species in association with commercial fishing vessels ranged from just over 20 Great Skuas to 3500 Fulmars. The highest total numbers of seabirds associated with commercial fishing vessels were found near otter trawlers and stern trawlers, relatively small numbers of seabirds were associated with purse seiners, beamtrawlers and anchor seiners. Great Black-backed Gulls, Herring Gulls and Lesser Black-backed Gulls (in summer) were the only species of which the overall distribution in the North Sea was clearly positively influenced by the presence of fishing vessels. The spatial and temporal variations in the overall distribution of Fulmar, Gannet, Great Skua, and Kittiwake could not be explained by differences in fishing vessel abundance.

Generally, consumption rates of offal and discards were higher in February and November than in May and August. Overall con- 
sumption rates were estimated at: $95 \%$ for offal, $80 \%$ for roundfish, $20 \%$ for flatfish and $6 \%$ for benthic invertebrates. The competition for fishery waste increased between summer and winter and from south to north. In comparison to proportions of each species present, Fulmars and Kittiwakes obtained more offal than expected. For experimentally discarded gadids, feeding success of Fulmars and Kittiwakes was comparatively low and Gannets had very high success rates. Lesser Black-backed Gulls and Herring Gulls were the most important consumers of gadids in the southeastern North Sea. Of experimentally discarded clupeids, Fulmars obtained considerably less than their numerical abundance might predict. Gannets obtained significantly more clupeids than gulls in most seasons and subregions, but particularly in the northern and western parts of the North Sea. Kittiwakes, Lesser Black-backed Gulls and Herring Gulls were the most important consumers of clupeids in the southeastern North Sea.

Larger scavenging seabirds tended to consume larger discards than smaller seabirds. The median length of roundfish ranged from 14 $\mathrm{cm}$ in Common Gulls to $25 \mathrm{~cm}$ in Gannets and Great Skuas. The median width of flatfish consumed by seabirds ranged from 3.5 $\mathrm{cm}$ in Fulmars and Kittiwakes to $6.5 \mathrm{~cm}$ in Gannets and Great Black-backed Gulls. Many discards were stolen from smaller birds by larger species, resulting in the success rates of the former tending to be lower than those of the latter. Gannet, Great Black-backed Gull and Great Skua were consistently the species highest in rank in the dominance hierarchy, whereas Fulmar and Kittiwakes were most vulnerable to robbery. Small species such as Kittiwakes and Common Gulls usually avoided fights for discards. Great Black-backed Gulls and Great Skuas obtained most discards through kleptoparasitism.

The most prominent types of fishing vessels in the North Sea are beamtrawlers, bottom trawlers, pelagic or midwater trawlers, pair trawlers, purse seiners, anchor seiners, Scottish seiners, long-liners and small boats using gill nets or tangle nets. Demersal fisheries for gadids by trawl and seine, pelagic fisheries for clupeids and mackerel, and beamtrawl fisheries produce large amounts of discards and offal.

The total amount of discards in the North Sea has been estimated as $120,000 \mathrm{t}$ of roundfish, 200,000 t flatfish and 180,000 t benthic invertebrates. Beamtrawl fisheries produce comparatively large amounts of discards of which a relatively small proportion (roundfish, smaller flatfish, offal) can be utilised by seabirds. Demersal and pelagic fisheries for roundfish produce comparatively small amounts of discards which can all be utilised by scavenging seabirds. The annual amount of offal produced in North Sea fisheries $111 \%$ of the mass of roundfish and $6.5 \%$ of the mass of flatfish) was estimated at nearly 70,000 tonnes. Between 2.5 and 3.5 million seabirds are potentially supported by fishery waste in the North Sea.

A general reduction in fishing effort (and therefore of catch and discards) will probably lead to more intense competition and thus would there for lead to a decline in foraging success of species with the highest vulnerability to robbery. The effects of a reduction in discards and offal discharges would be greater under adverse conditions (prolonged storms, winter) than in summer. The development of commercial fisheries this century has provided an important extra source of food, as a result of which several species have apparently increased in numbers and spread over larger areas. If circumstances arise when discards and offal were no longer produced or discharged, and if these birds could not turn to alternative foods, these populations would be negatively affected. The results of this study may be used to help predict the possible effects of measures to reduce the amounts of discards directly or to reduce fishing effort for seabirds on a regional scale and on species level. 


\section{NEDERLANDSE SAMENVATTING}

Ornithologen afkomstig van zes instituten in landen rondom de Noordzee hebben waarnemingen verricht aan boord van visserij onderzoeksschepen tijdens de 'International Bottom Trawl Surveys' van februari 1993, mei, augustus en november 1994. De waarnemingen waren bedoeld om seizoensfluctuaties in de verspreidingspatronen van visafval consumerende zeevogels in de Noordzee in kaart te brengen en om de aantrekkingskracht van vissersschepen op vogels te bestuderen. Prooikeuze en consumptie van zeevogels werden onderzocht tijdens experimenten waarbij bijvangst (discards) en snijafval (offah gecontroleerd overboord werden gezet. De interacties van de verschillende scheepsvolgende vogelsoorten werden bestudeerd om na te gaan welke soorten het meest kwetsbaar waren voor kleptoparasitisme. De ruimtelijke verspreiding van vissersschepen werd tegelijkertijd onderzocht terwijl interviews van vissers, literatuurstudie en eigen waarnemingen inzicht moesten verschaffen in de manier waarop en welke hoeveelheid bijvangst en snijafval in de commerciële visserij voor vogels beschikbaar komen, en van welke vormen van visserij vogels het meest profiteerden.

De verspreiding van acht algemene soorten, Noordse Stormvogel Fulmarus glacialis, Jan van Gent Morus bassanus, Grote Jager Catharacta skua, Stormmeeuw Larus canus, Kleine Mantelmeeuw Larus fuscus, Zilvermeeuw Larus argentatus, Grote Mantelmeeuw Larus marinus, en Drieteenmeeuw Rissa tridactyla, werd in kaart gebracht op grond van de transect tellingen en tellingen achter schepen. De totale aantallen van deze soorten in de Noordzee liepen naar schatting uiteen van $1,5-4,0$ miljoen exemplaren in february tot $3,0-6,5$ miljoen exemplaren in november. De Noordse Stormvogel en de Drieteenmeeuw waren veruit de talrijkste soorten. De Noordse Stormvogel, de Jan van Gent en de Drieteenmeeuw kwamen het gehele jaar in grote aantallen voor, de Stormmeeuw, de Zilvermeeuw en de Grote Mantelmeeuw waren vooral talrijk in de winter, terwijl de Grote Jager en de Kleine Mantelmeeuw 's zomers de grootste aantallen be- reikten. Over het algemeen was de soortsamenstelling onder de door het vissende schip aangetrokken vogels een goede afspiegeling van de aantallen op zee in de verschillende gebieden en seizoenen. Een uitzondering werd gevormd door de Drieteenmeeuw, waarvan 's zomers, waneer de grootste aantallen in de Noordzee werden aangetroffen, relatief weinig exemplaren door vissersschepen werden aangetrokken.

Het aantal actieve vissersschepen in de Noordzee variëerde naar schatting tussen de 800 en 1800 stuks. Boomkorvissers (voor platvis en/of garnalen) kwamen het meest voor (28\%), gevolgd door bordenvissers en hektrawlers $(27 \%)$, staand want vissers (of 'long-liners'; $11 \%)$, purse seiners $(7 \%)$, spanvissers $(7 \%)$ en ankerkuil vissers $(2 \%)$. Boomkorvissers (inclusief garnalenvissers), staand want vissers en ankerkuil vissers domineerden in de zuidoostelijke helft van de Noordzee. Purse seiners, spanvissers, hektrawlers and bordenvissers kwamen vooral in de centrale en noordelijke Noordzee veel voor.

De grootste aantallen door commerciële vissersschepen aangetrokken vogels liepen uiteen van minder dan 10 Grote Jagers tot ongeveer 3500 Noordse Stormvogels. De grootste aantallen vogels werden gezien bij bordenvissers en hektrawlers in de noordelijke Noordzee, relatief kleine aantallen werden aangetrokken door purse seiners, boomkorvissers en Deense ankerkuilvissers. De Grote Mantelmeeuw, de Zilvermeeuw en de Kleine Mantelmeeuw waren de enige soorten waarvan het voorkomen op zee duidelijk positief werd beïnvloed door de aantallen vissersschepen. Seizoenpatronen noch de ruimtelijke verspreiding van Noordse Stormvogel, Jan van Gent, Grote Jager en Drieteenmeeuw konden afdoende worden verklaard door verschillen in visserij-intensiteit.

Over het algemeen werd een groter deel van de bijvangst en het snijafval geconsumeerd in de winter dan in de zomer en bovendien nam de consumptie over het algemeen toe van zuid(oost) naar noord(west). In totaal werd van het snijafval $95 \%$ door zeevogels geconsumeerd terwijl deze percentages voor de bij- 
vangst uiteenliepen van $80 \%$ van alle rondvis, via $20 \%$ van de platvis tot $6 \%$ van de benthische ongewervelden. Noordse Stormvogel en Drieteenmeeuw consumeerden meer snijafval dan kon worden verwacht op grond van de aantallen vogels bij het schip. Beide soorten waren aanzienlijk minder succesvol waar het ging om consumptie van kabeljauwachtigen. In de meeste gebieden was het foerageersucces van de Jan van Gent waar het ging om kabeljauwachtigen het grootst, maar de Kleine Mantelmeeuw en de Zilvermeeuw waren de belangrijkste consumenten in de zuidoostelijke Noordzee. Ook van haringachtigen consumeerden Noordse Stormvogels veel minder dan kon worden verwacht op grond van de aanwezige aantallen vogels. Ook van deze vissen werden door Jan van Genten relatief grote aantallen bemachtigd, terwijl de voornaamste consumenten in de zuidoostelijke Noordzee de Drieteenmeeuw, Zilvermeeuw en Kleine Mantelmeeuw waren.

Grote vogelsoorten consumeerden over het algemeen grotere vissen dan kleinere. De mediane lengte van door vogels geconsumeerde rondvis liep uiteen van $14 \mathrm{~cm}$ voor de Stormmeeuw tot $25 \mathrm{~cm}$ voor de Grote Jager en de Jan van Gent. De mediane breedte van door vogels geconsumeerde platvis liep uiteen van $3.5 \mathrm{~cm}$ voor de Noorse Stormvogel en de Drieteenmeeuw tot $6.5 \mathrm{~cm}$ voor de Jan van Gent en de Grote Mantelmeeuw. Grote soorten waren vaak in staat om vissen af te pikken van kleinere soorten, zodat het foerageersucces van de laatste groep vaak aanmerkelijk lager lag. De Jan van Gent, de Grote Mantelmeeuw en de Grote Jager bemachtigden een aanzienlijk deel van hun vis door piraterij, terwijl zij hierdoor nauwelijks vis verloren. De Noordse Stormvogel en de Drieteenmeeuw waren de meest kwetsbare soorten. Kleine soorten zoals de Drieteenmeeuw en de Stormmeeuw bleken de meeste gevechten eenvoudig te vermijden.

De belangrijkste vormen van visserij in de Noordzee zijn de boomkorvisserij, demersale visserij (bodem trawls), pelagische visserij (pelagische trawls), spanvisserij, purse seiners, (Deense) ankerkuil vissers, lijnenvissers en staand want en warnetvissers. Demersale visserij voor kabeljauwachtigen, de pelagische visserij op Haring, Makreel en Horsmakreel en de boomkorvisserij zijn de grootste producenten van bijvangst en snijafval.

De totale hoeveelheden overboord gezette bijvangst in de Noordzee worden geschat op 120.000 ton rondvis, 200.000 ton platvis, en 180.000 ton benthische ongewervelden. Boomkorvissers produceren een grote hoeveelheid visafval waarvan een relatief klein deel (offal, rondvis en kleinere platvis) geschikt is voor consumptie voor zeevogels. De demersale en pelagische visserij voor rondvis produceren meestal naar verhouding weinig discards, maar hiervan kan vrijwel alles door vogels worden geconsumeerd. De jaarlijkse hoeveelheid overboord gezette snijafval $111 \%$ van het gewicht bij rondvis, $6.5 \%$ van het gewicht bij platvis) bedraagt bijna 70.000 ton. Tussen 2,5 en 3,5 miljoen zeevogels kunnen van de genoemde hoeveelheden bijvangst en snijafval in leven blijven.

Een vermindering in visserij-intensiteit zal leiden tot een grotere competitite achter visserschepen waardoor het foerageersucces van de voor kleptoparasitisme meest kwetsbare soorten zal afnemen. De effecten op vogels van een vermindering van de hoeveelheid overboord gezette bijvangst zal het grootst zijn in de winter of na aanhoudende storm. Van de in deze eeuw sterk toegenomen visserij in de Noordzee hebben verschillende zeevogels kunnen profiteren. Het is aannemelijk dat de populaties van deze soorten, indien ze niet in staat blijken te zijn om over te schakelen naar alternatieve voedselbronnen, als gevolg van een vermindering van de overboord gezette bijvangst zullen afnemen. Aan de hand van de resultaten van dit onderzoek kunnen de gevolgen van verschillende maatregelen op bepaalde soorten of in bepaalde delen van de Noordzee worden voorspeld.

\section{DEUTSCHE ZUSAMMENFASSUNG}

Ornithologen von sechs Institutionen rund um die Nordsee nahmen an Fahrten von Fischereiforschungsschiffen im Rahmen des "International Bottom Trawl Survey" im Februar 1993 
sowie Mai, August und November 1994 teil. Die Beobachtungen an Bord zielten dara, saisonale Muster in der räumlichen Verbreitung von Fischereiabfall fressenden Seevögeln in der Nordsee zu bestimmen und die Attraktivität von Fischereifahrzeugen für diese Arten zu untersuchen. Die Auswahl und Nutzung von Discards (wieder über Bord gebene Teile des Fangs) durch Seevögel wurde anhand von Experimenten quantifiziert. Dominanz-Hierarchien wurden untersucht, um für jede Vogelart Informationen über die Anfälligkeit gegenüber Kleptoparasitismus zu erhalten. Die räumliche Verteilung von Fisereifahrzeugen in der Nordsee und die Art und Weise der Produktion von Discards wurden studiert. Mit diesen Ergebnissen wurde die Attraktivität der verschiedenen Fischereitypen für Seevögel analysiert und die Gesamtzahl aktiver Fischkutter in verschieden Nordsee-Regionen ermittelt.

Saisonale Schwankungen in den räumlichen Verbreitungsmustern und der Anziehungskraft von Fischkuttern werden für acht häufige Seevogelarten beschrieben: Eissturmvogel Fulmarus glacialis, Baßtölpel Morus bassanus, Skua Catharacta skua, Sturmmöwe Larus canus, Heringsmöwe Larus fuscus, Silbermöwe Larus argentatus, Mantelmöwe Larus marinus und Dreizehenmöwe Rissa tridactyla. Die Gesamtzahl dieser Seevögel in der Nordsee wurde auf zwischen 1,5-4,0 Millionen Individuen im Februar und 3,0-6,5 Millionen im November geschätzt. Am häufigsten waren Eissturmvögel und Dreizehenmöwen. Eissturmvögel, Baßtölpel und Dreizehenmöwen waren das ganze Jahr über zahlreich. Sturm-, Silber- und Mantelmöwen waren vergleichsweise selten im Sommer, wohingegen Skuas und Heringsmöwen im Winter selten waren. Die saisonalen und räumlichen Variationen in der relativen Häufigkeit und Artenzusammensetzung der Seevögel auf See spiegelte sich generell in Anzahl und Artenzusammensetzung der Seevögel an Fischereifahrzeugen wider. Eine bemerkswerte Ausnahme bildete die Dreizehenmöwe, die anscheinend im Winter leichter von Fischkuttern angelockt wurde als im Sommer, während ihre Gesamtzahl im Sommer am größten war.
Die Anzahl fischender Fischereifahrzeuge in der Nordsee variierte zwischen geschätzten 800 und 1800 Booten. Aufgrund geringer Beprobung enthält diese Schätzung jedoch küstennah operierende Fischereiflotten nur in unzureichendem Maße. Baumkurren- und Garnelenkutter ("Krabbenkutter") waren die am häufigsten festgestellten Typen (28\%) in der Nordsee, gefolgt von Heckfängern (incl. Schleppnetzen mit Scherbrett; 27\%), Stellnetzkuttern (bzw. Langleinenkuttern; $11 \%)$, Ringwadenkuttern (7\%), Gespannfischern (7\%) und Snurrewadekuttern (2\%). Baumkurren-, Garnelen-, Stellnetz- und Snurrewade-Kutter dominierten in der südöstlichen Hälfte der Nordsee und waren nur selten im Nordwesten anzutreffen. Ringwadenkutter, Gespannfischer und Heckfänger waren die häufigsn Typen in der zentralen, nördlichen und nordwestlichen Nordsee.

Maximalzahlen von schiffsvolgenden Seevogelarten an kommerziellen Fischkuttern rangierten zwischen etwas über 20 Skuas und 3500 Eissturmvögeln. Die höchsten Gesamtzahlen von mit Fischkuttern assoziierten Seevögeln wurden hinter Heckfängern angetroffen, relativ kleine Zahlen konnten für Ringwaden-, Baumkurren- und Snurrewade-Kutter ermittelt werden. Mantel-, Silber- und Heringsmöwe (im Sommer) waren die einzigen Arten, deren Verbreitung in der Nordsee klar positiv beeinflußt wurde durch die Anwesenheit von Fischkuttern. Die räumlichen und zeitlichen Variationen in der Gesamt-Verbreitung von Eissturmvogel, Baßtölpel, Skua und Dreizehenmöwe konnten nicht allein durch Unterschiede in der Häufigkeit von Fischkuttern erklärt werden.

Der Anteil gefressener Schlachtabfälle (Eingeweide) und Discards war im Winter (Februar und November) höher als im Sommer (Mai und August). Gemittelt über alle Experimente betrug der Anteil gefressener Objekte $95 \%$ für Schlachtabfälle, $80 \%$ für Rundfische, $20 \%$ für Plattfische und $6 \%$ für benthische Invertebraten. Die Konkurrenz um Fischereiprodukte nahm von Sommer zu Winter und von Süden nach Norden zu. Verglichen mit ihrem Anteil an den Schiffsfolgern erbeuteten Eissturmvögel und Dreizehenmöwen mehr Slachtabfälle als 
erwartet. Für experimentell über Bord gegebene Dorschartige (Gadiden) war der Freßerfolg von Eissturmvögeln und Dreizehenmöwen vergleichsweise gering, Baßtölpel hingegen waren allgemein sehr erfolgreich. Herings- und Silbermöwen waren die bedeutendsten NutznieBer von Gadiden in der südöstlichen Nordsee. Eissturmvögel erbeuteten über Bord gegebene Heringsartige (Clupeiden) beträchtlich seltener als aufgrund ihrer Häufigkeit zu erwarten war. Clupeiden wurden in den meisten Jahreszeiten und Regionen von Baßtölpeln signifikant häufiger ergattert als von Möwen, besonders gilt dies für die nördliche und westliche Nordsee. Dreizehen-, Herings- und Silbermöwen waren die wichtigsten Konsumenten von Clupeiden in der südöstlichen Nordsee.

Verglichen mit kleineren Arten fraßen größere Seevogelarten tendenziell größere Discards. Längen-Mediane für gefressene Rundfische bewegten sich zwischen $14 \mathrm{~cm}$ bei der Sturmmöwe und $25 \mathrm{~cm}$ bei Baßtölpel und Skua. Die Breiten-Mediane für gefressene Plattfische schwankten zwischen $3,5 \mathrm{~cm}$ beim Eissturmvogel und $6,5 \mathrm{~cm}$ bei Baßtölpel und Mantelmöwe. Viele Discards wurden kleinen Vogelarten durch große Arten gestohlen, was zu einem tendenziell höheren Freßerfolg großer Seevogelarten führte. Baßtölpel, Mantelmöwe und Skua waren durchweg die Arten, die in der Dominanz-Hierarchie am höchsten standen, während Eissturmvogel und Dreizehenmöwe am anfälligsten gegenüber Kleptoparasitismus waren. Kleinere Arten wie Dreizehen- und Sturmmöwe vermieden für gewöhnlich Kämpfe um Discards. Mantelmöwen und Skuas erbeuteten die meisten Fische durch Kleptoparasitismus.

Die wichtigsten Fischereifahrzeuge in der Nordsee sind Baumkurrenkutter, Bodenschleppnetzkutter, pelagische Kutter, Gespannfischer, Ringwaden- und Snurrewaden-Kutter, Langleinenkutter sowie kleine Stellnetzkutter. Bodenfischereien auf Gadiden mittels Schleppnetzen und Waden, pelagische Fischereien auf Clupeiden und Makrele sowie die Baumkurren-Fischerei auf Plattfische produzieren große Mengen an Discards und Schlachtabfällen.
Die Gesamtmenge an Discards in der Nordsee wird auf $120.000 \mathrm{t}$ Rundfisch, $200.000 \mathrm{t}$ Plattfisch und $180.000 \mathrm{t}$ benthische Invertebraten pro Jahr geschätzt. Die Baumkurren-Fischerei produziert vergleichsweise große Mengen an Discards, von denen ein relativ kleiner Teil (Rundfische, kleinere Plattfische, Schlachtabflle) von Seevögeln genutzt werden kann. Boden- und pelagische Fischereien auf Rundfische produzieren vergleichsweise geringe Mengen an Discards, die aber vollständig von Seevögeln genutzt werden können. Die durch Fischereien in der Nordsee alljährlich produzierte Menge an Schlachtabfällen $111 \%$ der Rundfisch-Masse und 6,5\% der Plattfisch-Masse) werden auf nahezu $70.000 \mathrm{t}$ geschätzt. Zwischen 2,5 und 3,5 Millionen Seevögel können in der Nordsee potentiell von Fischereiabfällen leben.

Eine generelle Reduzierung des Fischereiaufwandes (und damit des Fangs und der Discards) wird wahrscheinlich $\mathrm{zu}$ intensiverer Konkurrenz und damit verringertem Freßerfolg von Arten mit hoher Anfälligkeit gegenüber Kleptoparasitismus führen. Die Effekte einer Reduktion von Discards und Schlachtabfällen dürften unter ungünstigen Bedingungen (lange Sturmphasen, Winter) größer sein als z.B. im Sommer. Die Entwicklung der kommerziellen Fischereien in diesem Jahrhundert hat eine bedeutende, zusätzliche Nahrunguelle hervorgebracht, die anscheinend zu einer Zunahme und Ausbreitung mehrerer Vogelarten geführt hat. Sollten Discards und Schlachtabfälle nicht länger produziert oder auf See über Bord gegeben werden, und diese Vogelarten nicht auf alternative Nahrung ausweichen (können), würden deren Bestände negativ beeinflußt werden. Die Ergebnisse dieser Studie können helfen, die möglichen Auswirkungen von Maßnahmen zur direkten Reduzierung der Discardmengen bzw. zur Reduzierung des Fischereiaufwandes auf Seevögel abzuschätzen, sowohl regional als auch auf Artenniveau.

\section{NORSK SAMMENDRAG}

På havforskningsfartøyer som deltok $i$ internasjonale bunntrålundersøkelser (IBTS) i februar 1993, mai, august og november 1994, 
deltok også ornitologer fra seks institusjoner fra landene rundt Nordsjøen. Observasjoner ombord skulle gi informasjon om sesongmessige varisjoner $\mathrm{i}$ fordelingsmønsteret for sjøfugl $\mathrm{i}$ Nordsjøen, med vekt på arter som utnytter fiskeriavfall (fiskeslo, vrakfisk (små fisk, ikke kommersielle arter) og bunndyr), og i hvor stor grad disse artene blir tiltrukket av fiskebåter. Eksperimentelle utslipp av fiskeriavfall ble gjennomført for å vise hvordan sjøfuglene utnytter ulike deler av dette avfallet. Dominanshierarkier ble studert for å unders $ø$ ke hvor utsatt hver art er for å bli frarøvet maten av andre arter. Fordelingen av fiskefartøyer i Nordsjøen og rutiner for utslipp av fiskeriavfall ble også undersøkt, og dette ble lagt til grunn for å analysere hvor attraktive ulike fiskerier er for sjøfugl, og hvor stor den aktive fiskeflåten er i ulike regioner av Nordsjøen.

Sesongmessige variasjoner i fordelingsmønster og tiltrekking til fiskefartøyer er beskrevet for åtte vanlige sjøfuglarter som utnytter fiskeriavfall: Havhest, havsule, storjo, fiskemåke, sildemåke, gråmåke, svartbak og krykkje.Totalt antall av disse artene i Nordsjøen er beregnet å variere fra 1,5-4,0 millioner individer $\mathrm{i}$ februar til 3,0-6,5 millioner individer i november. Mest tallrike var havhest og krykkje. Havhest, havsule og krykkje var tallrike hele året, fiskemåse, gråmåse og svartbak var forholdsvis fåtallige sommerstid, mens storjo og sildemåse var forholdsvis fåtallige vinterstid. Samlet sett ble sesongmessige og geografiske forskjeller i fordeling og antall av de ulike artene gjenspeilet $i$ antall og artssammensetning av sjøfugl som ble tiltrukket av havforskningsfartøyene. Et klart unntak i så måte var krykkje, som i større grad ble tiltrukket av fiskefartøyer om vinteren enn om sommeren, selv om det var størst antall fugl til sjøs sommerstid.

Antall fiskefartøyer i aktivt fiske i Nordsjøen ble anslått til å variere mellom 800 og 1800 båter. Dette tallet er imidlertid ikke fullt ut dekkende for fiskeflåten som opererer nær kysten på grunn av mangelfull dekning av denne sonen. Bomtrålere og reketrålere var mest tallrike $(28 \%)$, fulgt av hekktrålere (27\%), settegarnfartøyer (eller linebåter; 11\%), snurpere $(7 \%)$ og partrålere $(7 \%)$. Bomtrålere, reketrålere og settegarnfartøyer var i overvekt i den sørøstre halvdelen av Nordsjøen, men ble sjelden sett i nordvestre deler. Snurpere, partrålere og hekktrålere var den mest vanlige typen i den sentrale, nordlige og nordvestre delen av Nordsjøen.

Maksimum antall for de sjøfuglartene som ble sett i tilknytning til kommersielle fiskefartøyer varierte fra litt over 20 storjo til 3500 havhest. Høyest totaltall av sjøfugl i tilknytning til kommersielle fiskefartøyer ble funnet nær hekktrålere, mens relativt lite sjøfugl ble tiltrukket av snurpere og bomtrålere. Svartbak, gråmåse og sildemåse (sommerstid) var de eneste artene der fordelingsmønsteret i Nordsjøen viste en klar positiv sammenheng med forekomsten av fiskefartøyer. Hverken tidsmessige eller geografiske forskjeller i forekomsten av havhest, havsule, storjo, og krykkje kunne forklares ut fra forskjeller i forekomsten av fiskebåter.

Sjøfugl tar en større andel av fiskeriavfallet om vinteren (februar og november) enn om sommeren (mai og august). Utnyttelsesgraden er anslått til $95 \%$ for fiskeslo (innmat m.m.), $80 \%$ for rundfisk, $20 \%$ for flatfisk og $6 \%$ for bunnlevende evertebrater. Konkurransen om fiskeriavfallet økte fra sommer til vinter og fra sør til nord. Sammenlignet med andelen tilstede av hver art, tok havhest og krykkje mer innmat enn forventet. Havhest og krykkje konsumerte relativt få av eksperimentelt tilbudte torskefisker, mens havsule derimot tok en forholdsmessig meget stor andel av disse. Sildemåse og gråmåse var de viktigste komsumentene av torskefisker i den sørøstre delen av Nordsjøen. Av eksperimentelt tilbudte sildefisker tok havhesten betydelig mindre enn dens tallmessige forekomst skulle tilsi. Havsula tok betydelig mer sildefisker enn det måsene gjorde $i$ alle sesonger og alle sub-regioner, særlig $i$ nordlige og vestlige deler av Nordsjøen. Krykkje, sildemåse og gråmåse var de viktigste konsumentene av sildefisker i sørøstre deler av Nordsjøen.

Store avfallsspisende sjøfugler tenderte mot å konsumere større fisk enn de som ble tatt av de mindre artene. Gjennomsnittslengden (median) for rundfisk som ble tatt av sjøfugl varierte 
fra $14 \mathrm{~cm}$ for fiskemåse til $25 \mathrm{~cm}$ for havsule og storjo. Gjennomsnittsbredden for flatfisk som ble spist av sjøfugl varierte fra $3,5 \mathrm{~cm}$ for havhest og krykkje til $6,5 \mathrm{~cm}$ for havsule og svartbak. Mye av det som ble sluppet ut, ble stjålet fra mindre fugler av de større artene, noe som resulterte $\mathrm{i}$ lavere suksess i kampen om maten for de minste artene sammenlignet med de store artene. Havsule, svartbak og storjo var gjennomgående de artene som sto høyest $\mathrm{i}$ rang $\mathrm{i}$ dominanshierarkiet, mens havhest og krykkje var mest utsatt for robbing (kleptoparasittisme). Små arter som krykkje og fiskemåse unngikk vanligvis kamp om maten. Svartbak og storjo fikk det meste av fiskeriavfallet gjennom robbing.

De vanligste fiskefartøyene i Nordsjøen er bomtrålere, hekktrålere, partrålere, snurpere, linebåter og små garnbåter. Fiske på bunnen etter torskefisk med trål eller snurpenot, pelagisk fiske etter sildefisker og makrell samt fiske med bomtrålere produserer store mengder fiskeavfall.

Den samlede mengden av fiskeavfall i Nordsjøen er estimert til $120,000 \mathrm{t}$ rundfisk, 200,000 t flatfisk og 180,000 t bentiske evertebrater. Bomtrålere produserer relativt store mengder fiskeavfall der bare en liten del (rundfisk, små flatfisk, fiskeslo) kan utnyttes av sjøfuglene. Bunnfiske og pelagisk fiske etter rundfisk produserer relativt lite fiskeavfall, som imidlertid kan utnyttes så og si fullt ut av sjøfuglene. Årlige utslipp av fiskeslo fra fiskeriene i Nordsjøen $111 \%$ av vekta av rundfisk og $6,5 \%$ av vekta av flatfisk) er beregnet til nær 70,000 tonn. Mellom 2,5 og 3,5 millioner sjøfugler kan potesielt ernære seg av fiskeriavfall i Nordsjøen.

En reduksjon av fiskeaktiviteten log dermed også av fangst og fiskeriavfall) vil trolig føre til skjerpet konkurranse og dermed mindre vellykket fødesøk for de artene som er mest utsatt for å bli frarøvet maten. Virkningene av en reduksjon i utslipp av vrakfisk og fiskeslo kan bli større under ugunstige forhold (perioder med sterk vind, vinterstid) enn sommerstid. Utviklingen av kommersielle fiskerier i dette århundret har resultert $\mathrm{i}$ en viktig ekstra næ- ringskilde, som har medført at flere sjøfuglarter tilsynelatende har økt $\mathrm{i}$ antall og spredt seg over større områder. Dersom det skulle oppstå en situasjon der fiskeriavfall ikke lenger blir sluppet ut og disse fuglene ikke kan skifte til alternative næringskilder, kan populasjonene bli negaivt påvirket. Resultatene fra dette arbeidet kan brukes til å prøve å forutsi mulige følger for sjøfugl på regionalt nivå eller på artsnivå av tiltak som blir satt inn for å redusere mengden av fiskeriavfall direkte eller for å redusere fisket.

\section{DANSK RESUMÉ}

Ornitologer fra seks institutioner fra landene rundt om Nordsøen deltog på havforskningsfartøjer som led i de internationale bundtrawl-undersøgelser (IBTS) i februar 1993 samt maj, august og november 1994. Observationerne ombord skulle give informationer om sæsonmæssige variationer i fordelingsmønsteret og tiltrækning til fiskefartøjer hos havfugle i Nordsøen, med vægten lagt på arter som udnytter fiskeriaffald ('scavengers'). Eksperimentelle udslip af fiskeriaffald blev gennemført for at vise hvorledes havfuglene udnytter de forskellige dele af affaldet. Dominanshierakier blev studeret for at undersøge hvor udsat de forskellige arter er for at blive frarøvet føde af andre arter. Fordelingen af fiskefartøjer i Nordsøen og rutiner for udslip af fiskeriaffald blev også undersøgt, og dette blev lagt til grund for at analysere hvor attraktive forskellige fiskerier er for havfugle, og hvor stor den aktive fiskeriflåde er i forskellige regioner af Nordsøen.

Sæsonmæssige varaitioner i fordelingsmønsteret og tiltrækning til fiskerifartøjer er beskrevet for de otte almindelige havfuglearter som udnytter fiskeriaffald: mallemuk, sule, storkjove, stormmåge, sildemåge, sølvmåge, svartbag og ride. Mallemuk, sule og ride var almindelige hele året, stormmåge, sølvmåge og svartbag var forholdsvis fåtallige i sommerhalvåret, mens storkjove og sildemåge var forholdsvis fåtallige $\mathrm{i}$ vinterhalvåret. Antallet såvel som artssammensætningen af havfugle, som blev tiltrukket til fiskebådene, afspejlede generelt de sæsonmæssige og geografiske udbredelsesmønstre af de forskellige arter i Nordsøen. En 
klar undtagelse var dog riden, som i større grad blev tiltrukket af fiskefartøjer om vinteren end om sommeren, på trods af en større sommer- end vinterbestand.

Antallet af aktivt fiskende fiskefartøjer i Nordsøen blev anslået til at variere mellem 800 og 1800 både. Dette tal er imidlertid ikke fuldt ud dækkende for fiskeriflåden som opererer nær kysten på grund af en mangelfuld dækning af denne zone. Bomtrawlere og rejetrawlere var de hyppigste $(28 \%)$, fulgt af hæk- og sidetrawlere $(27 \%)$, garnbåde, snurrevods- og langlinebåde $(11 \%)$, notbåde (7\%) og par-trawlere (7\%). Bomtrawlere, rejetrawlere og garnbåde var dominerende i den sydøstlige del af Nordsøen, men blev sjældent set $\mathrm{i}$ de nordvestlige dele. Notbåde, par-trawlere, hæktrawlere og sidetrawlere var hyppigst i den centrale, nordlige og nordvestlige del af Nordsøen.

Maksimum antal af de pågældende fuglearter varierede fra lidt over 20 storkjove til 3500 mallemuk. Det største antal af havfugle blev tiltrukket til hæk- og sidetrawlere, hvorimod relativt få fugle blev tiltrukket af notbåde og bomtrawlere. Sildemåge, sølvmåge og svartbag var de eneste af disse fuglearter, hvis udbredelse viste en positiv korrelation med forekomsten af fiskefartøjer. Hverken tidsmæssige eller geografiske forskelle $\mathrm{i}$ forekomsten af mallemuk, sule, storkjove og ride kunne forklares ved tilstedeværelsen af fiskefartøjer.

Havfugle tager en større andel af fiskeaffaldet om vinteren (februar og november) end om sommeren (maj og august). Udnyttelsesgraden er anslået til $95 \%$ for indmad, $80 \%$ for rundfisk, $20 \%$ for fladfisk og $6 \%$ for bundlevende invertebrater. Konkurrencen om fiskeriaffaldet steg fra sommer til vinter og fra syd til nord. Sammenlignet med frekvensen af de enkelte arter ved fiskeskibene, tog mallemuk og ride mere indmad end forventet. Mallemuk og ride konsumerede relativt få af de eksperimentelt tilbudte torskefisk, mens sule derimod tog en forholdmæssig meget stor andel af disse. Sildemåge og sølvmåge var de vigtigste konsumenter af torskefisk $\mathrm{i}$ den sydøstlige del af Nordsøen. Af eksperimentelt tilbudte sildefisk tog mallemuk betydlig mindre end forventet.
Sule tog betydeligt flere sildefisk end mågerne gjorde $\mathrm{i}$ alle sæsoner og alle regioner, især $\mathrm{i}$ den nordlige og vestlige del af Nordsøen. Ride, sildemåge og sølvmåge var de vigtigste konsumenter af sildefisk $\mathbf{i}$ den sydøstlige del af Nordsøen.

Store (affaldsspisende) havfugle havde en tendens til at konsumere større udsmid end de mindre arter. Gennemsnitslængden (median) for rundfisk som blev taget af havfugle varierede fra $14 \mathrm{~cm}$ for stormmåge til $25 \mathrm{~cm}$ for sule og storkjove. Gennemsnitsbredden for fladfisk som blev spist af havfugle varierede fra $3,5 \mathrm{~cm}$ for mallemuk og ride til $6,5 \mathrm{~cm}$ for sule og svartbag. De større fuglearter stjal en del affald fra de mindre fuglearter, hvilket resulterede $\mathrm{i}$ lavere succes i kampen om maden for de mindre arter sammenlignet med de større arter. Sule, svartbag og storkjove var gennemgående de arter som var placeret højest $\mathrm{i}$ dominanshierakiet, mens mallemuk og ride var mest udsat for tyveri (kleptoparasitisme). Små arter som ride og stormmåge undgik normalt kamp om maden. Storkjove og svartbag fik det meste af fiskeriaffaldet gennem tyveri.

De hyppigste fiskefartøjer i Nordsøen. er bomtrawlere, hæk- og sidetrawlere, par-trawlere, notbåde, garnbåde, snurrevodsbåde og langlinebåde. Bundfiskeri efter torskefisk med trawl eller not, pelagisk fiskeri efter sildefisk og makrel samt fiskeri med bomtrawl produkserer store mængder fiskeriaffald.

Den samlede mængde af fiskeriaffald er estimeret til $120.000 \mathrm{t}$ rundfisk, $200.000 \mathrm{t}$ fladfisk og $180.000 \mathrm{t}$ bentiske invertebrater. Bomtrawlere produkserer relativt store mængder fiskeraffald, hvoraf kun en mindre del (rundfisk, små fladfisk, indmad) kan udnyttes af havfuglene. Bundfiskeri og pelagisk fiskeri efter rundfisk produkserer forholdvis lidt fiskeriaffald, som imidlertid kan udnyttes så at sige fuldt ud af havfuglene. Det årlige udsmid af indmad fra fiskerierne i Nordsøen $111 \%$ af vægten af rundfisk og $6,5 \%$ af vægten af fladfisk) er beregnet til nær 70.000 tons, en mængde der potentielt kan ernære mellem 2,5 og 3,5 millioner havfugle. 
En reduktion i fiskeriaktiviteten log dermed også af fangst og fiskeriaffald) kan medføre en skærpet interspecifik konkurrence mellem havfugle som udnytter fiskeriaffald, og kan formodentlig dermed føre til en mindre vellykket fødesøgning hos de mindre arter. Virkningerne af en reduktion i udsmiddet af fisk og maveindhold vil være større under ugunstige forhold (storm, vinter) end om sommeren. I tilfælde af at der skulle opstå en situation, hvor fiskeriaffald ikke længere blev smidt ud fra fiskebåde i Nordsøen og disse fuglearter ikke ville have adgang til alternative fødekilder, kan disse populationer blive negativt påvirket. Resultaterne af dette arbejde kan bruges til på regional såvel som på artmæssig basis at forudsige mulige følger for havfugle af tiltag som bliver sat ind for at reduksere mængden af fiskeriaffald direkte eller for at reduksere fiskeriet.

\section{RESUMEN}

En febrero de 1993 y en mayo, agosto y noviembre de 1994, ornitólogos pertenecientes a seis instituciones de países situados alrededor del Mar del Norte se embarcaron en buques de investigaciones pesqueras involucrados en el International Bottom Trawl Survey (IBTS) (Isnpección Internacional sobre la Pesca de Arrastre). Se hicieron observaciones encaminadas a valorar variaciones temporales en la distribución de aves marinas carroñeras en el Mar del Norte y a estudiar la atracción que ejercen los barcos de pesca sobre estas aves. La selección y el consumo de descartes de pesca por aves marinas se cuantificó por medio de descartes experimentales. Con objeto de obtener información sobre la vulnerabilidad de cada especie a ser robado se estudió la jerarquía de dominación entre las distintas especies de aves. También se investigaron la distribución espacial de barcos de pesca en el Mar del Norte y sus métodos de arrojar descartes. Los resultados se utilizaron para analizar la atracción de las aves marinas hacia diferentes tipos de pesquerías, y para calcular el número total de barcos de pesca activos en distintas regiones del Mar del Norte.

En este trabajo se describen las fluctuaciones temporales en los modelos de distribución espacial y la atracción hacia barcos de pesca de ocho especies marinas comunes. Entre éstas se incluyen fúlmares Fulmarus glacialis, alcatraces Morus bassanus, págalos grandes Catharacta skua, gaviota cana Larus canus, gaviota sombría Larus fuscus, gaviota argéntea Larus argentatus, gavión Larus marinus y gaviota tridáctila Rissa tridactyla. Se estimó que el número total de estas aves marinas en el Mar del Norte se encuentra en el rango de 1.5-4.0 millones de individuos en febrero a 3.0-6.5 millones de individuos en noviembre. Las especies más abundantes fueron los fúlmares y las gaviotas tridáctilas. Los fúlmares, alcatraces y gaviotas tridáctilas fueron abundantes durante todo el año. Las gaviotas canas, gaviotas argénteas, y gaviones fueron más escasos durante el verano, mientras que los págalos grandes y las gaviotas sombrias fueron escasas durante el invierno. En general, la variación espacial y temporal de la abundancia relativa y la composición de especies de aves marinas en el mar era equiparable al número de aves y composición de especies de aves carroñeras atraídas a los barcos de investigaciones pesqueras. Una importante excepción fue la gaviota tridáctila, la cual parecía estar más atraída por los barcos pesqueros en invierno que en verano, aunque el máximo múmero obtenido para esta especie fue en el verano.

El número total de barcos de pesca (activos, no en tránsito) en el Mar del Norte se estimó entre 800 y 1800 . Sin embargo, este número no tiene en cuenta muchos de los barcos que faenan cerca de la costa, ya que esta zona apenas se muestreó. Los tipos de barcos de pesca más numerosos son arrastreros tangoneros y camaroneros $(28 \%)$, seguidos de arrastreros de popa o arrastreros de popa con puertas $(27 \%)$, palangreros $(11 \%)$, barcos con redes al cerco de jareta $(7 \%)$, bous $(7 \%)$ y Jabega (anchor seiners) (2\%). Los arrastreros tangoneros, camaroneros, palangreros y Jabega (anchor seiners) fueron los más abundantes en la mitad sureste del Mar del Norte, pero escasos en el noroeste. Barcos con redes al cerco de jareta, bous, arrastreros de popa $\gamma$ arrastreros de popa con puertas fueron los tipos de barco más comunes en las regiones 
central, norte y noroeste del Mar del Norte.

El número máximo de individuos de cada especie de ave marina asociados a barcos de pesca varió de poco más de 20 págalos grandes a 3500 fúlmares. Los números de aves marinas más elevados se encontraron cerca de arrastreros de popa y arrastreros de popa con puertas. Alrededor de barcos con redes al cerco de jareta, arrastreros tangoneros y Jabega (anchor seiners) se contaron relativamente pocos individuos. Las únicas especies para las que la distribución total en el Mar del Norte estaba clara y positivamente influida por la presencia de barcos de pesca fueron gavión, gaviota argéntea y gaviota sombría (en verano). Las variaciones espaciales y temporales en la distribución total de fúlmares, alcatraces, págalos grandes y gaviotas tridáctilas no pueden explicarse solamente por la diferencia en la abundancia de barcos de pesca.

Las tasas de consumo de despojos y descartes fueron mayores durante el invierno (febrero $y$ noviembre) que durante el verano (mayo $y$ agosto). Las tasas de consumo totales se estimaron en $95 \%$ para despojos, $80 \%$ para peces no planos, $20 \%$ para peces planos y $6 \%$ para invertebrados bénticos. La competencia por desechos aumentó del verano al invierno y del sur al norte. Comparando con el porcentage de cada especie presente, los fúlmares y las gaviotas tridáctilas consumieron más despojos de los esperados. En cuanto a los descartes experimentales de gádidos, los fúlmares y las gaviotas tridáctilas tuvieron un éxito de alimentación relativamente bajo, mientras que el de los alcatrazes fue muy alto. Las gaviotas sombrías y las gaviotas argénteas fueron los consumidores de gádidos más importantes en el sureste del Mar del Norte. En cuanto a los descartes experimentales de cupleidos, los fúlmares obtuvieron considerablemente menos de lo que se podría predecir por su abundancia. Los alcatrazes obtuvieron significativamente más cupleidos que las gaviotas en la mayoría de las estaciones de año y en la mayoría de las sub-regiones, particularmente en la parte norte y oeste del Mar del Norte. Los consumidores de cupleidos más importantes en el sureste del Mar del Norte fueron las gaviotas tridáctilas, las gaviotas sombría $\mathrm{V}$ argéntea.

Las aves marinas carroñeras de mayor tamaño tienden a consumir descartes de mayor tamaño que las especies de aves marinas más pequeñas. La mediana de la longitud de peces no planos consumida por las aves marinas varía entre $14 \mathrm{~cm}$ en gaviotas canas y $25 \mathrm{~cm}$ en alcatraces y págalos grandes. La mediana de la anchura de los peces planos consumidos por aves marinas varía entre $3.5 \mathrm{~cm}$ en fúlmares $y$ gaviotas tridáctilas y $6.5 \mathrm{~cm}$ en alcatraces $y$ gaviones. Las aves marinas de mayor tamaño roban muchos descartes de las especies más pequeñas, por lo que el éxito de las últimas tiende a ser más bajo. Las especies con mayor rango en la jerarquía de dominación fueron alcatraces, gaviones y págalos grandes, mientras que los fúlmares y gaviotas tridáctilas fueron las más cleptoparasitadas. Las especies más pequeñas como la gaviota tridáctila y la gaviota cana evitaban normalmente luchar para conseguir descartes. Los gaviones y los págalos grandes consiguieron la mayoría de los descartes cleptoparasitando a otras aves.

Los principales tipos de barcos pesqueros en el Mar del Norte son arrastreros tangoneros, arrastreros de fondo, arrastreros pelágicos y de media profundidad, bous, barcos de pesca al cerco de jareta, Jabega (anchor seiner), jábegas escocesas, palangreros $y$ otros barcos de menor tamaño. Las pesquerías de gádidos con redes de fondo (arrastreras y jábegas), las pesquerías de cupleidos y caballa en aguas más superficiales, y los arrastreros tangoneros, producen gran cantidad de descartes y despojos.

La cantidad total de descartes en el Mar del Norte se ha estimado en 120000 toneladas de peces no planos, 200000 toneladas de peces planos y 180000 toneladas de invertebrados bénticos. Los arrastreros tangoneros producen relativamente grandes cantidades de descartes de los que, una relativa pequeña proporción (peces no planos, peces pequeños, despojos) pueden ser utilizados por las aves marinas. Las pesquerías de peces no planos (pelágicas y de fondo) producen relativamente pequeñas can- 
tidades de descartes que pueden ser utilizados por aves marinas carroñeras. La cantidad anual de despojos producidas en las pesquerías del Mar del Norte $111 \%$ de la masa de los peces no planos y $6.5 \%$ de la masa de los peces planos) se estimó en casi 70000 toneladas. Entre 2.5 y 3.5 millones de aves marinas pueden ser mantenidas en potencia por los descartes de las pesquerías en el Mar del Norte.

Una reducción general en la intensidad de pesca (y por lo tanto en captura y descarte) llevaría probablemente a una competencia más intensa entre las aves $y$, en consecuencia, a un descenso en el éxito alimentación de las especies más cleptoparasitadas. Los efectos de una reducción en la cantidad de descartes y vertidos de despojos serían mayores en condiciones adversas (periodos de mal tiempo prolongados, invierno) que en el verano. El desar- rollo de la industria pesquera en este siglo ha significado un aporte de alimento adicional importante para las aves marinas y ha resultado en un aumento en el número de algunas especies y en una distribución más extensa de las mismas. Si se llegase a la situación en la que no se produjesen ni se vertiesen más despojos ni descartes, y si las aves no pudiesen cambiar a otros alimentos alternativos, estas poblaciones se verían negativamente afectadas. Los resultados de este estudio pueden ser utilizados para predecir los posibles efectos en aves marinas (a escala regional y a nivel de especies) de medidas tomadas para reducir la cantidad de descartes o para reducir la intensidad de pesca. 


\section{Abbreviations and terms}

BhG Black-headed Gull Larus ridibundus

C subregion, central North Sea (see figure 2.1.1)

$\mathrm{CE}$

CG

subregion, central eastern part of the North Sea (see figure 2.1.1)

CT

Common Gull Larus canus

Common Tern Sterna hirundo

CW

density

discards

ESASD

subregion, central western part of the North Sea (see figure 2.1.1)

number of birds per $\mathrm{km}^{2}$ (derived from strip-transect counts)

unmarketable fish in commercial fisheries, normally set overboard

European Seabirds At Sea Database, maintained in Aberdeen at Joint Conservation Committee: combined database holding seabirds at sea data

fishing vessel Commercial fishing vessel, being a trawler, (purse) seiner, long-liner, or whatever type excluding fisheries research vessels, actually engaged in fishing (not just steaming)

Ful Fulmar Fulmarus glacialis

Gan Gannet Morus bassanus

GBG

GG

Great Black-backed Gull Larus marinus

GSk

Glaucous Gull Larus hyperboreus

GU

Great Skua Catharacta skua

$H G$

IBN-DLO

IBTS

IC

Division of Environmental and Evolutionary Biology, Glasgow University G12 8QQ, Scotland, U.K.

Herring Gull Larus argentatus

ICES

DLO-Institute for Forestry and Nature Research, Texel, The Netherlands

International Bottom Trawl Survey

Inter-callibration cruise, onboard RV Pelagia, January 1993 and March 1994

International Council for the Exploration of the Seas, General secretary: Palægade 2-4, DK-1261 Copenhagen, Denmark

ICES-squares $0.5^{\circ}$ latitude $\times 1^{\circ}$ longitude rectangles

IG

Iceland Gull Larus glaucoides

JNCC

Offshore Animals Branch, Joint Nature Conservation Committee, 16-17 Rubislaw Terrace, AB1 1XE Aberdeen, Scotland, U.K.

Kit Kittiwake Rissa tridactyla

LBG

LG

Lesser Black-backed Gull Larus fuscus

Little Gull Larus minutus

NE

NINA

subregion, northeastern part of the North Sea (see figure 2.1.1)

NIOZ

Norsk Institutt for Naturforskning, Tungasletta 2, N-7004 Trondheim, Norway

Netherlands Institute for Sea Research, P.O. Box 59, 1790 AB Den Burg, Texel, The Netherlands

NW

OC

offal

$\mathrm{S}$

Sk

subregion, northwestern part of the North Sea (see figure 2.1.1)

Ornis Consult Ltd, 140 Vesterbrogade, 1620 København V, Denmark

intestines and liver of gutted fish

subregion, Southern Bight $\left(51^{\circ} \mathrm{N}\right.$ to $53^{\circ} 30^{\prime} \mathrm{N}$; see figure 2.1.1)

subregion, Skagerrak and Kattegat (see figure 2.1.1)

subregion

one of 7 subregions defined for this study (NW, NE, Sk, CW, C, CE or S; see figure 2.1.1)

VWH

Institut für Vogelforschung 'Vogelwarte Helgoland', Postfach 1220, D-2192 Helgoland, Germany 
Names of birds and discarded items mentioned in this report

Fulmar Fulmarus glacialis

Sooty Shearwater Puffinus griseus Manx Shearwater Puffinus puffinus Leach's Petrel Oceanodroma leucorhoa

Storm Petrel Hydrobates pelagicus

Gannet Morus bassanus

Cormorant Phalacrocorax carbo

Shag Phalacrocorax aristotelis

Mallard Anas platyrhynchos

Pomarine Skua Stercorarius pomarinus

Arctic Skua Stercorarius parasiticus

Long-tailed Skua Stercorarius longicaudus

Great Skua Catharacta skua

Mediterranean Gull Larus melanocephalus

Little Gull Larus minutus

Sabine's Gull Larus sabini

Black-headed Gull Black-headed Gull

Common Gull Larus canus

Lesser Black-backed Gull Larus fuscus

Herring Gull Larus argentatus

Yellow-legged Gull Larus cachinnans

Iceland Gull Larus glaucoides

Glaucous Gull Larus hyperboreus

Great Black-backed Gull Larus marinus

Kittiwake Rissa tridactyla

Sandwich Tern Sterna sandvicensis

Common Tern Sterna hirundo

Arctic Tern Sterna paradisaea

Black tern Chlidonias niger

Guillemot Uria aalge

Razorbill Alca torda

Little Auk Alle alle

Puffin Fratercula arctica

Black Guillemot Cepphus gry/le

Benthic invertebrates

Sea-mouse Aphrodite aculeata

Brown shrimp Crangon crangon

Common prawn Palaemon serratus

Aesop prawn Pandalus montagui

Edible crab Cancer pagurus

Spider crab Macropodia spp.

Masked crab Corystes cassivelaunus

Swimming Crab Liocarcinus holsatus

Nephrops Nephrops norvegicus

Hermit crab Pagurus bernhardus
Sea-potato Echinocardium cordatum

Sea-urchin Psammechinus miliaris

Common starfish Asterias rubens

starfish Astropecten irregularis

Brittle star Ophiura spp.

Ascidian Ascidia spp.

Cephalopods

Common octopus Octopus vulgaris

flying squid Ommastrephes sp.

\section{Flatfish}

Roker Raja clavata

Skate Raja batis

Angler Lophius piscatorius

Turbot Scophthalmus maximus

Brill Scophthalmus rhombus

Megrim Lepidorhombus whiffiagonus

Norw. topknot Phrynorhombus norvegicus

Scaldfish Arnoglossus laterna

Plaice Pleuronectes platessa

Flounder Platichthys flesus

Dab Limanda limanda

Lemon sole Microstomus kitt

Witch Glyptocephalus cynoglossus

Long rough dab Hippoglossoides platessoides

Halibut Hippoglossus hippoglossus

Sole Solea solea

Solenette Buglossidium luteum

Jellyfish

Brown stinging jellyfish Cyanea capillata

Roundfish

Hagfish Myxine glutinosa

Dogfish Scyliorhinus canicula

Spurdog Squalus acanthias

Monkfish Squatina squatina

Rat-fish Chimaera monstrosa

Herring Clupea harengus

Sprat Sprattus sprattus

Pilchard Sardina pilchardus

Allis shad Alosa alosa

Lesser Argentine Argentina sphyraena

Cod Gadus morhua

Silvery pout Gadiculus argenteus

Haddock Melanogrammus aeglefinus

Whiting Merlangius merlangus

Blue whiting Micromesistius poutassou 
Poor cod Trisopterus minutus Norway pout Trisopterus esmarkii

Bib Trisopterus luscus

Pollack Pollachius pollachius

Saithe Pollachius virens

Four-bearded rockling Enchelyopus cimbrius

Ling Molva molva

Hake Merluccius merluccius

Blue-mouth Helicolenus dactylopterus

Red-fish Sebastes marinus

Norway haddock Sebastes viviparus

Tub gurnard Trigla Iucerna

Grey gurnard Eutrigla gurnardus

Bull-rout Myoxocephalus scorpius
Hooknose Agonus cataphractus

Lumpsucker Cyclopterus lumpus

Scad Trachurus trachurus

Red mullet Mullus surmuletus

Greater weever Trachinus draco

Lesser weever Echiichtys vipera

Snake blenny Lumpenus lampretaeformis sandeel Ammodytes spp.

Greater sandeel Hyperoplus lanceolatus

Dragonet Callionymus Iyra

Spotted Dragonet Callionymus maculatus

Sand goby Pomatoschistus minutus

Mackerel Scomber scombrus 


\section{INTRODUCTION}

"I can risk suggesting that not a fortnight has passed lexcept in weather or war of exceptional severity) during the last fifty years, in which every breeding fulmar from Grimsey to Land's End has not had a trawler crew gut a haul within reach of a food-flight. That the fulmars take advantage of this is something that every trawlerman knows, even if ornithologists (who seldom travel on trawlers or even fishery research-vessels) have been rather slow on the up-take"

From: 'SOME POSSIBLE CAUSES OF THE FULMAR'S SPREAD', chapter 19 in 'THE FULMAR' by James Fisher (1952), Collins, London.

North Sea fisheries increased dramatically since the end of the 19th century and this has provided an increasing opportunity for scavenging seabirds to utilise foods that would otherwise not be available to them. Bycatch, often demersal roundfish and flatfish, and the intestines of gutted fish are discarded in enormous quantities and several species of seabirds which are incapable of diving to the seabed exploit this food resource with great success. The rapid increase in populations of Fulmars, Gannets and several species of gulls has often be attributed to this artificial source of food (e.g. Fisher 1952, Harris 1970, Goldbach \& Hansen 1979, Croxall et al. 1984, Furness 1992).

Discarding the unwanted parts of the catch (i.e. bycatch, unmarketable fish and entrails of gutted fish) is common practice, probably since fisheries began. It was in the late 19th century that fishery biologists became concerned about this spillage of valuable resources, when Weigelt (1891) investigated the nature, amount, use and exploitation of fishery waste produced by German fisheries. During the second half of this century, with a rapid increase in fishing effort, these concerns increased because large proportions of young fish of commercial species were killed as a result of the discarding practices (e.g. Sahrhage 1958,
1959). Meanwhile, the influence of fisheries is not only of interest for fishery science and the fishing industry but also for other biological and environmental sciences focussing on anthropogenic activities.

The data in this report support the idea that scavenging seabirds make extensive use of fishery waste, above all of offal and roundfish, but also to some extent of flatfish, cephalopods and benthic invertebrates. Previous studies have focussed on single seasons or smaller areas (e.g. Hudson \& Furness 1989, Furness et al. 1988, 1992, Garthe 1993b, Camphuysen et al. 1993). A previous EC funded project was the first synoptic study of discard utilisation by scavenging seabirds throughout the North Sea, focusing on the winter situation (Camphuysen et al. 1993). The follow-up project was designed to assess seasonal fluctuations in the distribution and overall numbers of scavenging seabirds and fisheries on a North Sea scale $\left(51^{\circ}-62^{\circ} \mathrm{N}, 4^{\circ} \mathrm{W}-12^{\circ} \mathrm{E}\right)$. It was meant to refine knowledge on the attraction of fishing vessels for seabirds, and to assess seasonal fluctuations in discards consumption. The results are valuable tools to be used when the implications of new regulations in commercial fisheries in the North Sea are to be assessed for seabirds. Basic questions were: 
$\rightarrow$ Which seabirds are common scavengers at trawlers in the North Sea?

$\rightarrow$ How numerous are these birds in winter, spring, summer and autumn?

$\rightarrow$ How are these seabirds distributed in each season?

$\rightarrow$ How are North Sea fisheries distributed?

$\rightarrow$ Which fisheries attract most seabirds ?

$\rightarrow$ Which part of discards is utilized by seabirds and how do scavenging seabirds interact at the trawl?

$\rightarrow$ How large a proportion of discards and offal is consumed by scavenging seabirds?

$\rightarrow$ How large amounts of discards and offal are released in the North Sea?

$\rightarrow$ How large a number of scavenging seabirds can potentially be supported by fishery waste in commercial fisheries in the North Sea?

and finally, as a derivative,

$\rightarrow$ What effect will measures to reduce discards in commercial fisheries have on seabirds?

The work was carried out during the International Bottom Trawl Surveys (IBTS) in January-February 1993, May-June 1994, AugustSeptember 1994, and October-November 1994 on board a variety of fisheries research vessels (chapter 3 ). The fact that the work was carried out from research vessels rather than from fishing vessels was a limitation, but this was offset by the opportunity to achieve thorough coverage of the whole North Sea in a short period of time. A total of 27 observers were engaged in field work connected with the two projects, recruited from seven institutions in five countries around the North Sea.

Anticipated results from this project included an overview (maps) of spatial distribution and relative abundance of scavenging seabirds in four seasons (February, May, August and November) all over the North Sea, information on co-occurrence of seabirds and fishing vessels on a North Sea wide scale, descriptions of dominance hierarchies in areas differing in species composition and relative abundance of scavenging seabirds, and quantifications of proportions of discarded biota which are consumed by seabirds. Field work included systematic counts of seabirds and fishing vessels at sea and counts of seabirds assembling at the stern of the fishery research vessels and fishing vessels (chapter 2.2). Spatial distribution patterns, numbers (relative abundance and estimates of total numbers), species composition and age composition of scavenging seabirds in the North Sea are described using the results of strip-transect counts, stern counts and counts of birds associated with nearby trawlers (chapters 4.1-3). It was attempted to identify (types) and count fishing vessels in the North Sea (trawler counts) and to assess which species of scavenging seabirds were attracted to these fisheries (stern counts at close range of nearby fishing vessels) (chapters 4.4-5). An assessment of the proportion of discarded biota which is consumed by seabirds was made by means of discard experiments at trawling stations onboard research vessels (chapter 4.6). The quantitative study of discard and offal consumption broadly followed the methodology developed by Hudson \& Furness (1988), studying scavenging seabirds at trawlers around Shetland in summer. Inter-specific relationships between scavenging seabirds were studied to assess which species suffer most from kleptoparasitism and, hence, which species are most likely to be affected by a reduction of the amount of discards due to reductions in fishing effort (chapter 4.7). North Sea fisheries and specific discard practices are described on the basis of fishermens interviews, 
literature and personal observations (chapter 4.8). For each of the common scavenging species, the results were summarised in the species accounts (chapter 5). Current knowledge on quantities of discarded fish in commercial fisheries in the North Sea is summarised and consumption rates of seabirds as found in this study throughout the North Sea were used to estimate total consumption by scavenging seabirds and to calculate the total number of seabirds which could potentially be supported by fishery wastes alone (chapter 6).

\subsection{AUTHORS}

This report, being the final report to the European Commission, is written as a joint effort by the subcontractors in the project 'Consumption of discards by seabirds in the North Sea' (EC DG XIV research contract BIOECO/93/10) and includes the information collected during the previous project 'Seabirds feeding on discards in winter in the North Sea' (EC DG XIV research contract 92/3505). The writing of the final report was organised in a way that several authors drafted chapters which were then read by others. Chapter 4.6 on discards utilisation was written by Bob Furness, chapters 4.7 (kleptoparasitism) and 6 (the amount of discards produced and the numbers of seabirds potentially supported) were compiled by Stefan Garthe. Chris Winter drafted chapter 4.8 (North Sea fisheries and discard practices) using information obtained by fishermens interviews in a large number of harbours around the North Sea (performed by Belén Calvo, Kees Camphuysen, Jan Durinck, Kenny Ensor, Arne Follestad, Stefan Garthe, Genevieve Leaper, and Chris Winter). The comparison of the distribution of fishing vessels and seabirds in chapter 4.5 was written by Henrik Skov. The remaining chapters were written by the first author, who also edited the report. Genevieve Leaper and Mark Tasker have checked the English. Danish, Dutch, German, Norwegian and Spanish summaries were translated from the English summary by Henrik Skov, Kees Camphuysen, Stefan Garthe, Arne Follestad and Belén Calvo respectively. All maps were prepared by Chris Winter and Kees Camphuysen. The tables for chapter 4.6 and Appendix $A$ were prepared by Kenny Ensor and Belén Calvo, those for chapter 4.7 and 6 by Stefan Garthe, the remaining tables were produced by Kees Camphuysen and Chris Winter. Abundance estimates from the European Seabirds at Sea database (chapter 4.2) were provided by Mark Tasker. The report provides a consensus view from the subcontractors engaged in the former project, which was reached after discussing the results at the Seabird Group Conference in Glasgow in March 1995.

\subsection{ACKNOWLEDGEMENTS}

We would like to thank Captains P.O. Bengston and L. Hansson and crew and cruise leaders O. Hagström and N. Håkonsson (RV Argos), Captains R.O. Jolliffe and B. Chapman and crew and cruise leaders T. Macer and J. Cotter (RV Cirolana), cruise leader H. Degel and Captain F.R. Larsen and crew (RV Dana), Captain A. Souwer and crew (RV Pelagia), cruise leader J. Lahn-Johannessen and Captain E. Kleven and crew (RV $M$. Sars), cruise leader D. Skagen, Captain Magnus Stenevik and crew (RV G.O. Sars), Captains and chief scientists $P$. Ramsay, A. Newton, K. Coull, C. Brazier and all the crew (RV Scotia), cruise leaders F. van Beek, A. Corten, H. Heessen and Captain A. Krijgsman and crew (RV Tridens), and cruise leaders H. Dornheim and S. Ehrich and Captain I. Seelmann and crew (RV Walther Herwig), cruise leader $\mathrm{Y}$. Vérin and Captain J. Paugam and crew (RV Thalassa) for their co-operation onboard. We would like to thank Frank Albers, Stefan Groenewold, Ommo Hüppop, Andrew Stronach, Uwe Walter and Olaf Zeiske for their co-operation during (one of the) the inter-callibration cruises onboard RV Pelagia. Most of the authors were also enga- 
ged in the field work, but Per Andell, Colin Barton, Olaf Flore, Jens Lund Hansen, Eduard Koopman, Max Nitske, Henk Offringa, Claire Pollock and Carolyn Stone are thanked for their effort at sea. Maarten van Arkel, Han Lindeboom (NIOZ) and Ommo Hüppop (VWH) are thanked for their advice, assistance and encouragement during all phases of the project, from proposal to final report.

\section{METHODS}

Methods used for this project were basically similar to those in the earlier study (Camphuysen et al. 1993). Slight modifications and better standardisation of methods improved both field-work and data processing. A short cruise was undertaken in March 1994 onboard RV Pelagia, in order to train project participants in methods and computer processing. This cruise was also used to develop a new method of counting nearby fishing vessels using radar. In this chapter, fieldand analysis methods and species selection are described in detail.

\subsection{SUBREGIONS}

Results are presented for the entire North Sea $\left(51-62^{\circ} \mathrm{N}, 4^{\circ} \mathrm{W}-12^{\circ} \mathrm{E}\right)$. The North Sea and Skagerrak/Kattegat were divided into 7 subregions on the basis of ICES areas IVa-c and IIla (figure 2.1.1). ICES area IVa, the northern part of the North Sea was split into two halves (subregions NW and NE), the central North Sea, ICES area IVb, was divided into three parts (subregions CW, C and CE respectively), ICES area IVc, the Southern Bight, and area IIla, the Skagerrak/Kattegat area, formed subregions $\mathrm{S}$ and $\mathrm{Sk}$ respectively. The area of these subregions was calculated as:

$\begin{array}{lr}\text { NW } & 156,906 \mathrm{~km}^{2} \\ \mathrm{NE} & 97,271 \mathrm{~km}^{2} \\ \text { Sk } & 58,972 \mathrm{~km}^{2} \\ \text { CW } & 69,447 \mathrm{~km}^{2} \\ \text { C } & 140,933 \mathrm{~km}^{2} \\ \text { CE } & 62,781 \mathrm{~km}^{2} \\ \text { S } & 56,763 \mathrm{~km}^{2} \\ & \\ \text { Total } & 643,053 \mathrm{~km}^{2}\end{array}$

\subsection{FIELD METHODS}

The fisheries research vessels engaged in the IBTS usually trawled for half an hour in each ICES square visited, steaming approximately 2-3 hours between fishing stations (figure 2.2.1). Seabirds were counted in strip-transects only while steaming. Separate counts were made of the number of birds attracted during fishing to determine the maximum number at each haul. During both steaming and fishing, the numbers of fishing vessels within 3 nautical miles of the ship were assessed at $\mathbf{3 0} \mathrm{min}$ intervals using radar and a visual check to identify vessels. Flocks of birds associated with nearby fishing vessels were identified and counted whenever possible (depending on distance and light conditions). Discard experiments were usually performed while the ship was stationary when the net was lifted and brought on deck.

\section{Strip-transects}

While steaming between trawling stations, observers on the top-deck counted seabirds within a strip-transect $190^{\circ}$ forward and on one side of the ship). The strip was usually $300 \mathrm{~m}$ wide, but was occasionally reduced to $200 \mathrm{~m}$ or less in response to poor weather conditions. Strip-transect counts included a snapshot count for flying birds (Tasker et al. 1984). From these counts, seabird densities were calculated $\left(\mathrm{n} / \mathrm{km}^{2}\right)$. Species, age, plumage, number, behaviour (e.g. swimming, flying, feeding), distance from the ship, and direction of flight were recorded routinely. Associations with fishing vessels, the observation vessel, hydrographical features or 


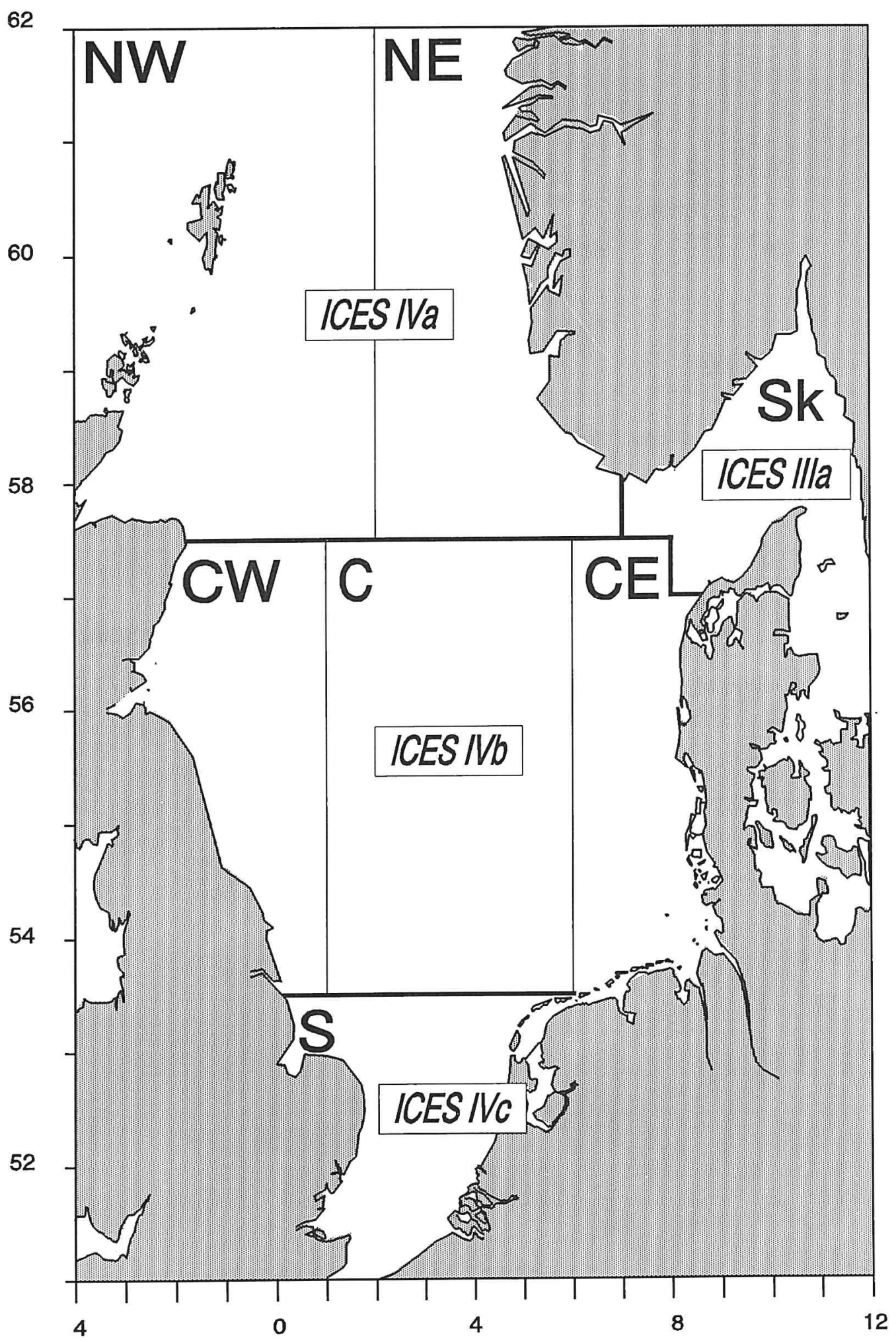

Figure 2.1.1 Subregions in the North Sea used for this project, and ICES fishing areas IVa-c and IIIa. 


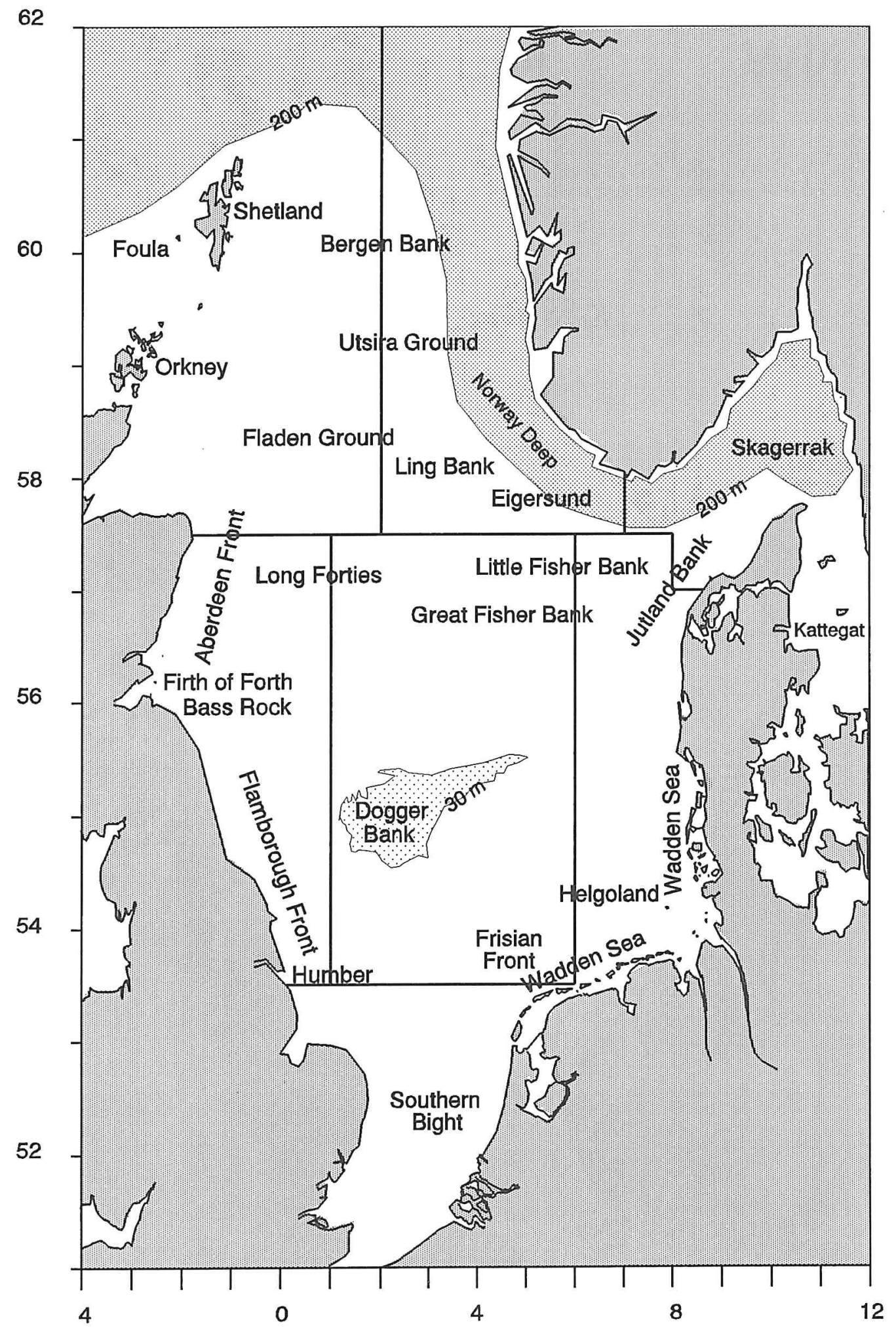

Figure 2.1.2 Place names in the North Sea, mentioned in this report 


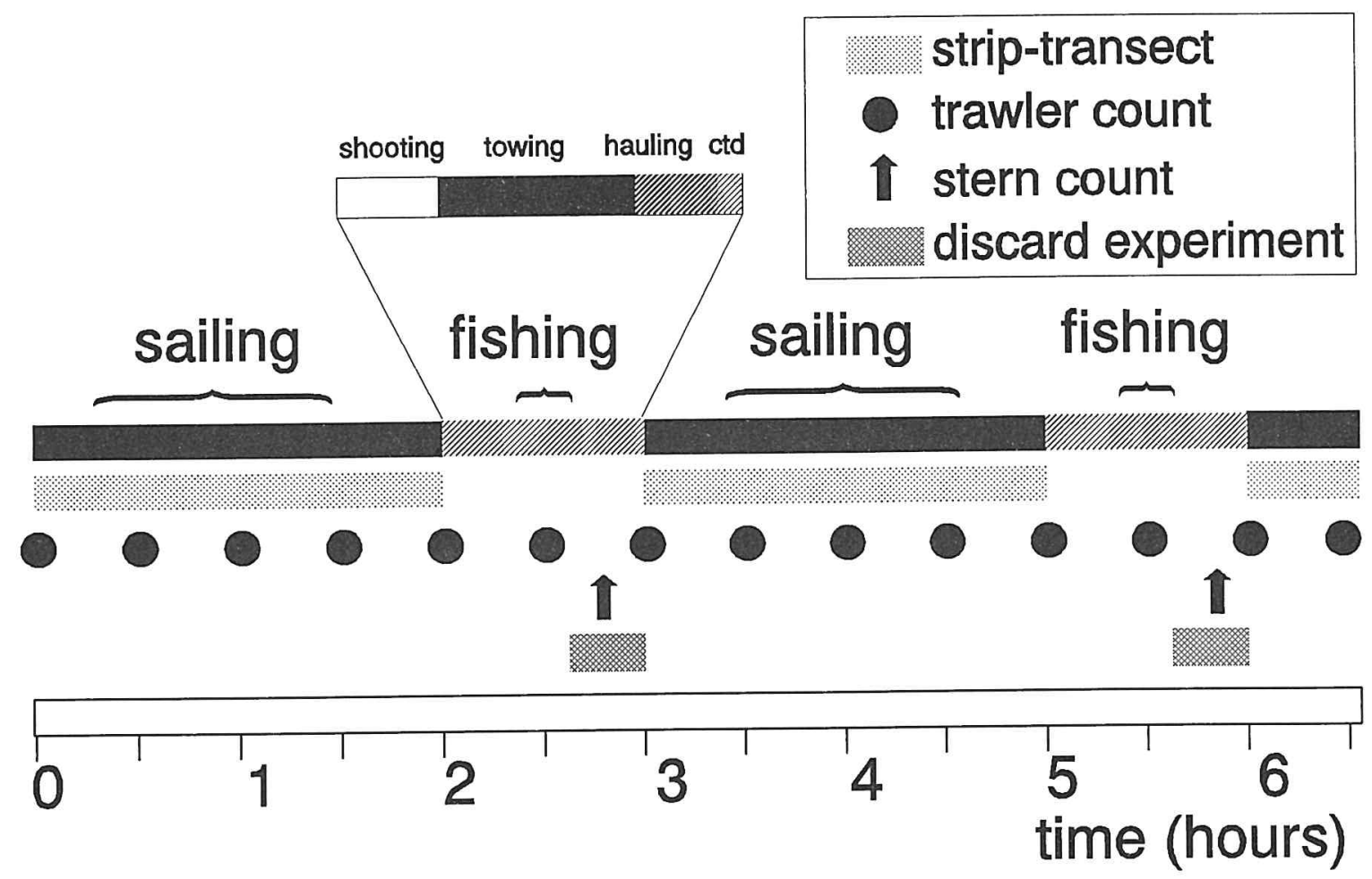

Figure 2.2.1 Schematic impression of field-work during IBTS: planning of strip-transect counts during steaming, stern counts and discard experiments at the end of the fishing period, and trawler counts at regular intervals. Counts of seabirds associated with nearby fishing vesse/s were performed opportunistically.

floating matter were also recorded. Birds in transect were normally counted accurately but when exceptionally high densities were encountered, numbers had to be estimated. A scan of all seabirds seen ahead of the ship (again within $90^{\circ}$ ) was performed in addition to the strip-transect. The scan was mainly used to study the distribution of scarce seabirds which spend much time on the wing (e.g. shearwaters, storm petrels, rarer gulls) and to enlarge the samples for analyses of age composition, sex-ratio and plumage in other species.

\section{Stern counts}

Stern counts were designed to assess the numbers of seabirds assembling at the ship during fishing and were performed from the position which offered the best view (either top-deck, bridge-wing or stern). When numbers were small, accurate counts could be made of associated birds. However, at several hauls more than 1000 scavengers were associated with the ship and numbers of each species had to be estimated. For each species, the maximum number present at any stage of the haul was recorded, together with age classes or plumage types. These maximum counts were used for distribution analysis. Discard experiments were not necessarily carried out when maximum numbers were present and in such cases counts were made of numbers present during experimental discarding. These counts were only used in analysis of discard experiments.

\section{Counts of seabirds at fishing vessels}

When fishing vessels were observed at close range, associated scavenging seabirds were identified and counted as accurately as possible (either to species or species group). 
Vessel type, name and activity were recorded whenever possible. These observations were usually made from the top-deck during steaming, but records were kept separately from the strip-transect data.

\section{Trawler counts}

In February 1993, all sightings of fishing vessels were recorded during transect counts but it was felt that a more systematic and reliable method was required. In 1994, the ship's radar was used to detect fishing vessels, with the advantage that a larger area could be surveyed regardless of visibility and distances could be measured accurately. At regular intervals, usually every half hour, the number of reflections on the radar screen was counted within 3 bands away from the ship $(<1,1-2$, and $2-3$ nautical miles). A visual check outside was made to assess the number of working fishing vessels, platforms and other vessels. Fishing vessels steaming (not fishing) were regarded as 'other vessels'. When distant vessels could not be seen by eye, they were assigned to category according to the ratio of fishing vessels, platforms and other vessels among those visible. Reflections that appeared to have been caused by buoys were ignored. Fishing vessels were identified to type whenever possible, in the following categories: beamtrawler, stern trawler, otter trawler, pair of trawlers, shrimper, purse seiner, anchor seiner, set-net boat, shellfisher, or small vessel (variable gear, usually only for inshore fishing). In February 1993, trawlers were observed during steaming from the top deck, but not systematically surveyed by means of radar counts.

\section{Discard experiments}

A fresh sample of fish, offal and benthic invertebrates (if available) was taken from each haul to be used for experimental discarding. The intention was to discard roundfish, flatfish, offal and benthic invertebrates in a ratio of $2: 2: 1: 1$, but in practice this was not possible. Flatfish and benthic invertebrates were under-represented in most catches and offal was not available on a regular basis. Items were identified, measured to the nearest $\mathrm{cm}$ in length and thrown overboard. Attempts by seabirds to pick up and swallow the item were recorded on tape, noting the species and age class of the bird and whether the item was eaten, dropped or stolen. If it was dropped or stolen, the same notes were made for the second and subsequent birds, until the item was finally lost (sunk) or swallowed. Experimental discarding was usually carried out when vessels were stationary as the net was lifted and brought on deck, during routine discarding of the ship if possible, but also occasionally during towing or steaming. Practical constraints made it impossible to standardise vessel activity for all discard experiments. When the number of scavengers was very small, or birds did not respond to the discards offered, for example because they were attracted to nearby trawlers, experiments were discontinued.

\section{Fleet / fisheries information}

Information on fleet composition and on discard practices was obtained from various sources. Fleet information was derived from official statistics or data files, but also from harbour masters and fisheries officers. Discarding practices onboard different vessels were described both from first hand information (interviews with fishermen) and second hand information (scientists onboard fishing vessels, written reports). Substantial information was obtained during harbour visits and interviews with fishermen in Lerwick and Scalloway (Shetland), Fraserburgh, Peterhead, Aberdeen, Pittenweem and Eyemouth (East Scotland), North Shields, Whitby and Scarborough (Northeast England), Lowestoft (Southeast England), Texel, Harlingen, Den Helder and IJmuiden (The Netherlands), Greetsiel, Norddeich, Bremerhaven, Cuxhaven, Friedrichskoog, Büsum and Tönning (Germany), Hanstholm and Hirtshals (Denmark). 


\subsection{DATA ANALYSIS}

Data was analysed for each IBTS: February 1993, May 1994, August 1994, and November 1994 and results are presented to show seasonal differences. Most analysis was on a subregional level, but the Skagerrak, which was only visited occasionally has not been included in all tables.

Strip-transects (chapter 4.1-2)

Observer effort for each survey is shown as the routes sailed during which strip-transect counts were performed (chapter 3 ) and the area surveyed $\left(\mathrm{km}^{2}\right)$ per quarter ICES square (15' latitude x 30' longitude; chapter 4$)$. The distribution of counts per subregion was not considered to differ significantly from random and the total number of seabirds at sea was calculated by multiplying the densities of seabirds found in each area with the area of the subregion. For these calculations, seabirds in transect which were clearly associated with nearby fishing vessels were not included, these being considered separately (see below). The age composition of scavenging seabirds was calculated for each subregion, using all observations of aged birds observed from transect and scan data. The distribution and estimated total numbers of seabirds at sea (but now including birds in transect which were associated with a nearby fishing vessel) were compared with similar data collected previously for the European Seabirds At Sea database (ESAS unpubl. data, Stone et al. 1995).

\section{Stern counts (chapter 4.3)}

The maximum counts for each haul were used to study the distribution of scavenging seabirds in the North Sea. Maximum counts were plotted, using the following abundance classes: $0,1-9,10-99$, and $\geq 100$ birds. Stern counts were analysed per subregion. For each stern count, the distance to the nearest coast was calculated and the relative abundance of scavengers was calculated and tabulated for distance classes from the coast: $1-25,25-50,50-100$, and $>100 \mathrm{~km}$.
Abundance estimates of ship-followers in each subregion comprised mean number observed per haul (total number of the species divided by number of hauls), maximum (highest number observed at a haul), presence (\% of hauls at which the species was present), proportion of adult birds (\%). Note that the mean derived from data with a highly skewed (non-normal) distribution, although satisfactory for our purposes here, is limited in statitistical terms. The median of the data might be more appropriate statistically, but less informative as in many cases the median would be zero. The age composition of scavenging seabirds at the stern was compared with that found 'at sea' during strip-transect counts using G-test.

Trawler counts (chapter 4.4)

Densities of fishing vessels were calculated from the radar snapshots $197 \mathrm{~km}^{2}$ surveyed per snapshot) and used to estimate the total numbers of fishing vessels in each subregion (by multiplying the density with area of the subregion). Densities were mapped per $0.5^{\circ}$ latitude $\times 1^{\circ}$ longitude square and the relative abundance of beamtrawlers, shrimpers, otter/stern trawlers, pairs of trawlers, purse seiners and set-net boats were assessed and tabulated per subregion. In the February 1993 IBTS, fishing vessels were recorded by visual observations only and it was assumed that all those within $2 \mathrm{~km}$ of the ship (i.e. a $4 \mathrm{~km}$ wide transect) were recorded (Camphuysen et al. 1993). Total numbers of fishing vessels per subregion during this survey were estimated from the numbers observed multiplied by the distance travelled $(\mathrm{km})$ multiplied by 4 .

Counts of seabirds at trawlers (chapter 4.5) Counts of seabirds associated with fishing vessels were treated in a similar way as stern counts at research vessels, but the results have not been mapped. Counts were analysed per subregion, and abundance estimates again comprised mean, maximum, and presence (\%) (see above). These counts were used to calculate the number of sea- 
birds associated with commercial fisheries in the North Sea. For each subregion, the mean number of each species associated with fishing vessels was multiplied by the total number of fishing vessels calculated from radar counts. These estimates of total numbers of birds associated with fisheries were added to the estimates derived from striptransect counts (see above), the sum representing the total numbers of scavenging seabirds in the North Sea. A z-test was performed to compare areas with higher/lower use by scavenging seabirds with areas with/without trawlers as determined through radar observations.

Discard experiments (chapter 4.6-7)

Locations of discard experiments in which at least 25 roundfish were offered were plotted and roundfish consumption rates were mapped in the following classes: $<50 \%$, 50$75 \%, 75-90 \%$, and $>90 \%$ consumed. Results of experimental discarding were analysed by subregion and the relative abundance of scavengers was calculated using stern counts made during the discard experiment (i.e. not necessarily the 'maximum counts' at each haul, as discussed earlier). Consumption rates for benthic invertebrates, flatfish, roundfish and offal were calculated for each subregion. The observed rates were compared with expected consumption rates calculated from the relative numerical abundance of each species during discard experiments. The percentages of all discarded items that were swallowed by a given seabird species divided by the percent of all birds present at the trawl that were this species were calculated and tabulated as:

\section{success index (S.I.)}

The frequency with which experimentally discarded items were stolen by birds of one species from another were also calculated. Combining data from all experimental discarding sessions, the number of experimental discards stolen by birds of one species divided by the number of experimental discards stolen birds from this species from others was calculated and tabulated as the:

\section{robbery index (R.I.)}

Quartiles and medians of roundfish length $(\mathrm{cm})$ and flatfish width $(0.5 \mathrm{~cm})$ for the most abundant discards were calculated by subregion and differences between length distributions were tested by Kruskal-Wallis 1-way ANOVA. For roundfish discards, total length was used as a measurement of size, ignoring the fact that circumference or height varied between species. In flatfish, however, fish width was used for analysis, a measurement which was calculated from the total length assessed during experimental discarding ( $c f$. Camphuysen (1994a). An analysis on the basis of width in flatfish appears to be more appropriate when dealing with gape-limited predators. Only fish species discarded in large quantities (over 250 offered) were analysed individually. For these species (listed in chapter 2.4), length distributions $(\mathrm{cm})$ of roundfish and width distributions $(0.5 \mathrm{~cm})$ of flatfish were tabulated for items that sunk or were consumed by one of the scavenging species. Minimum, median and maximum sizes of fish for the most abundant experimental discards were calculated and differences between common scavengers in size choices were compared by Kruskal-Wallis 1-way ANOVA.

Fleet / fisheries information (chapter 4.8)

The information obtained from interviews with fishermen interviews, (including fishing grounds, gear used and discards produced) and from observations in harbours (fleet composition) was compared with official statistics from various sources (e.g. Blom \& Van der Hak 1993, Anon. 1994b, 1995). From this information the main fisheries in the North Sea are described, focussing on target species and amounts and nature of fishery waste. Quantities of discards, as a fraction of the total catch and derived from landings statistics, are summarised in chapter 6 . 


\subsection{SPECIES SELECTION}

\section{Seabirds}

Over 30 species of seabirds have been recorded as scavengers at fishing vessels in the Northeast Atlantic region (Camphuysen 1993a). Many of these occur only occasionally and in small numbers. In this report, data are analysed in detail only for scavengers of which $>25$ individuals were attracted during a haul in at least one of the four surveys. The 8 common scavengers were:

\section{Fulmar Fulmarus glacialis \\ Gannet Morus bassanus \\ Great Skua Catharacta skua \\ Common Gull Larus canus \\ Lesser Black-backed Gull Larus fuscus \\ Herring Gull Larus argentatus \\ Great Black-backed Gull Larus marinus \\ Kittiwake Rissa tridactyla}

The following species occurred only occasionally at the trawl in small numbers:

\section{Sooty Shearwater Puffinus griseus \\ Manx Shearwater Puffinus puffinus \\ Pomarine Skua Stercorarius pomarinus \\ Arctic Skua Stercorarius parasiticus \\ Little Gull Larus minutus \\ Black-headed Gull Larus ridibundus \\ Glaucous Gull Larus hyperboreus \\ Sandwich Tern Sterna sandvicensis \\ Common Tern Sterna hirundo \\ Arctic Tern Sterna paradisaea \\ Guillemot Uria aalge \\ Razorbill Alca torda}

These species are discussed briefly in the species accounts (chapter 5.9) and included in 'others' in the analysis results elsewhere in this report.

\section{Discards}

During discard experiments, a wide variety of fish, benthic animals, cephalopods, jellyfish and 'offal' were offered to scavenging seabirds. Items were classified into four major groups: roundfish, flatfish, benthic invertebrates and offal. Insufficient jellyfish and cephalopods were discarded for meaningful analysis. Only few taxa were discarded in large enough quantities to warrant individual analysis:

\section{offal \\ Herring Clupea harengus \\ Whiting Merlangius merlangus \\ Haddock Melanogrammus aeglefinus \\ Sprat Sprattus sprattus \\ Norway pout Trisopterus esmarkii \\ Cod Gadus morhua}

In the analysis, Herring and Sprat were usually treated together as 'clupeids', Haddock, Whiting, and Cod, together with Saithe and Norway Pout as 'gadids'.

\section{CRUISE REPORTS}

\subsection{RESEARCH VESSELS}

A total of eleven different research vessels were engaged in this project. The fisheries research vessel (FRV) Argos, a $62 \mathrm{~m}$ long vessel owned by the Institute of Marine Research at Lysekil (Sweden), was joined in February 1993 by an ornithologist from Ornis Consult (OC). Trawling stations west of Skagen (Denmark) were clumped (see for details Camphuysen et al. 1993). FRV Ciro/ana, a $72.5 \mathrm{~m}$ long ship owned by the Ministry of Agriculture, Fisheries and Food (U.K.), was joined in the August and November 1994 IBTS cruises. Observers onboard were from the Joint Nature Conservation Committee (JNCC). FRV Dana was joined by a mixed team from JNCC and OC during the February IBTS in 1993, and by ornithologists from OC in November 1994. This ship is $78 \mathrm{~m}$ long and owned by the Danish Institute for Fisheries. For the inter-calibration cruises, both in January 1993 and in March 1994, RV Pelagia was used. This ship is a research vessel owned by the Netherlands Institute for Sea Research (NIOZ), with a length of $66 \mathrm{~m}$, and for these purposes equipped with a small 
beamtrawl, operated from the stern of the ship. During these cruises, representatives from all partners in this project were onboard. The Norwegian fisheries research vessel, the $47.5 \mathrm{~m}$ long Michael Sars and the $70 \mathrm{~m}$ long G.O. Sars are owned by the Norwegian Institute for Marine Research in Bergen. Ornithologists from the Norwegian Institute for Nature Research (NINA) joined the first vessel in May and the latter in November 1994. The $69 \mathrm{~m}$ long FRV Scotia, owned by the Scottish Office Agriculture and Fisheries Department trawled from an Aframe at the stern, using an 'Aberdeentrawl' (see below). Ornithologists onboard this ship were from Glasgow University, and in February 1993 a mixed team was formed with the JNCC. This ship was engaged in February 1993, May 1994 and August 1994. FRV Thalassa, owned by the French Institute for Sea Exploitation Research, was joined during the August 1994 IBTS by ornithologists from the Institute for Bird Research "Vogelwarte Helgoland" (VWH). FRV Tridens // was engaged in all surveys. This ship, owned by the Directorate of Fisheries of the Dutch Ministry of Agriculture, Nature Management and Fisheries, has a length of 73.5 metres. Ornithologists onboard this ship were employed by NIOZ, but with the assistance of volunteers from the Institute for Forestry and Nature Research (IBN-DLO) in May and August 1994. FRVs Walther Herwig // (80 m, 1993) and her successor Walther Herwig III (65 m, 1994), combined in further discussions and analysis, are owned by the German Fisheries Research Institute in Hamburg (Germany). The Walther Herwig was joined by ornithologists from VWH and engaged in the IBTS of February 1993 and May 1994. A GOV trawl, operated from the stern, was the standard gear for the IBTS surveys and was used on most ships. Only RV Scotia, in the August survey, used a so-called 'Aberdeen-trawl', a slightly different bottom trawl compared to the GOV. To summarise, the following ships were joined for the inter-calibration trips (IC) in 1993 and 1994, and IBTS cruises in Fe- bruary 1993 (F), May (M), August (A) and November $1994(\mathrm{~N})$ :

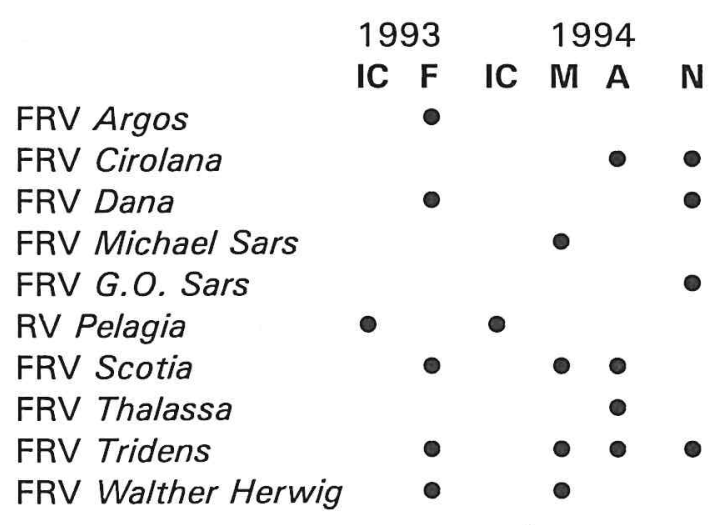

\subsection{OBSERVERS}

A total of 27 different observers were engaged in field work connected to this project, including (in alphabetical order per institute) Belén Calvo and Kenny Ensor (GU), Stefan Groenewold and Olaf Zeiske (Hamburg University), Colin Barton, Genevieve Leaper, Claire Pollock, Carolyn Stone and Andrew Stronach (JNCC), Arne Follestad (NINA), Kees Camphuysen, Henk Offringa and Chris Winter (NIOZ), Per Andell, Jens Lund Hansen, Max Nitske (OC), Frank Albers, Olaf Flore, Ommo Hüppop, Stefan Garthe, Felix Jachmann, Kirstin Janssen, Henrike Schünemann, Birgit Sprotte and Uwe Walter (VWH). Observers onboard FRV Tridens were assisted by Hans van Berkel and Eduard Koopman (IBN-DLO) in May and August 1994. To summarise:

Frank Albers

Per Andell

Colin Barton

Hans van Berkel

Belén Calvo

Kees Camphuysen

Kenny Ensor

Olaf Flore

Arne Follestad

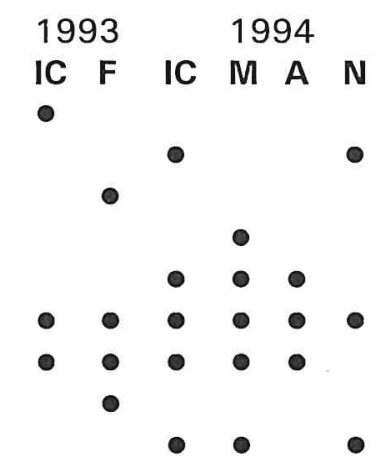




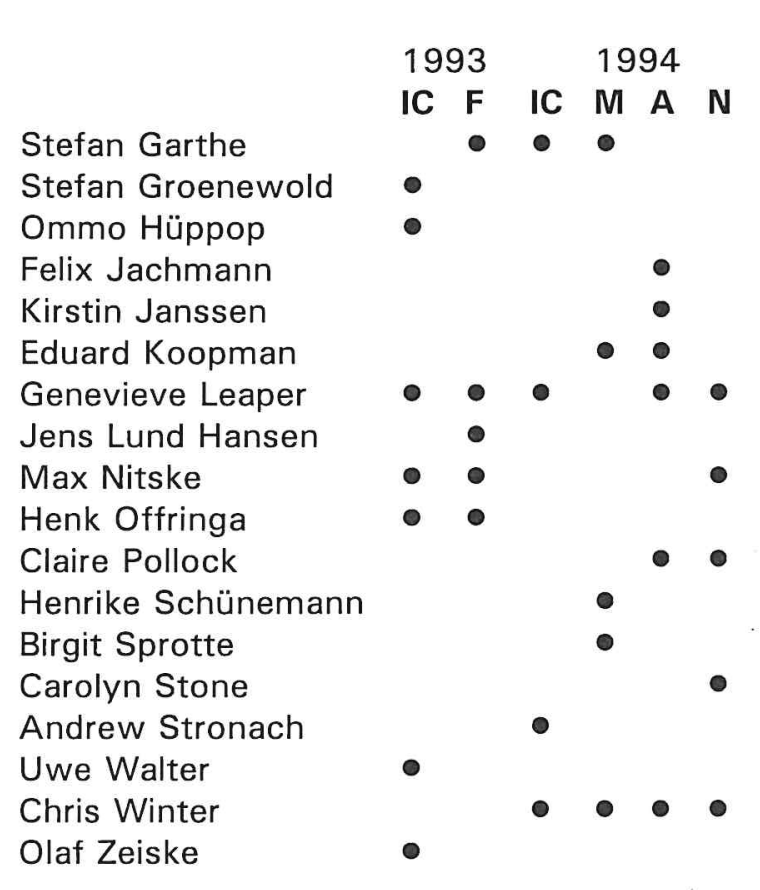

\subsection{CRUISE REPORTS}

Inter-calibration, January 1993

To standardise field methods in February 1993, a 4 day cruise was scheduled for 2528 January 1993 onboard RV Pelagia. Due to very bad weather, the ship was delayed but sailed on 27 and 28 January. The participants were trained in methods of striptransect counts, experimental discarding, stern counts, counts of seabirds associated with nearby fishing vessels and computer processing. The ship was joined by representatives of all partners in the project 'Seabirds feeding on discards in winter in the North Sea' (Camphuysen et al. 1993 for further details). The ship worked mainly in S, and briefly in $\mathrm{C}$ (table 3.3.1).

\section{IBTS, February 1993}

The survey was conducted between 23 January and 25 February, and the fisheries research vessels Argos, Dana, Scotia, Tridens, and Walther Herwig // were joined by observers from JNCC, GU, NIOZ, OC and VWH (Camphuysen et al. 1993). Days at sea for each of these vessels were:

$\begin{array}{ll}\text { FRV Argos } & \text { 8-25 February } \\ \text { FRV Dana } & 3-18 \text { February } \\ \text { FRV Scotia } & 1-19 \text { February } \\ \text { FRV Tridens } & 2-25 \text { February } \\ \text { FRV Walther Herwig } & \text { 23 January-12 February }\end{array}$

Most subregions were thoroughly surveyed and visited by at least two vessels. The Skagerrak, however, was mainly worked by FRV Argos and only briefly visited by FRV Dana (figure 3.3.1). Just over 280 hours of observation were spent on strip-transect counts (1750 $\mathrm{km}^{2}$ surveyed; table 3.3.1), 188 hauls of the net were recorded by means of stern counts, scavengers associated with 82 nearby fishing vessels were counted, and 101 discard experiments were performed during which nearly 6500 fish were offered.

\section{Inter-calibration, March 1994}

Poor weather prevailed again during the inter-calibration cruise in 1994. A light $6 \mathrm{~m}$ beamtrawl was operated at the stern of the ship, with tickler chains as used in beamtrawl fisheries with flatfish as the main target. A series of small hauls were made to attract more birds at the ship and subregions $\mathrm{S}$ and $\mathrm{C}$ were visited from 22 to 24 March. Participants were divided into in teams of differing composition for training in striptransect counts, stern counts, counts of fishing vessels, counts of seabirds associated with fishing vessels and discard experiments. The field-work and computer processing were evaluated at a meeting at $\mathrm{NIOZ}$ on 25 March.

\section{IBTS, May 1994}

The survey was conducted between 14 April and 12 June and the fisheries research vessels Scotia, Michael Sars, Tridens, and Walther Herwig III were joined by observers from GU, NINA, NIOZ, and VWH (figure 3.3.2; Camphuysen et al. 1994a). Periods at sea for each of these vessels:

$\begin{array}{ll}\text { FRV Scotia } & 14 \text { April-4 May } \\ \text { FRV Michael Sars } & 16 \text { May-3 June } \\ \text { FRV Tridens } & 2-26 \mathrm{May} \\ \text { FRV Walther Herwig } & 12 \mathrm{May}-12 \text { June }\end{array}$



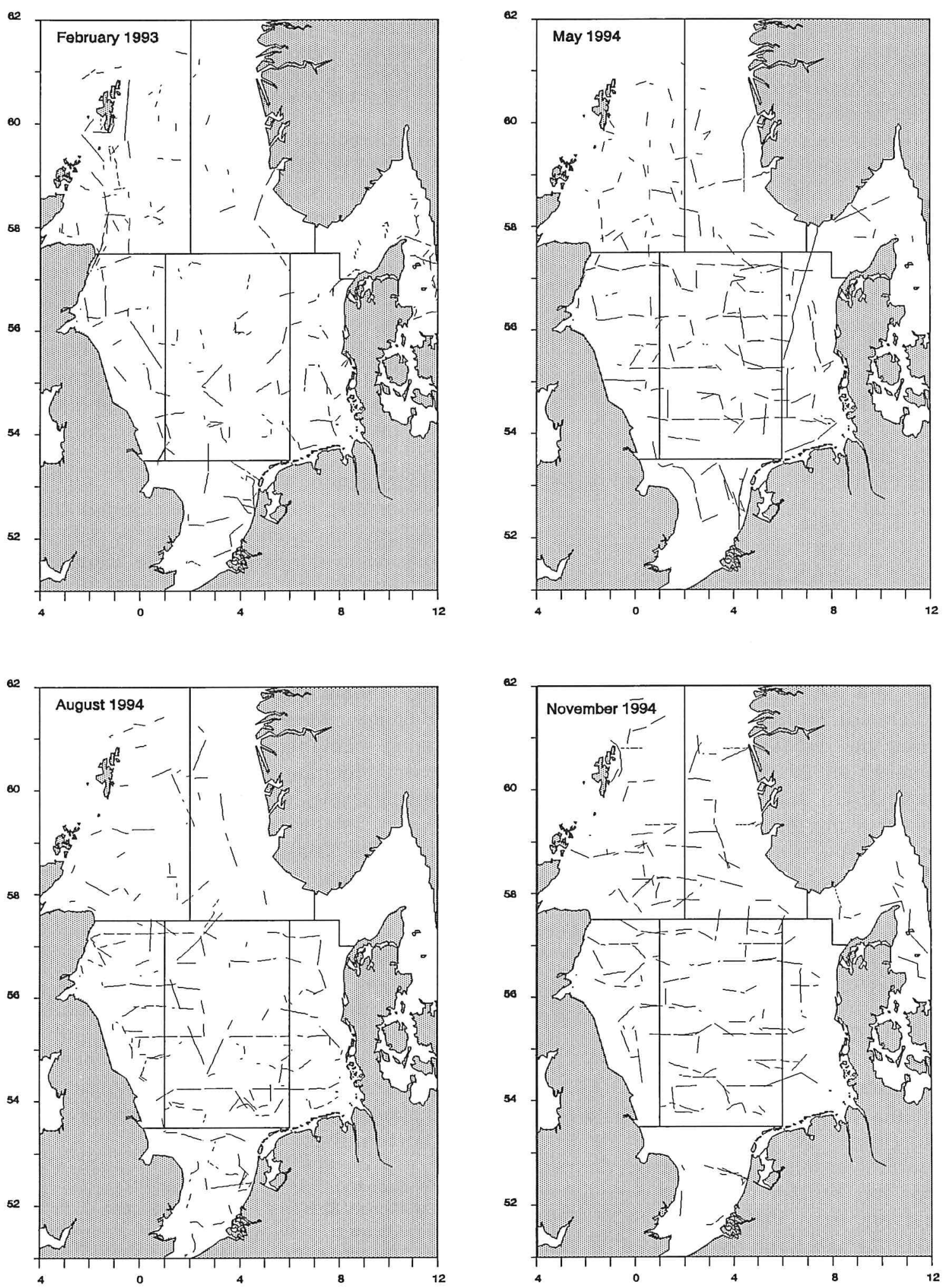

Figure 3.3.1-4 Strip-transect counts during IBTS cruises 1993-94 (route sailed) 
Table 3.3.1 Observer effort $\left(\mathrm{km}^{2}\right.$ surveyed and $\mathrm{km}$ steamed) during strip-transect counts in the February 1993 IBTS, including inter-calibration trip in January.

\begin{tabular}{|c|c|c|c|c|c|c|c|c|c|c|c|c|c|c|c|c|}
\hline \multirow[b]{2}{*}{ Subreg } & \multicolumn{9}{|c|}{$\mathrm{km}^{2}$ surveyed } & \multicolumn{7}{|c|}{$\mathrm{km}$ travelled } \\
\hline & NW & NE & Sk & $\mathrm{cW}$ & C & $\mathrm{CE}$ & $\mathbf{s}$ & $\Sigma$ & NW & NE & Sk & $\mathrm{cW}$ & C & CE & S & $\Sigma$ \\
\hline Argos & & & 198 & & & & & 198 & & & 658 & & & & & 658 \\
\hline Scotia & 179 & 38 & & 71 & 29 & & & 317 & 596 & 126 & & 238 & 96 & & & 1055 \\
\hline Dana & & & 10 & 71 & 195 & 86 & & 362 & & & 33 & 235 & 650 & 288 & & 1205 \\
\hline Pelagia & & & & & & & 46 & 46 & & & & & & & 180 & 180 \\
\hline Tridens // & 146 & & & 122 & 45 & 47 & 178 & 539 & 526 & & & 407 & 151 & 155 & 593 & 1833 \\
\hline Walther Herwig & 106 & 44 & & 28 & 73 & 39 & & 291 & 389 & 186 & & 102 & 259 & 174 & & 1110 \\
\hline$\Sigma$ & 431 & 82 & 207 & 292 & 342 & 172 & 2251 & 1752 & 1510 & 312 & 691 & 9831 & 1155 & 616 & 774 & 6042 \\
\hline
\end{tabular}

Table 3.3.2 Observer effort $\left(\mathrm{km}^{2}\right.$ surveyed and $\mathrm{km}$ steamed) during strip-transect counts in the May 1994 IBTS, including inter-calibration trip in March.

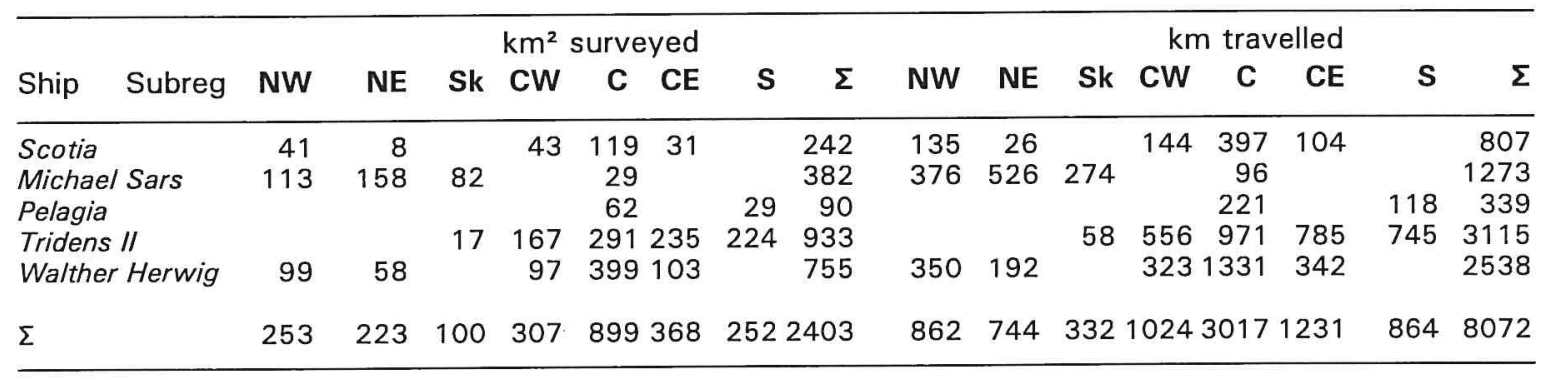

Table 3.з. 3 Observer effort $\left(\mathrm{km}^{2}\right.$ surveyed and $\mathrm{km}$ steamed) during strip-transect counts in the August 1994 IBTS.

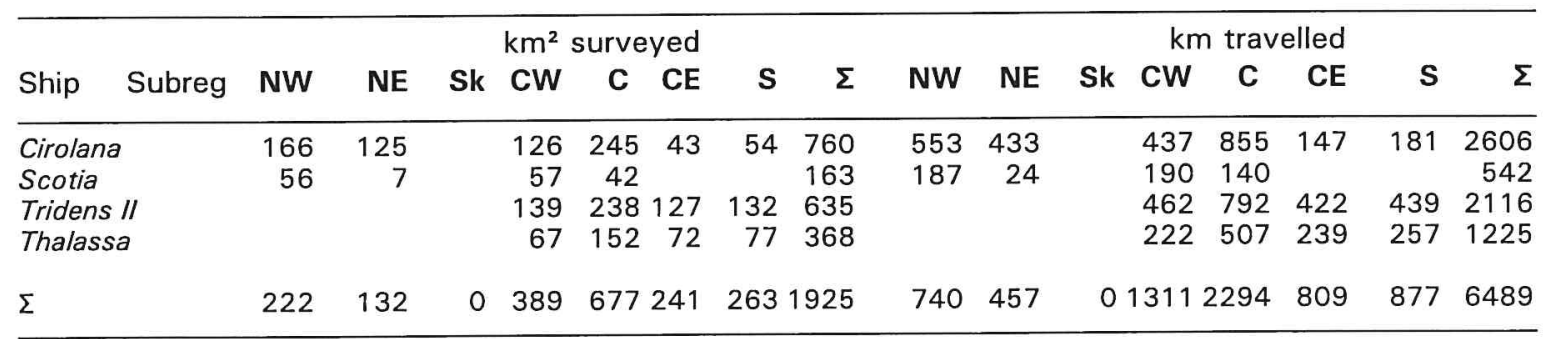

Table 3.3.4 Observer effort $\left(\mathrm{km}^{2}\right.$ surveyed and $\mathrm{km}$ steamed) during strip-transect counts in the November 1994 IBTS.

\begin{tabular}{|c|c|c|c|c|c|c|c|c|c|c|c|c|c|c|c|c|c|}
\hline \multirow[b]{2}{*}{ Ship } & \multirow[b]{2}{*}{ Subreg } & \multicolumn{9}{|c|}{$\mathrm{km}^{2}$ surveyed } & \multicolumn{7}{|c|}{$\mathrm{km}$ travelled } \\
\hline & & NW & NE & Sk & $\mathrm{CW}$ & C & CE & $\mathrm{S}$ & $\Sigma$ & NW & NE & Sk & $\mathrm{CW}$ & C & CE & $\mathbf{S}$ & $\Sigma$ \\
\hline \multirow{4}{*}{\multicolumn{2}{|c|}{$\begin{array}{l}\text { G.O. Sars } \\
\text { Dana } \\
\text { Tridens /I } \\
\text { Cirolana }\end{array}$}} & 160 & 160 & 12 & 78 & 121 & 23 & & 554 & 534 & 534 & 41 & 261 & 403 & 78 & & 1851 \\
\hline & & 79 & 58 & 130 & 93 & 166 & 81 & & 607 & 263 & 192 & 434 & 312 & 555 & 271 & & 2027 \\
\hline & & & & & 10 & 193 & 13 & 56 & 271 & & & & 32 & 679 & 45 & 213 & 969 \\
\hline & & 146 & 94 & & 122 & 255 & 48 & 58 & 723 & 492 & 314 & & 406 & 860 & 159 & 193 & 2424 \\
\hline \multicolumn{2}{|l|}{$\Sigma$} & 385 & 312 & 142 & 303 & 735 & 165 & 1142 & 2155 & 1289 & 1040 & 475 & 10112 & 2497 & 553 & 406 & 7271 \\
\hline
\end{tabular}


Most subregions were thoroughly surveyed, but the Southern Bight (subregion S) was only worked by RV Tridens. Just over 340 hours of observation were spent on striptransect counts $\left(2300 \mathrm{~km}^{2}\right.$ surveyed; table 3.3.2), 268 hauls of the net were recorded by means of stern counts, $107,670 \mathrm{~km}^{2}$ were scanned by using radar equipment for half hour counts of fishing vessels within 3 miles around the ship $116.7 \%$ of the total North Sea area), scavengers associated with 93 nearby fishing vessels were counted, and 166 discard experiments were performed during which just over 11,000 fish were offered.

\section{IBTS, August 1994}

The survey was conducted between 2 August and 19 September and the fisheries research vessels Cirolana, Scotia, Thalassa, and Tridens were joined by observers from JNCC, GU, NIOZ, and VWH (figure 3.3.3; Camphuysen et al. 1994b). Days at sea for each of these vessels were:

$\begin{array}{ll}\text { FRV Cirolana } & 5-29 \text { August } \\ \text { FRV Scotia } & 2-22 \text { August } \\ \text { FRV Thalassa } & \text { 3-19 September } \\ \text { FRV Tridens } & 15-26 \text { August }\end{array}$

Most subregions, except Sk (not visited), were thoroughly surveyed and visited by at least 2 research vessels. Nearly 300 hours of observation were spent on strip-transect counts (1925 km² surveyed; table 3.3.3), 202 hauls of the net were recorded by means of stern counts, $94,380 \mathrm{~km}^{2}$ were scanned by using radar equipment for half hour counts of fishing vessels within 3 miles around the ship $114.7 \%$ of the total North Sea area), scavengers associated with 85 nearby fishing vessels were counted, and 127 discard experiments were performed during which over 9600 fish were offered.

\section{IBTS, November 1994}

The survey was conducted betweem 11 October and 24 November and the fisheries research vessels Cirolana, Dana, G.O. Sars, and Tridens were joined by observers from
JNCC, NINA, NIOZ, and OC (figure 3.3.4). Days at sea for each of these vessels were:

$\begin{array}{ll}\text { FRV Dana } & 26 \text { October-20 November } \\ \text { FRV Cirolana } & 21 \text { October-24 November } \\ \text { FRV G.O. Sars } & 11 \text { October-8 November } \\ \text { FRV Tridens } & 24 \text { October-4 November }\end{array}$

Most subregions, except Sk (only Dana) and $\mathrm{S}$ (Tridens and Cirolana briefly), were thoroughly surveyed and visited by at least 2 research vessels. Over 350 hours of observation were spent on strip-transect counts (2155 km² surveyed; table 3.3.4), 191 hauls of the net were recorded by means of stern counts, $100880 \mathrm{~km}^{2}$ were scanned by using radar equipment for half hour counts of fishing vessels within 3 miles around the ship $(15.7 \%$ of the total North Sea area), scavengers associated with 36 nearby fishing vessels were counted, and 142 discard experiments were performed during which nearly 7000 fish were offered.

\section{RESULTS}

\subsection{DISTRIBUTION OF SEABIRDS AT SEA}

The overall distribution of seabirds at sea in the North Sea changes considerably between seasons (Stone et al. 1995). In summer, cliff nesting species, such as Fulmar Fulmarus glacialis, Kittiwake Rissa tridactyla and auks, are found concentrated off the coasts of Northeast England and Scotland and around Helgoland, whereas several Larus-gulls (e.g. Black-headed Gull Larus ridibundus, Common Gull L. canus, and Herring Gull L. argentatus) are mainly confined to inshore waters in the southeastern half of the Sea. Some species are passage migrants in spring and/or autumn (e.g. Sooty Shearwater Puffinus griseus, Pomarine Skua Stercorarius pomarinus, Little Gull Larus minutus), others are winter visitors (e.g. Glaucous Gull Larus hyperboreus). Differences in feeding methods, feeding habitat and the availability of preferred prey are key factors underlying differences in spatial distribution patterns of the different 
species of seabirds within the North Sea. Scavenging seabirds are obviously attracted by fishing fleets (Wahl \& Heinemann 1979), but there is not a single species in the North Sea whose distribution can be fully explained in terms of fishing vessel abundance.

During strip-transect counts in the North Sea some 54 species of seabirds and waterfowl were recorded. Only a fraction of these species can be classified as 'scavenging seabirds'. Of 29 species which were attracted by fishing research vessels at any of the 849 hauls that were sampled, eight species were common. This section deals with results of transect counts of seabirds at sea during steaming (assumed not to be influenced by the research vessel) and provides distribution patterns and abundance estimates of the eight common scavenging seabirds recorded in our surveys and briefly reports on scarcer species (chapter 2.4). The distribution maps show observer effort (figures 4.1.1-4) and distribution of common scavenging species (figures 4.1.5-34) for each of the four surveys (except Great Skua Catharacta skua, which was not numerous enough to warrant a presentation for February and May). Densities shown in the distribution maps are derived from all birds recorded in transect including those associated with fishing vessels. Tables 4.1.1-4 give the estimated total number of birds in each subregion exc/uding those associated with fishing vessels. Numbers at fishing vessels were calculated separately and are considered in chapters $4.4 \& 4.5$.

\section{Coverage}

The North Sea was synoptically covered in each of the surveys. In February 1993, all subregions were visited by at least two research vessels, covering a total sea area of ca. $1750 \mathrm{~km}^{2}$ (figure 4.1.1). Observer effort was highest in subregions NW, CW and C, while coverage in northeast was rather poor. It was concluded that the coastal area (within $10 \mathrm{~km}$ from the nearest coast) was inadequately surveyed in all subregions, except off Aberdeen (northeast Scotland) and off Noord-Holland (Netherlands; Camphuysen et al. 1993). The central North Sea (C) was very well studied in May 1994, when $37.4 \%$ of all work was conducted in this region (figure 4.1.2). All subregions were visited by at least two research vessels, but coverage in the Skagerrak (Sk) was comparatively poor. There were considerable differences in timing of these surveys by the different research vessels, ranging from late April-early May for RV Scotia to mid Maymid June for RV Walther Herwig (see chapter 3.3). A total of ca. $2400 \mathrm{~km}^{2}$ was surveyed. The Skagerrak was not visited in August 1994, and subregion NE was relatively poorly covered (figure 4.1.3). Most effort was again in the central North Sea (C, $35.2 \%$ ) but all subregions except $\mathrm{Sk}$ were visited by at least two vessels, covering a total of ca. $1900 \mathrm{~km}^{2}$. The survey by RV Thalassa alone was in September rather than August (see chapter 3.3). In November 1994, most subregions were quite well surveyed and visited by at least two research vessels, covering a total of ca. $2150 \mathrm{~km}^{2}$ (figure 4.1.4). The central North Sea (C) was again the subregion most thoroughly surveyed $(34.1 \%$ of effort). In conclusion, it must be stressed that although synoptical coverage was achieved in all surveys, the coastal zone was usually not surveyed. Because many species concentrate in coastal areas, this has inevitably led to underestimates of the total numbers of seabirds at sea and we are unable to provide a complete picture of the associations between seabirds and fisheries. For the offshore zone, these surveys have provided the best overview of seabird distribution in the North Sea ever achieved in such a short span of time.

\section{Seabirds observed}

During the transect counts in 1993 and 1994, 54 species of seabirds and waterfowl were seen, including 2 species of shearwaters, 2 species of storm petrels, 4 species of skuas, 8 species of gulls, 4 species of terns, 5 species of auks, Fulmar, Gannet Morus bassanus, Cormorant Phalacrocorax carbo 
Table 4.1.1 Estimated total numbers of seabirds (x 1000, right) at sea in February 1993, calculated from densities of birds (left) in strip-transects in each of the subregions, while excluding seabirds associated with fishing vessels.

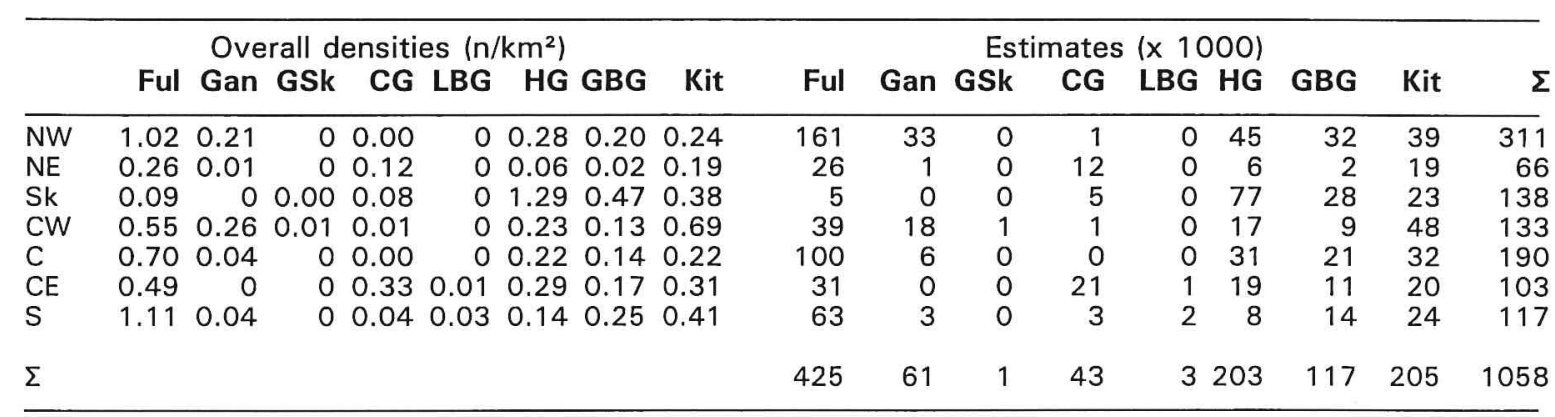

Table 4.1.2 Estimated total numbers of seabirds in May 1994.

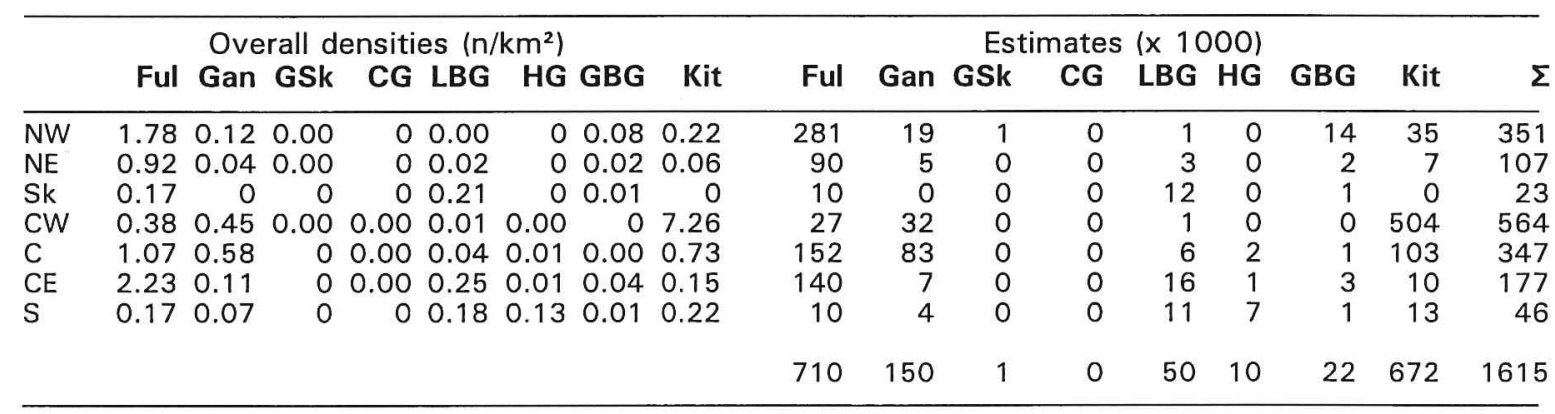

Table 4.1.3 Estimated total numbers of seabirds at sea in August 1994.

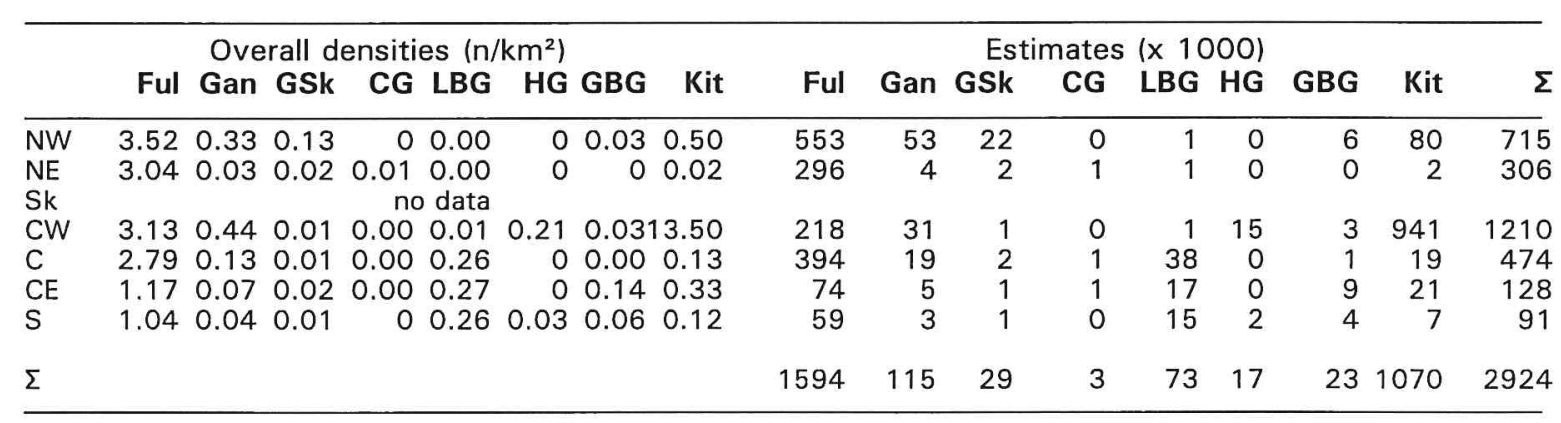

Table 4.1.4 Estimated total numbers of seabirds at sea in November 1994

\begin{tabular}{|c|c|c|c|c|c|c|c|c|c|c|c|c|c|c|c|c|c|}
\hline & \multicolumn{7}{|c|}{ Overall densities $\left(\mathrm{n} / \mathrm{km}^{2}\right)$} & \multicolumn{10}{|c|}{ Estimates (x 1000) } \\
\hline & Ful & Gan & GSk & CG & LBG & HG & GBG & Kit & Ful & Gan & GSk & CG & LBG & HG & GBG & Kit & $\Sigma$ \\
\hline NW & 7.58 & 0.25 & 0.00 & 0 & 0.01 & 0.30 & 0.18 & 0.75 & 1190 & 40 & 0 & 0 & 2 & 48 & 29 & 119 & 1428 \\
\hline $\mathrm{NE}$ & 2.89 & 0.26 & 0.00 & & 0.00 & 0.16 & 0.16 & 0.09 & 282 & 26 & 0 & 0 & 0 & 17 & 16 & 9 & 350 \\
\hline Sk & 0.47 & 0.00 & 0 & 0.07 & & 0.32 & 0.16 & 0.15 & 28 & 0 & 0 & 5 & 0 & 19 & 10 & 9 & 71 \\
\hline $\mathrm{CW}$ & 0.59 & 0.19 & 0 & 0.01 & 0.00 & 4.29 & 0.14 & 0.88 & 41 & 13 & 0 & 1 & 0 & 298 & 10 & 62 & 425 \\
\hline C & 1.11 & 0.30 & 0.02 & 0.00 & 0.02 & 0.14 & 0.11 & 0.92 & 158 & 44 & 3 & 1 & 3 & 21 & 17 & 13 & 377 \\
\hline CE & 0.77 & 0.06 & 0.01 & 0.02 & & 0.75 & 0.24 & 0.52 & 49 & 4 & 1 & 2 & 0 & 48 & 16 & 33 & 153 \\
\hline $\mathrm{s}$ & 0.00 & 0.78 & 0 & 0.07 & 0.12 & 0.06 & 0.21 & 0.22 & 0 & 45 & 0 & 4 & 7 & 3 & 12 & 13 & 84 \\
\hline$\Sigma$ & & & & & & & & & 1748 & 172 & 4 & 13 & 12 & 454 & 110 & 375 & 2888 \\
\hline
\end{tabular}


and Shag $P$. aristotelis. Common scavengers at the trawl, such as Fulmar, Gannet, Lesser Black-backed Gull Larus fuscus, Herring Gull, Great Black-backed Gull Larus marinus, and Kittiwake, were widespread and often numerous at sea. The occurrence of seabird species in the North Sea is summarised below for each survey, using four abundance classes $10=0.1-1 / 100 \mathrm{~km}$ sailing, $0=1-$ $10 / 100 \mathrm{~km}$ sailing, $0=10-100 / 100 \mathrm{~km}$ sailing, $0=>100 / 100 \mathrm{~km}$ sailing):

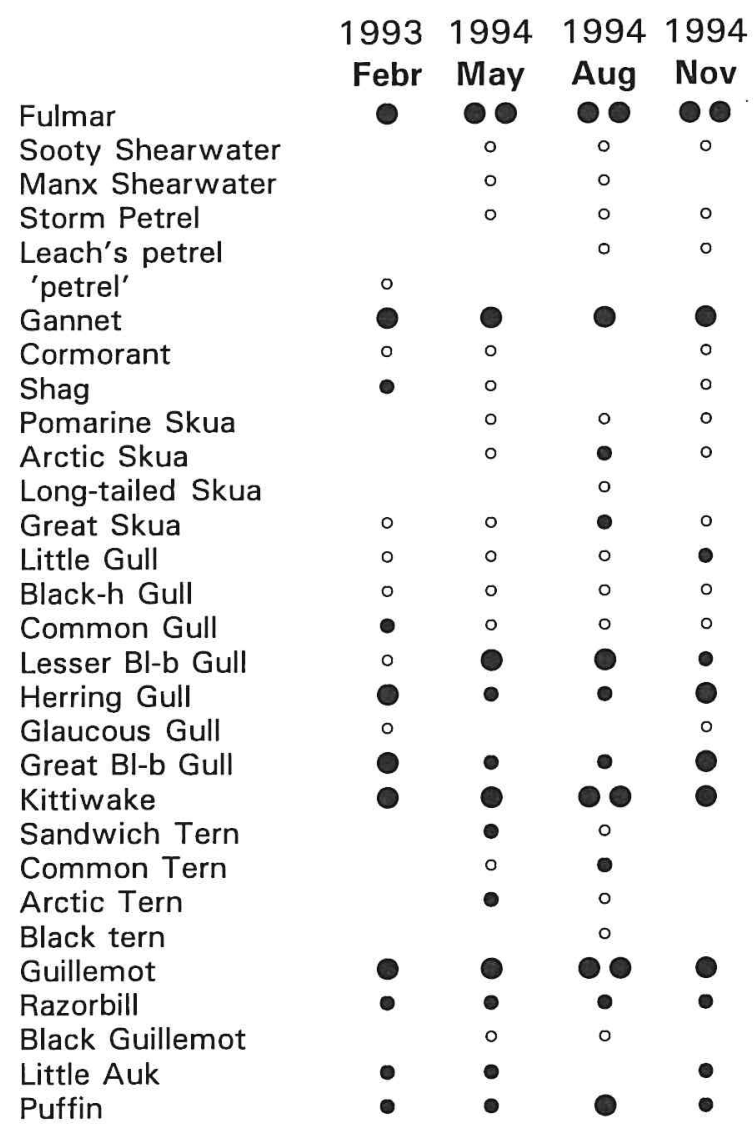

Generally, diversity was greatest in May and August, whereas the total number of birds observed was highest in August and November. Four species - Fulmar, Gannet, Kittiwake and Guillemot Uria aalge - were abundant throughout the year, while all other species showed distinct seasonal patterns in abundance. Non-scavenging species which were never associated with fishing activities, the
Leach's Petrel Oceanodroma leucorhoa, Black Guillemot Cepphus grylle, Little Auk Alle alle and Puffin Fratercula arctica). are not considered further in this report.

\section{Fulmar Fulmarus glacialis}

Fulmars were abundant and widespread throughout the year, but were particularly numerous in the northwestern three-quarters of the North Sea (subregions NW, NE, CW and $\mathrm{C}$ ). In all seasons, this species appeared to avoid inshore areas in the south of the study area, especially in the German Bight. The Southern Bight was only of importance in February 1993, after a period of storms in the preceding month. In February, it was estimated from strip-transect counts that nearly half a million Fulmars occurred in the North Sea, excluding those associated with fishing vessels (table 4.1.1). The highest densities were found around Shetland, off Northeast Scotland and, remarkably, in the Southern Bight (figure 4.1.5). Low densities occurred in the central North Sea, off East England, in the Skagerrak and Kattegat area. The proportion of 'coloured' Fulmars (L, D, DD phase, indicating a high arctic origin) was highest in February $11.3 \%$ coloured, $n=$ 3939; table 4.1.5), especially in subregion NE (4.2\%). In May, Fulmars were abundant in the northwestern two-thirds of the North Sea, with high densities off Shetland, but concentrations also off Southwest Norway and West Denmark, between $4^{\circ}$ and $8^{\circ} \mathrm{E}$ (figure 4.1.6). In these latter areas, several groups of hundreds of actively feeding Fulmars were recorded in waters which held very few fishing vessels. The feeding behaviour observed and the fact that prey were too small to be visible from the ship, suggest that these birds were probably feeding on zooplankton. Low densities were found in the southern North Sea and Fulmars were quite scarce in the German Bight. It was estimated that nearly three-quarters of a million Fulmars occurred in the North Sea during this survey (table 4.1.2). Coloured individuals were rare, indicating that birds of high arctic origin had left the North Sea 
Table 4.1.5 Relative abundance of 'coloured' and light phase Fulmars (percentage 'coloured' if $n>20$ l per subregion during strip-transect counts in the North Sea for each survey.

\begin{tabular}{|c|c|c|c|c|c|c|c|c|c|c|c|c|}
\hline$\%$ col & $\begin{array}{c}\mathrm{Fe} \\
\mathrm{col}\end{array}$ & $\begin{array}{l}\text { bruary } \\
\text { light }\end{array}$ & $\% \mathrm{col}$ & $\mathrm{col}$ & $\begin{array}{l}\text { May } \\
\text { light }\end{array}$ & $\%$ col & $\mathrm{col}$ & $\begin{array}{c}\text { August } \\
\text { light }\end{array}$ & $\%$ col & $\begin{array}{l}\mathrm{Nc} \\
\mathrm{col}\end{array}$ & $\begin{array}{c}\text { vember } \\
\text { light }\end{array}$ & \\
\hline $\begin{array}{l}\text { NW } \\
\text { NE } \\
\text { Sk } \\
\text { CW } \\
\text { C } \\
\text { CE } \\
\text { S }\end{array}$ & $\begin{array}{r}13 \\
5 \\
9 \\
7 \\
5 \\
11\end{array}$ & $\begin{array}{r}1865 \\
114 \\
3 \\
354 \\
829 \\
235 \\
489\end{array}$ & $\begin{array}{l}0.7 \\
4.2 \\
\\
2.5 \\
0.8 \\
2.1 \\
2.2\end{array}$ & $\begin{array}{l}2 \\
4 \\
1\end{array}$ & $\begin{array}{r}3103 \\
3555 \\
110 \\
564 \\
1903 \\
1283 \\
137\end{array}$ & $\begin{array}{l}0.0 \\
0.1 \\
0.0 \\
0.4 \\
0.2 \\
0.1 \\
0.0\end{array}$ & $\begin{array}{r}5 \\
12\end{array}$ & $\begin{array}{r}2578 \\
926 \\
\\
2940 \\
4648 \\
445 \\
369\end{array}$ & $\begin{array}{l}0.1 \\
0.4 \\
\\
0.2 \\
0.3 \\
0.0 \\
0.0\end{array}$ & $\begin{array}{r}63 \\
32 \\
\\
2 \\
28 \\
1\end{array}$ & $\begin{array}{r}12269 \\
3272 \\
271 \\
750 \\
1700 \\
221 \\
4\end{array}$ & $\begin{array}{l}0.5 \\
1.0 \\
0.0 \\
0.3 \\
1.6 \\
0.5\end{array}$ \\
\hline$\Sigma$ & 50 & 3889 & 1.3 & 9 & 10655 & 0.1 & 23 & 11906 & 0.2 & 126 & 18487 & 0.7 \\
\hline
\end{tabular}

Table 4.1.6 Relative abundance of adult and immature Gannets (percentage adults if $n>20$ ) per subregion during strip-transect counts in the North Sea for each survey.

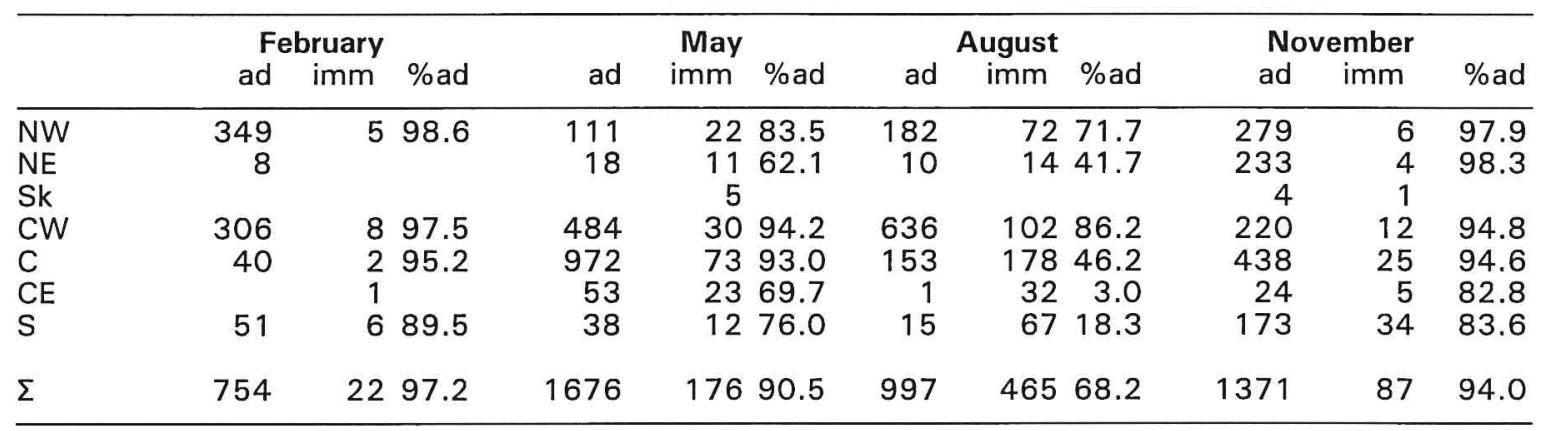

Table 4.1.7 Relative abundance of adult and immature Common Gulls.

\begin{tabular}{|c|c|c|c|c|c|c|c|c|c|c|c|c|}
\hline & \multicolumn{3}{|c|}{ February } & \multicolumn{3}{|c|}{ May } & \multicolumn{3}{|c|}{ August } & \multicolumn{2}{|c|}{ November } & \multirow[b]{2}{*}{$\% a d$} \\
\hline & ad & & $\% a d$ & ad & $\mathrm{imm}$ & \%ad & ad & imm & \%ad & ad & imm & \\
\hline NW & 5 & & & & & & & 2 & & 1 & & \\
\hline NE & 68 & 23 & 74.7 & & 4 & & 3 & 4 & & 3 & 2 & \\
\hline Sk & 20 & 1 & 95.2 & 2 & & & & & & 7 & 2 & \\
\hline $\mathrm{CW}$ & 12 & 2 & & 8 & & & 1 & 4 & & 6 & 4 & \\
\hline C & 3 & & & 4 & 3 & & 1 & 8 & & 7 & 4 & \\
\hline CE & 71 & 9 & 88.8 & 3 & 7 & & & 2 & & 3 & 2 & \\
\hline S & 74 & 8 & 90.2 & 8 & 20 & 28.6 & 1 & $\overline{1}$ & & 23 & 6 & 79.3 \\
\hline$\Sigma$ & 253 & 43 & 85.5 & 25 & 34 & 42.4 & 6 & 21 & 22.2 & 50 & 20 & 71.4 \\
\hline
\end{tabular}

Table 4.1.8 Relative abundance of adult and immature Lesser Black-backed Gulls.

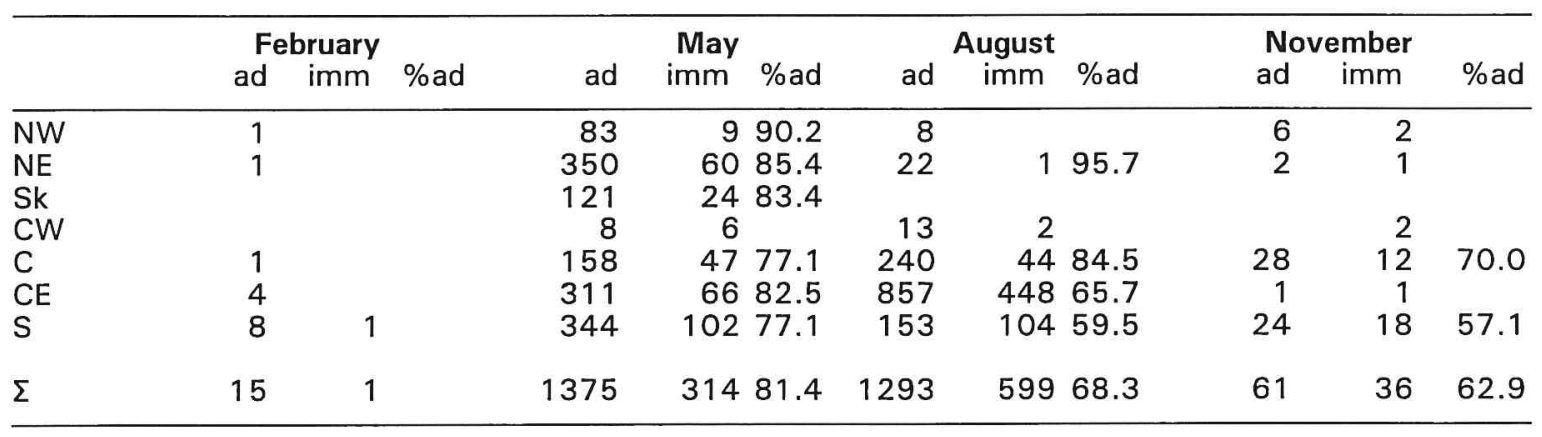


(0.1\% coloured, $n=10,664$; table 4.1.5). Similarly, in August, most Fulmars were light phase birds $(0.2 \%$ coloured, $n=11,906)$. Total numbers at sea in the North Sea had doubled compared to the early summer period, with estimated numbers of over 1.5 million Fulmars (table 4.1.3). Moderate to high densities were observed everywhere in the North Sea, except in inshore waters of East England, the Southern Bight and the German Bight (figure 4.1.7). The central North Sea was of greater importance for Fulmars than in other seasons. Numbers were even higher in November, with an estimated 1.7 million Fulmars in the North Sea (table 4.1.4). The distribution was quite uneven, however, with very large numbers in the northern North Sea (1.4 million birds estimated for subregions NW and NE combined), and low to moderate densities elsewhere (figure 4.1.8). The proportion of coloured individuals had increased to $0.7 \% \quad \mathrm{n}=$ 18,613; table 4.1.5).

\section{Gannet Morus bassanus}

Numbers of Gannets at sea in all seasons (tables 4.1.1-4.1.4) were high compared to the North Sea breeding population, which was recently estimated at ca. 40,000 pairs (Lloyd et al. 1991). The western half of the North Sea was of greatest significance at all times of year (subregions NW, CW and C), and Gannets were quite scarce in the Skagerrak and German Bight. Numbers were lowest in February with an estimated total of just over 60,000 Gannets, more than half of which occurred in subregion NW (table 4.1.1, figure 4.1.9). Moderate to high densities were also encountered off the Firth of Forth. Virtually all Gannets observed in February were adults $197.2 \%, \mathrm{n}=776$; table 4.1.6), confirming that immatures winter outside the North Sea. In May, the estimated number of Gannets in the North Sea had more than doubled to 150,000 individuals, the majority of which were seen in the central North Sea and off the eastern coast of Scotland (table 4.1.2, figure 4.1.10). Moderate to high densities were recorded only in an area close to the northwest of the Dogger Bank, where gannets were feeding on Herring Clupea harengus in association with White-beaked Dolphins Lagenorhynchus albirostris and White-sided Dolphins L. acutus (Camphuysen et al. 1995). This feeding concentration formed was unusual in that many of the foraging birds had come from the Bass Rock, over $300 \mathrm{~km}$ away. On the basis of ship-based surveys in the North Sea in the early 1980s it was concluded that foraging trips rarely exceed $150 \mathrm{~km}$ from the colony and that most are less than $50 \mathrm{~km}$ (Tasker et al. 1985a). Low densities occurred in the southern and eastern North Sea and Gannets were not observed in the Skagerrak area. One tenth of the Gannets observed in May were immatures $190.5 \%$ adult, $n=1852$; table 4.1.6), but in the central North Sea (subregion C) and off the British east coast (CW) the proportion was lower (93.4\% adult, $n=1559$ ). In August, low to moderate densities were found across the western half of the North Sea but only a few birds were seen in the German Bight. Locally high densities occurred only off Shetland (figure 4.1.11). It was estimated that around 115,000 Gannets were present in the North Sea (table 4.1.3), 68.2\% of which were adult ( $n=1462$; table 4.1 .6 ). In the western half of the North Sea, $82.5 \%$ of the Gannets were mature birds $(n=992)$, while immatures predominated in the central North Sea (C), the Southern Bight (S) and in the German Bight. In November, Gannets were more widespread than during the previous surveys (figure 4.1.12). High numbers were recorded in the northern and central North Sea, but also in the Southern Bight. Overall, it was estimated that just over 170,000 Gannets occurred in the North Sea (table 4.1.4). With $94.0 \%$ of the Gannets being adults $(n=$ 1458; table 4.1.6), it is obvious that many immatures had already left the North Sea.

\section{Great Skua Catharacta skua}

Great Skuas were scarce at sea in late winter and early summer. Numbers peaked in August but were quite low again by Novem- 
Table 4.1.9 Relative abundance of adult and immature Herring Gulls.

\begin{tabular}{|c|c|c|c|c|c|c|c|c|c|c|c|c|}
\hline & \multicolumn{3}{|c|}{ February } & \multicolumn{3}{|c|}{ May } & \multicolumn{3}{|c|}{ August } & \multicolumn{2}{|c|}{ November } & \multirow[b]{2}{*}{$\% a d$} \\
\hline & ad & $\mathrm{imm}$ & $\%$ ad & ad & imm & $\%$ ad & ad & imm & $\%$ ad & ad & imm & \\
\hline NW & 336 & 114 & 74.7 & 1 & & & 22 & 2 & 91.7 & 157 & 105 & 59.9 \\
\hline Sk & 500 & 101 & 83.2 & 8 & 21 & 27.6 & & & & 38 & 12 & 76.0 \\
\hline $\mathrm{CW}$ & 65 & 65 & 50.0 & 3 & 9 & & 98 & 109 & 47.3 & 141 & 160 & 46.8 \\
\hline C & 84 & 70 & 54.5 & 4 & 25 & 13.8 & & & & 133 & 135 & 49.6 \\
\hline $\mathrm{S}$ & 63 & 36 & 63.6 & 87 & 70 & 55.4 & 8 & 6 & & 10 & 18 & 35.7 \\
\hline$\Sigma$ & 1140 & 455 & 71.5 & 127 & 139 & 47.7 & 128 & 118 & 52.0 & 854 & 595 & 58.9 \\
\hline
\end{tabular}

Table 4.1.10 Relative abundance of adult and immature Great Black-backed Gulls.

\begin{tabular}{|c|c|c|c|c|c|c|c|c|c|c|c|c|}
\hline & \multicolumn{3}{|c|}{ February } & \multicolumn{3}{|c|}{ May } & \multicolumn{3}{|c|}{ August } & \multicolumn{2}{|c|}{ November } & \multirow[b]{2}{*}{$\%$ ad } \\
\hline & ad & $\mathrm{imm}$ & $\%$ ad & ad & imm & $\%$ ad & ad & imm & $\%$ ad & ad & imm & \\
\hline NW & 185 & 143 & 56.4 & 4 & 15 & & 31 & 10 & 75.6 & 132 & 92 & 58.9 \\
\hline NE & 19 & 5 & 79.2 & 52 & 22 & 70.3 & 1 & 1 & & 106 & 64 & 62.4 \\
\hline $\mathrm{Sk}$ & 99 & 30 & 76.7 & 14 & 7 & & & & & 17 & 6 & 73.9 \\
\hline $\mathrm{CW}$ & 39 & 65 & 37.5 & 1 & 5 & & 23 & 6 & 79.3 & 32 & 31 & 50.8 \\
\hline C & 48 & 46 & 51.1 & 23 & 24 & 48.9 & 25 & 9 & 73.5 & 65 & 111 & 36.9 \\
\hline CE & 32 & 25 & 56.1 & 5 & 39 & 11.4 & 24 & 52 & 31.6 & 29 & 19 & 60.4 \\
\hline$S$ & 93 & 54 & 63.3 & 2 & 28 & 6.7 & 35 & 27 & 56.5 & 34 & 19 & 64.1 \\
\hline$\Sigma$ & 515 & 368 & 58.3 & 101 & 140 & 41.9 & 139 & 105 & 57.0 & 415 & 342 & 54.8 \\
\hline
\end{tabular}

Table 4.1.11 Relative abundance of adult and immature Kittiwakes.

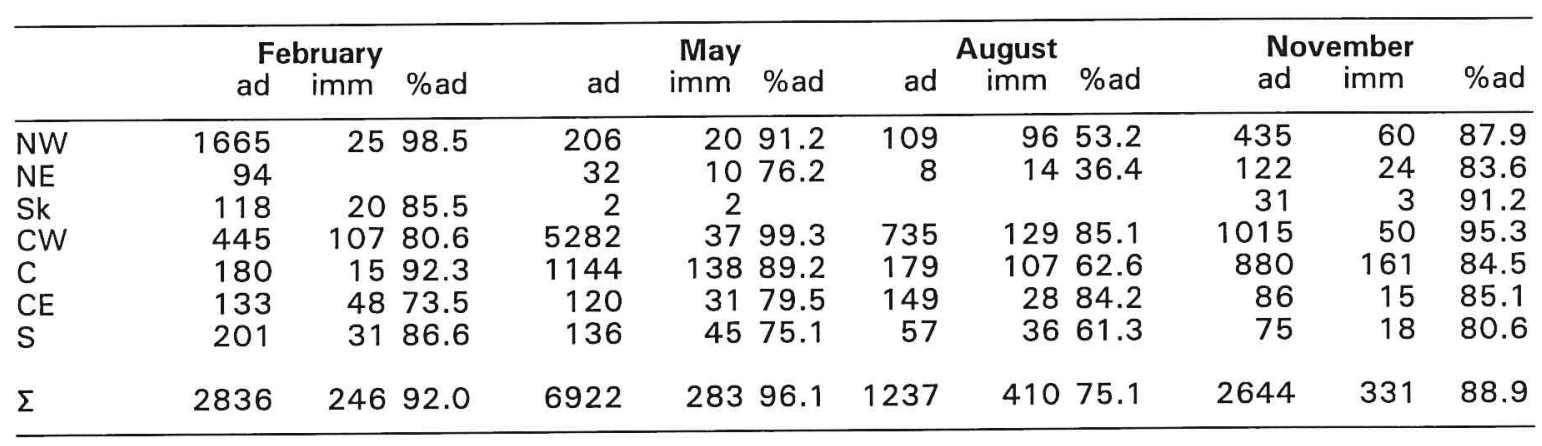


ber. From strip-transect counts it was estimated that both in February 1993 and in May 1994 ca. 1000 Great Skuas occurred in the North Sea (table 4.1.1-2; not mapped). In early summer the distribution of Great Skuas is known to be concentrated around the breeding colonies on Orkney and Shetland (Tasker et al. 1985b). Unfortunately, much of this area (e.g. around Foula, the most important breeding station) was not surveyed in May. Numbers calculated from the survey results are therefore likely to be seriously underestimated. In May, virtually all records of Great Skuas were in subregion NW, with occasional sightings in NE and CW. In August, Great Skuas occurred throughout the North Sea at low to moderate densities, although they were generally more numerous in the west (figure 4.1.13). Of the estimated ca. 29,000 individuals, the majority $(22,000)$ were in the northwestern subregion (table 4.1.3). In November, the distribution pattern had changed (figure 4.1.14). Much smaller numbers of Great Skuas occurred in the North Sea (estimated at ca. 4000 individuals; table 4.1.4) and scattered birds were found mainly in the southern half of the central subregion (C) and off Denmark (CE). Very small numbers were recorded in the north, despite extensive surveys around Orkney and Shetland.

\section{Common Gull Larus canus}

Common Gulls, were numerous only in the southeastern North Sea and Skagerrak. The Common Gull is mainly a winter visitor to the North Sea and estimated total numbers ranged from less than 1000 in May to over 40,000 in February (tables 4.1.1-4). Common Gulls were not seen offshore north of $58^{\circ} \mathrm{N}$. In February, moderate to high densities were found in inshore waters of The Netherlands and the German Bight (figure 4.1.15). Low to moderate densities were recorded in the Skagerrak and Kattegat and off the Humber (East England). Of an estimated 43,000 individuals present in the North Sea, more than half $(24,000)$ were found in subregions CE and $S$ and another 5000 in the Skagerrak/Kattegat region (Sk). The estimate of 12,000 individuals in subregion NE, was derived from some flocks in the Norwegian fjords; none were seen offshore. Some $85 \%$ of the Common Gulls observed were adult birds $(n=296$; table 4.1.7). By contrast, in May, over half the Common Gulls were immatures $(42.4 \%$ adult, $n=59)$. Low densities occurred in subregions CW, C, $C E$ and $S$ (figure 4.1.16). It was estimated from this survey that less than $1000 \mathrm{Com}$ mon Gulls were present in the North Sea but more extensive surveys in the coastal waters of The Netherlands, the German Bight, Denmark and Norway would be expected to record much higher numbers. A northward coastal migration in these waters normally peaks in April and May, and continues into July (Platteeuw et al. 1994). In August, the scattered records of Common gulls were mainly in offshore areas (figure 4.1.17). Overall numbers were still very low (estimated ca. 3000; table 4.1.3) and most of the birds were immatures $(22.2 \%$ adult, $n=27$; table 4.1.7). In November, sightings were almost completely confined to the southeastern half of the North Sea and Kattegat (figure 4.1.18), and again were mainly in offshore areas. It was estimated that about 13,000 Common Gulls occurred in the North Sea this time of year, of which 5000 were found in subregion Sk and another 4000 in S (table 4.1.4). The proportion of adults had increased to $71.4 \%(n=70$; table 4.1 .7$)$.

\section{Lesser Black-backed Gull Larus fuscus}

Lesser Black-backed Gulls are mainly summer visitors to the North Sea, with estimated total numbers ranging from 3000 in winter to over 70,000 in summer (tables 4.1.1-4). Most were found in inshore waters of the southeastern half of the North Sea, but Lesser Black-backed Gulls were also recorded offshore. Many juveniles had moved out to sea immediately after the breeding season. In February, Lesser Black-backed Gulls were very scarce and scattered birds were located in the German and Southern Bights only (figure 4.1.19). The majority of the estima- 
Table 4.1.12 Relative abundance at sea of species which were only scarcely reported as associates at the trawl. Total number of birds observed (left) and birds per $100 \mathrm{~km}$ travelled (scan data; $\mathrm{n} / \mathrm{km}$, right; - = no data).

\begin{tabular}{|c|c|c|c|c|c|c|c|c|c|c|c|c|c|c|}
\hline $\begin{array}{l}\text { Sooty Shearwater } \\
\text { February } \\
\text { May } \\
\text { August } \\
\text { November }\end{array}$ & $\begin{array}{l}\text { NW } \\
\\
1 \\
1\end{array}$ & NE & $\begin{array}{r}13 \\
-\quad 2\end{array}$ & $\begin{array}{l}9 \\
1\end{array}$ & $\begin{array}{r}\mathrm{CE} \\
1 \\
\end{array}$ & 1 & $\begin{array}{r}\Sigma \\
0 \\
1 \\
23 \\
5\end{array}$ & $\begin{array}{r}\text { NW } \\
0 \\
0 \\
0.1 \\
0.1\end{array}$ & $\begin{array}{r}\text { NE } \\
0 \\
0 \\
0 \\
0\end{array}$ & $\begin{array}{r}\text { Sk } \\
0 \\
0 \\
- \\
0\end{array}$ & $\begin{array}{r}\text { CW } \\
0 \\
0 \\
1.0 \\
0.1\end{array}$ & $\begin{array}{r}C \\
0 \\
0 \\
0.4 \\
0.0\end{array}$ & $\begin{array}{r}C E \\
0 \\
0.1 \\
0 \\
0\end{array}$ & $\begin{array}{r}S \\
0 \\
0 \\
0 \\
0.2\end{array}$ \\
\hline $\begin{array}{l}\text { Manx Shearwater } \\
\text { February } \\
\text { May } \\
\text { August } \\
\text { November }\end{array}$ & NW & NE & $\begin{array}{r}1 \\
-\quad 15\end{array}$ & $\begin{array}{l}2 \\
1\end{array}$ & $\mathrm{CE}$ & 3 & $\begin{array}{r}\Sigma \\
0 \\
7 \\
18 \\
0\end{array}$ & $\begin{array}{r}\text { NW } \\
0 \\
0.1 \\
0.3 \\
0\end{array}$ & $\begin{array}{r}\text { NE } \\
0 \\
0 \\
0 \\
0\end{array}$ & $\begin{array}{r}\text { Sk } \\
0 \\
0 \\
- \\
0\end{array}$ & $\begin{array}{r}\text { CW } \\
0 \\
0.1 \\
1.1 \\
0\end{array}$ & $\begin{array}{r}C \\
0 \\
0.1 \\
0.0 \\
0\end{array}$ & $\begin{array}{r}\text { CE } \\
0 \\
0 \\
0 \\
0\end{array}$ & $\begin{array}{r}S \\
0 \\
0.3 \\
0 \\
0\end{array}$ \\
\hline $\begin{array}{l}\text { Pomarine Skua } \\
\text { February } \\
\text { May } \\
\text { August } \\
\text { November }\end{array}$ & NW & NE & - 1 & $\begin{array}{r}17 \\
1\end{array}$ & $\begin{array}{l}1 \\
1\end{array}$ & $\begin{array}{l}2 \\
2\end{array}$ & $\begin{array}{r}\Sigma \\
0 \\
0 \\
21 \\
7\end{array}$ & $\begin{array}{r}\text { NW } \\
0 \\
0 \\
0 \\
0.2\end{array}$ & $\begin{array}{r}\text { NE } \\
0 \\
0 \\
0.2 \\
0\end{array}$ & $\begin{array}{r}\text { Sk } \\
0 \\
0 \\
- \\
0\end{array}$ & $\begin{array}{r}\text { CW } \\
0 \\
0 \\
0 \\
0.0\end{array}$ & $\begin{array}{r}C \\
0 \\
0 \\
0.7 \\
0.0\end{array}$ & $\begin{array}{r}\text { CE } \\
0 \\
0 \\
0.1 \\
0.1\end{array}$ & $\begin{array}{r}S \\
0 \\
0 \\
0.2 \\
0.5\end{array}$ \\
\hline $\begin{array}{l}\text { Arctic Skua } \\
\text { February } \\
\text { May } \\
\text { August } \\
\text { November }\end{array}$ & $\begin{array}{r}\text { NW } \\
3 \\
9 \\
1\end{array}$ & $\begin{array}{c}\text { NE } \\
1\end{array}$ & -20 & $\begin{array}{r}\mathrm{C} \\
1 \\
34 \\
5\end{array}$ & 15 & 13 & $\begin{array}{r}\Sigma \\
0 \\
4 \\
92 \\
6\end{array}$ & $\begin{array}{r}\text { NW } \\
0 \\
0.3 \\
1.2 \\
0.1\end{array}$ & $\begin{array}{r}\text { NE } \\
0 \\
0 \\
0.2 \\
0\end{array}$ & $\begin{array}{r}\text { Sk } \\
0 \\
0 \\
- \\
0\end{array}$ & $\begin{array}{r}\text { CW } \\
0 \\
0 \\
1.5 \\
0\end{array}$ & $\begin{array}{l}C \\
0 \\
0.0 \\
1.5 \\
0.3\end{array}$ & $\begin{array}{r}\text { CE } \\
0 \\
0 \\
1.9 \\
0\end{array}$ & $\begin{array}{r}S \\
0 \\
0 \\
1.5 \\
0\end{array}$ \\
\hline $\begin{array}{l}\text { Little Gull } \\
\text { February } \\
\text { May } \\
\text { August } \\
\text { November }\end{array}$ & NW & $\mathrm{NE}$ & Sk CW & $\begin{array}{r}C \\
2 \\
32\end{array}$ & $\begin{array}{r}\mathrm{CE} \\
13 \\
2 \\
2\end{array}$ & $\begin{array}{l}S \\
10 \\
15 \\
41\end{array}$ & $\begin{array}{r}\Sigma \\
10 \\
30 \\
2 \\
75\end{array}$ & $\begin{array}{r}\text { NW } \\
0 \\
0 \\
0 \\
0\end{array}$ & $\begin{array}{r}\text { NE } \\
0 \\
0 \\
0 \\
0\end{array}$ & $\begin{array}{r}\text { Sk } \\
0 \\
0 \\
- \\
0\end{array}$ & $\begin{array}{r}\text { CW } \\
0 \\
0 \\
0 \\
0\end{array}$ & $\begin{array}{r}C \\
0 \\
0.1 \\
0 \\
1.2\end{array}$ & $\begin{array}{l}\text { CE } \\
0 \\
1.1 \\
0.2 \\
0.3\end{array}$ & $\begin{array}{r}\mathrm{S} \\
1.3 \\
1.7 \\
0 \\
10.1\end{array}$ \\
\hline $\begin{array}{l}\text { Black-headed Gull } \\
\text { February } \\
\text { May } \\
\text { August } \\
\text { November }\end{array}$ & NW & NE & $\begin{array}{r}\text { Sk CW } \\
1 \\
1 \\
-\quad 11 \\
1\end{array}$ & $\begin{array}{r}\mathrm{C} \\
12 \\
6 \\
1 \\
26\end{array}$ & $\begin{array}{r}\mathrm{CE} \\
1 \\
7 \\
1\end{array}$ & $\begin{array}{r}\mathrm{S} \\
14 \\
13 \\
3 \\
15\end{array}$ & $\begin{array}{l}\Sigma \\
28 \\
27 \\
15 \\
43\end{array}$ & $\begin{array}{r}\text { NW } \\
0 \\
0 \\
0 \\
0\end{array}$ & $\begin{array}{r}\text { NE } \\
0 \\
0 \\
0 \\
0\end{array}$ & $\begin{array}{r}\text { Sk } \\
0 \\
0 \\
- \\
0\end{array}$ & $\begin{array}{l}\text { CW } \\
0.1 \\
0.1 \\
0.8 \\
0.0\end{array}$ & $\begin{array}{r}C \\
1.0 \\
0.2 \\
0 \\
1.0\end{array}$ & $\begin{array}{r}\text { CE } \\
0.2 \\
0.6 \\
0 \\
0.1\end{array}$ & $\begin{array}{l}S \\
1.8 \\
1.5 \\
0.3 \\
3.7\end{array}$ \\
\hline $\begin{array}{l}\text { Glaucous Gull } \\
\text { February } \\
\text { May } \\
\text { August } \\
\text { November }\end{array}$ & $\begin{array}{r}\text { NW } \\
11\end{array}$ & $\begin{array}{r}\text { NE } \\
1\end{array}$ & Sk CW & C & $\begin{array}{r}\mathrm{CE} \\
2\end{array}$ & $S$ & $\begin{array}{r}\Sigma \\
14 \\
0 \\
0 \\
8\end{array}$ & $\begin{array}{r}\text { NW } \\
0.7 \\
0 \\
0 \\
0.5\end{array}$ & $\begin{array}{r}\text { NE } \\
0.3 \\
0 \\
0 \\
0.1\end{array}$ & $\begin{array}{r}\text { Sk } \\
0 \\
0 \\
- \\
0\end{array}$ & $\begin{array}{r}\text { CW } \\
0 \\
0 \\
0 \\
0\end{array}$ & $\begin{array}{l}\text { C } \\
0 \\
0 \\
0 \\
0\end{array}$ & $\begin{array}{r}\text { CE } \\
0.3 \\
0 \\
0 \\
0\end{array}$ & $\begin{array}{l}5 \\
0 \\
0 \\
0 \\
0\end{array}$ \\
\hline $\begin{array}{l}\text { Sandwich Tern } \\
\text { February } \\
\text { May } \\
\text { August } \\
\text { November }\end{array}$ & NW & NE & $\begin{array}{r}\text { Sk CW } \\
\quad 29\end{array}$ & $C$ & $\begin{array}{l}97 \\
11\end{array}$ & $\begin{array}{r}S \\
41 \\
6\end{array}$ & $\begin{array}{r}\Sigma \\
0 \\
167 \\
17 \\
0\end{array}$ & $\begin{array}{r}\text { NW } \\
0 \\
0 \\
0 \\
0\end{array}$ & $\begin{array}{r}\text { NE } \\
0 \\
0 \\
0 \\
0\end{array}$ & $\begin{array}{r}\text { Sk } \\
0 \\
0 \\
- \\
0\end{array}$ & $\begin{array}{r}\text { CW } \\
0 \\
2.8 \\
0 \\
0\end{array}$ & $\begin{array}{l}\text { C } \\
0 \\
0 \\
0 \\
0\end{array}$ & $\begin{array}{r}\text { CE } \\
0 \\
7.9 \\
1.4 \\
0\end{array}$ & $\begin{array}{r}S \\
0 \\
4.7 \\
0.7 \\
0\end{array}$ \\
\hline $\begin{array}{l}\text { Common Tern } \\
\text { February } \\
\text { May } \\
\text { August } \\
\text { November }\end{array}$ & NW & NE & Sk CW & $C$ & $\begin{array}{r}C E \\
37 \\
125\end{array}$ & $\begin{array}{l}S \\
17\end{array}$ & $\begin{array}{r}\Sigma \\
0 \\
37 \\
150 \\
0\end{array}$ & $\begin{array}{r}\text { NW } \\
0 \\
0 \\
0 \\
0\end{array}$ & $\begin{array}{r}\text { NE } \\
0 \\
0 \\
0 \\
0\end{array}$ & $\begin{array}{r}\text { Sk } \\
0 \\
0 \\
- \\
0\end{array}$ & $\begin{array}{r}C W \\
0 \\
0 \\
0.4 \\
0\end{array}$ & $\begin{array}{r}C \\
0 \\
0 \\
0.1 \\
0\end{array}$ & $\begin{array}{r}\text { CE } \\
0 \\
3.0 \\
15.5 \\
0\end{array}$ & $\begin{array}{l}S \\
0 \\
0 \\
1.9 \\
0\end{array}$ \\
\hline $\begin{array}{l}\text { Arctic Tern } \\
\text { February } \\
\text { May } \\
\text { August } \\
\text { November }\end{array}$ & NW & $\mathrm{NE}$ & Sk CW & $\begin{array}{r}2 \\
19\end{array}$ & $\mathrm{CE}$ & $\begin{array}{l}1 \\
3\end{array}$ & $\begin{array}{r}\Sigma \\
0 \\
89 \\
25 \\
0\end{array}$ & $\begin{array}{r}\text { NW } \\
0 \\
0.3 \\
0 \\
0\end{array}$ & $\begin{array}{r}\text { NE } \\
0 \\
9.9 \\
0 \\
0\end{array}$ & $\begin{array}{r}\text { Sk } \\
0 \\
0.3 \\
- \\
0\end{array}$ & $\begin{array}{r}\text { CW } \\
0 \\
0.4 \\
0.2 \\
0\end{array}$ & $\begin{array}{r}C \\
0 \\
0.1 \\
0.8 \\
0\end{array}$ & $\begin{array}{r}\text { CE } \\
0 \\
0.3 \\
0 \\
0\end{array}$ & $\begin{array}{r}S \\
0 \\
0.1 \\
0.3 \\
0\end{array}$ \\
\hline
\end{tabular}


ted 3000 birds in the North Sea in this month were adults, but the sample was small (table 4.1.8). In May, the situation had changed considerably. Low to moderate densities occurred in the eastern half of the North Sea and scattered birds were found elsewhere (figure 4.1.20). Of an estimated 50,000 Lesser Black-backed Gulls in the North Sea during this survey, a large proportion were found in Sk $(12,000), \operatorname{CE}(16,000)$ and $S(11,000 ;$ table 4.1.2). Estimates of total numbers must be considered conservative because coastal waters around large colonies in The Netherlands, Germany and Southeast England were not surveyed. An area offshore from Texel, known to be an important feeding area of Lesser Black-backed Gulls nesting on the Dutch Wadden Sea islands was also incompletely covered. Extensive ship-based surveys in Dutch waters between 1987 and 1993 have shown that over 80,000 individuals may occur in the Dutch sector alone in April and May (Camphuysen \& Leopold 1994). Adults predominated in all subregions (overall $81.4 \%$ adult, $n=1689$; table 4.1.8). In August, just over two-thirds of the Lesser Black-backed Gulls observed were adult birds $(68.3 \%$ adult, $n=$ 1892; table 4.1.8). Many recently fledged juveniles were observed far from the coast in the centre of the North Sea. Moderate and locally high densities of birds were found in the southern North Sea (S, C and CE). Another local concentration, mainly of adults was found in an area off southern Norway with extensive fishing activities. Of an estimated 73,000 individuals occurring in the North Sea, 38,000 were found in the central North Sea (C), 32,000 in the German Bight and Southern Bight (CE, S) and only 3,000 elsewhere. In November, overall numbers were reduced to an estimated 12,000 individuals (table 4.1.4), the majority of which were found in the southern half of the North Sea (figure 4.1.22). Nearly three-quarters of the Lesser Black-backed gulls were adults (71.4\% adult, $n=70$; table 4.1 .8 ), indicating that most immatures leave the North Sea before adults.

\section{Herring Gull Larus argentatus}

The Herring Gull is a common breeding species around the North Sea and also occurs in large numbers as a winter visitor from Scandinavia and Russia. Large numbers were found in both offshore and inshore areas in November and February. In the breeding season, numbers were low numbers offshore and only low to moderate inshore, the unsurveyed coastal zone being undoubtedly of greater importance. In February, Herring Gulls were numerous and widespread in the North Sea (figure 4.1.23). High numbers were estimated to occur in NW 145,000 individuals), Sk $(77,000)$ and in the central North Sea (C 31,000; table 4.1.1). Low to moderate densities of birds were found off northeast Scotland and Shetland, in the Skagerrak and Kattegat, in the German Bight and Dutch inshore waters. Densities were usually low offshore. Nearly three-quarters of the Herring Gulls observed were mature birds (71.5\% adult, $n=1595$; table 4.1.9) and the proportion was even higher in the Skagerrak a relatively high proportion were adult birds $(83.2 \%$ adult, $n=601)$. In the prebreeding season, in May, Herring Gulls disappeared from most offshore areas. Of an estimated 10,000 individuals in the North Sea, some 7000 Herring Gulls were found in the Southern Bight, in inshore waters of The Netherlands (figure 4.1.24, table 4.1.2). Small numbers were found in the German Bight (CE) and in the central North Sea (C), but Herring Gulls were rare elsewhere. $\mathrm{Al}$ most all those observed in the central North Sea were immatures $(13.8 \%$ adult, $n=29$; table 4.1.9) while in the Southern Bight and German Bight adults were more numerous (57.5\% adult, $n=193$ ). In August, Herring Gulls were rare at sea, except off the east coast of Scotland (figure 4.1.25). The moderate to high densities in this area accounted for about 15,000 of the estimated 17,000 Herring Gulls in the North Sea. Nearly half the birds off the Scottish coast were adults (47.3\% adult, $n=207$; table 4.1.9). In November, very large numbers of swimming Herring Gulls were recorded in transect on 
Table 4.1 .13 Relative abundance at sea of species which were only scarcely reported as associates at the trawl. Numbers in transect (left) and densities (n/km ${ }^{2}$, right) per subregion (= no data.)

\begin{tabular}{|c|c|c|c|c|c|c|c|c|c|c|c|c|c|c|c|}
\hline Guillemot & NW & NE & Sk & CW & C & CE & $S$ & $\Sigma$ & NW & NE & Sk & $\mathrm{CW}$ & C & CE & $\mathrm{S}$ \\
\hline February & y 525 & 8 & 235 & 1393 & 496 & 41 & 384 & 3082 & 1.2 & 0.1 & 1.1 & 4.8 & 1.4 & 0.2 & 1.7 \\
\hline May & 307 & 10 & 1 & 1144 & 848 & 52 & 79 & 2441 & 1.2 & 0.0 & 0.0 & 3.7 & 0.9 & 0.1 & 0.3 \\
\hline August & 1420 & 172 & - & 11303 & 411 & 155 & 13 & 1 3474 & 6.4 & 1.3 & - & 29.1 & 0.6 & 0.6 & 0.0 \\
\hline Nov & 1066 & 136 & 159 & 4762 & 2297 & 84 & 24 & 4242 & 2.8 & 0.4 & 1.1 & 1.5 & 3.1 & 0.5 & 0.2 \\
\hline Razorbill & NW & NE & Sk & CW & C & CE & $S$ & $\Sigma$ & NW & NE & $\mathrm{Sk}$ & $\mathrm{CW}$ & C & $\mathrm{CE}$ & $\mathrm{S}$ \\
\hline February & 22 & & 53 & 85 & 55 & 19 & 136 & 370 & 0.1 & 0 & 0.3 & 0.3 & 0.2 & 0.1 & 0.6 \\
\hline May & 17 & 1 & & 114 & 32 & & 9 & 173 & 0.1 & 0.0 & 0 & 0.4 & 0.0 & 0 & 0.0 \\
\hline August & 114 & & - & 445 & 2 & & & 561 & 0.5 & 0 & - & 1.1 & 0.0 & 0 & 0 \\
\hline Novembe & er 6 & & 103 & 48 & 147 & 7 & 6 & 317 & 0.0 & 0 & 0.7 & 0.1 & 0.2 & 0.0 & 0.1 \\
\hline
\end{tabular}

Table 4.1.14 Estimates of total numbers of seabirds (x 1000) calculated from strip-transect counts (conform tables 4.1.1-4), but including birds associated with trawlers in transect ('normal'), compared with abundances estimates according to the observer with the highest overall densities of seabirds ('corrected'; see text; Van der Meer \& Camphuysen in press).

\begin{tabular}{|c|c|c|c|c|c|c|c|c|c|}
\hline Survey & Ful & Gan & GSk & CG & LBG & HG & GBG & Kit & $\Sigma$ \\
\hline February (normal) & 425 & 61 & 1 & 44 & 3 & 204 & 117 & 205 & 1060 \\
\hline (corrected) & 699 & 84 & 2 & 223 & 3 & 354 & 167 & 746 & 2278 \\
\hline (normal) & 724 & 150 & 1 & 0 & 125 & 37 & 23 & 673 & 1733 \\
\hline (corrected) & 810 & 268 & 3 & 2 & 140 & 37 & 26 & 1451 & 2737 \\
\hline \multirow{2}{*}{$\begin{array}{l}\text { August (normal) } \\
\text { (corrected) }\end{array}$} & 1780 & 115 & 29 & 3 & 127 & 17 & 27 & 1073 & 3171 \\
\hline & 3412 & 166 & 171 & 14 & 143 & 9 & 3 & 3421 & 7339 \\
\hline \multirow{2}{*}{$\begin{array}{c}\text { November (normal) } \\
\text { (corrected) }\end{array}$} & 1753 & 172 & 4 & 14 & 12 & 466 & 118 & 378 & 2917 \\
\hline & 1577 & 187 & 9 & 15 & 12 & 292 & 228 & 1280 & 3600 \\
\hline
\end{tabular}


one occasion off Aberdeen. This flock has greatly inflated the estimated total numbers in subregion CW (nearly 300,000 individuals; table 4.1.4) and seems unlikely to be representative as two other vessels reported only low to moderate densities of Herring Gulls in CW. If this flock is excluded from extrapolation, the estimated total for the whole North Sea is about 200,000 individuals, similar to the total for February, and still a considerable increase in numbers since the summer. Just over half the Herring Gulls observed were mature birds $158.9 \%$ adult, $n=1449$; table 4.1.9). Herring Gulls were widespread in the northeastern two-thirds of the study area (figure 4.1.26), with locally high densities in several areas. As well as the large numbers off Aberdeen (CW), substantial numbers also occurred in NW $(48,000)$ and CE $(48,000)$. Herring Gulls from northern Scandinavia and the Murmansk region move south after the breeding season to winter around the Norwegian south coast, in the North Sea and in Britain (Schüz 1933, Stanley et al. 1981, Cramp \& Simmons 1983, Coulson et al. 1984). Herring Gulls breeding along the east coast of Britain, in southern Norway, Sweden and along the west coast of Denmark, Germany and The Netherlands are fairly sedentary. Outside the breeding season these birds occur dispersed along the coast, usually within $200 \mathrm{~km}$ from their natal colonies (Thomson 1924, Jørgensen 1973, Møller 1981). Thus it would seem reasonable to conclude that most of the Herring Gulls recorded in offshore area during winter surveys arewinter visitors from nordic populations.

\section{Great Black-backed Gull Larus marinus}

Great Black-backed Gulls were common and widespread during most of the year, but increased in numbers in winter (tables 4.1.14). They were encountered in scattered low to moderate densities both offshore and inshore. Comparing the estimated numbers at sea, which ranged from 22,000 to over 100,000 individuals, with the very small
North Sea breeding population (c. 24,000 pairs; Cramp \& Simmons 1983, Lloyd et al. $1991)$ it is obvious that many Great Blackbacked Gulls wintering in the North Sea originate from other populations. In February, it was estimated that 117,000 Great Blackbacked Gulls occurred in the North Sea (table 4.1.1), with moderate densities of birds in scattered areas around Shetland, off the Dutch coast, in the German Bight and in the Skagerrak (figure 4.1.27). Just over half the Great Black-backed Gulls in February were adult (58.3\% adult, $n=883$; table 4.1.10). Numbers dropped considerably in spring and in May it was estimated that just over 20,000 Great Black-backed Gulls occurred in the North Sea. Most of these were found in the northeastern half of the North Sea. Age composition varied, with a very low proportion of adults in the Southern Bight and German Bight (9.4\%, $n=74$; table 4.1.10), but considerably more adults than immatures in NE $(70.3 \%$ adults, $n=74)$. In the western North Sea very small numbers of Great Black-backed Gulls were observed except off Shetland (figure 4.1.28). The situation in August was quite similar, with an overall estimate of 23,000 individuals (table 4.1.3), widespread in scattered low to moderate densities over most of the North Sea. Adults were more numerous in the northwestern half of the North Sea (NW, CW, C; $76.0 \%$ adults, $n=104$; table 4.1.10), while immatures predominated in the southeast (S, CE; $42.7 \%$ adults, $n=138$ ). Numbers increased in all subregions in autumn and from the November survey it was estimated that between 10,000 and 30,000 Great Blackbacked Gulls occurred in each of the subregions (table 4.1.4). Just over half the Great Black-backed Gulls were mature birds (54.8\%, $n=757$; table 4.1.10), with the lowest proportion of adults in the central North Sea (C, 36.9\% adult, $n=176$ ). Great Black-backed Gulls were observed throughout the North Sea in this period, and no one area was clearly more important for this species than any other (figure 4.1.30). 


\section{Kittiwake Rissa tridactyla}

The Kittiwakes was the second most numerous scavenging seabird in the North Sea, with overall numbers varying from an estimated 200,000 in February to well over a million individuals in August. In summer, waters off the British east coast were of greatest significance, while Kittiwakes were more widespread in autumn and winter. In February, Kittiwakes were widespread, but with comparatively low densities in the central North Sea (figure 4.1.31). Moderate to high densities of birds were reported in the Southern Bight, off southwest Norway, eastern Scotland, Orkney and Shetland. It was estimated that ca. 205,000 Kittiwakes were present in the North Sea (table 4.1.1), of which $92.0 \%$ were adult $(n=3282$; table 4.1.11). Between 20,000 and 50,000 Kittiwakes were present in each subregion. In May, most Kittiwakes were found in the western half of the North Sea, with moderate to high densities in the Dogger Bank region and off the east coast of Britain (figure 4.1.32). Low to moderate densities of birds were found in some areas of the northern and central North Sea, but Kittiwakes were rather scarce in the far southeast of the surveyed areas. An estimated 672,000 Kittiwakes were present in the North Sea. Subregion CW held the majority with over half a million birds and another 100,000 were mainly concentrated off northeast Scotland and in the central North Sea. The high estimates of Kittiwakes numbers for subregion $\mathrm{CW}$ were influenced by sightings of large flocks of fishing Kittiwakes. The largest attregations of feeding Kittiwakes, operating in groups ranging from 10-300 individuals, were recorded on 6 May 1994 at Long Forties, just to the northeast of Aberdeen Bank. There were no fishing vessels in this area. Some of the feeding flocks included small numbers of Gannets, while auks were scarce in these waters. Within the centre of Kittiwake distribution (NW, CW, C), virtually all birds were adult $(97.1 \%$ adult, $n=6827$; table 4.1 .11 ), whereas a quarter were immatures in the rest of the
North Sea. In August, the distribution of Kittiwakes was even more strongly clumped, with an estimated 940,000 individuals (95.3\% adults, $n=1065$; table 4.1 .11 ) in subregion CW out of a North Sea total of $c a$. 1.1 million Kittiwakes (table 4.1.3). Very high numbers were recorded off East Scotland and in the Moray Firth. The most important concentrations were located at the Aberdeen Front, the transition zone between stratified water of the central North Sea and mixed coastal waters off East Scotland, on 19 August 1994. Within a zone ca. $25 \mathrm{~km}$ wide, Kittiwakes were actively feeding in groups of several hundreds and densities peaked at 1250 birds per $\mathrm{km}^{2}$ (Camphuysen 1994c). Razorbills A/ca torda were also abundant in the area where Kittiwakes were feeding, while very dense concentrations of Guillemots were observed in an adjacent area slightly further offshore. Fishing vessels were not observed in these waters. Low to moderate and locally high densities were found off East England and in the German Bight. Kittiwakes were remarkably scarce in the northeastern North Sea (NE, 2000). The species was more widespread in November with the majority of the estimated total of 375,000 (table 4.1.4) in the central (C, 130,000) and northwestern North Sea (NW, 119,000). The Dogger Bank area consistently held moderate to high densities and Kittiwakes were frequently observed in feeding associations with Guillemot. Surface shoaling immature Herring was identified as their main prey (Camphuysen et al. in prep.).

\section{Other species}

Of the other species of seabirds seen at sea during transect counts a further 17 were occasionally associated with the research vessels. Most these species were also scarce at sea and their spatial distribution has therefore been described on the basis of the $90^{\circ}$ scan (table 4.1.12). Sooty Shearwater and Manx Shearwater Puffinus puffinus were observed in very small numbers in summer and autumn. Only a few hundred Manx Shearwaters breed in the North Sea (in Orkney 
and Shetland), while the majority of the world population nests on islands off western Britain and Ireland (Lloyd et al. 1991, Brooke \& Tasker 1994). Sooty Shearwaters breed in the southern hemisphere (Cramp \& Simmons 1977). There were no sightings in February, only one in May and Sooty Shearwaters remained very scarce in August (23) and November (5). Most records were off the British coast (NW and CW) and in the central North Sea. Manx Shearwaters were only seen during the summer surveys (May and August), with sightings being most frequent off the British coast (subregions NW and (W). Storm Petrels Hydrobates pelagicus were rarely seen except in August (14 out of a total of 18 birds). Almost all birds seen were in the north (NW and NE), while two sightings in November were near the coast off East England (CW) and the Netherlands (S). There were no records in February. Almost all sightings of Cormorants (a total of 51 individuals) were in the Skagerrak and Kattegat in February 1993. There were also three records close to the Norwegian coast and one off southeast England in winter. In May, a single bird was seen in the central North Sea (C) to the west of Denmark. Shags were very rare offshore. In February 1993, 200 birds were recorded, largely concentrated off the Scottish coast (NW). Pomarine Skua and Arctic Skua Stercorarius parasiticus were observed in very small and small numbers respectively, mainly in August. The Pomarine Skuas in the North Sea probably originate from Russian tundras, while Arctic Skuas have breeding populations in Shetland and Orkney (ca. 3000 pairs; Lloyd et al. 1991) and Scandinavia. Pomarine Skuas were mainly seen in the southeastern half of the North Sea in August (C, CE and S), indicating that these migrants followed the 'overland' route from the White Sea to the Baltic and the North Sea (Glutz von Blotzheim \& Bauer 1982, Cramp \& Simmons 1983). Arctic Skuas were most numerous and widespread in August. Sightings were frequent in the west (NW and CW), central North Sea (C) and the southeast (CE, S).
Very small numbers were observed in May, mainly around Shetland, and Arctic Skuas were just outnumbered by Pomarines in November. Long-tailed Skuas Stercorarius longicaudus are rare in the North Sea and only four were sighted (3 in subregion C, 1 in S) in late August/September. Little Gulls in the North Sea originate from colonies in the Baltic states, Finland and Russia (Brindley \& del Nevo 1994). Although mainly a passage migrant in spring and autumn, smaller numbers also winter in the North Sea. The surveys were just too late to record both spring (peak late April) and autumn migrations which peak in late September and October (Garthe 1993a, Platteeuw et al. 1994), so it is not surprising that overall numbers were rather low. Sightings of Little Gulls were restricted to the southeastern half of the North Sea (subregions C, CE and S) with small numbers were seen during all surveys. Sightings of the Black-headed Gull were confined to the southern half of the North Sea (subregions CW, C, CE, and S). Small numbers were seen in all seasons. Larger numbers would have been expected if observer effort had been greater in the coastal zone. Glaucous Gulls are winter visitors to the North Sea and the species was absent in May and August. Most records were in the northern North Sea. Sandwich Tern Sterna sandvicensis, Common Tern Sterna hirundo, and Arctic Tern Sterna paradisaea are summer visitors and were seen in May and August only. Common Terns were mainly confined to the southeastern North Sea, whereas Arctic Terns were widespread. Sandwich Terns were strictly coastal, and were observed in subregions $\mathrm{S}, \mathrm{CE}$ and $\mathrm{CW}$. Two Black Terns Chlidonias niger were seen in August/September close to the Dutch coast (S). In February 1993, small numbers of Guillemots and Razorbills were reported scavenging at research vessels as well as at fishing vessels. From strip-transect counts, abundance estimates per subregions for each of the surveys were made, from which the overall distribution can be discussed (table 4.1.13). The highest densities were reported 
off the British coast (NW and CW), particularly in August, but both species were seen in most subregions in all of the surveys.

\section{Associations with fishing vessels}

A minority of the seabirds recorded during strip-transect counts were 'labelled' by the observer as being obviously associated with a fishing vessel. A larger proportion of Larusgulls, most notably Lesser Black-backed Gull, than of other species, such as Fulmar, Gannet and Kittiwake, were associated with fishing vessels:

proportion ass.

species with fishing vessel sample

Lesser BI-b Gull

$38 \%$

4281

Herring Gull

Great Bl-b Gull

$12 \%$

5269

Common Gull

$9 \%$

2448

$7 \%$

Fulmar

$5 \%$

Gannet

$3 \%$

48769

5944

Kittiwake

$2 \%$

21219

Assuming that the chance would be similar for each species to be seen in association with a fishing vessel, the differences between the above percentages could be interpreted as differences in the relative importance of fishing vessels as feeding stations for these species. Unfortunately, the turnover at boats of the different species is quite different. Fulmar numbers tend to build-up for a long time, whereas Gannets suddenly zoom in on fishing vessels when the catch is brought on deck, while most individuals leave again as soon as they lose interest. Offshore flocks of large gulls have a tendency to stay intact for a long time after the fishing vessel has left or follow such vessels at some distance to arrive en masse as soon as the discarding onboard is resumed. But while the comparison of the attraction of fishing vessels for different species on this basis is a risky exercise, there is no reason why the seasonal fluctuations within species could not be examined. Gannets were hardly recorded near fishing vessels in May and
August, whereas 4\% (November) and 11\% (February) of the birds seen in winter were in association of such boats. Kittiwakes ranged from $3 \%-7 \%$ in winter, while less than $1 \%$ were found near fishing vessels in the summer months. The opposite was found in Fulmars, in which smaller numbers were 'labelled' as associated with fishing vessels in winter $(3 \%)$ than in summer $(6 \%)$. In Great Black-backed Gulls the proportions ranged from $6 \%$ in November to $12 \%$ in February, but were $9 \%$ and $7 \%$ respectively in May and August. Of all 88,388 individuals of the above species which were recorded during strip-transect counts, $6 \%$ occurred in association with fishing vessels, with no significant differences between seasons. This aspect is dealt with further in chapter 4.5 .
Figures 4.1.1 - 34 show the observer effort and densities of seabirds observed during strip-transect counts in the North Sea. Four maps are given on each page, presenting the results of each of the four surveys. Observer effort is presented by different shadings per quarter ICES square (i.e. 0.25- latitude $\times 0.5^{\circ}$ longitude rectangles), ranging from $<2 \mathrm{~km}^{2}$ to $>25 \mathrm{~km}^{2}$. For each of the common scavenging seabirds, densities $\left(\mathrm{n} / \mathrm{km}^{2}\right)$ are presented by different shadings ranging from $<1.0$ to $\geq 5.0$ individuals per $\mathrm{km}^{2}$. Visited rectangles where no birds were seen are indicated by the lightest shading. Numbers of Great Skuas in February and May were too small to warrant the presentation of distribution maps. 

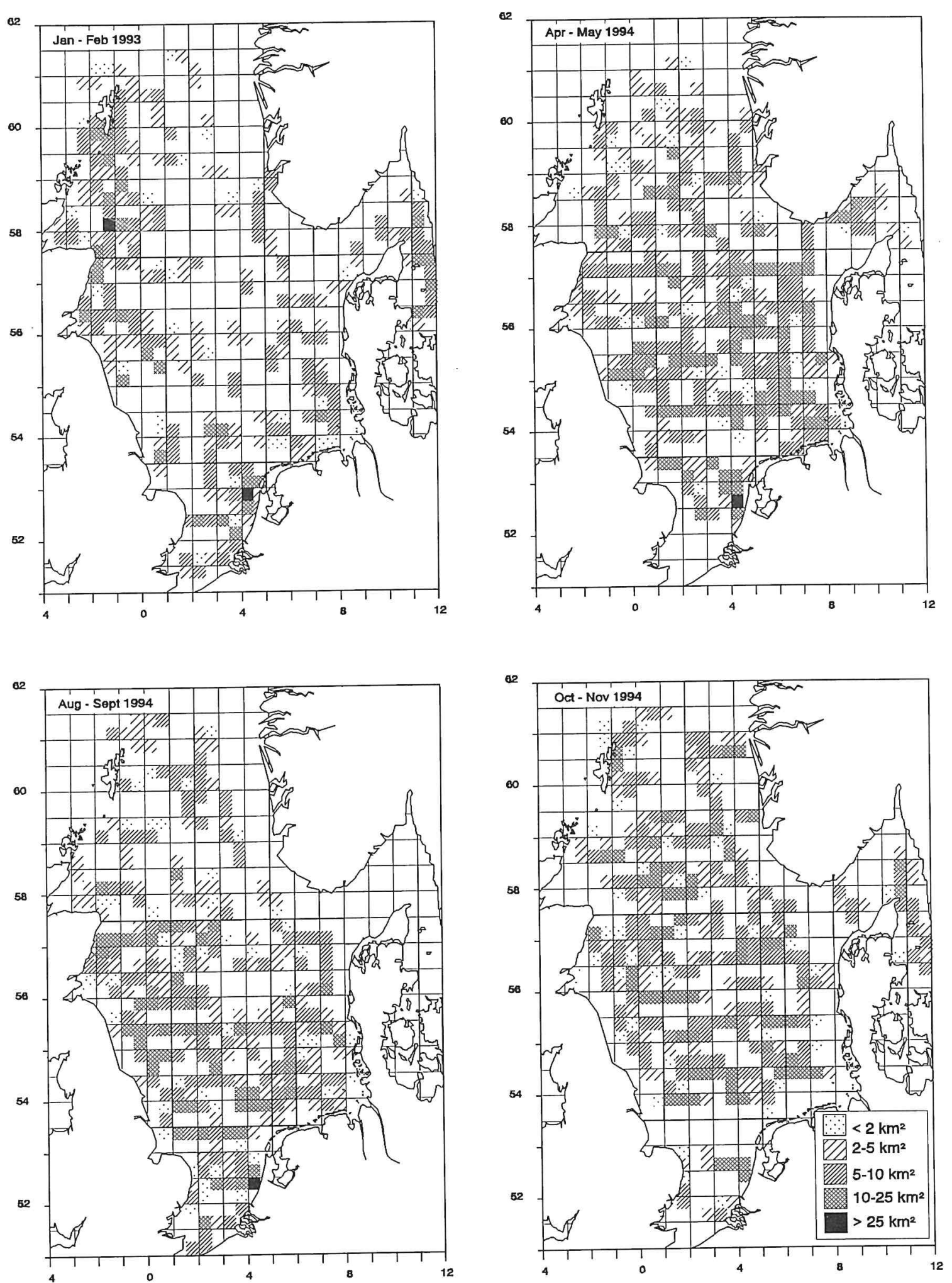

Figure 4.1.1-4 Observer effort, strip-transect counts $\left(\mathrm{km}^{2}\right.$ surveyed per quarter ICES square) 

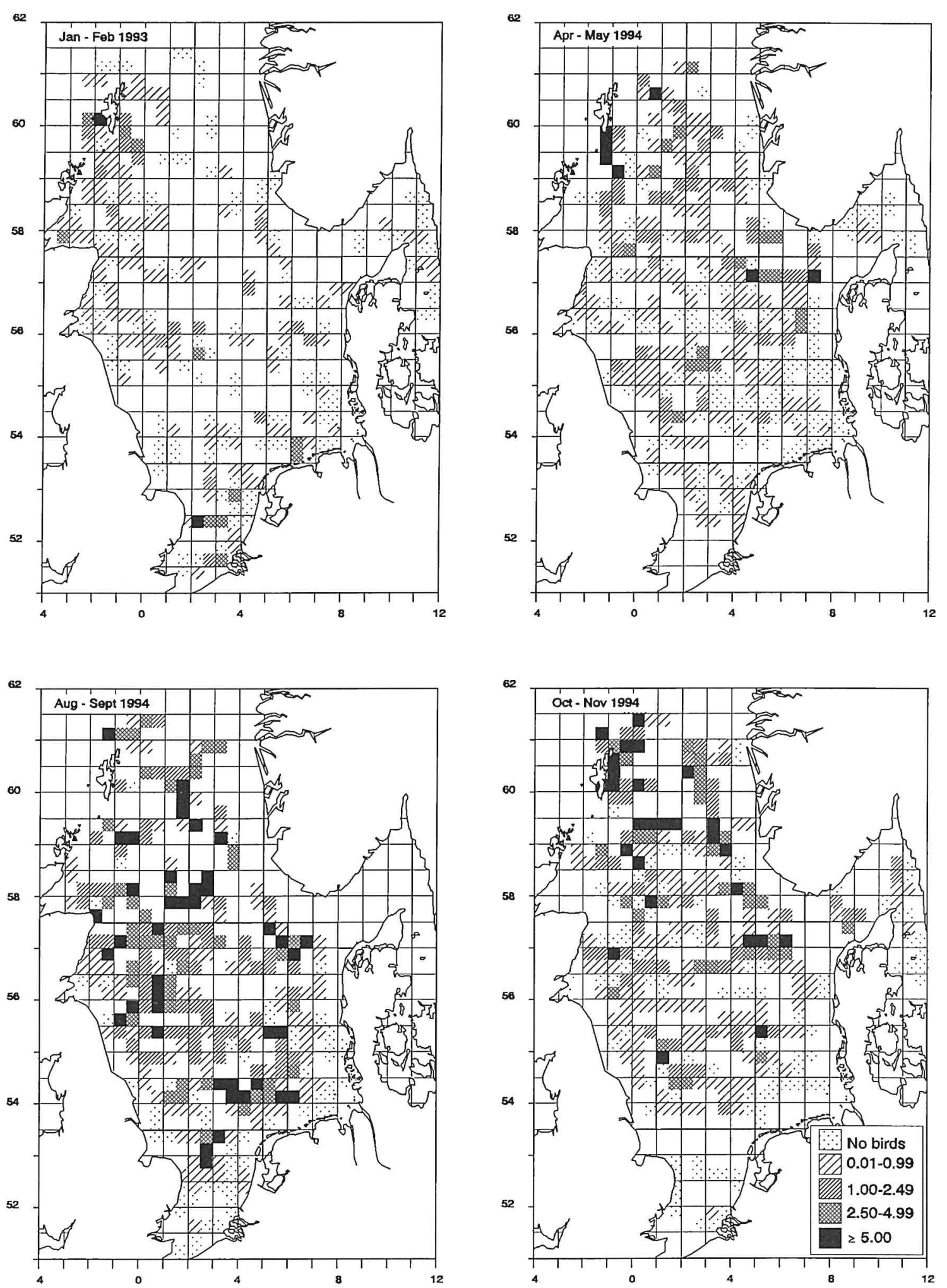

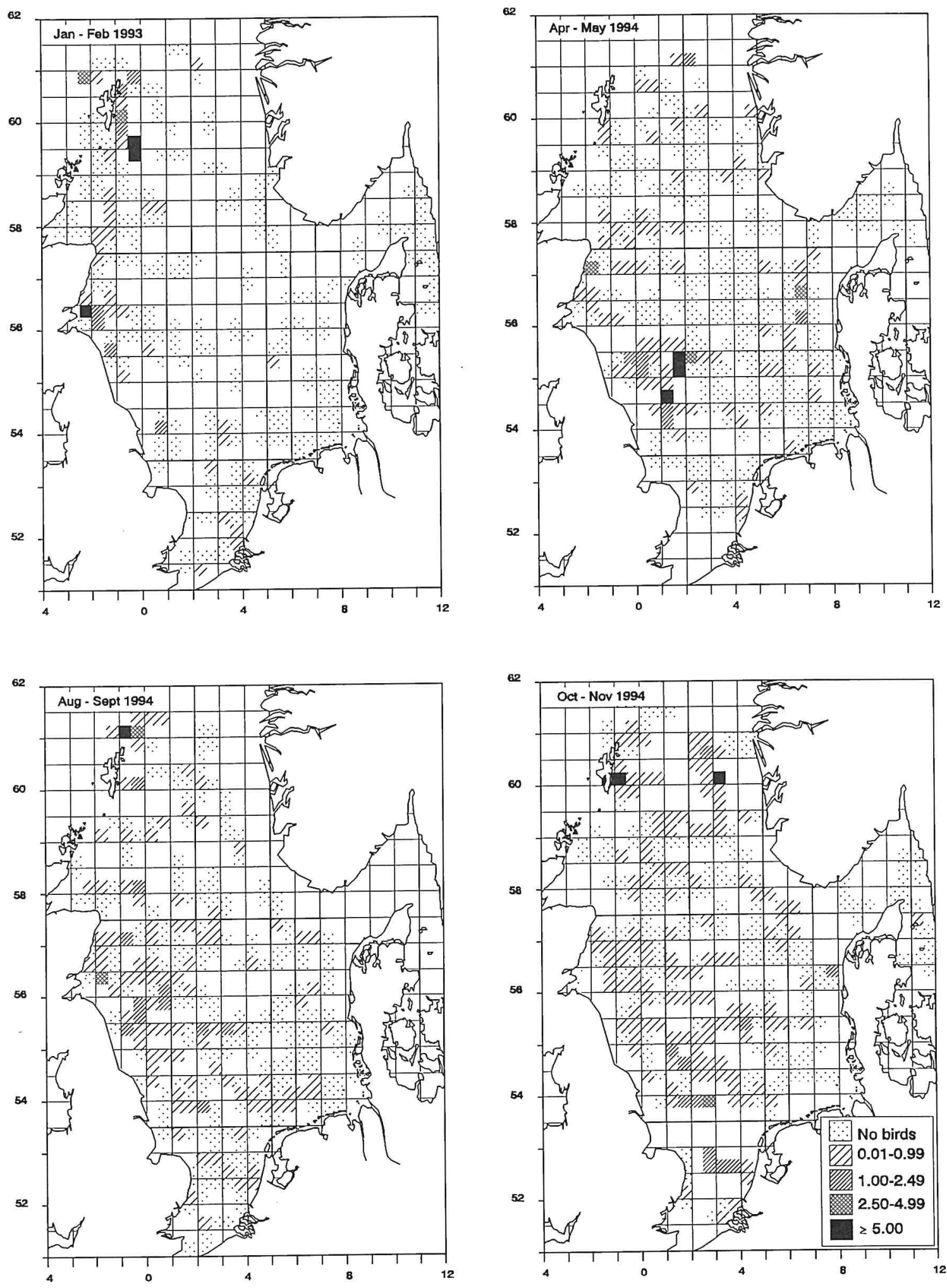

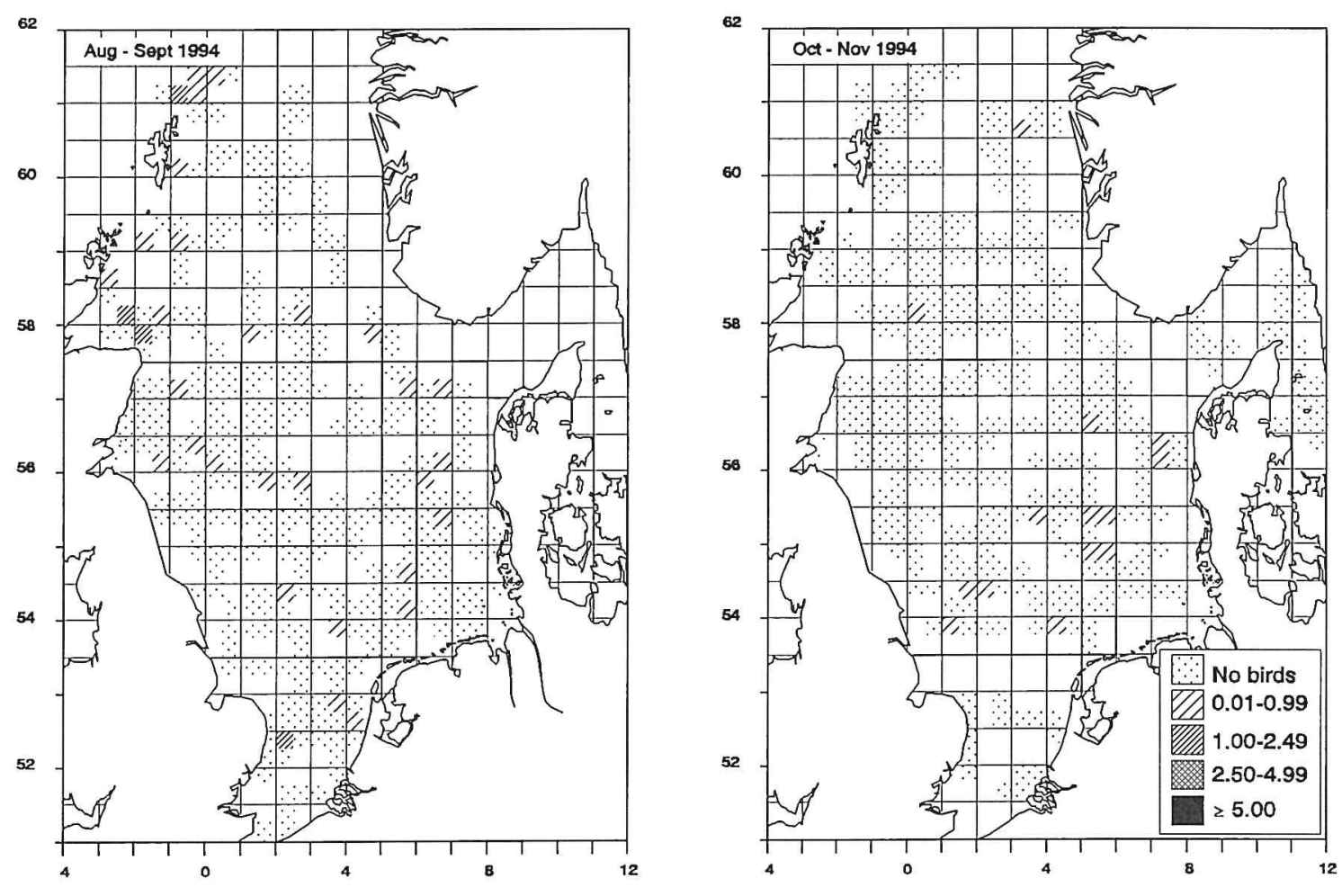

Figure 4.1.13-14 Distribution of Great Skua from strip-transect counts 

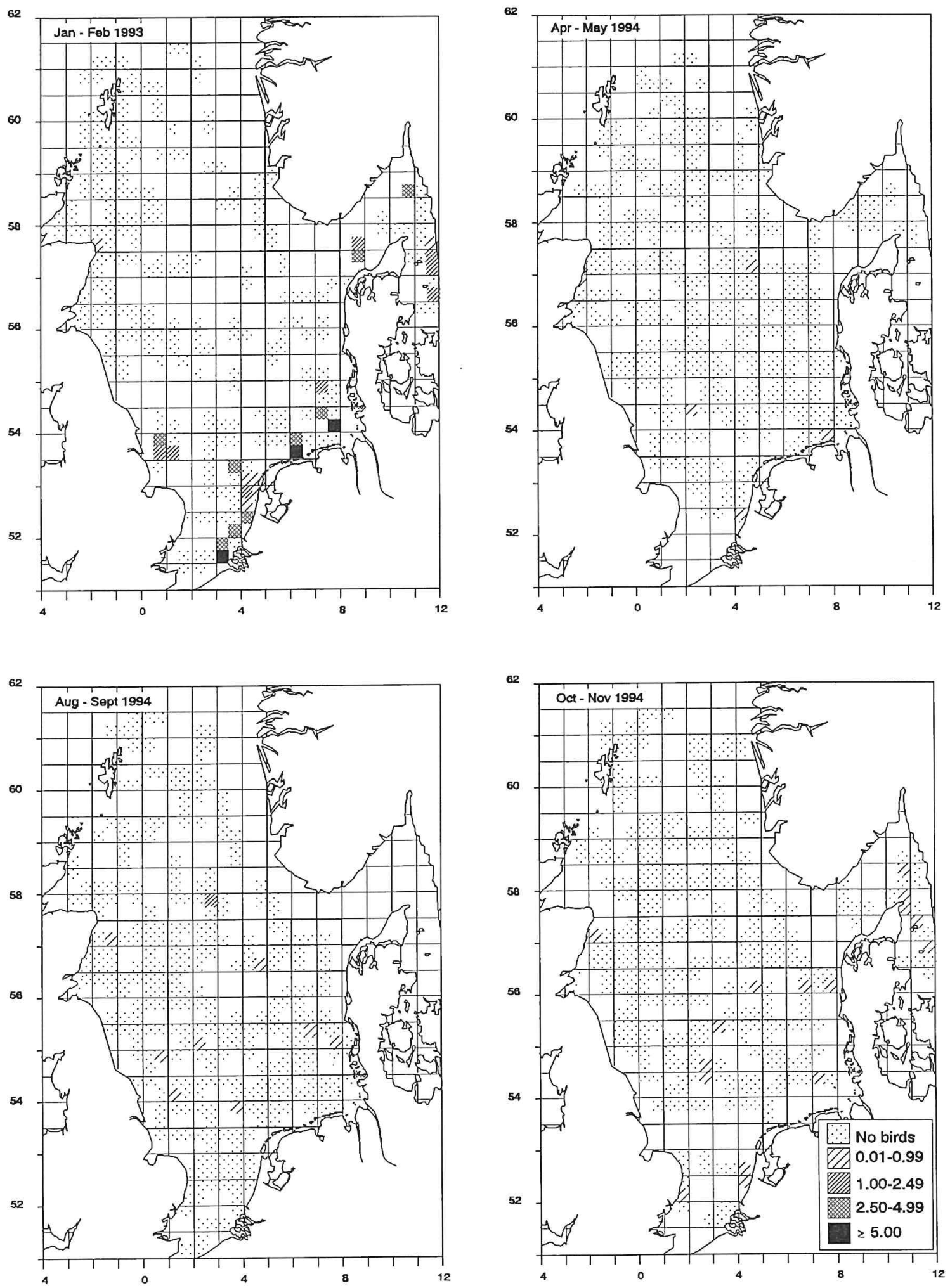

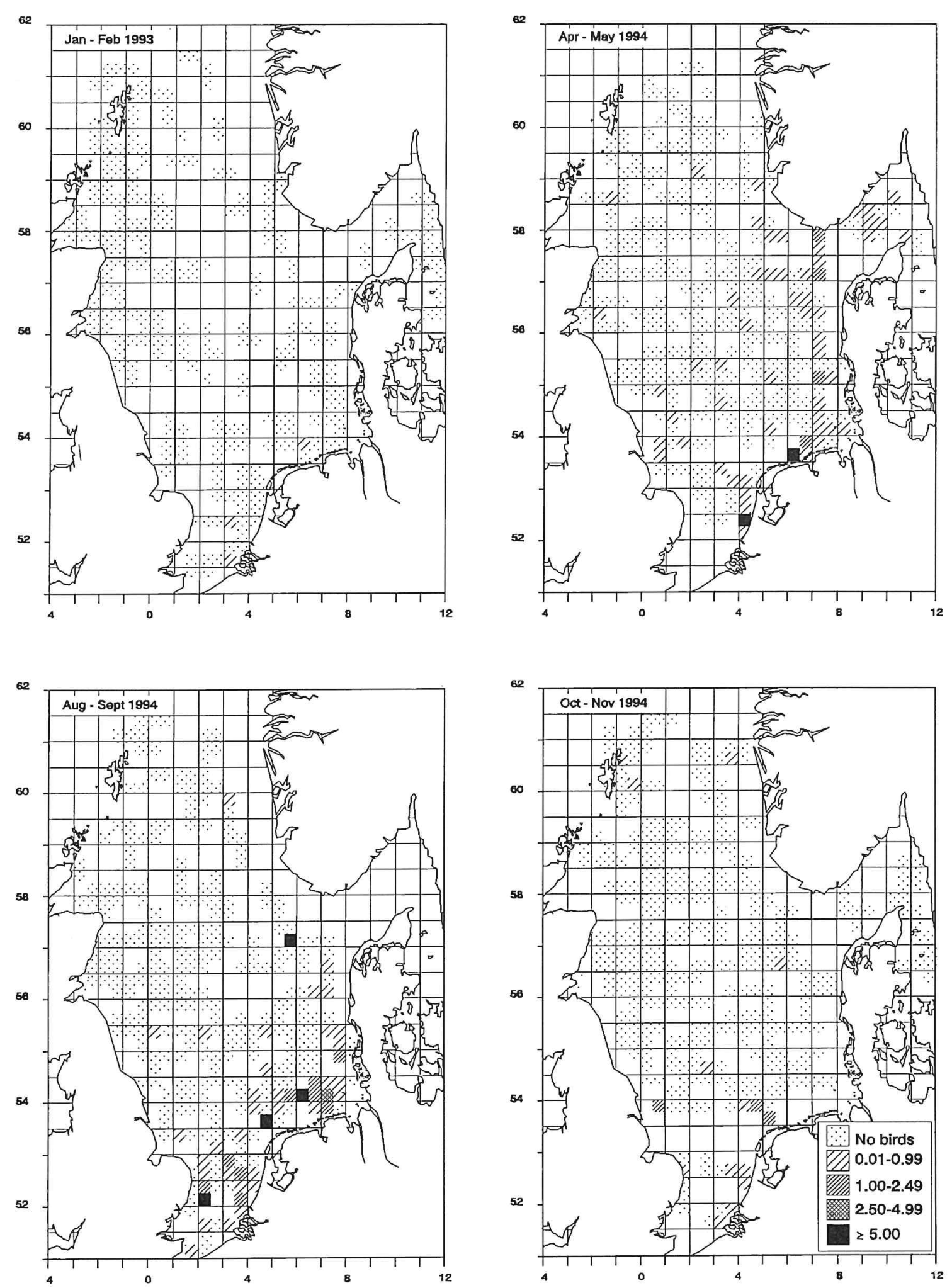

Figure 4.1.19-22 Distribution of Lesser Black-backed Gull from strip-transect counts 

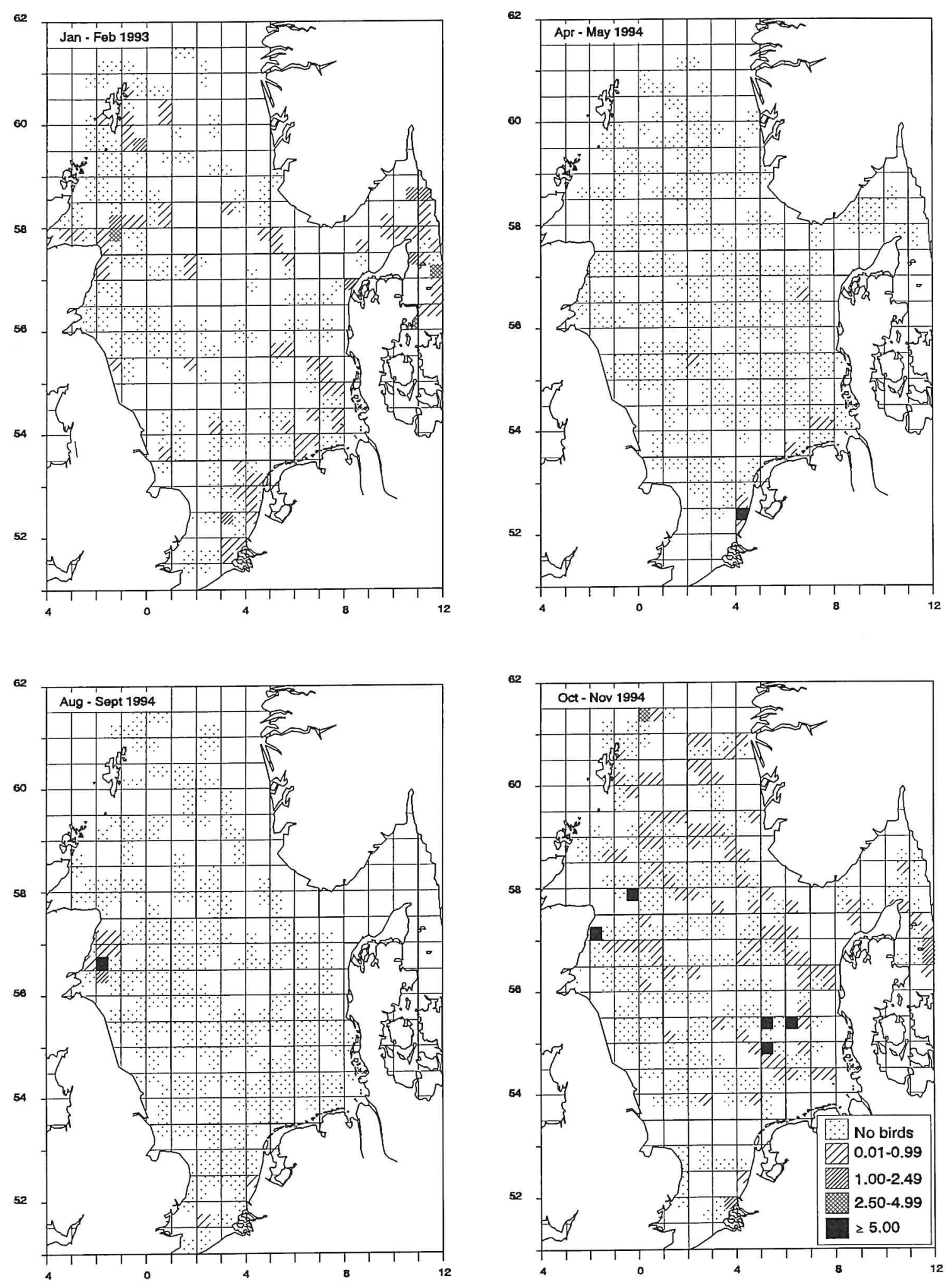

Figure 4.1.23-26 Distribution of Herring Gull from strip-transect counts 

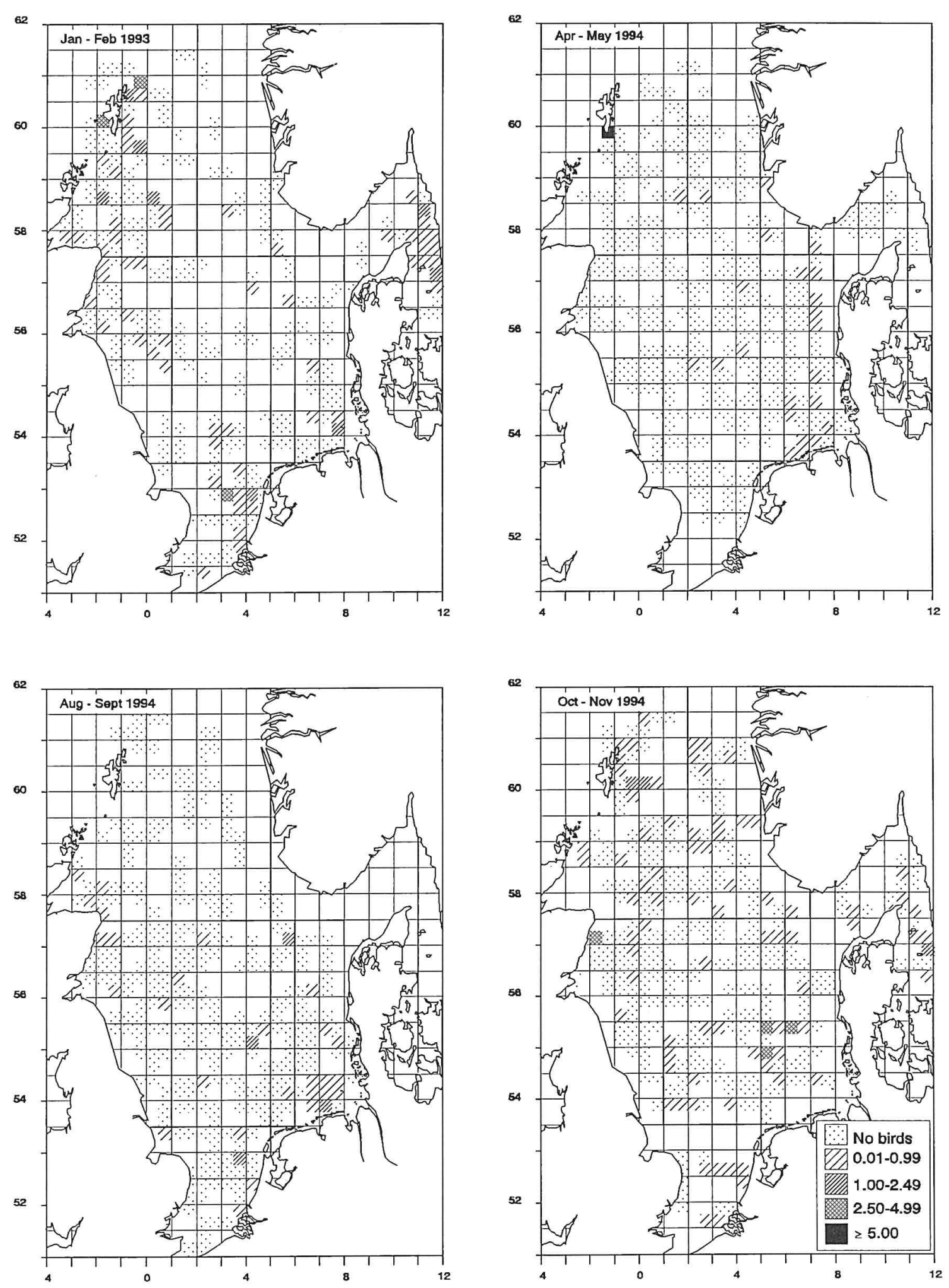

Figure 4.1.27-30 Distribution of Great Black-backed Gull from strip-transect counts 

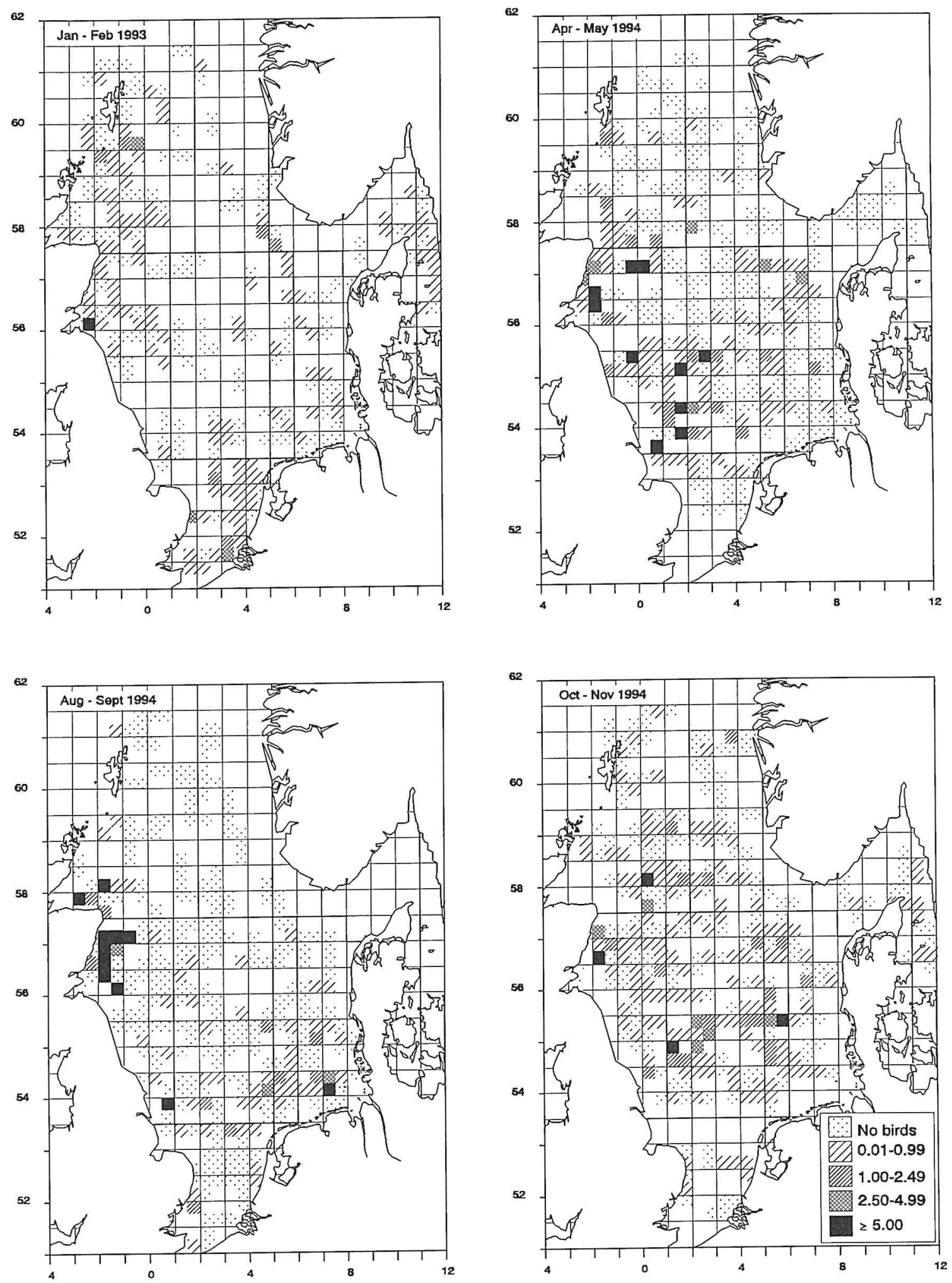


\section{Estimates of total numbers: inter-observer variance}

Transect counts indexes of population size, representing an unknown proportion of the actual numbers of birds present, and, as such, they are subject to bias (Sauer et al. 1994). There has been very little investigation into inter-observer variance or comparison of data provided by observers with different skills/training or field methods. Observers undoubtly differ considerably in their ability to detect and identify birds but data from trained observers have generally been accepted at face value, to be incorporated into the database. This project provided a unique opportunity to investigate the effect of different observers on the database because the surveys by the various vessels overlapped both spatially and temporally. The accuracy of estimates suffers from at least two methodological shortcomings of the sampling procedure. Firstly, sampling is restricted to non-randomly chosen sample plots (a strip transect or a segment of a strip transect may be regarded as a sample plot). Strictly speaking, in such case probability sampling theory can not provide the basis for inference. Secondly, the strip transect counts themselves could be subject to inaccuracy. Detection and identification of birds may be influenced by weather and seastate conditions, characteristics of the ship such as height of the observation platform, and the skills of the different observers. The effect of different observer teams was examined using the results of strip-transect counts from each of the four surveys (Van der Meer \& Camphuysen in press).

A total of ten different fisheries research vessels were engaged in the four surveys (survey no. 1-4) selected for this project, in size ranging from $48-80 \mathrm{~m}$ total length. A total of 20 observers were recruited from 6 different sources. It was supposed that for each survey within each subregion the expected number of birds observed by a team is directly proportional to the area surveyed, multiplied by the effect due to seastate, multiplied by an observer effect. Two seas- tate categories were distinguished: calm (seastate 1-3) and moderate to rough (seastate 4-6; Mitchell et al. 1980). The observer effect was characterised by the observer team (A-F). No attention was paid to withinteam differences in ship type or individual observers. For the random variation the assumption of a Poisson-like distribution (where the dispersion of the data is equal to some unknown constant, the so-called dispersion factor, multiplied by the dispersion predicted by the Poisson model) seems reasonable. This leads to the log-linear model:

\section{$\log$ (expected number of birds) $=$ constant $+\log$ (area) + (effect due to survey * subregion) + (effect due to seastate) + (observer effect)}

(see for further details Van der Meer \& Camphuysen in press). Parameter estimates for the observer effects show that major differences occur among observer teams. For example, team $A$ reported (in the same survey, and the same subregion) about 2-3 times more Kittiwakes than teams $D$ and $E$. These teams in turn reported about 3-5 times more Kittiwakes than teams B, C, and F. Although the ship transects within each subregion were neither randomly nor systematically located, they largely overlapped (figures 3.3.1-4, tables 3.3.1-4) and the consistency of differences between observer teams suggests that such differences are genuine. Observer differences were probably mainly caused by (a) differences in methods (performance of snap-shot, one or two observers, use of binoculars to detect birds, observations made from inside or on deck) and (b) individual skills. The former aspect was tackled during the inter-calibration cruises, but it appeared differences in methods between teams could not be fully eliminated. Differences between observers in this study were significant and clearly have major impact on estimates of total abundance. For example, if observer effects are ignored (and it is assumed that all teams observe all birds in the transect), the total number of Fulmars 
in the North Sea during the August survey is estimated at 1.8 million birds. If observer effects are taken into account (and if it is assumed that only the team with highest overall densities does not miss or doublecount birds) the estimate increases to more than 3.5 million birds (table 4.1.14).

\section{Conclusions}

Of the 29 species which were attracted during fishing, eight species were common at sea in any one season, including Fulmar, Gannet, Great Skua, Common Gull, Lesser Black-backed Gull, Herring Gull, Great Blackbacked Gull and Kittiwake. Of these species, Fulmar, Gannet and Kittiwake occurred all year in large numbers. Common Gull, Herring Gull and Great Black-backed Gull were most numerous in winter and Great Skua and Lesser Black-backed Gull were most numerous in summer. Fulmar, Gannet, Great Skua and Kittiwake were particularly numerous in the northwestern half of the North Sea, whereas Common Gull and Lesser Blackbacked Gull were most abundant in the Skagerrak, German Bight and Southern Bight. Great Black-backed Gull and Herring Gull were widespread. Estimates of total numbers of seabirds at sea as derived from striptransect counts during these surveys are probably on the conservative side, because (1) the coastal zone was poorly covered and (2) inter-observer differences appeared to have been substantial.

\subsection{TOTAL NUMBERS OF SEABIRDS AT SEA}

European Seabirds at Sea database; brief history

Studies of seabirds at sea in European waters began as long ago as the 1920s (Jespersen 1930, Wynne-Edwards 1935). These studies, and most of those until the 1970s, were essentially academic in nature, focusing on migration patterns and how seabirds related to their marine environment. The discovery of oil in the North Sea raised con- cerns that seabirds would be placed at risk, and led to demands to find which areas of the North Sea were most important for seabirds and when. Within the United Kingom, the 'Seabirds at Sea Team' (SAST) was established in 1979, largely to meet these demands. SAST started by surveying the northern North Sea, and has gone on to carry out surveys in virtually all UK waters and many adjacent areas. An early step was the establishment of standard methods for counting birds at sea that gave an acceptable estimate of birds per unit area, comparatively free of major sources of bias (Tasker et al. 1984).

Seabirds are, however, wide ranging animals, and can move considerable distances in short periods of time. In order to understand their distribution and movements, both for pure biological reasons and for conservation purposes, they need to be studied over their full range. Fortunately, several further projects commenced in European waters based in states bordering both the North and Baltic Seas. Most of these projects used the same or compatible survey methods with the standard developed earlier. In 1991, as part of the North Sea ministerial process, funding was received from the UK government to bring together data sets from north-western Europe and form the European Seabirds at Sea Database (ESAS). This project established common standards for combining the data and brought together over one million records, concerning some 13 million seabirds from waters of north-western Europe, including data from Norway, Sweden, Denmark, Germany, The Netherlands, Belgium and the United Kingdom. The project produced an atlas of seabird vulnerability to oil pollution in the North Sea (Carter et al. 1993) and several other atlases of bird distribution and vulnerability have been published or are nearing completion le.g. Camphuysen \& Leopold 1994, Jensen et al. 1994, Stone et al. 1995). The ESAS database is available as a valuable source of information for research. It has been used, for example, as part of the earlier study into seabirds feeding on fishery 
Table 4.2.1 Estimated total numbers of seabirds (x 1000, right) at sea in January-February, based on strip-transect counts in European Seabirds at Sea Database.

\begin{tabular}{|c|c|c|c|c|c|c|c|c|c|c|c|c|c|c|c|c|c|}
\hline & & verall & densi & ties ( $r$ & $\mathrm{n} / \mathrm{km}^{2}$ & & & & & & $i m a$ & $\operatorname{tes}(x$ & 100 & 00) & & & \\
\hline & Ful & Gan & GSk & CG & LBG & HG & GBG & Kit & Ful & Gan G & & CG I & BG & HG & GBG & Kit & $\Sigma$ \\
\hline $\begin{array}{l}\mathrm{NW} \\
\mathrm{NE} \\
\mathrm{Sk} \\
\mathrm{CW} \\
\mathrm{C} \\
\mathrm{CE} \\
\mathrm{S}\end{array}$ & $\begin{array}{l}3.15 \\
1.82 \\
0.74 \\
0.90 \\
1.74 \\
0.55 \\
0.32\end{array}$ & $\begin{array}{l}0.19 \\
0.12 \\
0.00 \\
0.39 \\
0.27 \\
0.00 \\
0.03\end{array}$ & $\begin{array}{r}0 \\
0.01 \\
0.00 \\
0.00 \\
0.00 \\
0.00 \\
0.00\end{array}$ & $\begin{array}{l}0.00 \\
0.18 \\
0.73 \\
0.07 \\
0.01 \\
1.46 \\
1.54\end{array}$ & $\begin{array}{l}0.00 \\
0.04 \\
0.00 \\
0.00 \\
0.00 \\
0.01 \\
0.02\end{array}$ & $\begin{array}{l}0.76 \\
0.21 \\
5.00 \\
2.98 \\
0.77 \\
1.17 \\
3.43\end{array}$ & $\begin{array}{l}0.33 \\
0.15 \\
0.86 \\
0.98 \\
0.50 \\
0.28 \\
0.73\end{array}$ & $\begin{array}{l}3.42 \\
1.62 \\
1.74 \\
0.89 \\
1.35 \\
0.64 \\
1.00\end{array}$ & $\begin{array}{r}494 \\
177 \\
44 \\
63 \\
245 \\
35 \\
18\end{array}$ & $\begin{array}{r}29 \\
12 \\
0 \\
27 \\
39 \\
0 \\
2\end{array}$ & $\begin{array}{l}0 \\
1 \\
0 \\
0 \\
0 \\
0 \\
0\end{array}$ & $\begin{array}{r}1 \\
17 \\
43 \\
5 \\
1 \\
92 \\
87\end{array}$ & $\begin{array}{l}0 \\
4 \\
0 \\
0 \\
0 \\
1 \\
1\end{array}$ & $\begin{array}{r}119 \\
20 \\
295 \\
207 \\
108 \\
74 \\
195\end{array}$ & $\begin{array}{l}51 \\
14 \\
51 \\
68 \\
71 \\
18 \\
41\end{array}$ & $\begin{array}{r}537 \\
157 \\
102 \\
62 \\
190 \\
40 \\
57\end{array}$ & $\begin{array}{r}1231 \\
402 \\
535 \\
432 \\
654 \\
260 \\
401\end{array}$ \\
\hline 2 & & & & & & & & & 1076 & 109 & 1 & 246 & & 1018 & $\begin{array}{l}3 \\
3141\end{array}$ & 1145 & 3915 \\
\hline
\end{tabular}

Table 4.2.2 Estimated total numbers of seabirds in May-June (ESAS Database).

\begin{tabular}{|c|c|c|c|c|c|c|c|c|c|c|c|c|c|c|c|c|c|}
\hline \multirow{9}{*}{$\begin{array}{l}\mathrm{NW} \\
\mathrm{NE} \\
\mathrm{Sk} \\
\mathrm{CW} \\
\mathrm{C} \\
\mathrm{CE} \\
\mathrm{S}\end{array}$} & \multicolumn{6}{|c|}{ Overall densities $\left(\mathrm{n} / \mathrm{km}^{2}\right)$} & \multirow[b]{2}{*}{ GBG } & \multirow[b]{2}{*}{ Kit } & \multirow[b]{2}{*}{ Ful } & \multicolumn{5}{|c|}{ Estimates (x 1000) } & \multirow[b]{2}{*}{ GBG } & \multirow[b]{2}{*}{ Kit } & \multirow[b]{2}{*}{$\Sigma$} \\
\hline & Ful & Gan & GSk & CG & LBG & HG & & & & Gan & SSk & CG & LBG & HG & & & \\
\hline & 9.23 & 0.20 & 0.09 & 0.00 & 0.01 & 0.41 & 0.12 & 2.45 & 1449 & 31 & 14 & 0 & 2 & 64 & 18 & 384 & 1962 \\
\hline & 2.52 & 0.06 & 0.02 & 0.00 & 0.09 & & 0.00 & & & 6 & 2 & 0 & 9 & 0 & 0 & 9 & 271 \\
\hline & 0.77 & 0.01 & & 0.17 & 0.61 & 0.51 & 0.12 & 0.05 & 45 & 1 & 0 & 10 & 36 & 30 & 7 & 3 & 132 \\
\hline & 0.98 & 0.28 & 0.00 & 0.02 & 0.04 & 0.98 & 0.11 & 2.3 & 68 & 19 & 0 & 1 & 3 & 68 & 7 & 160 & 32 \\
\hline & 1.16 & 0.03 & & 0.00 & 0.03 & 0.07 & 0.00 & 0.40 & 163 & 4 & 0 & 0 & 4 & 10 & 1 & 57 & 23 \\
\hline & 1.14 & 0.02 & 0.00 & 0.08 & 0.52 & 0.3 & 0.09 & 0.2 & 72 & 1 & 0 & 5 & 32 & 25 & 5 & 17 & 15 \\
\hline & 0.38 & 0.02 & 0.00 & 0.08 & 1.17 & 2.39 & 0.03 & 0.17 & 22 & 1 & 0 & 4 & 66 & 136 & 2 & 10 & 241 \\
\hline$\Sigma$ & & & & & & & & & 2064 & 63 & 16 & 20 & 152 & 333 & 40 & 640 & 3328 \\
\hline
\end{tabular}

Table 4.2.3 Estimated total numbers of seabirds at sea, August-September (ESAS Database).

\begin{tabular}{|c|c|c|c|c|c|c|c|c|c|c|c|c|c|c|c|c|c|}
\hline & & verall & densi & ies ( $r$ & $\mathrm{n} / \mathrm{km}^{2}$ & & & & & & tim & tes $(x$ & $\times 10$ & 00) & & & \\
\hline & Ful & Gan & GSk & CG & LBG & HG & GBG & Kit & Ful & Gan & jSk & CG & LBG & HG & GBG & Kit & $\Sigma$ \\
\hline $\begin{array}{l}N W \\
N E \\
\text { Sk } \\
C W \\
C \\
C E \\
S\end{array}$ & $\begin{array}{r}6.12 \\
14.96 \\
3.82 \\
4.35 \\
3.24 \\
4.51 \\
0.69\end{array}$ & $\begin{array}{l}0.39 \\
0.11 \\
0.04 \\
0.74 \\
0.12 \\
0.09 \\
0.17\end{array}$ & $\begin{array}{l}0.14 \\
0.03 \\
0.06 \\
0.09 \\
0.02 \\
0.04 \\
0.03\end{array}$ & $\begin{array}{l}0.00 \\
0.02 \\
0.07 \\
0.01 \\
0.01 \\
0.05 \\
0.04\end{array}$ & $\begin{array}{l}0.00 \\
0.14 \\
1.03 \\
0.09 \\
0.03 \\
0.46 \\
0.39\end{array}$ & $\begin{array}{l}0.21 \\
0.09 \\
0.65 \\
0.36 \\
0.01 \\
0.18 \\
1.22\end{array}$ & $\begin{array}{l}0.16 \\
0.57 \\
0.28 \\
0.65 \\
0.05 \\
0.13 \\
0.21\end{array}$ & $\begin{array}{l}2.07 \\
0.17 \\
0.31 \\
3.52 \\
0.21 \\
0.31 \\
0.20\end{array}$ & $\begin{array}{r}960 \\
1455 \\
225 \\
302 \\
457 \\
283 \\
39\end{array}$ & $\begin{array}{r}62 \\
10 \\
2 \\
52 \\
17 \\
6 \\
10\end{array}$ & $\begin{array}{r}21 \\
3 \\
3 \\
6 \\
3 \\
2 \\
2\end{array}$ & $\begin{array}{l}0 \\
2 \\
4 \\
1 \\
1 \\
3 \\
2\end{array}$ & $\begin{array}{r}1 \\
13 \\
61 \\
6 \\
4 \\
29 \\
22\end{array}$ & $\begin{array}{r}33 \\
9 \\
39 \\
25 \\
1 \\
11 \\
69\end{array}$ & $\begin{array}{r}26 \\
55 \\
16 \\
45 \\
7 \\
8 \\
12\end{array}$ & $\begin{array}{r}325 \\
16 \\
18 \\
244 \\
30 \\
19 \\
11\end{array}$ & $\begin{array}{r}1428 \\
1563 \\
368 \\
681 \\
520 \\
361 \\
167\end{array}$ \\
\hline & & & & & & & & & 3721 & 159 & 40 & 13 & 136 & 187 & 169 & 663 & 5088 \\
\hline
\end{tabular}

Table 4.2.4 Estimated total numbers of seabirds at sea, October-November (ESAS Database).

\begin{tabular}{|c|c|c|c|c|c|c|c|c|c|c|c|c|c|c|c|c|c|}
\hline & \multicolumn{6}{|c|}{ Overall densities $\left(\mathrm{n} / \mathrm{km}^{2}\right)$} & \multirow[b]{2}{*}{ GBG } & \multirow[b]{2}{*}{ Kit } & \multirow[b]{2}{*}{ Ful } & \multicolumn{5}{|c|}{ Estimates (x 1000) } & \multirow[b]{2}{*}{ GBG } & \multirow[b]{2}{*}{ Kit } & \multirow[b]{2}{*}{$\Sigma$} \\
\hline & Ful & Gan & GSk & CG & LBG & HG & & & & Gan GS & & CG L & LBG & HG & & & \\
\hline $\begin{array}{l}\text { NW } \\
\text { NE } \\
\text { Sk } \\
\text { CW } \\
\text { C } \\
\text { CE } \\
\text { S }\end{array}$ & $\begin{array}{r}11.00 \\
4.95 \\
1.64 \\
1.40 \\
1.92 \\
2.10 \\
0.23\end{array}$ & $\begin{array}{l}0.22 \\
0.21 \\
0.04 \\
0.31 \\
0.26 \\
0.15 \\
0.36\end{array}$ & $\begin{array}{l}0.01 \\
0.01 \\
0.00 \\
0.01 \\
0.01 \\
0.01 \\
0.01\end{array}$ & $\begin{array}{l}0.00 \\
0.02 \\
0.30 \\
0.06 \\
0.03 \\
0.15 \\
0.67\end{array}$ & $\begin{array}{l}0.31 \\
0.01 \\
0.02 \\
0.07 \\
0.01 \\
0.03 \\
0.38\end{array}$ & $\begin{array}{l}3.05 \\
1.39 \\
4.36 \\
2.68 \\
0.27 \\
1.00 \\
5.60\end{array}$ & $\begin{array}{l}0.98 \\
0.26 \\
0.49 \\
1.27 \\
0.50 \\
0.23 \\
0.95\end{array}$ & $\begin{array}{l}4.67 \\
1.02 \\
2.31 \\
2.02 \\
1.46 \\
1.31 \\
0.79\end{array}$ & $\begin{array}{r}1726 \\
481 \\
96 \\
97 \\
270 \\
132 \\
13\end{array}$ & $\begin{array}{r}35 \\
21 \\
2 \\
21 \\
37 \\
9 \\
20\end{array}$ & $\begin{array}{l}2 \\
1 \\
0 \\
0 \\
1 \\
0 \\
0\end{array}$ & $\begin{array}{r}0 \\
2 \\
18 \\
4 \\
4 \\
9 \\
38\end{array}$ & $\begin{array}{r}49 \\
1 \\
1 \\
5 \\
2 \\
2 \\
22\end{array}$ & $\begin{array}{r}478 \\
135 \\
257 \\
186 \\
38 \\
63 \\
318\end{array}$ & $\begin{array}{r}153 \\
25 \\
29 \\
88 \\
70 \\
14 \\
54\end{array}$ & $\begin{array}{r}733 \\
99 \\
136 \\
141 \\
206 \\
82 \\
45\end{array}$ & $\begin{array}{r}3176 \\
765 \\
539 \\
542 \\
628 \\
311 \\
510\end{array}$ \\
\hline$\Sigma$ & & & & & & & & & 2815 & 145 & 4 & 75 & & 1475 & 4331 & 1442 & 6471 \\
\hline
\end{tabular}


waste in the North Sea (Camphuysen et al. 1993) and to compare seabird distribution with that of fish stocks (Jensen et al. 1994).

\section{Abundance estimates: ESAS versus IBTS}

For the current project, abundance estimates were derived from the ESAS database and these were compared with estimates calculated from the IBTS censuses conducted in 1993 and 1994 under the two 'discards projects'. Estimates of abundance calculated from the ESAS database are listed in tables 4.2.1-4. For these estimates, birds in transect but associated with fishing vessels were included. Densities and estimates of total numbers were calculated over the same seven subregions as used throughout this report and the data are the sum of all information collected from 1979-92 (ESAS 2nd update). ESAS estimates were calculated over January-February (table 4.2.1), MayJune (table 4.2.2), August-September (table 4.2.3), and October-November (table 4.2.4) and compared with total numbers of seabirds calculated to occur within the North Sea during the four surveys of the current project. Estimates for 1993-94 surveys are derived from a combination of results from transect counts (but excluding birds associated with fishing vessels; i.e. tables 4.1.1-4), plus the birds at fishing vessels calculated from the mean number at boats (tables 4.5.2-9) multiplied by the total number of boats in each subregion (table 4.4.4).

\section{Total numbers according to ESAS}

Of the eight main species under consideration in this project, the Fulmar is the most abundant and widespread. Between one (Jan-Feb) and four million individuals (AugSep) were estimated to occur in North Sea waters, with highest densities in the northern North Sea (subregions NW and NE). Numbers were comparatively small in the Skagerrak (Sk ranged 44,000 in Jan-Feb to 225,000 in Aug-Sep), but lowest in the Southern Bight (S ranged 13,000 in Oct-Nov to 39,000 in Aug-Sep). Numbers of Gannets ranged from just over 60,000 in May-June to around 160,000 in August-September and this species was also common in all seasons. The northern and western half of the North Sea (NW, NE, CW) was of much greater significance than the eastern seaboard (Sk, $\mathrm{CE})$. In the latter area a maximum of only a few thousands were estimated to occur. The Great Skua was scarce in winter (1000 JanFeb, 4000 Oct-Nov), but more numerous in summer $(16,000$ May-Jun; 40,000 AugSep). In early summer, most records were around the breeding stations in Orkney and Shetland, whereas by August Great Skuas occurred in low densities in all subregions. Common Gulls differ from the species discussed so far, with highest densities in winter in the southeastern half of the North Sea and in the Skagerrak. Peak numbers were found in January-February (nearly a quarter of a million individuals) and low numbers were observed in summer $(20,000$ May-Jun, 13,000 Aug-Sep). The most important areas for Common Gulls were the Southern and German Bights, the Skagerrak and coastal waters around southwest Norway. Small numbers were found along the British east coast. Lesser Black-backed Gulls had a fairly similar overall distribution, but mainly as a summer visitor in the North Sea. Abundance estimates peaked in May-June (ca. 150,000 individuals) and August-September (nearly $140,000)$. It is difficult to explain the 50,000 Lesser Black-backed Gulls in subregion NW in October-November, by which time the majority of this species has migrated southwards out of the North Sea. The third most abundant species is the Herring Gull, of which over a million individuals spend the winter in the North Sea. In summer, overall numbers were still higher than those of Lesser Black-backed Gulls, but only a fraction of the winter population. Herring Gulls were widespread in all seasons, but the Southern Bight (year round), Skagerrak (particularly in winter) and waters around Shetland and Orkney and off the British east coast (winter) are of particular significance. Numbers of Great Black-backed Gulls varied by a factor of 10 from 40,000 in May-June to 430,000 
Table 4.2.5 Comparisons of estimated total numbers $(x 1000)$ of seabirds in the North Sea based on ESAS Database over January-February (left) and the February 1993 IBTS (right).

ESAS Database Jan-Feb $\quad$ IBTS Febr'93 IBTS/ Ful Gan GSk CG LBG HG GBG Kit $\Sigma$ Ful Gan GSk CG LBG HG GBG Kit $\Sigma$ ESAS

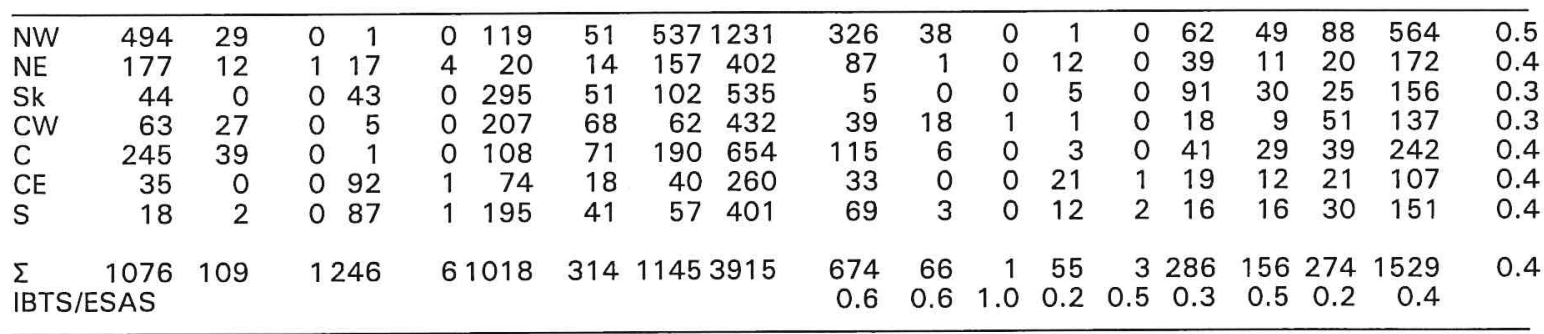

Table 4.2.6 Comparisons of estimated total numbers (x1000) of seabirds in the North Sea based on ESAS Database over May-June (left) and the May 1994 IBTS (right).

\begin{tabular}{|c|c|c|c|c|c|c|c|c|c|c|c|c|c|c|c|c|c|c|c|}
\hline & & & AS D & atab & lase $\mathrm{N}$ & lay-Ju & & & & & & & & IBT & $\mathrm{S} \mathbf{M a}$ & & . & & IBTS/ \\
\hline & Ful & Gan & GSk & CG & LBG & HG & GBG & Kit & $\Sigma$ & Ful & Gan & GSk & CG & & & & Kit & $\Sigma$ & \\
\hline NW & 1449 & 31 & 14 & 0 & 2 & 64 & 18 & 3841 & 1962 & 303 & 19 & 1 & 0 & 1 & 0 & 14 & 38 & 377 & 0.2 \\
\hline & & 6 & 2 & 0 & 9 & 0 & & & & & & & 0 & 4 & 0 & 2 & 7 & & 0.5 \\
\hline $5 k$ & 4 & 1 & 0 & 10 & 36 & 30 & 7 & 3 & 132 & 11 & 0 & 0 & 0 & 13 & 0 & 1 & 0 & 25 & 0.2 \\
\hline CW & 6 & 19 & 0 & 1 & 3 & 6 & 7 & 160 & & & 3 & 0 & 0 & 1 & 0 & 0 & 505 & & 1.7 \\
\hline & 163 & 4 & 0 & 0 & 4 & 10 & 1 & 57 & 235 & 211 & 83 & 0 & 0 & 12 & 2 & 1 & 106 & & $\varepsilon$ \\
\hline CE & & 1 & 0 & 5 & 32 & 2 & & & & & 7 & 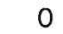 & c & 1 & 1 & 3 & 10 & & 1. \\
\hline & 22 & $i$ & 0 & 4 & 66 & 136 & 2 & 10 & 241 & 14 & 4 & 0 & 1 & 41 & 56 & 2 & 15 & 137 & 0.6 \\
\hline 37 & $\begin{array}{l}2064 \\
\text { SAS }\end{array}$ & 63 & 16 & 20 & 152 & 333 & 40 & 6403 & 3328 & $\begin{array}{r}846 \\
0.4\end{array}$ & $\begin{array}{r}151 \\
2.4\end{array}$ & $\begin{array}{r}1 \\
0.1\end{array}$ & $\begin{array}{r}1 \\
0.1\end{array}$ & $\begin{array}{r}90 \\
0.6\end{array}$ & $\begin{array}{r}59 \\
0.2\end{array}$ & $\begin{array}{r}23 \\
0.6\end{array}$ & $\begin{array}{r}681 \\
1.1\end{array}$ & $\begin{array}{r}1863 \\
0.6\end{array}$ & 0.6 \\
\hline
\end{tabular}

Table 4.2.7 Comparisons of estimated total numbers ( $x 1000$ ) of seabirds in the North Sea based on ESAS Database over August-September (left) and the August 1994 IBTS (right).

\begin{tabular}{|c|c|c|c|c|c|c|c|c|c|c|c|c|c|c|c|c|c|c|c|}
\hline & & & SAS D & atab & ase $A$ & ug-Sep & & & & & & & & BTS A & Augus & & & & IBTS/ \\
\hline & Ful & Gan & GSk & CG & LBG & $\mathrm{HG}$ & GBG & Kit & $\Sigma$ & Ful & Gan & GSk & CG & LBG & HG & GBG & Kit & $\Sigma$ & ESAS \\
\hline $\begin{array}{l}\text { NW } \\
\text { NE } \\
\text { Sk } \\
\text { CW } \\
C \\
\text { CE } \\
\text { S }\end{array}$ & $\begin{array}{r}960 \\
1455 \\
225 \\
302 \\
457 \\
283 \\
39\end{array}$ & $\begin{array}{r}62 \\
10 \\
2 \\
52 \\
17 \\
6 \\
10\end{array}$ & $\begin{array}{r}21 \\
3 \\
3 \\
6 \\
3 \\
2 \\
2\end{array}$ & $\begin{array}{l}0 \\
2 \\
4 \\
1 \\
1 \\
3 \\
2\end{array}$ & $\begin{array}{r}1 \\
13 \\
61 \\
6 \\
4 \\
29 \\
22\end{array}$ & $\begin{array}{r}33 \\
9 \\
39 \\
25 \\
1 \\
11 \\
69\end{array}$ & $\begin{array}{r}26 \\
55 \\
16 \\
45 \\
7 \\
8 \\
12\end{array}$ & $\begin{array}{r}3251 \\
161 \\
18 \\
244 \\
30 \\
19 \\
11\end{array}$ & $\begin{array}{l}428 \\
563 \\
368 \\
681 \\
520 \\
361 \\
167\end{array}$ & $\begin{array}{r}620 \\
507 \\
0 \\
226 \\
414 \\
76 \\
59\end{array}$ & $\begin{array}{r}54 \\
4 \\
0 \\
34 \\
19 \\
5 \\
3\end{array}$ & $\begin{array}{r}23 \\
2 \\
0 \\
1 \\
2 \\
1 \\
1\end{array}$ & $\begin{array}{l}0 \\
1 \\
0 \\
0 \\
1 \\
1 \\
0\end{array}$ & $\begin{array}{r}1 \\
4 \\
0 \\
1 \\
39 \\
102 \\
17\end{array}$ & $\begin{array}{r}0 \\
0 \\
0 \\
15 \\
0 \\
0 \\
2\end{array}$ & $\begin{array}{r}6 \\
0 \\
0 \\
3 \\
1 \\
12 \\
4\end{array}$ & $\begin{array}{r}80 \\
2 \\
0 \\
942 \\
23 \\
22 \\
9\end{array}$ & $\begin{array}{r}784 \\
520 \\
0 \\
1222 \\
499 \\
219 \\
95\end{array}$ & $\begin{array}{l}0.5 \\
0.3 \\
0.0 \\
1.8 \\
1.0 \\
0.6 \\
0.6\end{array}$ \\
\hline$\sum_{\text {IBTS }}$ & $\begin{array}{l}3721 \\
\text { SAS }\end{array}$ & 159 & 40 & 13 & 136 & 187 & 169 & 6635 & 5088 & $\begin{array}{r}1902 \\
0.5\end{array}$ & $\begin{array}{r}119 \\
0.7\end{array}$ & $\begin{array}{r}30 \\
0.8\end{array}$ & $\begin{array}{r}3 \\
0.2\end{array}$ & $\begin{array}{r}164 \\
1.2\end{array}$ & $\begin{array}{r}17 \\
0.1\end{array}$ & $\begin{array}{l}261 \\
0.2\end{array}$ & $\begin{array}{r}078 \\
1.6\end{array}$ & $\begin{array}{r}3339 \\
0.7\end{array}$ & 0.7 \\
\hline
\end{tabular}

Table 4.2.8 Comparisons of estimated total numbers ( 1000 ) of seabirds in the North Sea based on ESAS Database over October-November (left) and the November 1994 IBTS (right).

\begin{tabular}{|c|c|c|c|c|c|c|c|c|c|c|c|c|c|c|c|c|c|c|c|}
\hline & Ful & $\begin{array}{c}E \\
\text { Gan }\end{array}$ & $\begin{array}{l}\text { GAS D } \\
\text { GSK }\end{array}$ & $\begin{array}{c}\text { Datab } \\
\text { CG }\end{array}$ & $\begin{array}{l}\text { ase Oc } \\
\text { LBG }\end{array}$ & $\begin{array}{c}\text { ct-Nov } \\
\text { HG }\end{array}$ & GBG & Kit & $\Sigma$ & Ful & Gan & GSk & $\begin{array}{l}\text { IBTS } \\
\text { CG }\end{array}$ & $\begin{array}{l}\text { Nov } \\
\text { LBG }\end{array}$ & $\begin{array}{c}\text { vembe } \\
\text { HG }\end{array}$ & GBG & Kit & $\Sigma$ & $\begin{array}{l}\text { IBTS/ } \\
\text { ESAS }\end{array}$ \\
\hline $\begin{array}{l}\text { NW } \\
\text { NE } \\
\text { Sk } \\
\text { CW } \\
\text { C } \\
\text { CE } \\
\text { S }\end{array}$ & $\begin{array}{r}1726 \\
481 \\
96 \\
97 \\
270 \\
132 \\
13\end{array}$ & $\begin{array}{r}35 \\
21 \\
2 \\
21 \\
37 \\
9 \\
20\end{array}$ & $\begin{array}{l}2 \\
1 \\
0 \\
0 \\
1 \\
0 \\
0\end{array}$ & $\begin{array}{r}0 \\
2 \\
18 \\
4 \\
4 \\
9 \\
38\end{array}$ & $\begin{array}{r}49 \\
1 \\
1 \\
5 \\
2 \\
2 \\
22\end{array}$ & $\begin{array}{r}478 \\
135 \\
257 \\
186 \\
38 \\
63 \\
318\end{array}$ & $\begin{array}{r}153 \\
25 \\
29 \\
88 \\
70 \\
14 \\
54\end{array}$ & $\begin{array}{r}733 \\
99 \\
136 \\
141 \\
206 \\
82 \\
45\end{array}$ & $\begin{array}{l}3176 \\
765 \\
539 \\
542 \\
628 \\
311 \\
510\end{array}$ & $\begin{array}{r}1234 \\
315 \\
33 \\
51 \\
163 \\
52 \\
0\end{array}$ & $\begin{array}{r}41 \\
26 \\
0 \\
15 \\
44 \\
4 \\
45\end{array}$ & $\begin{array}{l}0 \\
0 \\
0 \\
0 \\
3 \\
1 \\
0\end{array}$ & $\begin{array}{l}0 \\
0 \\
5 \\
1 \\
1 \\
2 \\
4\end{array}$ & $\begin{array}{l}2 \\
0 \\
0 \\
0 \\
3 \\
0 \\
7\end{array}$ & $\begin{array}{r}48 \\
20 \\
32 \\
298 \\
23 \\
48 \\
10\end{array}$ & $\begin{array}{l}29 \\
17 \\
14 \\
10 \\
18 \\
16 \\
13\end{array}$ & $\begin{array}{r}132 \\
11 \\
11 \\
67 \\
135 \\
34 \\
13\end{array}$ & $\begin{array}{r}1513 \\
391 \\
100 \\
473 \\
397 \\
161 \\
92\end{array}$ & $\begin{array}{l}0.5 \\
0.5 \\
0.2 \\
0.9 \\
0.6 \\
0.5 \\
0.2\end{array}$ \\
\hline $\begin{array}{l}\sum \\
\mid \mathrm{BTS} \text { | }\end{array}$ & $\begin{aligned} & 2815 \\
& \text { ESAS }\end{aligned}$ & 145 & 4 & 75 & 821 & 475 & 433 & 14426 & 347 & $\begin{array}{r}1848 \\
0.7\end{array}$ & $\begin{array}{r}175 \\
1.2\end{array}$ & $\begin{array}{r}4 \\
1.0\end{array}$ & $\begin{array}{r}13 \\
0.2\end{array}$ & $\begin{array}{r}12 \\
0.1\end{array}$ & $\begin{array}{r}479 \\
0.3\end{array}$ & $\begin{array}{r}117 \\
0.3\end{array}$ & $\begin{array}{r}403 \\
0.3\end{array}$ & $\begin{array}{r}3127 \\
0.5\end{array}$ & 0.5 \\
\hline
\end{tabular}


in October-November. In all seasons, Great Black-backed Gulls were widespread, present in all subregions at roughly equal densities. The Kittiwake is the second most abundant of species considered here, with overall numbers ranging from approximately 650,000 in summer to 1.5 million in October-November. The most important areas are the northwestern North Sea and waters of the English northeast coast (subregions NW and (W). The Southern Bight and German Bight are relatively unimportant areas for this species.

Total numbers of seabirds in the North Sea: ESAS and IBTS compared

The overall estimates on the basis of IBTS surveys in 1993 and 1994 are approximately half those derived from the ESAS database (tables 4.2.5-8). The abundance estimates for Common Gull (all year) and Herring Gull (summer) from the IBTS are particularly low compared to ESAS. For these species, the differences can be explained by the typically inshore distributions in these seasons. In winter, when Herring Gulls occur more frequently offshore, the estimates from ESAS and IBTS are better matched. Estimates for Fulmar derived from ESAS are generally twice as high as those from the IBTS, but the overall distribution is similar. The large numbers of Fulmars in the Southern Bight in February 1993 is clearly unsual and may be related to severe weather in January. Estimated numbers of Gannets in May from the IBTS survey were considerably higher than those from ESAS, the difference lying in the high densities in subregions $\mathrm{CW}$ and $\mathrm{C}$ in May 1994. These observations were unusual in that substantial numbers of Gannets from Bass Rock were foraging over $300 \mathrm{~km}$ away from the colony (Camphuysen et al. 1995). At other times of year, estimates from the IBTS are a lot closer to the ESAS estimates than for any of the other species except the Great Skua. In May, when most Great Skuas are at or very near their colonies in Shetland and Orkney, overall numbers were seriously underestimated by the offshore oriented
IBTS surveys. In the other seasons, IBTS and ESAS estimates and distribution patterns match quite well. As discussed earlier, Common Gull numbers were certainly underestimated by the IBTS surveys, but the seasonal pattern is very similar to that found in ESAS. IBTS estimates of Lesser Black-backed Gulls were rather low in November, when overall numbers are comparatively small, but similar to those from ESAS in (early) summer. This species ventures further out to sea during the breeding season than the Herring Gull (Camphuysen in press), which supports the suggestion the inshore distribution of some species accounted at least partly for the low estimates from the IBTS project. Herring Gull estimates derived from IBTS were low compared to ESAS, particularly in summer when breeding birds mainly forage inland or in the littoral zone. Estimates of numbers of Kittiwakes derived from the IBTS surveys were low in winter and high in summer in comparison to ESAS. Both in May and August this has been caused by very high estimates for subregion $\mathrm{CW}$ (IBTS/ESAS $=3.1$ and 3.9 respectively). In both May and August 1994, major feeding concentrations were located in areas where high numbers have not been frequently recorded in previous years.

\section{Conclusions}

In conclusion, estimates derived from the IBTS surveys in 1993 and 1994 appear to be rather conservative. However, overall distribution patterns and seasonal patterns match quite well with ESAS database. To obtain a more complete picture of total numbers of seabirds at sea, the coastal zone should be studied in more detail in North Sea wide surveys. For the purpose of this study it was considered most practical to use the range of abundance estimates derived from the two datasets as described in this chapter. Hence, for the eight species under consideration in this study, it was estimated that in February between 1.5 million and 4.0 million individuals occurred in the North Sea, 0.7-1.1 million of which were Fulmars, 0.3-1.0 million were Herring Gulls and 0.3-1.1 million were Kitti 
Table 4.2.9 Abundance estimates (millions) of commonly scavenging seabirds in the North Sea, from estimates derived from ESAS Database and from IBTS surveys in 1993 and 1994 (see text).

\begin{tabular}{lcccc}
\hline & February & May & August & November \\
\hline Fulmar & $0.7-1.1$ & $0.8-2.1$ & $1.9-3.7$ & $1.8-2.8$ \\
Gannet & $0.1-0.1$ & $0.1-0.2$ & $0.1-0.2$ & $0.1-0.2$ \\
Great Skua & $<0.1$ & $<0.1$ & $<0.1$ & $<0.1$ \\
Common Gull & $0.1-0.2$ & $<0.1$ & $<0.1$ & $<0.1$ \\
Lesser Bl-b Gull & $<0.1$ & $0.1-0.2$ & $0.1-0.2$ & $<0.1$ \\
Herring Gull & $0.3-1.0$ & $0.1-0.3$ & $<0.1-0.2$ & $0.5-1.5$ \\
Great Bl-b Gull & $0.2-0.3$ & $<0.1$ & $<0.1$ & $0.1-0.4$ \\
Kittiwake & $0.3-1.1$ & $0.6-0.7$ & $0.7-1.1$ & $0.4-1.4$ \\
All species & $1.5-4.0$ & $2.0-3.5$ & $3.5-5.0$ & $3.0-6.5$ \\
\hline
\end{tabular}

wakes (table 4.2.9). In May, between 2.0 and 3.5 million individuals were estimated to occur, 0.8-2.1 million of which were Fulmars, 0.6-0.7 million were Kittiwakes. In August, between 3.5 and 5.0 million scavenging seabirds occurred in the North Sea, 1.9-3.7 million of which were Fulmars, 0.71.1 million were Kittiwakes. Finally, in November, between 3.0 and 6.5 million seabirds were estimated to occur in the North Sea proper, of which 1.8-2.8 million Fulmars, 0.5-1.5 million Herring Gulls and 0.41.4 million Kittiwakes. All other species probably did not exceed 300,000 individuals at any season.

\subsection{SEABIRDS SCAVENGING AT THE STERN}

The attraction of scavenging seabirds to fishing vessels was studied indirectly by means of stern counts onboard fisheries research vessels. The aim of stern counts was to assess species and age composition of scavengers at the trawl and how this varied between subregions. The total numbers associated with commercial fishing vessels tend to be higher because their fishing activities are more continuous. Having determi- ned in the previous project which of the ship's activities were most attractive to scavenging seabirds, in the 1994 surveys the maximum number of each species at a given haul (the 'maximum count') was assessed and used as an index of its abundance. All seabirds associated with the ship were recorded, whether or not discard experiments were performed. In total, from all research vessels, stern counts were made for 849 hauls, ranging from 188 hauls in February to 268 hauls in May (table 4.3.1, figures 4.3.1-4). Usually a haul was followed by several hours of steaming at full speed before the net was shot again. A notable exception occurred during the May 1994 survey, when the RV Walther Herwig spent several days fishing in four small areas (boxes, hauls 99-111, 134-150, 175-198, and 215-225; figure 4.3.2). The mean number of birds from stern counts in each box was used in plotting distribution maps. Twentynine species were recorded as ship-associates during trawling, and only a few species were commonly present. Ranking these species for each survey in four abundance classes $100=>100 /$ haul, $0=10$ $100 /$ haul, $\bullet=1-10 /$ haul, $\circ=<1 /$ haul), the occurrence and relative abundance of these species in the North Sea can be summarised 
as follows:

\begin{tabular}{|c|c|c|c|c|}
\hline & 1993 & 1994 & 1994 & 1994 \\
\hline & Febr & May & Aug & Nov \\
\hline $\begin{array}{l}\text { Fulmar } \\
\text { Sooty Shearwater }\end{array}$ & 0 & & $\begin{array}{c}0 \\
0\end{array}$ & $\begin{array}{c}0 \\
0\end{array}$ \\
\hline Manx Shearwater & o & & & \\
\hline $\begin{array}{l}\text { Storm Petrel } \\
\text { Gannet }\end{array}$ & 0 & 0 & $\stackrel{\circ}{\circ}$ & (0) \\
\hline Cormorant & & $\circ$ & & \\
\hline Shag & & & & $\circ$ \\
\hline Pomarine Skua & & $\circ$ & $\circ$ & $\circ$ \\
\hline Arctic Skua & & $\circ$ & $\circ$ & o \\
\hline Long-tailed Skua & & & o & \\
\hline Great Skua & o & $\circ$ & - & $\circ$ \\
\hline Mediterranean Gull & o & & & \\
\hline Little Gull & $\circ$ & $\circ$ & $\circ$ & $\circ$ \\
\hline Sabine's Gull & & & $\circ$ & \\
\hline Black-h Gull & $\circ$ & $\circ$ & $\circ$ & o \\
\hline Common Gull & - & $\circ$ & $\circ$ & - \\
\hline Lesser Bl-b Gull & o & O & 0 & - \\
\hline Herring Gull & 0 & $\bullet$ & $\circ$ & - \\
\hline Yellow-legged Gull & & & & \\
\hline Iceland Gull & $\circ$ & & & \\
\hline Glaucous Gull & $\circ$ & & & $\circ$ \\
\hline Great BI-b Gull & ○ & - & - & \\
\hline Kittiwake & 0 & 0 & $\bullet$ & 00 \\
\hline Sandwich Tern & & $\circ$ & & \\
\hline Common Tern & & $\circ$ & $\circ$ & \\
\hline Arctic Tern & & $\circ$ & 0 & \\
\hline Black Tern & & $\circ$ & $\circ$ & \\
\hline Guillemot & o & & & \\
\hline Razorbill & o & & & \\
\hline
\end{tabular}

Fulmar, Gannet, Lesser Black-backed Gull, Herring Gull, Great Black-backed Gull and Kittiwake were attracted in large numbers during most of the year, although distinct seasonal patterns were evident. Common Gull and Black-headed Gull would probably have been recorded in larger numbers had further surveys been conducted closer inshore, particularly off the Dutch and German coasts (Berghahn \& Rösner 1992, Camphuysen 1993a, Walter \& Becker 1994). Great Skuas appeared at the trawl in small numbers through the year, but particularly in late summer. The remaining twenty species are not considered to contribute significantly to overall consumption of discards.

\section{Fulmar}

Fulmars were the most abundant scavengers at the trawl in most of the North Sea during much of the year. In each of the surveys peak numbers assembling at the trawl were in the range of 2000-2500 Fulmars. Fulmars were not evenly distributed over the entire North Sea. The largest numbers were usually reported in the northwest (subregions NW, $\mathrm{NE}, \mathrm{CW}$ and C), whereas moderate to small numbers were found in subregions $\mathrm{Sk}, \mathrm{CE}$ and $S$ (figures 4.3.5-8). Interestingly, the border-line between large numbers assembling at the trawl and low numbers at the trawl, both during the May, August and November surveys, closely matching the borders between homohaline areas and areas which are stratified throughout the year (Lee 1980), or (in summer) the predicted positions of frontal boundaries which separate water masses in which stratified conditions occur in the central and northern North Sea (large numbers of Fulmars) from the regions that are well mixed (small numbers of Fulmars; see Pingree \& Griffiths 1978). Hence, fishing vessels attracted Fulmars only in areas where they normally occurred, whereas substantial fisheries in the Southern Bight, the German Bight and the Skagerrak were normally not attended by Fulmars in any significant numbers. Only in February, high numbers of Fulmars could assemble at the trawl virtually everywhere in the North Sea, but Fulmars were still scarce in the Skagerrak and Kattegat and in the inner German Bight (figure 4.3.5). Violent storms (force 11-12 Beaufort) in January have perhaps disturbed the distribution pattern and, as a result, numbers of Fulmars at the trawl in the Southern Bight were surprisingly high (table 4.3.2). Massive numbers were recorded at the trawl around Orkney and Shetland and high numbers occurred in subregion NE. In May, high numbers of Fulmars occurred at the trawl in all northern subregions (NW, NE, $\mathrm{CW}, \mathrm{C}$ ), and in the offshore half of CE (figure 4.3.6). Numbers of Fulmars at the trawl were low in the coastal zones of $\mathrm{CE}$, in the Southern Bight (S) and in the Skagerrak. In August, a similar distribution pattern emerged, although high numbers occurred mainly in the northwestern half of the North Sea, 
Table 4.3.1 Number of hauls and associated maximum stern counts of scavenging seabirds at research vessels per subregion for each of the surveys.

\begin{tabular}{ccccrr}
\hline Subregion & February & May & August & November & $\Sigma$ \\
\hline NW & 36 & 66 & 35 & 49 & 186 \\
NE & 8 & 20 & 21 & 24 & 73 \\
Sk & 38 & 11 & 0 & 15 & 64 \\
CW & 13 & 38 & 37 & 27 & 115 \\
C & 49 & 85 & 59 & 57 & 250 \\
CE & 24 & 38 & 27 & 11 & 100 \\
S & 20 & 10 & 23 & 8 & 61 \\
$\Sigma$ & 188 & 268 & 202 & 191 & 849 \\
\hline
\end{tabular}

Table 4.3.2 Mean number, maximum and presence (\%) of Fulmars at the stern of research vessels per subregion for each of the surveys. The relative abundance of 'coloured' and light phase individuals (percentage 'coloured' if $n>20$ ) is given in the second half of the table.

\begin{tabular}{|c|c|c|c|c|c|c|c|c|c|c|c|c|c|c|c|}
\hline \multirow{3}{*}{$\begin{array}{l}\text { Subr } \\
\text { NW }\end{array}$} & \multicolumn{3}{|c|}{ February } & \multirow[b]{2}{*}{ mean } & \multicolumn{2}{|c|}{ May } & \multicolumn{3}{|c|}{ August } & \multirow{2}{*}{\multicolumn{3}{|c|}{$\begin{array}{l}\text { November } \\
\text { mean max prs } \%\end{array}$}} & \multicolumn{3}{|c|}{ Overall } \\
\hline & mean & $\max$ & prs $\%$ & & $\max$ & prs $\%$ & mean & mas & prs $\%$ & & & & mean & $\max p$ & s $\%$ \\
\hline & 164.8 & 2000 & 100 & 266.0 & 1800 & 100 & 332.3 & 2500 & 100 & 208.0 & 2300 & 98 & 243.6 & 2500 & 99 \\
\hline NE & 360.9 & 800 & 100 & 218.0 & 1100 & 95 & 385.0 & 1302 & 100 & 156.6 & 700 & 100 & 261.5 & 1302 & 99 \\
\hline Sk & 0.9 & 7 & 24 & 17.5 & 120 & 27 & & & & 18.6 & 186 & 47 & 7.9 & 186 & 30 \\
\hline $\mathrm{CW}$ & 43.2 & 240 & 92 & 553.8 & 2500 & 100 & 121.7 & 801 & 97 & 84.4 & 330 & 93 & 246.9 & 2500 & 97 \\
\hline C & 24.3 & 302 & 84 & 90.8 & 2000 & 96 & 66.1 & 800 & 92 & 49.2 & 253 & 84 & 62.4 & 2000 & 90 \\
\hline CE & 13.3 & 130 & 50 & 31.9 & 482 & 74 & 8.0 & 60 & 52 & 2.5 & 15 & 55 & 17.7 & 482 & 60 \\
\hline S & 23.6 & 353 & 65 & 2.9 & 12 & 70 & 2.0 & 10 & 57 & 0.0 & & 0 & 9.0 & 353 & 54 \\
\hline \multirow[t]{2}{*}{$\Sigma$} & 60.6 & 2000 & 70 & 194.5 & 2500 & 91 & 140.5 & 2500 & 86 & 101.3 & 2300 & 83 & 131.0 & 2500 & 83 \\
\hline & $\mathrm{col}$ & light & $\%$ col & $\mathrm{col}$ & light & $\%$ col & col & light & $\%$ col & $\mathrm{col}$ & light & $\% \mathrm{col}$ & & & \\
\hline NW & & & & 2 & 4667 & 0.0 & 31 & 11447 & 0.0 & 203 & 4034 & 4.8 & & & \\
\hline NE & & & & & 3610 & 0 & 19 & 7865 & 0.2 & 55 & 2533 & 2.1 & & & \\
\hline Sk & & & & & 192 & 0 & & & & & 275 & 0 & & & \\
\hline CW & & & & 5 & 2490 & 0.2 & 2 & 4420 & 0.0 & 4 & 1461 & 0.3 & & & \\
\hline C & & & & 24 & 4144 & 0.6 & 7 & 3656 & 0.2 & 43 & 2371 & 1.8 & & & \\
\hline CE & & & & 2 & 1209 & 0.2 & & 216 & 0 & 1 & 11 & & & & \\
\hline $\mathrm{S}$ & & & & & 29 & 0 & & 47 & 0 & 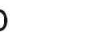 & & & & & \\
\hline$\Sigma$ & & no dat & & 33 & 16341 & 0.2 & 312 & 27651 & 0.1 & 306 & 10685 & 2.8 & & & \\
\hline
\end{tabular}


and low to moderate numbers elsewhere (figure 4.3.7). The border line between high and low numbers at the trawl was very strict at the Flamborough Front (northeast of the Humber; Pingree \& Griffiths 1978), the Frisian Front (northwest off Texel; De Gee et al. 1991), at the predicted transition zone in the German Bight (Pingree \& Griffiths 1978), but also off Aberdeen, where the Aberdeen front formed an abrupt border line for this species (Camphuysen 1994c). In November, Fulmar distribution closely matched the borders between homohaline areas and areas which are stratified throughout the year (Lee 1980). High numbers were still found in the north and northwest (NW, NE, CW and C), but few were seen in subregions $S k$ and $C E$ and none in the Southern Bight (S).

\section{Gannet}

Mean numbers of Gannets at the trawl were remarkably constant through the year (table 4.3.3) and the overall distribution pattern varied only in detail (figures 4.3.9-12). In February, moderate to large numbers of Gannets assembled at the trawl off northeast Scotland, Orkney and Shetland, and at a few stations in the central North Sea (C) and in the Southern Bight (S). Gannets were scarce in the eastern half of the North Sea and in the Skagerrak/Kattegat region (figure 4.3.9). Up to 250 Gannets were counted at a single haul in subregion NW. Almost all birds were adults $(98.8 \%$ adult, $n=1752$; table 4.3.3), especially in the north. In May, hardly any Gannets were observed at the trawl in the Southern Bight, German Bight and Skagerrak/Kattegat region (S, CE, Sk), low numbers occurred in the central North Sea (except in the western half of subregion C) and northern North Sea (NW, NE), but large numbers were found in $\mathrm{CW}$ (figure 4.3.10, table 4.3.3). Considerable numbers of (mainly mature) Gannets assembled at the trawl several hundreds of kilometres away from the two colonies off the British east coast (Bass Rock and Bempton Cliffs; Camphuysen et al. 1995). The proportion of immatures had increased considerably since
February $(85.6 \%$ adult, $n=3675)$, particularly in the central North Sea $178.1 \%$ adult, $n=201)$ and in NW (78.3\% adult, $n=993$; table 4.3.3). In August, three-quarters of all Gannets observed at the trawl were adult birds $(77.6 \%$ adult, $n=1416)$ and adults numerically predominated only in NW and CW (i.e. near breeding stations). High numbers at the trawl were frequently observed in $\mathrm{CW}$ and occasionally in NW, small numbers occurred elsewhere. Gannets were slightly more widespread as scavengers in August compared to May (figure 4.3.11), but most birds in the southern and eastern halves of the North Sea were immatures. In November, moderate to high numbers of Gannets were observed at several fishing stations in the Southern Bight, but the core area for scavenging Gannets was still the western half of the North Sea, up to Shetland (figure 4.3.12). Proportionally more adults were recorded in November $189.5 \%$ adult, $n=$ 1488; table 4.3.3) compared to August, indicating that many immatures had left the North Sea already.

\section{Great Skua}

With a maximum of 23 Great Skuas assembled at the trawl during a single haul, this species is one of the scarcer scavengers which occurred regularly. In February, Great Skuas were rare, but in May scattered sightings occurred, particularly at fishing stations in NW and NE (35\% of all hauls) and in CW (32\%; table 4.3.4). Great Skuas were rare during fishing in the other subregions. The species became widespread in August, just after the breeding season, when small numbers occurred at the trawl in all subregions under study (table 4.3.4, figure 4.3.13). Groups of more than 10 Great Skuas occurred only at fishing stations in NW and CW. In November, most records of Great Skuas were in the central North Sea (CW, C; figure 4.3.14).

\section{Common Gull}

Common Gulls were seen most frequently at the trawl in winter and mainly in inshore 
Table 4.3.3 Mean number, maximum and presence (\%) of Gannets at the stern of research vessels per subregion for each of the surveys. The relative abundance of adult and 'immatu$r e^{\prime}$ Gannets (percentage adult if $n>20$ ) is given in the second half of the table.

\begin{tabular}{|c|c|c|c|c|c|c|c|c|c|c|c|c|c|c|c|}
\hline \multirow[t]{2}{*}{ Subr } & \multicolumn{3}{|c|}{ February } & \multicolumn{3}{|c|}{ May } & \multicolumn{3}{|c|}{ August } & \multicolumn{2}{|c|}{ November } & \multicolumn{4}{|c|}{ Overall } \\
\hline & mean & $\max$ & prs $\%$ & mean & $\max$ & prs \% & mean & $\max$ & ors \% r & mean & $\max$ & prs $\%$ & mean & $\max$ & prs $\%$ \\
\hline NW & 37.4 & 250 & 81 & 15.0 & 180 & 74 & 4.2 & 28 & 77 & 4.8 & 72 & 82 & 14.6 & 250 & 78 \\
\hline NE & 12.4 & 35 & 100 & 0.9 & 4 & 40 & 0.8 & 6 & 43 & 3.8 & 22 & 67 & 3.1 & 35 & 56 \\
\hline Sk & 0.0 & 1 & 3 & 0.0 & & 0 & & & & 0.3 & 4 & 13 & 0.1 & 4 & 5 \\
\hline $\begin{array}{l}\text { CW } \\
88\end{array}$ & 13.1 & 88 & 69 & 64.5 & 310 & 92 & 30.0 & 355 & 89 & 20.3 & 98 & 89 & 37.2 & 355 & \\
\hline C & 2.4 & 44 & 41 & 2.4 & 70 & 44 & 1.9 & 30 & 49 & 9.0 & 75 & 70 & 3.8 & 75 & 50 \\
\hline CE & 0.1 & 1 & 8 & 0.3 & 2 & 21 & 0.7 & 4 & 44 & 1.2 & 5 & 45 & 0.5 & 5 & 27 \\
\hline$S$ & 2.8 & 24 & 45 & 0.2 & 2 & 10 & 0.5 & 4 & 26 & 9.9 & 27 & 88 & 2.4 & 27 & 38 \\
\hline \multirow[t]{2}{*}{$\Sigma$} & 9.5 & 250 & 41 & 13.7 & 310 & 51 & 7.0 & 355 & 57 & 7.8 & 98 & 70 & 9.9 & 355 & 55 \\
\hline & ad & $\mathrm{imm}$ & $\%$ ad & ad & $\mathrm{imm}$ & $\%$ ad & ad & $\mathrm{imm}$ & $\%$ ad & ad & $\mathrm{imm}$ & $\% a d$ & & & \\
\hline NW & 1297 & 9 & 99.3 & 778 & 215 & 78.3 & 96 & 50 & 65.8 & 223 & 11 & 95.3 & & & \\
\hline NE & 98 & 1 & 99.0 & 13 & 4 & & 2 & 15 & & 90 & 1 & | 98.9 & & & \\
\hline Sk & & 1 & & & & & & & & 5 & & & & & \\
\hline $\mathrm{CW}$ & 165 & 5 & 97.1 & 2194 & 257 & 89.5 & 952 & 158 & 85.8 & 497 & 55 & 90.0 & & & \\
\hline C & 115 & 3 & 97.5 & 157 & 44 & 78.1 & 41 & 71 & 36.6 & 453 & 61 & 88.1 & & & \\
\hline CE & 2 & & & 4 & 7 & & 5 & 14 & & 13 & & & & & \\
\hline S & 54 & 2 & 96.4 & & 2 & & 3 & 9 & & 51 & 28 & 364.6 & & & \\
\hline$\Sigma$ & 1731 & 21 & 98.8 & 3146 & 529 & 85.6 & 1099 & 317 & 77.6 & 1332 & 156 & 89.5 & & & \\
\hline
\end{tabular}

Table 4.3.4 Mean number, maximum and presence (\%) of Great Skuas at the stern of research vessels per subregion for each of the surveys.

\begin{tabular}{|c|c|c|c|c|c|c|c|c|c|c|c|c|c|c|c|}
\hline \multirow[t]{2}{*}{ Subr } & \multicolumn{3}{|c|}{ February } & \multicolumn{3}{|c|}{ May } & \multicolumn{3}{|c|}{ August } & \multicolumn{2}{|c|}{ November } & \multicolumn{4}{|c|}{ Overall } \\
\hline & mean & ax & prs $\%$ & mean & $\max$ & prs $\%$ & mean & $\max p$ & rs $\%$ & mean & $\max$ & prs \% & mean & $\max$ & prs $\%$ \\
\hline NW & 0.0 & & 0 & 0.8 & 10 & 35 & 4.8 & 23 & 80 & 0.2 & 7 & 6 & 1.2 & 23 & 29 \\
\hline NE & 0.0 & & c & 0 . & 2 & 35 & 1.0 & 4 & 48 & 0 . & & 0 & 0.4 & 4 & 23 \\
\hline Sk & 0.0 & & 0 & 0.0 & & 0 & & & & 0.0 & & 0 & 0.0 & & 0 \\
\hline $\mathrm{CW}$ & 0.0 & & 0 & 0.4 & 4 & 32 & 1.0 & 11 & 51 & 0.3 & 2 & 26 & 0.5 & 11 & 33 \\
\hline C & 0. & & c & & 1 & 1 & 0.4 & 3 & 22 & 0.4 & 5 & 26 & 0.2 & 5 & 12 \\
\hline $\mathrm{CE}$ & 0.0 & & c & 0.0 & 1 & 3 & 0.4 & 6 & 19 & 0.0 & & 0 & 0.1 & 6 & 6 \\
\hline $\mathrm{S}$ & 0.1 & 1 & 5 & 0.0 & & 0 & 0.3 & 2 & 26 & 0.0 & & 0 & 0.1 & 2 & 11 \\
\hline$\Sigma$ & 0.0 & 1 & 1 & 0.3 & 10 & 16 & 1.3 & 23 & 40 & 0.2 & 7 & 13 & 0.5 & 23 & 18 \\
\hline
\end{tabular}


waters in the North Sea (subregions Sk, CE, S). In February, Common Gulls were numerous inshore scavengers, with a maximum of 150 individuals at a single haul, in a inshore band ranging from southeast England to southwest Sweden (figure 5.3.15). Observations at the same time within the Wadden Sea area and in the coastal strip (within 5 $\mathrm{km}$ from the coast) showed that Common Gulls were abundant at fishing vessels (M.F. Leopold pers. comm.; Camphuysen 1993a). In the central North Sea, along most of the British east coast and particularly in the north, Common Gulls were scarce or absent. In all subregions where Common Gulls occurred in numbers at the trawl, adults predominated $186.0 \%$ adult, $n=708$; table 4.3.5). In May, Common Gulls were rarely observed at the trawl, anywhere in the North Sea, and most of the few birds observed were immatures $117.6 \%$ adult, $n=34$; figure 4.3.16, table 4.3.5). Similarly, very small numbers were observed at the trawl in August, scattered over most of the central North Sea (figure 4.3.17) and most these birds were immatures $130.8 \%$ adult, $n=$ 39). Inshore waters in the German Bight were poorly covered in November, but it is obvious that the frequency of sightings of Common Gulls and the total number of birds involved (with a maximum of ca. 90 at a haul) had increased, particularly in the southeastern half of the study area (figure 4.3.18). In the Southern Bight and in the Skagerrak, where the mean number at the trawl was highest, adults predominated (ca. $85 \%$ table 4.3.5). Elsewhere, immatures were relatively more numerous.

\section{Lesser Black-backed Gull}

Lesser Black-backed Gulls were typically summer scavengers. Most of the population left the North Sea in November and February. Although this species breeds around the North Sea, the core of its northwest European distribution lies in the southeastern North Sea and its occurrence as a scavenger varied accordingly between subregions (figures 4.3.20-21). In February, Lesser Black-back- ed Gulls were rare in most of the North Sea, except in the Southern Bight where they were attracted to $55 \%$ of the hauls (figure 4.3.19, table 4.3.5). Most Lesser Blackbacked Gulls at research vessels in February were adults (90.9\% adult, $n=44)$. In May, the picture had changed completely and Lesser Black-backed Gulls were numerous and widespread in most subregions (figure 4.3.20). Numbers at the trawl peaked between 100 and 200 individuals in five subregions ( $N E$, Sk, C, CE, and $S$ ) and at least two-thirds of the hauls in each subregion attracted at least some Lesser Black-backed Gulls (table 4.3.6). Many of the scavenging Lesser Black-backed Gulls, substantial numbers of which were recorded well offshore, were immatures $(55.6 \%$ adult, $n=3578)$. In August, Lesser Black-backed Gulls had a more inshore distribution and the majority occurred in the southeastern half of the North Sea (figure 4.3.21). Up to $300-400$ individuals were recorded at a single haul in subregions CE and S, while the species occurred less frequently, and in considerably smaller numbers, elsewhere (table 4.3.6). Only half the birds aged were adults $150.0 \%$ adult, $n=2495$ ) and it was obvious that many recently fledged juveniles had moved to sea, immediately after the breeding season. In November, numbers of scavenging Lesser Black-backed Gulls had fallen considerably and occasional large groups were attracted only in the southern half of the North Sea (figure 4.3.22). A majority of the gulls seen in November were adults $171.8 \%$ adult, $\mathrm{n}=287$; table 4.3.6).

\section{Herring Gull}

Herring Gulls were typically widespread winter scavengers, both in inshore and offshore areas (figures 4.3.23-26). Being abundant breeding species around the North Sea, it is remarkable to note how few scavenging Herring Gulls were reported in May and, particularly, in August. In February, Herring Gulls were numerous scavengers throughout the North Sea (figure 4.2.23), but particularly in inshore waters (up to 100 
Table 4.3.5 Mean number, maximum and presence (\%) of Common Gulls at the stern of research vessels per subregion for each of the surveys. The relative abundance of adult and 'immature' gulls (percentage adult if $n>20$ ) is given in the second half of the table.

\begin{tabular}{|c|c|c|c|c|c|c|c|c|c|c|c|c|c|c|c|}
\hline \multirow[t]{2}{*}{ Subr } & \multicolumn{3}{|c|}{ February } & \multicolumn{3}{|c|}{ May } & \multicolumn{3}{|c|}{ August } & \multicolumn{2}{|c|}{ November } & \multicolumn{4}{|c|}{ Overall } \\
\hline & mean & $\max$ & prs $\%$ & mean & $\max$ & prs \% & mean & $\max$ & prs \% & mean & $\max$ & prs \% & mean & $\max$ & prs \% \\
\hline NW & 0.0 & & 0 & 0.0 & 1 & 3 & 0.1 & 2 & 6 & 0.1 & 2 & 8 & 0.1 & 2 & 4 \\
\hline NE & 0.0 & & 0 & 0.3 & 5 & 5 & 0.2 & 1 & 24 & 0.0 & 1 & 4 & 0.2 & 5 & 10 \\
\hline Sk & 3.6 & 14 & 82 & 0.0 & & 0 & & & & 4.1 & 28 & 53 & 3.1 & 28 & 61 \\
\hline $\mathrm{CW}$ & 0.4 & 2 & 31 & 0.0 & 1 & 3 & 0.2 & 2 & 11 & 0.2 & 2 & 15 & 0.2 & 2 & 11 \\
\hline C & 1.1 & 14 & 24 & 0.2 & 5 & 7 & 0.3 & 4 & 19 & 0.9 & 7 & 35 & 0.5 & 14 & 20 \\
\hline CE & 12.7 & 81 & 58 & 0.3 & 8 & 13 & 0.2 & 2 & 15 & 2.3 & 8 & 55 & 3.5 & 81 & 29 \\
\hline$S$ & 12.7 & 150 & 75 & 0.0 & & 0 & 0.1 & 2 & 4 & 14.5 & 92 & 75 & 6.1 & 150 & 36 \\
\hline \multirow[t]{2}{*}{$\Sigma$} & 4.0 & 150 & 40 & 0.1 & 8 & 6 & 0.2 & 4 & 13 & 1.4 & 92 & 26 & 1.3 & 150 & 20 \\
\hline & ad & $\mathrm{imm}$ & $\%$ ad & ad & imm & $\%$ ad & ad & $\mathrm{imm}$ & $\%$ ad & \multicolumn{2}{|c|}{ ad imm } & $\%$ ad & & & \\
\hline NW & & & & & 2 & & & 3 & & 1 & 6 & & & & \\
\hline NE & & & & 1 & 4 & & 1 & 4 & & & 1 & & & & \\
\hline Sk & 124 & 11 & 91.9 & & & & & & & 30 & 4 & 88.2 & & & \\
\hline $\mathrm{CW}$ & 3 & 2 & & & 1 & & 2 & 5 & & 2 & 3 & & & & \\
\hline C & 47 & 5 & 90.4 & 2 & 12 & & 6 & 11 & & 29 & 17 & 63.0 & & & \\
\hline CE & 220 & 44 & 83.3 & 3 & 9 & & 1 & 4 & & 19 & 6 & 76.0 & & & \\
\hline$S$ & 215 & 37 & 85.3 & & & & 2 & & & 96 & 20 & 82.8 & & & \\
\hline$\Sigma$ & 609 & 99 & 86.0 & 6 & 28 & 17.6 & 12 & 27 & 30.8 & 177 & 57 & 75.6 & & & \\
\hline
\end{tabular}

Table 4.3.6 Mean number, maximum and presence (\%) of Lesser Black-backed Gulls at the stern of research vessels per subregion for each of the surveys. The relative abundance of adult and 'immature' gulls (percentage if $n>20$ ) is given in the second half of the table.

\begin{tabular}{|c|c|c|c|c|c|c|c|c|c|c|c|c|c|c|c|}
\hline \multirow[t]{2}{*}{ Subr } & \multicolumn{3}{|c|}{ February } & \multicolumn{3}{|c|}{ May } & \multicolumn{3}{|c|}{ August } & \multicolumn{3}{|c|}{ November } & \multicolumn{3}{|c|}{ Overall } \\
\hline & mean & $\max$ & prs $\%$ & mean & $\max$ & prs $\%$ & mean & $n \max$ & prs $\%$ & mean & $\max$ & prs $\%$ & mean & $\max$ & prs $\%$ \\
\hline NW & 0.0 & & 0 & 5.4 & 42 & 71 & 0.4 & 5 & 17 & 0.3 & 5 & 12 & 2.1 & 42 & 32 \\
\hline NE & 0.0 & & 0 & 42.1 & 200 & 100 & 11.3 & 56 & 67 & 0.5 & 5 & 25 & 14.9 & 200 & 55 \\
\hline Sk & 0.0 & & 0 & 33.4 & 100 & 73 & & & & 0.0 & & 0 & 5.7 & 100 & 13 \\
\hline $\mathrm{CW}$ & 0.0 & & 0 & 6.7 & 22 & 74 & 1.7 & 25 & 35 & 3.8 & 100 & 7 & 3.7 & 100 & 37 \\
\hline $\mathrm{C}$ & 0.0 & 1 & 2 & 11.5 & 110 & 76 & 4.4 & 41 & 51 & 1.2 & 22 & 25 & 5.2 & 110 & 44 \\
\hline CE & 0.1 & 1 & 8 & 21.9 & 180 & 76 & 27.7 & 350 & 81 & 2.3 & 6 & 45 & 16.1 & 350 & 58 \\
\hline$S$ & 2.1 & 13 & 55 & 21.7 & 125 & 60 & 51.0 & 385 & 74 & 10.5 & 38 & 100 & 24.8 & 385 & 69 \\
\hline \multirow[t]{2}{*}{$\Sigma$} & 0.2 & 13 & 7 & 14.4 & 200 & 76 & 12.4 & 385 & 50 & 1.6 & 100 & 21 & 7.9 & 385 & 42 \\
\hline & $\mathrm{ad}$ & imm & $\%$ ad & ad & $\mathrm{imm}$ & $\%$ ad & ad & imm & $\%$ ad & \multicolumn{2}{|c|}{ ad imm } & $\%$ ad & & & \\
\hline NW & & & & 179 & 179 & 50.0 & 12 & 1 & & 11 & 4 & & & & \\
\hline NE & & & & 509 & 132 & 79.4 & 234 & 3 & 98.7 & 7 & 4 & & & & \\
\hline Sk & & & & 310 & 57 & 84.5 & & & & & & & & & \\
\hline $\mathrm{CW}$ & & & & 108 & 148 & 42.2 & 32 & 32 & 50.0 & 102 & 1 & 99.0 & & & \\
\hline C & & 1 & & 396 & 510 & 43.7 & 143 & 116 & 55.2 & 38 & 31 & 55.1 & & & \\
\hline CE & 2 & & & 336 & 497 & 40.3 & 225 & 524 & 30.0 & 18 & 7 & 72.0 & & & \\
\hline $\mathrm{s}$ & 38 & 3 & 92.7 & 151 & 66 & 69.6 & 602 & 571 & 51.3 & 30 & 34 & 46.9 & & & \\
\hline$\Sigma$ & 40 & 4 & 90.9 & 1989 & 1589 & 55.6 & 1248 & 1247 & 50.0 & 206 & 81 & 71.8 & & & \\
\hline
\end{tabular}


$\mathrm{km}$ away from the coast; table 4.3.10). Peak numbers observed at the trawl were in the range of 500-700 individuals, and these occurred in NW and Sk (table 4.3.7). Twothirds of all scavenging Herring Gulls were adults $(65.7 \%$ adult, $n=9312)$. In all subregions, at least 9 out of 10 hauls attracted some Herring Gulls. In May, this had radically changed. Although occasionally up to 200 Herring Gulls assembled at a trawl (subregions NE and Sk), the species was rather scarce and occurred in less than $25 \%$ of the hauls in other subregions (figure 4.3.24, table 4.3.7). Again, two-thirds were mature birds $(65.3 \%$ adult, $n=435)$, but in $S k$, with comparatively large numbers, $85.1 \%$ were adults $(n=235)$. As mentioned earlier, coverage in Dutch and German inshore waters was not ideal and earlier studies indicated that very large numbers of scavenging Herring Gulls occur within $10 \mathrm{~km}$ from the coast in this region (Camphuysen 1993a, Garthe 1993b, Garthe \& Hüppop 1994, Camphuysen in press). In August, Herring Gull distribution and abundance had changed again. With the notable exception of inshore waters off eastern Scotland, Herring Gulls were not present in significant numbers anywhere in the North Sea (figure 4.3.25). As in chapter 4.1, Herring Gulls occurred in substantial numbers in strip-transects off the Scottish east coast but in very small numbers elsewhere, so it is obvious that the North Sea was abandoned by Herring Gulls just after the breeding season. Only a third of the Herring Gulls scavenging at the trawl were adults $(37.5 \%$ adult, $n=816$; table 4.3.8). The November cruises demonstrated a massive return of this species, particularly in the northern and eastern North Sea. Up to 1000 Herring Gulls assembled at one ship (subregion NW) and in most subregions at least at 8 out of 10 hauls Herring Gulls were attracted (table 4.3.8). Numbers were particularly large in the Fladengrund area (central northern North Sea) and off Shetland and Norway. Just less than half the Herring Gulls observed at the trawl were adults $141.7 \%$ adult, $n=2173$ ).

\section{Great Black-backed Gull}

Great Black-backed Gulls occurred as scavengers through the year, but were seen least frequently though in August (table 4.3.8). Its distribution varied between seasons, but with highest numbers usually in subregions NW, NE and Sk. In February, scavenging numbers at the trawl were higher than during any of the other surveys. Most Great Black-backed Gulls were reported around Orkney and Shetland (NW) and in the Kattegat (Sk; figure 4.3.27). The species was rather scarce in subregion $\mathrm{CW}$, but elsewhere at least 8 out of 10 hauls attracted this species and two-thirds were adults (64.3\% adult, $n=4362$; table 4.3.8). In May, Great Black-backed Gulls were particulalry numerous in the northern North Sea and, locally in the central North Sea (figure 4.3.28). Up to 150 gulls were counted at a single haul (NW). A third of the gulls were adults in May (33.8\% adult, $n=1816$; table 4.3.8), but in the southern half of the North Sea only a tenth of the birds assembled at trawls were mature $(9.2 \%$ adult, $n=876)$. The presence of Great Black-backed Gulls at the trawl ranged from 'occasionally' (10\% of all hauls) in the Southern Bight to 'frequentIy' $(80-95 \%)$ in the northern North Sea. Low numbers were observed in the German Bight and in the Skagerrak. The overall distribution of this species as a scavenger at the trawl overlapped almost completely with Lesser Black-backed Gulls, except in Moray Firth (northeast Scotland), where the smaller species was comparatively rare. In August, Great Black-backed Gull were proportionally numerous in the southern North Sea and in inshore waters off East Britain (figure 4.3.29, table 4.3.8). The central northern North Sea, very important in May, was virtually free of Great Black-backed Gulls. Up to 150 Great Black-backed Gulls at a single haul were reported in subregion CE. As before, a third of the birds were adults $137.5 \%$ adult, $n=816$; table 4.3.8). The highest proportion of mature birds was found in NW, where nearly three-quarters were adult birds. In November, the central northern North Sea 
Table 4.3.7 Mean number, maximum and presence (\%) of Herring Gulls at the stern of research vessels per subregion for each of the surveys. The relative abundance of adult and 'immature' gulls (percentage adult if $n>20$ ) is given in the second half of the table.

\begin{tabular}{|c|c|c|c|c|c|c|c|c|c|c|c|c|c|c|c|}
\hline \multirow[t]{2}{*}{ Subr } & \multicolumn{3}{|c|}{ February } & \multicolumn{3}{|c|}{ May } & \multicolumn{3}{|c|}{ August } & \multicolumn{2}{|c|}{ November } & \multicolumn{4}{|c|}{ Overall } \\
\hline & mean & $\max$ & prs $\%$ & mean & $\max$ & prs $\%$ & mean & $\max$ & prs $\%$ & mean & $\max$ & prs \% & mean & $\max$ & prs $\%$ \\
\hline NW & 88.0 & 580 & 89 & 1.9 & 23 & 45 & 0.1 & 2 & 9 & 184.7 & 1000 & 96 & 66.4 & 1000 & 60 \\
\hline $\mathrm{NE}$ & 36.0 & 70 & 100 & 10.2 & 200 & 15 & 0.2 & 4 & 5 & 76.5 & 430 & 96 & 31.9 & 430 & 48 \\
\hline Sk & 104.1 & 650 & 100 & 21.4 & 152 & 64 & & & & 56.1 & 360 & 100 & 78.6 & 650 & 94 \\
\hline CW & 21.7 & 110 & 92 & 0.4 & 4 & 21 & 3.8 & 66 & 19 & 6.5 & 44 & 81 & 5.3 & 110 & 43 \\
\hline C & 16.7 & 210 & 90 & 0.2 & 5 & 11 & 0.1 & 3 & 2 & 19.5 & 190 & 91 & 7.8 & 210 & 42 \\
\hline $\mathrm{CE}$ & 21.8 & 120 & 92 & 0.7 & 6 & 29 & 0.2 & 2 & 11 & 88.4 & 330 & 100 & 15.3 & 330 & 47 \\
\hline S & 27.1 & 220 & 90 & 1.9 & 15 & 20 & 0.5 & 8 & 17 & 21.0 & 117 & 88 & 12.1 & 220 & 51 \\
\hline \multirow[t]{2}{*}{$\Sigma$} & 50.9 & 650 & 93 & 2.4 & 200 & 26 & 0.8 & 66 & 9 & 74.1 & 1000 & 93 & 28.9 & 1000 & 52 \\
\hline & ad & $\mathrm{imm}$ & $\%$ ad & ad & $\mathrm{imm}$ & $\%$ ad & ad & $\mathrm{imm}$ & $\%$ ad & ad & $\mathrm{imm}$ & $\%$ ad & & . & \\
\hline NW & 2203 & 850 & 72.2 & 58 & 70 & 45.3 & 2 & 2 & & 2813 & 2451 & 53.4 & & & \\
\hline NE & 208 & 80 & 72.2 & & 3 & & & 4 & & 673 & 844 & 44.4 & & & \\
\hline Sk & 2803 & 1151 & 70.9 & 200 & 35 & 85.1 & & & & 567 & 268 & 67.9 & & & \\
\hline $\mathrm{CW}$ & 117 & 110 & 51.5 & 4 & 11 & & 82 & 59 & 58.2 & 55 & 46 & 54.5 & & & \\
\hline C & 316 & 423 & 42.8 & & 9 & & & 3 & & 381 & 498 & 43.3 & & & \\
\hline CE & 272 & 238 & 53.3 & 10 & 16 & 38.5 & 4 & 1 & & 421 & 551 & 43.3 & & & \\
\hline$S$ & 202 & 339 & 37.3 & 12 & 7 & & 7 & 4 & & 35 & 133 & 20.8 & & & \\
\hline$\Sigma$ & 6121 & 3191 & 65.7 & 284 & 151 & 65.3 & 95 & 73 & 56.5 & 4945 & 4791 & 50.8 & & & \\
\hline
\end{tabular}

Table 4.3.8 Mean number, maximum and presence (\%) of Great Black-backed Gulls at the stern of research vessels per subregion for each of the surveys. The relative abundance of adult and 'immature' gulls (percentage if $n>20$ ) is given in the second half of the table.

\begin{tabular}{|c|c|c|c|c|c|c|c|c|c|c|c|c|c|c|c|}
\hline \multirow[t]{2}{*}{ Subr } & \multicolumn{3}{|c|}{ February } & \multicolumn{3}{|c|}{ May } & \multicolumn{3}{|c|}{ August } & \multicolumn{2}{|c|}{ November } & \multicolumn{4}{|c|}{ Overall } \\
\hline & mean & $\max$ & prs $\%$ & mean & $\max$ & prs $\%$ & mean & $\max$ & prs $\%$ & mean & $\max$ & prs $\%$ & mean & $\max$ & prs $\%$ \\
\hline NW & 50.1 & 220 & 97 & 9.0 & 154 & 80 & 2.1 & 26 & 29 & 32.9 & 175 & 94 & 22.0 & 220 & 77 \\
\hline NE & 35.8 & 65 & 100 & 23.4 & 100 & 95 & 0.6 & 5 & 29 & 14.1 & 120 & 96 & 15.1 & 120 & 77 \\
\hline Sk & 33.4 & 250 & 100 & 2.7 & 20 & 36 & & & & 11.5 & 90 & 73 & 23.0 & 250 & 83 \\
\hline CW & 8.2 & 26 & 77 & 12.4 & 56 & 71 & 3.5 & 63 & 41 & 8.8 & 51 & 70 & 8.2 & 63 & 62 \\
\hline C & 9.6 & 60 & 84 & 3.2 & 38 & 56 & 1.0 & 13 & 29 & 6.6 & 60 & 63 & 4.7 & 60 & 57 \\
\hline CE & 12.9 & 45 & 83 & 1.2 & 9 & 45 & 12.5 & 150 & 44 & 30.9 & 209 & 73 & 10.3 & 209 & 57 \\
\hline $\mathrm{S}$ & 10.8 & 68 & 85 & 0.1 & 1 & 10 & 9.0 & 72 & 57 & 10.0 & 54 & 88 & 8.2 & 72 & 62 \\
\hline \multirow[t]{2}{*}{$\Sigma$} & 23.7 & 250 & 90 & 7.0 & 154 & 63 & 4.0 & 150 & 36 & 16.5 & 209 & 79 & 12.2 & 250 & 66 \\
\hline & ad & $\mathrm{imm}$ & $\%$ ad & ad & $\mathrm{imm}$ & $\%$ ad & ad & imm & $\%$ ad & \multicolumn{2}{|c|}{ ad imm } & $\%$ ad & & & \\
\hline NW & 1230 & 557 & 68.8 & 258 & 338 & 43.3 & 52 & 21 & 71.2 & 398 & 436 & 47.7 & & & \\
\hline NE & 188 & 98 & 65.7 & 252 & 162 & 60.9 & 8 & 4 & & 101 & 179 & 36.1 & & & \\
\hline Sk & 858 & 402 & 68.1 & 22 & 8 & 73.3 & & & & 131 & 42 & 75.7 & & & \\
\hline $\mathrm{CW}$ & 36 & 31 & 53.7 & 52 & 419 & 11.0 & 63 & 68 & 48.1 & 82 & 110 & 42.7 & & & \\
\hline C & 243 & 208 & 53.9 & 25 & 233 & 9.7 & 23 & 34 & 40.4 & 69 & 205 & 25.2 & & & \\
\hline CE & 166 & 130 & 56.1 & 4 & 42 & 8.7 & 83 & 253 & 24.7 & 101 & 239 & 29.7 & & & \\
\hline$S$ & 82 & 133 & 38.1 & & 1 & & 77 & 130 & 37.2 & 25 & 55 & 31.3 & & & \\
\hline$\Sigma$ & 2803 & 1559 & 64.3 & 613 & 1203 & 33.8 & 306 & 510 & 37.5 & 907 & 1266 & 41.7 & & & \\
\hline
\end{tabular}


gained importance again, but Great Blackbacked Gulls increased in numbers as scavengers in all subregions (figure 4.3.30, table 4.3.8). Just less than half the birds were adults $(41.7 \%$ adult, $n=2173)$, except in the Skagerrak, where three-quarters were mature birds (75.7\% adult, $n=173)$. Up to 200 Great Black-backed Gulls assembled at a single haul and only in the central North Sea did the frequency of its presence drop below $70 \%$ of all hauls.

\section{Kittiwake}

The second most numerous scavengers in the North Sea were Kittiwakes. Numbers at the trawl peaked in November and were, generally, considerably higher in winter than in summer. Kittiwakes were widespread in all seasons, occurring both inshore and offshore in large numbers and adults were always much more numerous at the trawl than immatures and juveniles. In February, Kittiwakes were abundant and widespread, occurring in all subregions in substantial numbers (figure 4.3.31, table 4.3.9). Overall, Kittiwakes were present at $95 \%$ of all hauls recorded, and were attracted at all hauls in four subregions (NW, NE, CW and CE). Up to 450 Kittiwakes were attracted and, except in the Skagerrak region, usually several hundreds of Kittiwakes were present at each haul. Nine out of ten Kittiwakes in February were adults $(92.0 \%, n=11,472)$, except in Skagerrak, where a third were immatures (63.0\% adult, $n=403)$. In May, Kittiwakes rather scarce in Sk, in most of the German Bight and Southern Bight and in large portions of the northern North Sea (figure 4.3.32). The presence at the trawl dropped to $74 \%$ (table 4.3 .9 ) and was particularly low in NE $(40 \%)$ and Sk $(18 \%)$. Up to 300 Kittiwakes assembled at the trawl, but flocks of over a hundred individuals were only reported from subregions $\mathrm{CW}$ and $\mathrm{C}$. Nearly $90 \%$ of the Kittiwakes observed were adults (89.4\%, $n=4816)$. The overall impression is that Kittiwake distribution showed a contraction towards the breeding stations (on the British east coast), at least as compared with its distribution in February. The breeding status of adult Kittiwakes scavenging at the stern in the central North Sea is uncertain, but it should be noted that mass-feedings of 'naturally feeding' adult Kittiwakes occurred at hundreds of kilometres away from the nearest colonies, far offshore Aberdeen in May. In August, the distribution had changed again. Kittiwakes had become more widespread, but numbers at the trawl were even smaller than in May (table 4.3.9, figure 4.3.33). The eastern and southern North Sea had gained importance, but the overall presence as scavengers at the trawl was still stuck at $75 \%$ of all hauls. Up to 200 Kittiwakes were attracted in the central North Sea, but such a figure was quite an exception. The proportion of mature birds had fallen to $69.7 \%(n=1830)$, which was obviously caused by the fledged juveniles. In the northern North Sea, the proportion of immatures (NW and NE $41.1 \%$ adult, $n=$ 270) was considerably higher than further to the south and adults were comparatively numerous off the British east coast (CW $84.3 \%$ adult, $n=389$ ). Much larger numbers were attracted in November, when the overall mean at the trawl had increased tenfold from 10 (in August) to 115 individuals per haul. Up to 1600 Kittiwakes were assembled during a haul (subregion NW) and several hundreds of birds at the trawl were not unusual in most subregions. Kittiwakes were comparatively scarce in the Southern Bight (poorly sampled) and in the Skagerrak. Nine out of ten Kittiwakes at the trawl were adults (88.6\% adult, $n=14,187)$. Very large numbers of Kittiwakes were observed in the Fladenground region (central northern North Sea).

\section{Total number of scavengers}

Except in February, when large numbers of scavengers could be observed at fishing stations anywhere in the North Sea (figure 4.3.35), there was an overall tendency of comparatively high numbers at trawls in the northwestern two-thirds of the North Sea (figures 4.3.36-38). Off the east coast of 
Table 4.3.9 Mean number, maximum and presence (\%) of Kittiwakes at the stern of research vessels per subregion for each of the surveys. The relative abundance of adult and 'immatu$r e^{\prime}$ gulls (percentage adult if $n>20$ ) is given in the second half of the table.

\begin{tabular}{|c|c|c|c|c|c|c|c|c|c|c|c|c|c|c|c|}
\hline \multirow[t]{2}{*}{ Subr } & \multicolumn{3}{|c|}{ February } & \multirow[b]{2}{*}{ mean } & \multicolumn{2}{|c|}{ May } & \multicolumn{3}{|c|}{ August } & \multicolumn{2}{|c|}{ November } & \multicolumn{4}{|c|}{ Overall } \\
\hline & mean & $\max$ & prs \% & & $\max$ & prs $\%$ & mean & $\max$ & prs $\%$ & mean & $\max$ & prs $\%$ & mean & $\max$ & prs \% \\
\hline NW & 132.1 & 452 & 100 & 13.7 & 100 & 85 & 5.1 & 40 & 69 & 270.8 & 1580 & 100 & 102.8 & 1580 & 89 \\
\hline NE & 218.9 & 362 & 100 & 0.9 & 6 & 40 & 4.4 & 13 & 95 & 39.5 & 195 & 92 & 38.5 & 362 & 79 \\
\hline Sk & 10.6 & 65 & 92 & 0.6 & 4 & 18 & & & & 21.6 & 65 & 93 & 11.5 & 65 & 80 \\
\hline $\begin{array}{l}\text { CW } \\
93\end{array}$ & 78.2 & 250 & 100 & 60.1 & 290 & 97 & 10.5 & 83 & 86 & 84.8 & 520 & 93 & 52.0 & 520 & \\
\hline $\begin{array}{l}\mathrm{C} \\
82\end{array}$ & 50.8 & 400 & 90 & 14.3 & 270 & 72 & 12.9 & 200 & 71 & 86.4 & 525 & 100 & 37.6 & 525 & \\
\hline CE & 28.6 & 150 & 100 & 11.0 & 62 & 68 & 9.7 & 55 & 67 & 26.1 & 125 & 91 & 16.5 & 150 & 78 \\
\hline $\mathrm{S}$ & 50.5 & 175 & 95 & 10.3 & 83 & 70 & 6.3 & 28 & 365 & 12.0 & 29 & 88 & 22.2 & 175 & 79 \\
\hline \multirow[t]{2}{*}{$\Sigma$} & 64.4 & 452 & 95 & 18.5 & 290 & 74 & 9.1 & 200 & 75 & 115.9 & 1580 & 96 & 48.3 & .1580 & 84 \\
\hline & ad & $\mathrm{imm}$ & $\%$ ad & ad & $\mathrm{imm}$ & $\%$ ad & ad & $\mathrm{imm}$ & $\%$ ad & ad & $\mathrm{imm}$ & $\%$ ad & & & \\
\hline NW & 4481 & 205 & 5.6 & 776 & 131 & 85.6 & 78 & 100 & 43.8 & 6419 & 949 & 87.1 & & & \\
\hline$N E$ & 40 & 11 & 99.4 & 12 & 5 & & 33 & 59 & 35.9 & 599 & 125 & 82 & & & \\
\hline Sk & 254 & 149 & 63.0 & 5 & 2 & & & & & 283 & 21 & 93.1 & & & \\
\hline $\mathrm{CW}$ & 636 & 53 & 92.3 & 2206 & 77 & 96.6 & 328 & 61 & 84.3 & 1379 & 99 & 93.3 & & & \\
\hline C & 2102 & 280 & 88.2 & 901 & 180 & 83.3 & 530 & 232 & 69.6 & 3601 & 379 & 90.5 & & & \\
\hline CE & 551 & 51 & 91.5 & 366 & 51 & 87.8 & 199 & 64 & 75.7 & 215 & 22 & 90.7 & & & \\
\hline$S$ & 787 & 172 & 82.1 & 41 & 63 & 39.4 & 107 & 39 & 73.3 & 77 & 19 & 80.2 & & & \\
\hline$\Sigma$ & 10551 & 921 & 92.0 & 4307 & 509 & 89.4 & 1275 & 5556 & 69.7 & 12573 & 1614 & - 88.6 & & & \\
\hline
\end{tabular}

Figures 4.3.1 - 44 show the observer effort and numbers of seabirds associated with research vessels as a result of 'stern counts' in the North Sea. Four maps are given on each page, presenting the results of each of the four surveys. Observer effort is presented as numbered plots of hauls (188 in February, 268 in May, 202 in August, 191 in November). For each of the common scavenging seabirds, numbers at the stern are presented in four abundance classes, ranging from none (blank) to $\geq 100$ individuals (largest symbol, black). Numbers of Great Skuas in February and May were too small to warrant the presentation of distribution maps. In May, one of the research vessels spent considerable time fishing in so-called 'boxes' (figure 4.3.2). The mean of the number of birds associated with the vessel was given on the maps of each species. Figures 4.3.35-38 show total numbers of birds at the stern, for practical reasons on a different scale, ranging from none (blank) to $\geq 1000$ birds (largest symbol, black). The presence of rarer birds at the stern are plotted in figures 4.3.39-44. Areas in which each species occurred rather more frequently are 'connected' by a background shading. 

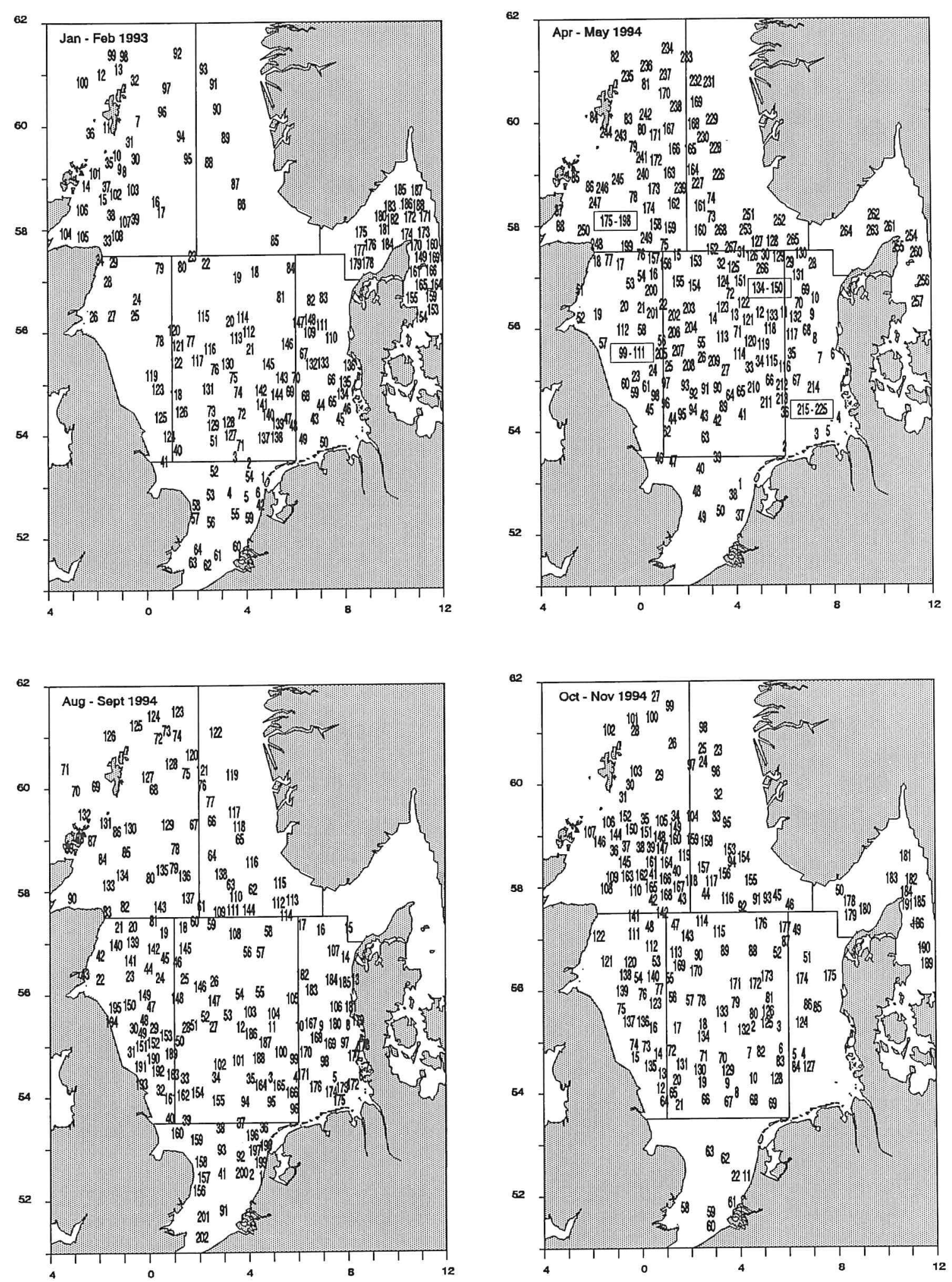

Figure 4.3.1-4 Observer effort for stern counts (numbered hauls) 

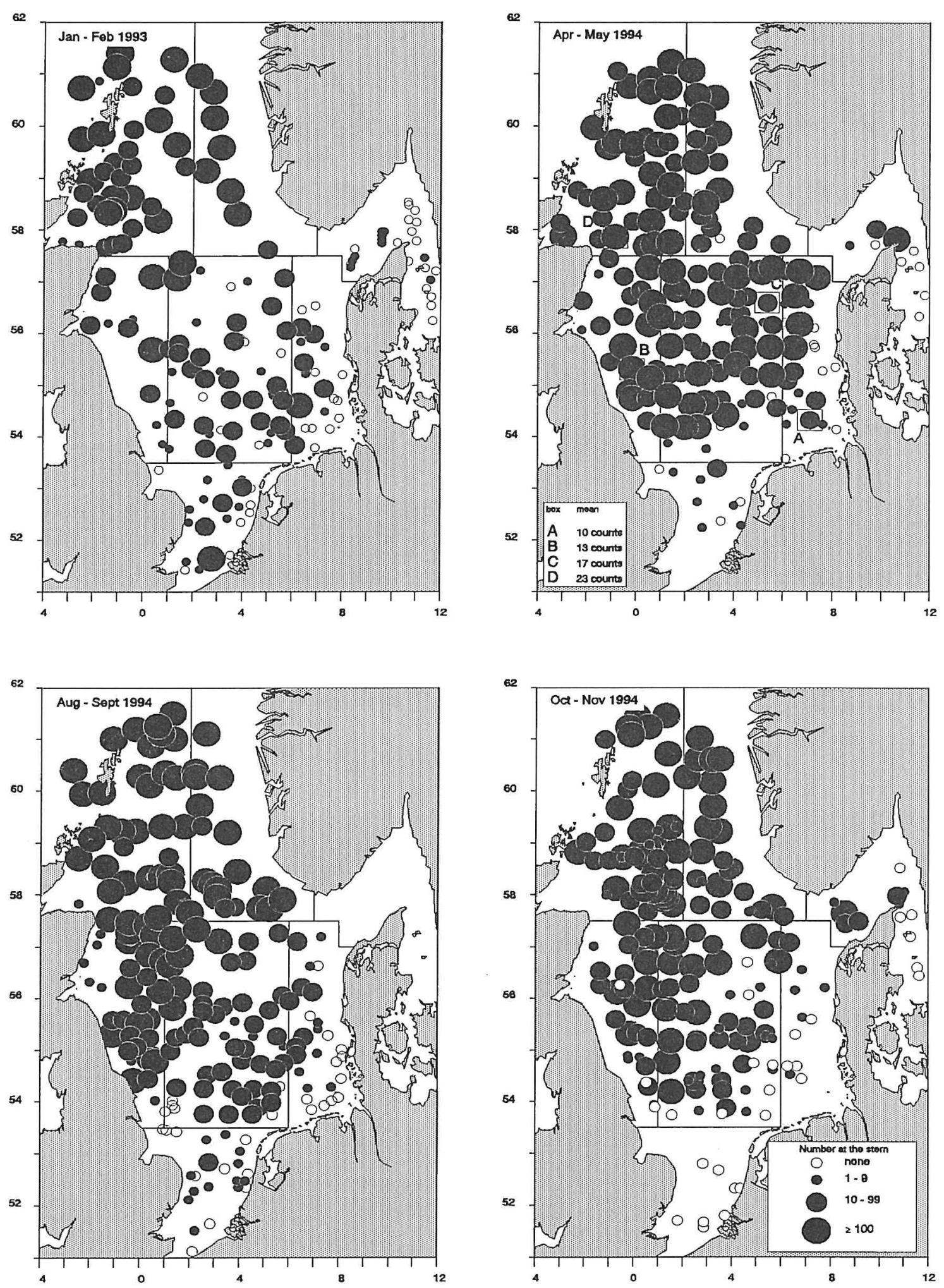

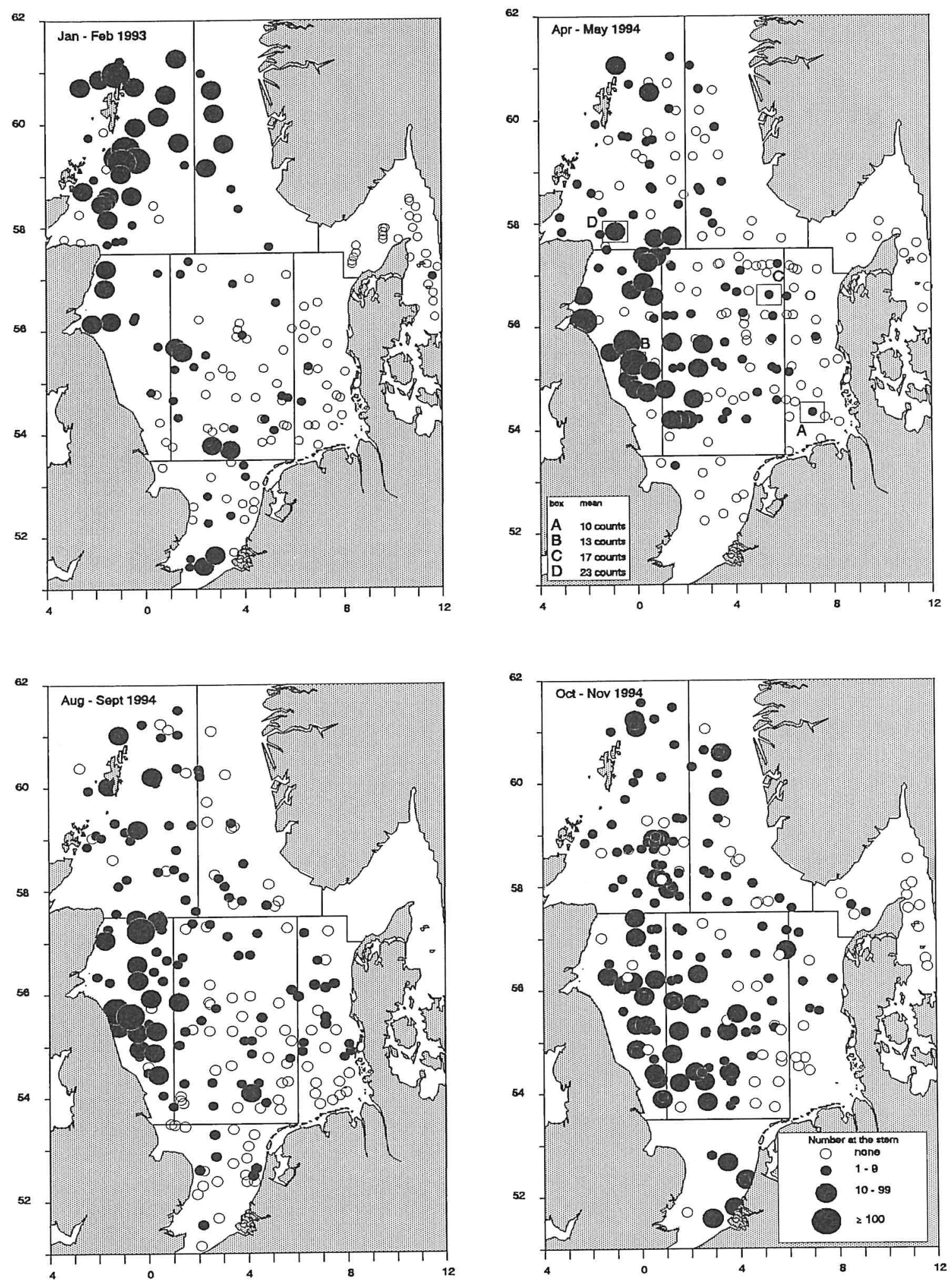

Figure 4.3.9-12 Distribution of Gannet from stern counts 

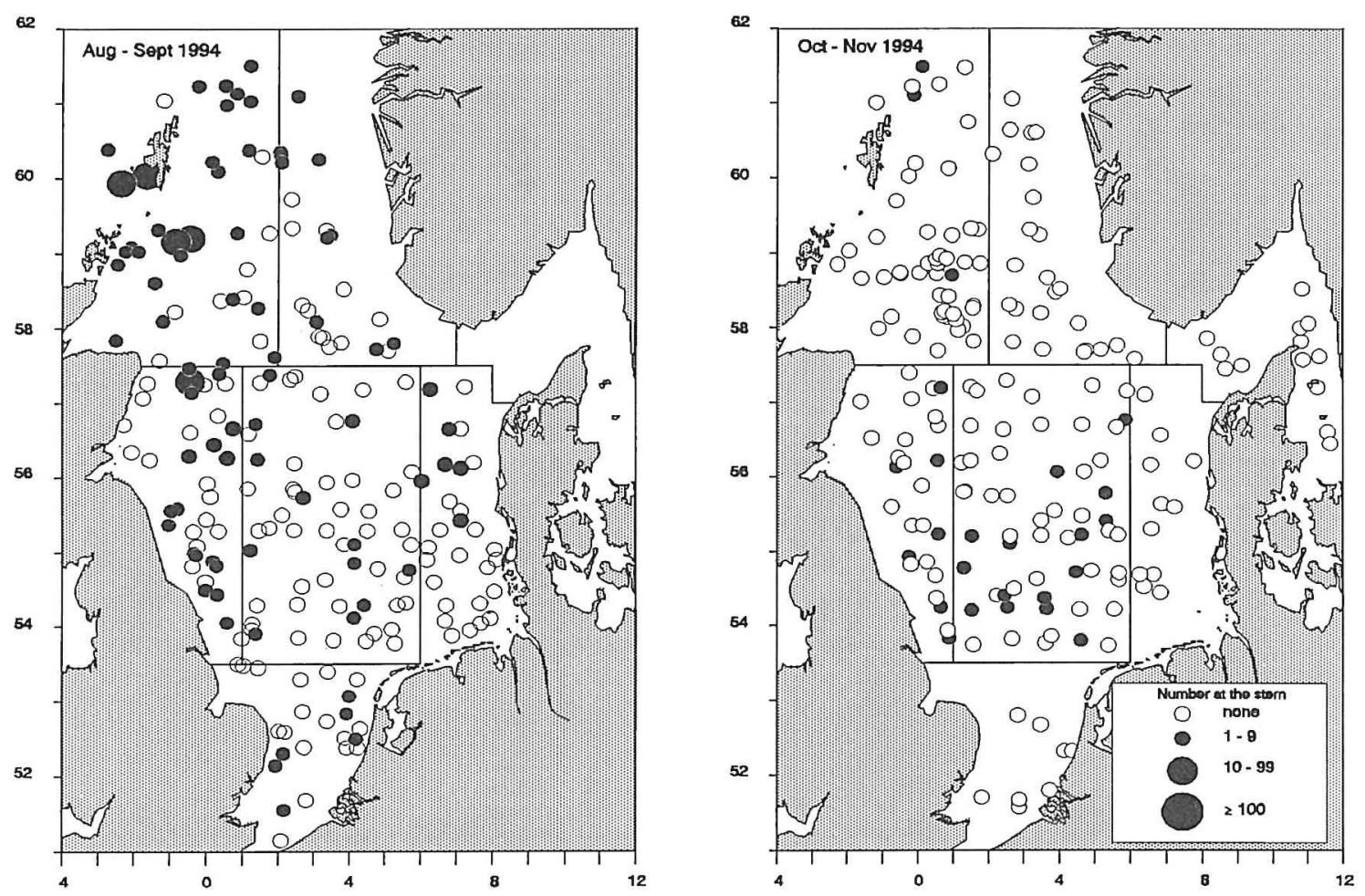

Figures 4.3.13-14 Distribution of Great Skua from stern counts 

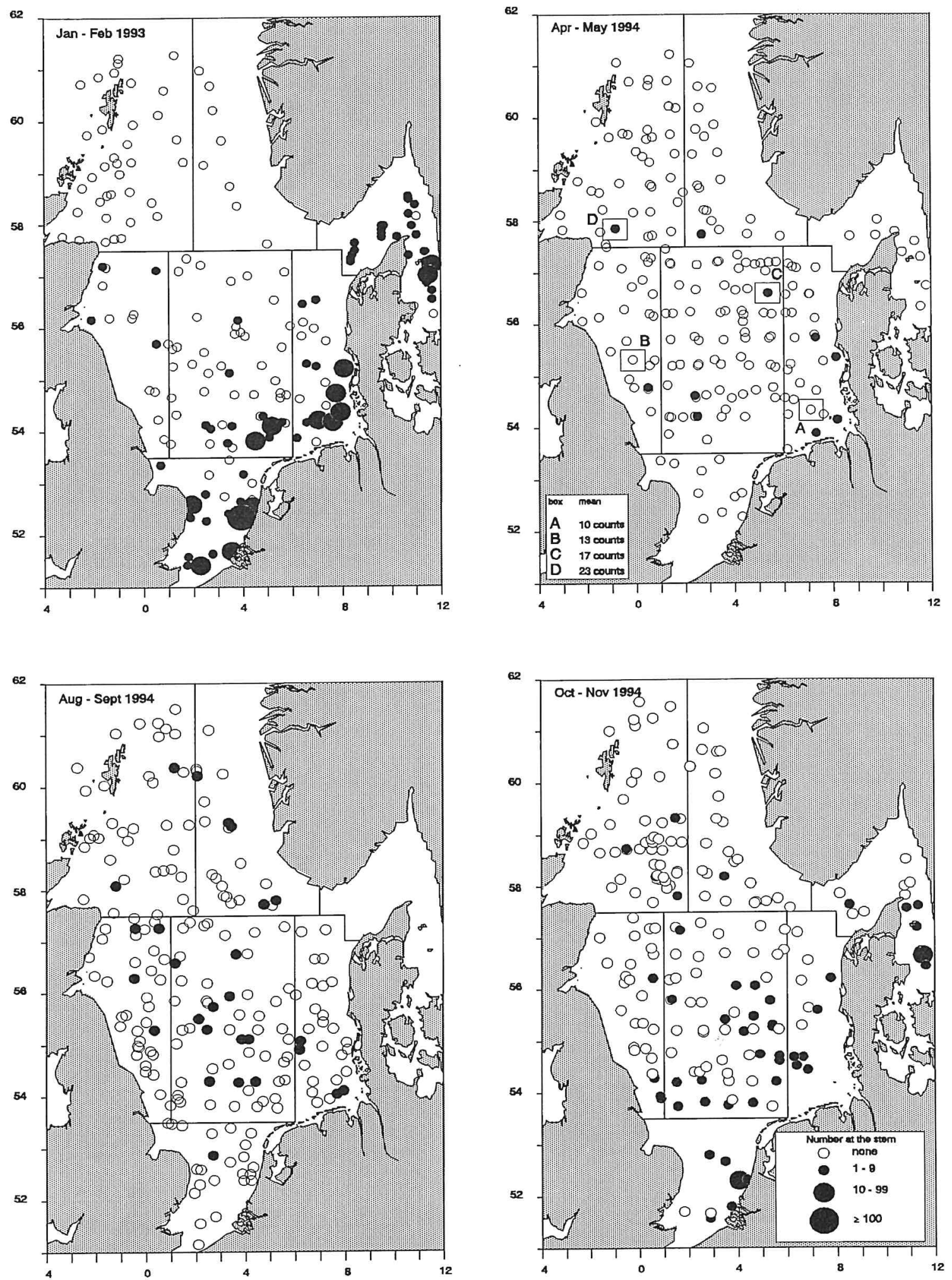

Figure 4.3.15-18 Distribution of Common Gull from stern counts 

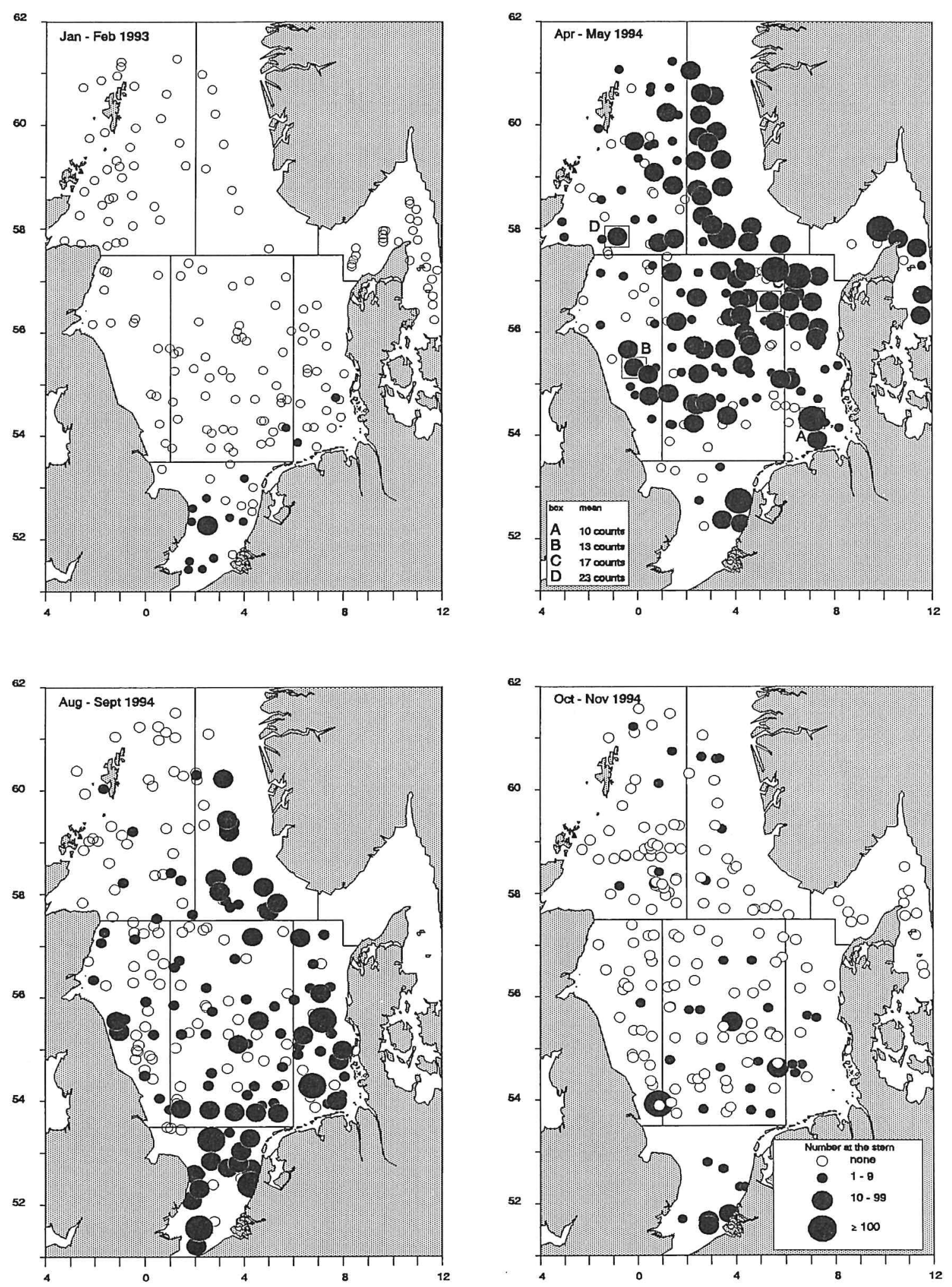

Figure 4.3.19-22 Distribution of Lesser Black-backed Gull from stern counts 

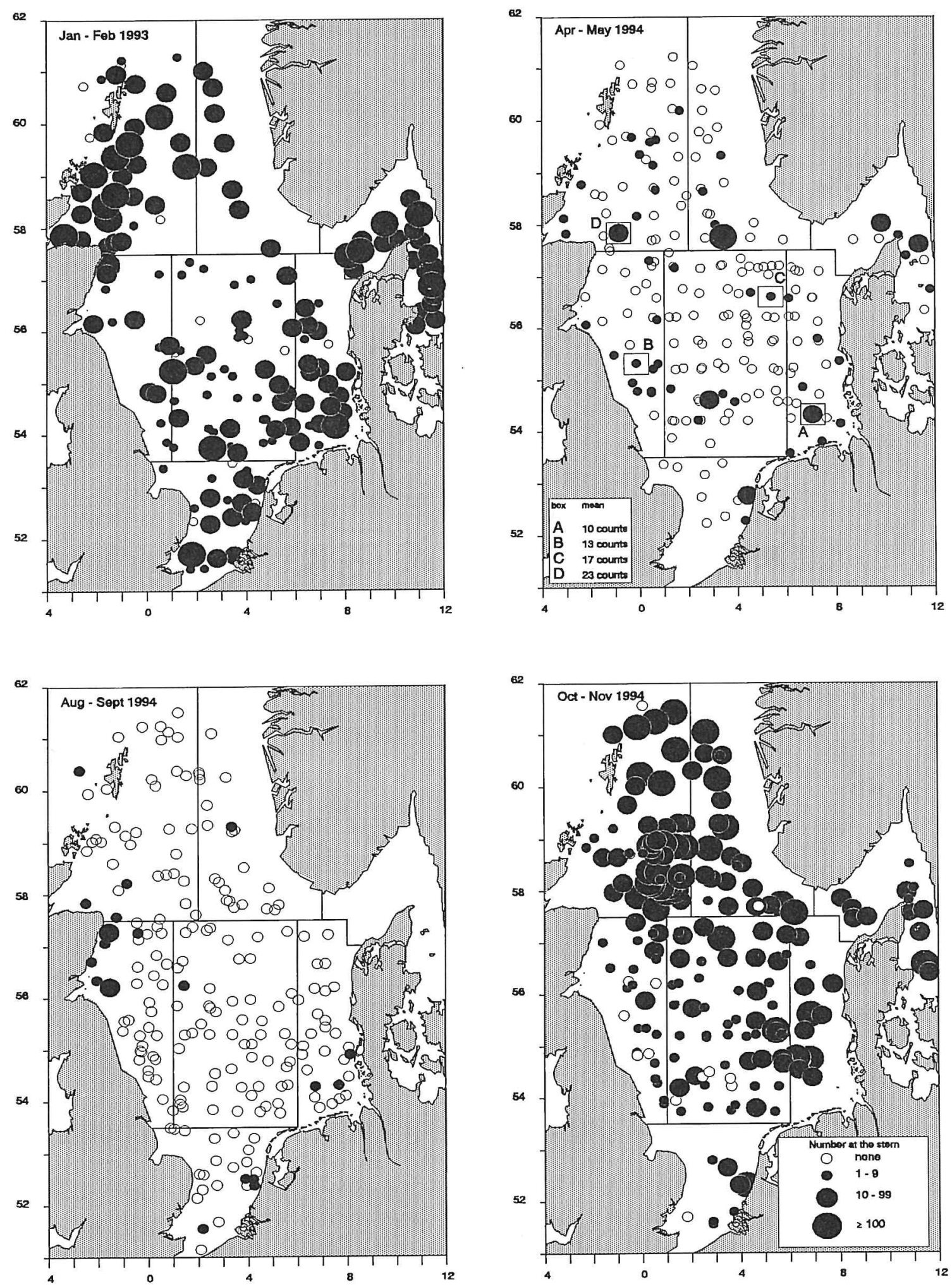

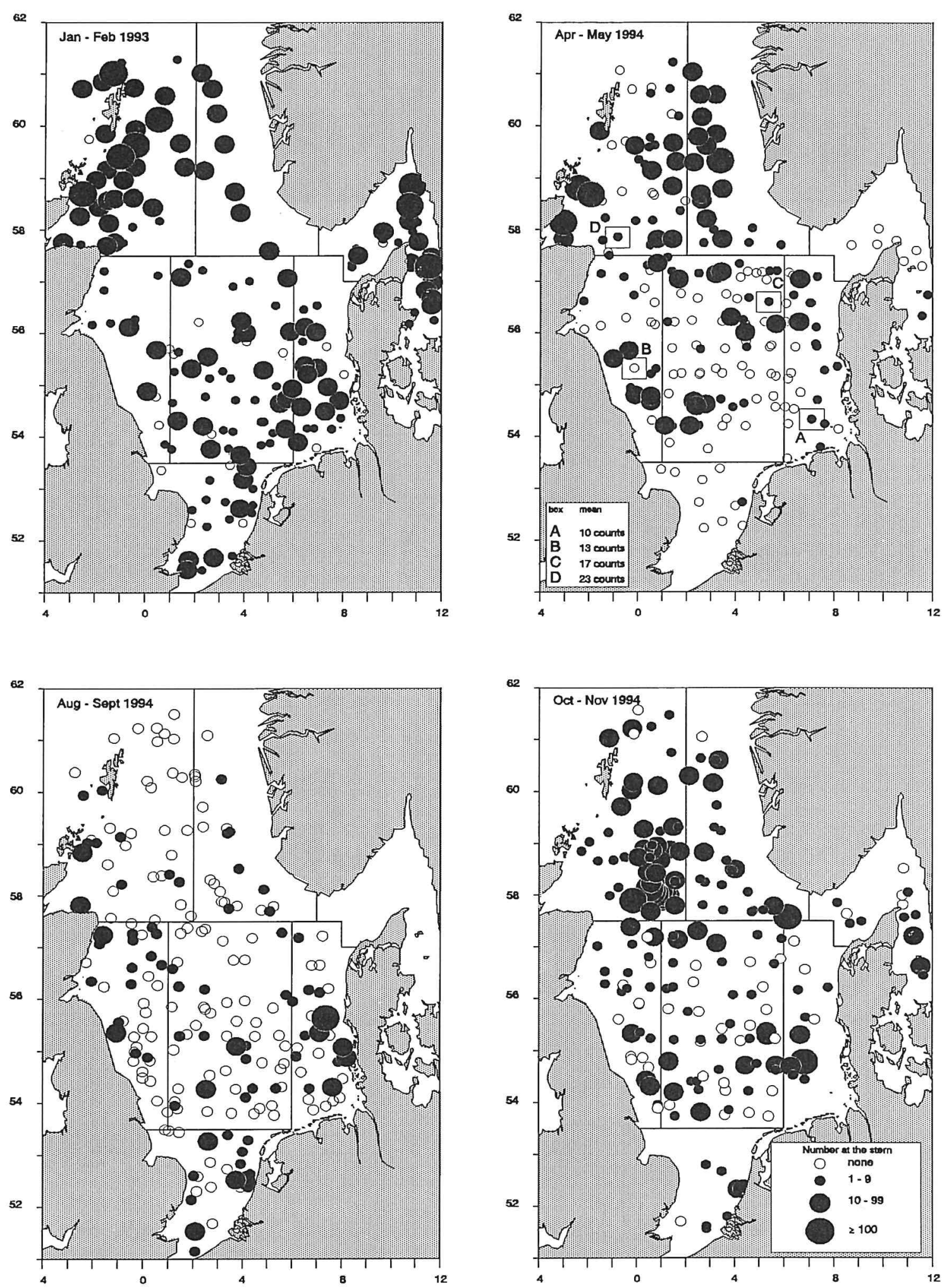

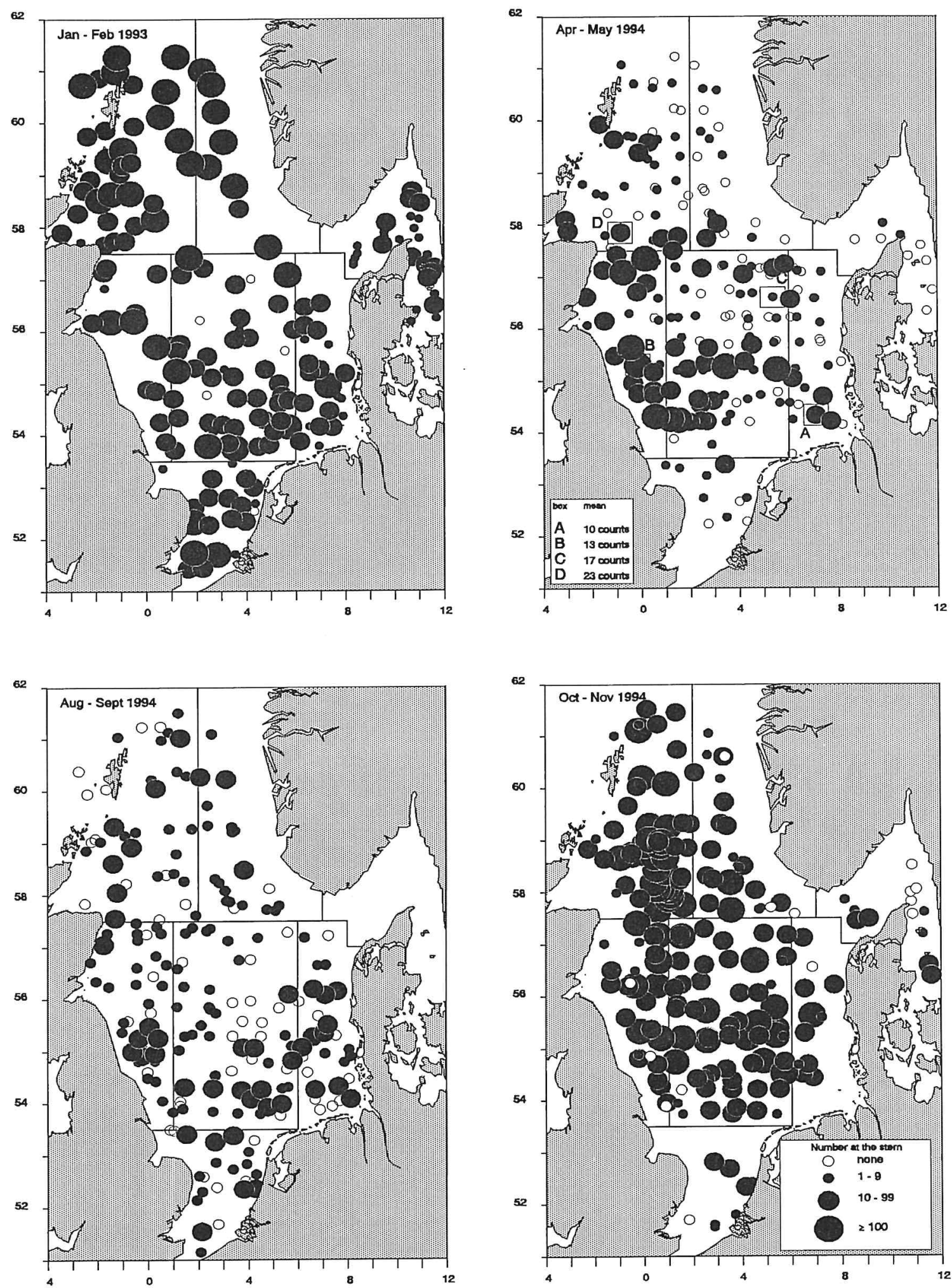

Figure 4.3.31-34 Distribution of Kittiwake from stern counts 

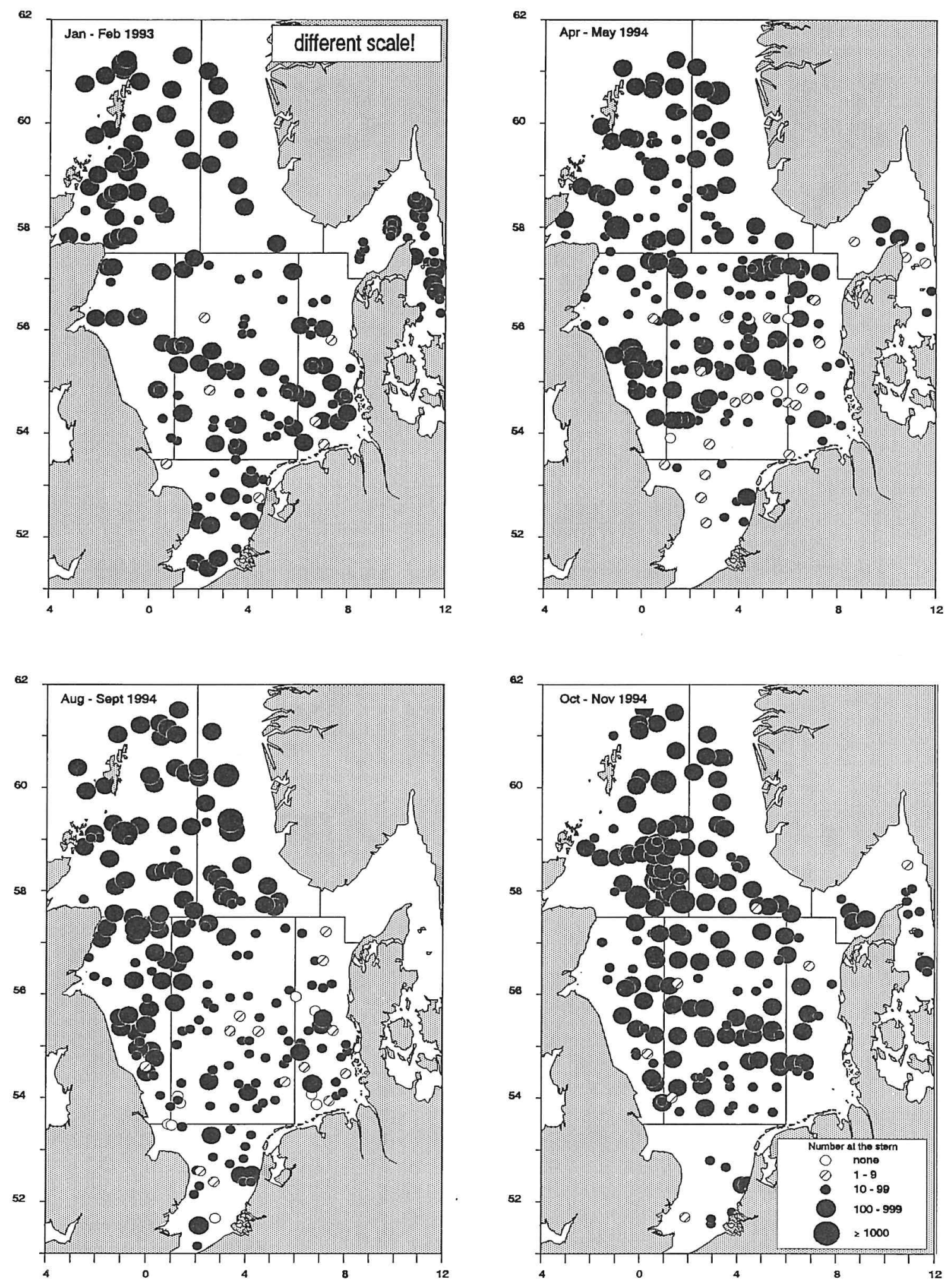

Figure 4.3.35-38 Total numbers of scavengers at the stern 

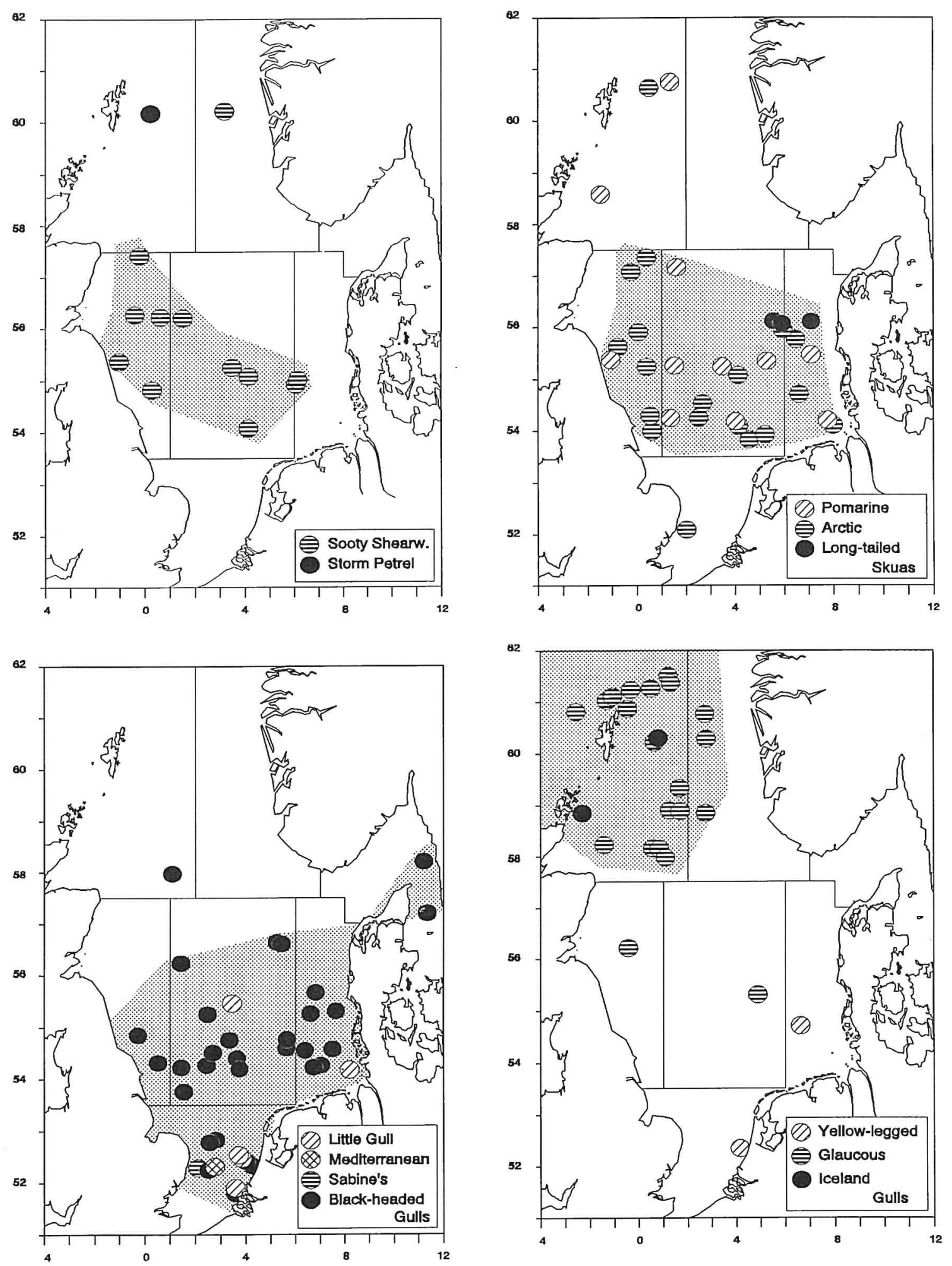

Figure 4.3.39-42 Rarer seabirds at the stern: shearwaters, storm petrels, skuas and gulls 

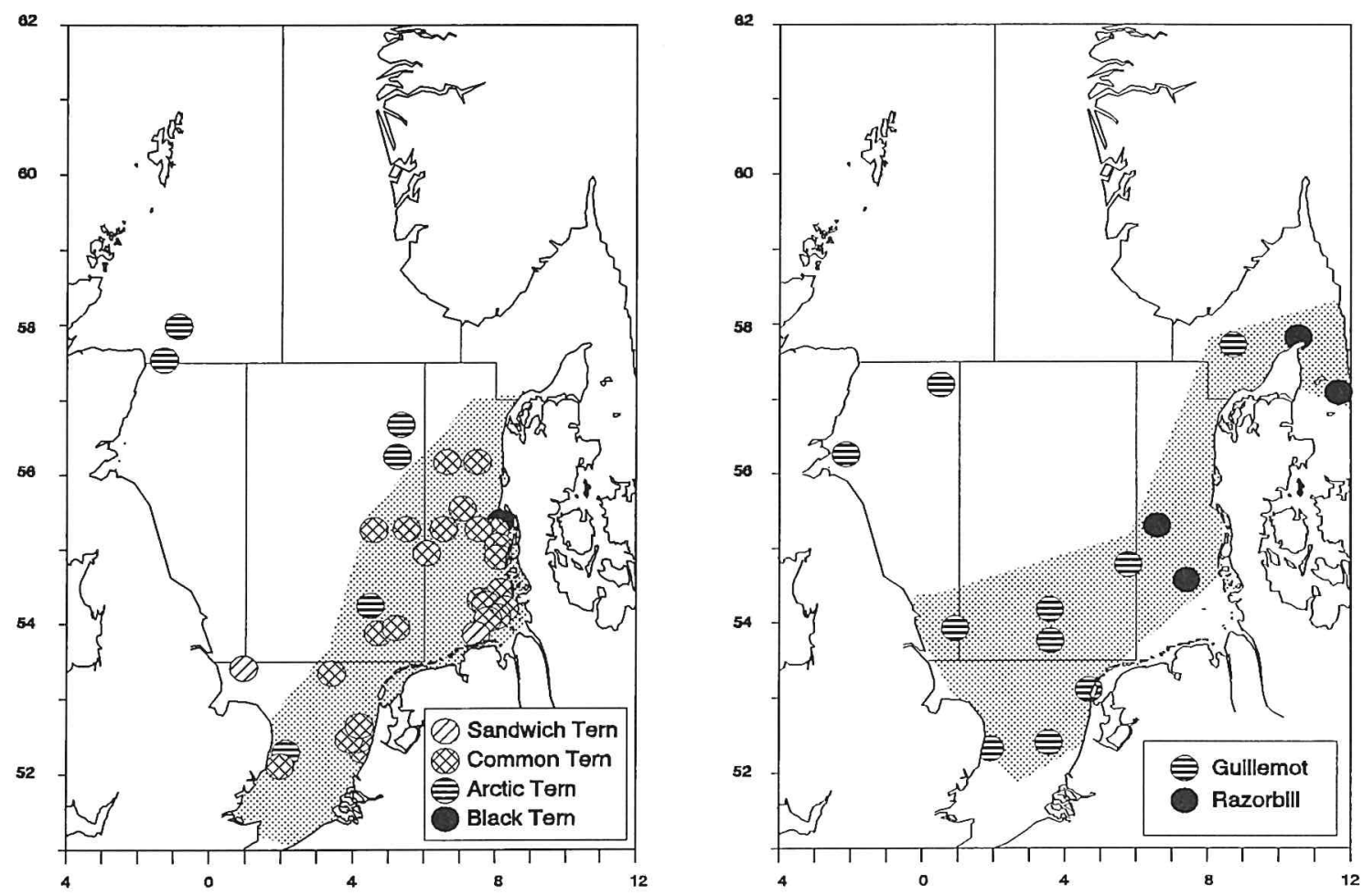

Figure 4.3.43-44 Rarer seabirds at the stern: terns and auks

Scotland, and in the central northern North Sea numbers of scavengers assembling at the stern were usually well in excess of a few hundreds of individuals. Obviously, Fulmars were often numerically predominating in these waters.

Age composition at the stern compared to age composition at sea

Both during strip-transect counts and during stern counts it was always attempted to age the Gannets and gulls. Because flocks of gulls in association with the research vessels were often large and difficult to count, it was not practical to try and age gulls on the level of calendar years, but rather in agegroups: adults, immatures and juveniles (i.e. 1 st calendar year or first half of second calendar year). In the final analysis, we have further reduced this subdivision as to adults and non-adults (named: immatures; tables 4.1.6-11, 4.3.3-9). For Fulmars, in which immatures cannot be recognised from plumage characteristics, the ratio between 'coloured birds' (dark phase, coded L, D, and
DD by Van Franeker \& Wattel 1982) and 'light birds' (coded LL), or birds which were certainly from arctic origin and birds that originated most probably from boreal colonies, was assessed (tables 4.1.5, 4.3.2). In this section, the ratios between adult and immature Gannets and gulls and coloured and light phase Fulmars from transect counts and stern counts were compared (table 4.3.10).

In February 1993, the proportion of coloured Fulmars at the stern was not assessed. In May and August, proportions of coloured birds were very low in both samples. Significantly more coloured birds were seen at the stern than at sea in May, while in August, when the difference was not significant, nearly the reverse was true. In November, numbers of coloured birds at the stern were significantly higher than the numbers recorded at sea. For Gannets, the overall tendency of much larger numbers of adults than immatures and comparatively more immatures in summer than in winter was the same in both samples, although significantly diffe- 
rent ratios were found in all surveys. The differences were not consistent, with rather fewer adults at the stern than at sea in May and November, but more in February and August. In Common Gulls, again, the overall tendency was much the same in both samples, with comparatively large numbers of adults in winter and more immatures in summer. The differences in age ratios were small, and not significant in February and August. In Lesser Black-backed Gulls, adults predominated in both samples on similar levels in winter. In summer, however, significantly more immatures were observed at the stern than could be expected from the transect counts. In Herring Gulls, which were most numerous in winter, the proportion of adults at the stern was signficantly lower than that at sea. In summer, the reverse was true, but not significant in August. For Great Black-backed Gulls, in three out of four surveys, the proportion of adults at the stern was significantly lower than that at sea, whereas in February the reverse was found. For Kittiwakes, the age ratios at the stern and at sea were similar in winter, whereas in summer the proportion of adults at the stern was significantly lower than that found at sea.

\section{Distance to the coast}

The observed distribution patterns incidate that most of the common species of scavengers occurred both offshore and inshore in substantial numbers. Fulmars were the most typical of the offshore scavengers. Mean numbers increased away from the coast in all surveys (table 4.3.11). Gannets occurred relatively frequently and were comparatively numerous between 25 and $100 \mathrm{~km}$ away from the coast. Great Skuas were widespread, but least common in the coastal strip. Common Gulls were typically inshore scavengers. Lesser Black-backed Gulls occurred in fair numbers offshore, but in the breeding season, adults were comparatively numerous closer to the coast. Herring Gulls were strictly coastal in summer, but widespread in winter when much larger numbers arrived in the North Sea. Great Black-backed Gulls were equally frequent and equally numerous in all distance zone, with a tendency to larger numbers in the coastal zone in February. Kittiwakes were widespread and occurred offshore and inshore in substantial numbers. In summer, Fulmars were most numerous in the central and northwestern North Sea over stratified water masses, avoiding the inshore zone where water masses were mixed. For Larus-gulls the overall distribution pattern was much the reverse. It often appeared the the species composition changed abruptly after crossing the invisible border between the two water masses, both in numbers of birds in transect and in the species composition at fishing stations on either side.

\section{Other species}

Several other species were seen in small numbers at the trawl. Sooty Shearwaters were observed singly or in twos, often scavenging in the periphery of the flock of shipfollowers (sometimes attacked by Fulmars and Great Skuas), mainly in August and in the central North Sea or off East Scotland (figure 4.3.39). Most sightings were just to the east of the core feeding area for this species in autumn, which is in a $100 \mathrm{~km}$ wide band off the coast of Scotland and northeast England, particularly off Flamborough Head (Hall et al. 1987, Camphuysen 1995). A Manx Shearwater approached a research vessel during hydrographical sampling in the Skagerrag area in February 1993. A single Storm Petrel was observed in August near Shetland (figure 4.3.39). One Cormorant was associated with a research vessel in the central North Sea in May and a Shag was associated with a research vessel working off Orkney in November. Pomarine and Arctic Skuas were most frequently attracted in August and November, mainly in the central North Sea (subregions CW, C, and CE), but only in small numbers (figure 4.3.40). Very small numbers of both species were observed at the trawl in May. Ten out of 15 Pomarine Skuas were juveniles or immatures, while some $50 \%$ of the Arctic Skuas were not adult. Sightings of Long-tailed Skuas at the trawl comprised four juveniles in August west of Denmark (three records; figure 4.3.30). A single Mediterranean Gull Larus melanocephalus was observed in February, off southeast England (figure 4.3.41). Little Gulls were occasionally observed in the southeastern North Sea in each of the four surveys. Black-headed Gulls were observed frequently, particularly in a band across the 
Table 4.3.10 Age composition of Fulmar, Gannet and gulls during transect counts and at stern compared with G-test $\left(p>0.05=n . s, p<0.05={ }^{*}, p<0.01={ }^{*}, p<0.001 *^{* *}\right)$..

\begin{tabular}{|c|c|c|c|c|c|c|c|c|}
\hline \multirow[b]{2}{*}{ Fulmar } & \multicolumn{3}{|c|}{ Transect counts } & \multicolumn{4}{|c|}{ Stern counts } & \multirow{2}{*}{$\begin{array}{l}\text { G-test } \\
p<\end{array}$} \\
\hline & col & light & $\%$ col & col & light & $\%$ col & G adj & \\
\hline February & 50 & 3889 & 1.3 & & & & & \\
\hline May & 9 & 10655 & 0.1 & 33 & 16341 & 0.2 & 6.22 & $*$ \\
\hline August & 23 & 11906 & 0.2 & 31 & 27651 & 0.1 & & n.s. \\
\hline November & 126 & 18487 & 0.7 & 306 & 10685 & 2.8 & 204.9 & $* * *$ \\
\hline Gannet & ad & imm & $\%$ ad & ad & $\mathrm{imm}$ & $\%$ ad & $\mathbf{G}$ adj & $\mathrm{p}<$ \\
\hline February & 754 & 22 & 97.2 & 1731 & 21 & 98.8 & 7.93 & $*$ \\
\hline May & 1676 & 176 & 90.5 & 3146 & 529 & 85.6 & 246 & $* * *$ \\
\hline August & 997 & 465 & 68.2 & 1099 & 317 & 77.6 & 32.41 & $* * *$ \\
\hline November & 1371 & 87 & 94.0 & 1332 & 156 & 89.5 & 20.12 & $* * *$ \\
\hline Common Gull & ad & $\mathrm{imm}$ & $\%$ ad & ad & $\mathrm{imm}$ & $\%$ ad & G adj & $\mathrm{p}<$ \\
\hline February & 253 & 43 & 85.5 & 609 & 99 & 86.0 & & n.s. \\
\hline May & 25 & 34 & 42.4 & 6 & 28 & 17.6 & 6.29 & $*$ \\
\hline August & 6 & 21 & 22.2 & 12 & 27 & 30.8 & & n.s. \\
\hline November & 50 & 20 & 71.4 & 177 & 57 & 75.6 & 7.94 & $*$ \\
\hline Lesser Bb Gull & ad & $\mathrm{imm}$ & $\%$ ad & ad & $\mathrm{imm}$ & $\%$ ad & G adj & $\mathrm{p}<$ \\
\hline February & 15 & 1 & 93.8 & 40 & 4 & 90.9 & & n.s. \\
\hline May & 1375 & 314 & 81.4 & 1989 & 1589 & 55.6 & 353.4 & $* * *$ \\
\hline August & 1293 & 599 & 68.3 & 1248 & 1247 & 50.0 & 150 & $* * *$ \\
\hline November & 61 & 36 & 62.9 & 206 & 81 & 71.8 & & n.s. \\
\hline Herring Gull & ad & imm & $\%$ ad & ad & imm & $\%$ ad & G adj & $p<$ \\
\hline February & 1140 & 455 & 71.5 & 6121 & 3191 & 65.7 & 20.63 & $* * *$ \\
\hline May & 127 & 139 & 47.7 & 284 & 151 & 65.3 & 20.87 & $* * *$ \\
\hline August & 128 & 118 & 52.0 & 95 & 73 & 56.5 & & n.s. \\
\hline November & 854 & 595 & 58.9 & 4945 & 4791 & 50.8 & 33.73 & $* * *$ \\
\hline Great Bb Gull & ad & $\mathrm{imm}$ & $\%$ ad & ad & imm & $\%$ ad & G adj & $\mathrm{p}<$ \\
\hline February & 515 & 368 & 58.3 & 2803 & 1559 & 64.3 & 10.99 & $* * *$ \\
\hline May & 101 & 140 & 41.9 & 613 & 1203 & 33.8 & 6.096 & $*$ \\
\hline August & 139 & 105 & 57.0 & 306 & 510 & 37.5 & 28.92 & $* * *$ \\
\hline November & 415 & 342 & 54.8 & 907 & 1266 & 41.7 & 38.67 & $* * *$ \\
\hline Kittiwake & ad & $\mathrm{imm}$ & $\%$ ad & ad & $\mathrm{imm}$ & $\%$ ad & $\mathbf{G}$ adj & $\mathrm{p}<$ \\
\hline February & 2836 & 246 & 92.0 & 10551 & 921 & 92.0 & & n.s. \\
\hline May & 6922 & 283 & 96.1 & 4307 & 509 & 89.4 & 202.1 & $* * *$ \\
\hline August & 1237 & 410 & 75.1 & 1275 & 555 & 69.7 & 12.8 & $* * *$ \\
\hline November & 2644 & 331 & 88.9 & 12573 & 1614 & 88.6 & & n.s \\
\hline
\end{tabular}


Table 4.3.11 Mean number and presence (\%) at the stern of research vessels in relation to distance to the nearest coast (classes 1-25, 25-50, 50-100 and >100 km). The mean was calculated as total number observed at the stern divided by total number of counts in that zone.

\begin{tabular}{|c|c|c|c|c|c|c|c|c|c|c|c|c|}
\hline \multirow[b]{2}{*}{$\begin{array}{cc}\text { Distance } & 1-25 \\
\text { Counts } & 39\end{array}$} & \multicolumn{2}{|c|}{ February } & \multicolumn{4}{|c|}{ May } & \multicolumn{3}{|c|}{ August } & \multicolumn{3}{|c|}{ November } \\
\hline & $\begin{array}{rr}-50 & -100 \\
36 & 52\end{array}$ & $\begin{array}{r}>100 \\
61\end{array}$ & $\begin{array}{r}1-25 \\
22\end{array}$ & $\begin{array}{r}-50 \\
16\end{array}$ & $\begin{array}{r}-100 \\
88\end{array}$ & $\begin{array}{r}>100 \\
142\end{array}$ & $\begin{array}{r}1-25 \\
19\end{array}$ & $\begin{array}{rr}-50 & -100 \\
33 & 56\end{array}$ & $\begin{array}{r}>100 \\
94\end{array}$ & $\begin{array}{r}1-25 \\
13\end{array}$ & $\begin{array}{rr}-50 & -100 \\
17 & 45\end{array}$ & $\begin{array}{r}>100 \\
116\end{array}$ \\
\hline $\begin{array}{lr}\text { Fulmar } & \\
\text { mean } & 5 \\
\text { pres\% } & 30.8\end{array}$ & $\begin{array}{rr}108 & 33 \\
75.0 & 75.0\end{array}$ & $\begin{array}{r}91 \\
86.9\end{array}$ & $\begin{array}{r}42 \\
50.0\end{array}$ & $\begin{array}{r}43 \\
81.3\end{array}$ & $\begin{array}{r}389 \\
92.0\end{array}$ & $\begin{array}{r}115 \\
97.2\end{array}$ & $\begin{array}{r}56 \\
47.4\end{array}$ & $\begin{array}{r}44 \\
69.783 .9\end{array}$ & $\begin{array}{r}167 \\
100.0\end{array}$ & $\begin{array}{r}15 \\
46.2\end{array}$ & $\begin{array}{rr}53 & 62 \\
64.7 & 73.3\end{array}$ & $\begin{array}{r}133 \\
93.1\end{array}$ \\
\hline $\begin{array}{cr}\text { Gannet } & \\
\text { mean } & 2 \\
\text { pres\% } & 15.4\end{array}$ & $\begin{array}{rr}23 & 11 \\
47.2 & 40.4\end{array}$ & $\begin{array}{r}6 \\
55.7\end{array}$ & $\begin{array}{r}4 \\
31.8\end{array}$ & $56.3^{9}$ & $\begin{array}{r}35 \\
63.6\end{array}$ & $\begin{array}{r}3 \\
46.5\end{array}$ & $\begin{array}{r}4 \\
47.4\end{array}$ & $\begin{array}{rr}8 & 15 \\
48.5 & 55.4\end{array}$ & $\begin{array}{r}3 \\
63.8\end{array}$ & $\begin{array}{r}2 \\
38.5\end{array}$ & $\begin{array}{rr}15 & 10 \\
70.6 & 66.7\end{array}$ & $\begin{array}{r}7 \\
75.9\end{array}$ \\
\hline $\begin{array}{ll}\text { Great } & \text { Skua } \\
\text { mean } & 0 \\
\text { pres } \% & 0.0\end{array}$ & $\begin{array}{rr}0 & 0 \\
2.8 & 0.0\end{array}$ & $\begin{array}{r}0 \\
0.0\end{array}$ & $\begin{array}{r}1 \\
13.6\end{array}$ & $\begin{array}{r}1 \\
25.0\end{array}$ & $\begin{array}{r}0 \\
26.1\end{array}$ & $\begin{array}{r}0 \\
9.9\end{array}$ & $\begin{array}{r}3 \\
21.1\end{array}$ & $\begin{array}{rr}2 & 2 \\
51.5 & 48.2\end{array}$ & $\begin{array}{r}1 \\
35.1\end{array}$ & $\begin{array}{r}0 \\
0.0\end{array}$ & $\begin{array}{rr}0 & 0 \\
11.8 & 11.1\end{array}$ & $\begin{array}{r}0 \\
15.5\end{array}$ \\
\hline $\begin{array}{cc}\text { Common } & \text { Gull } \\
\text { mean } & 10 \\
\text { pres\% } & 71.8\end{array}$ & $\begin{array}{rr}6 & 3 \\
50.0 & 40.4\end{array}$ & $\begin{array}{r}0 \\
14.8\end{array}$ & $\begin{array}{r}0 \\
13.6\end{array}$ & $\begin{array}{r}0 \\
0.0\end{array}$ & $\begin{array}{r}0 \\
5.7\end{array}$ & $\begin{array}{r}0 \\
4.9\end{array}$ & $\begin{array}{r}0 \\
10.5\end{array}$ & $\begin{array}{rr}0 & 0 \\
0.0 & 7.1\end{array}$ & $\begin{array}{r}0 \\
22.3\end{array}$ & $\begin{array}{r}8 \\
46.2\end{array}$ & $\begin{array}{rr}2 & 2 \\
23.5 & 31.1\end{array}$ & $\begin{array}{r}0 \\
21.6\end{array}$ \\
\hline $\begin{array}{cc}\text { Lesser } & \text { Black- } \\
\text { mean } & 0 \\
\text { pres\% } & 12.8\end{array}$ & $\begin{array}{cc}\text { backed Gull } \\
0 & 0 \\
13.9 & 7.7\end{array}$ & $\begin{array}{r}0 \\
0.0\end{array}$ & $\begin{array}{r}19 \\
59.1\end{array}$ & $\begin{array}{r}16 \\
68.8\end{array}$ & $\begin{array}{r}16 \\
81.8\end{array}$ & $\begin{array}{r}12 \\
75.4\end{array}$ & $\begin{array}{r}12 \\
68.4\end{array}$ & $\begin{array}{rr}21 & 23 \\
57.6 & 50.0\end{array}$ & $\begin{array}{r}3 \\
44.7\end{array}$ & $\begin{array}{r}2 \\
23.1\end{array}$ & $\begin{array}{rr}3 & 3 \\
23.5 & 22.2\end{array}$ & $\begin{array}{r}1 \\
20.7\end{array}$ \\
\hline $\begin{array}{cr}\text { Herring } & \text { Gull } \\
\text { mean } & 86 \\
\text { pres\% } & 92.3\end{array}$ & $\begin{array}{rr}76 & 43 \\
91.7 & 96.2\end{array}$ & $\begin{array}{r}21 \\
90.2\end{array}$ & $\begin{array}{r}10 \\
59.1\end{array}$ & $\begin{array}{r}1 \\
25.0\end{array}$ & $\begin{array}{r}2 \\
35.2\end{array}$ & $\begin{array}{r}2 \\
15.5\end{array}$ & $\begin{array}{r}4 \\
36.8\end{array}$ & $\begin{array}{rr}0 & 1 \\
18.2 & 7.1\end{array}$ & $\begin{array}{r}0 \\
2.1\end{array}$ & $\begin{array}{r}25 \\
100.0\end{array}$ & $\begin{array}{rr}54 & 52 \\
88.2 & 91.1\end{array}$ & $\begin{array}{r}91 \\
93.1\end{array}$ \\
\hline $\begin{array}{cc}\text { Great } & \text { Black-b } \\
\text { mean } & 33 \\
\text { pres } \% & 84.6\end{array}$ & $\begin{array}{r}\text { acked Gul l } \\
36 \quad 19 \\
88.994 .2\end{array}$ & $\begin{array}{r}15 \\
90.2\end{array}$ & $\begin{array}{r}9 \\
54.5\end{array}$ & $\begin{array}{r}3 \\
50.0\end{array}$ & $\begin{array}{r}10 \\
76.1\end{array}$ & $\begin{array}{r}6 \\
57.7\end{array}$ & $\begin{array}{r}10 \\
63.2\end{array}$ & $\begin{array}{rr}7 & 5 \\
42.4 & 35.7\end{array}$ & $\begin{array}{r}1 \\
28.7\end{array}$ & $\begin{array}{r}10 \\
84.6\end{array}$ & $\begin{array}{rr}16 & 11 \\
76.5 & 73.3\end{array}$ & $\begin{array}{r}19 \\
80.2\end{array}$ \\
\hline $\begin{array}{l}\text { Kittiwake } \\
\text { mean } \\
\text { pres\% } 94.9\end{array}$ & $100.0^{66} 96 . .^{66}$ & $\begin{array}{r}8 \\
91.8\end{array}$ & $\begin{array}{r}7 \\
50.0^{7}\end{array}$ & $\begin{array}{r}30 \\
81.3\end{array}$ & $\begin{array}{rr}0 & 36 \\
3 & 85.2\end{array}$ & $\begin{array}{r}8 \\
69.0\end{array}$ & $\begin{array}{r}8 \\
63.2\end{array}$ & $\begin{array}{rr}6 & 10 \\
57.6 & 82.1\end{array}$ & $\begin{array}{r}10 \\
78.7\end{array}$ & $\begin{array}{r}11 \\
100.0\end{array}$ & $\begin{array}{rr}61 & 46 \\
94.1 & 86.7\end{array}$ & $\begin{array}{r}163 \\
100.0\end{array}$ \\
\hline
\end{tabular}

central North Sea (possibly migrants crossing the North Sea from Denmark to Britain or vice versa), in the Southern Bight and in the Kattegat area. Most sightings were in November. A single Sabine's Gull Larus sabini was reported off southeast England in August. Adult Yellow-legged Gulls Larus cachinnans were observed twice: in the German Bight and off the Dutch coast. Glaucous Gulls were frequently attracted occurred mainly around Shetland during the winter surveys (February and November; figure 4.3.42). Most sightings were of juveniles or immatures. Iceland Gulls Larus glaucoides were rare, but occurred in much the same area in winter. Scavenging terns at the trawl were a southeastern North Sea phenomenon (figure 4.3.43). There were only two records of Sandwich Terns in the German Bight and off East England, but Common Terns were frequently reported in August, often in small groups of an adult or two with one or more juveniles, and occasionally in May. Most these sightings referred to adults accompanying one or more juveniles. Arctic Terns were seen mainly in May with just two sightings of juveniles in August. This species was more often seen offshore than the Common Tern, and also recorded off northeast Scotland. Black Terns were observed twice in association with research vessels (May and August). In February 1993, several Guillemots and Razorbills were attracted to the research vessels (figure 4.3.44) and successful feeding attempts were observed on these occasions (birds diving towards the net and surfacing with fish). Scavenging auks were occasionally observed in association with fishing vessels in this same winter. 


\section{Conclusions}

A total of 29 different species of seabirds were attracted to fishing research vessels, including four species of Procellariiforms, the Gannet, two species of cormorants, four species of skuas, 12 species of gulls, five species of terns and two species of auks. Four species, the Mediterranean Gull, Sabine's Gull, Yellow-legged Gull and Iceland Gull, had not been recorded during striptransect counts. Razorbills and Guillemots are abundant seabirds in the North Sea, which were only rarely attracted to fishing vessels. Otherwise the seasonal and spatial variations in relative abundance and species composition of seabirds at sea were well reflected in the numbers and species composition of scavenging seabirds attracted to the fishing research vessels. A notable exception was the Kittiwake which appeared to be more readily attracted in winter than in summer whereas numbers at sea peaked in summer. In most gulls, there was a tendency of proportionally lower numbers of adults at the stern (stern counts) than at sea (transect counts) when overall numbers in the North Sea were largest (Lesser Black-backed Gull in summer, Herring Gull in winter, Kittiwake in summer), except in Common Gulls, where the reverse was found. Age composition at the stern was often significantly different from that found at sea, but overall fluctuations (spatial and temporal) were usually very similar. Most of the common species of scavengers attracted by research vessels occurred both offshore and inshore in substantial numbers. Fulmars were the most typical of the offshore scavengers. There was an overall tendency of comparatively high numbers at trawls in the northwestern two-thirds of the North Sea. Fulmars and Kittiwakes numerically dominated in this area, whereas large Larus-gulls predominated in the southeastern half of the study area (Skagerrak, German Bight, Southern Bight).

\subsection{DISTRIBUTION OF FISHING VESSELS}

The distribution of different types of fishing vessels in the North Sea was assessed by means of 'trawler counts' using the radar at regular intervals during steaming. The type and activity of fishing vessels were recorded from visual observations (chapter 2.2). Densities of boats $\left(\mathrm{n} / \mathrm{km}^{2}\right)$ were calculated and mapped per $0.5^{\circ}$ latitude $\times 1.0^{\circ}$ longitude square. For February 1993, when the radar technique had not been developed, the visual counts have been plotted as 'number of boats per km steamed' (table 4.4.3, figures $4.4 .1,4.4 .5)$. Fishing vessels were not always easy to identify to type. Certain types, such as beamtrawlers, are more distinctive than others. Long-liners were not recorded, although they are known to work in areas such as off Jutland (Denmark). Despite the problems of identification of different types, interesting distribution patterns have emerged for the major types of fishery.

\section{Observer effort}

The entire North Sea and Skagerrak were covered in each survey, except in August when the Skagerrak was not visited (figures 4.4.1-4). As with other aspects of the study, coastal areas were not adequately surveyed, with little effort within $10 \mathrm{~km}$ from the coast, and little can be concluded about coastal fisheries. Coverage of the Norwegian Deep was aslo patchy. For the remaining area, however, coverage was very good and in the 1994 surveys, while using the radar snap-shots $\left(97 \mathrm{~km}^{2}\right.$ covered per count), sampled just over $15 \%$ of the entire North Sea area (usually at least $10 \%$ of each subregion, with a maximum of $28 \%$ of subregion $\mathrm{CW}$ in August; table 4.4.1). Because radar counts provided more reliable data than the observations of fishing vessels in February 1993, the analyses below are based on the May, August and November cruises in 1994, unless otherwise stated.

It is good practice at sea to avoid collisions. Hence, research vessels steer around fishing vessels, obeying the traffic rules at 
Table 4.4.1 Observer effort $\left(\mathrm{km}^{2}\right.$ surveyed) and percentage covered of total area using radar snap-shots to count fishing vessels within a radius of 3 nautical miles around the ship.

\begin{tabular}{lrrrrrr}
\hline Subregion & \multicolumn{2}{c}{ May } & \multicolumn{2}{c}{ August } & \multicolumn{2}{c}{ November } \\
coverage & $\%$ & coverage & $\%$ & coverage & $\%$ \\
\hline NW & 20,660 & 13 & 14,450 & 9 & 19,400 & 12 \\
NE & 12,420 & 13 & 7,950 & 8 & 15,620 & 16 \\
Sk & 5,920 & 10 & 0 & & 6,010 & 10 \\
CW & 14,450 & 21 & 19,210 & 28 & 15,910 & 23 \\
C & 34,340 & 24 & 30,360 & 22 & 30,750 & 22 \\
CE & 14,940 & 24 & 10,480 & 17 & 7,760 & 12 \\
S & 9,600 & 17 & 11,930 & 21 & 5,430 & 10 \\
$\Sigma$ & 112,330 & 17 & 94,380 & 15 & 100,880 & 16 \\
\hline
\end{tabular}

sea. In order to investigate whether this had biased the data (with comparatively small numbers of vessels or pltforms near the ship), numbers of observed reflections in the three bands around the ship $10-1 \mathrm{~nm}, 1-2$ $\mathrm{nm}, 2-3 \mathrm{~nm}$ ) were compared with the expected number of reflections based on the area of each band (table 4.4.2). The number of recorded reflections was in accordance with expectation for all research vessels. Hence, there is no reason to assume that traffic intensity has been underestimated as a result of navigational routines.

\section{Weekend effect}

Several fishing fleets spend Sundays in harbour and most fish is marketed on Fridays and Saturdays. Most of the research vessels operated seven days of the week (only RVs Argos and Tridens spent weekends routinely in harbours). To test for a 'weekend effect' in the data (with smaller numbers of boats at sea during weekends) the number of boats observed for each day of the week (Monday-Sunday) was compared with the expected number based on observer effort (number of counts each day; table 4.4.3). Significant differences were found; on Fridays, Saturdays and Sundays, numbers of fishing vessels at sea were considerably lower than expected, especially in the Southern Bight (S) and subregion NE. In the other subregions, a 'weekend effect' is not significant or much less pronounced.

Total numbers of fishing vessels at sea From counts in February 1993, it was calculated that just over 1500 fishing vessels were active in the North Sea, using the assumption that all fishing vessels within $2 \mathrm{~km}$ on both sides of the research vessel were recorded; table 4.4.4). Comparatively high densities were reported in the Southern Bight and German Bight, off East England, around northern Shetland and off southwest Norway between Bergen Bank $\left(60^{\circ} \mathrm{N}, 3^{\circ} \mathrm{E}\right)$ and Utsira Ground $\left(59^{\circ} \mathrm{N}, 3^{\circ} \mathrm{E}\right.$; figure 4.4 .5$)$. In areas with high densities of fishing vessels, more than one fishing boat was observed per 4 nautical miles $(7 \mathrm{~km})$ of steaming. Of a total of 82 fishing vessels observed during these surveys, 71 were identified, including:

49 beamtrawlers (41) or shrimpers (8)

10 stern or otter trawlers

8 pair trawlers (6) or purse seiners (2)

4 'small boats' (probably anchor seiners or set net fishing boats)

Beamtrawlers and shrimpers predominated in the southern North Sea but were not recorded north of $55^{\circ} \mathrm{N}$. Stern trawlers were the only type around Shetland and apart from two boats working the southern edge of the 
Table 4.4.2 Observed and expected number of radar reflections caused by vessels or platforms within 1 mile, within 1-2 mile and within 2-3 mile around research vessels 11994 (BTSS). Expected numbers were calculated on the basis of surface area $\left(\mathrm{km}^{2}\right)$ in each ring; differences between observed and expected number were tested using the G-test.

\begin{tabular}{|c|c|c|c|c|c|c|c|c|c|}
\hline \multirow[b]{2}{*}{ Ship } & \multicolumn{3}{|c|}{ Observed } & \multicolumn{3}{|c|}{ Expected } & \multicolumn{3}{|c|}{ G-test } \\
\hline & 1 mile & 2 mile & 3mile & 1 mile & 2 mile & 3mile & $\mathrm{G}=$ & $\mathrm{df}$ & $p=$ \\
\hline Cirolana & 26 & 60 & 116 & 22 & 67 & 112 & 0.64 & 2 & n.s. \\
\hline Dana & 8 & 31 & 43 & 9 & 27 & 46 & 0.44 & 2 & n.s: \\
\hline Pelagia & 6 & 14 & 27 & 5 & 16 & 26 & 0.24 & 2 & n.s. \\
\hline G.O. Sars & 5 & 17 & 36 & 6 & 19 & 32 & 0.43 & 2 & n.s. \\
\hline M. Sars & 11 & 46 & 46 & 11 & 34 & 57 & 2.98 & 2 & n.s. \\
\hline Scotia & 20 & 50 & 77 & 16 & 49 & 82 & 0.61 & 2 & n.s. \\
\hline Thalassa & 14 & 57 & 119 & 21 & 63 & 106 & 2.46 & 2 & n.s. \\
\hline Tridens & 53 & 188 & 355 & 66 & 199 & 331 & 2.58 & 2 & n.s. \\
\hline Walther Herwig & 10 & 37 & 71 & 13 & 39 & 66 & 0.33 & 2 & n.s. \\
\hline$\Sigma$ & 145 & 469 & 847 & 162 & 487 & 812 & 2.02 & 2 & n.s. \\
\hline
\end{tabular}

Table 4.4.3 A 'weekend effect' in trawler counts: observed and expected number of fishing vessels from Monday through Sunday in each subregion (radar snapshot data from May, August and November IBTS combined). Expected numbers were calculated on the basis of the number of counts; differences between observed and expected number were tested using the G-test $\left(p>0.05=n . s, p<0.05={ }^{*}, p<0.01={ }^{*}, p<0.001 * *\right)$.

\begin{tabular}{|c|c|c|c|c|c|c|c|c|c|c|c|c|}
\hline Subr & & mon & tue & wed & thu & fri & sat & sun & totals & G adj $=$ & df & $\mathbf{p}=$ \\
\hline \multirow[t]{3}{*}{ NW } & Counts & 47 & 52 & 91 & 93 & 81 & 116 & 82 & 562 & & & \\
\hline & Fishing vessels & 4 & 6 & 14 & 12 & 5 & 13 & 7 & 61 & & & \\
\hline & Expected & 5 & 6 & 10 & 10 & 9 & 13 & 9 & 61 & 2.4 & 6 & n.s. \\
\hline \multirow[t]{3}{*}{ NE } & Counts & 40 & 89 & 52 & 51 & 70 & 31 & 38 & 371 & & & \\
\hline & Fishing vessels & 14 & 27 & 4 & 12 & 7 & 0 & 0 & 64 & & & \\
\hline & Expected & 7 & 15 & 9 & 9 & 12 & 5 & 7 & 64 & 26.2 & 6 & $* * *$ \\
\hline \multirow[t]{3}{*}{ Sk } & Counts & 15 & & 28 & 22 & 12 & 32 & 14 & 123 & & & \\
\hline & Fishing vessels & 1 & & 4 & 1 & 7 & 2 & 1 & 16 & & & \\
\hline & Expected & 2 & & 4 & 3 & 2 & 4 & 2 & 16 & 5.3 & 5 & n.s. \\
\hline \multirow[t]{3}{*}{ CW } & Counts & 88 & 113 & 74 & 77 & 76 & 20 & 63 & 511 & & & \\
\hline & Fishing vessels & 10 & 18 & 14 & 4 & 14 & 2 & 5 & 68 & & & \\
\hline & Expected & 11 & 15 & 11 & 11 & 11 & 3 & 6 & 68 & 4.9 & 6 & n.s. \\
\hline \multirow[t]{3}{*}{ C } & Counts & 104 & 192 & 210 & 179 & 108 & 128 & 63 & 984 & & & \\
\hline & Fishing vessels & 5 & 34 & 29 & 43 & 10 & 18 & 3 & 142 & & & \\
\hline & Expected & 15 & 28 & 30 & 26 & 16 & 18 & 9 & 142 & 14.6 & 6 & * \\
\hline \multirow[t]{3}{*}{ CE } & Counts & 35 & 65 & 87 & 88 & 5 & 23 & 39 & 342 & & & \\
\hline & Fishing vessels & 3 & 33 & 27 & 38 & 3 & 8 & 4 & 116 & & & \\
\hline & Expected & 12 & 22 & 30 & 30 & 2 & 8 & 13 & 116 & 14.3 & 6 & * \\
\hline \multirow[t]{3}{*}{$\mathbf{S}$} & Counts & 65 & 21 & 9 & 66 & 40 & 19 & 58 & 278 & & & \\
\hline & Fishing vessels & 55 & 27 & 1 & 20 & 3 & 0 & 5 & 111 & & & \\
\hline & Expected & 26 & 8 & 4 & 26 & 16 & 8 & 23 & 111 & 57.6 & 6 & $* * *$ \\
\hline \multirow[t]{3}{*}{$\Sigma$} & Counts & 394 & 532 & 551 & 576 & 392 & 369 & 317 & 3171 & & & \\
\hline & Fishing vessels & 92 & 145 & 93 & 130 & 49 & 43 & 26 & 578 & & & \\
\hline & Expected & 72 & 97 & 100 & 105 & 71 & 67 & 65 & 578 & 41.6 & 6 & $* * *$ \\
\hline
\end{tabular}


Dogger Bank $\left(54^{\circ} 10^{\prime} \mathrm{N}\right)$, were all observed north of $55^{\circ} \mathrm{N}$ (Camphuysen et al. 1993). After extrapolation, total numbers of beamtrawlers and shrimpers were estimated at 544 vessels $(35.5 \%$ of the boats observed), of which 491 occurred in subregions $C, C E$, and $S$ (table 4.4.5). Stern trawlers were the second most numerous type, with an estimated 264 vessels $(17.2 \%$ of boats), of which 234 occurred in NW.

In May 1994, a small but distinct 'weekend effect' was apparent, resulting in a $5 \%$ higher estimate of total numbers of fishing vessels in the North Sea from counts between Monday and Thursday than from counts during the whole week combined (table 4.4.4). The total for the North Sea of around 1500 fishing vessels was similar to February, but there were regional differences. Densities of fishing vessels were particularly high in the Southern Bight (S) and at the Little Fisher Bank, around the border of the Danish and Norwegian sectors of the North Sea (figure 4.4.6). Several heavily loaden Danish industrial fishing vessels were observed crossing the North Sea at ca. $57^{\circ} \mathrm{N}$ to Denmark, but these fleets were not encountered at their fishing grounds (i.e. not recorded in radar census). A very large Norwegian fleet, numbering at least 40 seiners and stern trawlers within a radius of 10 nautical miles was encountered at $57^{\circ} 15^{\prime} \mathrm{N}$, $04^{\circ} 52^{\prime} \mathrm{E}$ on 18 May 1994 (just to the north of the Great Fisher Bank). Beamtrawlers predominated in the Southern Bight. Of an overall estimate of 1457 fishing vessels in the North Sea, 995 vessels occurred in the southeastern North Sea (C, CE and S; table 4.4.4). Overall, $14 \%$ were set net fishing boats, $41.5 \%$ were beamtrawlers or shrimpers and $20.3 \%$ were stern or otter trawlers (table 4.4.5).

In August, there was again a considerable difference between estimated numbers of fishing vessels from counts between Monday and Thursday (1739) and during the entire week (1363). Except in the central North Sea and in the Southern Bight, numbers of fishing vessels counted were higher than in the other surveys and scattered moderate to high densities of fishing vessels were slightly more widespread than in May (figures 4.4.7, 4.4.9-10). Extensive fisheries occurred off northwest Denmark, southwest Norway (Bergen Bank area) and in the German Bight. There were more stern trawlers (mainly NW, NE and CW), purse seiners (NW and $\mathrm{CE}$ ) and pair trawlers (NE) at sea in August than in May and fewer beamtrawlers (mainly in C, CE and S; table 4.4.5).

In November the estimated number of fishing vessels was lower than in other months $(804$ boats Monday-Sunday, 889 boats Monday-Thursday; table 4.4.4). In all subregions, fewer fishing vessels were at sea than in August and only the northernmost subregions held more vessels than in the May survey (figures 4.4.9-10). Clusters of fishing vessels were present off northeast Scotland, well offshore west of Denmark and off east England (figure 4.4.8). As found earlier, beamtrawlers predominated in the southern half of the North Sea, stern and otter trawlers in the northern half (table 4.4.5).

Types of fishing vessels: the distribution of fisheries

Beamtrawlers $(25.6 \%)$ and sterntrawlers $(22.0 \%)$ were the most common types of fishing vessels observed during systematic surveys in 1994 ( $n=578$; table 4.4.6). About 100 fishing vessels remained unidentified. Beamtrawlers were typical of the southeastern North Sea and predominated south of $54^{\circ} 30^{\prime} \mathrm{N}$, particularly to the east of $2^{\circ} \mathrm{E}$. Sightings ranged from the Southern Bight to the Little Fisher Bank off south Norway (ca. $57^{\circ} \mathrm{N}$; figure 4.4.13). Beamtrawlers were numerically dominant Shrimpers were undoubtedly underestimated (as were coastal seabirds), because this fishery is concentrated close to land and within the Wadden Sea. Shrimpers and small beamtrawlers were not always easy to separate. The total numbers of (small) beamtrawlers and/or shrimpers in the North Sea, estimated from radar surveys, ranged from ca. 200 in November 
to 400 in May (table 4.4.5). From surveys in February 1993 it was estimated that well over 500 such vessels were active in the North Sea. Purse seiners were rare to the south of $55^{\circ} \mathrm{N}$ (figure 4.4.14). A concentration of purse seiners occurred around the Little Fisher Bank, in an area used for industrial fishing. Stern and otter trawlers were also numerous in this area. Estimates of the total numbers of purse seiners ranged from ca. 30 in May to 130 in August. Pair trawlers also had a mainly northerly distribution, but pairs of trawlers were occasionally recorded in the Southern Bight and the German Bight. It was estimated that between ca. 75 (November) and 150 (August) boats trawled as pairs in the North Sea. Anchor seiners were mainly observed in the German Bight and off northwest Jutland (Denmark; figure 4.4 .15$)$. Less than 50 were recorded for the whole North Sea, but this is probably an underestimate due to difficulty of identification. Set net fishing boats were widespread in the southeastern half of the North Sea, a spatial distribution pattern similar to that described for beamtrawlers, but with comparatively small numbers in coastal waters. Net markers (flags and colourful buoys) were observed in the same area. Total numbers estimated to occur in the North Sea ranged from nearly 90 in November to 150 in August. Stern and otter trawlers predominated in the northwestern half of the North Sea, with large fleets occasionally being observed at the Little Fisher Bank and between Bergen Bank and Utsira Ground along the Norwegian Deep (Norskerenna; $58^{\circ} 30^{\prime} \mathrm{N}-60^{\circ} \mathrm{N}, 4^{\circ} \mathrm{E}$; figure 4.4.16). Total numbers were estimated to range from nearly 300 stern or otter trawlers in May and August (and February 1993) to 430 in August.

\section{Conclusions}

The estimated total number of active fishing vessels in the North Sea varied between 800 and 1800 boats. Numbers of trawlers were significantly higher during the week (Monday-Thursday) than in weekends (FridaySunday). Overall numbers were lowest
Figures 4.4.1 - 8 show observer effort and densities of fishing vessels as a result of strip-transect counts in February 1993 and radar counts in May, August and November 1994. Four maps are given on each page, presenting the results of each of the four surveys. Observer effort is presented by different shadings, for February 1993 lrather inaccurate observations per $1^{\circ}$ latitude $x 1^{\circ}$ longitude rectangle, for the 1994 surveys per $0.5^{\circ}$ latitude $\times 1^{\circ}$ longitude rectangle. Note that the legends for February ( $\mathrm{km}$ steamed, ranging from none (blank) to $>150 \mathrm{~km}$ (black)) differ from those for the 1994 surveys inumber of radar counts, i.e. samples of $97 \mathrm{~km}^{2}$, ranging from none (blank) to $>10$ per rectangle (black)). Similarly, legends for the fishery distribution are different for the February survey and the 1994 surveys. For February, the number of fishing vessels per $\mathrm{km}$ steamed is given by shadings, ranging from none seen llightest shading) to $>0.15$ vessels per $\mathrm{km}$ (black). From radar counts, numbers of fishing vessels per $100 \mathrm{~km}^{2}$ are presented in shadings ranging from none (lightest shading) to $>1.0$ (black).

Figures 4.4 .9 - 10 are diagrams showing total number of fishing vessels estimated for each subregion in 1994 (radar counts). Compared are numbers based on counts during all days of the week, and numbers over Mondays-Thursdays, as a demonstration of the 'weekend effect'.

Figures 4.4.11 - 14 are maps with plots of sightings of different types of fishing vessels. Figure 4.4 .11 presents sightings of beamtrawlers (black symbols, $n=148$ ) and shrimpers (shaded symbols, $n=14$ ). Figure 4.4.12 presents sightings of purse seiners (black, $n=38$ ) and pair trawlers (shaded, $n=43$ ). Figure 4.4 .13 presents sightings of anchor seiners (black, $n=12$ ) and set net fishing vessels (shaded, $n=66$ ). Figure 4.4.14 presents sightings of stern trawlers (black, $n=127$ ) and otter trawlers (shaded, $n=28$ ). For these maps, the results of all 1994 surveys were pooled. 

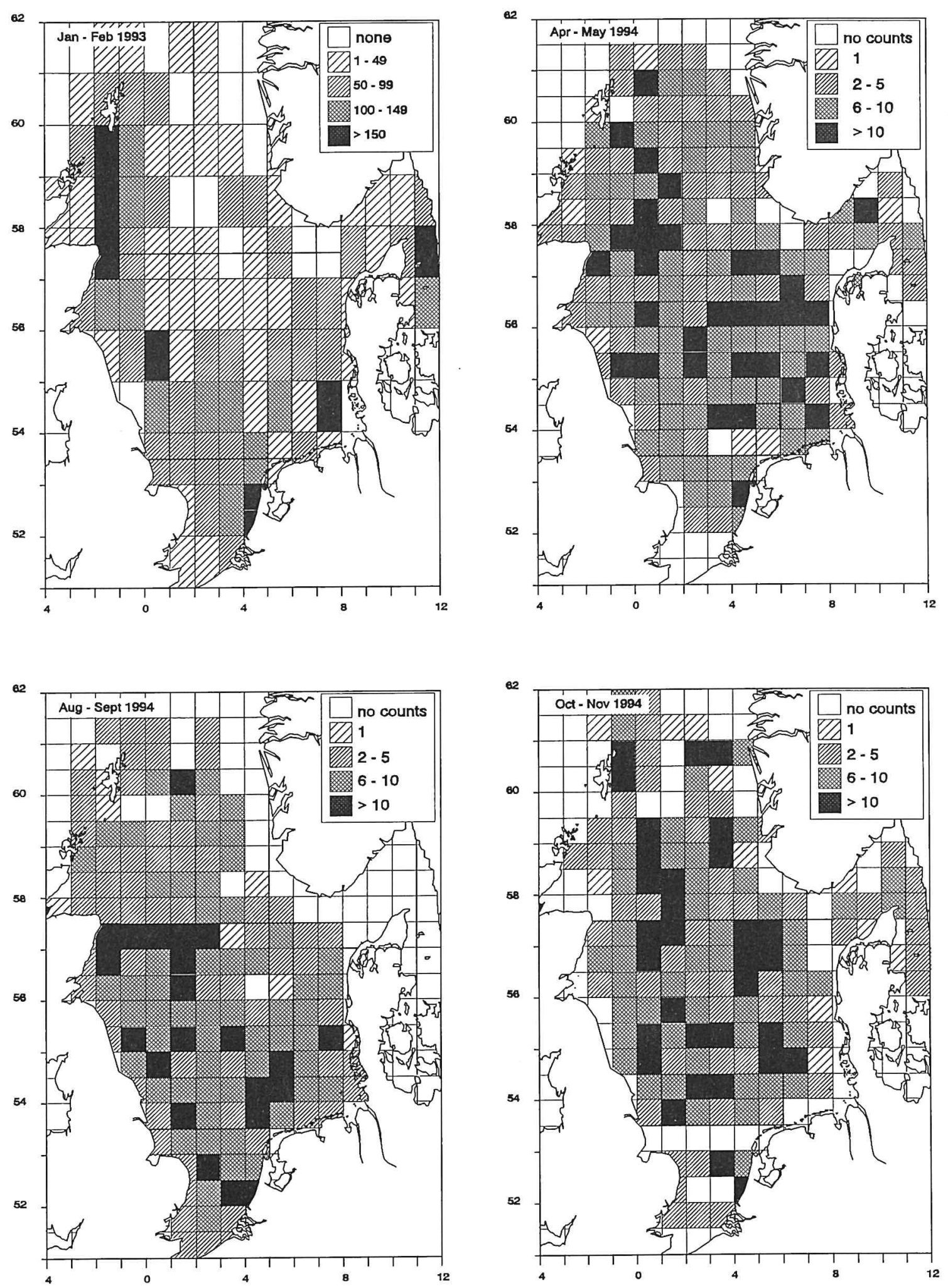

Figure 4.4.1-4 Observer effort for counts of fishing vessels. 

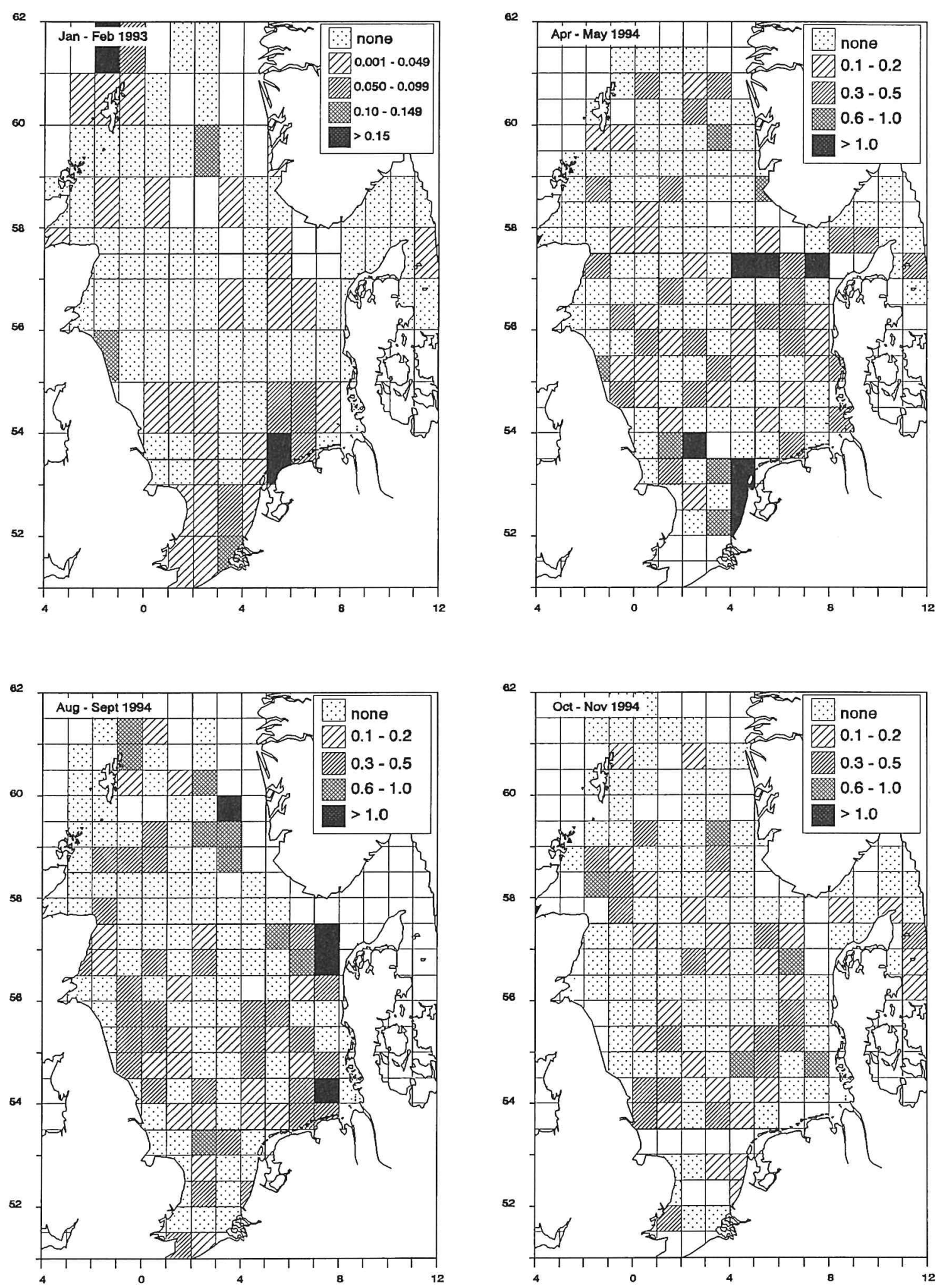

Figure 4.4.5-8 Distribution of fishing vessels in the North Sea. 

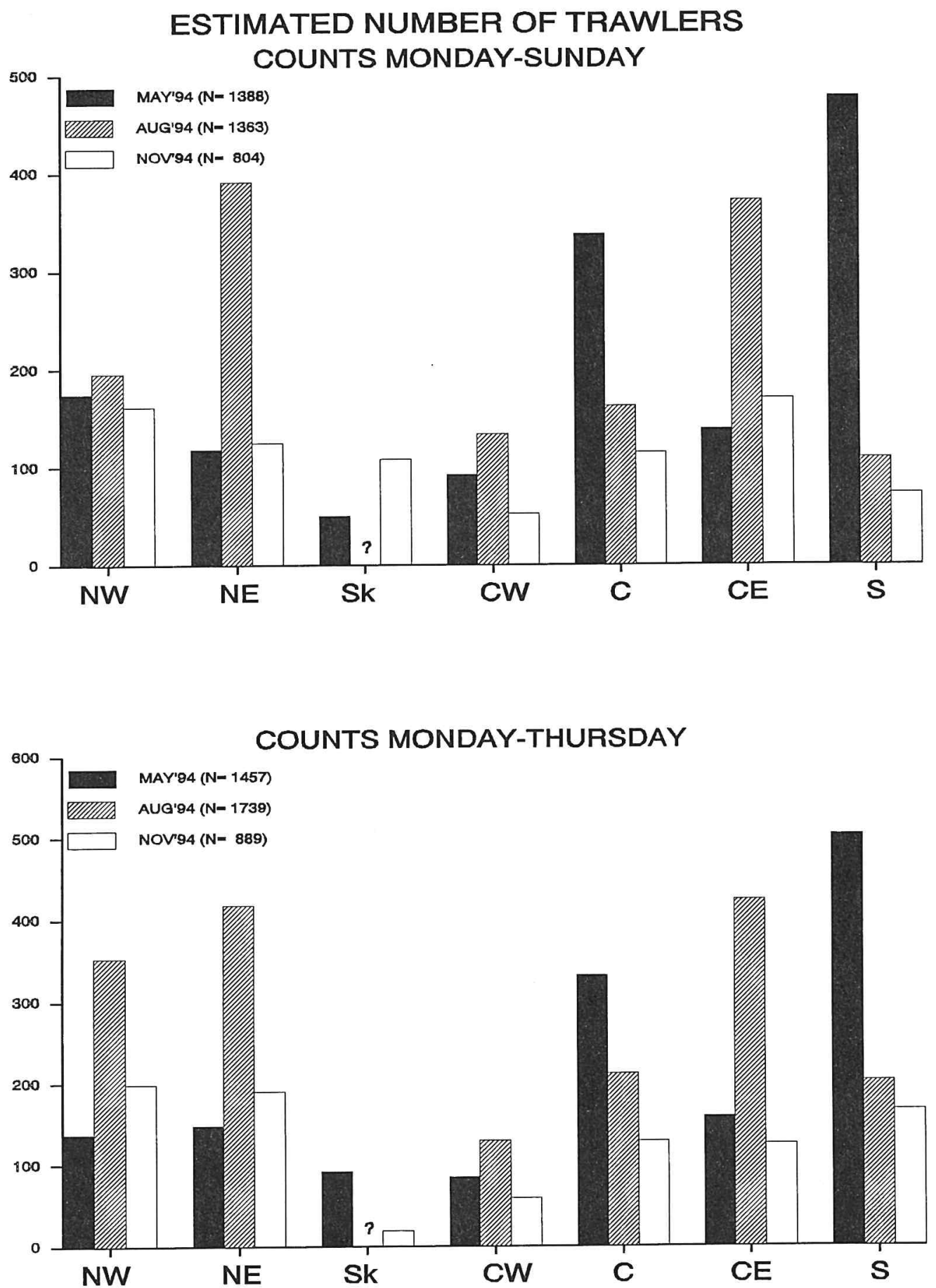

Figure 4.4.9-10 Estimated total numbers of fishing vessels per subregion from radar snapshots throughout the week and from Mondays to and including Thursdays 

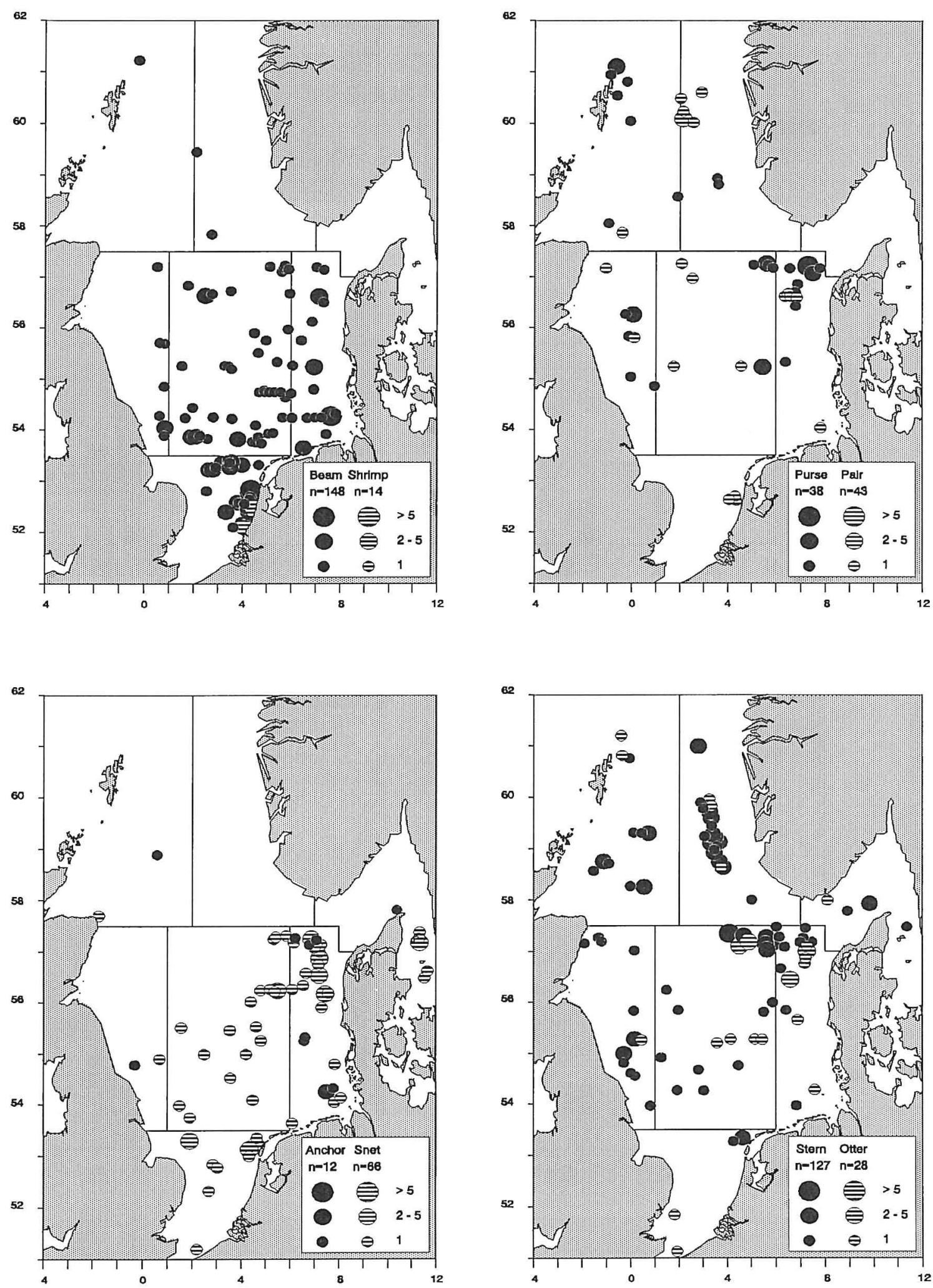

Figure 4.4.11-14 Sightings of different types of fishing vessels during the 1994 surveys 
Table 4.4.4 Estimated numbers of fishing vesse/s in the North Sea, based on radar snapshots, Monday-Sunday and Monday-Thursday. Estimates for February 1993 based on assumed $4 \mathrm{~km}$ wide transect counts (see Camphuysen et al. 1993 for details)

\begin{tabular}{|c|c|c|c|c|c|c|}
\hline \multirow{2}{*}{$\begin{array}{l}\text { February } 1993 \\
\text { Subr }\end{array}$} & \multicolumn{3}{|c|}{ Surveys Monday-Sunday } & & & \\
\hline & & & & & & \\
\hline NW & 6047 & 0.002 & $\begin{array}{l}338 \\
311\end{array}$ & & & \\
\hline NE & 1250 & 0.003 & 311 & & & \\
\hline Sk & 2471 & 0.001 & 95 & & & \\
\hline $\mathrm{CW}$ & 3931 & 0.002 & 106 & & & \\
\hline C & 4669 & 0.003 & 421 & & & \\
\hline CE & 5415 & 0.003 & 93 & & & \\
\hline$S$ & 7035 & 0.003 & 169 & & & \\
\hline \multicolumn{3}{|l|}{$\Sigma$} & 1533 & & & \\
\hline $\begin{array}{l}\text { May } 1994 \\
\text { Subr }\end{array}$ & radar cour & nts Mond & -Sunday & \multirow{2}{*}{\multicolumn{3}{|c|}{ 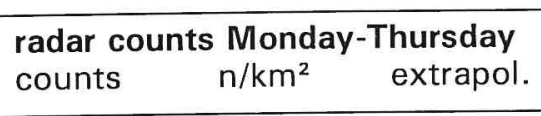 }} \\
\hline & Counts & $\mathrm{n} / \mathrm{km}^{2}$ & extrapol. & & & \\
\hline $\begin{array}{l}\text { NW } \\
\text { NE }\end{array}$ & 213 & 0.001 & 175 & 106 & 0.000 & 137 \\
\hline $\begin{array}{l}\mathrm{NE} \\
\mathrm{Sk}\end{array}$ & 102 & 0.001 & 118 & 54 & 0.001 & 148 \\
\hline $\begin{array}{l}\text { Sk } \\
\text { CW }\end{array}$ & 61 & 0.000 & 50 & 33 & 0.001 & 92 \\
\hline $\mathrm{CW}$ & 148 & 0.001 & 92 & 93 & 0.001 & 85 \\
\hline $\mathrm{C}$ & 353 & 0.002 & 337 & 267 & 0.002 & 332 \\
\hline $\begin{array}{l}\text { CE } \\
S\end{array}$ & 154 & 0.002 & 139 & 118 & 0.002 & 159 \\
\hline S & 99 & 0.008 & 478 & 94 & 0.008 & 504 \\
\hline$\Sigma$ & 1130 & & 1388 & 765 & & 1457 \\
\hline \multirow{2}{*}{$\begin{array}{l}\text { August } 1994 \\
\text { Subr }\end{array}$} & \multicolumn{3}{|c|}{ radar counts Monday-Sunday } & \multirow{2}{*}{\multicolumn{3}{|c|}{$\begin{array}{l}\text { radar counts Monday-Thursday } \\
\begin{array}{ll}\text { counts } \mathrm{n} / \mathrm{km}^{2} & \text { extrapol. }\end{array}\end{array}$}} \\
\hline & Counts & $\mathrm{n} / \mathrm{km}^{2}$ & extrapol. & & & \\
\hline NW & 149 & 0.001 & 195 & 55 & 0.002 & 353 \\
\hline $\begin{array}{l}N E \\
S k\end{array}$ & 82 & 0.004 & 391 & 72 & 0.004 & 417 \\
\hline Sk & & no data & & & & \\
\hline $\mathrm{CW}$ & 198 & 0.001 & 134 & 138 & 0.001 & 130 \\
\hline C & 313 & 0.001 & 162 & 226 & 0.001 & 212 \\
\hline CE & 108 & 0.005 & 371 & 90 & 0.006 & 424 \\
\hline$S$ & 123 & 0.001 & 109 & 46 & 0.003 & 203 \\
\hline$\Sigma$ & 973 & & 1363 & 627 & & 1739 \\
\hline $\begin{array}{l}\text { November } 1994 \\
\text { Subr }\end{array}$ & \multicolumn{3}{|c|}{ radar counts Monday-Sunday } & \multicolumn{3}{|c|}{$\begin{array}{l}\text { radar counts Monday-Thursday } \\
\begin{array}{ll}\text { counts } \mathrm{n} / \mathrm{km}^{2} & \text { extrapol. }\end{array}\end{array}$} \\
\hline NW & 200 & 0.001 & extrapol. & 122 & 0.001 & 199 \\
\hline NE & 161 & 0.001 & $\begin{array}{l}162 \\
124\end{array}$ & 100 & 0.001 & 190 \\
\hline Sk & 62 & 0.001 & 108 & 32 & 0.000 & 19 \\
\hline $\mathrm{CW}$ & 164 & 0.000 & 52 & 121 & 0.000 & 59 \\
\hline C & 317 & 0.000 & 114 & 191 & 0.000 & 129 \\
\hline CE & 80 & 0.002 & 170 & 67 & 0.001 & 125 \\
\hline$s$ & 56 & 0.001 & 73 & 21 & 0.002 & 167 \\
\hline$\Sigma$ & 1040 & & 804 & 654 & & 889 \\
\hline
\end{tabular}


Table 4.4.5 Distribution of fishing vessel types, extrapolated for total numbers at sea during the week in May, August and November 1994. Snet = Set net boat, Beam = beamtrawler, Shri $=$ shrimper, Stern $=$ stern trawler, Otter $=$ otter trawler, Pair = pair trawler, Anchor $=$ Anchor seiner, Sein = purse seiner, small = small boat (variable gear), ? = unidentified trawler. Estimates for February 1993 based on assumed $4 \mathrm{~km}$ wide transect counts /see Camphuysen et al. 1993 for details).

\begin{tabular}{|c|c|c|c|c|c|c|c|c|c|}
\hline $\begin{array}{l}\text { February } 19 \\
\text { Region }\end{array}$ & $\begin{array}{l}993 \\
\text { Snet }\end{array}$ & $\begin{array}{c}\text { Beam/ } \\
\text { Shri }\end{array}$ & $\begin{array}{l}\text { Stern/ } \\
\text { Otter }\end{array}$ & Pair & Anchor & Sein & small & $?$ & $\Sigma$ \\
\hline $\begin{array}{l}\text { NW } \\
\text { NE } \\
\text { Sk } \\
\text { CW } \\
C \\
\text { CE } \\
\text { S }\end{array}$ & $\begin{array}{l}0 \\
0 \\
0 \\
0 \\
0 \\
0 \\
0\end{array}$ & $\begin{array}{r}0 \\
0 \\
0 \\
53 \\
241 \\
81 \\
169\end{array}$ & $\begin{array}{r}234 \\
0 \\
0 \\
0 \\
30 \\
0 \\
0\end{array}$ & $\begin{array}{r}52 \\
0 \\
0 \\
0 \\
60 \\
0 \\
0\end{array}$ & $\begin{array}{l}0 \\
0 \\
0 \\
0 \\
0 \\
0 \\
0\end{array}$ & $\begin{array}{r}0 \\
0 \\
0 \\
0 \\
30 \\
12 \\
0\end{array}$ & $\begin{array}{r}0 \\
0 \\
95 \\
0 \\
0 \\
0 \\
0\end{array}$ & $\begin{array}{r}52 \\
311 \\
0 \\
53 \\
60 \\
0 \\
0\end{array}$ & $\begin{array}{r}338 \\
311 \\
95 \\
106 \\
421 \\
93 \\
169\end{array}$ \\
\hline$\Sigma$ & 0 & 544 & 264 & 112 & 0 & 42 & 95 & 476 & 1533 \\
\hline $\begin{array}{l}\text { May } 1994 \\
\text { Region }\end{array}$ & Snet & $\begin{array}{c}\text { Beam/ } \\
\text { Shri }\end{array}$ & $\begin{array}{l}\text { Stern/ } \\
\text { Otter }\end{array}$ & Pair & Anchor & Sein & small & $?$ & $\Sigma$ \\
\hline $\begin{array}{l}\mathrm{NW} \\
\mathrm{NE} \\
\mathrm{Sk} \\
\mathrm{CW} \\
\mathrm{C} \\
\mathrm{CE} \\
\mathrm{S}\end{array}$ & $\begin{array}{r}0 \\
0 \\
0 \\
0 \\
41 \\
38 \\
53\end{array}$ & $\begin{array}{r}0 \\
0 \\
0 \\
15 \\
62 \\
21 \\
313\end{array}$ & $\begin{array}{r}0 \\
29 \\
40 \\
24 \\
136 \\
34 \\
24\end{array}$ & $\begin{array}{r}0 \\
39 \\
0 \\
10 \\
0 \\
0 \\
41\end{array}$ & $\begin{array}{r}0 \\
0 \\
0 \\
0 \\
0 \\
13 \\
0\end{array}$ & $\begin{array}{r}8 \\
0 \\
0 \\
0 \\
4 \\
21 \\
0\end{array}$ & $\begin{array}{r}0 \\
20 \\
0 \\
0 \\
0 \\
0 \\
0\end{array}$ & $\begin{array}{r}167 \\
29 \\
10 \\
44 \\
95 \\
13 \\
47\end{array}$ & $\begin{array}{r}175 \\
118 \\
50 \\
92 \\
337 \\
139 \\
478\end{array}$ \\
\hline$\Sigma$ & 132 & 410 & 286 & 90 & 13 & 33 & 20 & 404 & 1389 \\
\hline $\begin{array}{l}\text { August } 199 \\
\text { Region }\end{array}$ & 4 & $\begin{array}{c}\text { Beam/ } \\
\text { Shri }\end{array}$ & $\begin{array}{l}\text { Stern/ } \\
\text { Otter }\end{array}$ & Pair & Anchor & Sein & small & $?$ & $\Sigma$ \\
\hline $\begin{array}{l}\mathrm{NW} \\
\mathrm{NE} \\
\mathrm{Sk} \\
\mathrm{CW} \\
\mathrm{C} \\
\mathrm{CE} \\
\mathrm{S}\end{array}$ & $\begin{array}{r}4 \\
23 \\
96 \\
19\end{array}$ & $\begin{array}{r}11 \\
12 \\
\\
4 \\
51 \\
138 \\
67\end{array}$ & $\begin{array}{r}54 \\
232 \\
\\
51 \\
37 \\
42 \\
14\end{array}$ & $\begin{array}{c}22 \\
73 \\
\text { [ no data ] } \\
7 \\
28 \\
24 \\
0\end{array}$ & $\begin{array}{r}0 \\
0 \\
5 \\
5 \\
0 \\
18 \\
0\end{array}$ & $\begin{array}{r}43 \\
0 \\
\\
25 \\
19 \\
42 \\
0\end{array}$ & $\begin{array}{l}0 \\
0 \\
0 \\
0 \\
0 \\
0\end{array}$ & $\begin{array}{r}54 \\
73 \\
40 \\
4 \\
5 \\
12 \\
10\end{array}$ & $\begin{array}{l}195 \\
390 \\
\\
135 \\
163 \\
372 \\
110\end{array}$ \\
\hline$\Sigma$ & 153 & 283 & 430 & 154 & 22 & 129 & 0 & 194 & 1365 \\
\hline $\begin{array}{l}\text { November } 1 \\
\text { Region }\end{array}$ & $\begin{array}{l}1994 \\
\text { Snet }\end{array}$ & $\begin{array}{c}\text { Beam/ } \\
\text { Shri }\end{array}$ & $\begin{array}{l}\text { Stern/ } \\
\text { Otter }\end{array}$ & Pair & Anchor & Sein & small & $?$ & $\Sigma$ \\
\hline $\begin{array}{l}\text { NW } \\
\text { NE } \\
\text { Sk } \\
C W \\
C \\
\text { CE } \\
\text { S }\end{array}$ & $\begin{array}{r}0 \\
0 \\
69 \\
4 \\
14 \\
0 \\
0\end{array}$ & $\begin{array}{r}0 \\
6 \\
0 \\
26 \\
73 \\
49 \\
63\end{array}$ & $\begin{array}{r}113 \\
100 \\
10 \\
13 \\
14 \\
32 \\
10\end{array}$ & $\begin{array}{r}16 \\
0 \\
0 \\
9 \\
0 \\
49 \\
0\end{array}$ & $\begin{array}{r}8 \\
0 \\
20 \\
0 \\
0 \\
16 \\
0\end{array}$ & $\begin{array}{r}24 \\
12 \\
0 \\
0 \\
9 \\
16 \\
0\end{array}$ & $\begin{array}{r}0 \\
0 \\
0 \\
10 \\
0 \\
0 \\
0 \\
0\end{array}$ & $\begin{array}{l}0 \\
6 \\
0 \\
0 \\
5 \\
8 \\
0\end{array}$ & $\begin{array}{r}162 \\
124 \\
108 \\
52 \\
114 \\
170 \\
73\end{array}$ \\
\hline$\Sigma$ & 87 & 217 & 292 & 73 & 44 & 62 & 10 & 19 & 804 \\
\hline
\end{tabular}


Table 4.4.6 Frequencies of main types of fishing vessels in the North Sea in each subregion from radar snapshops and visual checks ( $n=578$ sightings, all 1994 surveys combined).

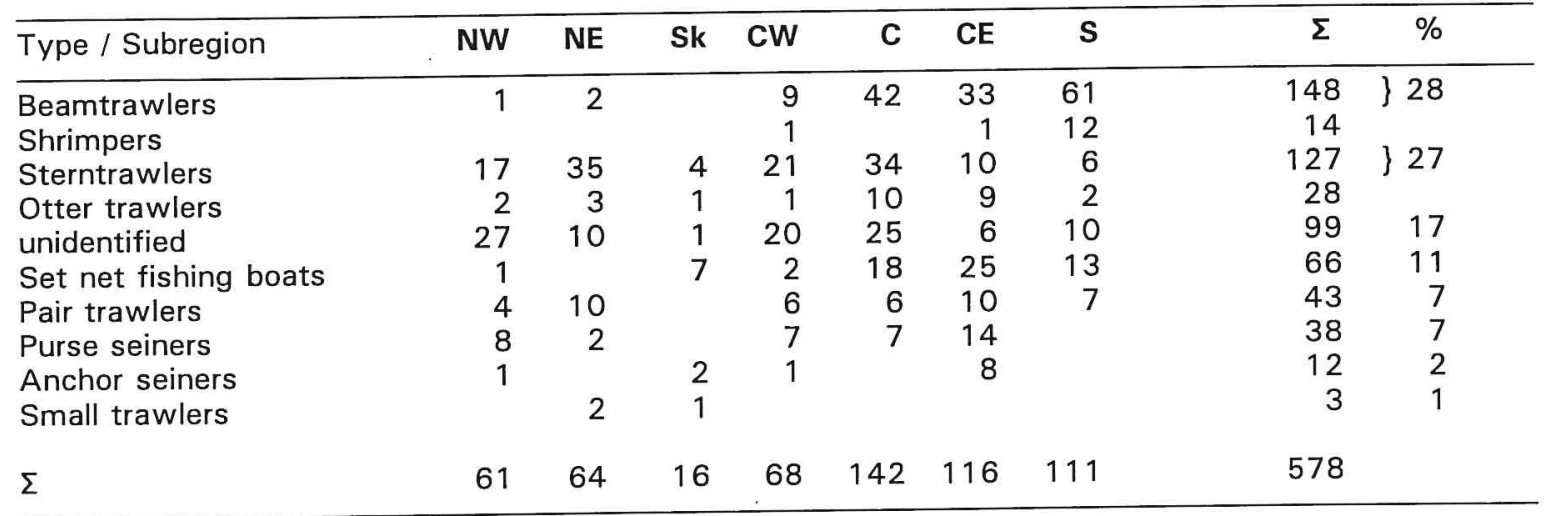

in November (800-900 vessels) and highest in August (1350-1750 vessels) (tables 4.4.3-4). Of the positively identified fishing vessels, beamtrawlers and shrimpers were the most numerous type $(28 \%)$, followed by stern or otter trawlers (27), set net fishing vessels (or long liners; $11 \%$ ), purse seiners $(7 \%)$, pair trawlers $(7 \%)$ and anchor seiners (2\%) (table 4.4.6). Beamtrawlers, shrimpers, set net fishing vessels and anchor seiners predominated in the southeastern half of the North Sea and these vessels were rare in the northwest (figures 4.4.11-14). Purse seiners, pair trawlers, stern trawlers and otter trawlers were the most common types in the central, northern and northwestern North Sea and these were rare in the German Bight and Southern Bight (figures 4.4.11-14).

\subsection{SEABIRDS SCAVENGING AT FISHING VESSELS}

The distribution of seabirds and fishing vessels have been described independently in chapters 4.1 and 4.4 . In this chapter, the distribution of birds associated with commercial fishing vessels will be considered. During steaming, nearby fishing vessels were routinely checked for the presence of scavenging seabirds but flocks of associated birds could only been counted at close range (varying with viewing conditions). Therefore, the sample is a small proportion of the total number of fishing vessels observed in the radar snapshots. In all four surveys combined, 272 working fishing vessels (not in transit) were encountered at sufficiently short range to count the associated birds (table 4.5.1). Counts were made at the closest point of approach and the boats could thus be engaged in towing, shooting, hauling, or lifting the net. Earlier investigations have shown that numbers of birds at fishing vessels peak when the catch is sorted, but it was usually impossible to tell if sorting or discarding were taking place. Numbers of birds can be quite low during towing and, as the most prolonged stage of fishing, a substantial number of observations must have been conducted at this time. As fishing vessels were sampled randomly regarding activity, the counts should represent the average number of birds associated with fishing vessels at any one time. However, the counts at commercial vessels differ from stern counts at research vessels in that the latter were maximum counts. The counts were designed to assess overall numbers of scavengers at commercial boats, to compare with numbers at research vessels, with species composition as second priority. At a distance smaller, scarcer species are easily 
Table 4.5.1 Number of fishing vessels, apparently fishing (not steaming) at which associated birds were counted, per subregion for each of the surveys.

\begin{tabular}{lrrrrr}
\hline Subregion \survey & February & May & August & November & $\boldsymbol{\Sigma}$ \\
\hline NW & 13 & 4 & 4 & 3 & 24 \\
NE & 4 & 4 & 14 & 7 & 29 \\
Sk & 4 & 3 & - & 5 & 12 \\
CW & 6 & 6 & 14 & 1 & 27 \\
C & 14 & 27 & 13 & 13 & 67 \\
CE & 8 & 16 & 16 & 1 & 41 \\
S & 33 & 25 & 12 & 2 & 72 \\
$\Sigma$ & 82 & 85 & 73 & 32 & 272 \\
\hline
\end{tabular}

Table 4.5.2 Mean number (mean), maximum (max) and extrapolated number (x 1000) of Fulmars at the stern of fishing vessels per subregion for each of the surveys.

\begin{tabular}{|c|c|c|c|c|c|c|c|c|c|c|c|c|}
\hline Subl & survey & Febrt & Jary & & & Иay & & Augu & & & Noveml & ber \\
\hline & mean & $\max$ & extrap & mean & $\max$ & extrap & mean & $\max e$ & extrap & mean & $\max$ & extrap \\
\hline NW & 488.5 & 3500 & 165 & 123.3 & 230 & 22 & 345.0 & 500 & 67 & 273.3 & 400 & 44 \\
\hline NE & 197.5 & 600 & 61 & 220.0 & 400 & 26 & 539.3 & 2000 & 211 & 266.0 & 1000 & 33 \\
\hline Sk & 0.3 & 1 & 0 & 11.7 & 35 & 1 & & no data & & 50.0 & 200 & 5 \\
\hline CW & 0.3 & 1 & 0 & 47.0 & 225 & 4 & 56.5 & 380 & 8 & 200.0 & 200 & 10 \\
\hline C & 35.7 & 250 & 15 & 174.0 & 2000 & 59 & 124.1 & 650 & 20 & 41.3 & 150 & 5 \\
\hline CE & 24.5 & 150 & 2 & 140.6 & 750 & 20 & 6.1 & 30 & 2 & 15.0 & 15 & 3 \\
\hline $\mathrm{S}$ & 35.8 & 700 & 6 & 8.1 & 62 & 4 & 0.5 & 2 & 0 & 0.0 & & 0 \\
\hline & & 3500 & 250 & & 2000 & 135 & & 2000 & 308 & & 1000 & 100 \\
\hline
\end{tabular}

Table 4.5.3 Mean number (mean), maximum (max) and extrapolated number (x 1000) of Gannets at the stern of fishing vessels per subregion for each of the surveys.

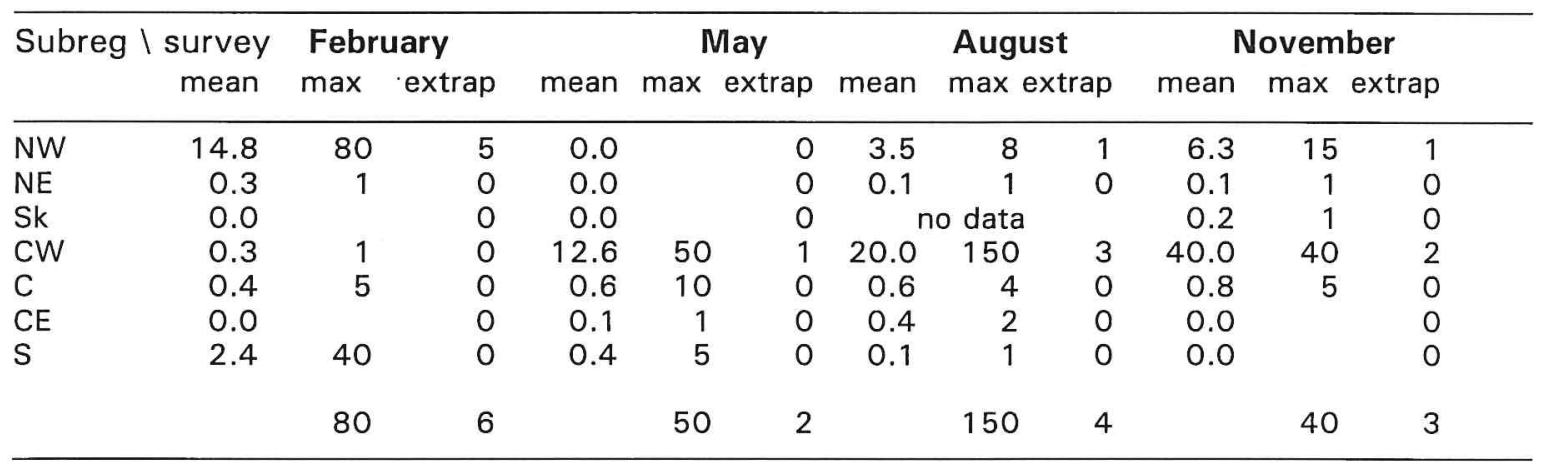


overlooked. Species and age composition derived from stern counts at research vessels are therefore more accurate. An attempt was made to describe numbers of ship-followers at different types of fishing vessels and in each of the subregions.

\section{Fulmar}

The Fulmar was the commonest species seen at fishing vessels (table 4.5.2-10). Particularly high numbers were observed at fishing vessels in the northern North Sea (3500 as a maximum in NW in February), and occasionally in the central North Sea (2000 as maximum in C in May). In February, up to 700 Fulmars were observed in association with a fishing vessel in the Southern Bight, but otherwise, groups of over 100 Fulmars were quite rare in the southern and eastern North Sea and in the Skagerrak (table 4.5.2). In the central and western half of the North Sea several hundreds of Fulmars at boats were more frequently reported. The observed maxima at fishing vessels are similar to or slightly lower than (November) maxima recorded at the stern of research vessels (table 4.3.2). The overall picture, although based on a small sample (272 boats) is quite similar to distribution patterns as derived from stern counts at research vessels. Again, the boundary between larger and low numbers at boats, during the May, August and November surveys, closely matched the borders between homohaline areas and waters which are stratified throughout the year (Lee 1980; see figures 4.3.6-8). On the basis of (mean) numbers observed at fishing vessels in each subregion, and the total number of fishing vessels in that region as derived from radar snap-shots (chapter 4.4), it was estimated that the total numbers of Fulmars associated with fishing vessels ranged from 100,000 in November to just over 300,000 in August (table 4.5.2). These figures, coupled with estimated total numbers derived from striptransect counts (chapter 4.1), lead to the following estimates for numbers of Fulmars in the North Sea and the conclusion that the minimum amount of time spent at fishing vessels during daylight hours ranged from $5 \%$ in November to $37 \%$ in February:

$\begin{array}{lcccc} & 1993 & 1994 & 1994 & 1994 \\ & \text { Febr } & \text { May } & \text { Aug } & \text { Nov } \\ \text { in transect }(\times 1000) & 425 & 710 & 1594 & 1748 \\ \text { at fishing vessels } & 250 & 135 & 308 & 100 \\ & & & & \\ \text { Totals }(x 1000) & 675 & 845 & 1902 & 1848 \\ \% \text { at fishing vessels } & 37 & 19 & 16 & 5\end{array}$

An overall mean of $19 \%(n=4)$ of the Fulmars in the North Sea associated with fishing vessels following these calculations, is considerably higher than the $5 \%$ of all Fulmars labelled as 'associated with fishing vessels' during strip-transect counts (chapter 4.1). However, at the scale of transect width $(300 \mathrm{~m})$, the tendency of boats to avoid each other must surely have reduced numbers of birds in association with fishing vessels in transect. These percentages can be considered minimum estimates of the time spent near fishing vessels, but comparisons between species cannot easily be made because of substantial differences in turnover around fishing vessels.

\section{Gannet}

The few large flocks of scavenging Gannets that were reported at fishing vessels were mainly in the western half of the North Sea (table 4.5.3). The observed maximum of 150 Gannets (subregion CW, August) is low compared to peaks of 250 (February), 310 (May), and 355 (August) recorded at the stern of research vessels. Earlier studies have demonstrated that concentrations of Gannets build up very rapidly, and that Gannets leave the ship immediately when they lose interest for whatever reason (Camphuysen et al. 1993). Hence, the chance of recording maximum or near maximum numbers of Gannets during the short encounter with a fishing vessel at sea is probably lower than for any of the other species with a longer turnover time. Calculated on the basis of the (mean) numbers observed at commercial boats in each subregion, multiplied by the 
Table 4.5.4 Mean number (mean), maximum (max) and extrapolated number (x 1000) of Great Skuas at the stern of fishing vessels per subregion for each of the surveys.

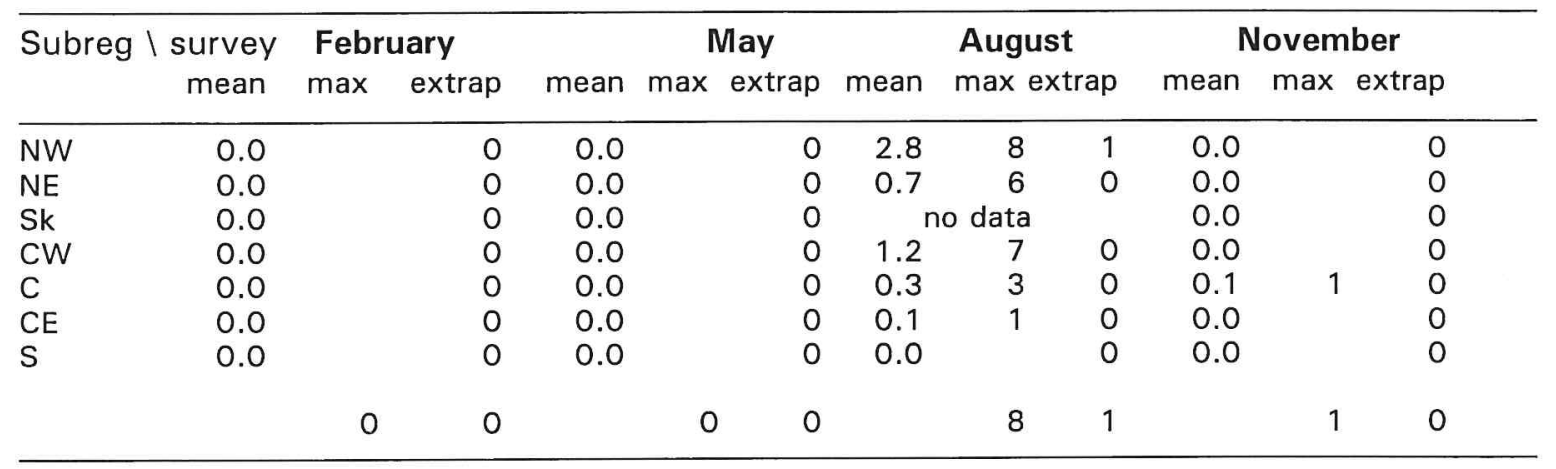

Table 4.5.5 Mean number (mean), maximum (max) and extrapolated number (x 1000) of Common Gulls at the stern of fishing vessels per subregion for each of the surveys.

\begin{tabular}{|c|c|c|c|c|c|c|c|c|c|c|c|c|}
\hline \multirow{2}{*}{\multicolumn{2}{|c|}{$\begin{array}{c}\text { Subreg } \backslash \text { survey } \\
\text { mean }\end{array}$}} & \multicolumn{2}{|c|}{ February } & \multicolumn{4}{|c|}{ May } & \multirow{2}{*}{\multicolumn{2}{|c|}{$\begin{array}{l}\text { August } \\
\text { max extrap }\end{array}$}} & \multicolumn{3}{|c|}{ November } \\
\hline & & $\max$ & extrap & mean & $\max$ & extrap & mean & & & mean & $\max$ & extrap \\
\hline NW & 0.0 & & 0 & 0.0 & & 0 & 0.0 & & 0 & 0.0 & & 0 \\
\hline NE & 0.0 & & 0 & 0.0 & & 0 & 0.0 & & 0 & 0.0 & & 0 \\
\hline Sk & 3.3 & 5 & 0 & 0.0 & & 0 & & 10 data & & 0.6 & 3 & 0 \\
\hline $\mathrm{CW}$ & 0.0 & & 0 & 0.0 & & 0 & 0.0 & & 0 & 0.0 & & 0 \\
\hline C & 6.4 & 50 & 3 & 0.2 & 6 & 0 & 0.0 & & 0 & 0.8 & 10 & 0 \\
\hline $\mathrm{CE}$ & 3.1 & 15 & 0 & 0.3 & 4 & 0 & 0.0 & & 0 & 0.0 & & 0 \\
\hline \multirow[t]{2}{*}{$\mathrm{S}$} & 51.9 & 500 & 9 & 2.6 & 10 & 1 & 0.0 & & 0 & 2.5 & 3 & 0 \\
\hline & & 500 & 12 & & 10 & 1 & & 0 & 0 & & 10 & 0 \\
\hline
\end{tabular}

Table 4.5.6 Mean number (mean), maximum (max) and extrapolated number (x 1000) of Lesser Black-backed Gulls at the stern of fishing vessels per subregion for each of the surveys.

\begin{tabular}{|c|c|c|c|c|c|c|c|c|c|c|c|c|}
\hline & Irvey & Febr & Jary & & & May & & Augu & & & ovem & \\
\hline & & $\max$ & extrap & mean & $\max$ & extrap & mean & & & mean & $\max$ & extrap \\
\hline NV & 0.0 & & 0 & 0.0 & & 0 & 0.0 & & 0 & 0.0 & & 0 \\
\hline NE & 0.0 & & 0 & 10.0 & 40 & 1 & 7.2 & 30 & 3 & 0.0 & & 0 \\
\hline Sk & 0.0 & & 0 & 11.0 & 25 & 1 & & 10 data & & 0.0 & & 0 \\
\hline $\mathrm{CW}$ & 0.0 & & 0 & 0.0 & & 0 & 0.1 & 1 & 0 & 0.0 & & 0 \\
\hline C & 0.0 & & 0 & 16.8 & 160 & 6 & 5.2 & 32 & 1 & 1.5 & 20 & 0 \\
\hline $\mathrm{CE}$ & 0.0 & & 0 & 17.1 & 85 & 2 & 228.7 & 1200 & 85 & 0.0 & & 0 \\
\hline $\mathrm{s}$ & 0.5 & 15 & 0 & 62.3 & 600 & 30 & 18.8 & 140 & 2 & 0.0 & & 0 \\
\hline & & 15 & 0 & & 600 & 40 & & 1200 & 91 & & 20 & 0 \\
\hline
\end{tabular}


total number of fishing vessels in that region (chapter 4.4), it was estimated that during these surveys the total numbers of Gannets associated with fishing vessels ranged from 2000 in May to just over 6000 in February (table 4.5.3). These figures, coupled with estimates derived from strip-transect counts (chapter 4.1), lead to the following estimates of total numbers of Gannets in the North Sea and the conclusion that the amount of time spent at fishing vessels ranged from $1 \%$ in May in to $9 \%$ in February:

$\begin{array}{lcccc} & 1993 & 1994 & 1994 & 1994 \\ & \text { Febr } & \text { May } & \text { Aug } & \text { Nov } \\ \text { in transect }(\times 1000) & 61 & 150 & 115 & 172 \\ \text { at fishing vessels } & 6 & 2 & 4 & 3 \\ & & & & \\ \text { Totals }(\times 1000) & 67 & 152 & 119 & 175 \\ \% \text { at fishing vessels } & 9 & 1 & 3 & 2\end{array}$

As in the Fulmar, these figures suggest that Gannets spent more time around fishing vessels in the February survey than was recorded in any of the other cruises.

\section{Great Skua}

Great Skuas were recorded only rarely in association with fishing vessels, except in August, with the exception in the Southern Bight where none were recorded, small numbers occurred occasionally. This finding is in accordance with results from strip-transect counts and stern counts at research vessels. Great Skuas are widespread in the North Sea late summer, but highly concentrated in the NW (around breeding stations in Shetland and Orkney) or virtually absent in the other seasons. The observed maxima and the frequency of sightings at fishing vessels are both below numbers at the stern of research vessels (table 4.3.4). However, Great Skuas usually arrive later at the stern of a fishing vessel, after the flock of scavengers has grown to a considerable size, they use a much wider area around the ship to kleptoparasitise other birds and, as Gannets, leave the ship immediately when they lose interest. As a result, the chances of recording Great Skuas during the short encounters with fishing vessels were comparatively low. Calculated on the basis of the (mean) numbers observed at commercial boats in each subregion, multiplied by the total number of fishing vessels in that region (chapter 4.4), it was estimated that during these surveys the total numbers of Great Skuas at any one time associated with fishing vessels were very small and peaked in August at ca. 1000 individuals (table 4.5.4). These figures, coupled with estimates derived from strip-transect counts (chapter 4.1), lead to the following estimates of total numbers of Great Skuas in the North Sea and that the amount of time spent at fishing vessels ranged from $<0.1 \%$ to a minimum of $3 \%$ in August:

$\begin{array}{lcccc} & 1993 & 1994 & 1994 & 1994 \\ & \text { Febr } & \text { May } & \text { Aug } & \text { Nov } \\ \text { in transect }(\times 1000) & 1 & 1 & 29 & 4 \\ \text { at fishing vessels } & 0 & 0 & 1 & 0 \\ & & & & \\ \text { Totals }(\times 1000) & 1 & 1 & 30 & 4 \\ \% \text { at fishing vessels } & 0 & 0 & 3 & 0\end{array}$

\section{Common Gull}

The only period that substantial numbers of Common Gulls were recorded scavenging at fishing vessels was in winter. These were mainly in inshore waters of the southeastern half of the North Sea and in the Skagerrak (table 4.5.5). Up to 500 individuals were recorded at a single boat, but this was exceptional. Small numbers were observed in May, exclusively in the southeastern North Sea, but Common Gulls were not recorded at fishing vessels in August. Stern counts at research vessels resulted in a rather different picture (table 4.3.5). Common Gulls were frequently recorded in August, although numbers were very small, and Common Gulls were widespread in November with peak numbers of nearly 100 individuals in the Southern Bight. It seems probable that small numbers of Common Gulls among flocks of gulls scavenging at fishing vessels observed from some distance were overlooked, so that the estimated total numbers associated with fishing vessels should be treated with cauti- 
Table 4.5.7 Mean number (mean), maximum (max) and extrapolated number (x 1000) of Herring Gulls at the stern of fishing vessels per subregion for each of the surveys.

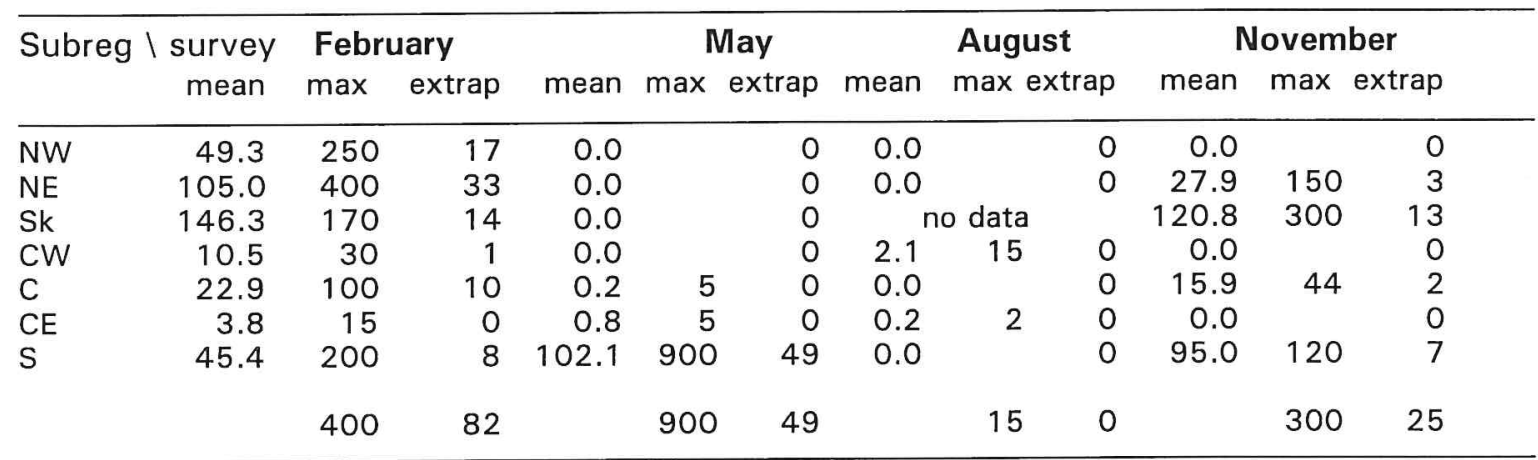

Table 4.5.8 Mean number (mean), maximum (max) and extrapolated number (x 1000) of Great Black-backed Gulls at the stern of fishing vessels per subregion for each of the surveys.

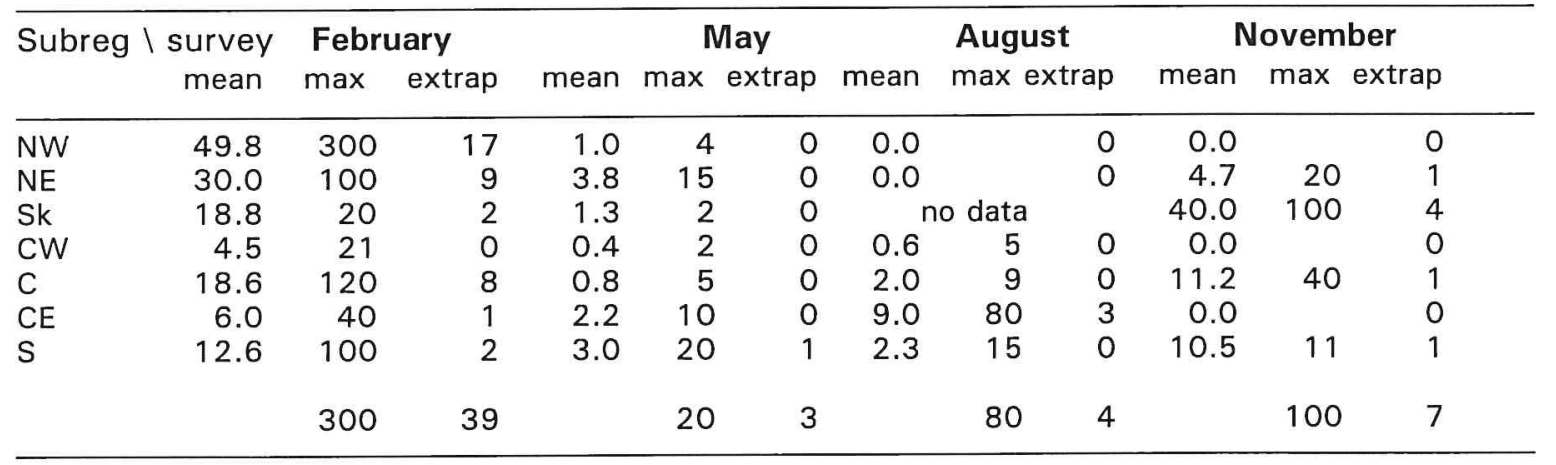

Table 4.5.9 Mean number (mean), maximum (max) and extrapolated number (x 1000) of Kittiwakes at the stern of fishing vessels per subregion for each of the surveys.

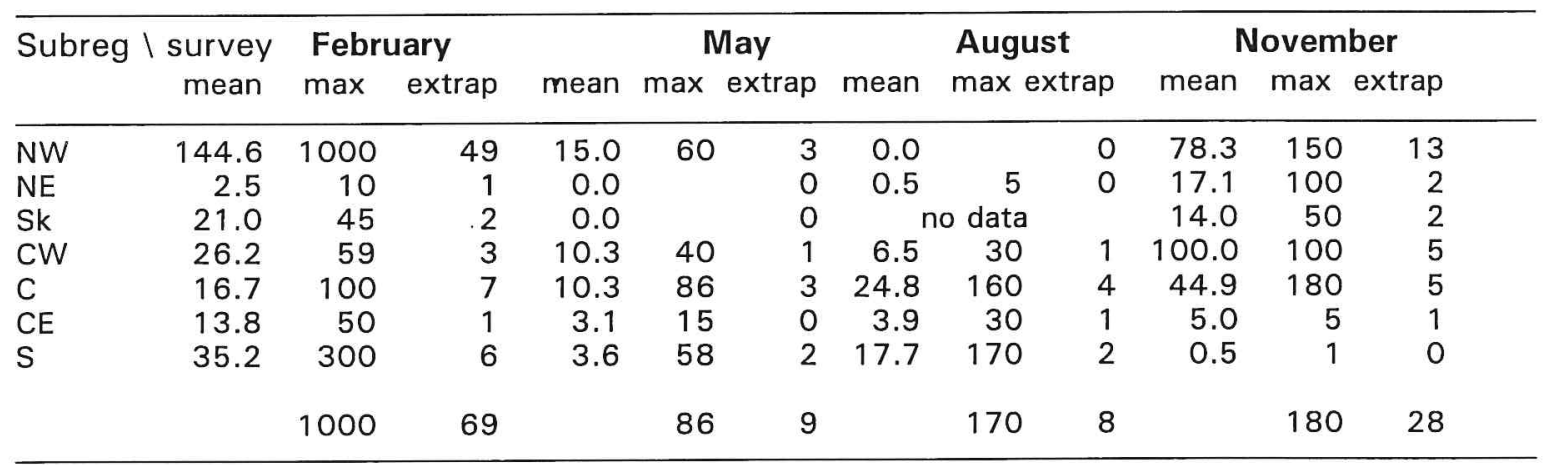


on. Calculated on the basis of the (mean) numbers observed at commercial boats in each subregion, multiplied by the total number of fishing vessels in that region (chapter 4.4), it was estimated that during these surveys the total numbers of Common Gulls associated with fishing vessels at any one time ranged from none in August to 12,000 in February (table 4.5.5). These figures, coupled with estimates derived from striptransect counts (chapter 4.1), lead to the following estimates of total numbers of Common Gulls in the North Sea and that the amount of time spent in daylight at fishing vessels in February amounted to $22 \%$ :

$\begin{array}{lcccc} & 1993 & 1994 & 1994 & 1994 \\ & \text { Febr } & \text { May } & \text { Aug } & \text { Nov } \\ \text { in transect }(\times 1000) & 43 & 0 & 3 & 13 \\ \text { at fishing vessels } & 12 & 1 & 0 & 0 \\ & & & & \\ \text { Totals }(\times 1000) & 55 & 1 & 3 & 13 \\ \% \text { at fishing vessels } & 22 & 100 & 0 & 0\end{array}$

Numbers observed in association with fishing vessels in May, August and November were very small but several individuals may have been overlooked considering the stern counts at fisheries research vessels (chapter 4.3).

\section{Lesser Black-backed Gull}

A distinct seasonal pattern of Lesser Blackbacked Gulls in the North Sea was found in counts of birds in associated with fishing vessels. Large flocks of scavenging gulls, sometimes numbering $>1000$ individuals, were recorded in summer (May and August), while small numbers were found in winter, mainly in the southern North Sea (table 4.5.6). Off the east coast of Britain, Lesser Black-backed Gulls were seldom observed at fishing vessels, while substantial numbers occurred off southwest Norway. During stern counts at research vessels, Lesser Black-backed Gulls were numerous in November, particularly in the Southern Bight and in subregion CW (table 4.3.6). At fishing vessels in $\mathrm{CW}$, only a single Lesser Blackbacked Gull was reported (August), whereas the presence of this species during stern counts at research vessels in this subregion ranged from $35-74 \%$ in May and August (table 4.3.6). Peak numbers at the stern of fishing vessels and research vessels were otherwise of a similar order of magnitude (maxima of several hundreds of birds in May and August). On the basis of the (mean) numbers observed at commercial boats in each subregion, multiplied by the total number of fishing vessels in that region (chapter 4.4), it was estimated that during these surveys the total numbers of Lesser Blackbacked Gulls associated with fishing vessels at any one time ranged from none in February and November to 91,000 in August (table 4.5.6). These figures, coupled with estimates derived from strip-transect counts (chapter 4.1), lead to the following estimates of total numbers of Lesser Biack-backed Gulls in the North Sea and that the amount of daylight time spent at fishing vessels ranged from $44 \%$ to $55 \%$ in summer (May and August):

$\begin{array}{lcccc} & 1993 & 1994 & 1994 & 1994 \\ & \text { Febr } & \text { May } & \text { Aug } & \text { Nov } \\ \text { in transect }(\times 1000) & 3 & 50 & 73 & 12 \\ \text { at fishing vessels } & 0 & 40 & 91 & 0 \\ & & & & \\ \text { Totals }(\times 1000) & 3 & 90 & 164 & 12 \\ \% \text { at fishing vessels } & 0 & 44 & 55 & 0\end{array}$

Stern counts at research vessels in February and November indicate that small numbers of Lesser Black-backed Gulls associated with fishing vessels were probably overlooked (chapter 4.3).

\section{Herring Gull}

Herring Gulls were particularly numerous at boats in winter, but peak numbers $(900$ individuals) were observed in May (table 4.5.7). More extensive surveys in summer in the coastal zone would, without doubt, have revealed much larger numbers of Herring Gulls in the Southern Bight and the German Bight (Camphuysen 1993ab, Garthe 1993b, Camphuysen 1994b). It is remarkable that not a single Herring Gull was recorded in 
Table 4.5.10 Mean number (mean), maximum (max) and extrapolated number (x 1000) of unidentified gulls at the stern of fishing vessels per subregion for each of the surveys.

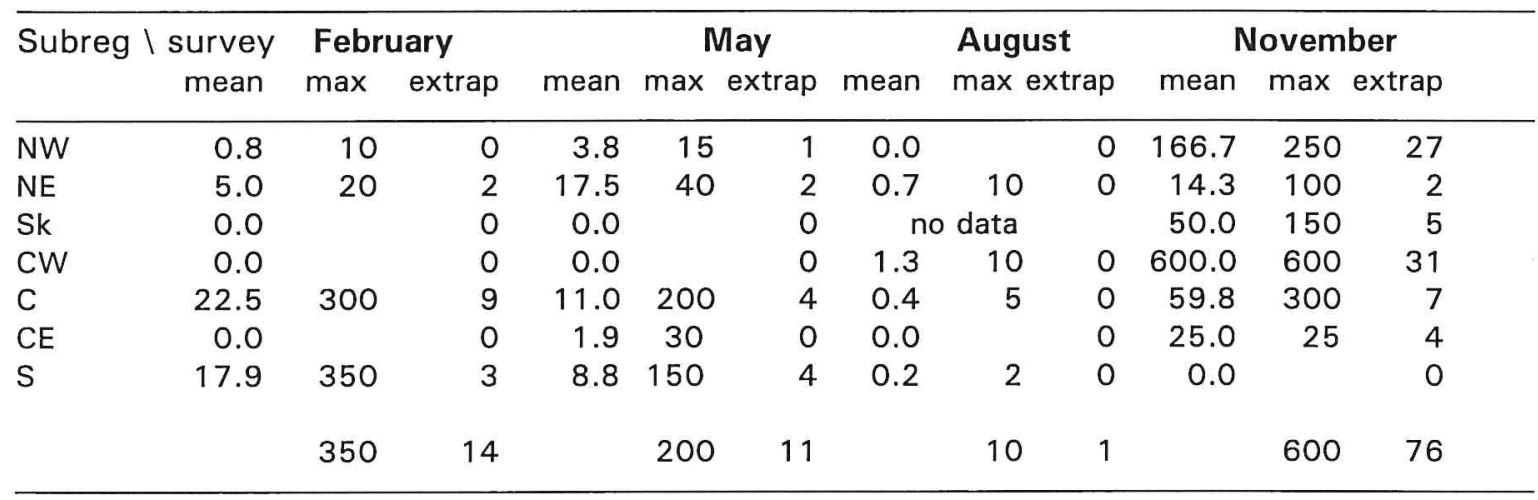

Table 4.5.11 Comparisons of presence (\%) of scavenging seabirds at the stern of fishing vessels (comm) and in association with research vessels (RV).

\begin{tabular}{lrrrrrrrrrr}
\hline & \multicolumn{3}{c}{$\begin{array}{c}\text { February } \\
\text { Species }\end{array}$} & \multicolumn{3}{c}{ May } & \multicolumn{3}{c}{ August } & \multicolumn{2}{c}{ November } & \multicolumn{2}{c}{ comm } & RV & comm & RV & comm & RV & comm & RV & comm & RV \\
\hline Fulmar & 54 & 70 & 69 & 91 & 70 & 86 & 72 & 83 & 65 & 83 \\
Gannet & 24 & 41 & 14 & 51 & 34 & 57 & 31 & 70 & 25 & 55 \\
Gr Skua & 0 & 1 & 0 & 16 & 22 & 40 & 3 & 13 & 6 & 18 \\
Comm Gull & 33 & 40 & 13 & 6 & 0 & 13 & 13 & 26 & 15 & 20 \\
L Bl-b Gull & 2 & 7 & 52 & 76 & 41 & 50 & 3 & 21 & 28 & 42 \\
Herr Gull & 65 & 93 & 26 & 26 & 5 & 9 & 41 & 93 & 34 & 52 \\
Gr Bl-b Gul & 57 & 90 & 31 & 63 & 16 & 36 & 38 & 79 & 36 & 66 \\
Kittiwake & 62 & 95 & 32 & 74 & 34 & 75 & 72 & 96 & 46 & 84 \\
sample & 82 & 188 & 85 & 268 & 73 & 202 & 32 & 191 & 272 & 849 \\
\hline
\end{tabular}

Table 4.5.12 Frequencies of main types of fishing vessels in the North Sea in each subregion from sightings during steaming $(n=272$ sightings, all surveys combined).

\begin{tabular}{|c|c|c|c|c|c|c|c|c|c|}
\hline Type / Subregion & NW & NE & Sk & CW & C & CE & $\mathbf{S}$ & $\Sigma$ & $\%$ \\
\hline Beamtrawlers & & & & 3 & 29 & 21 & 51. & 104 & 43 \\
\hline Shrimpers & & & & & & 1 & $13^{\circ}$ & 14 & \\
\hline Sterntrawlers & 16 & 20 & 2 & 13 & 18 & 3 & 1 & 73 & \} 29 \\
\hline Otter trawlers & 1 & 1 & 2 & & 1 & 1 & & 6 & \\
\hline Pair trawlers & 3 & 3 & & 2 & 5 & 2 & 3 & 18 & 7 \\
\hline Set net fishing boats & & & 3 & & 7 & 3 & 4 & 17 & 6 \\
\hline unidentified & 2 & 4 & & 3 & 4 & 1 & & 14 & 5 \\
\hline Purse seiners & 2 & 1 & & 5 & 3 & 3 & & 14 & 5 \\
\hline Anchor seiners & & & 1 & & & 6 & & 7 & 3 \\
\hline Small trawlers & & & 4 & & & & & 4 & 1 \\
\hline Shellfish boats & & & & 1 & & & & 1 & 0 \\
\hline$\Sigma$ & 24 & 29 & 12 & 27 & 67 & 41 & 72 & 272 & \\
\hline
\end{tabular}


association with fishing vessels in subregion $\mathrm{CW}$ in November, despite the strip-transect counts giving an estimate of nearly 300,000 individuals in these waters (table 4.1.4). Stern counts at research vessels produced rather different results in most surveys, including Herring Gulls being present at $81 \%$ of all hauls in subregion $\mathrm{CW}$ in November (table 4.3.7)! Scavenging Herring Gulls were much more widespread and considerably more numerous in May than indicated by counts at commercial boats, but the same prominent dip in numbers at sea (except in $\mathrm{CW}$ off Aberdeen) occurred. Maxima recorded at the stern of research vessels were usually considerably higher than numbers observed in association with fishing vessels. On the basis of the (mean) numbers observed at commercial boats in each subregion, multiplied by the total number of fishing vessels in that region (chapter 4.4), it was estimated that during these surveys the total numbers of Herring Gulls associated with fishing vessels at any one time ranged from 15,000 in August to just over 80,000 in February (table 4.5.7). These figures, coupled with estimates derived from strip-transect counts (chapter 4.1), lead to the following estimates of total numbers of Herring Gulls in the North Sea and that the amount of daylight time spent at fishing vessels ranged from none in August to $83 \%$ in May:

$\begin{array}{lcccc} & 1993 & 1994 & 1994 & 1994 \\ & \text { Febr } & \text { May } & \text { Aug } & \text { Nov } \\ \text { in transect }(\times 1000) & 203 & 10 & 17 & 454 \\ \text { at fishing vessels } & 82 & 49 & 0 & 25 \\ \text { Totals }(\times 1000) & 285 & 59 & 17 & 479 \\ \% \text { at fishing vessels } & 29 & 83 & 0 & 5\end{array}$

From stern counts at research vessels in the western half of the North Sea, where large numbers of Herring Gulls occurred in striptransect counts, it is concluded that the importance of fishing vessels for Herring Gulls in these waters, as deduced from observations of birds in association with commercial fishing vessels, is seriously underestimated.

\section{Great Black-backed Gull}

Most Great Black-backed Gulls were observed as scavengers in winter (February and November), but small numbers occurred over most of the North Sea in summer (table 4.5.8). Peak numbers at fishing vessels ranged from only 20 individuals in May to 300 gulls in February. These figures are well in accordance with stern counts at research vessels, except for May and August in the northern half of the North Sea (table 4.3.8). Great Black-backed Gulls were readily attracted in August in subregions NW and NE (presence $29 \%$ ) with maxima of nearly 30 individuals, while none were seen at fishing vessels in these subregions. Maxima at fishing vessels in May in the northern North Sea (up to 60 in NW, none in NE and Sk) were very low compared to the frequent sightings of gulls at the stern of research vessels at that time, with maxima of 154 in NW (presence 80\%), 100 in $\operatorname{NE}(95 \%)$ and 20 in Sk $(36 \%)$. On the basis of the (mean) numbers observed at commercial boats in each subregion, multiplied by the total number of fishing vessels in that region (chapter 4.4), it was estimated that during these surveys the total numbers of Great Blackbacked Gulls associated with fishing vessels at any one time ranged from 3000 in May to nearly 40,000 in February (table 4.5.8). These figures, coupled with estimates derived from strip-transect counts (chapter 4.1), lead to the following estimates of total numbers of Great Black-backed Gulls in the North Sea and that the amount of time spent at fishing vessels ranged from $6 \%$ in November to $25 \%$ in February:

$\begin{array}{lcccc} & 1993 & 1994 & 1994 & 1994 \\ & \text { Febr } & \text { May } & \text { Aug } & \text { Nov } \\ \text { in transect }(\times 1000) & 117 & 22 & 23 & 110 \\ \text { at fishing vessels } & 39 & 3 & 4 & 7 \\ & & & & \\ \text { Totals }(\times 1000) & 156 & 25 & 27 & 117 \\ \% \text { at fishing vessels } & 25 & 12 & 15 & 6\end{array}$




\section{Kittiwake}

Kittiwakes were obviously the second most numerous scavenger in the North Sea. However, despite being abundant at sea throughout the year, with a peak abundance in late summer (tables 4.1.1-4), numbers at fishing vessels fell considerably in summer (table 4.5.9). Interestingly, in August, when very high numbers of Kittiwakes occurred in the western half of the North Sea, numbers at fishing vessels peaked away from this core area (in the southeastern North Sea, subregions $C, C E$ and $S$ ). A similar, but less pronounced, pattern can be seen in the stern counts at research vessels (table 4.3.9). Only small numbers of Kittiwakes were seen at fishing vessels or were attracted to fisheries research vessels in waters which were extremely rich in these birds, indicating that 'natural feeding' was of greater significance in these areas. Peak numbers associated with fishing vessels (usually no more than several hundreds, occasionally 1000) were of the same order as peak numbers at research vessels. On the basis of the (mean) numbers observed at commercial boats in each subregion, multiplied by the total number of fishing vessels at any one time in that region (chapter 4.4 ), it was estimated that during these surveys the total numbers of Kittiwakes associated with fishing vessels ranged from 8000 in August to nearly 70,000 in February (table 4.5.9). These figures, coupled with estimates derived from strip-transect counts (chapter 4.1), lead to the following estimates of total numbers of Kittiwakes in the North Sea and the conclusion that the amount of time in daylight spent at fishing vessels ranged from $1 \%$ in summer (May and August) to $25 \%$ in February:

$\begin{array}{lcccc} & 1993 & 1994 & 1994 & 1994 \\ & \text { Febr } & \text { May } & \text { Aug } & \text { Nov } \\ \text { in transect }(\times 1000) & 205 & 672 & 1070 & 375 \\ \text { at fishing vessels } & 69 & 9 & 8 & 28 \\ & & & & \\ \text { Totals }(\times 1000) & 274 & 681 & 1078 & 403 \\ \% \text { at fishing vessels } & 25 & 1 & 1 & 7\end{array}$

From estimates of total numbers of seabirds in the North Sea, calculated on the basis of strip transect results, 'trawler counts' and counts of seabirds associated with nearby fishing vessels, between 4 and $50 \%$ of the common scavengers recorded at sea were associated at any one time in daylight with fishing vessels:

proportion ass.

species with fishing vessel sample

$\begin{array}{lrrr}\text { Lesser Bl-b Gull } & 50 \% & \text { (May-Aug) } \\ \text { Herring Gull } & 39 \% & \text { (Nov-May) } \\ \text { Fulmar } & 19 \% & \text { (all year) } \\ \text { Great Bl-b Gull } & 15 \% & \text { (all year) } \\ \text { Common Gull } & 11 \% & \text { (Nov-Feb) } \\ \text { Kittiwake } & 9 \% & \text { (all year) } \\ \text { Gannet } & 4 \% & \text { (all year) }\end{array}$

However, stern counts at research vessels indicated that, particularly for the large $\mathrm{La}$ rus-gulls, counts at fishing vessels tended to underestimate the attraction of fishing vessels in terms of presence (table 4.5.11) and total numbers, so that the relative importance of commercial fisheries is probably even greater than the above figures suggest. The percentages, suggesting minimum estimates of the time spent around fishing vessels, should be treated with caution. Turnover rates of the different species varied enormously, so that comparisons between species are flawed. Later in this chapter, it is investigated to what degree the abundance and spatial distribution of fishing vessels has influenced the distribution of different seabird species.

\section{Types of fishing vessels:} attractiveness of different fisheries

Of 272 fishing vessels at which associated seabirds were counted, only $5 \%$ remained unidentified (table 4.5.12). Beamtrawlers or shrimpers $(43 \%)$ and sterntrawlers or otter trawlers $(29 \%)$ predominated, as in the radar counts of fishing vessels $128 \%$ and $27 \%$ respectively, $n=578$; table 4.4.6). The largest numbers of seabirds were attracted 
Table 4.5.13 Mean numbers of scavenging seabirds (rounded to nearest 10 birds) associated with the main types of fishing vessels in the North Sea per subregion lall surveys combined; $=$ trawler type not observed, $O=$ mean number of scavengers below 5 individuals).

\begin{tabular}{lrrrrrrrrr}
\hline Type / Subregion & sample & NW & NE & Sk & CW & C & CE & S & $\Sigma$ \\
\hline Otter trawler & 6 & 520 & 2030 & 90 & - & 20 & 0 & - & 470 \\
Stern trawler & 73 & 600 & 360 & 30 & 150 & 260 & 370 & 190 & 370 \\
unidentified & 14 & 1170 & 340 & - & 50 & 160 & 0 & - & 340 \\
Pair trawlers & 18 & 150 & 510 & - & 0 & 150 & 40 & 450 & 240 \\
Set net fishing boats & 17 & - & - & 270 & - & 310 & 220 & 20 & 240 \\
Shrimpers & 14 & - & - & - & - & - & 20 & 220 & 200 \\
Small fishing boat & 4 & - & - & 190 & - & - & - & - & 190 \\
Purse seiners & 14 & 160 & 350 & - & 140 & 250 & 160 & - & 190 \\
Beamtrawlers & 104 & - & - & - & 30 & 100 & 190 & 190 & 170 \\
Anchor seiners & 7 & - & - & 400 & - & - & 120 & - & 160 \\
Shellfish boats & 1 & - & - & - & 10 & - & - & - & 10 \\
\hline
\end{tabular}

Table 4.5.14 Mean numbers scavenging seabirds (rounded to nearest 10 birds) associated with the main types of fishing vessels $(n>5$ sightings in sample) in the North Sea (all surveys combined).

\begin{tabular}{lrrrrrrrrrrr}
\hline Type / Species & sample & Ful & Gan & GSk & CG & LBG & HG & GBG & Kit & gull & $\Sigma$ \\
\hline Otter trawlers & 6 & 430 & 0 & 0 & 0 & 0 & 0 & 0 & 0 & 20 & 470 \\
Stern trawlers & 73 & 250 & 10 & 0 & 0 & 10 & 10 & 10 & 40 & 30 & 370 \\
unidentified & 14 & 190 & 0 & 0 & 0 & 0 & 70 & 40 & 10 & 20 & 340 \\
Pair trawlers & 18 & 140 & 0 & 0 & 10 & 0 & 0 & 0 & 10 & 10 & 240 \\
Set net fishing boats & 17 & 150 & 0 & 0 & 0 & 10 & 20 & 10 & 10 & 30 & 240 \\
Shrimpers & 14 & 0 & 0 & 0 & 90 & 0 & 40 & 0 & 0 & 0 & 200 \\
Purse seiners & 14 & 160 & 0 & 0 & 0 & 0 & 10 & 0 & 0 & 0 & 190 \\
Beamtrawlers & 104 & 20 & 0 & 0 & 0 & 50 & 40 & 10 & 30 & 10 & 170 \\
Anchor seiners & 7 & 70 & 0 & 0 & 0 & 20 & 40 & 20 & 0 & 0 & 160 \\
\hline
\end{tabular}

to otter and stern trawlers in the northern North Sea, comparatively small numbers occurred at purse seiners, beamtrawlers, and anchor seiners (table 4.5.13). Purse seiners usually attracted more birds than beamtrawlers in the central North Sea (CW, C and CE). Only a single shellfish boat was recorded, but this type of vessel is presumably of little interest for scavenging seabirds. Higher densities of seabirds were found in the northern North Sea than in the southeastern North Sea. The higher mean numbers associated with stern/otter trawlers (typical for northern North Sea) than beamtrawlers (mainly found in the southeast) are therefore more likely to reflect the local abundance of birds than the attractiveness of different fisheries. However, in subregions where both beamtrawlers and stern trawlers were present (CW, $C, C E$, and $S$ ), overall numbers associated with stern trawlers were higher.

Fulmars occurred at most types of fishing vessels except shrimpers (inshore fisheries) but were also scarce at beamtrawlers (table 4.5.14). Highest numbers of Larus-gulls were associated with beamtrawlers and shrimpers. Pair trawling and purse seining attracted small numbers of gulls but large numbers of Fulmars. This may be related to the lower amounts of discards produced by these (particularly the latter) pelagic fishing methods. Set net fishing boats (perhaps including some misidentified long-liners) and anchor seiners attracted large numbers of a 
variety of species. These fisheries target comparatively large fish and probably produce mainly offal (see chapter 4.8 ).

\section{Comparison of the distribution of fishing vessels and seabirds}

Spatial patterns observed in the main groups of fishing fleets in the North Sea and the eight key species of seabirds were compared to obtain an idea to what degree the abundance and distribution of fishing vessels may have influenced the general distribution of different species of seabirds. During this project large differences in the apparent attraction of fishing vessels have been observed for different species of seabirds. It can be assumed that for some species the distribution in the North Sea is partly controlled by fishing vessel activities, while for other species the influence of the variation in fishing vessel distribution may be negligible or at least masked by other factors such as natural resources of food, distance to the colonies, environmental conditions or others. Observations of fishing vessels were split into three groups, comprising 'large fishing vesse/s' (sterntrawlers, otter trawlers, pair trawlers and purse seiners), 'small fishing vesse/s', and 'beamtrawlers' (beamtrawlers and shrimpers). The distribution of the three groups of fishing vessels overlapped in the central North Sea (see figures 1.4.13-16), but most 'large fishing vessels' were observed in the north, most 'beamtrawlers' and 'small fishing vessels' were seen in the southeast.

The general distribution of all species of seabirds across the North Sea showed some remarkably different trends which, among other factors, may have been caused by 'affinities' for different fisheries. The distribution of Fulmar (both associated and non-associated) indicated an avoidance of homohaline areas and areas with a strong influence from brackish water (low surface salinity). Hence, in certain areas with prominent fishing activities like the German Bight and the Kattegat Fulmars were comparatively scarce (figures $4.1 .5-8$ and $4.3 .5-8$ ). The trends in the distribution of the Gannet, which occurred in relatively small numbers in the eastern regions of the North Sea, contradicted the patterns of all three groups of fishing vessels, not only in the breeding season, but also in winter (figures 4.1.9-12 and 4.3.9-12). During the non-breeding seasons, Common Gulls avoided areas with high surface salinity, and their distribution therefore clearly differed from the distribution of 'large fishing vessels' (figures 4.1.15-18 and figures 4.3.15-18). Lesser Black-backed Gulls and Herring Gulls occurred commonly in most regions of the North Sea, Lesser Black-Backed Gull mainly during the breeding seasons, Herring Gull mainly during the non-breeding seasons. The largest numbers of both species coincided with the distribution of 'large fishing vessels' in the north, and with 'beamtrawlers' in the southeast (figures 4.1.19-22 and figures 4.3.19-22, figures 4.1.23-26 and figures 4.3.23-26). During the non-breeding seasons, Great Black-backed Gull was the most widespread of the key species of birds, occurring dispersed in all areas (figures 4.1.27-30 and figures 4.3.27-30). Kittiwake distribution varied greatly with season, the species being concentrated off the British east coast during the breeding seasons and dispersed during the non-breeding seasons (figures 4.1.31-34 and figures 4.3.41-34). This means that its distribution seemed to overlap with the distribution of all three groups of fishing vessels during the non-breeding seasons, but being very different from the distribution of any fishing vessel during the rest of the year.

\section{Conclusions}

The maximum numbers of seabirds in association with commercial fishing vessels ranged from just over 23 individuals in the Great Skua to 3500 individuals in the Fulmar (tables 4.5.2-10). Species composition of scavenging seabirds associated with fishing research vessels was more diverse than that around commercial fishing vessels, indicating that distant observations lead to underesti- 
mates of the number of species attracted to fisheries. This conclusion was supported by the fact that the presence (\%) of scavenging seabirds at hauls of research vessels were always higher than indicated by observations of distant commercial boats (table 4.5.11). The highest numbers of seabirds associated with commercial fishing vessels were found near otter trawlers and stern trawlers, the commonest type in the northern North Sea. Fulmars were particularly numerous in association with these fishing vessels (table 4.5.13). Relatively small numbers of seabirds were associated with purse seiners. Fulmars were the commonest seabirds in associated with purse seiners (table 4.5.13). Relatively small numbers of seabirds were associated with beamtrawlers and anchor seiners which is probably partly a reflection of the fact that these types occur in the southeastern North Sea, where seabird densities were comparatively low. Larus-gulls were the commonest scavenging seabirds in these waters at these boats and numbers of Fulmars in association with beamtrawlers were comparatively small (table 4.5.13). Great Black-backed Gulls, Herring Gulls and Lesser Black-backed Gulls (in summer) were the only species of which the distribution at sea was clearly positively influenced by the presence of fishing vessels.

\subsection{DISCARD EXPERIMENTS: CONSUMPTION RATES AND FEEDING EFFICIENCY}

During the IBTS programmes a major part of our project was to carry out experimental discarding of roundfish, flatfish, offal and benthos, in order to examine the patterns of consumption of these items by scavenging seabirds, and variations in relation to discard species and size, season, location within the North Sea, and abundances of adult and immature seabirds scavenging at the vessel. These studies were made following procedures established by Hudson \& Furness (1988) during a study of scavenging seabirds feeding on discards and offal at light trawlers at Shetland. In total, 536 sessions of experimental discarding were held (table 4.6.1). The methods used were described in chapter 2 , but it should be reiterated here that although the present study makes use of research vessels, and these are clearly not exactly comparable to fishing vessels in terms of the quantities, size distributions or patterns of presentation of discards, the use of research vessels during IBTS surveys has the advantage of allowing a standardised and synoptic picture to be obtained over the whole North Sea. By performing studies in February 1993, May, August and November

Table 4.6.1 Number of discard experiments and associated stern counts of scavenging seabirds at research vessels per subregion for each of the surveys.

\begin{tabular}{lrrrrr}
\hline Subregion & February & May & August & November & $\Sigma$ \\
\hline NW & 28 & 47 & 32 & 41 & 148 \\
NE & 9 & 16 & 16 & 17 & 58 \\
Sk & 0 & 6 & 0 & 10 & 16 \\
CW & 12 & 25 & 24 & 19 & 80 \\
CE & 11 & 23 & 9 & 8 & 51 \\
C & 33 & 47 & 35 & 42 & 157 \\
S & 8 & 2 & 11 & 5 & 26 \\
$\Sigma$ & 101 & 166 & 127 & 142 & 536 \\
\hline
\end{tabular}


Table 4.6.2 Items experimentally discarded from research vessels in areas of the North Sea during the 1993 and 1994 IBTS surveys.

\begin{tabular}{|c|c|c|c|c|c|c|c|c|c|}
\hline Type & Item & NW & NE & CW & C & CE & $\mathbf{S}$ & Sk & $\Sigma$ \\
\hline \multirow[t]{3}{*}{ Cephalopod } & Octopus & 4 & 0 & 0 & 0 & 0 & 0 & 0 & 4 \\
\hline & Ommastrephes & 2 & 0 & 0 & 7 & 0 & 0 & 0 & 9 \\
\hline & Squid & 20 & 1 & 2 & 31 & 27 & 10 & 0 & 91 \\
\hline \multirow[t]{20}{*}{ Benthic } & Ascidian & 0 & 0 & 0 & 0 & 1 & 0 & 0 & 1 \\
\hline & Astropecten & 48 & 7 & 20 & 24 & 0 & 0 & 0 & 99 \\
\hline & Brittle Star & 1 & 0 & 1 & 1 & 6 & 0 & 0 & 9 \\
\hline & Crayfish & 1 & 0 & 0 & 0 & 0 & 0 & 0 & 1 \\
\hline & Crustacea spp. & 2 & 0 & 0 & 2 & 0 & 0 & 0 & 4 \\
\hline & Edible Crab & 0 & 0 & 0 & 0 & 2 & 0 & 0 & 2 \\
\hline & Hermit Crab & 65 & 10 & 12 & 23 & 4 & 0 & 0 & 114 \\
\hline & Jellyfish & 2 & 2 & 0 & 3 & 0 & 1 & 0 & 8 \\
\hline & Masked Crab & 6 & 1 & 1 & 18 & 25 & 1 & 1 & 53 \\
\hline & Nephrops & 40 & 17 & 7 & 2 & 2 & 0 & 7 & 75 \\
\hline & Octopus & 1 & 0 & 1 & 0 & 0 & 2 & 0 & 4 \\
\hline & Pandalus & 6 & 0 & 0 & 0 & 0 & 0 & 0 & 6 \\
\hline & Prawn & 102 & 1 & 2 & 1 & 3 & 0 & 10 & 119 \\
\hline & Sea Potato & 0 & 2 & 0 & 1 & 0 & 0 & 0 & 3 \\
\hline & Sea-urchin & 31 & 1 & 1 & 10 & 1 & 0 & 5 & 49 \\
\hline & Seamouse & 19 & 6 & 3 & 38 & 3 & 0 & 7 & 76 \\
\hline & Shrimp & 19 & 0 & 4 & 0 & 0 & 0 & 0 & 23 \\
\hline & Spider Crab & 4 & 1 & 5 & 1 & 0 & 0 & 0 & 11 \\
\hline & Squid & 1 & 2 & 3 & 2 & 0 & 1 & 0 & 9 \\
\hline & Starfish & 50 & 14 & 29 & 64 & 15 & 18 & 5 & 195 \\
\hline & Sw Crab & 51 & 2 & 2 & 36 & 8 & 8 & 5 & 112 \\
\hline & Urchin & 0 & 4 & 0 & 0 & 0 & 0 & 0 & 4 \\
\hline \multirow[t]{8}{*}{ Offal } & Cod eggs & 0 & 0 & 0 & 2 & 0 & 0 & 0 & 2 \\
\hline & Cod head & 0 & 0 & 1 & 0 & 0 & 0 & 0 & 1 \\
\hline & Fish eggs & 0 & 0 & 2 & 0 & 0 & 0 & 0 & 2 \\
\hline & Fish head & 0 & 0 & 6 & 31 & 0 & 0 & 0 & 37 \\
\hline & Fish sperm & 0 & 0 & 0 & 11 & 0 & 0 & 0 & 11 \\
\hline & Fish tail & 0 & 0 & 2 & 0 & 0 & 0 & 0 & 2 \\
\hline & Offal & 2367 & 976 & 1129 & 1061 & 71 & 98 & 87 & 5789 \\
\hline & Ray egg & 0 & 0 & 0 & 1 & 0 & 0 & 0 & 1 \\
\hline \multirow[t]{2}{*}{ Jellyfish } & BS Jellyfish & 0 & 0 & 2 & 0 & 1 & 0 & 0 & 3 \\
\hline & Jellyfish. & 0 & 0 & 0 & 1 & 0 & 0 & 0 & 1 \\
\hline \multirow[t]{15}{*}{ Flatfish } & Angler & 5 & 0 & 0 & 1 & 0 & 0 & 0 & 6 \\
\hline & $\mathrm{Dab}$ & 171 & 69 & 185 & 739 & 310 & 41 & 22 & 1537 \\
\hline & Flatfish spp. & 0 & 0 & 0 & 1 & 0 & 0 & 0 & 1 \\
\hline & Flounder & 0 & 0 & 0 & 0 & 1 & 1 & 0 & 2 \\
\hline & Lemon Sole & 93 & 1 & 39 & 16 & 2 & 0 & 0 & 151 \\
\hline & Lr Dab & 291 & 123 & 68 & 177 & 28 & 1 & 44 & 732 \\
\hline & Megrim & 7 & 1 & 0 & 0 & 0 & 0 & 0 & 8 \\
\hline & Norw Topknot & 0 & 0 & 0 & 1 & 0 & 0 & 0 & 1 \\
\hline & Plaice & 19 & 11 & 22 & 26 & 37 & 22 & 3 & 140 \\
\hline & Roker & 1 & 1 & 0 & 0 & 0 & 5 & 0 & 7 \\
\hline & Scaldfish & 2 & 0 & 0 & 3 & 0 & 0 & 0 & 5 \\
\hline & Skate & 2 & 3 & 7 & 2 & 0 & 0 & 0 & 14 \\
\hline & Sole & 0 & 0 & 0 & 13 & 4 & 1 & 1 & 19 \\
\hline & Solenette & 0 & 0 & 0 & 17 & 2 & 2 & 0 & 21 \\
\hline & Witch & 1 & 0 & 1 & 1 & 0 & 0 & 1 & 4 \\
\hline \multirow[t]{3}{*}{ Roundfish } & Allis Shad & 1 & 0 & 0 & 0 & 0 & 0 & 0 & 1 \\
\hline & Angler & 0 & 0 & 0 & 1 & 0 & 0 & 0 & 1 \\
\hline & Argentine & 86 & 8 & 0 & 0 & 0 & 0 & 0 & 94 \\
\hline
\end{tabular}


Table 4.6.2 continued

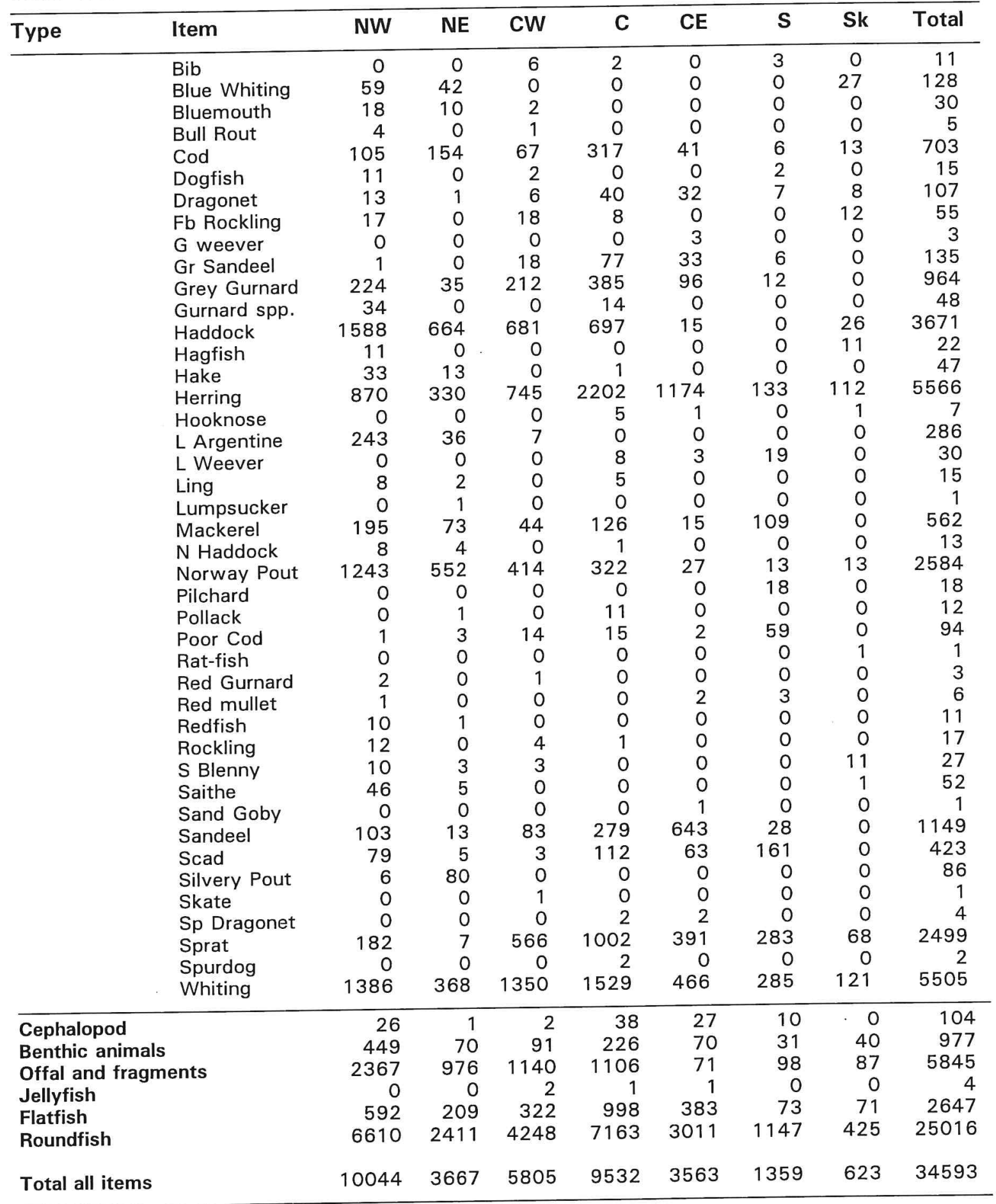


Table 4.6.3 Quartiles and median lengths of experimental discards (of all types except offal) in each area during February 1993 surveys.

\begin{tabular}{lrrrrrrrr}
\hline Discard length (cm) & NW & NE & CW & C & CE & S & Sk & Total \\
\hline 25 centile & 18 & 17 & 16 & 14 & 13 & 11 & 15 \\
Median & 24 & 18 & 18 & 16 & 15 & 14 & 18 \\
Rank of median & 1 & $2=$ & $2=$ & 4 & 5 & 6 & 24 & 23 \\
75 centile & 29 & 23 & 21 & 21 & 19 & 24 & 5832 \\
Sample size & 1486 & 539 & 652 & 2158 & 447 & 550 & 19.3 \\
Mean & 23.5 & 20.2 & 18.8 & 17.3 & 16.2 & 17.7 & 0.09 \\
Standard error & 0.17 & 0.21 & 0.17 & 0.12 & 0.22 & 0.31 & \\
\hline
\end{tabular}

Table 4.6.4 Quartiles and median lengths of experimental discards (of all types except offal) in each area during May 1994 surveys.

\begin{tabular}{lrrrrrrrr}
\hline Discard length (cm) & NW & NE & CW & C & CE & S & Sk & Total \\
\hline 25 centile & 16 & 14 & 16 & 14 & 12 & 10 & 13 & 14 \\
Median & 20 & 17 & 20 & 18 & 14 & 13 & 16 & 17 \\
Rank of median & $1=$ & 4 & $1=$ & 3 & 6 & 7 & 5 & 22 \\
75 centile & 24 & 22 & 24 & 21 & 17 & 22 & 20 & 10206 \\
Sample size & 2734 & 609 & 1896 & 2242 & 2353 & 73 & 299 & 18.1 \\
Mean & 19.9 & 17.9 & 20.0 & 18.1 & 14.9 & 16.0 & 17.0 & 0.06 \\
Standard error & 0.11 & 0.27 & 0.13 & 0.11 & 0.10 & 0.79 & 0.33 & \\
\hline
\end{tabular}

Table 4.6.5 Quartiles and median lengths of experimental discards (of all types except offal) in each area during August 1994 surveys.

\begin{tabular}{lrrrrrrrr}
\hline Discard length $(\mathrm{cm})$ & NW & NE & CW & C & CE & S & Sk & Total \\
\hline 25 centile & 17 & 16 & 14 & 17 & 11 & 17 & 16 \\
Median & 22 & 22 & 20 & 20 & 16 & 22 & 21 \\
Rank of median & $1=$ & $1=$ & $4=$ & $4=$ & 6 & $1=$ & 24 \\
75 centile & 27 & 27 & 24 & 24 & 22 & 24 & 25 \\
Sample size & 1758 & 783 & 1435 & 1778 & 2070 & 355 & 20.6 \\
Mean & 22.3 & 21.8 & 19.3 & 20.0 & 16.7 & 21.2 & 0.09 \\
Standard error & 0.17 & 0.25 & 0.17 & 0.16 & 0.36 & 0.30 & \\
\hline
\end{tabular}

Table 4.6.6 Quartiles and median lengths of experimental discards (of all types except offal) in each area during November 1994 surveys.

\begin{tabular}{lrrrrrrrr}
\hline Discard length (cm) & NW & NE & CW & C & CE & S & Sk & Total \\
\hline 25 centile & 12 & 13 & 15 & 12 & 12 & 16 & 15 & 12 \\
Median & 16 & 16 & 20 & 15 & 15 & 24 & 18 & 16 \\
Rank of median & $4=$ & $4=$ & 2 & $6=$ & $6=$ & 1 & 3 & 23 \\
75 centile & 23 & 22 & 25 & 21 & 18 & 27 & 24 & 6704 \\
Sample size & 1907 & 733 & 895 & 2286 & 395 & 272 & 216 & 17.7 \\
Mean & 17.9 & 17.3 & 20.1 & 17.6 & 15.2 & 22.4 & 19.5 & 0.08 \\
Standard error & 0.16 & 0.25 & 0.22 & 0.12 & 0.20 & 0.47 & 0.40 & \\
\hline
\end{tabular}


1994, we can examine seasonal changes in discard and offal utilisation by scavenging seabirds that may come about as a result of seasonal changes in such factors as scavenging seabird species composition, age frequency, abundance, distribution through the North Sea, and relative availability of alternate foods. Although care was taken to discard only freshly-caught fish, the size range of fish discarded was much greater than that normally discarded from commercial vessels and the rate of discarding was generally less, providing a less powerful attraction for scavenging seabirds. The primary aims of this part of the project were (1) to assess the proportion of discards of each type and size consumed by scavenging seabirds, (2) to examine differences between subregions in the species composition of seabirds scavenging on discards, (3) to determine the variations in proportions of discards consumed in different seasons and subregions, (4) to record the selectivity and competitive abilities of different species and age classes of scavenging seabirds. Interpretation must always be made with caution, though, where results are being extrapolated to the situation regarding commercial vessels.

\section{Numbers of items of each type experimentally discarded}

During the four seasons discard experiments were carried out over most areas of the North Sea, though data were collected in the Skaggerak only in May and November (figures 4.6.1-4). Over the four seasons a total of 34,589 items were experimentally discarded, with similar effort in each quarter (table 4.6.1). It was intended to provide more roundfish and offal discards and few discards of benthos or flatfish because it was known that scavenging seabirds prefer to consume offal and roundfish and often ignore benthos or flatfish, so numbers of items discarded reflect selectivity by scientists. It was preferable to obtain more data for types of discards favoured by seabirds. Nevertheless, numbers of some items were often limited and so totals were constrained by availability, especially in the case of offal. Frequencies of different types of discards provided bear no relationship to the frequencies with which particular discards occur from commercial fisheries. 25,016 (72.3\%) were discards of roundfish, 5845 (16.9\%) were discards of offal, $2647(7.7 \%)$ were discards of flatfish, $977(2.8 \%)$ were discards of benthic animals, 104 were discards of cephalopods $(0.3 \%)$ and 4 were discards of jellyfish (table 4.6.2). The largest number, $10,044(29.0 \%)$, of the experimental discards were discarded in the NW subregion.

\section{Lengths of experimental discards}

Sizes of items discarded varied significantly among subregions within seasons (tables 4.6.3-13). In general, discards tended to be larger in the NW subregion except in November when median sizes were similar in all subregions except for particularly large sized discards in the $\mathrm{S}$ subregion (but for a small number of items discarded). Considering only flatfish discards, and expressing size in terms of fish width, there is a slight trend for flatfish sizes experimentally discarded to be larger further south (tables 4.6.7-9). Examining the patterns for individual fish species (tables 4.6.10-13), variation in size distributions of fish experimentally discarded is highly significant among subregions, but not clearly consistent over species. In the February sample (table 4.6.10) seven of the nine major types of fish discarded (Herring, Sprat Sprattus sprattus, Cod Gadus morhua, Haddock Melanogrammus aeglefinus, Whiting Merlangius merlangus, gurnards (Trigla spp., Eutrigla spp.) and Dab Limanda limanda) had larger median length in the NW subregion than for the North Sea as a whole. A similar pattern was evident in the other seasonal samples, with NW subregion having larger median lengths than the North Sea as a whole for Herring, Sprat, Whiting and sandeel Ammodytes spp. in May (table 4.6.11), for Herring, Cod, Whiting, Norway Pout Trisopterus esmarckii, Dab, Mackerel Scomber scombrus and Scad Trachurus trachurus in August (table 4.6.12) and for Whiting, 
Table 4.6.7 Quartiles and median widths of experimental discards of flatfish in each area during May 1994 surveys.

\begin{tabular}{lrrrrrrrr}
\hline Discard width (cm) & NW & NE & CW & C & CE & S & Sk & Total \\
\hline 25 centile & 4 & 5 & 6 & 6 & 5 & 7 & 3 & 5 \\
Median & 5 & 5 & 7 & 7 & 7 & 5 & 6 \\
Rank of median & $4=$ & $4=$ & $1=$ & $1=$ & $1=$ & & $4=$ & 5 \\
75 centile & 7 & 6 & 7 & 7 & 7 & & 56 & 7 \\
Sample size & 262 & 34 & 106 & 343 & 274 & 1 & 4.8 & 6.4 \\
Mean & 5.5 & 5.9 & 7.0 & 6.9 & 6.7 & 7.8 & 0.23 & 0.06 \\
Standard error & 0.11 & 0.22 & 0.16 & 0.08 & 0.11 & - & 0.23 \\
\hline
\end{tabular}

Table 4.6.8 Quartiles and median widths of experimental discards of flatfish in each area during August 1994 surveys.

\begin{tabular}{lrrrrrrrr}
\hline Discard width (cm) & NW & NE & CW & C & CE & S & Sk & Total \\
\hline 25 centile & 5 & 4 & 6 & 5 & 5 & 5 & 5 \\
Median & 7 & 5 & 7 & 6 & 7 & 6 & 6 \\
Rank of median & $1=$ & 6 & $1=$ & $4=$ & $1=$ & $4=$ & 7 & 7 \\
75 centile & 8 & 6 & 8 & 7 & 7 & 7 & 644 \\
Sample size & 147 & 60 & 129 & 244 & 49 & 15 & 6.4 \\
Mean & 6.6 & 5.4 & 7.1 & 6.3 & 6.3 & 6.5 & 0.07 \\
Standard error & 0.19 & 0.21 & 0.16 & 0.09 & 0.23 & 0.38 & & \\
\hline
\end{tabular}

Table 4.6.9 Quartiles and median widths of experimental discards of flatfish in each area during November 1994 surveys.

\begin{tabular}{lrrrrrrrr}
\hline Discard width (cm) & NW & NE & CW & C & CE & S & Sk & Total \\
\hline 25 centile & 3 & 4 & 5 & 4 & 6 & 5 & 5 & 7 \\
Median & 4 & 5 & 6 & 6 & 6 & 8 & 7 & 6 \\
Rank of median & 7 & 6 & $3=$ & $3=$ & $3=$ & 1 & 2 & 7 \\
75 centile & 6 & 6 & 7 & 7 & 7 & 9 & 8 & 451 \\
Sample size & 97 & 89 & 51 & 162 & 30 & 8 & 14 & 5.6 \\
Mean & 4.8 & 5.2 & 6.1 & 5.8 & 6.3 & 7.7 & 7.2 & 0.09 \\
Standard error & 0.16 & 0.17 & 0.28 & 0.14 & 0.25 & 1.00 & 0.35 &
\end{tabular}




\begin{tabular}{|c|c|c|c|c|}
\hline & $\begin{array}{c}1993 \\
\text { Febr }\end{array}$ & $\begin{array}{l}1994 \\
\text { May }\end{array}$ & $\begin{array}{c}1994 \\
\text { Aug }\end{array}$ & $\begin{array}{l}1994 \\
\text { Nov }\end{array}$ \\
\hline CE & $\begin{array}{l}\text { Kit } \\
\text { HG } \\
\text { CG }\end{array}$ & $\begin{array}{c}\text { LBG } \\
\text { Kit } \\
\text { Ful }\end{array}$ & $\begin{array}{c}\text { Kit } \\
\text { LBG } \\
\text { GSk }\end{array}$ & $\begin{array}{c}\mathrm{HG} \\
\text { Kit } \\
\mathrm{GBG}\end{array}$ \\
\hline S & $\begin{array}{l}\text { Kit } \\
\text { HG } \\
\text { GBG }\end{array}$ & & $\begin{array}{c}\text { LBG } \\
- \\
-\end{array}$ & $\begin{array}{c}\text { HG } \\
\text { LBG } \\
\text { Kit }\end{array}$ \\
\hline
\end{tabular}

The top ranking consumers of clupeids show similarities to the top ranking consumers of gadids, though with a tendency for larger species to be more prominent among gadid consumers. This probably reflects the tendency for clupeids being discarded to be smaller than the gadids being discarded, so more suitable for smaller seabirds to swallow.

As with gadids, Fulmars obtained less, usually very considerably less, clupeids than their numerical abundance predicted (tables 4.6.34). Gannets obtained significantly more clupeids than did gulls for most subregion/season combinations. Although Gannets outperformed gulls consistently in the NW, in some seasons gulls did better than Gannets and in others worse than Gannets in $\mathrm{C}$ and $\mathrm{CW}$ (tables 4.6.35). Although there was significant heterogeneity in clupeid consumption by different gull species (tables 4.6.36-39) the patterns were inconsistent, though with Common Gulls generally doing less well than expected and Kittiwakes better than expected.

Success rates achieved by different age groups in scavenging gulls

Most scavenging seabirds that could be assigned to age categories were classified as adults, except in the case of Great Black-backed Gulls where immatures predominated (tables 4.3.3-4.3.9). The success indices for adult and immature (including subadult and juvenile) gulls suggest that adults have generally a slightly higher success at swallowing discards than immatures do (table 4.6.4041). Of 24 comparisons, adults had a higher success index than immatures in 15 cases

(chance variation would predict 12 cases). The difference is very small, and the frequent reversal of the anticipated superiority of adults may be a result of a) the fact that differences in success between adults and immatures are small and b) the highly variable nature of the age composition and success rates achieved from haul to haul.

Discard size selection by scavenging seabirds In general, larger scavenging seabirds tended to consume larger discards than taken by smaller species. This pattern held in all four seasons surveyed. Length distributions of fish, or width distributions of flatfish, that sank, or were taken by particular scavenging seabird species are given in Appendix A. and these data are summarised as minimum, median and maximum sizes swallowed by each species or sunk, in tables 4.6.42-45. The selection of fish is illustrated for each seasonal survey in figures 4.6.15-18. Fish that sank were often larger than average. Selection of flatfish (figures 5.5.1-5.8.1) also shows a preference for smaller flatfish discards among most seabird species.

It is evident that not only do birds select discards that are of a size they can handle, but also that there is considerable scramble competition for the fish discarded leading to kleptoparasitism. Of 5832 experimental discards in the February survey, 4935 were picked up and were eventually swallowed by seabirds but $857(17.4 \%)$ of these were stolen from the first bird by another before they could be swallowed. Of the 857 stolen items, $292(34.1 \%)$ were stolen a second time. Similar results were obtained in the other surveys (table 4.6.46) and consistently show that larger discards tend to be stolen more frequently before being swallowed. This kleptoparasitic behaviour is examined further in chapter 4.7, but there is strong evidence of the highly competitive nature of feeding on discards, and shows a tendency for the larger scavenging species to gain more from these interactions than the smaller species do. 


\section{Conclusions}

From discard experiments experiments onboard research vessels, overall consumption rates by scavenging seabirds can be estimated at $95 \%$ for offal $(n=5799), 80 \%$ for roundfish $(n=22,261), 20 \%$ for flatfish ( $n=$ 2407), and $6 \%$ for benthic invertebrates $(n=939)$. Consumption rates are higher in winter than in summer, indicating that several seabirds make less use of discards in summer because there are alternative (natural) sources of food more readily available. Consumption rates generally increased from south to north. Kittiwakes (winter) and Fulmars (summer), being the most abundant scavengers in most of the North Sea, took most discards. Larus-gulls gained importance in the southeastern North Sea and totally replaced the above mentioned pelagic seabirds as main consumers in the coastal zone of the German Bight, Southern Bight and Skagerrak.
Figures 4.6.1 - 4 show the numbered sessions of experimental discarding in each of the surveys 1101 in February, 166 in May, 127 in August and 142 in November).

Figures 4.6.5 - 6 are diagrams in which the total numbers of flatfish $(n=2414)$ and roundfish ( $n=23,389$ ) used during experimental discarding are presented per size class, including offered fish of which the fate is known (total bar), the fraction that was swallowed by seabirds (black bar) and the fraction that was only pecked on by seabirds (shaded bar). The width of flatfish was calculated from the measured total length, using formulae given in Camphuysen 1994a).

Figures 4.6.7 - 10 are maps showing variations in consumption rates by seabirds for roundfish during sessions of experimental discarding in which at least 25 roundfish (with known fate) were offered. Results are presented in classes ranging from $<50 \%$ consumed (blank) to $>90 \%$ consumed (black).

Figures 4.6.11 - 14 are diagrams in which for each survey the length distribution of experimentally discarded roundfish of which the fate is known is presented 14997 roundfish in February, 8357 in May, 4407 in August and 4500 in November). A line indicates the proportion of the fish that was consumed by seabirds (consumption rate, $\%)$, which shows that there is a tendency of higher consumption rates in smaller than in larger roundfish.

Figures 4.6.15 - 18 are line diagrams in which for all consumed roundfish in each of the surveys, the proportion (\%) consumed by any of the 5-6 main scavengers in each survey is plotted. For instance in figure 4.6.15, it can be seen that of roundfish $<20 \mathrm{~cm}$ over $50 \%$ was consumed by Kittiwakes, whereas for roundfish $>32 \mathrm{~cm}$ over $50 \%$ was consumed by Gannets. 

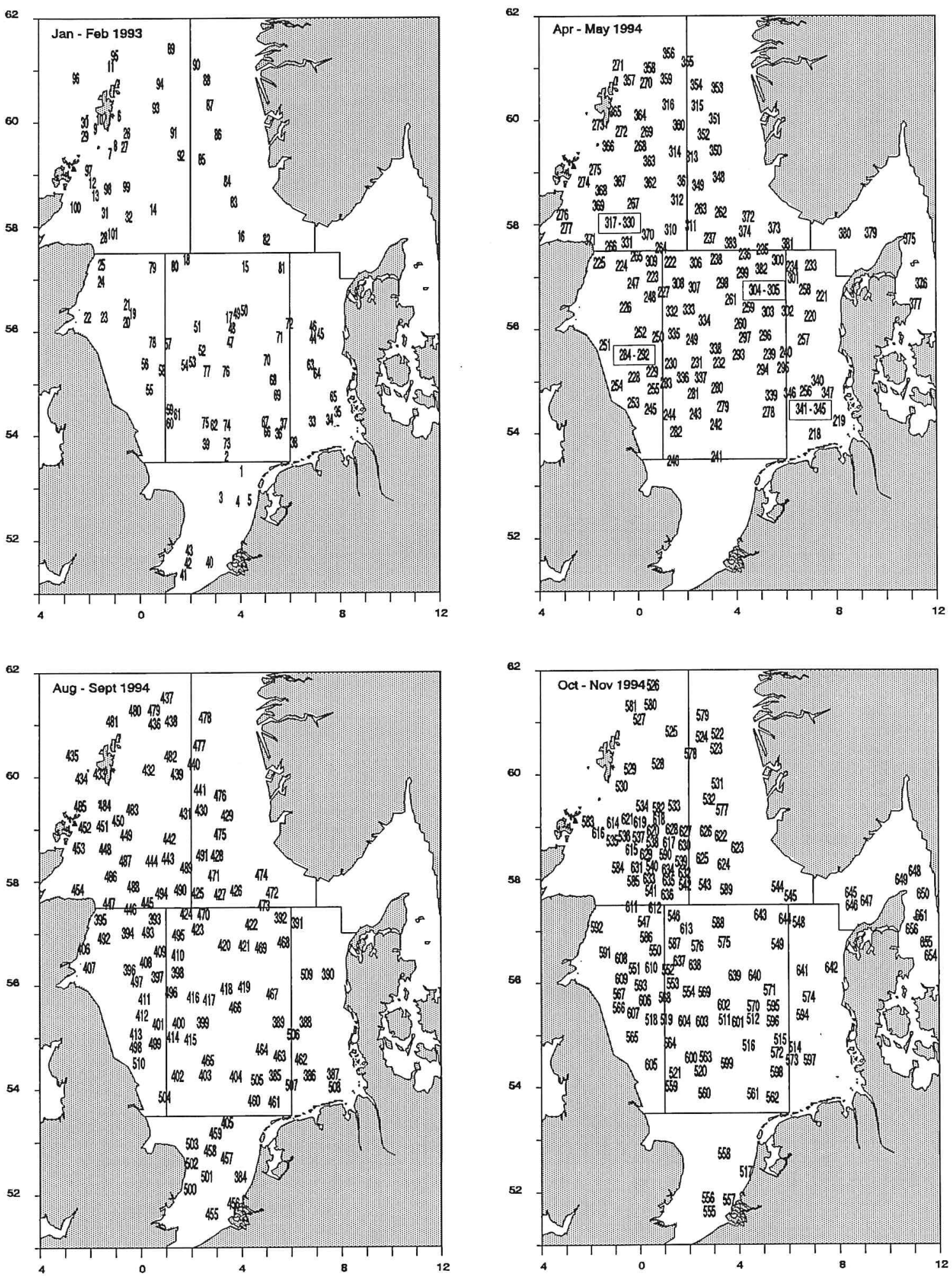

Figure 4.6.1-4 Observer effort for experimental discard (numbered experiments) 

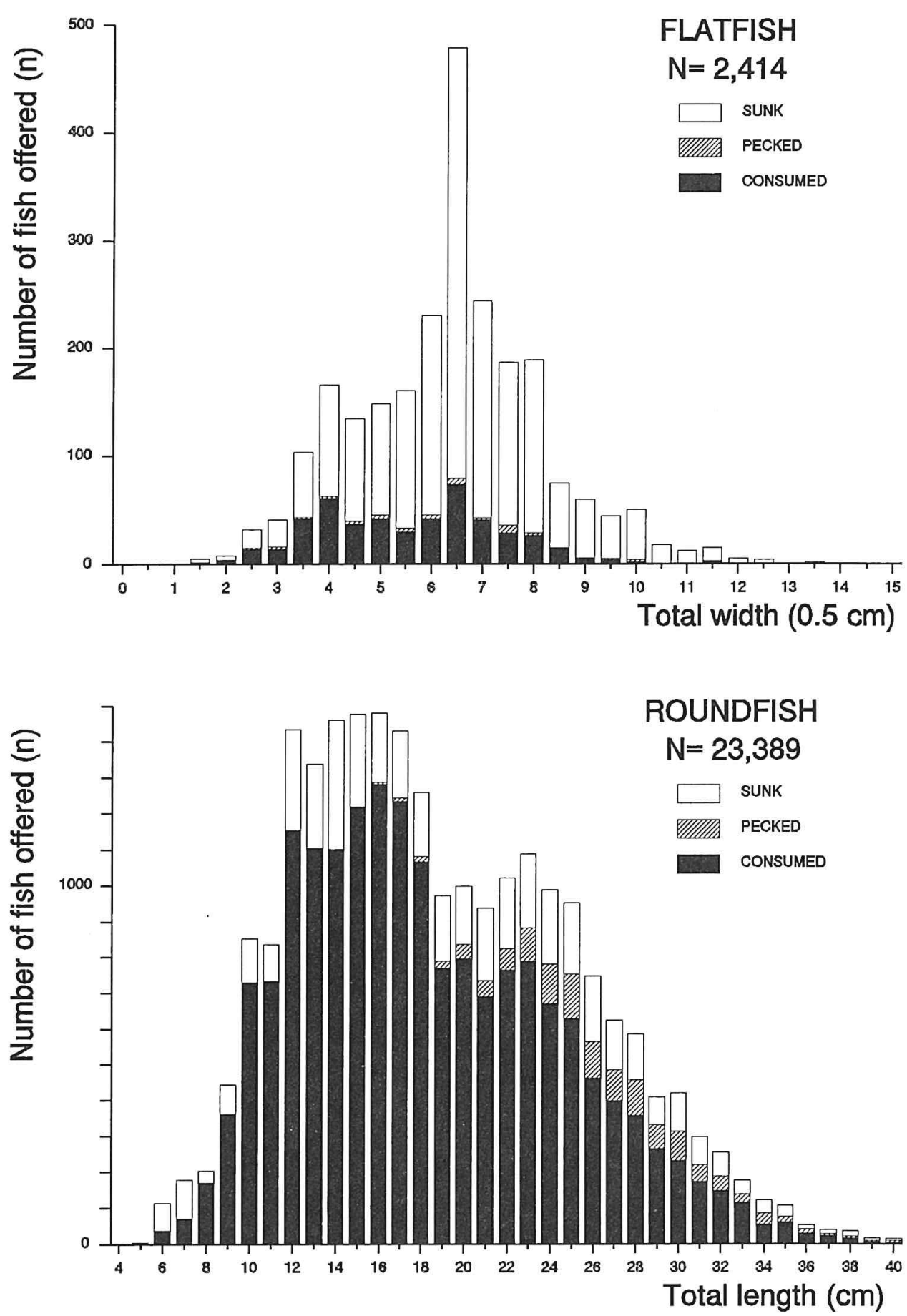

Figure 4.6.5-6 Width $(0.5 \mathrm{~cm})$ of flatfish and length $(\mathrm{cm})$ of roundfish offerd during experimental discarding of which fate was known, divided in proportions which were consumed, which were pecked on or which sunk 
Table 4.6.20 Consumption of experimentally discarded common gadids (Haddock, Whiting, Cod, Saithe, Norway pout) by scavenging seabirds in each area of the North Sea in February. S.I. = success index (percent of all gadids that were swallowed by this species divided by percent of all birds present that were this species). Where no birds or very few birds of a species were present the success index is not calculated and is marked "-".

\begin{tabular}{llrrrrrrrr}
\hline Area & Value & Ful & Gan & GBG & HG & Kit & CG & LBG & GSk Total \\
\hline NW & n & 18 & 385 & 180 & 125 & 314 & 0 & 0 & \\
& $\%$ & 1.8 & 35.9 & 18.1 & 12.6 & 31.5 & 0.0 & 0.0 & \\
& S.I. & 0.04 & 3.39 & 1.95 & 1.05 & 1.27 & - & - & \\
NE & n & 11 & 34 & 31 & 34 & 178 & 0 & 0 & 288 \\
& $\%$ & 3.8 & 11.8 & 10.8 & 11.8 & 61.8 & 0.0 & 0.0 & \\
& S.I. & 0.07 & 6.56 & 2.12 & 2.00 & 1.84 & - & - & \\
CW & n & 7 & 61 & 23 & 49 & 289 & 0 & 0 & 429 \\
& $\%$ & 1.6 & 14.2 & 5.4 & 11.4 & 67.4 & 0.0 & 0.0 & \\
& S.I. & 0.07 & 2.63 & 1.64 & 1.07 & 1.17 & 0.00 & - & \\
& n & 13 & 51 & 42 & 126 & 222 & 0 & 0 & 454 \\
& $\%$ & 2.9 & 11.2 & 9.3 & 27.8 & 48.9 & 0.0 & 0.0 & \\
CE & S.I. & 0.06 & 5.33 & 1.02 & 1.62 & 0.96 & 0.00 & - & \\
& n & 0 & 0 & 9 & 19 & 11 & 1 & 0 & 40 \\
& S.I. & 0.0 & 0.0 & 22.5 & 47.5 & 27.5 & 2.5 & 0.0 & \\
S & $n$ & 0.00 & - & 2.08 & 1.57 & 1.09 & 0.11 & - & \\
& $\%$ & 3 & 8 & 31 & 36 & 47 & 0 & 3 & \\
& S.I. & 2.3 & 6.2 & 24.2 & 28.1 & 36.7 & 0.0 & 2.3 & \\
& 0.08 & 6.20 & 1.86 & 1.73 & 0.96 & - & 2.56 & \\
\hline
\end{tabular}

Table 4.6.21 Consumption of experimentally discarded common gadids in May (see table 4.6.20 for conventions).

\begin{tabular}{llrrrrrrrrr}
\hline Area & Value & Ful & Gan & GBG & HG & Kit & CG & LBG & GSk Total \\
\hline NW & $n$ & 375 & 273 & 101 & 18 & 215 & 0 & 45 & 8 & 1035 \\
& $\%$ & 36.2 & 26.4 & 9.8 & 1.7 & 20.8 & 0 & 4.3 & 0.8 & \\
& S.I. & 0.42 & 5.49 & 3.39 & 2.79 & 1.73 & - & 2.49 & 3.08 & \\
NE & n & 152 & 11 & 68 & 4 & 0 & 0 & 79 & 2 & 316 \\
& $\%$ & 48.3 & 3.5 & 21.5 & 1.3 & 0 & 0 & 25.0 & 0.6 & \\
& S.I. & 0.66 & 11.67 & 2.72 & 0.38 & 0.00 & 0.00 & 3.07 & 4.29 & \\
CW & n & 190 & 387 & 4 & 2 & 172 & 0 & 3 & 1 & 759 \\
& $\%$ & 2.5 & 50.1 & 0.6 & 0.3 & 22.7 & 0 & 0.4 & 0.1 & \\
& S.I. & 0.32 & 5.42 & 0.34 & 5.00 & - & - & 0.42 & 1.67 & \\
C & n & 199 & 71 & 30 & 4 & 47 & 0 & 54 & 1 & 406 \\
& $\%$ & 49.0 & 17.5 & 7.4 & 1.0 & 11.6 & 0 & 1.3 & 0.2 & \\
& S.I. & 0.66 & 43.30 & 2.84 & 6.25 & 0.99 & 0.00 & 0.14 & - & \\
CE & n & 17 & 2 & 1 & 4 & 18 & 1 & 96 & 0 & 139 \\
& $\%$ & 12.2 & 1.4 & 0.7 & 2.9 & 13.0 & 0.7 & 69.0 & 0 & \\
& S.I. & 0.26 & 3.11 & 0.39 & 2.79 & 0.80 & 1.56 & 2.12 & - & \\
S & n & 1 & 0 & 0 & 0 & 2 & 0 & 2 & 0 & 5 \\
& $\%$ & 20.0 & 0 & 0 & 0 & 40.0 & 0 & 40.0 & 0 & \\
& S.I. & 2.56 & 0.00 & 0.00 & 0.00 & 1.44 & - & 0.68 & - & \\
Sk & n & 0 & 0 & 2 & 9 & 0 & 0 & 40 & 0 & 51 \\
& $\%$ & 0 & 0 & 3.9 & 17.6 & 0 & 0 & 78.4 & 0 & \\
& S.I. & 0.00 & - & 1.09 & 0.62 & 0.00 & - & 1.77 & - & \\
\hline
\end{tabular}


Table 4.6.22 Consumption of experimentally discarded common gadids in August lsee table 4.6.20 for conventions).

\begin{tabular}{|c|c|c|c|c|c|c|c|c|c|c|}
\hline Area & Value & Ful & Gan & GBG & $\mathrm{HG}$ & Kit & CG & LBG & GSk & Total \\
\hline NW & $\begin{array}{l}n \\
\% \\
\text { S.I. }\end{array}$ & $\begin{array}{r}363 \\
66.1 \\
0.69\end{array}$ & $\begin{array}{r}80 \\
14.6 \\
12.17\end{array}$ & $\begin{array}{r}36 \\
6.6 \\
11.00\end{array}$ & $\begin{array}{r}4 \\
0.7 \\
23.33\end{array}$ & $\begin{array}{r}8 \\
1.5 \\
1.03\end{array}$ & $\begin{array}{r}0 \\
0 \\
0.00\end{array}$ & $\begin{array}{r}2 \\
0.4 \\
3.64\end{array}$ & $\begin{array}{r}56 \\
10.2 \\
7.45\end{array}$ & 549 \\
\hline NE & $\begin{array}{l}n \\
\% \\
\text { S.I. }\end{array}$ & $\begin{array}{r}234 \\
76.2 \\
0.80\end{array}$ & $\begin{array}{r}14 \\
4.6 \\
23.00\end{array}$ & $\begin{array}{r}1 \\
0.3 \\
2.00\end{array}$ & $\begin{array}{r}0 \\
0 \\
0.00\end{array}$ & $\begin{array}{r}11 \\
3.6 \\
3.30\end{array}$ & $\begin{array}{r}0 \\
0 \\
0.00\end{array}$ & $\begin{array}{r}46 \\
15.0 \\
5.36\end{array}$ & $\begin{array}{r}1 \\
0.3 \\
1.20\end{array}$ & 307 \\
\hline $\mathrm{CW}$ & $\begin{array}{l}\text { n } \\
\% \\
\text { S.I. }\end{array}$ & $\begin{array}{r}265 \\
50.5 \\
0.72\end{array}$ & $\begin{array}{r}156 \\
29.7 \\
1.71\end{array}$ & $\begin{array}{r}23 \\
4.4 \\
2.17\end{array}$ & $\begin{array}{r}46 \\
8.8 \\
4.00\end{array}$ & $\begin{array}{r}21 \\
4.0 \\
1.54\end{array}$ & $\begin{array}{r}0 \\
0 \\
0.00\end{array}$ & $\begin{array}{r}9 \\
1.7 \\
1.71\end{array}$ & $\begin{array}{r}5 \\
1.0 \\
1.67\end{array}$ & 525 \\
\hline C & $\begin{array}{l}\text { n } \\
\% \\
\text { S.I. }\end{array}$ & $\begin{array}{r}281 \\
84.4 \\
1.11\end{array}$ & $\begin{array}{r}18 \\
5.4 \\
2.48\end{array}$ & $\begin{array}{r}2 \\
0.6 \\
0.52\end{array}$ & $\begin{array}{r}0 \\
0 \\
0.00\end{array}$ & $\begin{array}{r}13 \\
3.9 \\
0.26\end{array}$ & $\begin{array}{r}0 \\
0 \\
0.00\end{array}$ & $\begin{array}{r}18 \\
5.4 \\
1.07\end{array}$ & $\begin{array}{r}1 \\
0.3 \\
0.65\end{array}$ & 333 \\
\hline CE & $\begin{array}{l}\text { n } \\
\% \\
\text { S.I. }\end{array}$ & $\begin{array}{r}4 \\
5 \\
0.37\end{array}$ & $\begin{array}{r}0 \\
0 \\
0.00\end{array}$ & $\begin{array}{r}5 \\
6.3 \\
0.30\end{array}$ & $\begin{array}{r}1 \\
1.3 \\
3.82\end{array}$ & $\begin{array}{r}20 \\
25.0 \\
1.53\end{array}$ & $\begin{array}{r}1 \\
1.3 \\
3.82\end{array}$ & $\begin{array}{r}49 \\
61.3 \\
1.31\end{array}$ & $\begin{array}{r}0 \\
0 \\
0.00\end{array}$ & 80 \\
\hline $\mathbf{S}$ & $\begin{array}{l}n \\
\% \\
\text { S.I. }\end{array}$ & $\begin{array}{r}3 \\
6.8 \\
2.37\end{array}$ & $\begin{array}{r}0 \\
0 \\
0.00\end{array}$ & $\begin{array}{r}2 \\
4.5 \\
0.35\end{array}$ & $\begin{array}{r}0 \\
0 \\
0.00\end{array}$ & $\begin{array}{r}0 \\
0 \\
0.00\end{array}$ & $\begin{array}{r}0 \\
0 \\
0.00\end{array}$ & $\begin{array}{r}39 \\
88.6 \\
1.21\end{array}$ & $\begin{array}{r}0 \\
0 \\
0.00\end{array}$ & 44 \\
\hline
\end{tabular}

Table 4.6.23 Consumption of experimentally discarded common gadids (Haddock, Whiting, Cod, Saithe, Norway pout) in November (see table 4.6.20 for conventions).

\begin{tabular}{|c|c|c|c|c|c|c|c|c|c|c|c|c|}
\hline Area & Valu & le Ful & Gan & GBG & $\mathrm{HG}$ & Kit & CG & LBG & CG/HG & IG & GG & Total \\
\hline \multirow[t]{3}{*}{ NW } & $n$ & 70 & 60 & 69 & 314 & 579 & 1 & 1 & 2 & 2 & 4 & 1102 \\
\hline & $\%$ & 6.3 & 5.4 & 6.3 & 28.5 & 52.5 & 0.1 & 0.1 & .02 & 0.2 & 0.4 & \\
\hline & S.I. & 0.21 & 7.94 & 1.34 & 1.08 & 1.36 & 10.00 & 2.50 & - & - & . & \\
\hline \multirow[t]{3}{*}{ NE } & $n$ & 67 & 8 & 20 & 190 & 162 & 0 & 0 & 4 & 0 & 0 & 451 \\
\hline & $\%$ & 14.9 & 1.8 & 4.4 & 42.1 & 35.9 & 0.0 & 0.0 & 0.9 & 0.0 & 0.0 & \\
\hline & S.I. & 0.28 & 1.59 & 0.91 & 1.60 & 2.65 & & 0.00 & - & - & - & \\
\hline \multirow[t]{3}{*}{ CW } & $\mathrm{n}$ & 17 & 149 & 6 & 28 & 130 & 0 & 0 & 0 & 0 & 0 & 330 \\
\hline & $\%$ & 5.2 & 45.2 & 1.8 & 8.5 & 39.4 & 0.0 & 0.0 & 0.0 & 0.0 & 0.0 & \\
\hline & S.I. & 0.13 & 4.65 & 0.43 & 2.73 & 0.97 & 0.00 & 0.00 & - & - & - & \\
\hline \multirow[t]{3}{*}{ C } & $\mathrm{n}$ & 24 & 107 & 37 & 120 & 324 & 2 & 1 & 0 & 0 & 0 & 616 \\
\hline & $\%$ & 3.9 & 17.4 & 6.0 & 19.5 & 52.6 & $0 . \overline{3}$ & 0.2 & 0.0 & 0.0 & 0.0 & \\
\hline & S.I. & 0.14 & 3.45 & 1.57 & 1.73 & 1.05 & 0.58 & 0.29 & - & - & - & \\
\hline \multirow[t]{3}{*}{ CE } & $\mathrm{n}$ & 9 & 0 & 26 & 81 & 26 & 0 & 0 & 0 & 0 & 0 & 140 \\
\hline & $\%$ & 6.4 & 0.0 & 18.6 & 57.9 & 18.6 & 0.0 & 0.0 & 0.0 & 0.0 & 0.0 & \\
\hline & S.I. & 3.93 & 0.00 & 0.93 & 1.01 & 1.10 & 0.00 & 0.00 & & - & - & \\
\hline \multirow[t]{3}{*}{$s$} & $\mathrm{n}$ & 0 & 11 & - 2 & 0 & 0 & 0 & 5 & 0 & 0 & 0 & 18 \\
\hline & $\%$ & 0.0 & 61.1 & 11.1 & 0.0 & 0.0 & 0.0 & 25.8 & 0.0 & 0.0 & 0.0 & \\
\hline & S.I. & - & 4.81 & 0.86 & 0.00 & 0.00 & 0.00 & 1.91 & & - & - & \\
\hline \multirow[t]{3}{*}{ Sk } & $n$ & 0 & 0 & 10 & 47 & 40 & 1 & 0 & 0 & 0 & 0 & 98 \\
\hline & $\%$ & 0.0 & 0.0 & 10.2 & 48.0 & 40.8 & 1.0 & 0.0 & 0.0 & 0.0 & 0.0 & \\
\hline & S.I. & 0.00 & 0.00 & 1.00 & 0.96 & 2.12 & 0.27 & - & - & - & - & \\
\hline
\end{tabular}


Table 4.6.24 Observed and expected numbers of experimentally discarded gadids consumed by Fulmars and by other scavenging seabirds by areas of the North Sea during each of the surveys. Expected numbers calculated on the basis of the relative abundances of seabird species at the vessels during experimental discarding $\left(p>0.05=n . s, p<0.05={ }^{*}, p<\right.$ $0.01={ }^{*}, p<0.001^{* * *}$ ).

\begin{tabular}{|c|c|c|c|c|c|c|c|c|c|}
\hline Consumer & Category & Survey & NW & NE & $\mathrm{CW}$ & C & CE & $\mathbf{S}$ & Sk \\
\hline $\begin{array}{l}\text { Fulmar } \\
\text { Others } \\
x^{2} \\
\mathrm{p}<\end{array}$ & $\begin{array}{l}\text { Observed } \\
\text { Expected } \\
\text { Observed } \\
\text { Expected }\end{array}$ & February 1993 & $\begin{array}{r}18 \\
430.3 \\
978 \\
565.7 \\
695.6 \\
* * *\end{array}$ & $\begin{array}{r}11 \\
154.4 \\
277 \\
133.6 \\
287.1 \\
* * *\end{array}$ & $\begin{array}{r}7 \\
97.4 \\
422 \\
331.6 \\
108.5 \\
* * *\end{array}$ & $\begin{array}{r}13 \\
87.2 \\
441 \\
366.8 \\
78.1 \\
* * *\end{array}$ & $\begin{array}{r}0 \\
4.5 \\
40 \\
35.5 \\
5.1 \\
*\end{array}$ & $\begin{array}{r}3 \\
38.8 \\
125 \\
89.2 \\
47.3 \\
* * *\end{array}$ & \\
\hline $\begin{array}{l}\text { Fulmar } \\
\text { Others } \\
x^{2} \\
p<\end{array}$ & $\begin{array}{l}\text { Observed } \\
\text { Expected } \\
\text { Observed } \\
\text { Expected }\end{array}$ & May 1994 & $\begin{array}{r}375 \\
883.0 \\
660 \\
134.0 \\
2357.0 \\
* * *\end{array}$ & $\begin{array}{r}152 \\
232.6 \\
164 \\
83.4 \\
105.8 \\
* * *\end{array}$ & $\begin{array}{r}190 \\
60.1 \\
569 \\
698.9 \\
304.9 \\
* * *\end{array}$ & $\begin{array}{r}199 \\
300.7 \\
207 \\
105.3 \\
132.6 \\
* * *\end{array}$ & $\begin{array}{r}17 \\
65.9 \\
122 \\
73.1 \\
69.0 \\
* * *\end{array}$ & $\begin{array}{r}1 \\
0.4 \\
4 \\
4.6 \\
1.0 \\
\text { n.s. }\end{array}$ & $\begin{array}{r}0 \\
11.8 \\
51 \\
39.2 \\
15.4 \\
* * *\end{array}$ \\
\hline $\begin{array}{l}\text { Fulmar } \\
\text { Others } \\
x^{2} \\
\mathrm{p}<\end{array}$ & $\begin{array}{l}\text { Observed } \\
\text { Expected } \\
\text { Observed } \\
\text { Expected }\end{array}$ & August 1994 & $\begin{array}{r}363 \\
52.2 \\
186 \\
496.8 \\
1851.1 \\
* * *\end{array}$ & $\begin{array}{r}234 \\
292.9 \\
73 \\
14.1 \\
257.9 \\
* * *\end{array}$ & $\begin{array}{r}265 \\
370.6 \\
260 \\
154.4 \\
102.3 \\
* * *\end{array}$ & $\begin{array}{r}281 \\
252.7 \\
52 \\
80.3 \\
13.1 \\
* *\end{array}$ & $\begin{array}{r}4 \\
10.8 \\
76 \\
69.2 \\
4.9 \\
\text { n.s. }\end{array}$ & $\begin{array}{r}3 \\
1.3 \\
41 \\
42.7 \\
2.3 \\
\text { n.s. }\end{array}$ & \\
\hline $\begin{array}{l}\text { Fulmar } \\
\text { Others } \\
x^{2} \\
p<\end{array}$ & $\begin{array}{l}\text { Observed } \\
\text { Expected } \\
\text { Observed } \\
\text { Expected }\end{array}$ & November 1994 & $\begin{array}{r}70 \\
326.6 \\
1032 \\
775.4 \\
286.5 \\
* * *\end{array}$ & $\begin{array}{r}67 \\
242.7 \\
384 \\
208.3 \\
275.4 \\
* * *\end{array}$ & $\begin{array}{r}17 \\
133.2 \\
313 \\
196.8 \\
170.0 \\
* * *\end{array}$ & $\begin{array}{r}24 \\
175.0 \\
592 \\
441.0 \\
182.0 \\
* * *\end{array}$ & $\begin{array}{r}9 \\
2.3 \\
131 \\
137.7 \\
8.8 \\
*\end{array}$ & & $\begin{array}{r}0 \\
16.2 \\
98 \\
18.8 \\
349.9 \\
* * *\end{array}$ \\
\hline
\end{tabular}


Table 4.6.25 Observed and expected numbers of experimentally discarded gadids consumed by Gannets and by gulls by areas of the North Sea during each of the surveys. (see table 4.6.24 for conventions).

\begin{tabular}{|c|c|c|c|c|c|c|c|c|c|}
\hline Consumer & Category & Survey & NW & NE & CW & C & CE & $\mathbf{S}$ & Sk \\
\hline & & February 1993 & & & & & & & \\
\hline \multirow[t]{2}{*}{ Gannet } & Observed & & 358 & 34 & 61 & 51 & 0 & 8 & \\
\hline & Expected & & 182.9 & 10.5 & 29.5 & 11.5 & 0 & 1.8 & \\
\hline \multirow[t]{2}{*}{ Gulls } & Observed & & 620 & 243 & 361 & 390 & 40 & 117 & \\
\hline & Expected & & 795.1 & 266.5 & 392.5 & 429.5 & 40 & 123.2 & \\
\hline$x^{2}$ & & & 206.2 & 54.7 & 36.2 & 139.3 & - & 21.7 & \\
\hline \multirow[t]{2}{*}{$\hat{\mathrm{p}}$} & & & $* * *$ & $* * *$ & $* * *$ & $* * *$ & - & $* * *$ & \\
\hline & & May 1994 & & & & & & & \\
\hline \multirow[t]{2}{*}{ Gannet } & Observed & & 273 & 11 & 387 & 71 & 2 & & \\
\hline & Expected & & 217.3 & 1.9 & 254.2 & 15.5 & 1.0 & & \\
\hline \multirow[t]{2}{*}{ Gulls } & Observed & & 379 & 151 & 181 & 135 & 120 & & \\
\hline & Expected & & 434.7 & 160.1 & 313.8 & 190.5 & 121.0 & & \\
\hline$x^{2}$ & & & 21.4 & 44.1 & 125.6 & 214.9 & 1.0 & & \\
\hline \multirow[t]{2}{*}{$\mathrm{p}$} & & & $* * *$ & $* * *$ & $* * *$ & *** & n.s. & & \\
\hline & & August 1994 & & & & & & & \\
\hline \multirow[t]{2}{*}{ Gannet } & Observed & & 80 & 14 & 156 & 18 & 0 & 0 & \\
\hline & Expected & & 45.5 & 3.3 & 153.9 & 4.7 & 1.0 & 0.3 & \\
\hline \multirow[t]{2}{*}{ Gulls } & Observed & & 50 & 58 & 99 & 33 & 76 & 41 & \\
\hline & Expected & & 84.5 & 68.7 & 101.1 & 46.3 & 75.0 & 40.7 & \\
\hline$X^{2}$ & & & 40.2 & 36.4 & 0.1 & 41.5 & 1.0 & 0.3 & \\
\hline \multirow[t]{2}{*}{$\hat{p}$} & & & $* * *$ & $* * *$ & n.s. & $* * *$ & n.s. & n.s. & \\
\hline & & November 1994 & & & & & & & \\
\hline \multirow[t]{2}{*}{ Gannet } & Observed & & 60 & 8 & 149 & 107 & 0 & 11 & 0 \\
\hline & Expected & & 10.0 & 13.7 & 51.1 & 43.1 & 1.0 & 2.3 & 0.3 \\
\hline \multirow[t]{2}{*}{ Gulls } & Observed & & 972 & 376 & 164 & 485 & 131 & 7 & 98 \\
\hline & Expected & & 1022.0 & 470.3 & 261.9 & 548.9 & 130.0 & 15.7 & 97.7 \\
\hline$x^{2}$ & & & 252.4 & 21.3 & 224.2 & 102.2 & 1.0 & 11.1 & 0.3 \\
\hline$\hat{\mathrm{p}}$ & & & $* * *$ & $* * *$ & $* * *$ & $* * *$ & n.s. & $* * *$ & n.s. \\
\hline
\end{tabular}


Norway Pout, Grey Gurnard Eutrigla gurnardus, Mackerel and Scad in November (table 4.6.13). Most of the differences in size distributions of experimental discards among subregions were statistically significant when examined by Kruskal-Wallis 1-way nonparametric ANOVA. Nevertheless, differences in median sizes among subregions were generally small in relation to the range of sizes of all discards and are unlikely to contribute greatly to any differences in patterns in discard utilisation found between subregions.

\section{Fates of items experimentally discarded}

Since procedures for disposal of waste fish and benthos varied among research vessels it is important to establish whether scavenging seabird behaviour varied among vessels from which experimental discarding was performed, particularly since individual vessels tended to work predominantly in certain subregions and different vessels were used in different seasons, and numbers of items discarded varied considerably among vessels. 9657 items were discarded from RV Scotia, 6805 from RV Tridens/Pelagia, and smaller numbers from other vessels. In general, proportions of experimental discards that sank, were consumed, were pecked or were of unknown fate, tended to be fairly similar within seasons among vessels, and differences could possibly be attributed to differences in proportions of different types of discards. For example, lower rates of items sinking from experimental discards from RV Scotia (less than one fifth, in most other vessels between $25 \%$ and $35 \%$ ) can partly be attributed to the lower proportion of flatfish and benthos discarded from that vessel. However, looking only at fates of particular types of discards it seems that a lower proportion of roundfish experimental discards sank from the RV Scotia $110.6 \%$ February, $11.3 \%$ May, 20.8\% August) than from RV Tridens $(11.7 \%$ February, 33.3\% May, $39.1 \%$ August). The changes between seasons are the same for the two vessels. Both vessels found lovvest proportions sin- king in February and highest in August. This consistent pattern suggests that competition for discarded roundfish may have been higher in winter than in summer, a suggestion supported by stern count data showing much higher numbers of gulls at vessels in winter than in summer (tables 4.3.5-4.3.9). Differences in competition for discards may also explain the differences in proportions that sank between vessels, since RV Scotia worked mainly in further north and west than RV Tridens, and numbers of scavenging seabirds in stern counts were generally higher further north and west /tables 4.3.2-4.3.9). However, it is difficult to exclude the possibility that the fates of experimental discards varied among vessels in part according to characteristics of the vessels themselves.

Between the February survey and the others, a change in recording procedure was introduced, including 'pecked' as another category for the fate of discards. This acknowledged the fact that some discards were partly eaten by a few pecks being taken rather than the item being swallowed intact. However, proportions recorded as pecked were small $(<3.5 \%$ for any type of discard in any season; figures 4.6.5-6) and these were therefore excluded in calculations of consumption rates. Overall, for the seasons February, May, August, November respectively, consumption rates (excluding items only pecked on) were highest for offal, next highest for roundfish, lower for flatfish and very low for benthic animals:

$\begin{array}{lcccc} & 1993 & 1994 & 1994 & 1994 \\ \text { Offal } & \text { Febr } & \text { May } & \text { Aug } & \text { Nov } \\ & 100 & 94 & 94 & 97 \\ & (605) & (844) & (3282) & (1068) \\ \text { Roundfish } & 92 & 76 & 70 & 82 \\ & (4997) & (8357) & (4407) & (4500) \\ \text { Flatfish } & 35 & 22 & 10 & 20 \\ & (372) & (1059) & (613) & (363)\end{array}$

Benthic invertebrates $\begin{array}{lllll}17 & 8 & 3 & 3\end{array}$

(54) (441) (207) (237)


Table 4.6.10 Quartiles and medians of fish length $(\mathrm{cm})$ for the nine most abundant experimental discards, by areas of the North Sea during the February 1993 surveys. $n=$ sample size, $25 \%=1$ st quartile, $50 \%=$ median, $75 \%=3$ rd quartile. Differences between length distributions were tested by Kruskal-Wallis 1-way ANOVA $\left(p>0.05=\right.$ n.s, $p<0.05={ }^{*}$, $p<0.01=* *, p<0.001 * * *$ ).

\begin{tabular}{|c|c|c|c|c|c|c|c|c|c|c|}
\hline Fish Species & NW & NE & $\mathrm{CW}$ & C & CE & $\mathbf{S}$ & Sk & Total & ANOVA & $p<$ \\
\hline Herring $n$ & 65 & 165 & 119 & 958 & 319 & 94 & & 1720 & & \\
\hline $25 \%$ & 21 & 17 & 15 & 15 & 14 & 24 & & 15 & 432.8 & $* * *$ \\
\hline $50 \%$ & 26 & 18 & 15 & 16 & 15 & 25 & & 17 & & \\
\hline $75 \%$ & 29 & 20 & 17 & 19 & 18 & 27 & & 20 & & \\
\hline Sprat $n$ & 33 & 0 & 11 & 280 & 37 & 245 & & 606 & & \\
\hline $25 \%$ & 12 & - & 8 & 9 & 6 & 10 & & 9 & 94.5 & *** \\
\hline $50 \%$ & 13 & - & 9 & 10 & 10 & 11 & & 11 & & \\
\hline $75 \%$ & 13 & - & 13 & 11 & 11 & 13 & & 12 & & \\
\hline Cod n & 44 & 16 & 2 & 19 & 0 & 3 & & 84 & & \\
\hline $25 \%$ & 29 & 27 & - & 22 & - & - & & 28 & 19.7 & *** \\
\hline $50 \%$ & 31 & 30 & 26 & 27 & - & 36 & & 30 & & \\
\hline $75 \%$ & 35 & 31 & - & 31 & - & - & & 33 & & \\
\hline Haddock n & 455 & 205 & 110 & 180 & 0 & 0 & & 950 & & \\
\hline $25 \%$ & 19 & 16 & 18 & 20 & - & - & & 18 & 176.0 & $* * *$ \\
\hline $50 \%$ & 26 & 18 & 19 & 26 & - & - & & 21 & & \\
\hline $75 \%$ & 29 & 20 & 20 & 30 & - & - & & 28 & & \\
\hline Whiting $\mathrm{n}$ & 404 & 70 & 242 & 361 & 51 & 140 & & 1268 & & \\
\hline $25 \%$ & 23 & 24 & 17 & 15 & 19 & 17 & & 17 & 269.1 & *** \\
\hline $50 \%$ & 26 & 28 & 21 & 18 & 21 & 24 & & 23 & & \\
\hline $75 \%$ & 29 & 29 & 24 & 23 & 26 & 28 & & 27 & & \\
\hline N. pout $n$ & 221 & 35 & 111 & 24 & 0 & 0 & & 391 & & \\
\hline $25 \%$ & 16 & 16 & 15 & 12 & - & - & & 15 & 10.6 & * \\
\hline $50 \%$ & 17 & 17 & 17 & 16 & - & - & & 17 & & \\
\hline $75 \%$ & 17 & 18 & 17 & 17 & - & - & & 17 & & \\
\hline gurnards $\mathrm{n}$ & 45 & 3 & 14 & 65 & 2 & 1 & & 130 & & \\
\hline $25 \%$ & 20 & - & 19 & 17 & - & - & & 18 & 11.8 & * \\
\hline $50 \%$ & 23 & 20 & 24 & 20 & 28 & - & & 21 & & \\
\hline $75 \%$ & 26 & - & 30 & 24 & - & - & & 25 & & \\
\hline Dab $\quad \mathbf{n}$ & 20 & 2 & 32 & 201 & 28 & 21 & & 304 & & \\
\hline $25 \%$ & 20 & - & 18 & 16 & 11 & 18 & & 16 & 63.2 & *** \\
\hline $50 \%$ & 22 & 22 & 19 & 17 & 13 & 19 & & 18 & & \\
\hline $75 \%$ & 27 & - & 21 & 20 & 18 & 22 & & 21 & & \\
\hline L.R. Dab n & 42 & 26 & 4 & 5 & 1 & 0 & & 78 & & \\
\hline $25 \%$ & 18 & 17 & - & - & - & - & & 17 & 4.7 & n.s. \\
\hline $50 \%$ & 19 & 22 & 18 & 17 & - & - & & 19 & & \\
\hline $75 \%$ & 24 & 25 & - & - & - & - & & 24 & & \\
\hline
\end{tabular}


When cephalopods were included in calculations for benthic invertebrates, the consumption rates for benthos were estimated at $17 \%, 13 \%, 4 \%$ and $9 \%$ respectively. Clearly, for all types of discard, consumption rates were higher in the winter than in the summer, tending to reach lowest levels in the August sample and highest in February. Ranges of consumption rates were least in the most preferred and most disliked groups loffal $94-100 \%$, range $6 \%$; benthic animals/cephalopods $3-17 \%$, range $14 \%$ ), and varied more in the intermediate groups (roundfish 70-92\%, range 22\%; flatfish $10-35 \%$, range $25 \%$ ). This is exactly the pattern that would be expected if birds were to vary in selectivity according to the relative amount of competition for food in different seasons; preferred food should always be fully exploited. Poor quality foods should always be avoided where better is available, but the use of marginal foods should change in relation to the level of demand. From these experiments, overall, consumption rates can be estimated at $95 \%$ for offal $(n=$ $5799)$, $80 \%$ for roundfish ( $n=22,261)$, $20 \%$ for flatfish $(n=2407)$, and $6 \%$ for benthic invertebrates $(n=939)$.

\section{Consumption of experimental discards by} seabirds in different subregions

Proportions of experimental discards consumed, pecked or sunk varied slightly among subregions within seasons. In general, the proportion consumed tended to be higher further north (tables 4.6.14, figures 4.6.710). Results were also more consistent between seasons further north. Though this may be in part a reflection of the larger sample sizes in the northern areas, it is also consistent with the view that competition for discards is higher in the north so that consumption rates are both constant and high. Consumption was slightly less for larger discarded roundfish (figures 4.6.11-14).

Counts of numbers of scavenging seabirds associating with the research vessels during net hauls show differences in species composition in different subregions of the North
Sea as well as between seasons. In February, Gannets became less numerous from northwest to southeast, whereas Common Gulls became more numerous from northwest to southeast, and the mean number of birds at research vessels during discarding was highest in the two northern subregions. In May and in August, Gannets were predominantly present in the western subregions, almost all the birds in Sk were Herring Gulls or Lesser Black-backed Gulls, Fulmars formed a higher proportion of the total further north and west, while Kittiwakes formed an increasing proportion of the total further south. In November most species were more widely distributed, and while total numbers at research vessels decreased from northwest to southeast, species composition changed rather little (see chapter 4.3 for further details on seabirds associated with fishing research vessels). Numbers of experimentally discarded items consumed by, or pecked by, scavenging seabirds varied greatly among species of seabird and among subregions (tables 4.6.15-18). In February the main consumer was the Kittiwake, taking 2912 (54\%) of 5363 items consumed, while in May Fulmars took 3140 (43\%) of 7325 items consumed, and in August Fulmars took $4705(75 \%)$ of 6267 items consumed. In November, Kittiwakes returned to the top consumer position, taking 2827 (50\%) of 5649 items consumed. Thus Kittiwakes predominated in winter and Fulmars in summer. Geographically, major consumers in subregion NW in each of the surveys were:

$\begin{array}{ll}\text { Feb } & \text { Kitt, Gan, Ful } \\ \text { May } & \text { Ful, Gan, Kit } \\ \text { Aug } & \text { Ful, Gan, GSk } \\ \text { Nov } & \text { Kit, HG, Ful }\end{array}$

In contrast, for subregion CE the equivalent major consumers were:

$\begin{array}{ll}\text { Feb } & \text { Kit, HG, GBG } \\ \text { May } & \text { Ful, LBG, Kit } \\ \text { Aug } & \text { LBG, Kit, Ful } \\ \text { Nov } & \text { HG, Kit, GBG }\end{array}$


Table 4.6.11 Quartiles and medians of fish length $(\mathrm{cm})$ for the ten most abundant experimental discards, by areas of the North Sea during the April-May 1994 surveys. $n=$ sample size, $25 \%=1$ st quartile, $50 \%=$ median, $75 \%=3$ rd quartile. Differences between length distributions were tested by Kruskal-Wallis 1-way ANOVA $(p>0.05=n . s, p<0.05=$ *, $\left.p<0.01={ }^{* *}, p<0.001^{* * *}\right)$.

\begin{tabular}{|c|c|c|c|c|c|c|c|c|c|c|c|}
\hline \multicolumn{2}{|c|}{ Fish Species } & \multirow{2}{*}{$\begin{array}{l}\text { NW } \\
517\end{array}$} & \multirow{2}{*}{$\begin{array}{l}\text { NE } \\
69\end{array}$} & \multirow{2}{*}{$\frac{C W}{388}$} & \multirow{2}{*}{$\begin{array}{r}\text { C } \\
532\end{array}$} & \multirow{2}{*}{$\begin{array}{r}\text { CE } \\
778\end{array}$} & \multirow[t]{2}{*}{$\mathrm{s}$} & \multirow{2}{*}{$\frac{\text { Sk }}{72}$} & \multirow{2}{*}{$\begin{array}{c}\text { Total } \\
2356\end{array}$} & \multirow[t]{2}{*}{ ANOVA } & \multirow[t]{2}{*}{$p<$} \\
\hline Herring & $n$ & & & & & & & & & & \\
\hline & $25 \%$ & 22 & 18 & 21 & 15 & 13 & & 15 & 15 & 1553.5 & $* * *$ \\
\hline & $50 \%$ & 28 & 28 & 28 & 17 & 20 & & 18 & 22 & & \\
\hline & $75 \%$ & 30 & 41 & 35 & 24 & 23 & & 21 & 28 & & \\
\hline \multirow[t]{4}{*}{ Sprat } & $n$ & 22 & & 304 & 202 & 221 & 34 & 50 & 833 & & \\
\hline & $25 \%$ & 12 & & 11 & 11 & 6 & 8 & 9 & 8 & 386.4 & $* * *$ \\
\hline & $50 \%$ & 13 & & 12 & 12 & 7 & 10 & 10 & 11 & & \\
\hline & $75 \%$ & 13 & & 13 & 12 & 7 & 14 & 11 & 12 & & \\
\hline \multirow{4}{*}{ Haddock } & $n$ & 583 & 112 & 213 & 201 & 5 & & 10 & 1124 & & \\
\hline & $25 \%$ & 17 & 20 & 21 & 19 & 20 & & 18 & 18 & 129.6 & $* * *$ \\
\hline & $50 \%$ & 20 & 23 & 24 & 23 & 21 & & 20 & 22 & & \\
\hline & $75 \%$ & 24 & 25 & 28 & 27 & 25 & & 22 & 25 & & \\
\hline \multirow{4}{*}{ Whiting } & $n$ & 433 & 73 & 591 & 279 & 182 & 23 & 40 & 1621 & & \\
\hline & $25 \%$ & 20 & 24 & 18 & 15 & 16 & 18 & 18 & 18 & 211.7 & $* * *$ \\
\hline & $50 \%$ & 23 & 27 & 21 & 18 & 18 & 21 & 21 & 21 & & \\
\hline & $75 \%$ & 26 & 30 & 24 & 23 & 23 & 23 & 23 & 25 & & \\
\hline \multirow{4}{*}{ N. pout } & $n$ & 364 & 204 & 62 & 153 & & & & 783 & & \\
\hline & $25 \%$ & 13 & 13 & 13 & 13 & & & & 13 & 25.7 & $* * *$ \\
\hline & $50 \%$ & 14 & 14 & 14 & 16 & 14 & & & 14 & & \\
\hline & $75 \%$ & 16 & 16 & 17 & 15 & & & & 15 & & \\
\hline \multirow{4}{*}{ G. gurnaro } & rd $\mathrm{n}$ & 119 & 8 & 69 & 114 & 87 & 3 & & 400 & & \\
\hline & $25 \%$ & 19 & 19 & 20 & 21 & 19 & 22 & & 20 & 28.3 & $* * *$ \\
\hline & $50 \%$ & 21 & 22 & 21 & 23 & 21 & 23 & & 22 & & \\
\hline & $75 \%$ & 24 & 24 & 24 & 26 & 23 & - & & 24 & & \\
\hline \multirow[t]{4}{*}{ Dab } & $\mathrm{n}$ & 101 & 27 & 72 & 235 & 223 & 1 & 11 & 670 & & \\
\hline & $25 \%$ & 16 & 16 & 17 & 17 & 15 & - & 14 & 17 & 47.6 & $* * *$ \\
\hline & $50 \%$ & 18 & 17 & 18 & 19 & 18 & - & 20 & 18 & & \\
\hline & $75 \%$ & 19 & 18 & 20 & 21 & 19 & - & 22 & 20 & & \\
\hline \multirow{4}{*}{ L.R. Dab } & $n$ & 132 & 7 & 19 & 84 & 12 & & 42 & 296 & & \\
\hline & $25 \%$ & 13 & 13 & 16 & 17 & 14 & & 13 & 14 & 75.5 & $* * *$ \\
\hline & $50 \%$ & 15 & 13 & 17 & 18 & 16 & & 14 & 16 & & \\
\hline & $75 \%$ & 17 & 14 & 22 & 19 & 20 & & 17 & 18 & & \\
\hline \multirow{4}{*}{ Sandeel } & $\mathrm{n}$ & 103 & 10 & 69 & 261 & 628 & & & 1071 & & \\
\hline & $25 \%$ & 16 & 15 & 16 & 12 & 12 & & & 12 & 268.2 & $* * *$ \\
\hline & $50 \%$ & 17 & 18 & 18 & 15 & 12 & & & 13 & & \\
\hline & $75 \%$ & 18 & 19 & 19 & 20 & 13 & & & 17 & & \\
\hline \multicolumn{2}{|c|}{ G. Sandeel $n$} & & & 18 & 57 & 32 & 6 & & 113 & & \\
\hline & $25 \%$ & & & 16 & 21 & 17 & 22 & & 17 & 35.3 & *** \\
\hline & $50 \%$ & & & 16 & 22 & 18 & 24 & & 21 & & \\
\hline & $75 \%$ & & & 18 & 23 & 21 & 30 & & 22 & & \\
\hline
\end{tabular}


Thus scavenging seabird predominance varies considerably, between parts of the North Sea and seasonally. In all seasons and subregions, Fulmars accounted for $96.7 \%$ of the 1216 discards recorded as 'pecked'. This reflects the difficulty that Fulmars have in swallowing large items and their tendency to tear these up to ingest smaller fragments.

Success rates achieved by species of scavenging seabirds

Although certain species of seabirds consumed many more discards than others, for individual birds the important question is how successful they are in relation to competitors. Hudson \& Furness (1988) demonstrated very large differences in the success rates of different scavenging seabird species and showed that these were related to the size, and hence handling time, of discards. Success rates can be crudely defined as the proportion of discarded items of a particular type that are consumed by species $A$, divided by the proportion of all the scavenging seabirds at the vessel that are of species $A$ ('success index', S.I.). Thus if all seabirds are equally successful in obtaining discards the success index will be 1.0 for each species. A success index greater than 1.0 indicates that the species in question obtained a greater proportion of the discards than would have been expected from the numbers present. It is possible to test statistically for the significance of differences in success rates by comparing observed and expected numbers of discards obtained by particular species against the null hypothesis that numbers would be distributed in proportion to the relative numerical abundances of the seabird species. Note that these success indices do not account for differences in the energy values of items (such as result from differences in size) or for differences in the energy needs of seabirds of different body sizes. In practice, a Kittiwake and a Gannet with the same success index obtaining equal sized items could result in a fat Kittiwake and a hungry Gannet because the latter has a much greater energy requirement for main- tenance. The success index shows the relative competitive abilities of different seabirds but does not account for the differences in their needs or food size selectivity.

Considering each subregion and each season separately, numbers of items of offal consumed by different seabird species showed a tendency for Fulmars to take more than their numerical abundance predicted, while Kittiwakes also obtained more than predicted the majority of cases (tables 4.6.19). Most other species were markedly unsuccessful in getting offal. Given the tendency for Fulmars to form a higher proportion of the scavenging seabirds at research vessels in summer, it is not surprising that Fulmars took most of the experimentally discarded offal during the summer surveys (485 from 775 items consumed, or $63 \%$ in May and 2973 from 3100 items consumed, or $96 \%$ in August), to 164 taken by Kittiwakes in May $(21 \%)$ and 57 taken by Kittiwakes in August (2\%). In winter, when Kittiwake numbers at vessels are much higher, Fulmars took $57 \%$ in February and $20 \%$ in November to the Kittiwakes' $35 \%$ in February and $61 \%$ in November. Only when Fulmars and Kittiwakes were not present in large numbers did other species obtain more than trivial amounts of offal, as in Sk in May when Lesser Black-backed Gulls took 33 of 42 items swallowed. Particularly in winter, Fulmars took relatively less of the offal consumed further south in the North Sea. For experimentally discarded common gadids (Haddock, Whiting, Cod, Saithe Pollachius virens, Norway Pout) almost all measurements of success index of Fulmars gave values of considerably less than 1.0 regardless of subregion or season (tables 4.6.20-23). Conversely, the success index of Gannets was almost always considerably more than 1.0. Considering the numbers of gadid discards consumed the rank order of importance of consumers was for different subregions and seasons: 
Table 4.6.12 Quartiles and medians of fish length $(\mathrm{cm})$ for the ten most abundant experimental discards, by areas of the North Sea during the August 1994 surveys. $n=$ sample size, $25 \%=1$ st quartile, $50 \%=$ median, $75 \%=3$ rd quartile. Differences between length distributions were tested by Kruskal-Wallis 1-way ANOVA $(p>0.05=n . s, p<0.05=*$, $p<0.01=* *, p<0.001 * * *$ ).

\begin{tabular}{|c|c|c|c|c|c|c|c|c|c|c|c|}
\hline \multicolumn{2}{|c|}{ Fish Species } & \multirow{2}{*}{$\begin{array}{l}\text { NW } \\
226\end{array}$} & \multirow{2}{*}{$\begin{array}{l}\text { NE } \\
40\end{array}$} & \multirow{2}{*}{$\frac{\text { CW }}{164}$} & \multirow{2}{*}{$\begin{array}{r}C \\
215\end{array}$} & \multirow{2}{*}{$\begin{array}{l}\text { CE } \\
11\end{array}$} & \multirow{2}{*}{$\begin{array}{r}S \\
29\end{array}$} & \multirow[t]{2}{*}{ Sk } & \multirow{2}{*}{$\begin{array}{r}\text { Total } \\
685\end{array}$} & \multirow[t]{2}{*}{ ANOVA } & \multirow[t]{2}{*}{$\mathrm{p}<$} \\
\hline Herring & $\mathrm{n}$ & & & & & & & & & & \\
\hline & $25 \%$ & 24 & 25 & 22 & 16 & 16 & 17 & & 18 & 347.1 & $* * *$ \\
\hline & $50 \%$ & 26 & 27 & 25 & 17 & 18 & 18 & & 24 & & \\
\hline & $75 \%$ & 28 & 29 & 27 & 19 & 20 & 22 & & 26 & & \\
\hline \multirow[t]{4}{*}{ Sprat } & $n$ & 12 & 7 & 185 & 114 & 60 & 3 & & 381 & & \\
\hline & $25 \%$ & 10 & 10 & 12 & 10 & 9 & 10 & & 10 & 132.8 & $* * *$ \\
\hline & $50 \%$ & 11 & 11 & 13 & 12 & 10 & 11 & & 12 & & \\
\hline & $75 \%$ & 11 & 11 & 14 & 13 & 10 & & & 13 & & \\
\hline \multirow[t]{4}{*}{ Cod } & $n$ & 27 & 115 & 27 & 209 & 16 & 1 & & 395 & & \\
\hline & $25 \%$ & 21 & 21 & 23 & 21 & 22 & & & 21 & 11.9 & $*$ \\
\hline & $50 \%$ & 27 & 23 & 25 & 24 & 24 & & & 24 & & \\
\hline & $75 \%$ & 34 & 25 & 30 & 27 & 26 & & & 27 & & \\
\hline \multirow{4}{*}{ Haddock } & & 281 & 200 & 192 & 179 & & & & 852 & & \\
\hline & $25 \%$ & 20 & 21 & 13 & 21 & & & & 20 & 31.0 & $* * *$ \\
\hline & $50 \%$ & 24 & 23 & 22 & 24 & & & & 24 & & \\
\hline & $75 \%$ & 28 & 27 & 26 & 28 & & & & 28 & & \\
\hline \multirow[t]{4}{*}{ Whiting } & $\mathrm{n}$ & 242 & 112 & 339 & 449 & 80 & 87 & & 1319 & & \\
\hline & $25 \%$ & 21 & 15 & 19 & 17 & 13 & 22 & & 18 & 177.7 & $* * *$ \\
\hline & $50 \%$ & 25 & 25 & 23 & 20 & 16 & 24 & & 22 & & \\
\hline & $75 \%$ & 28 & 28 & 25 & 23 & 22 & 25 & & 25 & & \\
\hline \multirow[t]{4}{*}{ N. pout } & $\mathrm{n}$ & 208 & 114 & 204 & & & 13 & & 539 & & \\
\hline & $25 \%$ & 15 & 14 & 9 & & & 9 & & 10 & 152.8 & $* * *$ \\
\hline & $50 \%$ & 16 & 16 & 10 & & & 9 & & 15 & & \\
\hline & $75 \%$ & 17 & 17 & 15 & & & 10 & & 17 & & \\
\hline \multirow{4}{*}{$\begin{array}{r}\text { G.gurnard } \\
2 \\
5 \\
7\end{array}$} & $n$ & 74 & 12 & 89 & 112 & 1 & & & 288 & & \\
\hline & $25 \%$ & 19 & 20 & 20 & 21 & & & & 20 & 19.5 & $* * *$ \\
\hline & $50 \%$ & 21 & 21 & 22 & 24 & & & & 22 & & \\
\hline & $75 \%$ & 25 & 25 & 25 & 28 & & & & 26 & & \\
\hline \multirow[t]{4}{*}{ Dab } & $n$ & 34 & 29 & 62 & 202 & 39 & 14 & & 380 & & \\
\hline & $25 \%$ & 17 & 16 & 17 & 16 & 16 & 15 & & 16 & 28.9 & $* * *$ \\
\hline & $50 \%$ & 19 & 16 & 19 & 18 & 18 & 17 & & 18 & & \\
\hline & $75 \%$ & 22 & 18 & 20 & 19 & 20 & 20 & & 19 & & \\
\hline \multirow{4}{*}{ Mackerel } & $n$ & 79 & 60 & 26 & 47 & 3 & 49 & & 264 & & \\
\hline & $25 \%$ & 29 & 27 & 30 & 25 & 24 & 24 & & 27 & 43.4 & $* * *$ \\
\hline & $50 \%$ & 31 & 30 & 31 & 28 & 26 & 26 & & 30 & & \\
\hline & $75 \%$ & 34 & 32 & 33 & 31 & & 31 & & 32 & & \\
\hline \multirow[t]{4}{*}{ Scad } & & 59 & 1 & 1 & 79 & 19 & 34 & & 193 & & \\
\hline & $25 \%$ & 20 & & & 26 & 23 & 21 & & 23 & 35.2 & $* * *$ \\
\hline & $50 \%$ & 30 & & & 28 & 26 & 23 & & 27 & & \\
\hline & $75 \%$ & 32 & & & 31 & 27 & 25 & & 31 & & \\
\hline
\end{tabular}




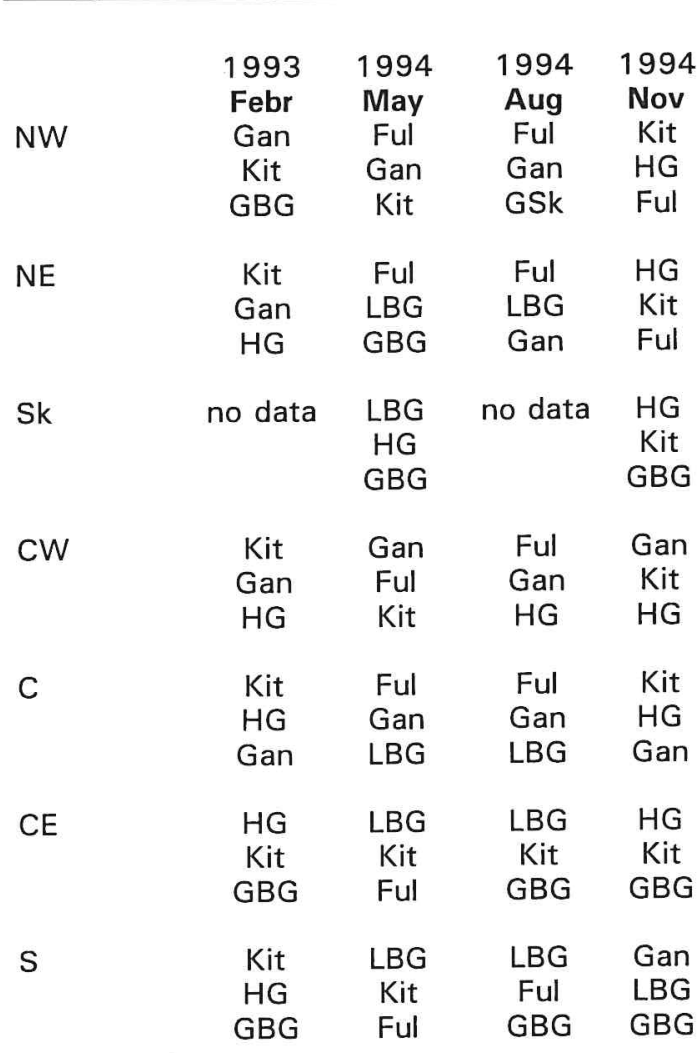

Thus even though the success index of Fulmars was very low, their numerical abundance resulted in their being major consumers of gadid discards in the two summer surveys in almost all subregions, and the single most important consumer in northern subregions. In the winter surveys, Fulmars were relatively less important consumers of gadids, with Kittiwakes and Herring Gulls achieving higher status than in summer. Further south, gulls tended to rank higher than in the northern regions, with Gannets and Fulmars more dominant further north. Even in the southern subregions where Common Gulls were more abundant, this species achieved only very low success in obtaining gadid discards. In the February survey, Fulmars obtained significantly less discarded gadids than their numbers predicted, in every subregion surveyed (table 4.6.24). This was also true in May in all subregions where Fulmars were present in reasonable numbers and good numbers of gadids were discarded (i.e. excluding $\mathrm{S}$ and $\mathrm{Sk}$ ). In August and Novem-

ber, Fulmars obtained less gadids than numbers predicted, differences being statistically significant in most subregions. Clearly Fulmars are less able to handle and swallow the gadids discarded than are other scavenging seabirds. Among the other species, Gannets stand out as having consistently higher success rates. In February, Gannets obtained significantly more gadid discards relative to their numbers present, than did gulls in all 5 subregions for which comparisons could be made (table 4.6.25). In May, the same as true in all 4 subregions for which there were adequate data. In August, Gannets did better than gulls in all 4 subregions for which there were adequate data, and the differences were statistically significant in three. In November, Gannets did significantly better than expected compared with gulls in 4 subregions. Considering only the various gull species, Common Gulls and Kittiwakes generally obtained less gadids than expected based on their numbers relative to other gulls, while the large Larus gulls fared slightly better, but the data were inadequate to determine relative success among Great Black-backed, Lesser Blackbacked and Herring Gulls (tables 4.6.26-29). Major consumers of experimentally discarded clupeids (tables 4.6.30-33) were:

\begin{tabular}{|c|c|c|c|c|}
\hline & 1993 & 1994 & 1994 & 1994 \\
\hline & Febr & May & Aug & Nov \\
\hline NW & Gan & Ful & Ful & Kit \\
\hline & Kit & Gan & GSk & $\mathrm{HG}$ \\
\hline & HG & GBG & Gan & Gan \\
\hline NE & Kit & LBG & Ful & $\mathrm{HG}$ \\
\hline & $\mathrm{HG}$ & GBG & Gan & GBG \\
\hline & Gan & Ful & GSk & Gan \\
\hline Sk & no data & LBG & no data & $\mathrm{HG}$ \\
\hline & & $\mathrm{HG}$ & & Kit \\
\hline & & & & \\
\hline $\mathrm{CW}$ & Kit & Gan & Gan & Kit \\
\hline & HG & Ful & Ful & GBG \\
\hline & Gan & Kit & Kit & Gan \\
\hline C & Kit & Ful & Ful & Kit \\
\hline & $\mathrm{HG}$ & Kit & Kit & Gan \\
\hline & GBG & LBG & LBG & $\mathrm{HG}$ \\
\hline
\end{tabular}


Table 4.6.13 Quartiles and medians of fish length $(\mathrm{cm})$ for the ten most abundant experimental discards, by areas of the North Sea during the November 1994 surveys. $n=$ sample size, $25 \%=1$ st quartile, $50 \%=$ median, $75 \%=3 r d$ quartile. Differences between length distributions were tested by Kruskal-Wallis 1-way ANOVA $(p>0.05=$ n.s, $p<0.05=$ *, $p<0.01=* *, p<0.001^{* * *}$ ).

\begin{tabular}{|c|c|c|c|c|c|c|c|c|c|c|c|}
\hline \multicolumn{2}{|c|}{ Fish Species } & \multirow[t]{2}{*}{ NW } & \multirow{2}{*}{$\begin{array}{c}\text { NE } \\
45\end{array}$} & \multirow{2}{*}{$\begin{array}{r}\text { CW } \\
79\end{array}$} & \multirow{2}{*}{$\begin{array}{r}\text { C } \\
532\end{array}$} & \multirow{2}{*}{$\begin{array}{l}\text { CE } \\
68\end{array}$} & \multirow{2}{*}{$\begin{array}{r}\mathbf{S} \\
10\end{array}$} & \multirow{2}{*}{$\begin{array}{l}\text { Sk } \\
40\end{array}$} & \multirow{2}{*}{$\begin{array}{r}\text { Total } \\
867\end{array}$} & \multirow[t]{2}{*}{ ANOVA } & \multirow[t]{2}{*}{$\mathrm{p}<$} \\
\hline Herring & $\mathrm{n}$ & & & & & & & & & & \\
\hline & $25 \%$ & & 21.5 & 21 & 11 & 12 & 15 & 15 & 12 & 300.5 & $* * *$ \\
\hline & $50 \%$ & & 24 & 22 & 14 & 16 & 21 & 18 & 16 & & \\
\hline & $75 \%$ & & 27 & 23 & 17 & 17 & 22 & 25 & 22 & & \\
\hline \multirow[t]{4}{*}{ Sprat } & $n$ & 120 & & 112 & 452 & 76 & 1 & 18 & 779 & & \\
\hline & $25 \%$ & 10 & & 13 & 12 & 11 & & 12 & 12 & 128.7 & $* * *$ \\
\hline & $50 \%$ & 12 & & 14 & 12 & 12 & & 14 & 12 & & \\
\hline & $75 \%$ & 12 & & 15 & 14 & 13 & & 15 & 14 & & \\
\hline \multirow{4}{*}{ Haddock } & $n$ & 349 & 164 & 199 & 149 & 10 & & 16 & 887 & & \\
\hline & $25 \%$ & 14 & 14 & 15 & 14 & 13 & & 16 & 14 & 8.2 & n.s. \\
\hline & $50 \%$ & 16 & 17 & 17 & 16 & 17 & & 18 & 16 & & \\
\hline & $75 \%$ & 24 & 25 & 27 & 26 & 21 & & 29 & 26 & & \\
\hline \multirow[t]{4}{*}{ Whiting } & $n$ & 408 & 130 & 247 & 527 & 153 & 35 & 81 & 1585 & & \\
\hline & $25 \%$ & 17 & 15 & 21 & 17 & 15 & 25 & 15 & 16 & 263.5 & $* * *$ \\
\hline & $50 \%$ & 23 & 18 & 23 & 19 & 17 & 27 & 18 & 20 & & \\
\hline & $75 \%$ & 26 & 22 & 26 & 23 & 18 & 29 & 21 & 25 & & \\
\hline \multirow[t]{4}{*}{ N. pout } & $n$ & 579 & 208 & 63 & 152 & 27 & & 13 & 1042 & & \\
\hline & $25 \%$ & 10 & 9 & 10 & 10 & 9 & & 15 & 10 & 141.3 & $* * *$ \\
\hline & $50 \%$ & 14 & 11 & 10 & 10 & 9 & & 15 & 11 & & \\
\hline & $75 \%$ & 16 & 14 & 11 & 12 & 9 & & 17 & 16 & & \\
\hline \multirow{4}{*}{$\begin{array}{r}\text { G. gurnard } \\
2 \\
5 \\
7\end{array}$} & d $n$ & 20 & 15 & 59 & 118 & 6 & 8 & & 226 & & \\
\hline & $25 \%$ & 21 & 22 & 20 & 19 & 17 & 15 & & 19 & 21.4 & $* * *$ \\
\hline & $50 \%$ & 24 & 25 & 23 & 22 & 19 & 19 & & 23 & & \\
\hline & $75 \%$ & 29 & 28 & 25 & 27 & 21 & 21 & & 26 & & \\
\hline \multirow[t]{4}{*}{ Dab } & $n$ & 16 & 11 & 27 & 99 & 21 & 5 & 11 & 190 & & \\
\hline & $25 \%$ & 13 & 13 & 16 & 16 & 17 & 15 & 18 & 16 & 21.3 & $* *$ \\
\hline & $50 \%$ & 16 & 14 & 18 & 18 & 18 & 21 & 19 & 18 & & \\
\hline & $75 \%$ & 17 & 17 & 20 & 20 & 19 & 24 & 23 & 20 & & \\
\hline \multirow{4}{*}{ L.R. Dab } & $\mathrm{n}$ & 78 & 66 & 19 & 57 & 6 & 1 & 2 & 229 & & \\
\hline & $25 \%$ & 13 & 14 & 13 & 13 & 15 & & & 14 & 8.6 & n.s. \\
\hline & $50 \%$ & 14 & 15 & 17 & 15 & 17 & & 19 & 15 & & \\
\hline & $75 \%$ & 18 & 18 & 19 & 18 & 20 & & & 18 & & \\
\hline \multirow{4}{*}{ Mackerel } & $n$ & 32 & 10 & 21 & 58 & 7 & 59 & & 187 & & \\
\hline & $25 \%$ & 28 & 31 & 27 & 26 & 27 & 24 & & 25 & 44.0 & $* * *$ \\
\hline & $50 \%$ & 33 & 32 & 27 & 27 & 28 & 25 & & 27 & & \\
\hline & $75 \%$ & 36 & 35 & 29 & 29 & 28 & 25 & & 30 & & \\
\hline \multirow[t]{4}{*}{ Scad } & $n$ & 6 & 4 & 3 & 36 & 3 & 127 & & 179 & & \\
\hline & $25 \%$ & 32 & 20 & 27 & 9 & 7 & 10 & & 10 & 47.5 & $* * *$ \\
\hline & $50 \%$ & 34 & 20 & 32 & 10 & 17 & 24 & & 23 & & \\
\hline & $75 \%$ & 35 & 24 & & 12 & & 28 & & 28 & & \\
\hline
\end{tabular}


Table 4.6.26 Observed and expected numbers of experimentally discarded gadids consumed by Great Black-backed gulls, Herring Gulls, Kittiwakes Lesser Black-backed Gulls and (where appropriate) Common Gulls by areas of the North Sea in February 1993 (see table 4.6.24 for conventions).

\begin{tabular}{|c|c|c|c|c|c|c|c|c|c|}
\hline Consumer & Category & Area & NW & NE & $\mathrm{CW}$ & C & CE & $\mathbf{S}$ & Sk \\
\hline \multirow[t]{2}{*}{ Great Bb Gull } & Observed & & 180 & 31 & 23 & 42 & 9 & 31 & \\
\hline & Expected & & 124.4 & 27.7 & 16.6 & 44.8 & 4.8 & 21.9 & \\
\hline \multirow[t]{2}{*}{ Herring Gull } & Observed & & 125 & 34 & 49 & 126 & 19 & 36 & \\
\hline & Expected & & 160.9 & 32.1 & 54.2 & 85.4 & 13.6 & 27.5 & \\
\hline \multirow[t]{2}{*}{ Kittiwake } & Observed & & 314 & 178 & 289 & 222 & 11 & 47 & \\
\hline & Expected & & 334.3 & 183.2 & 290.6 & 253.1 & 11.4 & 64.6 & \\
\hline \multirow[t]{2}{*}{ Common Gull } & Observed & & - & - & - & 0 & 1 & - & \\
\hline & Expected & & - & - & - & 6.1 & 10.0 & - & \\
\hline$x^{2}$ & & & & 34.1 & 0.6 & 3.0 & 29.3 & 13.9 & 11.2 \\
\hline$\hat{\mathrm{p}}$ & & & & $* * *$ & n.s. & n.s. & $* * *$ & * * & * * \\
\hline
\end{tabular}

Table 4.6.27 Observed and expected numbers of experimentally discarded gadids consumed by gulls by areas of the North Sea in May 1994 (see tables 4.6.24-27 for conventions).

\begin{tabular}{|c|c|c|c|c|c|c|c|c|c|}
\hline Consumer & Category & Area & NW & NE & $\mathrm{CW}$ & C & CE & $\mathbf{S}$ & Sk \\
\hline \multirow[t]{2}{*}{ Great Bb Gull } & Observed & & 101 & 68 & 4 & 30 & 1 & 0 & 2 \\
\hline & Expected & & 113.7 & 45.4 & 16.4 & 13.6 & 4.1 & 0.0 & 2.4 \\
\hline \multirow[t]{2}{*}{ Herring Gull } & Observed & & 18 & 4 & 2 & 4 & 4 & 0 & 9 \\
\hline & Expected & & 24.0 & 19.8 & 0.5 & 0.8 & 2.4 & 0.2 & 18.8 \\
\hline \multirow[t]{2}{*}{ Lesser Bb Gull } & I Observed & & 45 & 79 & 3 & 54 & 96 & 2 & 40 \\
\hline & Expected & & 68.2 & 81.7 & 8.9 & 48.8 & 74.2 & 2.5 & 29.3 \\
\hline \multirow[t]{2}{*}{ Kittiwake } & Observed & & 215 & 0 & 172 & 47 & 18 & 2 & 0 \\
\hline & Expected & & 173.1 & 1.7 & 79.7 & 60.7 & 37.3 & 1.2 & 0.5 \\
\hline \multirow[t]{2}{*}{ Common Gull } & Observed & & 0 & 0 & 0 & 0 & 1 & 0 & 0 \\
\hline & Expected & & - & 0.6 & - & 0.8 & 1.0 & - & - \\
\hline \multirow{2}{*}{\multicolumn{2}{|c|}{$x^{2}$}} & & 21.0 & 55.7 & 124.7 & 37.0 & 19.8 & 0.8 & 9.6 \\
\hline & $\mathrm{p}$ & & $* * *$ & $* * *$ & *** & *** & $* * *$ & n.s. & * \\
\hline
\end{tabular}

Table 4.6.28 Observed and expected numbers of experimentally discarded gadids consumed by gulls by areas of the North Sea in August 1994 (see tables 4.6.24-27 for conventions).

\begin{tabular}{|c|c|c|c|c|c|c|c|c|c|}
\hline Consumer & Category & Area & NW & NE & $\mathrm{CW}$ & C & CE & $\mathbf{S}$ & Sk \\
\hline Great Bb Gull & Observed & & 36 & 1 & 23 & 2 & 5 & 2 & \\
\hline & Expected & & 13.5 & 2.1 & $\begin{array}{r}17.6 \\
46\end{array}$ & $\begin{array}{r}1.8 \\
0\end{array}$ & $\begin{array}{r}18.9 \\
1\end{array}$ & $\begin{array}{r}5.5 \\
0\end{array}$ & \\
\hline Herring Gull & $\begin{array}{l}\text { Observed } \\
\text { Expected }\end{array}$ & & $\begin{array}{r}4 \\
0.6\end{array}$ & $\begin{array}{r}0 \\
0.7\end{array}$ & $\begin{array}{r}46 \\
19.1\end{array}$ & 0.2 & 0.3 & 0.3 & \\
\hline Lesser Bb Gull & Observed & & $\begin{array}{r}0.6 \\
2\end{array}$ & 46 & 9 & 18 & 49 & 39 & \\
\hline & Expected & & $2 . \overline{6}$ & 39.2 & 8.5 & 7.8 & 41.9 & 31.3 & \\
\hline Kittiwake & Observed & & 8 & 11 & 21 & 13 & 20 & 0 & \\
\hline Common Gull & Expected & & 32.7 & 15.3 & 52.8 & 22.8 & 14.7 & 3.9 & \\
\hline Common Gull & $\begin{array}{l}\text { Observed } \\
\text { Expected }\end{array}$ & & $\begin{array}{r}0 \\
0.6\end{array}$ & $\begin{array}{r}0 \\
0.7\end{array}$ & $\begin{array}{r}0 \\
1.0\end{array}$ & $\begin{array}{r}0 \\
0.5\end{array}$ & $\begin{array}{r}1 \\
0.3\end{array}$ & 0 & \\
\hline$x^{2}$ & & & 76.2 & 4.4 & 59.7 & 18.3 & $\begin{array}{r}0.3 \\
16.6\end{array}$ & $\begin{array}{l}0.1 \\
8.4\end{array}$ & \\
\hline$\hat{\mathrm{p}}$ & & & $* * *$ & n.s. & $* * *$ & ** & ** & n.s. & \\
\hline
\end{tabular}


Table 4.6.29 Observed and expected numbers of experimentally discarded gadids consumed by gulls by areas of the North Sea in November 1994 (see tables 4.6.24-27 for conventions).

\begin{tabular}{|c|c|c|c|c|c|c|c|c|c|}
\hline Consumer & Category & Area & NW & NE & $\mathrm{CW}$ & C & CE & $\mathbf{S}$ & Sk \\
\hline \multirow[t]{2}{*}{ Great Bb Gull } & Observed & & 69 & 20 & 6 & 37 & 26 & 2 & 10 \\
\hline & Expected & & 64.9 & 40.2 & 13.9 & 27.9 & 27.4 & 1.0 & 12.1 \\
\hline \multirow[t]{2}{*}{ Herring Gull } & Observed & & 314 & 190 & 28 & 120 & 81 & 0 & 47 \\
\hline & Expected & & 364.3 & 217.9 & 10.2 & 82.4 & 78.4 & 2.2 & 58.9 \\
\hline \multirow[t]{2}{*}{ Kittiwake } & Observed & & 579 & 162 & 130 & 324 & 26 & 0 & 40 \\
\hline & Expected & & 534.1 & 112.5 & 133.6 & 364.9 & 23.1 & 1.2 & 22.7 \\
\hline \multirow[t]{2}{*}{ Common Gull } & Observed & & 1 & 0 & 0 & 2 & 0 & 0 & 1 \\
\hline & Expected & & 0.2 & - & 0.3 & 3.8 & 2.0 & 1.5 & 4.3 \\
\hline \multirow{2}{*}{ Lesser Bb Gull } & I Observed & & 1 & 0 & 0 & 1 & 0 & 5 & \\
\hline & Expected & & 0.6 & 1.4 & 2.8 & 5.1 & 2.0 & 1.1 & \\
\hline$x^{2}$ & & & 14.4 & 36.9 & 38.7 & 28.9 & 4.5 & 19.7 & 18.5 \\
\hline p & & & $* * *$ & $* * *$ & * * * & $* * *$ & n.s. & $* * *$ & $* * *$ \\
\hline
\end{tabular}

Table 4.6.30 Consumption of experimentally discarded common clupeids (Herring, Sprat) by scavenging seabirds in each area of the North Sea in February 1993 surveys /see table 4.6.20 for conventions).

\begin{tabular}{|c|c|c|c|c|c|c|c|c|c|}
\hline Area & Value & Ful & Gan & GBG & $\mathrm{HG}$ & Kit & CG & LBG & Total \\
\hline \multirow[t]{3}{*}{ NW } & $n$ & 5 & 33 & 2 & 13 & 29 & 0 & 0 & 82 \\
\hline & $\%$ & 6.1 & 40.2 & 2.4 & 15.9 & 35.4 & 0.0 & 0.0 & \\
\hline & S.I. & 0.14 & 3.79 & 0.26 & 1.32 & 1.42 & - & - & \\
\hline \multirow[t]{3}{*}{ NE } & $\mathrm{n}$ & 1 & 5 & 3 & 20 & 123 & 0 & 0 & 152 \\
\hline & $\%$ & 0.7 & 3.3 & 2.0 & 13.2 & 80.9 & 0.0 & 0.0 & \\
\hline & S.I. & 0.01 & 1.83 & 0.39 & 2.24 & 2.41 & - & - & \\
\hline \multirow[t]{3}{*}{ CW } & $\mathrm{n}$ & 0 & 4 & 2 & 14 & 100 & 0 & 0 & 120 \\
\hline & $\%$ & 0.0 & 3.3 & 1.7 & 11.7 & 83.3 & 0.0 & 0.0 & \\
\hline & S.I. & 0.00 & 0.61 & 0.52 & 1.09 & 1.45 & - & - & \\
\hline \multirow[t]{3}{*}{ C } & $n$ & 4 & 1 & 24 & 148 & 948 & 12 & 0 & 1137 \\
\hline & $\%$ & 0.4 & 0.1 & 2.1 & 13.0 & 83.4 & 1.1 & 0.0 & \\
\hline & S.I. & 0.02 & 0.05 & 0.23 & 0.76 & 1.63 & 0.92 & - & \\
\hline \multirow[t]{3}{*}{ CE } & $\mathrm{n}$ & 3 & 0 & 37 & 90 & 142 & 48 & 0 & 320 \\
\hline & $\%$ & 0.9 & 0.0 & 11.6 & 28.1 & 44.4 & 15.0 & 0.0 & \\
\hline & S.I. & 0.08 & - & 1.07 & 0.93 & 1.75 & 0.68 & - & \\
\hline \multirow[t]{3}{*}{$\mathbf{S}$} & $\mathrm{n}$ & 1 & 0 & 6 & 29 & 238 & 0 & 2 & 277 \\
\hline & $\%$ & 0.4 & 0.0 & 2.2 & 10.5 & 85.9 & 0.0 & 0.7 & \\
\hline & S.I. & 0.01 & - & 0.17 & 0.65 & 2.25 & - & 0.78 & \\
\hline
\end{tabular}


Table 4.6.31 Consumption of experimentally discarded common clupeids (Herring, Sprat) by scavenging seabirds in each area of the North Sea in May 1994 (see table 4.6.20 for conventions).

\begin{tabular}{|c|c|c|c|c|c|c|c|c|c|c|c|c|}
\hline Area & Value & Ful & Gan & GBG & HG & Kit & CG & LBG & GSk & LG & $\mathrm{CT}$ & Total \\
\hline \multirow[t]{3}{*}{ NW } & $n$ & 184 & 145 & 73 & 5 & 25 & 0 & 22 & 10 & 0 & 0 & 464 \\
\hline & $\%$ & 39.7 & 31.3 & 15.7 & 1.1 & 5.4 & 0.0 & 4.7 & 2.2 & 0.0 & 0.0 & \\
\hline & S.I. & 0.47 & 6.51 & 5.43 & 1.80 & 0.45 & - & 2.72 & 8.46 & - & - & \\
\hline \multirow[t]{3}{*}{ NE } & $\mathrm{n}$ & 6 & 2 & 7 & 5 & 0 & 0 & 34 & 0 & 0 & 0 & 54 \\
\hline & $\%$ & 11.1 & 3.7 & 13.0 & 9.3 & 0.0 & 0.0 & 63.0 & 0.0 & 0.0 & 0.0 & \\
\hline & S.I. & 0.15 & 12.33 & 1.65 & 2.70 & 0.00 & 0.00 & 7.74 & 0.00 & - & - & \\
\hline \multirow[t]{3}{*}{ cW } & $\mathrm{n}$ & 170 & 267 & 0 & 1 & 147 & 0 & 9 & 0 & 0 & 0 & 594 \\
\hline & $\%$ & 28.6 & 44.9 & 0.0 & 0.2 & 24.7 & 0.0 & 1.5 & 0.0 & 0.0 & 0.0 & \\
\hline & S.I. & 3.61 & 4.86 & 0.00 & 3.33 & 2.87 & - & 1.56 & 0.00 & - & - & \\
\hline \multirow[t]{3}{*}{ C } & $\mathrm{n}$ & 264 & 33 & 6 & 1 & 134 & 0 & 72 & 0 & 0 & 0 & 510 \\
\hline & $\%$ & 51.8 & 6.5 & 1.2 & 0.2 & 26.3 & 0.0 & $14 . \overline{1}$ & 0.0 & 0.0 & 0.0 & \\
\hline & S.I. & 0.70 & 3.32 & 0.46 & 1.25 & 2.26 & 0.00 & 1.57 & - & - & - & \\
\hline \multirow[t]{3}{*}{ CE } & $\mathrm{n}$ & 70 & 2 & 0 & 4 & 83 & 1 & 144 & 0 & 2 & 1 & 307 \\
\hline & $\%$ & 22.8 & 0.7 & 0.0 & 5.2 & 27.0 & 1.3 & 46.9 & 0.0 & 0.7 & 1.3 & \\
\hline & S.I. & 0.48 & 1.56 & 0.00 & 5.00 & 1.65 & 2.89 & 1.44 & - & - & - & \\
\hline \multirow[t]{3}{*}{ S } & $\mathrm{n}$ & 0 & 0 & 0 & 0 & 8 & 0 & 0 & 0 & 0 & 0 & 8 \\
\hline & $\%$ & 0.0 & 0.0 & 0.0 & 0.0 & 100 & 0.0 & 0.0 & 0.0 & 0.0 & 0.0 & \\
\hline & S.I. & 0.00 & 0.00 & 0.00 & 0.00 & 3.60 & - & 0.00 & - & - & - & \\
\hline \multirow[t]{3}{*}{ Sk } & $\mathrm{n}$ & 6 & 0 & 0 & 19 & 0 & 0 & 73 & 0 & 0 & 0 & 98 \\
\hline & $\%$ & 6.1 & 0.0 & 0.0 & 19.4 & 0.0 & 0.0 & 74.5 & 0.0 & 0.0 & 0.0 & \\
\hline & S.I. & 0.26 & & 0.00 & 0.69 & 0.00 & - & 1.69 & - & - & - & \\
\hline
\end{tabular}

Table 4.6.32 Consumption of experimentally discarded common clupeids (Herring, Sprat) by scavenging seabirds in each area of the North Sea in August 1994 (see table 4.6.20 for conventions).

\begin{tabular}{llrrrrrrrr}
\hline Area & Value & Ful & Gan & GBG & HG & Kit & LBG & GSk & Total \\
\hline NW & $n$ & 57 & 25 & 17 & 7 & 0 & 1 & 53 & 160 \\
& $\%$ & 35.6 & 15.6 & 10.6 & 4.4 & 0.0 & 0.6 & 33.1 & \\
& S.I. & 0.37 & 13.00 & 17.67 & - & 0.00 & - & 24.16 & 23 \\
NE & $n$ & 12 & 5 & 1 & 0 & 1 & 1 & 3 & 23 \\
& $\%$ & 52.2 & 21.7 & 4.3 & 0.0 & 4.3 & 4.3 & 13.0 & \\
& S.I. & 0.55 & - & 28.67 & 0.00 & 3.94 & 1.54 & 52.00 & \\
CW & $n$ & 62 & 81 & 2 & 23 & 53 & 1 & 0 & 222 \\
& $\%$ & 27.9 & 36.5 & 0.9 & 10.4 & 23.9 & 0.5 & 0.0 & \\
& S.I. & 0.40 & 2.09 & 0.44 & 4.73 & 9.19 & 0.51 & 0.00 & \\
C & n & 150 & 1 & 0 & 0 & 33 & 5 & 0 & 189 \\
& $\%$ & 79.4 & 0.5 & 0.0 & 0.0 & 17.5 & 2.6 & 0.0 & \\
& S.I. & 1.05 & 0.23 & 0.00 & 0.00 & 1.18 & 0.51 & 0.00 & 1 \\
CE & n & 0 & 0 & 0 & 0 & 33 & 20 & 55 \\
& $\%$ & 0.0 & 0.0 & 0.0 & 0.0 & 61.1 & 37.0 & 1.9 & \\
& S.I. & 0.00 & 0.00 & 0.00 & 0.00 & 3.74 & 0.79 & 2.84 & 15 \\
S & n & 0 & 0 & 0 & 0 & 0 & 15 & 0 & 15 \\
& $\%$ & 0.0 & 0.0 & 0.0 & 0.0 & 0.0 & 100 & 0.0 & \\
& S.I. & 0.00 & 0.00 & 0.00 & 0.00 & 0.00 & 1.37 & 0.00 &
\end{tabular}


Table 4.6.33 Consumption of experimentally discarded common clupeids (Herring, Sprat) by scavenging seabirds in each area of the North Sea in November 1994 (see table 4.6.20 for conventions).

\begin{tabular}{llrrrrrrrrr}
\hline Area & Value & Ful & Gan & GBG & HG & Kit & LBG & BhG & GG & Total \\
\hline NW & $n$ & 4 & 17 & 4 & 45 & 128 & 0 & 0 & 1 & 199 \\
& $\%$ & 2.0 & 8.5 & 2.0 & 22.6 & 64.3 & 0.0 & 0.0 & 0.5 & \\
& S.I. & 0.07 & 12.50 & 0.43 & 0.86 & 1.67 & 0.00 & - & - & \\
NE & $n$ & 0 & 1 & 5 & 18 & 0 & 0 & 0 & 0 & 24 \\
& $\%$ & 0.0 & 4.2 & 20.8 & 75.0 & 0.0 & 0.0 & 0.0 & 0.0 & \\
& S.I. & 0.00 & 3.21 & 4.29 & 2.85 & 0.00 & 0.00 & - & - & \\
CW & n & 1 & 13 & 25 & 2 & 81 & 1 & 0 & 0 & 123 \\
& $\%$ & 0.8 & 10.6 & 20.3 & 1.6 & 65.9 & 0.8 & 0.0 & 0.0 & \\
& S.I. & 0.02 & 1.09 & 4.82 & 0.51 & 1.63 & - & - & - & \\
C & $n$ & 21 & 76 & 14 & 34 & 549 & 0 & 0 & 0 & 694 \\
& $\%$ & 3.0 & 11.0 & 2.0 & 4.9 & 79.1 & 0.0 & 0.0 & 0.0 & \\
& S.I. & 0.11 & 2.12 & 0.52 & 0.44 & 1.59 & 0.00 & - & - & \\
CE & $n$ & 0 & 0 & 1 & 63 & 41 & 0 & 0 & 0 & 105 \\
& $\%$ & 0.0 & 0.0 & 1.0 & 60.0 & 39.0 & 0.0 & 0.0 & 0.0 & \\
& S.I. & 0.00 & 0.00 & 0.05 & 1.04 & 2.30 & 0.00 & - & - & \\
& n & 0 & 0 & 1 & 4 & 1 & 2 & 0 & 0 & 8 \\
& $\%$ & 0.0 & 0.0 & 12.5 & 50.0 & 12.5 & 25.0 & 0.0 & 0.0 & \\
& S.I. & - & 0.00 & 0.97 & 1.85 & 1.81 & 1.85 & - & - & \\
Sk & n & 0 & 0 & 1 & 26 & 23 & 2 & 4 & 0 & 54 \\
& $\%$ & 0.0 & 0.0 & 1.9 & 48.1 & 42.6 & 3.7 & 7.4 & 0.0 & \\
& S.I. & 0.00 & 0.00 & 0.19 & 0.96 & 2.21 & - & - & - & \\
\hline
\end{tabular}

Table 4.6.34 Observed and expected numbers of experimentally discarded clupeids consumed by Fulmars and by other scavenging seabirds by areas of the North Sea during each of the surveys (see table 4.6.24 for conventions).

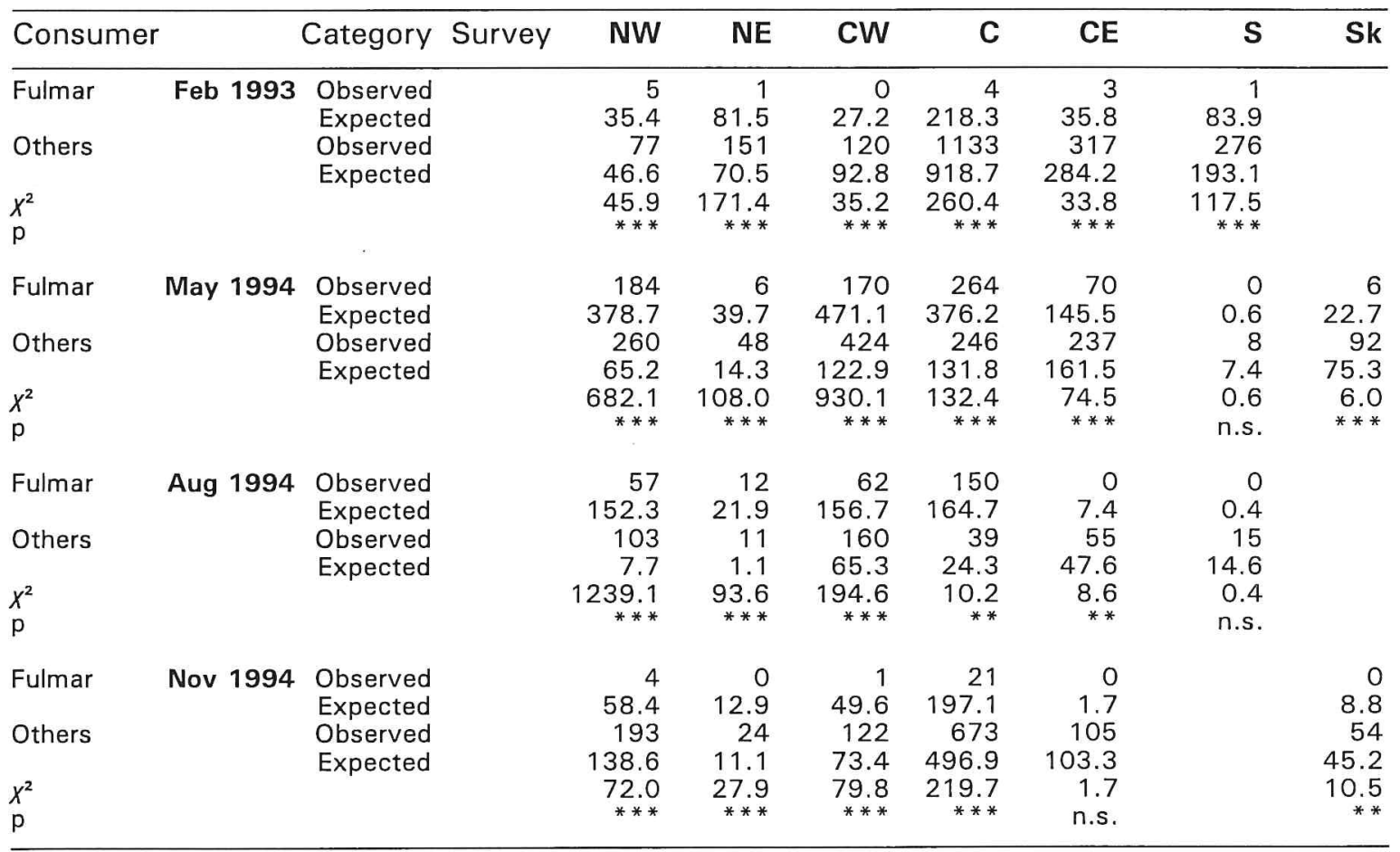


Table 4.6.35 Observed and expected numbers of experimentally discarded clupeids consumed by Gannets and by Gulls by areas of the North Sea during each of the surveys (see table 4.6.24 for conventions).

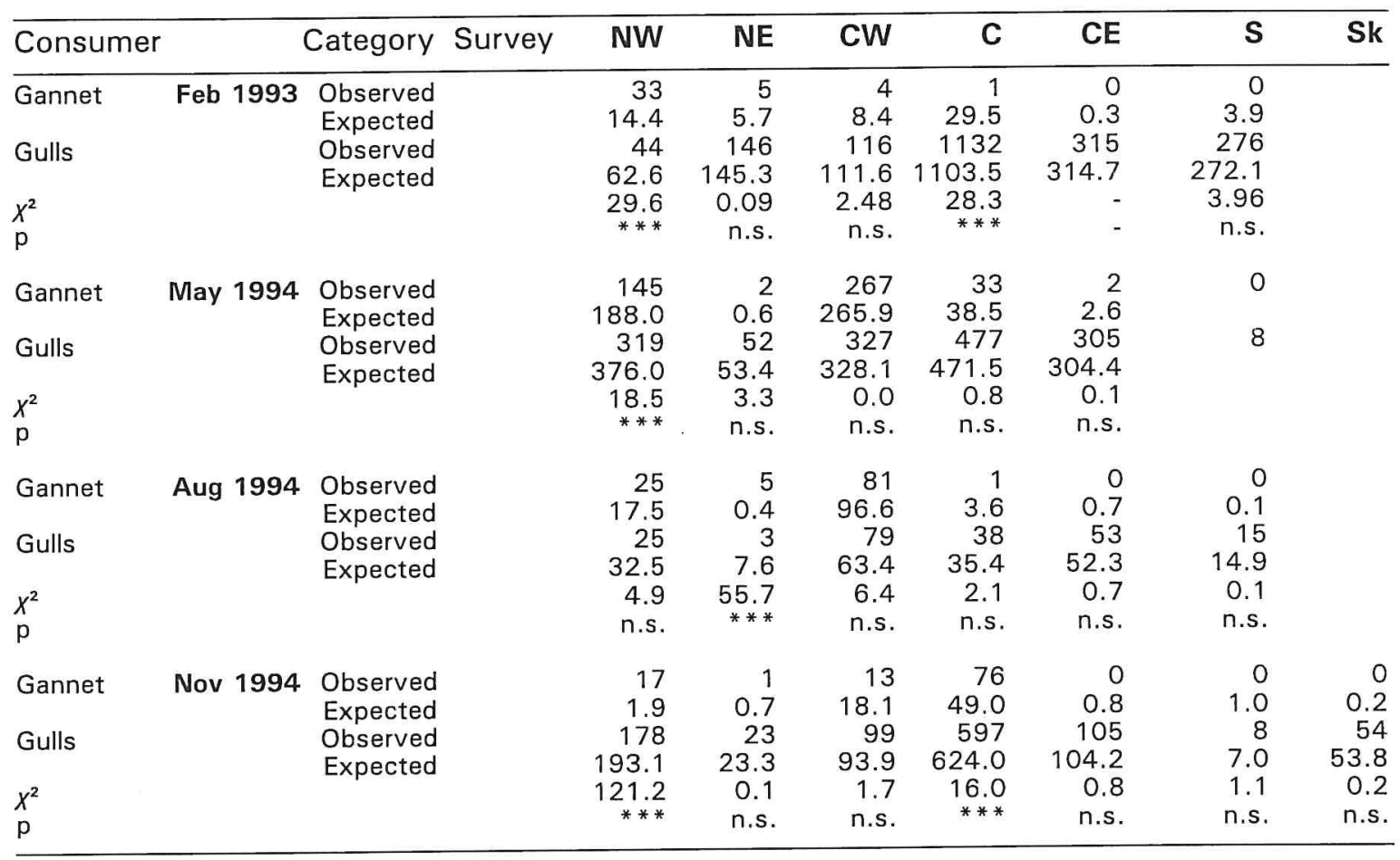

Table 4.6.36 Observed and expected numbers of experimentally discarded clupeids consumed by Great Black-backed Gulls, Herring Gulls, Kittiwakes and (where appropriate) Common Gulls by areas of the North Sea in February 1993 (see table 4.6.24 for conventions).

\begin{tabular}{|c|c|c|c|c|c|c|c|c|c|}
\hline Consumer & Category & Area & NW & NE & $\mathrm{CW}$ & C & CE & $\mathbf{S}$ & Sk \\
\hline \multirow[t]{2}{*}{ Great Bb Gulls } & Observed & & 2 & 3 & 2 & 24 & 37 & 6 & \\
\hline & Expected & & 8.8 & 16.6 & 5.3 & 130.2 & 38.4 & 52.4 & \\
\hline \multirow[t]{2}{*}{ Herring Gull } & Observed & & 13 & 20 & 14 & 148 & 90 & 29 & \\
\hline & Expected & & 11.4 & 19.3 & 17.4 & 247.9 & 108.4 & 65.8 & \\
\hline \multirow[t]{2}{*}{ Kittiwake } & Observed & & 29 & 123 & 100 & 948 & 142 & 238 & \\
\hline & Expected & & 23.9 & 110.1 & 93.4 & 734.7 & 90.6 & 154.8 & \\
\hline \multirow[t]{2}{*}{ Common Gull } & Observed & & - & - & - & 12 & 48 & - & \\
\hline & Expected & & - & - & - & 18.1 & 78.9 & - & \\
\hline$x^{2}$ & & & 6.62 & 12.7 & 3.19 & 190.9 & 44.4 & 106.4 & \\
\hline p & & & * & * * & n.s. & *** & *** & $* * *$ & \\
\hline
\end{tabular}


Table 4.6.37 Observed and expected numbers of experimentally discarded clupeids consumed by gulls by areas of the North Sea in May 1994 (see tables 4.6.24 and 36 for conventions).

\begin{tabular}{|c|c|c|c|c|c|c|c|c|c|}
\hline Consumer & Category & Area & NW & NE & CW & C & CE & $\mathbf{S}$ & Sk \\
\hline \multirow[t]{2}{*}{ Great Bb Gull } & Observed & & 73 & 7 & 0 & 6 & 0 & 0 & 0 \\
\hline & Expected & & 37.5 & 14.0 & 24.5 & 12.3 & 7.9 & - & 4.3 \\
\hline \multirow{2}{*}{ Herring Gull } & Observed & & 5 & 5 & 1 & 1 & 4 & 0 & 19 \\
\hline & Expected & & 7.9 & 6.1 & 0.8 & 0.8 & 4.6 & 0.4 & 33.9 \\
\hline \multirow[t]{2}{*}{ Lesser Bb Gull } & Observed & & 22 & 34 & 9 & 72 & 144 & 0 & 73 \\
\hline & Expected & & 22.5 & 25.2 & 13.4 & 44.2 & 144.8 & 5.1 & 52.9 \\
\hline \multirow[t]{2}{*}{ Kittiwake } & Observed & & 25 & 0 & 147 & 134 & 83 & 8 & 0 \\
\hline & Expected & & 57.1 & 0.5 & 120.0 & 55.0 & 72.7 & 2.4 & 1.0 \\
\hline \multirow[t]{2}{*}{ Common Gull } & Observed & & 0 & 0 & 0 & 0 & 1 & 0 & 0 \\
\hline & Expected & & - & 0.2 & - & 0.8 & 2.0 & - & - \\
\hline$x^{2}$ & & & 52.7 & 7.5 & 32.1 & 135.0 & 9.9 & 18.6 & 18.5 \\
\hline $\mathrm{p}$ & & & $* * *$ & n.s. & *** & *** & * & *** & $* * *$ \\
\hline
\end{tabular}

Table 4.6.38 Observed and expected numbers of experimentally discarded clupeids consumed by gulls by areas of the North Sea in August 1994 (see tables 4.6.24 and 36 for conventions).

\begin{tabular}{|c|c|c|c|c|c|c|c|c|c|}
\hline Consumer & Category & Area & NW & NE & CW & C & CE & $\mathbf{S}$ & Sk \\
\hline \multirow[t]{2}{*}{ Great Bb Gull } & Observed & & 17 & 1 & 2 & 0 & 0 & 0 & \\
\hline & Expected & & 6.7 & 0.1 & 14.0 & 2.0 & 13.2 & 2.0 & \\
\hline \multirow[t]{2}{*}{ Herring Gull } & Observed & & 7 & 0 & 23 & 0 & 0 & 0 & \\
\hline & Expected & & 0.3 & 0.0 & 15.2 & 0.2 & 0.2 & 0.1 & \\
\hline \multirow[t]{2}{*}{ Lesser Bb Gull } & Observed & & 1 & 1 & 1 & 5 & 20 & 15 & \\
\hline & Expected & & 1.3 & 2.2 & 6.8 & 8.9 & 29.2 & 11.4 & \\
\hline \multirow[t]{2}{*}{ Kittiwake } & Observed & & 0 & 1 & 53 & 33 & 33 & 0 & \\
\hline & Expected & & 16.3 & 0.8 & 42.1 & 26.2 & 10.2 & 1.4 & \\
\hline \multirow[t]{2}{*}{ Common Gull } & Observed & & 0 & 0 & 0 & 0 & 0 & 0 & \\
\hline & Expected & & 0.3 & 0.0 & 0.8 & 0.6 & 0.2 & - & \\
\hline$x^{2}$ & & & 182.1 & 8.8 & 22.9 & 6.3 & 67.5 & 4.6 & \\
\hline $\mathrm{p}$ & & & *** & * & $* * *$ & n.s. & $* * *$ & n.s. & \\
\hline
\end{tabular}

Table 4.6.39 Observed and expected numbers of experimentally discarded clupeids consumed by gulls by areas of the North Sea in November 1994 (see tables 4.6.24 and 36 for conventions).

\begin{tabular}{|c|c|c|c|c|c|c|c|c|c|}
\hline Consumer & Category & Area & NW & NE & CW & C & CE & $\mathbf{S}$ & Sk \\
\hline \multirow[t]{2}{*}{ Great Bb Gull } & Observed & & 4 & 5 & 25 & 14 & 1 & 1 & 1 \\
\hline & Expected & & 11.9 & 2.5 & 9.2 & 34.4 & 21.6 & 1.2 & 6.4 \\
\hline \multirow[t]{2}{*}{ Herring Gull } & Observed & & 45 & 18 & 2 & 34 & 63 & 4 & 26 \\
\hline & Expected & & 66.9 & 13.5 & $6 . \overline{8}$ & 101.6 & 61.9 & 2.5 & 31.3 \\
\hline \multirow[t]{2}{*}{ Kittiwake } & Observed & & 128 & 0 & 81 & 549 & 41 & 1 & 23 \\
\hline & Expected & & 98.1 & 7.0 & 88.8 & 450.1 & 18.3 & 1.4 & 12.0 \\
\hline \multirow[t]{2}{*}{ Lesser Bb Gull } & Observed & & 0 & & 1 & 0 & 0 & 2 & 2 \\
\hline & Expected & & 0.1 & 0.1 & 4.0 & 6.3 & 1.6 & 1.2 & 0.0 \\
\hline \multirow[t]{2}{*}{ Common Gull } & Observed & & & & 0 & 0 & 0 & 0 & 0 \\
\hline & Expected & & & & 0.2 & 4.6 & 1.6 & 1.7 & 2.3 \\
\hline$x^{2}$ & & & 21.6 & 11.1 & 33.7 & 89.7 & 51.0 & 3.3 & 27.9 \\
\hline $\mathrm{p}$ & & & $* * *$ & * & $* * *$ & $* * *$ & $* * *$ & n.s. & $* * *$ \\
\hline
\end{tabular}


Table 4.6.40 Consumption of experimentally discarded common gadids (Haddock, Whiting, Cod, Saithe, Norway pout) by adult and immature Herring Gulls Great Black-backed Gulls, Kittiwakes in the whole North Sea during each of the. S.I. = success index lpercent of all gadids that were swallowed by this age group, divided by percent of all birds present that were this age group, i.e. category '\%' below); 'immature' includes subadults and juveniles.

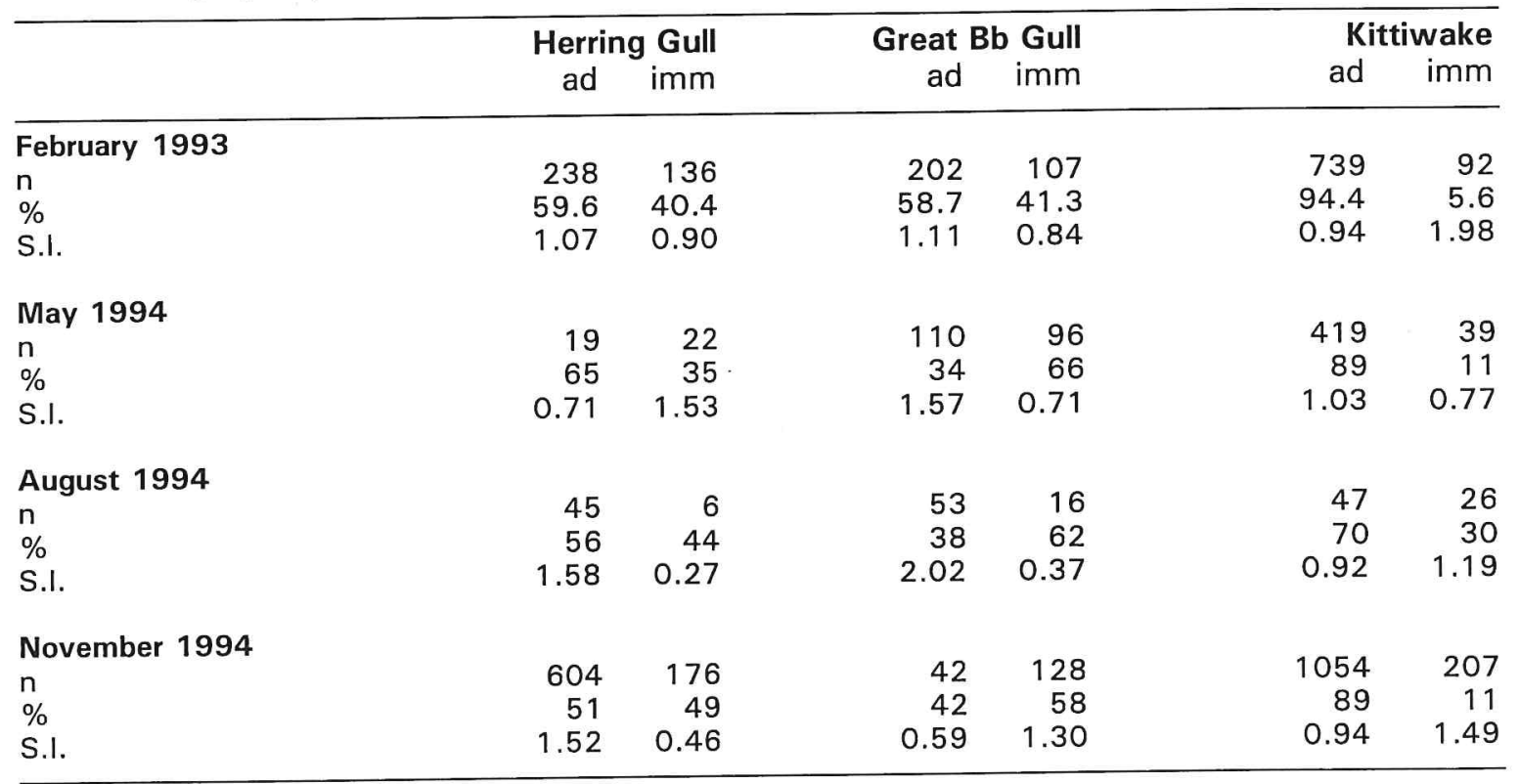

Table 4.6.41 Consumption of experimentally discarded common clupeids (Herring, Sprat) by adult and immature Herring Gulls, Great Black-backed Gulls, Kittiwakes in the whole North Sea during each of the surveys. See table 4.6.40 for conventions.

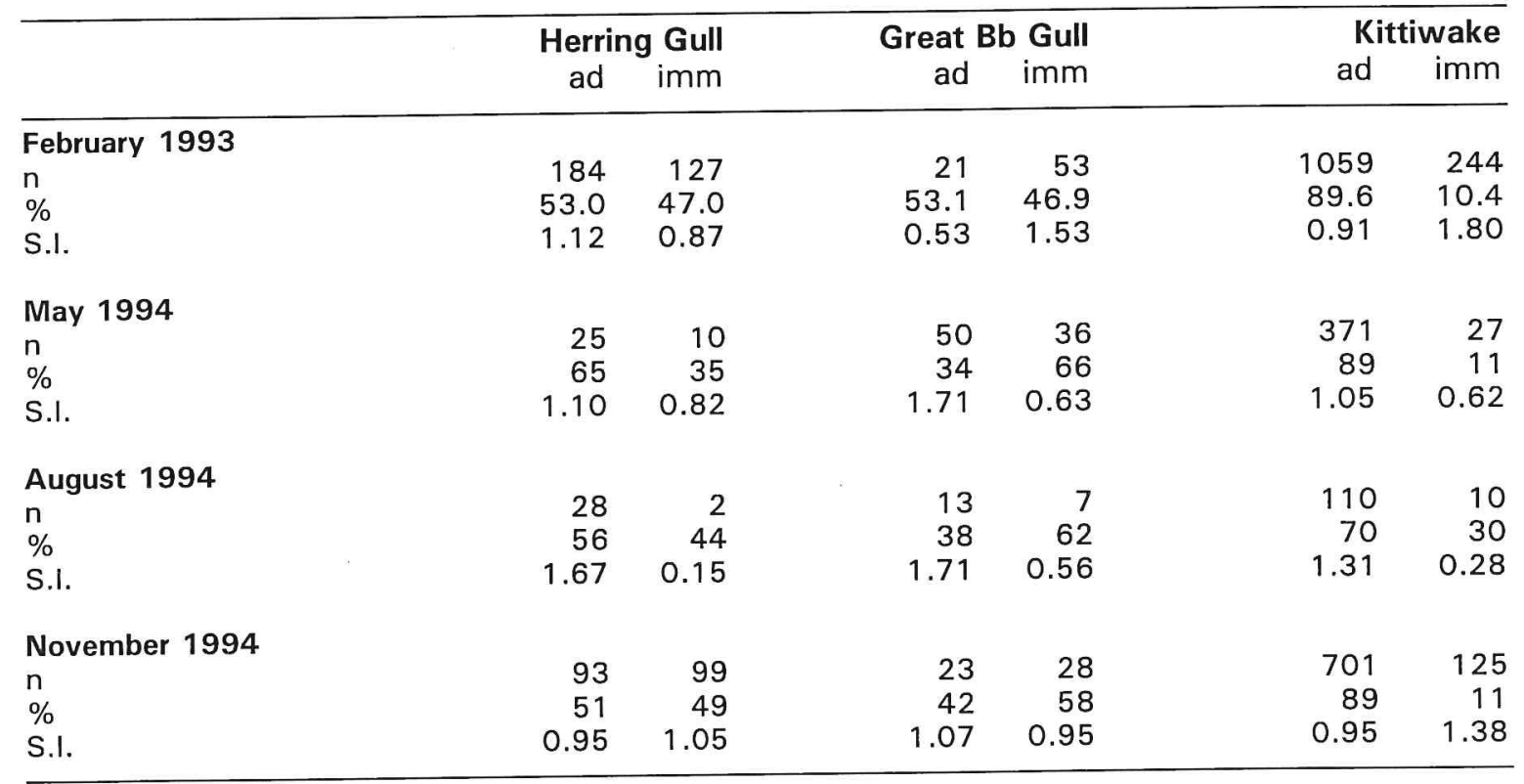


Table 4.6.42 Minimum, median and maximum of fish length $(\mathrm{cm})$ for the seven most abundant experimental discards in February 1993. $n=$ sample size. Differences between length choices were tested by Kruskal-Wallis 1-way ANOVA $(p>0.05=n . s, p<0.05=*$, $p<0.01=* *, p<0.001^{* * *}$.

\begin{tabular}{|c|c|c|c|c|c|c|c|c|c|c|}
\hline & & ffered & sunk & Ful & Gan & HG & GBG & Kit & ANOVA & $p<$ \\
\hline \multirow[t]{4}{*}{ Herring } & $\mathrm{n}$ & 1650 & 133 & 11 & 43 & 270 & 73 & 1069 & & \\
\hline & $\min$ & 8 & 10 & 9 & 14 & 10 & 12 & 8 & 250 & *** \\
\hline & median & 16 & 23 & 23 & 28 & 19 & 20 & 16 & & \\
\hline & $\max$ & 34 & 31 & 27 & 31 & 29 & 34 & 26 & & \\
\hline \multirow[t]{4}{*}{ Sprat } & $\mathrm{n}$ & 596 & 25 & 3 & 0 & 44 & 1 & 511 & & \\
\hline & $\min$ & 5 & 7 & 13 & & 7 & & 5 & 9.5 & * \\
\hline & median & 11 & 12 & 13 & 12 & 11 & 11 & & & \\
\hline & $\max$ & 16 & 14 & 15 & 15 & & & 16 & & \\
\hline \multirow[t]{4}{*}{ Haddock } & $\mathrm{n}$ & 875 & 104 & 10 & 196 & 107 & 116 & 342 & & \\
\hline & $\min$ & 11 & 11 & 14 & 16 & 12 & 15 & 11 & 471.4 & *** \\
\hline & median & 21 & 27 & 19.5 & 28 & 22 & 27 & 17.5 & & \\
\hline & $\max$ & 40 & 39 & 29 & 40 & 35 & 36 & 23 & & \\
\hline \multirow[t]{4}{*}{ Whiting } & $\mathrm{n}$ & 1179 & 43 & 35 & 230 & 259 & 160 & 447 & & \\
\hline & $\min$ & 8 & 13 & 15 & 15 & 11 & 13 & 8 & 647 & *** \\
\hline & median & 23 & 28 & 24 & 28 & 24 & 27 & 17 & & \\
\hline & $\max$ & 40 & 38 & 31 & 37 & 31 & 36 & 26 & & \\
\hline \multirow[t]{4}{*}{ N. Pout } & $\mathrm{n}$ & 363 & 10 & 5 & 58 & 18 & 2 & 270 & & \\
\hline & $\min$ & 10 & 14 & 13 & 11 & 15 & 16 & 10 & 9.1 & n.s. \\
\hline & median & 17 & 17 & 17 & 17 & 17 & 17.5 & 16 & & \\
\hline & $\max$ & 22 & 19 & 18 & 21 & 21 & 19 & 22 & & \\
\hline \multirow[t]{4}{*}{ Gurnards } & $n$ & 99 & 13 & 1 & 35 & 25 & 18 & 6 & & \\
\hline & $\min$ & 8 & 18 & & 15 & 8 & 12 & 12 & 26.1 & *** \\
\hline & median & 21 & 25 & 27 & 23 & 18 & 21.5 & 17.5 & & \\
\hline & $\max$ & 38 & 38 & & 35 & 25 & 35 & 29 & & \\
\hline \multirow[t]{4}{*}{ Dab } & $\mathrm{n}$ & 247 & 169 & 2 & 43 & 11 & 21 & 1 & & \\
\hline & $\min$ & 9 & 10 & 9 & 12 & 9 & 9 & & 17.3 & ** \\
\hline & median & 19 & 18 & 11.5 & 19 & 18 & 17 & 13 & & \\
\hline & $\max$ & 29 & 29 & .14 & 23 & 23 & 21 & & & \\
\hline
\end{tabular}


Table 4.6.43 Minimum, median and maximum of fish length $(\mathrm{cm})$ for the ten most abundant experimental discards in May 1994 (see table 4.6.42 for conventions).

\begin{tabular}{|c|c|c|c|c|c|c|c|c|c|c|}
\hline & offe & fered & sunk & Ful & Gan & HG & GBG & Kit & ANOVA & $p<$ \\
\hline \multirow{4}{*}{ Herring } & $n$ & 2357 & 762 & 542 & 384 & 21 & 80 & 181 & & \\
\hline & $\min$ & 8 & 8 & 9 & 12 & 14 & 16 & 9 & 284.6 & *** \\
\hline & median & 17 & 15 & 20 & 23 & 20 & 23 & 16 & & \\
\hline & $\max$ & 30 & 28 & 29 & 30 & 26 & 28 & 26 & & \\
\hline \multirow[t]{4}{*}{ Sprat } & $\mathrm{n}$ & 833 & 266 & 204 & 65 & 14 & 6 & 217 & & \\
\hline & $\min$ & 6 & 6 & 8 & 9 & 8 & 12 & 9 & 10.1 & * \\
\hline & median & 11 & 7 & 12 & 12 & 14 & 13 & 12 & & \\
\hline & $\max$ & 17 & 16 & 15 & 15 & 16 & 13 & 15 & & \\
\hline \multirow[t]{4}{*}{ Haddock } & $\mathrm{n}$ & 1124 & 282 & 201 & 323 & 19 & 99 & 62 & & \\
\hline & $\min$ & 12 & 12 & 12 & 14 & 16 & 13 & 12 & 151.5 & $* * *$ \\
\hline & median & 22 & 22 & 20 & 24 & 22 & 23 & 17 & & \\
\hline & $\max$ & 47 & 47 & 41 & 45 & 28 & 37 & 27 & & \\
\hline \multirow[t]{4}{*}{ Whiting } & $\mathrm{n}$ & 1621 & 173 & 512 & 356 & 19 & 89 & 235 & & \\
\hline & $\min$ & & 9 & 12 & 14 & 16 & 16 & 10 & 410.3 & $* * *$ \\
\hline & median & 21 & 20 & 20 & 25 & 23 & 26 & 17 & & \\
\hline & $\max$ & 39 & 36 & 39 & 38 & 29 & 38 & 25 & & \\
\hline \multirow[t]{4}{*}{ N. Pout } & $n$ & 783 & 99 & 348 & 48 & 2 & 17 & 159 & & \\
\hline & $\min$ & 10 & 12 & 10 & 12 & 14 & 12 & 11 & 18.7 & *** \\
\hline & median & 14 & 14 & 14 & 16 & 15 & 15 & 14 & & \\
\hline & $\max$ & 23 & 20 & 19 & 23 & 15 & 19 & 20 & & \\
\hline \multirow{4}{*}{ G.Gurnard } & $\mathrm{n}$ & 400 & 94 & 42 & 106 & 4 & 41 & 2 & & \\
\hline & $\min$ & 12 & 14 & 17 & 15 & 17 & 13 & 17 & 11.7 & * \\
\hline & median & 22 & 22 & 22 & 22 & 20 & 21 & 18 & & \\
\hline & $\max$ & 35 & 34 & 32 & 34 & 22 & 30 & 18 & & \\
\hline \multirow[t]{4}{*}{ Dab } & $\mathrm{n}$ & 670 & 527 & 6 & 59 & 3 & 14 & & & \\
\hline & $\min$ & 7 & 8 & 18 & 14 & 16 & 16 & & 6.24 & n.s. \\
\hline & median & 18 & 18 & 20 & 18 & 16 & 19 & & & \\
\hline & $\max$ & 30 & 30 & 21 & 24 & 19 & 22 & & & \\
\hline \multirow[t]{4}{*}{ L.R. Dab } & $\mathrm{n}$ & 297 & 188 & 24 & 31 & 6 & 5 & 7 & & \\
\hline & $\min$ & 7 & 8 & 7 & 13 & 12 & 15 & 11 & 22.81 & $* * *$ \\
\hline & median & 16 & 17 & 13 & 17 & 16 & 17 & 14 & & \\
\hline & $\max$ & 28 & 28 & 24 & 22 & 18 & 22 & 15 & & \\
\hline \multirow[t]{4}{*}{ Sandeel } & $\mathrm{n}$ & 1071 & 147 & 782 & 17 & & 4 & 56 & & \\
\hline & $\min$ & 10 & 10 & 10 & 12 & & 17 & 10 & 111.9 & $* * *$ \\
\hline & median & 13 & 19 & 13 & 18 & & 18 & 17 & & \\
\hline & $\max$ & 30 & 27 & 23 & 30 & & 26 & 21 & & \\
\hline \multirow{4}{*}{ G. sandeel } & $\mathrm{n}$ & 113 & 44 & 35 & & & 1 & 30 & & \\
\hline & $\min$ & 12 & 14 & 12 & & & - & 12 & 21.1 & $* * *$ \\
\hline & median & 21 & 19 & 22 & & & 23 & 17 & & \\
\hline & $\max$ & 32 & 32 & 31 & & & - & 24 & & \\
\hline
\end{tabular}


Table 4.6.44 Minimum, median and maximum of fish length $(\mathrm{cm})$ for the ten most abundant experimental discards in August 1994 (see table 4.6.42 for conventions).

\begin{tabular}{|c|c|c|c|c|c|c|c|c|c|c|}
\hline & & ffered & sunk & Ful & Gan & $\mathrm{HG}$ & GBG & Kit & ANOVA & $\mathbf{p}$ \\
\hline Herring & $\begin{array}{l}\mathrm{n} \\
\text { min } \\
\text { median } \\
\max \end{array}$ & $\begin{array}{r}685 \\
8 \\
24 \\
34\end{array}$ & $\begin{array}{r}133 \\
9 \\
18 \\
31\end{array}$ & $\begin{array}{r}318 \\
8 \\
23 \\
34\end{array}$ & $\begin{array}{l}96 \\
16 \\
26 \\
33\end{array}$ & $\begin{array}{l}18 \\
16 \\
24 \\
28\end{array}$ & $\begin{array}{l}20 \\
24 \\
26 \\
31\end{array}$ & $\begin{array}{r}5 \\
12 \\
16 \\
21\end{array}$ & 72.3 & *** \\
\hline Sprat & $\begin{array}{l}\mathrm{n} \\
\text { min } \\
\text { median } \\
\max \end{array}$ & $\begin{array}{r}381 \\
8 \\
12 \\
16\end{array}$ & $\begin{array}{r}136 \\
8 \\
13 \\
16\end{array}$ & $\begin{array}{r}78 \\
9 \\
11 \\
15\end{array}$ & $\begin{array}{l}16 \\
10 \\
14 \\
15\end{array}$ & $\begin{array}{l}12 \\
10 \\
11 \\
16\end{array}$ & & $\begin{array}{r}115 \\
8 \\
13 \\
15\end{array}$ & 15.1 & $* *$ \\
\hline Cod & $\begin{array}{l}\mathrm{n} \\
\text { min } \\
\text { median } \\
\max \end{array}$ & $\begin{array}{r}395 \\
7 \\
24 \\
47\end{array}$ & $\begin{array}{r}113 \\
12 \\
25 \\
37\end{array}$ & $\begin{array}{r}209 \\
8 \\
23 \\
47\end{array}$ & $\begin{array}{l}22 \\
19 \\
29 \\
38\end{array}$ & $\begin{array}{r}1 \\
- \\
24 \\
-\end{array}$ & $\begin{array}{r}1 \\
- \\
25 \\
-\end{array}$ & $\begin{array}{r}7 \\
7 \\
11 \\
19\end{array}$ & 34.91 & *** \\
\hline Haddock & $\begin{array}{l}\mathrm{n} \\
\text { min } \\
\text { median } \\
\max \end{array}$ & $\begin{array}{r}852 \\
7 \\
24 \\
42\end{array}$ & $\begin{array}{r}159 \\
9 \\
25 \\
42\end{array}$ & $\begin{array}{r}433 \\
7 \\
22 \\
35\end{array}$ & $\begin{array}{r}111 \\
14 \\
28 \\
35\end{array}$ & $\begin{array}{l}25 \\
11 \\
14 \\
28\end{array}$ & $\begin{array}{l}40 \\
10 \\
25 \\
31\end{array}$ & $\begin{array}{r}3 \\
14 \\
17 \\
17\end{array}$ & 94.4 & *** \\
\hline Whiting & $\begin{array}{l}\mathrm{n} \\
\min \\
\text { median } \\
\max \end{array}$ & $\begin{array}{r}1319 \\
6 \\
22 \\
40\end{array}$ & $\begin{array}{r}271 \\
7 \\
23 \\
39\end{array}$ & $\begin{array}{r}624 \\
7 \\
21 \\
40\end{array}$ & $\begin{array}{r}129 \\
15 \\
26 \\
38\end{array}$ & $\begin{array}{r}26 \\
7 \\
18 \\
24\end{array}$ & $\begin{array}{l}26 \\
15 \\
23 \\
32\end{array}$ & $\begin{array}{r}49 \\
6 \\
17 \\
26\end{array}$ & 120.3 & *** \\
\hline N. Pout & $\begin{array}{l}\mathrm{n} \\
\text { min } \\
\text { median } \\
\max \end{array}$ & $\begin{array}{r}539 \\
5 \\
15 \\
27\end{array}$ & $\begin{array}{r}48 \\
5 \\
9 \\
16\end{array}$ & $\begin{array}{r}435 \\
6 \\
15 \\
27\end{array}$ & $\begin{array}{r}6 \\
14 \\
16 \\
18\end{array}$ & & $\begin{array}{r}2 \\
10 \\
12 \\
14\end{array}$ & $\begin{array}{r}17 \\
7 \\
16 \\
18\end{array}$ & 1.88 & n.s. \\
\hline G. gurnard & $\begin{array}{l}\mathrm{n} \\
\text { min } \\
\text { median } \\
\max \end{array}$ & $\begin{array}{r}288 \\
10 \\
22 \\
37\end{array}$ & $\begin{array}{r}131 \\
10 \\
24 \\
35\end{array}$ & $\begin{array}{l}24 \\
18 \\
24 \\
34\end{array}$ & $\begin{array}{l}29 \\
17 \\
23 \\
37\end{array}$ & $\begin{array}{r}1 \\
- \\
16 \\
-\end{array}$ & $\begin{array}{l}23 \\
16 \\
20 \\
27\end{array}$ & & 15.92 & $* *$ \\
\hline Dab & $\begin{array}{l}\mathrm{n} \\
\text { min } \\
\text { median } \\
\max \end{array}$ & $\begin{array}{r}380 \\
9 \\
18 \\
28\end{array}$ & $\begin{array}{r}349 \\
10 \\
18 \\
26\end{array}$ & $\begin{array}{r}5 \\
9 \\
17 \\
20\end{array}$ & $\begin{array}{r}2 \\
14 \\
17 \\
19\end{array}$ & & $\begin{array}{r}2 \\
17 \\
18 \\
18\end{array}$ & $\begin{array}{l}1 \\
- \\
9 \\
-\end{array}$ & 2.02 & n.s. \\
\hline Mackerel & $\begin{array}{l}\mathrm{n} \\
\min \\
\text { median } \\
\max \end{array}$ & $\begin{array}{r}264 \\
22 \\
30 \\
40\end{array}$ & $\begin{array}{l}79 \\
22 \\
29 \\
40\end{array}$ & $\begin{array}{l}80 \\
23 \\
30 \\
40\end{array}$ & $\begin{array}{l}48 \\
24 \\
32 \\
39\end{array}$ & $\begin{array}{r}1 \\
- \\
24 \\
-\end{array}$ & $\begin{array}{r}7 \\
25 \\
28 \\
29\end{array}$ & & 18.13 & *** \\
\hline Scad & $\begin{array}{l}\mathrm{n} \\
\text { min } \\
\text { median } \\
\max \end{array}$ & $\begin{array}{r}193 \\
8 \\
27 \\
36\end{array}$ & $\begin{array}{r}102 \\
8 \\
27 \\
35\end{array}$ & $\begin{array}{l}28 \\
17 \\
24 \\
35\end{array}$ & $\begin{array}{l}32 \\
19 \\
31 \\
35\end{array}$ & $\begin{array}{r}1 \\
- \\
24 \\
-\end{array}$ & & & 12.59 & $* *$ \\
\hline
\end{tabular}


Table 4.6.45 Minimum, median and maximum of fish length $(\mathrm{cm})$ for the ten most abundant experimental discards in November 1994 (see table 4.6.42 for conventions).

\begin{tabular}{|c|c|c|c|c|c|c|c|c|c|c|}
\hline & & fered & sunk & Ful & Gan & $\mathrm{HG}$ & GBG & Kit & ANOVA & $p$ \\
\hline Herring & $\begin{array}{l}\mathrm{n} \\
\text { min } \\
\text { median } \\
\max \end{array}$ & $\begin{array}{r}867 \\
8 \\
16 \\
33\end{array}$ & $\begin{array}{r}137 \\
10 \\
21 \\
28\end{array}$ & $\begin{array}{l}23 \\
13 \\
23 \\
33\end{array}$ & $\begin{array}{r}56 \\
9 \\
25 \\
32\end{array}$ & $\begin{array}{r}126 \\
11 \\
23 \\
31\end{array}$ & $\begin{array}{l}19 \\
10 \\
23 \\
28\end{array}$ & $\begin{array}{r}388 \\
9 \\
14 \\
25\end{array}$ & 292.5 & $* * *$ \\
\hline Sprat & $\begin{array}{l}\mathrm{n} \\
\text { min } \\
\text { median } \\
\max \end{array}$ & $\begin{array}{r}779 \\
6 \\
12 \\
19\end{array}$ & $\begin{array}{r}164 \\
6 \\
13 \\
15\end{array}$ & $\begin{array}{l}14 \\
10 \\
14 \\
15\end{array}$ & $\begin{array}{r}51 \\
6 \\
12 \\
14\end{array}$ & $\begin{array}{l}66 \\
10 \\
12 \\
15\end{array}$ & $\begin{array}{r}32 \\
6 \\
14 \\
15\end{array}$ & $\begin{array}{r}434 \\
9 \\
12 \\
19\end{array}$ & 18.2 & $* *$ \\
\hline Haddock & $\begin{array}{l}\mathrm{n} \\
\text { min } \\
\text { median } \\
\max \end{array}$ & $\begin{array}{r}887 \\
9 \\
16 \\
40\end{array}$ & $\begin{array}{r}169 \\
10 \\
21 \\
38\end{array}$ & $\begin{array}{l}42 \\
10 \\
16 \\
37\end{array}$ & $\begin{array}{r}106 \\
14 \\
28 \\
40\end{array}$ & $\begin{array}{r}160 \\
9 \\
18 \\
31\end{array}$ & $\begin{array}{l}41 \\
12 \\
26 \\
34\end{array}$ & $\begin{array}{r}255 \\
10 \\
14 \\
24\end{array}$ & 286.6 & $* * *$ \\
\hline Whiting & $\begin{array}{l}\mathrm{n} \\
\min \\
\text { median } \\
\max \end{array}$ & $\begin{array}{r}1585 \\
7 \\
20 \\
42\end{array}$ & $\begin{array}{r}175 \\
7 \\
22 \\
33\end{array}$ & $\begin{array}{l}48 \\
10 \\
18 \\
31\end{array}$ & $\begin{array}{r}202 \\
10 \\
25 \\
36\end{array}$ & $\begin{array}{r}426 \\
11 \\
21 \\
32\end{array}$ & $\begin{array}{r}109 \\
12 \\
22 \\
34\end{array}$ & $\begin{array}{r}351 \\
7 \\
16 \\
30\end{array}$ & 54.8 & $* * *$ \\
\hline N. Pout & $\begin{array}{l}\mathrm{n} \\
\text { min } \\
\text { median } \\
\max \end{array}$ & $\begin{array}{r}1042 \\
7 \\
11 \\
32\end{array}$ & $\begin{array}{r}17 \\
9 \\
10 \\
32\end{array}$ & $\begin{array}{r}118 \\
8 \\
10 \\
19\end{array}$ & $\begin{array}{l}15 \\
14 \\
16 \\
17\end{array}$ & $\begin{array}{r}176 \\
8 \\
15 \\
22\end{array}$ & $\begin{array}{r}14 \\
8 \\
11 \\
16\end{array}$ & $\begin{array}{r}644 \\
7 \\
11 \\
21\end{array}$ & 54.8 & $* * *$ \\
\hline G. gurnard & $\begin{array}{l}\mathrm{n} \\
\text { min } \\
\text { median } \\
\max \end{array}$ & $\begin{array}{r}226 \\
13 \\
23 \\
42\end{array}$ & $\begin{array}{l}48 \\
13 \\
22 \\
38\end{array}$ & $\begin{array}{r}6 \\
22 \\
26 \\
33\end{array}$ & $\begin{array}{l}61 \\
15 \\
22 \\
34\end{array}$ & $\begin{array}{l}19 \\
15 \\
18 \\
28\end{array}$ & $\begin{array}{l}11 \\
18 \\
23 \\
27\end{array}$ & $\begin{array}{r}2 \\
15 \\
20 \\
25\end{array}$ & 18.5 & ** \\
\hline Dab & $\begin{array}{l}\mathrm{n} \\
\text { min } \\
\text { median } \\
\max \end{array}$ & $\begin{array}{r}190 \\
10 \\
18 \\
33\end{array}$ & $\begin{array}{r}151 \\
10 \\
18 \\
33\end{array}$ & $\begin{array}{r}1 \\
- \\
14 \\
-\end{array}$ & $\begin{array}{r}1 \\
- \\
19 \\
-\end{array}$ & $\begin{array}{l}11 \\
12 \\
14 \\
20\end{array}$ & $\begin{array}{r}3 \\
15 \\
15 \\
20\end{array}$ & $\begin{array}{r}3 \\
12 \\
18 \\
18\end{array}$ & 3.6 & n.s. \\
\hline LR dab & $\begin{array}{l}\mathrm{n} \\
\text { min } \\
\text { median } \\
\max \end{array}$ & $\begin{array}{r}229 \\
5 \\
15 \\
29\end{array}$ & $\begin{array}{r}139 \\
9 \\
15 \\
29\end{array}$ & $\begin{array}{r}12 \\
9 \\
14 \\
18\end{array}$ & $\begin{array}{l}10 \\
17 \\
19 \\
24\end{array}$ & $\begin{array}{l}25 \\
12 \\
15 \\
19\end{array}$ & $\begin{array}{r}5 \\
15 \\
17 \\
22\end{array}$ & $\begin{array}{r}10 \\
5 \\
11 \\
16\end{array}$ & 37.8 & $* * *$ \\
\hline Mackerel & $\begin{array}{l}\mathrm{n} \\
\text { min } \\
\text { median } \\
\max \end{array}$ & $\begin{array}{r}187 \\
20 \\
27 \\
40\end{array}$ & $\begin{array}{l}79 \\
22 \\
29 \\
40\end{array}$ & $\begin{array}{l}80 \\
23 \\
30 \\
40\end{array}$ & $\begin{array}{l}48 \\
24 \\
32 \\
39\end{array}$ & $\begin{array}{r}1 \\
- \\
24 \\
-\end{array}$ & $\begin{array}{r}7 \\
25 \\
28 \\
29\end{array}$ & & 4.1 & n.s. \\
\hline Scad & $\begin{array}{l}\mathrm{n} \\
\text { min } \\
\text { median } \\
\max \end{array}$ & $\begin{array}{r}179 \\
7 \\
23 \\
39\end{array}$ & $\begin{array}{r}39 \\
7 \\
10 \\
34\end{array}$ & $\begin{array}{r}1 \\
- \\
-\end{array}$ & $\begin{array}{r}38 \\
9 \\
24 \\
33\end{array}$ & $\begin{array}{r}2 \\
20 \\
27 \\
34\end{array}$ & $\begin{array}{r}1 \\
- \\
20 \\
-\end{array}$ & $\begin{array}{r}23 \\
7 \\
10 \\
11\end{array}$ & 33.36 & $* * *$ \\
\hline
\end{tabular}


Table 4.6.46 Frequency of robbing of experimentally discarded items by one bird from another; combined data for all North Sea experimental discarding sessions in each of the surveys. $n=$ sample size. Differences between length choices were tested by Kruskal-Wallis 1-way ANOVA.

\begin{tabular}{|c|c|c|c|c|c|c|c|c|c|c|c|}
\hline \multirow{2}{*}{$\begin{array}{l}\text { Discard } \\
\text { length } \\
\text { (cm) }\end{array}$} & \multirow{2}{*}{$1+$} & \multirow[b]{2}{*}{$2+$} & \multicolumn{5}{|c|}{$\begin{array}{r}\text { Number of birds handling fish } \\
\text { before it is swallowed }\end{array}$} & \multirow[b]{2}{*}{$1 \mathrm{st}$} & \multicolumn{3}{|c|}{$\begin{array}{r}\text { Percent stolen of items } \\
\text { handled by }\end{array}$} \\
\hline & & & $3+$ & $4+$ & $5+$ & $6+$ & $7+$ & & $2 n d$ & $3 r d$ & 4 th \\
\hline \multicolumn{12}{|c|}{ February 1993} \\
\hline$<10$ & 313 & 16 & 2 & 0 & 0 & 0 & 0 & 5 & 12 & 0 & 0 \\
\hline $11-15$ & 1245 & 68 & 11 & 4 & 1 & 0 & 0 & 6 & 16 & 36 & 25 \\
\hline $16-20$ & 1743 & 245 & 70 & 25 & 12 & 5 & 3 & 14 & 29 & 36 & 48 \\
\hline $21-25$ & 820 & 269 & 105 & 35 & 14 & 4 & 1 & 33 & 39 & 33 & 40 \\
\hline $26-30$ & 526 & 171 & 72 & 30 & 12 & 5 & 2 & 33 & 42 & 42 & 40 \\
\hline$>31$ & 288 & 88 & 32 & 12 & 8 & 3 & 2 & 31 & 36 & 38 & 67 \\
\hline \multicolumn{12}{|c|}{ May 1994} \\
\hline$<11$ & 226 & 1 & 0 & 0 & 0 & 0 & 0 & 0.4 & 0 & 0 & 0 \\
\hline $11-15$ & 2243 & 69 & 13 & 3 & 2 & 1 & 0 & 3.1 & 18.8 & 23.1 & 66.7 \\
\hline $16-20$ & 2043 & 256 & 58 & 26 & 16 & 5 & 2 & 12.5 & 22.7 & 44.8 & 61.5 \\
\hline $21-25$ & 1758 & 484 & 163 & 66 & 30 & 14 & 9 & 27.5 & 33.7 & 40.5 & 45.5 \\
\hline $26-30$ & 886 & 266 & 105 & 49 & 26 & 18 & 13 & 30.0 & 39.5 & 46.7 & 53.1 \\
\hline$>30$ & 207 & 84 & 25 & 11 & 7 & 3 & 2 & 40.6 & 29.8 & 44.0 & 63.6 \\
\hline \multicolumn{12}{|c|}{ August 1994} \\
\hline$<11$ & 313 & 15 & 2 & 1 & 0 & 0 & 0 & 4.7 & 13.3 & 50.0 & \\
\hline $11-15$ & 654 & 63 & 13 & 3 & 0 & 0 & 0 & 9.6 & 20.6 & 23.1 & 0 \\
\hline $16-20$ & 1038 & 143 & 31 & 13 & 4 & 2 & 1 & 13.8 & 21.7 & 41.9 & 30.8 \\
\hline $21-25$ & 1216 & 335 & 84 & 31 & 15 & 9 & 3 & 27.6 & 25.1 & 36.9 & 48.4 \\
\hline $26-30$ & 773 & 235 & 53 & 26 & 9 & 6 & 1 & 30.4 & 22.6 & 49.1 & 34.6 \\
\hline$>30$ & 318 & 79 & 24 & 7 & 3 & 3 & 1 & 24.8 & 30.4 & 29.2 & 42.9 \\
\hline \multicolumn{12}{|c|}{ Vovember 1994} \\
\hline$<11$ & 699 & 14 & 0 & 0 & 0 & 0 & 0 & 2.0 & 0 & 0 & 0 \\
\hline $11-15$ & 1694 & 86 & 13 & 1 & 0 & 0 & 0 & 5.1 & 15.1 & 7.7 & 0 \\
\hline $16-20$ & 1180 & 168 & 32 & 4 & 2 & 2 & 0 & 14.3 & 19.1 & 12.5 & 50.0 \\
\hline $21-25$ & 748 & 242 & 96 & 35 & 16 & 4 & 1 & 32.4 & 39.7 & 36.5 & 45.7 \\
\hline $26-30$ & 488 & 180 & 67 & 23 & 1 & 1 & 0 & 36.9 & 37.2 & 34.3 & 4.4 \\
\hline$>30$ & 180 & 51 & 26 & 10 & 5 & 2 & 0 & 28.3 & 60.0 & 38.5 & 50.0 \\
\hline
\end{tabular}




\subsection{KLEPTOPARASITISM AMONG SCAVENGING SEABIRDS}

Discharges of fishery waste from fishing vessels attract scavenging seabirds which compete for preferred items. For several species of seabirds, the preferred size and/or type of the discarded items overlaps and because the numbers of ship-followers are often high, competition for scraps is often severe. In the competition for the food resources provided by fishing boats some seabirds are more successful than others as shown by the success indices (chapter 4.6). There are a variety of strategies for obtaining discards. A small species such as the kittiwake relies on speed and agility to get to a (small) discarded item first (Camphuysen 1993b, 1994b). Some species feed on the periphery of feeding flocks, away from the heaviest fights, for others, such as Great Black-backed Gulls and Great Skuas, the most obvious competitive strategy is kleptoparasitism (Hudson 1989, Hudson \& Furness 1989). In this chapter the interactions between scavenging seabirds are analysed to investigate the dominance hierarchy in which some species suffer more from kleptoparasitism than others. Robbery indices (R.I., i.e. number of discards stolen from a species divided by the number of discards stolen by that species) were calculated indicating the success of seabirds as kleptoparasites.

\section{Handling of discards and offal by seabirds} Nearly $15 \%$ of roundfish discards eaten by seabirds were stolen from or lost by the first bird to pick up the item (table 4.7.1). Similarly, c. $22 \%$ of the flatfish discards picked up were stolen from or lost by the first bird to handle the fish (table 4.7.2). In contrast, virtually all the offal was swallowed by the first bird to pick up the item (table 4.7.3). For each bird species, consumption rates of discards are highest for sizes considerably smaller than the maximum size which can be swallowed. Large fish are more difficult to swallow, therefore requiring a longer hand- ling time (Hudson 1989) so it may be advantageous to select a slightly smaller fish. Increased handling time increases the chances of a fish being stolen before it can be swallowed. Roundfish less than $15 \mathrm{~cm}$ long were almost invariably swallowed by the first bird to pick the fish up (table 4.7.1) whereas one in four fish longer than $20 \mathrm{~cm}$ were lost (either dropped or stolen). Similarly, one in four flatfish of more than $6 \mathrm{~cm}$ width were stolen. Handling times vary between types of prey and of the four categories, flatfish were most frequently handled by more than one bird before being consumed. As said, offal was very rarely lost by the first bird, although large pieces may be torn apart by several birds.

\section{Interspecific interactions (1): kleptoparasitism}

The frequency with which items are stolen also varies among bird species. Species can be ranked in competitiveness according to the robbery index. For all discarded items, 3181 cases of kleptoparasitism were recorded (table 4.7.4). Most interactions were among Fulmars (986 items stolen), Gannets stealing from Fulmars (429 items), among Kittiwakes (362 items), Herring Gulls stealing from Kittiwakes (174 items), Great Blackbacked Gulls stealing from Kittiwakes (173 items) and among Gannets (148 items). Gannet, Great Black-backed Gull and Great Skua are consistently the most successful kleptoparasites while Kittiwake and Fulmar are the most vulnerable (table 4.7.5). Ignoring interactions between individuals of the same species, it was found that Gannets were capable of stealing 18 times more items from other birds than were lost by them through robbery (R.I. 17.9). On the other hand, Kittiwakes and Fulmars were robbed on 376 and 878 occasions respectively and obtained only 25 and 133 items respectively as kleptoparasites of other species (R.I. 0.1 and 0.2 respectively). There was some variation between seasons, regions and prey types and the species with moderate robbery indices, Herring Gull and 
Table 4.7.1 Frequency of robbing of experimentally discarded roundfish by one bird from another; combined data for all North Sea experimental discarding sessions.

\begin{tabular}{|c|c|c|c|c|c|c|c|c|c|c|c|c|c|}
\hline \multirow[t]{2}{*}{$\begin{array}{l}\text { length } \\
(\mathrm{cm})\end{array}$} & \multirow[t]{2}{*}{$\begin{array}{r}\text { sample } \\
\text { size }\end{array}$} & \multicolumn{6}{|c|}{$\begin{array}{l}\text { Number of birds handling } \\
\text { roundfish before swallowing }\end{array}$} & \multicolumn{6}{|c|}{$\begin{array}{l}\text { Percent of roundfish handled } \\
\text { before swallowed by birds }\end{array}$} \\
\hline & & 1 & 2 & 3 & 4 & 5 & $>5$ & $1 x$ & $2 x$ & $3 x$ & $4 x$ & $5 x$ & $>5 x$ \\
\hline$<11$ & 1376 & 1358 & 16 & 1 & 1 & 0 & 0 & 98.7 & 1.2 & 0.1 & 0.1 & 0 & 0 \\
\hline $11-15$ & 5308 & 5135 & 148 & 17 & 7 & 0 & 1 & 96.7 & 2.8 & 0.3 & 0.1 & 0 & 0 \\
\hline $16-20$ & 5148 & 4594 & 428 & 76 & 29 & 13 & 8 & 89.2 & 8.3 & 1.5 & 0.6 & 0.3 & 0.2 \\
\hline $21-25$ & 3543 & 2583 & 665 & 193 & 64 & 28 & 10 & 72.9 & 18.8 & 5.4 & 1.8 & 0.8 & 0.3 \\
\hline $26-30$ & 1715 & 1110 & 406 & 122 & 45 & 14 & 18 & 64.7 & 23.7 & 7.1 & 2.6 & 0.8 & 1.0 \\
\hline$>30$ & 639 & 434 & 142 & 41 & 10 & 8 & 4 & 67.9 & 22.2 & 6.4 & 1.6 & 1.3 & 0.6 \\
\hline total & 17729 & 15214 & 1805 & 450 & 156 & 63 & 41 & 85.8 & 10.2 & 2.5 & 0.9 & 0.4 & 0.2 \\
\hline
\end{tabular}

Table 4.7.2 Frequency of robbing of experimentally discarded flatfish by one bird from another; combined data for all North Sea experimental discarding sessions.

\begin{tabular}{|c|c|c|c|c|c|c|c|c|c|c|c|c|c|}
\hline \multirow[t]{2}{*}{$\begin{array}{l}\text { width } \\
\text { (cm) }\end{array}$} & \multirow[t]{2}{*}{$\begin{array}{r}\text { sample } \\
\text { size }\end{array}$} & \multicolumn{7}{|c|}{$\begin{array}{l}\text { Number of birds handling } \\
\text { flatfish before swallowing }\end{array}$} & \multicolumn{5}{|c|}{$\begin{array}{l}\text { Percent of flatfish handled } \\
\text { before swallowed by birds }\end{array}$} \\
\hline & & 1 & 2 & 3 & 4 & 5 & $>5$ & $1 x$ & $2 x$ & $3 x$ & $4 x$ & $5 x$ & $>5 x$ \\
\hline$<3.0$ & 22 & 21 & 1 & 0 & 0 & 0 & 0 & 95.5 & 4.5 & 0 & 0 & 0 & 0 \\
\hline $3.0-5.9$ & 257 & 203 & 39 & 12 & 1 & 2 & 0 & 79.0 & 15.2 & 4.7 & 0.4 & 0.8 & 0 \\
\hline $6.0-8.9$ & 204 & 156 & 37 & 8 & 1 & 1 & 1 & 76.5 & 18.1 & 3.9 & 0.5 & 0.5 & 0.5 \\
\hline$\geq 9.0$ & 10 & 5 & 3 & 2 & 0 & 0 & 0 & 50.0 & 30.0 & 20.0 & 0 & 0 & 0 \\
\hline total & 493 & 385 & 80 & 22 & 2 & 3 & 1 & 78.1 & 16.2 & 4.5 & 0.4 & 0.6 & 0.2 \\
\hline
\end{tabular}

Table 4.7.3 Frequency of robbing of experimentally discarded items by one bird from another; combined data for all North Sea experimental discarding sessions.

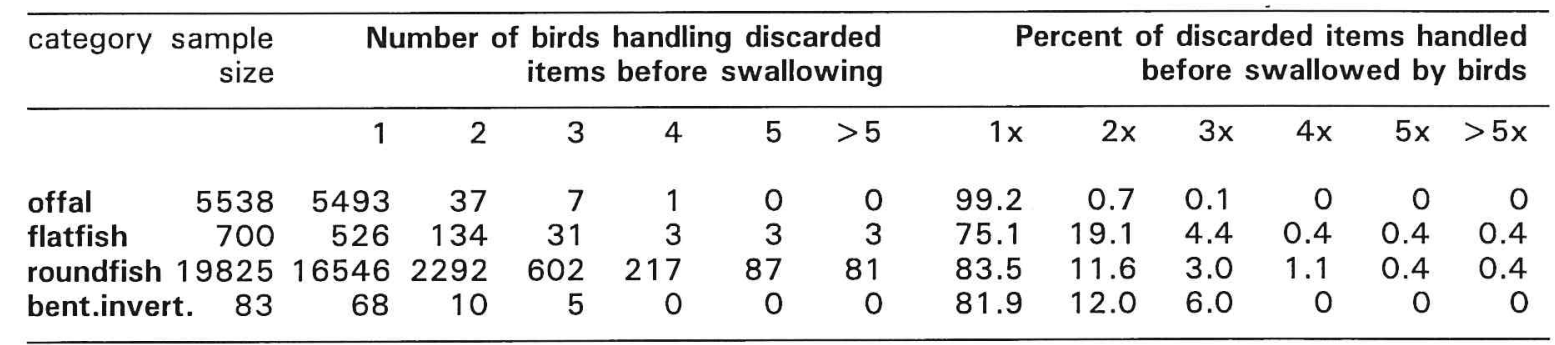


Lesser Black-backed Gull, were the most variable in terms of 'robbing success' (tables 4.7.6-8), which probably depended on the relative abundance of other species present. Herring Gulls were most successful in November, perhaps because Gannets and Great Skuas were less numerous during experimental discarding than at other times of year. In summer, Herring gulls were scarce as scavengers and lost more fish than they gained while Lesser Black-backs were common and just as successful as Great Blackbacked Gulls in stealing fish. Fulmars, although losing many more whole fish than they steal, were more successful in stealing offal. However, the number of kleptoparasitic interactions is small as offal is usually swallowed immediately.

\section{Interspecific interactions (2):}

items dropped

Some 2106 items were simply dropped by birds, without evidence of other birds attempting to steal the item. Fish were dropped because the species was not desirable, because the fish was too large, because grip was simply lost during take off, or for unknown reasons. Kittiwakes dropped more fish than they lost through robbery (compare tables 4.7.4 and 4.7.9). Ranking the feeding success of seabirds considering the items that were picked up after being dropped by others, it appears that Kittiwakes were least successful and Great Black-backed Gulls were most successful in picking up items that were dropped (table 4.7.10). Great Skuas, highly successful kleptoparasites, took only few fish that were simply dropped by other birds. These results further illustrate the fact that Kittiwakes were selecting items which they could immediately swallow, obtained by rapid actions near the ship. For Kittiwakes it was not profitable to face direct competition with larger scavengers and they largely avoided the intense fights. If a fish was lost for whatever reason, these gulls seldom attempted to pick it up again.

\section{Conclusions}

The results demonstrate that the scavenging seabird species in the North Sea have different abilities when competing for food. Small species such as Kittiwake have to catch and swallow prey items rapidly to avoid interactions with other, physically stronger species. If these small species do not succeed with this strategy they will often lose their prey to the species ranking higher in dominance hierarchy. Temporal and spatial effects influence the robbery index somewhat, but not decisively. Generally, the largest species rank highest in the robbery index with Gannet and Great Black-backed Gulls being least vulnerable to robbery. For these species kleptoparasitism is an effective strategy for obtaining food. The Kittiwake, on the other hand, as the smallest of the common scavengers, is rarely successful in stealing food from other species and very vulnerable to kleptoparasitic attacks by Herring Gulls, Fulmars, Gannets and Great Black-backed Gulls. Since the species highest in competition, Gannet, Great Black-backed Gull and Great Skua, are virtually absent during spring and summer in regions $C E$ and $S$, weaker species such as Fulmar and Kittiwake achieve higher values in the robbery index in these regions. The implication of these dominance hierarchies is, that a reduction in total quantities of discards produced and discharged in commercial fisheries will probably lead to a higher frequency of kleptoparasitic interactions. Hence, reduced success rates of species with a low robbery index such as Kittiwake, other small gulls and Fulmar should be anticipated. 
Table 4.7.4 Frequencies of interactions between scavenging seabirds during experimental discarding (1): occurrence of kleptoparasitism. Robbery indices (R.I.) are the number of discards stolen from a species divided by the number of discards stolen by that species.

\begin{tabular}{|c|c|c|c|c|c|c|c|c|c|c|c|c|c|c|}
\hline \multirow[b]{2}{*}{$\mathbf{s}$} & \multirow[b]{2}{*}{ Ful } & \multirow{2}{*}{$\begin{array}{r}\text { Ful } \\
986\end{array}$} & \multirow{2}{*}{$\frac{\text { Gan }}{429}$} & \multicolumn{2}{|c|}{$\begin{array}{l}\text { stolen by } \\
\text { GSk BHG }\end{array}$} & \multirow{2}{*}{$\begin{array}{r}\text { CG } \\
0\end{array}$} & \multirow{2}{*}{$\begin{array}{r}\text { LBG } \\
73\end{array}$} & \multirow{2}{*}{$\begin{array}{r}\text { HG } \\
82\end{array}$} & \multirow{2}{*}{$\frac{\mathbf{G G}}{0}$} & \multirow{2}{*}{$\begin{array}{r}\text { GBG } \\
173\end{array}$} & \multirow{2}{*}{$\begin{array}{c}\text { Kit } \\
17\end{array}$} & \multirow{2}{*}{$\begin{array}{r}\text { CT } \\
0\end{array}$} & \multirow{2}{*}{$\frac{\Sigma}{1864}$} & \multirow{2}{*}{$\begin{array}{l}\text { R.I. } \\
0.6\end{array}$} \\
\hline & & & & 104 & 0 & & & & & & & & & \\
\hline$t$ & Gan & 16 & 148 & 1 & 0 & 0 & 0 & 2 & 0 & 8 & 0 & 0 & 175 & 3.6 \\
\hline 0 & GSk & 2 & 8 & 12 & 0 & 0 & 0 & 0 & 0 & 2 & 0 & 0 & 24 & 5.0 \\
\hline I & BHG & 0 & 0 & 0 & 0 & 0 & 0 & 0 & 0 & 0 & 0 & 0 & 0 & \\
\hline e & CG & 1 & 0 & 0 & 0 & 0 & 0 & 0 & 0 & 1 & 0 & 0 & 2 & \\
\hline \multirow[t]{2}{*}{ n } & LBG & 7 & 1 & 1 & 0 & 0 & 79 & 4 & 0 & 16 & 0 & 0 & 108 & 1.5 \\
\hline & HG & 9 & 15 & 1 & 0 & 0 & 4 & 93 & 1 & 58 & 7 & 0 & 188 & 1.9 \\
\hline$f$ & GG & 0 & 0 & 0 & 0 & 0 & 0 & 1 & 0 & 0 & 0 & 0 & 1 & \\
\hline$r$ & GBG & 4 & 10 & 2 & 0 & 0 & 0 & 7 & 0 & 56 & 0 & 0 & 79 & 4.9 \\
\hline o & Kit & 94 & 20 & 0 & 1 & 3 & 11 & 174 & 0 & 73 & 362 & 0 & 738 & 0.5 \\
\hline \multirow[t]{2}{*}{$\mathrm{m}$} & CT & 0 & 0 & 0 & 0 & 1 & 0 & 0 & 0 & 0 & 1 & 0 & 2 & \\
\hline & $\Sigma$ & 1119 & 631 & 121 & 1 & 4 & 167 & 363 & 1 & 387 & 387 & & 3181 & \\
\hline
\end{tabular}

Table 4.7.5 Frequencies of interactions between scavenging seabirds during experimental discarding (2): dominance hierarchy as shown by robbery indices (R.I.).

\begin{tabular}{|c|c|c|c|c|c|c|c|c|c|c|c|}
\hline \multirow[b]{2}{*}{ s } & & \multicolumn{4}{|c|}{ stolen by } & \multirow[b]{2}{*}{ HG } & \multirow[b]{2}{*}{ Ful } & \multirow[b]{2}{*}{ Kit } & \multirow[b]{2}{*}{ other } & \multirow[b]{2}{*}{$\Sigma$} & \multirow[b]{2}{*}{ R.I. } \\
\hline & & Gan & GBG & GSk & LBG & & & & & & \\
\hline 0 & Gan & & 8 & 1 & 0 & 2 & 16 & 0 & 0 & 27 & 17.9 \\
\hline I & GBG & 10 & & 2 & 0 & 7 & 4 & 0 & 0 & 23 & 14.4 \\
\hline e & GSk & 8 & 2 & & 0 & 0 & 2 & 0 & 0 & 12 & 9.1 \\
\hline \multirow[t]{2}{*}{$\mathrm{n}$} & LBG & 1 & 16 & 1 & & 4 & 7 & 0 & 0 & 29 & 3.0 \\
\hline & HG & 15 & 58 & 1 & 4 & & 9 & 7 & 1 & 95 & 2.8 \\
\hline$f$ & Ful & 429 & 173 & 104 & 73 & 82 & & 17 & 0 & 878 & 0.2 \\
\hline$r$ & Kit & 20 & 73 & 0 & 11 & 174 & 94 & & 4 & 376 & 0.1 \\
\hline 0 & others & 0 & 1 & 0 & 0 & 1 & 1 & 1 & & 4 & \\
\hline $\mathrm{m}$ & $\Sigma$ & 483 & 331 & 109 & 88 & 270 & 133 & 25 & 5 & 1444 & \\
\hline
\end{tabular}


Table 4.7.6 Robbery index (number of experimental discards stolen by this species divided by the number of experimental discards stolen from this species) for roundfish and different regions during all experimental discarding sessions. Values are only listed for species with at least 5 interactions.

\begin{tabular}{|c|c|c|c|c|c|c|c|c|}
\hline species & $\begin{array}{r}\text { regions } \\
\text { all }\end{array}$ & NW & NE & Sk & CW & C & CE & $\mathbf{S}$ \\
\hline Gannet & 18.5 & 23.0 & 3.5 & - & 23.6 & $\infty$ & - & - \\
\hline Great Black-backed Gull & 12.4 & 5.8 & 20.5 & $\infty$ & 35.0 & 18.3 & 19.0 & $\infty$ \\
\hline Great Skua & 10.2 & 11.4 & 7.0 & - & - & - & - & - \\
\hline Lesser Black-backed Gull & 3.5 & 8.0 & 6.2 & - & 1.7 & 2.2 & 1.0 & 11.0 \\
\hline Herring Gull & 2.9 & 2.6 & 5.0 & 2.0 & 3.8 & 3.6 & 2.5 & 0.8 \\
\hline Fulmar & 0.1 & 0.1 & 0.2 & - & 0.2 & 0.2 & 0.7 & 0.3 \\
\hline Kittiwake & 0.1 & 0.2 & 0.0 & 0.0 & 0.0 & 0.0 & 0.4 & 0.0 \\
\hline interactions & 1169 & 426 & 163 & 17 & 281 & 207 & 41 & 34 \\
\hline
\end{tabular}

Table 4.7.7 Robbery index (number of experimental discards stolen by this species divided by the number of experimental discards stolen from this species) for roundfish and different seasons during all experimental discarding sessions. Values are only listed for species with at least 5 interactions.

\begin{tabular}{lrrrrr}
\hline species & $\begin{array}{r}\text { seasons } \\
\text { all }\end{array}$ & Feb & May & Aug & Nov \\
\hline Gannet & 18.5 & 7.5 & 20.4 & 43.3 & 3.3 \\
Great Black-backed Gull & 12.4 & 9.3 & 28.7 & 7.5 & 15.5 \\
Great Skua & 10.2 & - & 14.0 & 11.1 & - \\
Lesser Black-backed Gull & 3.5 & - & 1.7 & 8.2 & - \\
Herring Gull & 2.9 & 2.8 & 3.0 & 0.7 & 3.9 \\
Fulmar & 0.1 & 0.4 & 0.1 & 0.0 & 0.1 \\
Kittiwake & 0.1 & 0.1 & 0.1 & 0.0 & 0.0 \\
interactions & 1169 & 376 & 392 & 289 & 112 \\
\hline
\end{tabular}

Table 4.7.8 Robbery index (Number of experimental discards stolen by this species divided by the number of experimental discards stolen from this species) for different prey categories during all experimental discarding sessions. Values are only listed for species with at least 5 interactions.

\begin{tabular}{lrrrr}
\hline species & category & & & \\
& all & roundfish flatfish & offal \\
\hline Gannet & 17.9 & 18.3 & 4.0 & - \\
Great Black-backed Gull & 14.4 & 13.9 & 22.0 & - \\
Great Skua & 9.1 & 9.1 & - & - \\
Lesser Black-backed Gull & 3.0 & 3.2 & 1.0 & - \\
Herring Gull & 2.8 & 3.1 & 2.0 & 0.5 \\
Fulmar & 0.2 & 0.1 & 0.1 & 2.2 \\
Kittiwake & 0.1 & 0.1 & 0.0 & 0.1 \\
interactions & 2877 & 2736 & 88 & 47 \\
\hline
\end{tabular}


Table 4.7.9 Frequencies of interactions between scavenging seabirds during experimental discarding (3): items picked up which were dropped by earlier birds. Feeding success (succ) is indicated as the number of discards dropped by a species divided by the number of dropped discards picked up by that species.

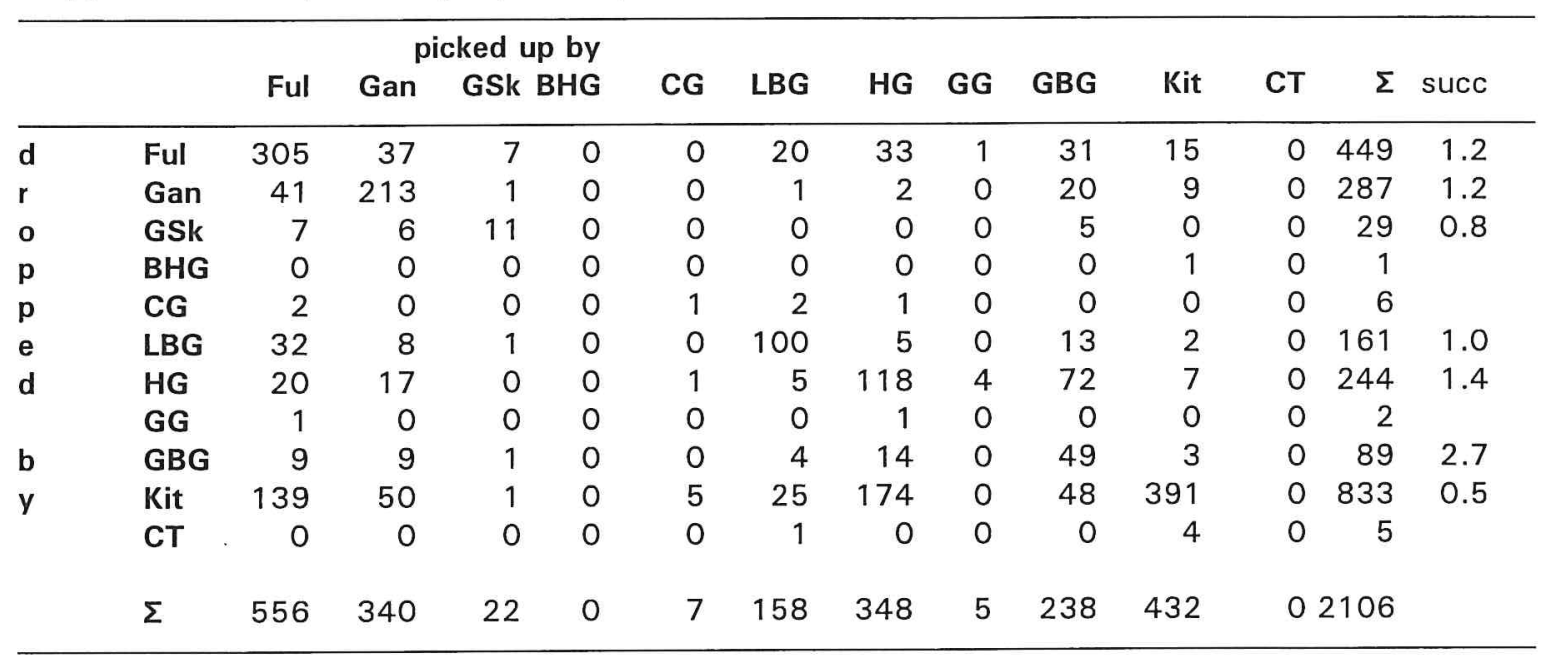

Table 4.7.10 Frequencies of interactions between scavenging seabirds during experimental discarding (4): differences in feeding success as shown by number of discards dropped divided by number of discards picked up.

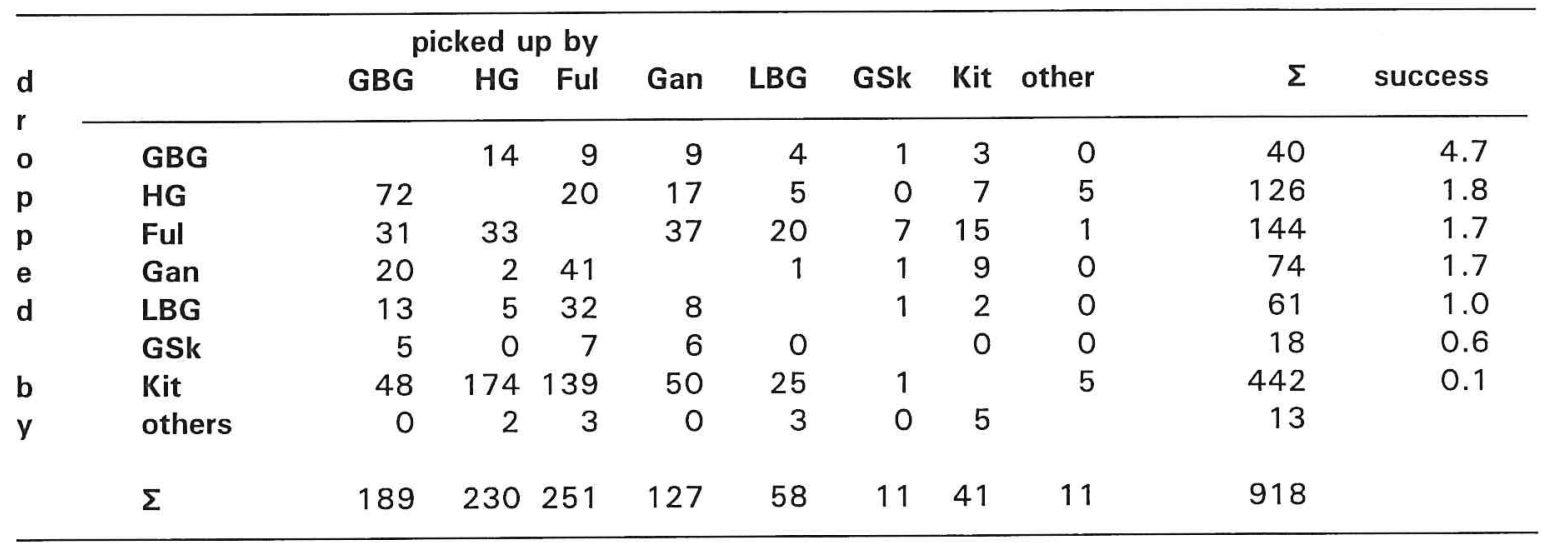




\subsection{DISCARD PRACTICES AND FLEET COMPOSITION}

A great variety of fishing gears is used in North Sea fisheries and the variety of different fishing vessels reflects this. Three different main categories of gears will be discussed in this chapter, including towed gears, surrounding gears, and fixed nets and longlines. Interviews with fishermen were basically meant to obtain a better idea of discard practices in the North Sea (methods as well as quantities). Obviously, from the point of view of a scavenging seabird, a gutting fisherman onboard a tiny little Danish anchor seining vessel could be more interesting than a fleet of vessels in industrial fisheries, which keep everything they catch onboard. Basic questions during these interviews were: what is the type of gear, where is most time spent fishing (inshore/offshore, a rough indication of fishing grounds), are there any significant differences in target species or fishing grounds during the year, does fishing take place both during the day and at night, is fish gutted onboard, and when and how is bycatch discarded. Cooperation from fishermen and fisheries scientists alike varied from enthusiastic, lengthy explanations to reluctant replies. It was aimed to cover the major types of fisheries in the North Sea, and additional information was obtained from scientists working onboard fishing vessels and (official) fleet statistics coupled with own observations in harbours and at sea.

\section{Towed gears (1): beamtrawl}

Several different types of towed gears are used in the North Sea, mainly to catch fish for human consumption. Depending on the front opening of the net, a towed gear is called a beamtrawl or an ordinary trawl (see below). All types of trawling are rather unselective, both with respect to the size and the species of fish caugth, and can therefore be expected to produce much discards.

In beamtraw/ fisheries, a funnel-shaped net is held open by a fixed construction, the beam. Tickler chains are dragged over the seabed in front of the net opening, rousing flatfish out of the soil. Beamtrawler fleets exist in Germany, The Netherlands, Belgium, England and Scotland. Dutch beamtrawlers from more northerly harbours fish mainly in the German Bight and to the north and northwest of the Wadden Sea islands. Beamtrawlers from harbours along the mainland coast of The Netherlands and Belgium mainly fish the south-western part of the North Sea, with principal areas like the Brown Ridge (Blom \& Van der Hak 1993). Scottish fishing is mainly directed off the Scottish east coast (Anon. 1993). Interviews showed that the main fishing grounds of the English beamtrawlers are in the western Central North Sea, but there is also significant effort in the north-east of the Central North Sea.

With the exception of the Scottish fleet, which mainly fish Plaice Pleuronectes platessa and Lemon Sole Microstomus kitt, the main target species are Sole Solea solea and Plaice (Anon. 1993). Common bycatch are Cod, Turbot Scophthalmus maximus, Monkfish Squatina squatina, Brill Scophthalmus rhombus and rays (Anon. 1993). The Dutch beamtrawl fleet, which comprises the majority of the North Sea beamtrawlers, can be divided into two groups; vessels of less than $300 \mathrm{Hp}$, mainly operating within the 12 miles zone and larger vessels operating usually to the south of $55^{\circ} \mathrm{N}$ and occasionally in the northern North Sea, but outside the 12 miles zone (Anon. 1993). A twelve meter beamtrawl is most commonly used gear for catching flatfish by large beamtrawlers. The newest generation of beamtrawlers are very powerful boats (2000 Hp or more) which fish day and night for Sole. Most German beamtrawlers targetting for Sole use lighter gear and mainly fish during the night. Smaller beamtrawlers $(\leq 300 \mathrm{Hp})$ with 4.5 meter beams are used inshore to catch Brown Shrimp Crangon crangon and/or Sole, depending on the availability (De Boer 1984). Large beamtrawlers cannot economically switch to other fisheries, because the operation costs of these vessels are very high. The 
smaller Dutch vessels may participate in other fisheries like otter trawl or pair trawl (Anon. 1993), but small German beamtrawlers tend to catch either Sole or shrimp. Some $80 \%$ of the Dutch shrimpers switch to flatfish fishery during the spawning season when adult Sole begin migrating to the coastal nursery grounds (March-May), the others continue to fish for Brown Shrimp during early summer (De Groot \& Lindeboom 1995). In Germany the situation is much the same (Garthe \& Damm in prep).

During one fishing trip Dutch beamtrawlers generally make four to five fishing days comprising of 50 - 80 fishing hours (Anon. 1993). This implicates nearly 24 hours of fishing per day. As Sole are scarcely available during daytime when using light gear, small German cutters operate primarily in the evening and at night (Garthe \& Damm in prep.). Fishermen interviews and observations by scientists onboard showed that the catch is sorted during towing, which is resumed immediately after the catch is brought on deck. The nets are shot again before the sorting and discarding commences. A haul takes approximately 0.5-2 hours. As fish are sorted and gutted on a conveyor-belt on most cutters, the discards are thrown overboard in a continous trickle. A substantial proportion of the discards fractions consists of benthic invertebrates and flatfish. Roundfish discards are usually rather insignificant and the amount of offal produced onboard beamtrawlers is comparatively small, because most is taken from flatfish (i.e. only about $6.5 \%$ of fish mass; Furness et al. 1988). The total amount of fishery waste produced in beamtrawlers is very large compared to the landed fraction. Estimates ranged from 2-21 kg of fish discarded on each $\mathrm{kg}$ landed Sole and Plaice (Van Beek 1990, Verboom 1991, Camphuysen 1993b, Garthe 1993, Fonds 1994ab; see chapter 6).

Towed gears (2): bottom trawl

Bottom trawls are used by both stern trawlers and otter trawlers. The otter door trawl is an example of those bottom trawls. A funnel-shaped net is pulled open sideways by two otter doors, floats or kites open the net vertically. The otter doors and the lines connecting the doors with the opening of the net drag over the seabed, herding fish towards the net. The regular landings of bottom trawls contain Cod, Haddock, Whiting, Saithe, Plaice and Sole (fishermen interviews, Anon. 1993). A large number of small Norwegian and Danish trawlers use otter door trawl, targetting on Sandeel, Sprat, Blue Whiting and Norway Pout (De Wolf 1990).

Every country adjoining the North Sea is active in bottom trawling and otter door and other demersal trawls are used in all three ICES divisions in the North Sea and in ICES division Illa (Anon. 1993). Interviews showed that the Northern North Sea (ICES division IVa) is exploited primarily by Norwegian, Danish, English and Scottish vessels, whereas the central parts are visited by all North Sea adjoining countries and Dutch and Belgian vessels fish the southern parts. The German bottom trawling is mainly restricted to the eastern part of the North Sea, whereas the English effort is highest along the coast of North-east England. In Britain and Scotland a switch from white fish in summer to prawn and Nephrops in winter appeared to be common (Anon. 1993, fishermen interviews). Danish fishermen stated that during a short summer period a number of bottom trawlers catch Sandeel, the rest of the year target species are Herring, Sprat or Cod. In Scotland a change was made from Sandeel (in summer) to white fish during the rest of the year. As many industrial vessels switch to fish for human consumption in winter, discard quantities will be very variable in bottom trawling.

Usually, in non-industrial bottom trawling, catches are gutted onboard during steaming or towing. A number of different discarding methods were mentioned; in German Cod fishery sorting, gutting and discarding are principally carried out directly after hauling, after which, until the next haul, none of these activities are carried out. Onboard 
many Danish and British vessels the catch is also sorted, gutted and discarded during towing, immediately after the haul. Especially the whitefish trawlers can be expected to produce comparatively large amounts of offal.

Pair trawling can either be demersal or pelagic. Because the power of (at least) two ships is available, and because no otter doors are needed (which produce a lot of resistance), in demersal pair trawling very large nets can be used to catch whitefish (Cod, Haddock and Whiting) and Plaice (De Boer 1984, fishermen interviews). Of these species Whiting is often regarded as bycatch. Although not all interviewed Scottish fishermen stated likewise, many demersal pair trawlers are essentially a component of the demersal trawl fleet, switching from single boat trawling to pair trawling in summer when fish are more difficult to catch and when the weather is usually better (Anon. 1993). In winter German, Dutch and Belgian cutters join in (sometimes) combined pair trawling for Cod in the English Channel and along the Belgian and Dutch coast (Anon. 1993, pers. obs.). According to Danish and Scottish Fishermen their 24 hours per day effort was concentrated all year in the Norwegian sector and West Skagerrak.

All fish is gutted onboard and offal and bycatch are discarded more or less continuously during all activities and all day and night. Whitefish trawlers can be expected to produce comparatively large amounts of offal.

Towed gears (3): pelagic trawls

A detected shoal of pelagic fish is caught by raising or lowering a net to the altitude of the shoal (by either increasing or lowering speed). Pelagic or midwater trawling is caried out by stern or pair trawlers and main target species are Herring, Mackerel and Scad. Very large, modern freezer trawlers are used in this type of fishery. The Dutch pelagic fleet consists of 11 freezer trawlers (Anon. 1993) and several (shrimp) trawlers switch to pair trawling for herring in a part of the year. These vessels may fish anywhere in or outside the North Sea, but a large number of Dutch (and French) freezer trawlers were encountered in the soutern North Sea during the May IBTS. Outside the Netherlands, no pelagic stern or pair trawlers were found by the interviewers. Dutch freezer trawlers do not normally produce discards or offal, because the catch is immediately deep frozen. However, whole catches are occasionally discarded when cold storage tanks for temporary storage of the catch appear to be overloaded. Unwanted species, such as postspawning herring, are discarded also after sorting (Couperus 1993). These fisheries can not be expected to produce offal. Smaller trawlers within the North Sea, which probably mainly catch Herring, cannot be expected to produce offal in significant amounts and their discard practices are uncertain.

\section{Surrounding gears (1): purse seine}

An oblong net, of which the upper string is provided with floats (=floatline), is shot in a circle around a detected shoal of fish. The lower string (=leadline) is provided with rings through which the purse line runs. When the net is closed, a brail or a fish pump is used to bring the fish onboard (De Boer 1984). Purse seines are most frequently used by British, Norwegian and Danish (industrial) fisheries, catching small pelagic fish, like Herring, Mackerel and Pilchard, which live in shoals (De Boer 1984). Fishermen interviews in Denmark and England showed the northern distribution of purse seining (ICES division IVa). The Norwegian sector and the Shetland Islands were mentioned. Norwegian vessels are fishing with purse seine for saithe in the inshore waters of western Norway (Anon. 1993). Danish purse seiners fish in the northern North Sea, in the Skagerrak, but also to the west of Scotland, mainly for Herring and Mackerel. Germany as well as The Netherlands have never been taking part in purse seining. Purse seining is often used in industrial fisheries, which will be the reason why all interviewed English 
fishermen declared that no discards are produced. However, often up to several tonnes of (dead) fish are discarded, when the catch is too big to bring onboard, as Danish fishermen stated. Scientists also noticed an enormous number of seabirds near a fleet of Norwegian industrial vessels. Apparently these birds (mostly Fulmars), gathering in dense concentrations near the stationary vessels, were feeding on organic material in waste water which was returned to the sea when the catch was pumped in. Not being discards in the strict sense, seabirds appeared to forage successfully around purse seiners.

\section{Surrounding gears (2): anchor seine}

A heavy fishline is attached to an anchored buoy and the ship, sailing a triangle, successively shoots the first fishing line, the funnelshaped net and the second fishing line. Back at the buoy the ship anchors after which the two fishlines are pulled in slowly, herding the fish towards the net. Danish seine or anchor seine, a typical Danish development (Snørrevod), is used for demersal fishing (flatfish and Cod). Danish seining is practised by Danish and English fishermen. In Denmark two fisheries can be identified, one for Plaice and one for Cod, Haddock and Plaice (Anon. 1993). In England anchor seining concentrates on Plaice and Cod, with the principal bycatch species being Lemon Sole, Haddock, Spurdog and Whiting. The main area of operation is the central part of the North Sea (ICES Division IVb) (Anon 1993). The catch is predominantly mature because young fish are quickly exhausted and therefore not chased by the lines (De Boer 1984). As a result, the bycatch is comparatively small. The fish is gutted onboard, often while the boat is stationary, and these fisheries can be expected to produce comparatively large amounts of offal.

\section{Surrounding gears (3): scottish seine}

Scottish fishermen use an almost identical method in which the ship does not anchor but slowly tows the gear during the hauling of the net: Scottish seine or fly dragging. Scottish seine also aims at demersal roundfish and therefore has a wider vertical net opening. This fishery is restricted to England and Scotland and the number of vessels active in fly dragging is obviously decreasing (Anon. 1993). Whereas the English are fishing for Cod and Plaice in the central North Sea (ICES division IVb), the Scottish are aiming for Haddock, with significant catches of Cod and Whithing along the east coast of Scotland an around the Shetland Islands (ICES division IVa and IVb) (Anon. 1993). No Scottish seiners were interviewed to obtain an idea of discarding practices.

\section{Fixed nets and long-lining}

Bottom set long line is suitable in areas with rough soil in which trawling is impossible. Drifting long line is the pelagic form of long lining. Long lining aims mainly at adult specimens of large fish species like Cod, Saithe, Ling, Torsk, Skate and Halibut, of which most are living solitary at that age. Because of the northerly distribution of most of these species, these fisheries are mainly practised around Scotland and Norway (in ICES division IVa). Scottish and Norwegian long-liners often use rather small boats (De Boer 1984). England has a long lining fleet with target species Cod, Spurdog, skates and rays (Anon. 1993, fishermen interviews). English long lining is mainly restricted to the inshore waters along the east and northeast English coasts, Norwegian fisheries are mainly directed Norwegian inshore waters (Anon. 1993). Long-liners were not seen during the surveys in 1993 and 1994, probably as a result of identification problems. Long-linging is a selective type of fishery, not catching young fish (De Boer 1984), and therefore offal will comprise the bulk of the fishery waste produced onboard. In Norway fishermen reported that the catch is normally handled below deck, several times a day. As a result, offal was not produced on a regular basis, but with 1-2 hour intervals, depending on the amount of fish. In Britain discarding takes place in the same manner. 
Gill nets and tangle nets are usually set around wrecks to catch Cod. These nets are also used in the spawning areas of Sole and Turbot. In Norwegian, Danish, English and Scottish fisheries gill nets are used. Tangle nets are common in English fisheries, with Cod, Sole, Turbot and Plaice as target species. Some Danish set net fleets fish for Cod during most of the year, others target on Turbot or Sole in the summer period and fish Cod in the rest of the year (Anon. 1993). In contrast to the pattern found by radar counts (chapter 4.4), many fishermen said to exploit inshore waters. According to the interviews, most set net fisheries were directed within 100 nautical miles from the coast, with principal areas such as the Jutland Bank and the Skagerrak. In ICES division IIla Hake Merluccius merluccius, Monkfish and Pollack Pollachius pollachius are target species for Danish gill net fisheries (Anon. 1993). In Germany, The Netherlands and Belgium gill net fisheries are very rare. English and to a lesser extent Scottish gill net fisheries aim for Cod, Dogfish and Hake. Like long-lining, gill-netting is a selective fishery which will therefore not discard many undersized fish. Landed fish are gutted at sea, as usual, and the larger gadids guarantee that the amounts of offal produced in these fisheries are comparatively large. Fishermen confirmed that the amount of bycatch is small, because the meshes used are rather large. The majority of the Danish set netters fish 24 hours per day, but a few only part of the year and are restricted to the coastal zone. Offal as well as bycatch are discarded in a few portions per day.

\section{Fleet information versus sightings of fishing vessels at sea}

At sea observations during surveys in 1993 and 1994 confirmed the common use of beamtrawl, bottom trawl, pelagic trawl, purse seine, gill-nets or tangle nets (set net fisheries), and anchor seines. Long-liners were not seen, but these were probably not recognized or mistaken for set net fishing vessels. Small Norwegian long-liners were probably not overlooked, but the Norwegian inshore waters were poorly surveyed. Large stern- or freezer trawlers were observed in the southern North Sea in August, but such vessels were otherwise scarce or absent.

\section{Conclusions}

The great variety of fishing gears used in the North Sea can be categorised as towed gears, surrounding gears, and fixed nets and long-lines. The most prominent types are beamtrawl (main targets flatfish and shrimp), bottom trawl (otter trawls; main targets gadids, flatfish, industrial fisheries), pelagic or midwater trawl (stern trawlers; main targets Herring, Mackerel and Scad), pair trawlers (main target either demersal, Cod, Haddock and Whiting, or pelagic, Herring), purse seine (main targets small pelagic fish which live in shoals; Herring, Mackerel, Pilchard), anchor seine (flatfish, Cod), Scottish seine (demersal roundfish), long-lines (large Cod, Saithe, Ling, Torsk, Skate, Halibut) and gill nets or tangle nets (Monkfish, Cod, Pollack, Hake, Sole, Turbot, Plaice). Three offshore fisheries generally or occasionally produce large amounts of discards and offal: demersal fisheries for gadids by trawl and seine, pelagic fisheries for clupeids and mackerel, and beamtrawl fisheries. Discards of large freezer trawlers vary enormously, from virtually nothing (only escaped fish) to a total catch comprising up to several tens of tonnes of fish at once. In all commercial fisheries, marketable roundfish and flatfish are normally gutted at sea and the offal is discarded, except in some Norwegian waters where discarding is prohibited. Norwegian fishing vessels have a tendency to keep offal onboard, because a market has been found for livers and entrails of gutted fish. Many fishing vessels sort and gut fish during towing for the next catch, leading to a continues trickle of discards and offal. Discards in industrial fisheries are small and mainly comprise escapes when the net is brought to the surface or while pumping the catch onboard. 


\section{SPECIES ACCOUNTS}

Following the descriptions of results obtained in four cruises in chapter 4 , the species accounts are meant to summarise the most striking results for each of the common scavenging seabirds in the North Sea. Summaries include (1) a brief description of each species, recent estimates of the North Sea breeding population, and a summary of current knowledge with respect to its status as a scavenger at fishing vessels, (2) spatial distribution and relative abundance at sea on the basis of transect counts during this project (chapter 4.1), and estimates of total numbers in the North Sea based on the surveys during this project and the European Seabirds at Sea database (chapter 4.2), (3) its occurrence as a scavenger at the stern of research vessels (chapter 4.3), and numbers associated with fishing vessels (chapter 4.45), and (4) prey selection, feeding efficiency, feeding strategy, and vulnerability to kleptoparasitism at the trawl (chapter 4.6-7).

\subsection{FULMAR FULMARUS GLACIALIS}

Fulmars are medium-sized, strong-billed, bullheaded, robust seabirds seabirds with a wingspan of just more than $100 \mathrm{~cm}$ and a mass of $700-900 \mathrm{~g}$ (Cramp \& Simmons 1977). The boreal population of Fulmars in warmer waters of the eastern North Atlantic has spread and increased markedly during the last 200 years, starting from Iceland and subsequently colonising the Faeroe Islands, the coasts of Britain and Ireland, France, Germany, and Norway (Fisher 1952, Cramp \& Simmons 1977). Spread and increase are described in detail by Fisher $(1952,1966)$ who argued correlation with an increase of offal, first from arctic whaling, then from commercial fisheries. The North Sea breeding population was recently estimated at just over 300,000 pairs (Tasker et al. 1987, Dunnet et al. 1990, Lloyd et al.1991, Tasker \& Becker 1992). Fulmars are well known as scavengers at fishing vessels (e.g. Van der
Heide 1938, Lockley \& Marchant 1951, Fisher 1952, Hillis 1971, Manikowski 1971, Dändliker \& Mülhauser 1988, Hudson \& Furness 1989, Garthe 1993b). The species is abundant around fishing vessels in arctic and subarctic waters, around Iceland, the Faeroe Islands and Scotland, off Norway and in the North Sea. It is also common in the Irish Sea but scarce or absent further south and in the Baltic (Camphuysen 1993a). Hudson \& Furness (1989) found that Fulmars obtained most of the offal discharged from whitefish trawlers around Shetland, excluding other species by their aggression, but that Fulmars usually ignored discarded whole fish. Similarly, Boswall (1960) reported that Fulmars obtained most of the offal which was experimentally discarded from a commercial trawler off northwest Scotland, but also that gulls and Gannets had a distinct advantage over Fulmars when the ship moved. In the southern North Sea, where Fulmars are less abundant, their status as scavengers was much less well known. Fulmars occurred in variable numbers at fishing vessels through the year (Camphuysen 1987, 1993b), particularly in the offshore zone (>50km from the nearest mainland coast). Garthe (1992) found Fulmars around Helgoland in small numbers, both in summer and in winter. Fulmars have an extremely varied diet, which includes fish, zooplankton, and carrion (see Camphuysen 1990 for review). Fulmars breeding on Foula (Shetland) were extensively feeding on sandeels during 1971 80 , while their breeding success was god (Furness 1983). In 1988, when breeding success was poor and while sandeels were largely unavailable for surface feeding birds, Fulmars took mainly discards and offal and sandeel comprised only $3 \%$ ot their diet (Furness 1989).

\section{Fulmars at sea}

Fulmars were abundant and widespread throughout the year, but were particularly numerous in the northwestern two-thirds or three-quarters of the North Sea (subregions NW, NE, CW and C). In fact, in all seasons, 
the species avoided a coastal zone in the southern half of the study area, which was narrow off East England and wide in the German Bight. The Southern Bight was only of importance in February 1993, after a period of violent storms in the preceding month. The proportion of 'coloured' Fulmars (indicating a high arctic origin) was highest in February compared to the other surveys (1.3\% coloured, $n=3939$; table 4.1.5). In May, dense concentrations were encountered in the Norwegian and Danish sectors, between $4^{\circ}$ and $8^{\circ} \mathrm{E}$ (figure 4.1.6). In these latter areas, several groups of hundreds of actively feeding Fulmars. These birds were apparently feeding on zooplankton. In August, moderate to high densities were observed everywhere in the North Sea, except in coastal waters of East England, of the Southern Bight and of the German Bight (figure 4.1.7). The central North Sea was of particular importance for Fulmars in this season. In November, Fulmar distribution was quite uneven, with very large numbers in the northern North Sea (1.4 million birds estimated for subregions NW and NE combined), and low to moderate densities elsewhere (figure 4.1.8). Fulmars were the most abundant species of the eight scavenging seabirds under consideration in this study. Abundance estimates ranged from minima of 700,000 individuals and 800,000 individuals in February and May to maxima of 2.8 million individuals in November and 3.7 million individuals in August (table 4.2.9).

\section{Fulmars at the stern}

Fulmars were the most abundant scavengers at the trawl in most of the North Sea and during most of the year. Peak numbers assembled at the trawl in each of the surveys were in the range of several thousand (2000-2500) Fulmars. Fulmars were not evenly distributed over the entire North Sea. The largest numbers were usually reported in subregions NW, NE, CW and C, whereas moderate to small numbers were found in Sk, CE and S (figures 4.3.5-8). Interestingly, the border-line between large numbers at the trawl and low numbers at the trawl, both during the May, August and November surveys, closely matching the borders between homohaline areas and areas which are stratified throughout the year (Lee 1980), or (in summer) the predicted positions of frontal boundaries which separate water masses in which stratified conditions occur in the central and northern North Sea (large numbers of Fulmars) from the regions that are well mixed (small numbers of Fulmars; see Pingree \& Griffiths 1978).

\section{Fulmars as scavengers}

Fulmars would normally fly around the ship in wide circles or alight on the water at some distance, to approach the vessel as soon as the net appeared near the surface. Fulmars landed near and rapidly swam towards floating fish, trying to scare away other birds with open wings and aggressive attacks. Small roundfish was normally swallowed whole, whereas larger roundfish was usually pecked on to reach liver and intestines. Groups of Fulmars had a strong tendency of disputing single fish while ignoring large quantities floating nearby. To obtain sinking discards, Fulmars were seen to dive up to a few metres deep, but normally only floating discards were consumed. Fulmars were unable to pick up anything while on the wing, which was a serious disadvantage for this species when the ship produced a steady trickle of discards and offal while steaming full speed.

Fulmars are particularly keen on offal and in most subregions and in most seasons Fulmars obtained more items of offal than their numerical abundance predicted. Fulmars and Kittiwakes, the other species which appeared to specialise on offal, took virtually all the offal presented during discard experiments and only when these two species were not present in large numbers did other species obtain more than trivial amounts of offal. Given the tendency for Fulmars to form a higher proportion of the scavenging seabirds at research vessels in summer, it is not surprising that Fulmars took most of the 
Table 5.1 Flatfish selection by common scavenging seabirds (arranged by mass), expressed as median, minimum and maximum body width $(0.5 \mathrm{~cm})$ consumed during experimental discarding. All experiments combined $(n=2647$ flatfish offered, 2414 of which with known fate). At least 400 flatfish of different size classes were offered in the presence of each species. Sample sizes refer to numbers of flatfish consumed by that species.

\begin{tabular}{lcccr}
\hline Species & mass $(\mathbf{g})$ & median width $(\mathbf{c m})$ & range $(\mathbf{c m})$ & sample $(\mathbf{n})$ \\
\hline Kittiwake & $300-500$ & 3.5 & $0.5-6.5$ & 28 \\
Common Gull & $300-500$ & - & - & 1 \\
Fulmar (swallowed) & $700-900$ & 3.5 & $1.0-6.0$ & 57 \\
Fulmar (pecked on) & & 6 & $2.5-11.0$ & 36 \\
Lesser Black-backed Gull & $700-1000$ & 4.5 & $2.5-9.0$ & 80 \\
Herring Gull & $800-1200$ & 5 & $1.5-8.5$ & 67 \\
Great Skua & $1300-1800$ & - & - & - \\
Great Black-backed Gull & $1100-2000$ & 6.5 & $3.0-9.0$ & 62 \\
Gannet & $2800-3200$ & 6.5 & $3.5-11.5$ & 198 \\
\hline
\end{tabular}

Table 5.2 Roundfish selection by common scavenging seabirds (arranged by mass), expressed as median, minimum and maximum total length $(\mathrm{cm})$ consumed during experimental discarding, all experiments combined $I n=25,016$ roundfish offered, 23,389 of which with known fate). At least 4450 roundfish of different size classes were offered in the presence of each species. Sample sizes refer to numbers of roundfish consumed by that species.

\begin{tabular}{lcccr}
\hline Species & mass $(\mathbf{g})$ & median length $(\mathbf{c m})$ & range (cm) & sample (n) \\
\hline Kittiwake & $300-500$ & 15 & $5-34$ & 5675 \\
Common Gull & $300-500$ & 14 & $6-22$ & 71 \\
Fulmar (swallowed) & $700-900$ & 16 & $6-33$ & 4594 \\
Fulmar (pecked on) & & 26 & $11-40$ & 1115 \\
Lesser Black-backed Gull & $700-1000$ & 18 & $6-32$ & 1218 \\
Herring Gull & $800-1200$ & 19 & $7-38$ & 1813 \\
Great Skua & $1300-1800$ & 25 & $10-36$ & 176 \\
Great Black-backed Gull & $1100-2000$ & 24 & $6-38$ & 1083 \\
Gannet & $2800-3200$ & 25 & $6-55$ & 3083 \\
\hline
\end{tabular}


experimentally discarded offal during the summer surveys (485 from 775 items consumed, or 63\% in May and 2973 from 3100 items consumed, or $96 \%$ in August). In winter, when Kittiwake numbers at vessels are much higher, Fulmars took $57 \%$ in February and $20 \%$ in November. In contrast, for experimentally discarded gadids and clupeids, success indices of Fulmars were mostly very low, regardless of subregion or season (tables 4.6.20-23, 4.3.34). In the February survey, Fulmars obtained significantly less discarded gadids than their numbers predicted, in every subregion surveyed (table 4.6.24). This was also true in May in all subregions where Fulmars were present in reasonable numbers and good numbers of gadids were discarded (i.e. excluding $S$ and Sk). In August, Fulmars obtained less gadids than numbers predicted in every subregion, differences being statistically significant in most subregions. In November, Fulmars obtained significantly less gadids than predicted in most subregions. Clearly Fulmars are less able to handle and swallow the gadids discarded than are other scavenging seabirds. With clupeids, Fulmars were equally 'unsuccesful', leading to much smaller numbers of clupeids consumed than expected (table 4.6.34). However, Fulmars were so numerous during most discard experiments, that most small roundfish were in fact consumed by these birds (figures 4.6.16-17). Considering the numbers of gadid discards consumed, Fulmars ranked highest in May and August in subregions NW, NE, CW in August, and $C$ and were the second most important scavengers in $\mathrm{CW}$ in May. With respect to clupeid consumption, Fulmars in May and August ranked highest in the central North Sea and subregion NW, being the second most important consumer in CW. In winter, rather trivial amounts of gadids and clupeids were consumed by Fulmars compared to species like Kittiwakes and Herring Gulls. Flatfish were usually ignored and of 2414 flatfish offered in the presence of Fulmars, only 57 fish were swallowed and another 36 were ripped open to reach and eat the intestines and liver.

Only small flatfish, varying in width between $1 \mathrm{~cm}$ and $6 \mathrm{~cm}$, were swallowed (median width $3.5 \mathrm{~cm}, \mathrm{n}=57$; table 5.1). Larger flatfish (range $2.5-11 \mathrm{~cm}$ width, median $6 \mathrm{~cm}, \mathrm{n}=36$ ) were pecked on only. The median width of flatfish swallowed by Fulmars $(3.5 \mathrm{~cm})$ was considerably less than the median of flatfish offered in their presence $(6.5 \mathrm{~cm}$; figure 5.1 .1$)$. Fulmars swallowed roundfish varying in length between 6 and $33 \mathrm{~cm}$ (median $16 \mathrm{~cm}, \mathrm{n}=4594$; table 5.2). Larger roundfish were only pecked on (ripped open to feed on liver and intestines) and most of these fish probably sunk later. The median length of roundfish which were pecked amounted to $26 \mathrm{~cm}$ (range $11-40 \mathrm{~cm}$, $n=1115)$. Compared to the median length of roundfish offered in the presence of Fulmars (18 cm; figure 5.1.2), swallowed fish were slightly smaller and pecked fish were considerably larger.

Fulmars usually operated in large groups and most fights for discarded fish and particles of offal were among individuals of the same species. Of 3181 fish stolen from one bird by another, nearly 1000 fish were stolen from one Fulmar by another (table 4.7.4). Fulmars were robbed on 878 occasions and obtained only 133 items as kleptoparasites of other species (R.I. 0.2). With such a robbery index, Fulmars must be considered highly vulnerable to robbery, being nearly the lowest in a dominance hierarchy on the basis of this index (table 4.7.5). Fulmars were consistently the second lowest in this hierarchy: in each subregion (table 4.7.6), each of the surveys (table 4.7.7), and for each of the categories of discarded fish (table 4.7.8). A notable exception was its feeding success with respect to offal consumption. Fulmars frequently dropped fish, but were quite successful (i.e. they gained more than they lost) picking up fish that were dropped by others (tables 4.7.9-10).

In conclusion, although one of the species most vulnerable to kleptoparasitism, Fulmars are highly successful scavengers at trawlers 

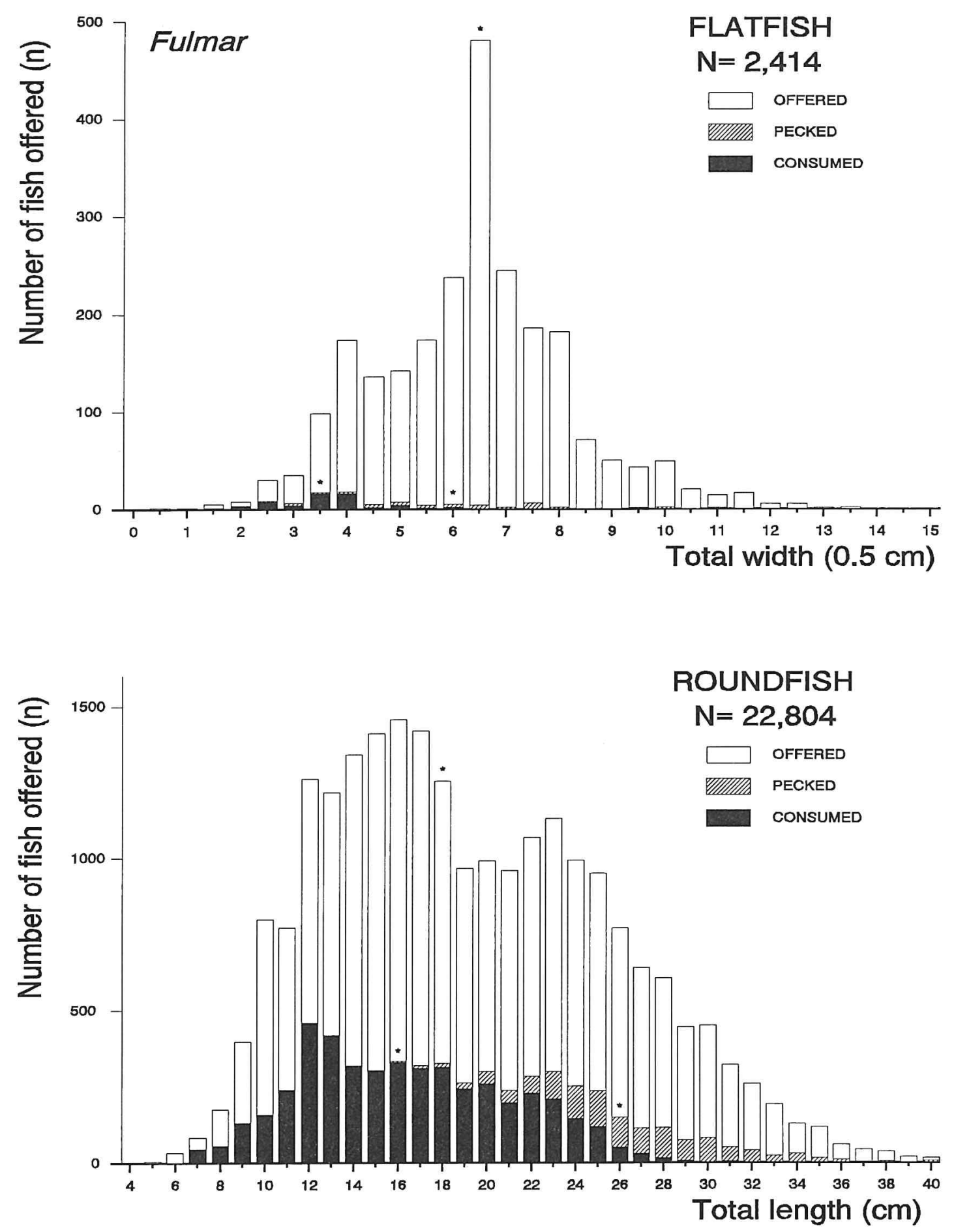

Figure 5.1.1-2 Width $(0.5 \mathrm{~cm})$ of flatfish and length $(1.0 \mathrm{~cm})$ of roundfish consumed (black) or pecked on (shaded) by Fulmars. Offered numbers $(n=2412$ flatfish, 22,804 roundfish) refer to discard experiments in which Fulmars were assembled at the stern. Medians are indicated with an *. 
which apparently obtain substantial proportions of their food in commercial fisheries. Diet studies in colonies indicated that discards and offal are mainly used when natural resources such as sandeel, herring and sprat or zooplankton are not suficiently available. In winter, when zooplankton is not available in large quantities for surface feeding seabirds, discards and offal may have played a significant role in the spread and increase of Fulmar populations during the last odd hundred years or so, by increasing the opportunities to feed under adverse conditions.

\subsection{GANNET MORUS BASSANUS}

Gannets are majestic, long-bodied, spearbilled and also the largest indigenous seabirds in the North Atlantic with a wingspan of nearly 2 metres and a mass of 28003200 g (Cramp \& Simmons 1977). Gannets catch shoaling fish by plunge diving, often from great heights (Nelson 1978, 1980). In contrast to Fulmars, the 'natural' feeding methods of Gannets are spectacular and distract attention from the frequent presence of Gannets as scavengers at fishing vessels. The North Sea breeding population of the Gannet is estimated at nearly 40,000 pairs, most of which breed on Shetland $(17,000)$, Bass Rock (Firth of Forth; 22,000) and Bempton Cliffs (780) (Lloyd et al. 1991). Numbers of Gannets around fishing vessels are usually not very large, compared with many of the scavenging gulls or Fulmars, but Gannets are commonly recorded as scavengers at fishing vessels in the entire Northeast Atlantic region, except in arctic waters (Camphuysen 1993a). Up to 1000 Gannets have been observed at fishing vessels (Manikowski 1971, Dändliker \& Mülhauser 1988), but these records are apparently quite exceptional (cf. Boswall 1960, Hillis 1971, Watson 1981, Dare 1982, Hudson \& Furness 1989, Furness et al. 1992, Garthe 1992, Camphuysen 1993a).From dietary studies of Gannets, conducted mostly during the breeding season, this species was sel- dom labelled as a frequent scavenger (Nelson 1966, 1978, Montevecchi et al. 1988, Martin 1989, Okill 1989). However, observations of Reinsch (1969) and Furness et al. (1992) do indicate that a substantial part of the food of Gannets may be obtained at fishing vessels. Gannets are highly aggressive at the trawl, screaming loudly before diving, and part of their success as scavengers is due to the ability to dive deep for fish which have already sunk (Reinsch 1969, Hudson \& Furness 1989). Furness et al. (1992) concluded that Gannets west of Britain mainly exploit discards in spring, when they reduced the feeding success of and partially displace Herring Gulls from feeding at boats.

\section{Gannets at sea}

For Gannets, the western half of the North Sea was of greatest significance in all seasons (subregions NW, CW and C), and Gannets were normally quite scarce in the Skagerrak and German Bight. In February, moderate to high densities were encountered off the Firth of Forth, low densities occurred in the Southern Bight and Gannets were quite rare to the east of $5^{\circ} \mathrm{E}$. Virtually all Gannets observed in February were adults $197.2 \%$, $n=776$; table 4.1.6). In May, most Gannets were seen in the central North Sea and off the Scottish East coast (table 4.1.2, figure 4.1.10). Important feeding concentrations were found just to the northwest of the Dogger Bank, operating in association with White-beaked Dolphins Lagenorhynchus albirostris and White-sided Dolphins L. acutus, feeding on herring (Camphuysen et al. 1995). This feeding concentration formed the only area in the North Sea where moderate to high densities occurred and was unusual in a sense that the birds foraging in these waters mainly originated from the Bass Rock, over $300 \mathrm{~km}$ away. Remarkably, Gannets ignored fishing vessels and fishing research vessels nearly completely while on transit to this feeding area. In August, low to moderate densities were found in the western half of the North Sea, with occasional 

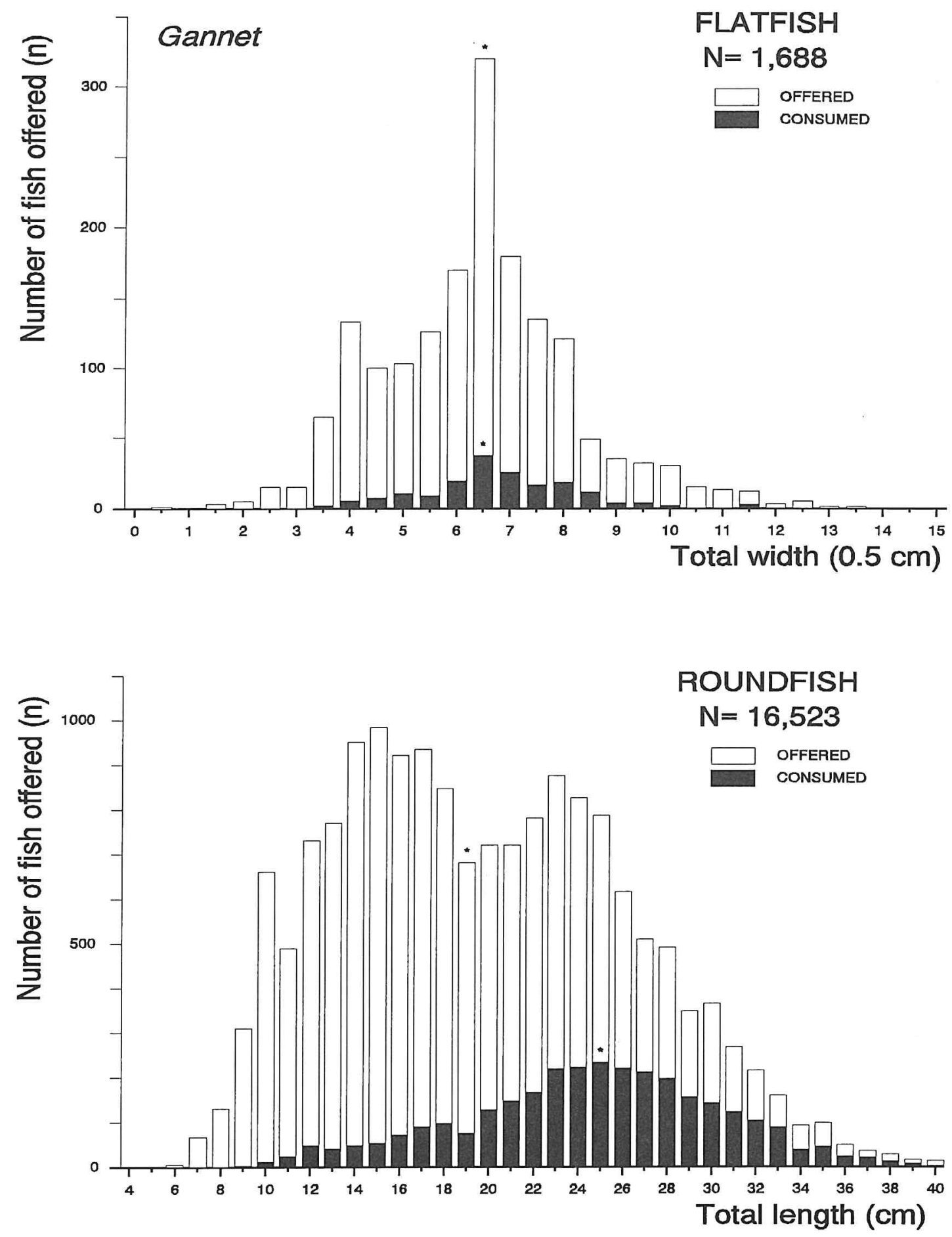

Figure 5.2.1-2 Width of flatfish and length of roundfish consumed by Gannets. See for conventions figures 5.1.1-2. 
high densities off Shetland (figure 4.1.11). Of all Gannets observed, $68.2 \%$ of were adult birds ( $n=1462$; table 4.1.6). Immatures numerically predominated in the central North Sea (C), the Southern Bight (S) and in the German Bight. In November, with Gannets being more widespread than during any of the other surveys (figure 4.1.12), 94.0\% of the birds were adults $(n=1458$; table 4.1.6), indicating that many immatures had already left the North Sea. Gannet numbers varied only slightly and abundance estimates ranged from 100,000-200,000 individuals in each of the surveys (table 4.2.9).

\section{Gannets at the stern}

Mean numbers of Gannets at the trawl were quite similar during most of the year (table 4.3.3) and the overall distribution pattern varied only in detail (figures 4.3.9-12). Gannets were normally scarce in the eastern half of the North Sea and in the Skagerrak/Kattegat region. Adults predominated, particularly in winter (>90\%). Of all Gannets recorded at sea, between $1 \%$ (May) and $9 \%$ (February) were observed in association with fishing vessels. However, these low figures should not instantly be interpreted as a sign that fisheries were of little significance for these birds. Turnover rate at the stern in Gannets was probably higher than any of the other species, with birds zooming in only if discards were produced and immediately leaving the ship if interest was lost.

\section{Gannets as scavengers}

Gannets were plunge divers, also while scavenging at the stern. As soon as discards were produced, Gannets would rush in and dive if fish of suitable size were seen afloat or sinking. Although shallow dives occurred, and some fish were even taken while swimming, Gannets would normally 'hammer' into the sea as if fishing and if shoaling fish needed to be dazzled. The depth these birds reached was difficult to estimate, but in the crystal clear water of the central and northwestern North Sea it could be seen that more than 10 metres deep is not unusual.
Most Gannets would aim for floating fish or fish that was just sinking (5-10 metres deep). Gannets would swim under water (using the wings) and seize fish from below. Gannets could take considerable time to select a fish while under water and several birds were seen to seize and reject up to four fish, only to surface with a fifth specimen. Several other species of seabirds, most notably Herring Gulls (e.g. Furness et al. 1988), have much lower feeding success rates when groups of Gannets started feeding at a fishing vessel. Few birds were able to continue feeding when a flock of over a hundred Gannets was active near a fishing vessel, except Fulmars which did not seem to be impressed at all.

Gannets took much less offal than expected from their numerical abundance during discard experiments (table 4.6.19). Feeding success was very high, however, for gadids and clupeids (tables 4.6.20-23, 4.6.30-33). In February, Gannets obtained significantly more gadid discards relative to their numbers present, than did gulls in all 5 subregions for which comparisons could be made (table 4.6.25). In May, the same as true in all 4 subregions for which there were adequate data. In August, Gannets did better than gulls in all 4 subregions for which there were adequate data, and the differences were statistically significant in three. In November, Gannets did better than expected compared with gulls, in 5 subregions, and significantly better in 4 of these. Gannets obtained significantly more clupeids than did gulls for most subregion/season combinations. Although Gannets outperformed gulls consistently in the NW, in some seasons gulls did better than Gannets and in others worse than Gannets in C and CW (tables 4.6.35).

Gannets were capable of swallowing larger fish than any of the other scavengers (tables 5.1-2, figures 4.6.15-18). The median width of 198 flatfish consumed by Gannets was $6.5 \mathrm{~cm}$ (range $3.5-11.5 \mathrm{~cm}$ ), which equals the median width of 1688 flatfish offered in the presence of these birds (figure 5.2.1). Roundfish taken by Gannets ranged in length 

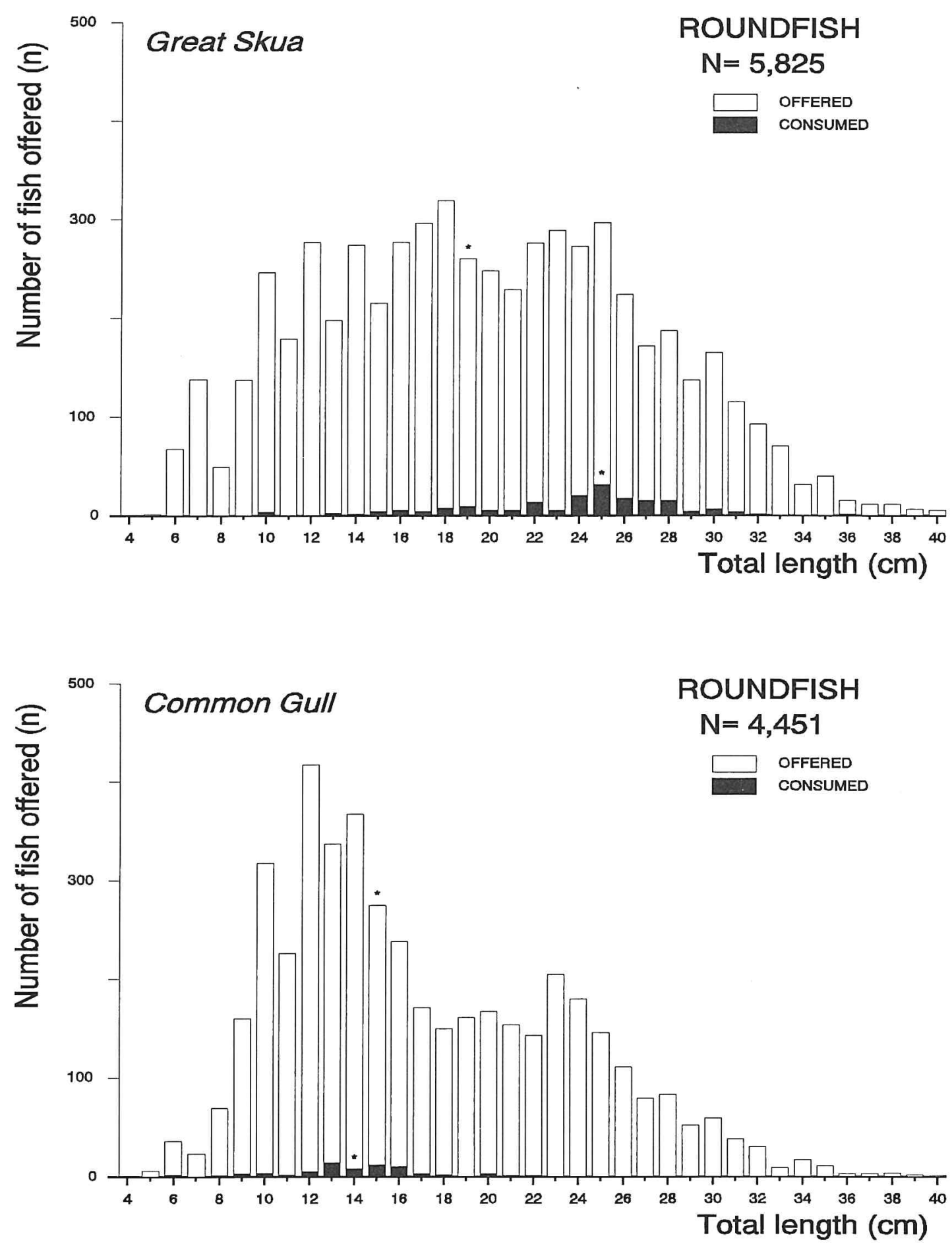

Figure 5.3.1-5.4.1 Length of roundfish consumed by Great Skuas (top) and Common Gull (below; see for conventions figures 5.1.1-2) 
from 6-55 cm, but few fish over $40 \mathrm{~cm}$ were offered and consumed. The median length of roundfish consumed by Gannets was $25 \mathrm{~cm}$ ( $n=3083$ ), which is considerably more than the median length of roundfish offered in the presence of this species (19 cm, $\mathrm{n}=16,523$; figure 5.2.2).

Gannets are individualists as scavengers and highly successful kleptoparasites. Of 3181 fish stolen from one bird by another, 148 fish were stolen from one Gannet by another (table 4.7 .4 ), but 483 other birds were robbed by Gannets whereas they lost only 27 fish through robbery from other birds (table 4.7.5), or Gannets were capable of stealing 18 times more items from other birds than were lost by them through robbery (R.I. 17.9). With such a robbery index, Gannets ranked usually highest in a dominance hierarchy on the basis of this index (table 4.7.5). Gannets frequently dropped fish, but were quite successful (i.e. they gained more than they lost) picking up fish that were dropped by others (tables 4.7.910).

In conclusion, Gannets are powerful scavengers at trawlers, which apparently use fisheries opportunistically and preferring natural prey when available. Slightly higher proportions of Gannets were observed in winter in association with fishing vessels than in summer, indicating the this resource is particularly important under adverse conditions when shoaling fish is more difficult to spot.

\subsection{GREAT SKUA CATHARACTA SKUA}

Great Skuas size generally as Herring Gulls, but with a heavier body, relatively shorter wings and tail, dark brown plumage, a heavy and hooked bill, and strong feet with raptorlike nails (Cramp \& Simmons 1977). Great Skuas have a wing span of around $140 \mathrm{~cm}$ and are with a mass of 1300-1800 the third heaviest scavenging seabird in the North Sea. Great Skuas obtain a significant portion of their food through robbery and are also known to kill (adult) seabirds up to the size of Herring and Lesser Black-backed Gulls. The most important colonies of Great Skuas in the North Sea are found in Shetland 16200 Apparently Occupied Territories in 1992; Sears et al. 1995) and Orkney (2018 AOT's; Meek et al. 1994). Scavenging or kleptoparasitising Great Skuas have been seen around fishing vessels in many places in the Northeast Atlantic, but overall numbers attending were usually rather small (Van der Heide 1938, Boswall 1960, Hillis 1971, 1973, Boswall 1977, Watson 1981, Dare 1982, Dändliker \& Mülhauser 1988, Hudson \& Furness 1988, 1989, Camphuysen 1993a, Garthe 1993b). Adult Great Skuas depend heavily on discards from whitefish trawlers around Shetland (Hudson \& Furness 1988). Numbers of Great Skuas in Shetland may therefore be affected by future changes in fishing practices, particularly by any reduction in the discarding practices as a result of mesh size regulations or fishing effort (Furness 1992, Sears et al. 1995).

\section{Great Skuas at sea}

Great Skuas were scarce at sea in late winter and early summer, peaked in August and were quite scarce again in November. Only in August, Great Skuas occurred all over the North Sea in scattered low to moderate densities (figure 4.1.13). Generally, Great Skuas were more numerous in the western half of the North Sea, but sightings were quite frequent in the central North Sea. In November, when much smaller numbers of Great Skuas were estimated to occur in the North Sea, scattered low densities mainly occurred in the southern half central North Sea (C) and off Denmark (CE). Very small numbers were recorded in the northern North Sea, despite extensive surveys off Orkney and Shetland. Great Skuas were the scarcest species of the eight scavenging seabirds under consideration in this study. Abundance estimates were always well below 50,000 individuals: 1000 in February, 16,000 in May, 30,000-40,000 in August and 4000 in November (tables 4.2.5-9). 


\section{Great Skuas at the stern}

With a maximum of 23 Great Skuas assembled at the trawl during a single haul, this species is one of the scarcer scavengers which occurred regularly. In February, Great Skuas were quite rare, but in May scattered sightings occurred, particularly at fishing stations in NW, NE and in CW (table 4.3.4). The species became most widespread in August, just after the breeding season, when small numbers occurred at the trawl in all subregions under study (figure 4.3.13). Groups of more than 10 Great Skuas occurred only at fishing stations in NW and $\mathrm{CW}$. In November, it was obvious that most individuals had left the North Sea already (figure 4.3.14). In August, some $3 \%$ of the 30,000 Great Skuas estimated to occur in the North Sea were observed in association with fishing vessels. This percentage would perhaps underestimate the significance of commercial fisheries for these birds, because Great Skuas seldom followed ships for prolonged periods of time.

\section{Great Skuas as scavengers}

In commercial fisheries around Shetland, Great Skuas are often observed to pick up fish themselves, or even to pull fish through the meshes of the net (RWF pers. comm.). However, the small numbers in association with research vessels were usually stealing fish which was just picked up by others. Foraging Great Skuas seldom alighted on the water, but were hovering over flocks of Fulmars or circling around the flock of scavenging gulls, only to select a victim for robbery. When a large fish was obtained the birds would normally fly away from the ship, alight, and swallow the fish.

Great Skuas were not very abundant and therefore seldom of great importance as consumers of any type of discards. However, considering the numbers of gadids and clupeids consumed, Great Skuas ranked third and second respectively in August in subregion NW and third with clupeids in August in NE.

Great Skuas were capable of swallowing larger roundfish than many of the other scavengers (tables 5.2). Roundfish taken by Great Skuas ranged in length from $10-36 \mathrm{~cm}$ $(n=176)$. The median length of roundfish consumed by Great Skuas was $25 \mathrm{~cm}$, which is considerably more than the median length of roundfish offered in the presence of this species $(19 \mathrm{~cm}, \mathrm{n}=5825$; figure 5.3.1).

With a robbery index of 9.1, Great Skuas ranked third in the order of most successful kleptoparasites (table 4.7.5). Only 12 fish were stolen from Great Skuas by other birds (mainly Gannets). This species obtained more fish as a result of kleptoparasitism than by picking up fish themselves, as indicated by a rather low feeding success considering fish picked up which was dropped by others (table 4.7.10).

In conclusion, Great Skuas were not very numerous, but successful scavengers at fishing vessels in the North Sea. During the breeding season, the majority of the birds was found around the breeding stations on Orkney and Shetland, with only very few individuals wandering around in the rest of the North Sea. In August, Great Skuas occurred in small numbers, scattered over most of the North Sea, and apparently obtained most of their food as kleptoparasites, whether or not around fishing vessels.

\subsection{COMMON GULL LARUS CANUS}

Common Gulls are much smaller than Herring Gulls, with a $40 \%$ shorter and slighter bill, $20 \%$ shorter wings and shorter legs, but are about $10 \%$ larger and bulkier than Kittiwakes, and have a wingspan of $120 \mathrm{~cm}$ and a mass of $300-500 \mathrm{~g}$ (Cramp \& Simmons 1983). Nearly 75,000 pairs of Common Gulls were estimated to nest in coastal colonies around the North Sea (Tasker et al. 1987, Lloyd et al. 1991). The largest breeding populations were found on Orkney $(14,000$ pairs), in The Netherlands (over 10,000 pairs) and in the Skagerrak (27,000 pairs). 
Few earlier studies on scavenging seabirds included Common Gulls lcf. Camphuysen 1993a). Common Gulls were absent or scarce at the trawl in most areas in the Northeast Atlantic, but were common in the southern North Sea (Berghahn \& Rösner 1992, Garthe 1992, Camphuysen 1993bc). From dietary studies of Common Gulls it was concluded that some populations of this species obtained a considerable amount of marine fish, much of which was apparently picked up at fishing vessels (Arbouw 1980, Arbouw \& Swennen 1985, Keijl et al. 1986, Prüter 1986). However, there were virtually no data to document the use of fishery waste by Common Gulls, and for that reason, Furness (1992) did not consider this species any further in his review. Camphuysen (1993b) demonstrated that $10.6 \%$ of all scavenging gulls $(n=63,523)$ associated with fishing vessels in the southern North Sea were Common Gulls. Most were recorded at fishing boats in winter and only in a narrow band along the (Dutch) coast. Exceptionally, over 900 Common Gulls were seen attending a trawler. The lack or at least scarcity of Common Gulls at fishing vessels in summer did not match conclusions drawn from diet studies in nearby coastal colonies nor the coastal observations of foraging Common Gulls in The Netherlands (Keijl et al. 1986, 1989).

\section{Common Gulls at sea}

Common Gulls, mainly being winter visitors in the North Sea, were numerous only in the southeastern North Sea and Skagerrak (figure 4.1.15). In May, rather small numbers were observed and over half of these were immatures $(42.4 \%$ adult, $n=59$; figure 4.1.16). Obviously, more extensive surveys in the coastal waters of The Netherlands, the German Bight, Denmark and Norway would have changed this picture, since coastal northward migration in these waters normally peaks in April and May, but may continue into July (Platteeuw et al. 1994). Scattered low densities occurred in August, particularly at relatively great distances from the coast (figure 4.1.17), but overall numbers were still very low. Again, most these birds were immatures $(22.2 \%$ adult, $n=27$; table 4.1.7). In November, most Common Gulls were observed in the southeastern half of the North Sea and in the Kattegat (figure 4.1.18), again with frequent sightings at relatively great distances from the coast. Some $71.4 \%$ of all Common Gulls were now adults $(n=70$; table 4.1 .7 ).

Common Gulls were usually rather scarce at sea, but abundance estimates derived from the cruises during this project were unreliable, because the coastal zone was badly covered. Abundance estimates derived from ESAS database ranged from 13,000 individuals in August to 250,000 individuals in February (tables 4.2.5-8).

\section{Common Gulls at the stern}

Common Gulls were typical scavengers in winter and mainly in coastal waters in the southeastern half of the study area (subregions Sk, CE, S). Unfortunately, coastal waters of the German Bight were poorly covered, particularly in the November survey. In February, Common Gulls were numerous inshore scavengers in a coastal band ranging from southeast England to southwest Sweden (figure 5.3.15). Parallel observations in the Wadden Sea area and the coastal strip within $5 \mathrm{~km}$ from the coast showed that Common Gulls were abundant at fishing vessels (M.F. Leopold pers. comm.; Camphuysen 1993a). In all subregions where Common Gulls occurred in numbers at the trawl, adults numerically predominated (86.0\% adult, $\mathrm{n}=708$; table 4.3.5). In May and August, Common Gulls were rarely observed at the trawl, anywhere in the North Sea. Numbers of Common Gulls attracted at the trawl increased in November, particularly in the southeastern half of the study area (figure 4.3.18). In the Southern Bight and in the Skagerrak, where the mean number at the trawl was highest, adults numerically predominated with ca. $85 \%$ (table 4.3.5) Elsewhere, immatures were relatively more numerous. 


\section{Common Gulls as scavengers}

The behaviour of Common Gulls at the trawl was rather similar to that of Kittiwakes. The small gulls would normally fly very near the ship, at the stern when the net came to the surface or near the place where discards were produced. Small discards were picked up by a rapid movement and either instantly swallowed mid-air, or the birds would fly off as fast as they could to avoid kleptoparasitism. Common Gulls would seldom alight on the water while foraging and these gulls were equally successful when the discarding ship was moving or stationary.

Few discards were consumed by Common Gulls, because overall numbers were usually very low. Success indices were low in most subregions, but in subregions $\mathrm{SK}$ and $\mathrm{CE}$, where comparatively many Common Gulls were joining the research vessels, feeding success was sometimes reasonable (e.g. tables 4.6.20-23). Numbers of Common Gulls were so much smaller than any of the other birds that its success was difficult to assess.

Common Gulls took rather small fish compared to the other scavengers (tables 5.2). Roundfish taken by this species ranged in length from $6-22 \mathrm{~cm}$. The median length of roundfish consumed by Common Gulls was $14 \mathrm{~cm}(n=71)$, which is slightly less than the median length of roundfish offered in the presence of this species $(15 \mathrm{~cm}, \mathrm{n}=4451$; figure 5.4.1).

Too few interactions were observed to investigate the position of Common Gulls in the dominance hierarchy during experimental discarding. Feeding behaviour (generally avoiding fights), position in the dominance hierarchy and position at the stern (foraging near the ship) were comparable with those of Kittiwakes.

In conclusion, Common Gulls are probably more important as scavenging seabirds around fishing vessels than the data obtained in this study indicated. From earlier studies, the southeastern North Sea and the Skagerrak are known to be important winte- ring areas for this species and inshore trawlers have frequently been seen with very substantial numbers of Common Gulls associated (Camphuysen 1993a). The offshore surveys within the present project did not contribute much to our knowledge, mainly because the core area for this species was poorly covered and because numbers at the trawl during experimental discarding were consequently rather low.

\subsection{LESSER BLACK-BACKED GULL LARUS FUSCUS}

Lesser Black-backed Gull measurements overlap with those of Herring Gulls, but most birds are noticeably less bulky with narrower, relatively longer wings and proportionally longer legs. Lesser Black-backed Gulls are $20-25 \%$ smaller and slighter than Great Black-backed Gulls, having a wing span of $150 \mathrm{~cm}$ and a mass of 700-1000 g (Cramp \& Simmons 1983). The breeding population of Lesser Black-backed Gulls in the North Sea is estimated at nearly 50,000 pairs by Tasker et al. (1987), but this must be considered an underestimate. In the southern North Sea $\left(51^{\circ}-56^{\circ} \mathrm{N}\right)$, around 32,000 pairs of Lesser Black-backed Gulls were known to breed (Camphuysen 1993a), whereas Tasker et al. (1987) list only nearly 20,000 pairs for this region. Lesser Black-backed Gulls were found as scavengers in the Irish Sea, but normally in rather small numbers (Boswall 1960, Hillis 1971, Verbeek 1977, Watson 1981, Dare 1982). Dändliker \& Mülhauser (1988) reported substantial numbers behind stern trawlers to the west of the Outer $\mathrm{He}$ brides, Furness et al. (1992) list this species among the 'common scavengers' for the Clyde area (southwest Scotland). Around Shetland, Lesser Black-backed Gulls are frequently reported in association with whitefish trawlers, but they were normally present in small numbers and absent during many hauls (Hudson \& Furness 1989). In the southern and southeastern North Sea, in summer, the Lesser Black-backed Gull is one 
of the most numerous scavengers behind fishing vessels (Garthe 1993, Camphuysen 1993abc, 1994ab, Camphuysen in press). Coastal breeding Lesser Black-backed Gulls have generally a more marine diet than the closely related Herring Gull and several studies have indicated the importance of fishery waste in the breeding season (Pearson 1968, Noordhuis 1987, Spaans et al. 1994). Structural food shortages, possibly related to declines in discard practices or fishing effort, negatively influenced the reproductive output in several breeding populations of Lesser Black-backed Gulls. Recent breeding failures on Skomer (Wales) have been attributed to à decline in fishery waste from Irish Sea trawlers (Walsh et al. 1990, Stone et al. 1992, Monaghan 1993). Experimental studies in the Bristol Channel and on Terschelling have shown that the provision of supplementary food raised the breeding success of Lesser Black-backed Gulls to normal levels (Hiom et al. 1991, Spaans et al. 1994).

\section{Lesser Black-backed Gulls at sea}

Lesser Black-backed Gulls were typically summer visitors in the North Sea (tables 4.1.1-4). Most gulls were found in the southeastern half of the North Sea, frequently offshore, but particularly in coastal waters, and immediately after the breeding season juveniles moved to open sea. In February, Lesser Black-backed Gulls were very scarce (figure 4.1.19). In May, the situation had changed considerably. Scattered low to moderate and high densities occurred the eastern half of the North Sea and scattered low densities were found elsewhere (figure 4.1.20). Adults predominated in all subregions (overall $81.4 \%$ adult, $n=1689$; table 4.1.8). In August, just over two-thirds of the Lesser Black-backed Gulls observed were adult birds $(68.3 \%$ adult, $n=1892$; table 4.1.8), and recently fledged juveniles were frequently observed as far away from the coast as in the centre of the North Sea. Scattered moderate to high densities were observed in the southern North Sea (S, C and $(E)$, and high densities were observed in the Norwegian sector in an area with extensive fishing activities. In November, overall numbers were strongly reduced and nearly three-quarters of the Lesser Black-backed gulls were adults $(71.4 \%$ adult, $n=70$; table 4.1.8), indicating that most immatures had already abandoned the North Sea for their more southerly wintering areas. Lesser Blackbacked Gulls were most numerous during the May and August surveys (estimated at 100,000-200,000 individuals) and were otherwise rather scarce at sea (table 4.2.9). By far the largest numbers were observed in the southeastern half of the North Sea.

\section{Lesser Black-backed Gulls at the stern}

Lesser Black-backed Gulls were typically summer scavengers, of which most of the population had left the North Sea in November and February. Although this species breeds around the North Sea, the core of its North Sea distribution lies in the southeast and its distribution as a scavenger varied accordingly between subregions (figures 4.3.20-21). In February, Lesser Black-backed Gulls were rare in most of the North Sea, except in the Southern Bight (figure 4.3.19). In May, this picture had changed completely and Lesser Black-backed Gulls were numerous and widespread in most subregions (figure 4.3.20). In August, Lesser Blackbacked Gulls had a more inshore distribution and the majority occurred in the southeastern half of the North Sea (figure 4.3.21). Only half the birds aged in August were adults $(50.0 \%$ adult, $n=2495)$ and it was obvious that many recently fledged juveniles had moved to sea, immediately after the breeding season. In November, numbers of scavenging Lesser Black-backed Gulls had fallen considerably and occasional large groups were attracted only in the southern half of the North Sea (figure 4.3.22). In summer, $44-55 \%$ of the Lesser Black-backed Gulls recorded at sea were seen in association with fishing vessels, a higher percentage than in most other species, indicating the importance of fisheries for these birds. 

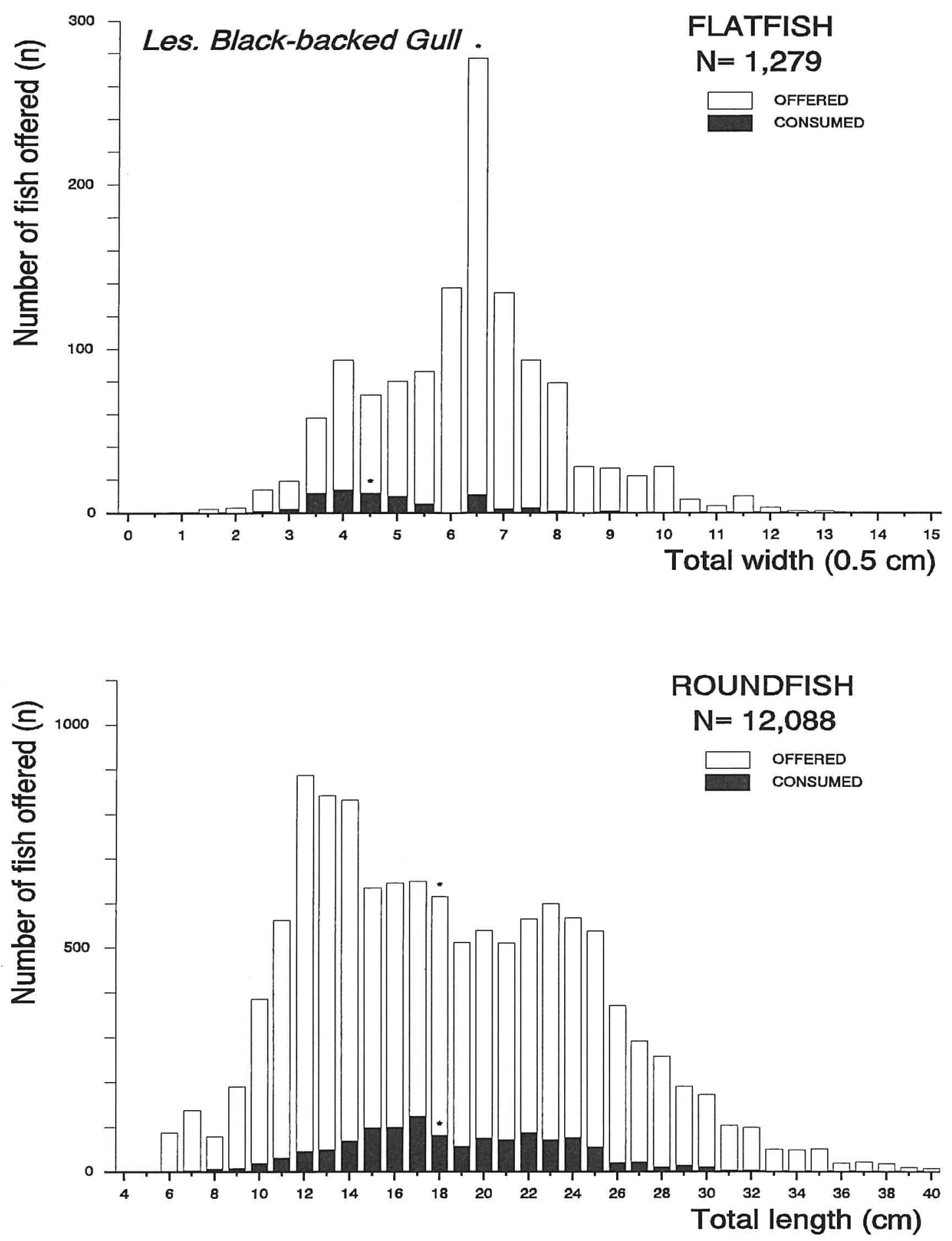

Figure 5.5.1-2 Width of flatfish and length of roundfish consumed by Lesser Black-backed Gull. See for conventions figures 5.1.1-2. 
Lesser Black-backed Gulls as scavengers In regions and seasons where Lesser Blackbacked Gulls were common, the ship was often joined by at least a few of these birds which followed even if discards were not produced for a long time. During fishing, groups of associated Lesser Black-backed Gulls would gradually increase in size, while the birds followed at some distance or alighted in a concentration of birds somewhere in front (expected track) of the ship. When the net came up, all gulls would rush towards the ship and fly over the net and around the ship, generally at greater distances than the small gulls (Common Gulls and Kittiwakes). From a trickle of discards, Lesser Black-backed Gulls would carefully select preferred items by eye and pick up fish and offal while still on the wing or with a shallow plunge dive. This species was apparently capable of diving up to half a metre or more, but seldom did so. Some of the fish was taken from other birds (robbery), but Lesser Black-backed Gulls seldom tried very persistenly to steal fish and rapidly gave up if its 'victim' did not drop the fish too rapidly.

Considering the numbers of gadid discards, Lesser Black-backed Gulls ranked highest in the order of important consumers in summer in subregions $\mathrm{CE}$ and $\mathrm{S}$, second in subregion $N E$, and third in the central North Sea (C). As clupeids consumers, these birds ranked first in May in NE, Sk and CE, in August in S and third in both May and August in $\mathrm{C}$. Considering gadid consumption, success indices of summering Lesser Black-backed Gulls were rather high in most subregions, except in the central North Sea (tables 4.6.21-22). Feeding success indices for clupeids were generally lower (tables 4.6.32-33).

Lesser Black-backed Gulls took medium sized fish (tables 5.1-2). The median width of 80 flatfish consumed by these gulls was $4.5 \mathrm{~cm}$ (range 2.5-9.0 cm), which is considerably less than the median width of 1279 flatfish offered in the presence of these birds (figure 5.5.1). Roundfish taken by Lesser
Black-backed Gulls ranged in length from 6$32 \mathrm{~cm}(n=1218)$. The median length of roundfish consumed by these birds was 18 $\mathrm{cm}$, which equals the median length of roundfish offered in the presence of this species (18 cm, $n=12,088$; figure 5.5.2).

The robbery index of Lesser Black-backed Gulls was just a bit higher than that of Herring Gulls, but both species should be considered moderately vulnerable to kleptoparasitism. Of 108 fish stolen from Lesser Blackbacked Gulls, 79 were taken by other individuals of that species, 29 by other seabirds (table 4.7.4-5). Many fish were simply dropped, but Lesser Black-backed Gulls obtained an equal amount of fish by picking up items dropped by others (mainly other Lesser Black-backed Gulls; table 4.7.9-10).

In conclusion, Lesser Black-backed Gulls are very important scavengers at fishing vessels in summer, particularly in the southeastern half of the study area. Directly after fledging, juveniles joined the adults as far away from the coast as the central North Sea to feed behind fishing vessels. Small numbers remained in the North Sea in winter, and most were seen in the Southern Bight in this season. Considering the very high proportion of gulls that were seen in association with fishing vessels during strip-transect counts and observations of gulls associated with nearby trawlers, higher than most other species of seabirds observed, it may be concluded that commercial fisheries play a key role in the pelagic ecology of this species. From diet studies in colonies, it could be deduced that discards formed only part of the diet and that breeding success was particularly high when 'natural' resources (clupeids) were abundantly available. However, several recent studies have now shown that a reduction of fishing effort near major breeding colonies have resulted in structural food shortages and poor breeding results. 

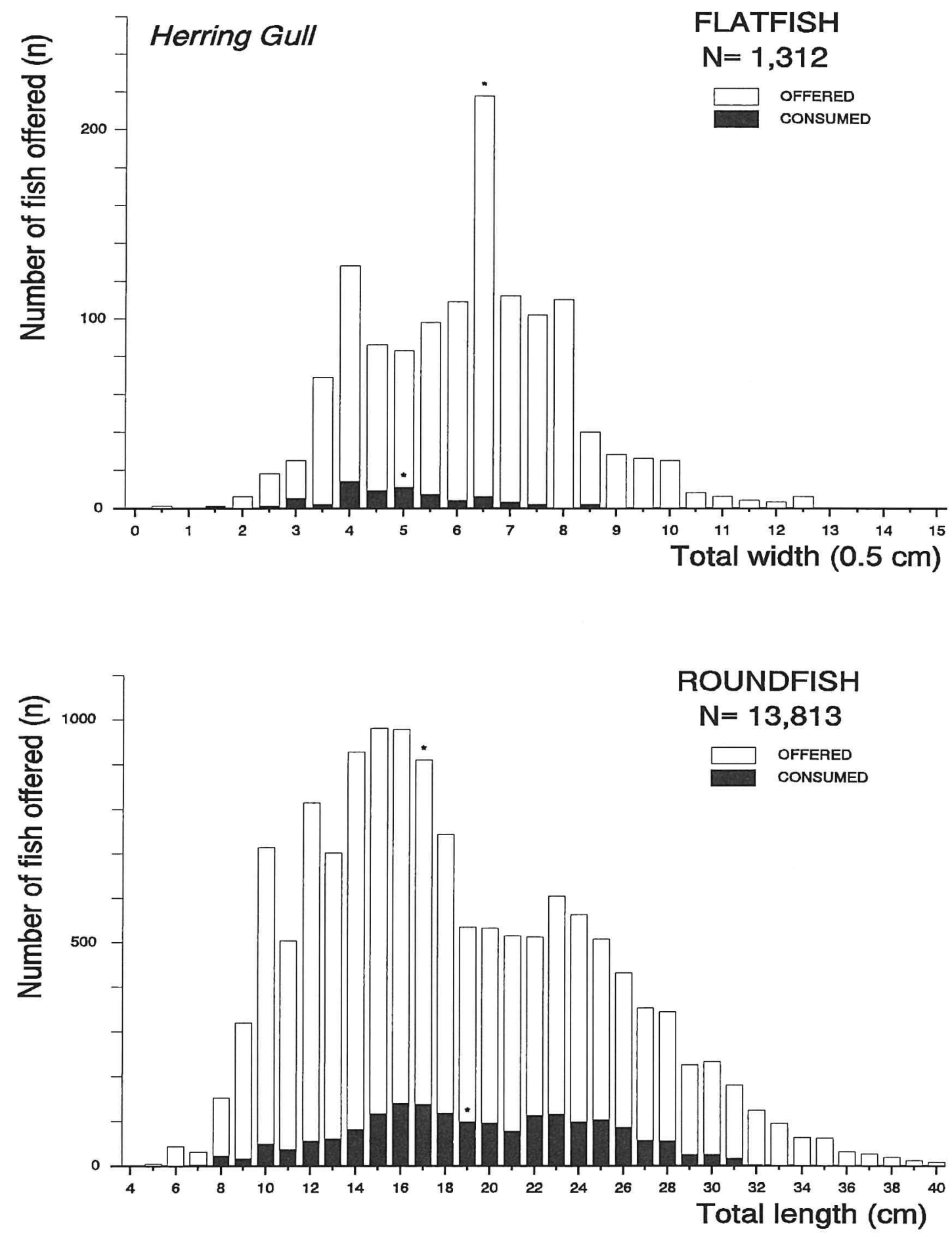

Figure 5.6.1-2 Width of flatfish and length of roundfish consumed by Herring Gull. See for conventions figures 5.1.1-2. 


\subsection{HERRING GULL LARUS ARGENTATUS}

Herring Gulls are large gulls which are extremely variable in size, of which smaller $q$ ? overlap with Lesser Black-backed Gulls and the largest ot o approach Great Black-backed Gulls. Herring Gulls have a powerfully hooked bill, a large head, deep chest, long and rather broad wings (wingspan $150 \mathrm{~cm}$ ), relatively short legs and a mass of 800-1200 g (Cramp \& Simmons 1983). The North Sea breeding population of Herring Gulls is estimated at nearly 240,000 pairs (Tasker et al. 1987, Lloyd et al. 1991). In summer some 150,000-200,000 Herring Gulls were found in the North Sea; lower numbers in relation to the breeding numbers than is the corresponding ratio for Lesser Black-backed Gulls, indicating that a substantial proportion of the (adult) Herring Gull population feeds in other habitats during the breeding season. Herring Gulls are common scavengers at fishing vessels in the Irish Sea, off West Scotland, around Shetland and in the North Sea (Camphuysen 1993a). Hillis (1971) recorded Herring Gulls as the chief scavenging species in the Irish Sea, with up to 500 individuals at a fishing vessel. Of 21,500 scavengers at the trawl of northern Irish Sea Nephrops-trawlers, $65.9 \%$ were Herring Gulls (Watson 1981). In the open Atlantic, off Ireland and West Scotland, small numbers of Herring Gulls were reported (Dare 1982, Dändliker \& Mülhauser 1988), but Herring Gulls occurred frequently off northern Norway (Strann \& Vader 1992). Hudson \& Furness (1989) found that proportions of Herring Gulls and Fulmars at fishing vessels interchanged at various distances from the nearest coast, with Herring Gulls becoming increasingly more numerous near land. In the southern North Sea the Herring Gull is one of the more important scavengers at fishing vessels, particularly close to the coast (Berghahn \& Rösner 1992, Garthe 1992, Camphuysen 1993a). Near Helgoland, $58 \%$ of experimentally discarded offal was taken by Herring Gulls and at least in the offshore waters of the German Bight, these gulls were extremely dependent on fishery waste (Hüppop \& Garthe 1993). Over 60\% of all scavenging Herring Gulls at commercial vessels off the Dutch coast were within $10 \mathrm{~km}$ of the shore, which is significantly different from expected frequencies based on trawler distribution in five distance zones to the coast $(\mathrm{G}=54.7, \mathrm{p}<0.001, \mathrm{df}=4$; Camphuysen 1993a). Significant correlations between Herring Gull densities at sea and the presence of fishing vessels were found in February, April, November and December. Camphuysen (1993b) found that Herring Gulls were most numerous at fishing vessels in the southern North Sea between October and July, but were virtually absent in August and September (when breeding birds moult their primaries). In the southern North Sea, Herring Gulls were the most numerous $148.6 \%$ of all identified gulls at fishing vessels, $n=63,523$ ) and frequent (presence $62.3 \%, n=461$ fishing vessels) scavengers.

\section{Herring Gulls at sea}

In contrast to the previous species, Herring Gulls were typically winter visitors in the North Sea, with high numbers offshore and inshore in November and February and low numbers offshore and low to moderate numbers in coastal waters in the breeding season. The Herring Gull is a common breeding species around the North Sea, but it is obvious that only coastal waters (particularly within $25 \mathrm{~km}$ from the nearest coast) is of significance for this species in the nesting season. In February, Herring Gulls were numerous and widespread in the North Sea (figure 4.1.23). Nearly three-quarters of the Herring Gulls observed were mature birds (71.5\% adult, $n=1595$; table 4.1 .9$)$. In the pre-breeding season, in May, Herring Gulls disappeared almost completely (figure 4.1.24, table 4.1.2). Small numbers were found in the German Bight and in the central North Sea, whereas Herring Gulls were quite rare elsewhere. In August, Herring Gulls were quite rare at sea, except off the east coast of Scotland, where moderate to high densities occurred (figure 4.1.25). Nearly 
half the gulls off the Scottish coast were adults (47.3\% adult, $n=207$; table 4.1.9). In November, Herring Gulls had returned en masse into the North Sea after an absence of half a year. Just over half the Herring Gulls observed were mature birds $158.9 \%$ adult, $n=1449$; table 4.1.9). Herring Gulls were widespread, with moderate to high densities in several areas. The overall picture, is of the greatest numbers and most frequent sightings in the northeastern twothirds of the study area (figure 4.1.26). Herring Gulls from northern Scandinavia and the Murmansk region move south after the breeding season to winter around the Norwegian south coast, in the North Sea and in Britain (Schüz 1933, Stanley et al. 1981, Cramp \& Simmons 1983, Coulson et al. 1984). Herring Gulls breeding along the east coast of Britain, in southern Norway, Sweden and along the west coast of Denmark, Germany and The Netherlands are fairly sedentary. Outside the breeding season these birds occur dispersed along the coast, usually within $200 \mathrm{~km}$ from their natal colonies (Thomson 1924, Jørgensen 1973, Møller 1981). The observations during shipbased surveys strongly suggest that Herring Gulls enter the North Sea area from the NE, to become widespread and abundant both offshore and inshore during winter, and that the Herring Gull as a 'winter visitor' in the North Sea refers to its nordic populations. Herring Gulls were most numerous in winter with total numbers estimated for February at 0.3-1.0 million individuals and for November at 0.5-1.5 million individuals (table 4.2.9). In summer, overall numbers probably did not exceed 200,000 individuals. Estimates based on the cruises in 1993 and 1994 must be considered conservative, because the coastal zone was not very well covered.

\section{Herring Gulls at the stern}

Totally complementary to the previous species, Herring Gulls were typically winter birds which then occurred widespread, both inshore and offshore (figures 4.3.23-26). Being abundant breeding species around the
North Sea, it is remarkable to note how few scavenging Herring Gulls were reported in May and, particularly, in August. In February, Herring Gulls were numerous scavengers all over the North Sea (figure 4.2.23), but particularly in coastal waters (up to $100 \mathrm{~km}$ away from the coast; table 4.3.10). Twothirds of all scavenging Herring Gulls were adults $(65.7 \%$ adult, $n=9312)$. In May, this had radically changed. Although occasionally up to 200 Herring Gulls assembled at a trawl (subregions NE and Sk), the species was rather scarce and occurred in less than $25 \%$ of the hauls in other subregions (figure 4.3.24). As mentioned earlier, coverage in Dutch and German coastal waters was rather poor and earlier studies indicate that very large numbers of scavenging Herring Gulls occur within $10 \mathrm{~km}$ from the coast in this region (Camphuysen 1993a, Garthe 1993b, Garthe \& Hüppop 1994, Camphuysen in press). In August, Herring Gull distribution and abundance had changed again. With the notable exception of coastal waters off East Scotland, Herring Gulls did not show up in significant numbers anywhere in the North Sea (figure 4.3.25). Only a third of the Herring Gulls scavenging at the trawl were adults $(37.5 \%$ adult, $n=816$; table 4.3.8). The November cruises demonstrated a massive return of this species, particularly in the northern and eastern North Sea. Up to 1000 Herring Gulls assembled at a ship (subregion NW) and in most subregions at least at 8 out of 10 hauls Herring Gulls were attracted (table 4.3.8). Numbers were particularly large in the Fladengrund area (central northern North Sea) and off Shetland and Norway. Just less than half the Herring Gulls observed at the trawl were adults $141.7 \%$ adult, $n=2173$ ). Of all Herring Gulls recorded at sea, up to $29 \%$ (February) and $83 \%$ (May) were observed in association with fishing vessels, indicating the importance of fisheries for this species.

\section{Herring Gulls as scavengers}

Flocks of Herring Gulls at the stern, just as Lesser Black-backed Gulls, would gradually 
increase in size during fishing (towing), constantly flying at some distance or alighting in tight groups in the expected track of the moving ship. When the net came up and near the surface the gulls would rush towards the ship and fly over the net. As Lesser Black-backed Gulls, this species would usually operate at slightly greater distances than the small gulls (Common Gulls and Kittiwakes). From a trickle of discards, items were selected by eye and fish and offal were picked up while still on the wing or with a shallow plunge dive. As the former species, Herring Gulls were seen to dive up to half a metre or more, but seldom did so. Occasionally, every fish which was not clear at the surface anymore was ignored by these gulls and only when another species picked it up there was an attempt to steal it. Herring Gulls were roughly equally successful as kleptoparasites of other species, but Herring Gulls were clearly more persistent to steal fish than Lesser Blackbacked Gulls and did not easily gave up if its 'victim' did not drop the fish too rapidly.

Considering the numbers of gadid discards, Herring Gulls ranked highest in the order of important consumers in winter in subregion $\mathrm{CE}$, second in subregion CE. Further, in February these gulls ranked second in $C$ and $S$ and third in NE, CW. In November, Herring Gulls ranked first in NE and $S k$, second in NW and $\mathrm{C}$ and third in CW. As clupeid consumers, these birds ranked first in November in NE, Sk and $C E$ and $C$ and second in NW, in February they ranked second in NE, CW, $C, C E$, and $S$ and third in NW. In summer, Herring Gulls obtained rather trivial amounts of both gadids and clupeids, except in August in CW where they ranked third considering gadid consumption. Success indices for gadids varied between 1 and 2 in winter and were more variable, but sometimes substantially higher, in summer (tables 4.6.20-23). Considering clupeids, success indices were slightly lower overall and, again, variable in summer. Feeding success of immature Herring Gulls was usually, but not always, considerably lower than that of adults (tables

\subsubsection{0-41).}

Herring Gulls, like the previous species, took medium sized fish (tables 5.1-2). The median width of 67 flatfish consumed by these gulls was $5 \mathrm{~cm}$ (range $1.5-8.5 \mathrm{~cm}$ ), which is considerably less than the median width of 1312 flatfish offered in the presence of these birds $(6.5 \mathrm{~cm}$; figure 5.6.1). Roundfish taken by Herring Gulls ranged in length from $7-38 \mathrm{~cm} \mathrm{(} n=1813)$. The median length of roundfish consumed by these birds was $19 \mathrm{~cm}$, making these fish slightly longer than roundfish consumed by Lesser Blackbacked Gulls (median $18 \mathrm{~cm}$ ), and which is 2 $\mathrm{cm}$ more than the median length of roundfish offered in the presence of this species $(17$ $\mathrm{cm}, \mathrm{n}=13,813$; figure 5.6.2).

The robbery index of Herring Gulls was just a bit lower than that of Lesser Black-backed Gulls, but both species should be considered moderately vulnerable to kleptoparasitism. Of 188 fish stolen from Herring Gulls, 93 were taken by other individuals of that species, but 58 by Great Black-backed Gulls (table 4.7.4-5). Over 240 fish were simply dropped, but Herring Gulls obtained more fish by picking up items that were dropped by others (mainly dropped by Kittiwakes; table 4.7.9-10).

In conclusion, Herring Gulls were very important scavengers in the winter half year, occurring in all subregions in substantial numbers and often with high feeding success. Herring Gulls were rather scarce offshore in summer, particularly in August when only locally in CW and NW some Herring Gulls were found. Previous studies of the coastal waters of the southeastern North Sea in summer have indicated that substantial numbers of Herring Gulls obtained at least part of their food at fishing vessels. It was concluded that most birds stayed very close inshore, mainly within $10 \mathrm{~km}$ from land (Camphuysen in press), which explains why during these surveys so few Herring Gulls were encountered. 

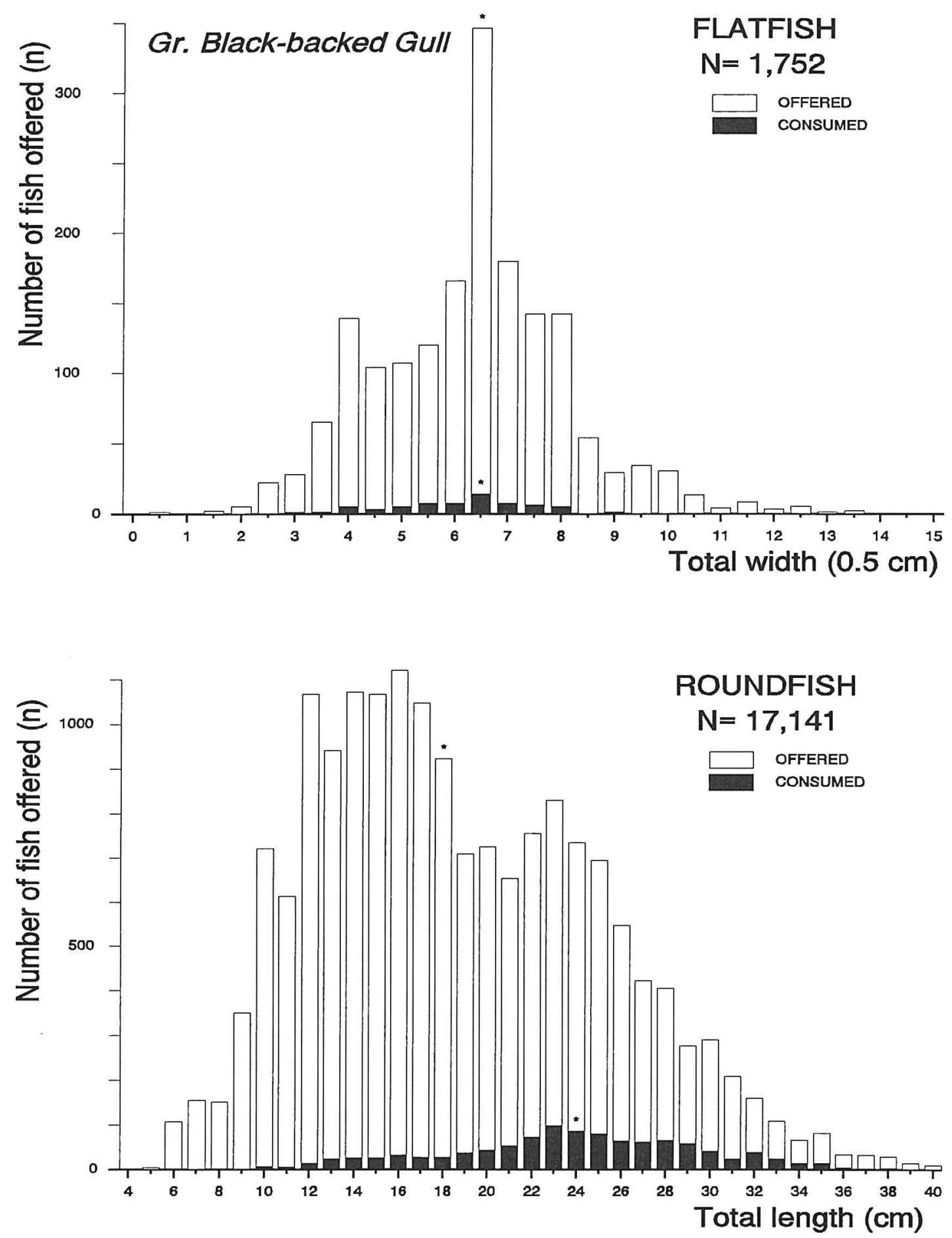

Figure 5.7.1-2 Width of flatfish and length of roundfish consumed by Great Black-backed Gull. See for conventions figures 5.1.1-2. 


\subsection{GREAT BLACK-BACKED GULL LARUS MARINUS}

Great Black-backed Gulls are very large to huge gulls with a particularly massive bill, a large angular head, long, broad wings and thick legs. Most Great Black-backed Gulls are $25 \%$ larger and bulkier than Lesser Black-backed Gulls, with no overlap in measurements. Its wingspan is $160 \mathrm{~cm}$ and these birds have a mass of $1100-2000 \mathrm{~g}$, making it the second most heavy scavenging seabird in the North Sea (Cramp \& Simmons 1983). Nearly 25,000 Great Black-backed Gulls are breed on North Sea coasts (Tasker et al. 1987, Dunnet et al. 1990, Tasker \& Becker 1992). Great Black-backed Gulls have been reported as scavengers at fishing vessels in most of the Northeast Atlantic region (Camphuysen 1993a). Numbers at commercial boats usually did not exceed a few hundreds of individuals (e.g. Boswall 1960, Hillis 1971, Watson 1981, Dare 1982, Dändliker \& Mülhauser 1988, Berghahn \& Rösner 1992, Garthe 1992, Camphuysen 1993a), but Hudson \& Furness (1989) recorded as many as 1100 Great Black-backed Gulls at a single haul near Shetland and Manikowski (1971) recorded maxima of 1500 and 2000 in October in the northern North Sea. Great Black-backed Gulls are powerful scavengers, at the top of the dominance hierarchy at the trawl, which obtain much by kleptoparasitism from other birds (Boswall 1960, Hillis 1971, Dändliker \& Mülhauser 1988, Hudson \& Furness 1988, 1989, Garthe 1992, Camphuysen 1993a).

\section{Great Black-backed Gulls at sea}

Great Black-backed Gulls were common and widespread during most of the year, but clearly increased in numbers in winter (tables 4.1.1-4). It was usually encountered in all subregions in scattered low to moderate densities, both offshore and inshore. Considering the very small North Sea breeding population (Cramp \& Simmons 1983, Lloyd et al. 1991), it is obvious that most Great
Black-backed Gulls originated from nordic populations, using the North Sea as an important wintering area. In February, scattered moderate densities occurred around Shetland, off the Dutch coast, in the German Bight and in the Skagerrak (figure 4.1.27). Just over half the Great Black-backed Gulls in February were mature birds $158.3 \%$ adult, $\mathrm{n}=883$; table 4.1.10). Numbers dropped considerably in spring and most gulls were found in the northeastern half of the North Sea. Age composition varied, with a very low proportion of adults in the Southern Bight and German Bight $19.4 \%, n=74$; table 4.1.10), and considerably more adults than immatures in NE $(70.3 \%$ adults, $n=74)$. Along the British coast, very small numbers of Great Black-backed Gulls were observed, except, locally, off Shetland (figure 4.1.28). The situation in August was quite similar: widespread in scattered low to moderate densities over most of the North Sea. Adults predominated in the northwestern half of the North Sea (NW, CW, C; $76.0 \%$ adults, $n=$ 104; table 4.1.10), while immatures predominated in the southeast (S, CE; $42.7 \%$ adults, $n=138$ ). Numbers increased strongly in all subregions in autumn (table 4.1.4). Still, just over half the Great Black-backed Gulls were mature birds $154.8 \%, \mathrm{n}=757$; table 4.1.10), with the lowest proportion of adults in the central North Sea (C, 36.9\% adult, $n=176)$. Great Black-backed Gulls were observed all over the North Sea in this period, and there was not one area which was clearly more important for this species than another (figure 4.1.30). Great Blackbacked Gulls were most numerous in winter, but occurred year round in substantial numbers. Total numbers were estimated at 200,000-300,000 individuals for February and at $100,000-400,000$ individuals for November (table 4.2.9). In summer, overall numbers probably did not exceed 100,000 individuals.

\section{Great Black-backed Gulls at the stern}

Great Black-backed Gulls occurred as scavengers through the year, least frequently 
though in August (table 4.3.8). Its distribution varied between seasons, but with highest numbers usually in subregions NW, NE and Sk. The recorded maximum of 250 individuals at a haul was considerably lower than the maximum of Lesser Black-backed Gull (400) and Herring Gull (1000). In February, scavenging numbers at the trawl were higher than during any of the other surveys and two-thirds were adults $164.3 \%$ adult, $n=$ 4362; table 4.3.8). In May, Great Blackbacked Gulls were particularly numerous in the northern North Sea and, locally in the central North Sea (figure 4.3.28). A third of these gulls were adults $133.8 \%$ adult, $n=$ 1816; table 4.3.8), but in the southern half of the North Sea only a fraction of the birds assembling at the trawl were mature $19.2 \%$ adult, $\mathrm{n}=\mathrm{876}$ ). In August, Great Blackbacked Gull were proportionally numerous in the southern North Sea and in coastal waters off East Britain (figure 4.3.29, table 4.3.8). The central northern North Sea, very important in May, was virtually free of Great Black-backed Gulls. As before, a third of the birds were adults $137.5 \%$ adult, $n=816$; table 4.3.8). In November, the central northern North Sea gained importance again, but Great Black-backed Gulls increased in numbers as scavengers in all subregions (figure 4.3.30, table 4.3.8). Just less than half the birds were adults $(41.7 \%$ adult, $n=$ 2173). In most seasons at least $10 \%$, but in February $25 \%$ of all Great Black-backed Gulls observed at sea occurred in association with fishing vessels, indicating that fisheries form an important source of food for these birds.

\section{Great Black-backed Gulls as scavengers}

It is tempting to use the word 'arrogance' when describing the foraging behaviour of Great Black-backed Gulls as a scavenger. This species would often not come very close to the ship, but stay away at 50-100 metres in the far end of the scavenging flock of gulls, only to pick up the larger fish that were ignored or dropped by other (smaller) birds. Many fish, however, were obtained by robbery. Great Black-backed Gulls are powerful, large birds and a species like the Kittiwake would usually give up an attempt to pick up a fish, simply because a Great Blackbacked Gulls flew past. More spectacular even were Great Black-backed Gulls robbing Fulmars in the central North Sea after a few tonnes of Herring were discarded from RV Tridens. Instead of picking up a few Herrings which were floating everywhere, the birds would slowly fly over the largest group of fighting Fulmars (20-30 birds disputing a single fish), lower and lower over the most intensily fighting Fulmars, lower again, with slow wingbeats and then simply lift the fish out of the crowd as if there were no birds about.

Considering the numbers of gadid and clupeid discards, Great Black-backed Gulls ranked usually not very high in the order of important consumers, mainly because overall numbers at the trawl were usually considerably smaller than several other species. With gadids, Great Black-backed Gulls ranked maximally third, including the following subregions and seasons: February NW, $\mathrm{CE}, \mathrm{S}$, May NE, Sk, August CE, S, and November $\mathrm{Sk}, \mathrm{CE}, \mathrm{S}$. As clupeid consumers, these birds ranked second in May in $\mathrm{NE}$, in November in NE and CW, and third in February in C and $\mathrm{S}$, in May in NW and in November in CE. Success indices for Great Blackbacked Gulls considering gadid consumption were similar or slightly lower than those of Herring Gulls in all seasons and subregions (tables 4.6.20-23). Clupeid consumption was rather insignificant in many occasions, except in the northern North Sea in August (S.I. 18-29, table 4.6.32) and in subregions $\mathrm{CW}$ and NE in November (table 4.6.33). Immatures had generally lower success indices that mature birds (tables 4.6.40-41).

Great Black-backed Gulls took large fish in comparison with most other scavengers, comparable in size to fish consumed by Gannets and Great Skuas (tables 5.1-2). The median width of 62 flatfish consumed by these gulls was $6.5 \mathrm{~cm}$ (range $3.0-9.0 \mathrm{~cm}$ ), which equals the median width of 1752 
flatfish offered in the presence of these birds $(6.5 \mathrm{~cm}$; figure 5.7.1). Roundfish taken by Great Black-backed Gulls ranged in length from $6-38 \mathrm{~cm} \quad(n=1083)$. The median length of roundfish consumed by these birds was $24 \mathrm{~cm}$, which is considerably more than the median length of roundfish offered in the presence of this species $(18 \mathrm{~cm}, \mathrm{n}=$ 17,141; figure 5.7.2).

Great Black-backed Gulls ranked second in the overall dominance hierarchy based on the robbery index (tables 4.7.6-8). Many more fish were stolen from other birds, mainly from Kittiwakes, Fulmars and Herring Gulls $(n=331)$ than were lost as a result of kleptoparasitism $(n=23$; tables 4.7.4-5). Great Black-backed Gulls were the most successful species picking up fish that were dropped by other birds (tables 4.7.9-10).

In conclusion, Great Black-backed Gulls were important and powerful scavengers which did not consume very large amounts of the discards produced, becuase they were usually not very numerous. Many of the items consumed at the trawl were stolen from other seabirds and the feeding success of smaller birds was negatively affected if larger groups of Great Black-backed Gulls came about. Great Black-backed Gulls occurred widespread and in all seasons, but were more abundant in winter than in summer.

\subsection{KITTIWAKE RISSA TRIDACTYLA}

Kittiwakes are small to medium-sized, essentially pelagic gulls, with a rather fine bill, round head, narrow body and relatively long and straight wings (Cramp \& Simmons 1983). With a wingspan of around $100 \mathrm{~cm}$ and a mass of $300-500 \mathrm{~g}$, this is one of the smaller scavenging seabirds in the North Sea, overlapping in size and mass with Common Gulls. The North Sea breeding population of Kittiwakes is estimated at 415,000 pairs, most of which breed on English and Scottish coasts (Tasker et al. 1987, Dunnet et al. 1990, Lloyd et al. 1991, Tasker \&
Becker 1992). Kittiwakes are well known as scavengers at fishing vessels in the Northeast Atlantic (Camphuysen 1993a). Hillis (1971) listed the Kittiwake as most numerous at fishing vessels in the Irish Sea after the Herring Gull (up to 200-300 at a time). Watson (1981) found that $25.6 \%$ of 21,500 recorded scavengers in the northern Irish Sea were Kittiwakes. Dare (1982) and Dändliker \& Mülhauser (1988) recorded small numbers of Kittiwakes at fishing vessels off northwest Scotland. Hudson \& Furness (1989) found that around Shetland, Kittiwakes were often present at the trawl in small numbers. Manikowski (1971) reported up to 2000 Kittiwakes at commercial fishing vessels in the northern North Sea (October). In the southern North Sea, up to 500 Kittiwakes were recorded near fishing vessels, and most were recorded in winter (September-March; Camphuysen 1993a). Kittiwakes were usually described as rather timid scavengers, feeding on the periphery of the main flock of scavengers at the trawl and avoiding the most heavy fights for scraps (Boswall 1960, Furness et al. 1988, Hudson \& Furness 1989). In the Clyde (West Scotland), Kittiwakes were never seen stealing fish from other scavengers (Furness et al. 1988). Several recent studies showed that Kittiwakes were successful in feeding on offal, particularly in areas where Fulmars were scarce (Garthe 1992, Camphuysen 1993a). From experiments in the Barents Sea, Erikstad et al. (1988) concluded that Kittiwakes followed fishing vessels on average for 8-10 hours (departure rate $4.2-5.1 \%$ per hour, turnover 32 hours). Significant correlations between densities of Kittiwakes at sea and presence of fishing vessels were only found in December and February (Tasker et al. 1987) suggesting that fishing vessels represent an important source of food during (late) winter, perhaps due to a reduction in the availability of their natural prey at this time.

\section{Kittiwakes at sea}

Kittiwakes were the second most numerous scavenging seabird in the North Sea. In sum- 

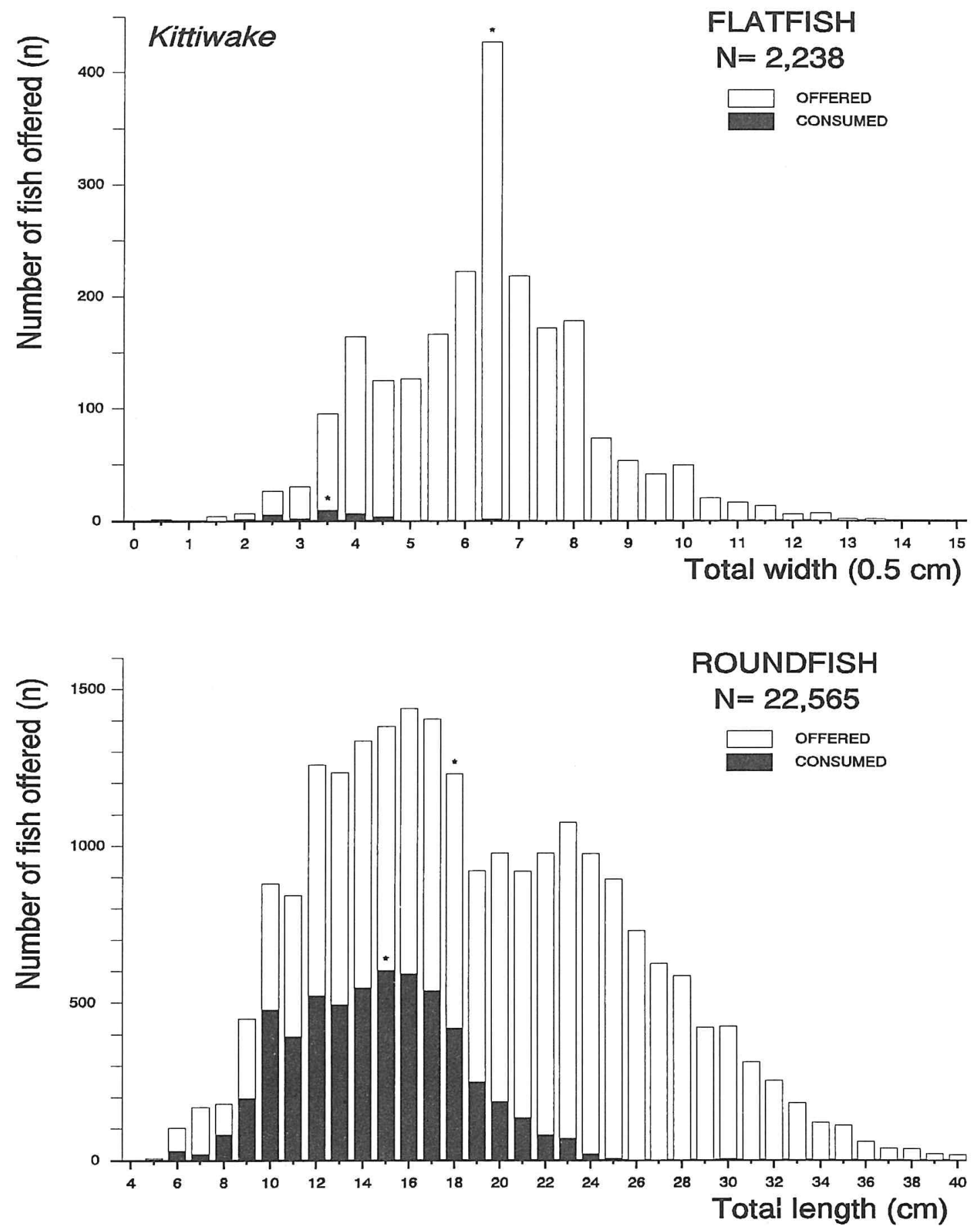

Figure 5.8.1 Width of flatfish and length of roundfish consumed by Kittiwake. See for conventions figures 5.1.1-2. 
mer, waters off the British east coast were of greatest significance for this species, whereas Kittiwakes were widespread in autumn and winter. In February, comparatively low densities occurred in the central North Sea (figure 4.1.31). Moderate to high densities were reported in the Southern Bight, off southwest Norway, in the Moray Firth and off Orkney and Shetland. 92.0\% were mature birds $(n=3282$; table 4.1.11). In May, most Kittiwakes were found in the western half of the North Sea, with moderate to high densities in the Dogger Bank region and off the east coast of England and Scotland (figure 4.1.32). Scattered low to moderate densities were found in the northern and central North Sea, but Kittiwakes were rather scarce further to the east and to the south. A large concentration of eagerly feeding Kittiwakes, operating in restless groups ranging in size from 10-300 individuals, were observed on 6 May 1994 at Long Forties, just to the northeast of Aberdeen Bank. There were no fishing vessels active in this area. Kittiwakes were sometimes joined by small numbers of Gannets, while auks were rather scarce in these waters. Within the centre of Kittiwake distribution (NW, CW, C), virtually all gulls were mature (97.1\% adult, $\mathrm{n}=6827$; table 4.1.11), whereas a quarter were immatures in the rest of the North Sea. In August, the distribution of Kittiwakes was even more strongly clumped, with very large numbers in subregion $\mathrm{CW}(95.3 \%$ adults, $\mathrm{n}=1065$; table 4.1.3, 4.1.11). The most important (feeding) concentrations were located at the Aberdeen Front, the transition zone between stratified water of the central North Sea and mixed coastal waters off East Scotland. On 19 August 1994, in places within a zone of $c a$. $25 \mathrm{~km}$ wide, densities peaked at 1250 Kittiwakes per $\mathrm{km}^{2}$ and all these birds were actively feeding in groups, usually comprising several hundreds of birds (Camphuysen 1994c). Fishing vessels were not observed in these waters. Kittiwakes became more widespread in November and high densties occurred everywhere in the North Sea, ex- cept in most coastal waters (figure 4.1.34). At the Dogger Bank, an area with consistently moderate to high densities of Kittiwakes, feeding associations with Guillemots were recorded frequently while surface shoaling immature Herring were identified as their main prey (Camphuysen et al. in prep.). Kittiwakes were the second most numerous species in the North Sea, with minimum abundance estimates ranging from 300,000400,000 individuals in winter to 600,000 700,000 individuals in summer and maximum estimates ranging from 1.1-1.4 million individuals and 0.7-1.1 million birds respectively (table 4.2.9).

\section{Kittiwakes at the stern}

The second most numerous scavenger in the North Sea was clearly the Kittiwake. Numbers at the trawl peaked in November and were, generally, considerably higher in winter than in summer. Kittiwakes were widespread in all seasons, occurring both inshore and offshore in large numbers and adults were always much more numerous at the trawl than immatures and juveniles. In February, Kittiwakes were abundant and widespread, occurring in all subregions in substantial numbers (figure 4.3.31, table 4.3.9). Nine out of ten Kittiwakes in February were adults $(92.0 \%, n=11,472)$, except in Skagerrak, where a third were immatures $163.0 \%$ adult, $n=403$ ). In May, Kittiwakes were rather scarce in the Skagerrak area, in most of the German Bight and Southern Bight and in large portions of the northern North Sea (figure 4.3.32). The presence at the trawl dropped to $74 \%$ (table 4.3 .9 ) and was particularly low in NE (40\%) and Sk (18\%). Nearly $90 \%$ of the Kittiwakes observed were adults $(89.4 \%, n=4816)$. The overall impression is that Kittiwake distribution showed a contraction towards the breeding stations (off the British east coast), at least as compared with its distribution in February. In August, the distribution had changed again. Kittiwakes had become more widespread, but numbers at the trawl were even smaller than in May (table 4.3.9, figure 
4.3.33). The eastern and southern North Sea had gained importance, but the overall presence as scavenger at the trawl was still stuck at $75 \%$ of all hauls. Up to 200 Kittiwakes were attracted in the central North Sea, but such a figure was quite an exception. The proportion of mature birds had fallen to $69.7 \%$ ( $n=1830$ ), which was obviously caused by the fledged juveniles. Much larger numbers were attracted in November, when the overall mean at the trawl had increased tenfold from 10 (in August) to 115 individuals per haul. Up to 1600 Kittiwakes were assembled during a haul (subregion NW) and several hundreds of birds formed no exception in most subregions. Nine out of ten Kittiwakes at the trawl were adults $188.6 \%$ adult, $n=14,187$ ). Of all Kittiwakes recorded at sea in winter, $7 \%$ (November) and $25 \%$ (February) were observed in association with fishing vessels. In summer, only $1 \%$ of the overall much larger numbers of birds were seen near these boats. These figures indicate that fisheries are much more important for these birds in winter than in summer.

\section{Kittiwakes as scavengers}

The feeding strategy of Kittiwakes at the trawl can be described as rapid action, and avoiding fights. Although Kittiwakes did rob other birds (mainly other Kittiwakes), they were highly vulnerable to robbery from larger gulls, Great Skuas and Gannets and therefore usually selected fish that could be instantly swallowed mid-air. Kittiwakes were constantly on the wing, often very close to the ship, and were usually the first to select fish and offal particles. When larger numbers of Fulmars appeared at the (stationary) ship, fighting for offal or discards just close to the side of the boat, Kittiwakes would disperse and feed at the periphery of the Fulmar flock, avoiding disputes with these aggressive birds. Again, rapid action on the wing, or a shallow plunge dive followed by immediate take off, was a guarantee for success. Kittiwakes would seldom alight on the water while foraging and these gulls were equally successful when the discarding ship was moving or stationary. Kittiwakes were quite capable of diving and were seen to reach nearly one metre depth.

Considering the numbers of gadid discards consumed, Kittiwakes ranked highest in February in subregions NE, CW, C and $\mathrm{S}$ and were the second most important scavengers in NW and CE. With respect to clupeid consumption, Kittiwakes in February ranked highest five out of six subregions, and were the second most important consumer in NW. In summer, particularly in August, rather trivial amounts of gadids and clupeids were consumed compared to species like Fulmar (NW, NE, CW, C) and Lesser Black-backed Gull (Sk, CE, S). Kittiwakes gained importance in November, particularly in NW, CW and C. Success indices of Kittiwakes consuming gadids varied between 0.5 and 2 in most seasons and subregions (tables 4.6.20-23). With respect to clupeid consumption, success indices were generally slightly higher, but also more variable (tables 4.6.30-33). In August, when comparatively small numbers of Kittiwakes were scavenging at fishing vessels and during experimental discarding, success indices for clupeids were particularly high in subregions $\mathrm{NE}, \mathrm{CW}$, and $\mathrm{CE}$ (table 4.6.32). In winter, success indices of immature Kittiwakes were generally higher than those of adults. In summer, rather the reverse was true, although the differences were smaller (tables 4.6.40-41).

Kittiwakes took small fish in comparison with most other scavengers, similar in size to fish taken by Common Gulls (tables 5.1-2). The median width of 28 flatfish consumed by these gulls was $3.5 \mathrm{~cm}$ (range 0.5-6.5 $\mathrm{cm})$, which is considerably less than the median width of 2238 flatfish offered in the presence of these birds $16.5 \mathrm{~cm}$; figure 5.8.1). Roundfish taken by Kittiwakes ranged in length from $5-34 \mathrm{~cm}(n=5675)$, but it should be noted that the larger roundfish were mostly slender bodied Greater Sandeels Hyperoplus lanceolatus. The median length of roundfish consumed by these birds was $15 \mathrm{~cm}$, which is considerably less than the 
median length of roundfish offered in the presence of this species $118 \mathrm{~cm}, \mathrm{n}=$ 22,565; figure 5.8.2).

Kittiwakes were extremely vulnerable to robbery, ranking lowest in the dominance hierarchy based on the robbery index (tables 4.7.6-8). Nearly 400 fish were lost through kleptoparasitism, whereas only 25 fish were stolen by Kittiwakes from other birds (table 4.7.5). Intre-specific interactions were frequent, considering the 362 fish stolen by one Kittiwake from another, comprising nearly $50 \%$ of all fish which were lost as a result of robbery. Kittiwakes were not very keen to pick up fish which were dropped by others, in fact they usually operated near the ship and tried new fish first (table 4.7.9-10).

In conclusion, Kittiwakes were among the most abudant scavengers in the North Sea, being common and widespread in all seasons. It appeared that commercial fisheries were more attractive for Kittiwakes in winter than in summer, apparently reflecting the difficulty to feed 'naturally' in winter as compared to summer. Because Kittiwakes were so numerous, the majority of all roundfish smaller than $20 \mathrm{~cm}$ offered during experimental discarding were consumed by this species.

\subsection{OTHER SPECIES}

None of the other species observed at the trawl obtained more than trivial amounts of the discards offered during experimental discarding. With the exception of Guillemots and Razorbill, most of the other species were not very common offshore in the North Sea. The auks were only attracted to fishing vessels and fishing research vessels in $\mathrm{Fe}$ bruary 1993, after a period of very string storms. In fact, the scavenging behaviour can be labelled as highly unusual and probably occurred only because the birds were extremely hungry. Typical was that most scavenging auks were attracted in the southeastern North Sea, mainly in the Southern and German Bights, away from their core distribution area in winter.

\section{THE AMOUNTS DISCARDED IN COMMERCIAL FISHERIES AND THE NUMBER OF SEABIRDS POTENTIALLY SUPPORTED}

Consumption rates of fishery waste by seabirds are now well known for the whole North Sea and all four seasons. For calculating the total number of seabirds which could be sustained by this food supply, accurate data on the amount of discards are needed. These are available for some fisheries, such as beamtrawl, and gadid fisheries, while for others the information is poor (pelagic fishery) or lacking (set net and industrial fisheries). Although the data are of considerably different quality and some extrapolation is still required, a rough estimate for the whole area can be given.

\section{Quantities of fish discarded}

In the last few years many data about discards have been published both by fishery and seabird biologists. In this report we leave out the coastal zone due to a lack in coverage during the four surveys within our study period. Hence, shrimp fishery which is almost completely restricted to the Wadden Sea area is not dealt with although extensive data have been compiled for the Wadden Sea (Tiews 1983, Tiews \& Wienbeck 1990, Berghahn 1990, Walter \& Becker 1994). Three offshore fisheries produce large amounts of discards: gadid fishery by trawl and seine, pelagic fishery for clupeids and mackerel, and beamtrawl fishery for Sole and Plaice. Although some estimates have been given previously, we concentrate chiefly on the actual data to match as well as possible the study period. Beamtrawl fishery is nowadays probably the most important fishery in the southern and southeastern North Sea. It is carried out predominantly by Dutch trawlers but also by Belgian, German and U.K. vessels (Anon. 1993). The main target spe- 
Table 6.1 Mass of discarded fish (tonnes) in the North Sea beamtrawl fishery for Sole, estimated from data in Anon. (1995), Fonds (1991), Fonds et al. (1992), Garthe (1993) and Bergman et al. (in prep.). Fish discards estimated as $7 x$ and benthic invertebrates estimated as 6x Sole landings (by mass). Data for 1993 are provisional (Anon. 1995).

\begin{tabular}{llcc}
\hline Year & $\begin{array}{c}\text { Sole } \\
\text { landings }(t)\end{array}$ & $\begin{array}{c}\text { fish } \\
\text { discards }(t)\end{array}$ & $\begin{array}{c}\text { benthic } \\
\text { invertebrates }(t)\end{array}$ \\
\hline 1989 & 21,821 & 152,747 & 130,926 \\
1990 & 35,133 & 245,931 & 210,798 \\
1991 & 33,535 & 234,745 & 201,210 \\
1992 & 29,349 & 205,443 & 176,094 \\
1993 & 31,170 & 218,190 & 187,020 \\
mean & 30,202 & 211,411 & 181,210 \\
\hline
\end{tabular}

Table 6.2 Estimated quantities of Haddock and Whiting discarded in the North Sea, 19711991 (from Anon. 1993)

\begin{tabular}{|c|c|c|c|c|c|}
\hline \multirow[b]{2}{*}{ Year } & \multicolumn{2}{|c|}{ Haddock } & \multicolumn{2}{|c|}{ Whiting } & \multirow{2}{*}{$\begin{array}{l}\text { Combined } \\
\text { Weight } \\
\text { ('OOO tonnes) }\end{array}$} \\
\hline & $\begin{array}{r}\text { Numbe } \\
\text { (millions) }\end{array}$ & $\begin{array}{l}\text { ers Weight } \\
\text { ('O0O tonnes) }\end{array}$ & $\begin{array}{l}\text { Numbe } \\
\text { (millions) }\end{array}$ & $\begin{array}{l}\text { rs Weight } \\
\text { ('000 tonnes) }\end{array}$ & \\
\hline 1971 & 1282 & 177 & 458 & 63 & 240 \\
\hline 1972 & 760 & 128 & 398 & 67 & 195 \\
\hline 1973 & 660 & 115 & 659 & 110 & 225 \\
\hline 1974 & 1091 & 167 & 477 & 85 & 252 \\
\hline 1975 & 1862 & 260 & 699 & 135 & 395 \\
\hline 1976 & 788 & 154 & 641 & 136 & 290 \\
\hline 1977 & 226 & 44 & 547 & 163 & 207 \\
\hline 1978 & 418 & 77 & 240 & 35 & 112 \\
\hline 1979 & 286 & 42 & 640 & 77 & 119 \\
\hline 1980 & 541 & 95 & 466 & 76 & 171 \\
\hline 1981 & 298 & 60 & 210 & 35 & 95 \\
\hline 1982 & 181 & 41 & 168 & 26 & 67 \\
\hline 1983 & 389 & 66 & 360 & 48 & 114 \\
\hline 1984 & 412 & 75 & 317 & 39 & 114 \\
\hline 1985 & 458 & 86 & 226 & 28 & 114 \\
\hline 1986 & 308 & 52 & 572 & 78 & 130 \\
\hline 1987 & 334 & 59 & 408 & 53 & 112 \\
\hline 1988 & 362 & 62 & 227 & 28 & 90 \\
\hline 1989 & 111 & 26 & 275 & 35 & 61 \\
\hline 1990 & 192 & 33 & 524 & 54 & 87 \\
\hline 1991 & 216 & 40 & 235 & 33 & 73 \\
\hline \multicolumn{6}{|l|}{ average } \\
\hline 87-91 & 243 & 44 & 334 & 41 & 85 \\
\hline
\end{tabular}


Table 6.3 Species composition of discards sampled in 1985 compared with species composition sampled in 1987. From Hudson (1986) and Furness (1987). 'Other species' comprise Angler, Dragonette, Hake, Scad, Lesser argentine, Ling, Mackerel, Monkfish, Skate.

\begin{tabular}{lrr}
\hline & \multicolumn{2}{c}{ Percent of total sample } \\
Fish species & 1985 & 1987 \\
\hline Haddock & 37.6 & 57.9 \\
Whiting & 34.0 & 18.8 \\
Long Rough Dab & 9.6 & 3.4 \\
Red Gurnard & 7.4 & 7.5 \\
Lemon Sole & 4.2 & 2.8 \\
Grey Gurnard & 2.6 & 0 \\
Cod & 1.2 & 3.9 \\
Witch & 1.2 & 2.3 \\
Norway Pout & 0.5 & 1.6 \\
Saithe & 0.5 & 0.1 \\
Megrim & 0.3 & 0.1 \\
Herring & 0.2 & 0.9 \\
Plaice & 0.2 & 0.6 \\
9 other species & $<0.1$ & $<0.1$ \\
& & 5305 \\
Total discards sampled & 7605 &
\end{tabular}

cies is Sole, but also Plaice and other flatfish species are of great commercial interest. Since the heavy gear used by these ships penetrates considerably into the sediment, the unwanted proportion of the catch is consistently high. Recent studies by Fonds (1991), Fonds et al. (1992), Garthe (1993b) and Bergman et al. in prep. have revealed that between 4 and $10 \mathrm{~kg}$ of fish discards (rough mean: $7 \mathrm{~kg}$ ) and between 4 and 11 $\mathrm{kg}$ of benthic invertebrates (rough mean: 6 $\mathrm{kg}$ ) are produced per $\mathrm{kg}$ of Sole landed. On this basis we can extrapolate the data using landing statistics of Sole in the North Sea (table 6.1). If we assume a proportion of $93 \%$ of flatfish and $7 \%$ of roundfish (Garthe $1993 b)$, the result for the whole beamtrawl fishery is on average 197,000 t flatfish and $15,000 \mathrm{t}$ roundfish per year for the period of 1989 to 1993 . Furthermore, about 181,000 $\mathrm{t}$ of benthic invertebrates were discarded. Based on regular sampling of the Scottish seine, trawl and light trawl fisheries, the Roundfish Working Group has estimated the number of Haddock and Whiting discarded by North Sea fisheries for gadids (Anon. 1993, table 6.2). 85,000 t have been discarded on average per year in the time from 1987 to 1991 . The numbers were much higher in the 1970s and also in the first half of the 1980s, and have declined due to a reduction of many gadid stocks in the North Sea (cf. Daan et al. 1990). It has to be added that Haddock and Whiting form only a part of the discards fraction (see below), resulting in higher values for the totals. Pelagic fisheries have been studied only few times with regard to discards. Because of incomplete coverage, Corten (1991) did not give any estimates of the total amount of discards in the Dutch Herring and Mackerel fisheries. Although the information is obviously poor, a rough estimate of the discards is valuable. Analogous to the procedure for beamtrawl fishery, a ratio of discards per unit mass of Herring caught was derived from the data given by Corten (1991). Summarizing all North Sea data in that report, 38 
Table 6.4a Lengths of Haddock discarded from whitefish boats around Shetland in April 1987 and June/July 1987 (after Furness 1987).

\begin{tabular}{|c|c|c|c|c|}
\hline Fish length & & 987 & & 987 \\
\hline$(\mathrm{cm})$ & $\mathrm{n}$ & $\%$ & $\mathrm{n}$ & $\%$ \\
\hline 15 & 1 & 0.1 & 0 & 0.0 \\
\hline 16 & 1 & 0.1 & 0 & 0.0 \\
\hline 17 & 5 & 0.4 & 1 & 0.1 \\
\hline 18 & 5 & 0.4 & 3 & 0.2 \\
\hline 19 & 4 & 0.3 & 11 & 0.6 \\
\hline 20 & 6 & 0.5 & 32 & 1.8 \\
\hline 21 & 2 & 0.2 & 60 & 3.3 \\
\hline 22 & 8 & 0.6 & 74 & 4.1 \\
\hline 23 & 26 & 2.0 & 101 & 5.6 \\
\hline 24 & 67 & 5.3 & 96 & 5.3 \\
\hline 25 & 88 & 6.9 & 152 & 8.4 \\
\hline 26 & 124 & 9.8 & 211 & 11.7 \\
\hline 27 & 179 & 14.1 & 283 & 15.7 \\
\hline 28 & 269 & 21.2 & 279 & 15.5 \\
\hline 29 & 254 & 20.0 & 276 & 15.3 \\
\hline 30 & 159 & 12.5 & 142 & 7.9 \\
\hline 31 & 57 & 4.5 & 66 & 3.7 \\
\hline 32 & 15 & 1.2 & 11 & 0.6 \\
\hline 33 & 0 & 0.0 & 2 & 0.1 \\
\hline 34 & 1 & 0.1 & 0 & 0.0 \\
\hline 35 & 0 & 0.0 & 2 & 0.1 \\
\hline Total & 1271 & & 1802 & \\
\hline median & 28 & & 27 & \\
\hline mean & 27.6 & & 26.6 & \\
\hline S.E. & 0.1 & & 0.1 & \\
\hline $\begin{array}{l}\text { Table } 6.4 b \\
\text { and June/ }\end{array}$ & $\begin{array}{l}\text { Vhiting } \\
\text { er Furn }\end{array}$ & $\begin{array}{l}\text { rded fr } \\
\text { 987). }\end{array}$ & ish bo & d She \\
\hline Fish length & & 987 & & 987 \\
\hline$(\mathrm{cm})$ & $\mathrm{n}$ & $\%$ & $\mathrm{n}$ & $\%$ \\
\hline 13 & 1 & 0.2 & 0 & 0.0 \\
\hline$\ddot{20}$ & 1 & 0.2 & 1 & 0.2 \\
\hline 21 & 2 & 0.4 & 3 & 0.6 \\
\hline 22 & $1 \overline{5}$ & 2.9 & 10 & 2.1 \\
\hline 23 & 31 & 6.1 & 21 & 4.3 \\
\hline 24 & 37 & 7.2 & 33 & 6.8 \\
\hline 25 & 47 & 9.2 & 48 & 9.9 \\
\hline 26 & 55 & 10.8 & 67 & 13.8 \\
\hline 27 & 63 & 12.3 & 97 & 20.0 \\
\hline 28 & 69 & 13.5 & 93 & 19.1 \\
\hline 29 & 84 & 16.4 & 64 & 13.2 \\
\hline 30 & 49 & 9.6 & 34 & 7.0 \\
\hline 31 & 42 & 8.2 & 11 & 2.3 \\
\hline 32 & 14 & 2.7 & 3 & 0.6 \\
\hline 33 & 0 & 0.0 & 0 & 0.0 \\
\hline 34 & 1 & 0.2 & 1 & 0.2 \\
\hline Total & 511 & & 486 & \\
\hline median & 28 & & 27 & \\
\hline mean & 27.8 & & 26.9 & \\
\hline S.E. & 0.1 & & 0.1 & \\
\hline
\end{tabular}


Table 6.4C Lengths of Red Gurnard discarded from whitefish boats around Shetland in April 1987 and June/July 1987 (after Furness 1987).

\begin{tabular}{|c|c|c|c|c|}
\hline \multirow{2}{*}{$\begin{array}{l}\text { Fish length } \\
(\mathrm{cm})\end{array}$} & \multicolumn{2}{|c|}{ April 1987} & \multicolumn{2}{|c|}{ June/July 1987} \\
\hline & $n$ & $\%$ & $\mathrm{n}$ & $\%$ \\
\hline 14 & 1 & 0.7 & 0 & 0.0 \\
\hline 15 & 2 & 1.3 & 4 & 1.6 \\
\hline 16 & 6 & 4.0 & 16 & 6.5 \\
\hline 17 & 14 & 9.4 & 37 & 14.9 \\
\hline 18 & 10 & 6.7 & 51 & 20.6 \\
\hline 19 & 16 & 10.7 & 27 & 10.9 \\
\hline 20 & 14 & 9.4 & 43 & 17.3 \\
\hline 21 & 17 & 11.4 & 22 & 8.9 \\
\hline 22 & 19 & 12.8 & 17 & 6.9 \\
\hline 23 & 17 & 11.4 & 7 & 2.8 \\
\hline 24 & 13 & 8.7 & 8 & 3.2 \\
\hline 25 & 7 & 4.7 & 7 & 2.8 \\
\hline 26 & 5 & 3.4 & 2 & 0.8 \\
\hline 27 & 7 & 4.3 & 1 & 0.4 \\
\hline 28 & 0 & 0.0 & 3 & 1.2 \\
\hline 29 & 1 & 0.7 & 2 & 0.8 \\
\hline 34 & 0 & 0.0 & 1 & 0.4 \\
\hline Total & 149 & & 248 & \\
\hline median & 21 & & 19 & \\
\hline mean & 21.1 & & 19.6 & \\
\hline S.E & 0.3 & & 0.2 & \\
\hline
\end{tabular}

$\mathrm{kg}$ of discards per $1,000 \mathrm{~kg}$ of marketable Herring result. Extrapolating with the total landings for 1988 , a crude figure of 19,000 $t$ of roundfish discards (chiefly undersized Mackerel, Herring and Saithe) can be expected. Due to fisheries policy during his sampling period, Corten (1991) does not believe that the way of discarding performed by the crew is realistic for the whole fleet. Therefore, he supposes that higher amounts of discards are produced when observers do not take part at cruises. It is unclear whether these data from Dutch pelagic pair trawlers can be transferred to other pelagic fisheries (e.g. danish seine, purse seine). However, for a rough estimate it should be relevant.

Species composition and size distributions of fish discards

The species composition as well as the size distribution varied remarkably between fisheries, fishing ground and time of the year. Examples of species composition and length distributions are given for Scottish whitefish trawlers (tables 6.3 and 6.4), for pelagically fishing Dutch pair trawlers (table 6.5) and for Dutch (table 6.6) and German (table 6.7) beamtrawlers. It is very obvious that the type of fishery has a greater influence on both length and species composition than the season. Generally, beamtrawl fisheries discharge discards in the highest rates of all fishing fleets. Because of the clear dominance of flatfish in the discards fraction of this fishery, seabirds have to select carefully for the few roundfish or have to take the less favoured flatfish (table 6.8). The opposite holds for pelagic and gadid fisheries: here, the amount of discards is less, but the type, though not necessarily the size, of discards available is more appropriate for seabirds.

\section{Quantities of offal discarded}

Offal (fish intestines and livers) is discharged when fish are gutted at sea. This type of food is taken in particularly high rates by 
Table 6.5 Length distributions of Herring and Mackerel in the discards fraction of pelagically fishing Dutch pair trawlers (after Corten 1991).

\begin{tabular}{lrrr}
\hline $\begin{array}{c}\text { Length } \\
(\mathrm{cm})\end{array}$ & $\begin{array}{c}\text { Herring } \\
\text { June/July } \\
\text { NW }\end{array}$ & $\begin{array}{c}\text { Herring } \\
\text { August } 1991 \\
\text { CW }\end{array}$ & $\begin{array}{c}\text { Mackerel } \\
\text { June/July } \\
\text { NW }\end{array}$ \\
\hline$<19$ & 0 & 80 & 0 \\
20 & 0 & 1280 & 0 \\
21 & 0 & 3760 & 96 \\
22 & 0 & 4640 & 480 \\
23 & 0 & 4720 & 1392 \\
24 & 0 & 2240 & 1680 \\
25 & 0 & 880 & 240 \\
26 & 1428 & 80 & 218 \\
27 & 4760 & 0 & 127 \\
28 & 4284 & 0 & 316 \\
29 & 4284 & 0 & 316 \\
30 & 2063 & 0 & 554 \\
31 & 793 & 0 & 580 \\
32 & 952 & 0 & 394 \\
33 & 159 & 0 & 289 \\
34 & 0 & 0 & 241 \\
35 & 0 & 0 & 184 \\
36 & 0 & 0 & 79 \\
37 & 0 & 0 & 79 \\
38 & 0 & 0 & 26 \\
39 & 0 & 0 & 26 \\
$>39$ & 0 & 0 & 52 \\
total & 0 & & 6923 \\
\hline
\end{tabular}

seabirds. For quantifying offal we presume that it represents $11 \%$ of the mass of roundfish and $6.5 \%$ of the mass of flatfish (Furness et al. 1988). It is assumed that all demersal fish (flatfish, gadids and few other) are gutted at sea and that all offal is discharged at sea. Although neither of these assumptions is completely correct (Furness et al. 1988), the largest proportions of demersal fish are probably gutted at sea and the offal is thrown over board afterwards. Thus, our estimate is based on statistics of the amount of all demersal fish landed from the North Sea (Grainger 1992). The figure of $69,200 \mathrm{t}$ for 1988 can be interpreted as the maximum quantity available and is slightly lower than calculations given by Furness et al. (1988) for $1982(83,700 \mathrm{t})$, as landings of demersal fish have decreased.

\section{Consumption rates by seabirds}

This study has found that, on average, 95\% of discarded offal, $80 \%$ of discarded roundfish, $20 \%$ of discarded flatfish and $6 \%$ of discarded benthic invertebrates have been consumed by scavenging seabirds (table 6.9, see also chapter 4.6). The mass of discards and offal consumed by birds during our study amounts to slightly more than $200,000 \mathrm{t}$ (table 6.9). The consumption rates are in the same magnitude of results of previous studies (table 6.8). Nevertheless, some differences exist between discarding practices on fishing vessels and on fisheries research vessels. They will altogether probably lead to an overestimate of consumption rates when working on research vessels. Since the items were mostly discarded one after the other and not only when discarding of the unwanted catch was carried out, birds were sometimes confronted with unusal situations. Thus, they had no choice between different 
type of fish. Also, rapidly sinking particles were consumed less frequently when discarding took place on a larger scale. However, some fish sank because few scavenging seabirds were attending research vessels on some occasions, a situation which is not commonly found with fishing vessels during fish discarding. Further points are listed by Camphuysen et al. (1993) and Garthe \& Hüppop (1994).

\section{Estimated numbers of scavenging seabirds} supported

This section is to show how many seabirds could live solely from discards and offal. In a previous section, the total amount of discards and offal in the North Sea has been estimated as $69,200 \mathrm{t}$ of offal, $119,000 \mathrm{t}$ of roundfish, $197,000 \mathrm{t}$ of flatfish and 181,200 t of benthic invertebrates. Converted into energy values, this can be considered as the amount of fishery waste of which a certain number of scavenging birds can be theoretically sustained. The energy requirements of seabirds have been studied in recent years. For their calculation, the following formula for free-ranging cold water seabirds given by Birt-Friesen et al. (1989) will be used:

$$
\begin{aligned}
& \log \text { (field metabolic rate) }^{1}= \\
& 3.13+0.646 \log \text { (body mass) }{ }^{2} \\
& 1 \text { = expressed in } \mathrm{kJ} \text { per day } \\
& { }^{2}=\text { expressed in } \mathrm{kg}
\end{aligned}
$$

Most of the scavenging seabirds in the North Sea fly considerable distances and have consequently high energetic needs. Thus, our estimate of the energy requirements can be considered as conservative. On the other hand, the formula above implies a field metabolic rate (FMR) of 3.8 times basal metabolic rate (BMR). Birds outside the breeding season are assumed to have lower energetic needs (Anon. 1994a), because they do not need to fly up and down their colonies to feed their chicks. However, for a rough calculation of the numbers of seabirds suppor- ted by discards and offal this figure can be applied. With an assimilation efficiency of $80 \%$, the energy intake of a $1,000 \mathrm{~g}$ seabird, which can be considered as a modelbird with medium size if compared to the scavengers found in the North Sea, must be around $1,350 \mathrm{~kJ}$ per day or $493,000 \mathrm{~kJ}$ per year.

Even for a large number of seabirds attending a trawler, it is not possible to swallow the whole bulk of fishery waste discharged. This can be due to the high amount of waste per time, often rapidly sinking items (sea urchins, Hermit crab Pagurus bernhardus), but also due to manoeuvres of the ship, escaping distance of the birds from the ship etc. Hence, we have to calculate the number of seabirds which could be sustained potentially from fishery waste. For this reason, we use the highest consumption rates found for each of the four categories in one of the subregions (except Skagerrak) during the "best" respective season: $100 \%$ for offal, $95 \%$ for roundfish, $60 \%$ for flatfish and $8 \%$ for benthic invertebrates. Calorific values are assumed to be $10 \mathrm{~kJ} / \mathrm{g}$ for offal, $5 \mathrm{~kJ} / \mathrm{g}$ for roundfish, $4 \mathrm{~kJ} / \mathrm{g}$ for flatfish and $2.5 \mathrm{~kJ} / \mathrm{g}$ for benthic invertebrates (table 6.9, values according to Camphuysen et al. 1993). A figure of 3.5 million $1,000 \mathrm{~g}$ seabirds results. Such calculations presuppose that discards and offal are evenly available in time. This is not the case in beamtrawl fisheries in the German Bight (Garthe \& Damm in prep.).

\section{Discussion}

Between 1.5-4.0 million and 3.0-6.5 million scavenging seabirds per season have been estimated to be present in the North Sea (table 4.2.9). Diet studies demonstrate that seabirds not only feed on discards and offal, but also, perhaps mainly, exploit natural resources (reviews in Camphuysen 1993c, Anon. 1994a). If we assume, however, that all scavengers consume only fishery waste, we could extrapolate the amount of discards and offal which could have been consumed during our study period. For this purpose, we also assume that the birds swallow the four 
Table 6.6 Length distributions of Dab, Plaice and Whiting in the discards fraction of Dutch beamtrawlers (after Van Beek 1990). Numbers are given per $100 \mathrm{~h}$ of fishing in region S.

\begin{tabular}{|c|c|c|c|c|c|}
\hline $\begin{array}{l}\text { Length } \\
(\mathrm{cm})\end{array}$ & $\begin{array}{c}\text { Dab } \\
\text { February } 1990\end{array}$ & $\begin{array}{c}\text { Dab } \\
\text { June } 1990\end{array}$ & $\begin{array}{l}\text { Plaice } \\
\text { February } 1990\end{array}$ & $\begin{array}{c}\text { Plaice } \\
\text { June } 1990\end{array}$ & $\begin{array}{l}\text { Whiting } \\
\text { June } 1990\end{array}$ \\
\hline 8 & 0 & 287 & 0 & 0 & 0 \\
\hline 9 & 0 & 335 & 0 & 0 & 0 \\
\hline 10 & 0 & 4017 & 0 & 0 & 0 \\
\hline 11 & 0 & 4352 & 0 & 0 & 0 \\
\hline 12 & 1391 & 2822 & 0 & 0 & 0 \\
\hline 13 & 3616 & 5404 & 0 & 0 & 0 \\
\hline 14 & 4503 & 20373 & 0 & 0 & 0 \\
\hline 15 & 7810 & 34959 & 68 & 0 & 0 \\
\hline 16 & 11989 & 51411 & 0 & 0 & 84 \\
\hline 17 & 26114 & 56050 & 130 & 0 & 84 \\
\hline 18 & 18811 & 35629 & 187 & 72 & 155 \\
\hline 19 & 16374 & 21473 & 956 & 538 & 299 \\
\hline 20 & 8652 & 17791 & 1549 & 514 & 347 \\
\hline 21 & 4825 & 9995 & 2184 & 801 & 96 \\
\hline 22 & 3216 & 2917 & 2085 & 2223 & 538 \\
\hline 23 & 1920 & 0 & 2647 & 2199 & 1064 \\
\hline 24 & 784 & 813 & 3753 & 2773 & 801 \\
\hline 25 & 1341 & 191 & 5013 & 1817 & 1566 \\
\hline 26 & 0 & 0 & 3509 & 1661 & 2379 \\
\hline 27 & 0 & 0 & 2661 & 263 & 1924 \\
\hline 28 & 0 & 0 & 1027 & 96 & 1530 \\
\hline 29 & 0 & 0 & 494 & 0 & 478 \\
\hline 30 & 0 & 0 & 318 & 0 & 394 \\
\hline 31 & 0 & 0 & 190 & 108 & 0 \\
\hline 32 & 0 & 0 & 0 & 0 & 323 \\
\hline 33 & 0 & 0 & 68 & 0 & 0 \\
\hline 34 & 0 & 0 & 0 & 0 & 0 \\
\hline total & 111343 & 268819 & 26839 & 13065 & 12062 \\
\hline
\end{tabular}

Table 6.7 Composition (\%) of the discards fraction in German beamtrawl fishery in the German Bight by mass and number of fish (after Garthe 1993).

\begin{tabular}{lcc}
\hline Species & mass (\%) & number (\%) \\
\hline Plaice & 51.7 & 47.7 \\
Dab & 29.7 & 39.3 \\
Flounder & 10.2 & 4.2 \\
Bull-rout & 2.6 & 1.2 \\
Grey Gurnard & 0.9 & 0.8 \\
Cod & 0.8 & 0.5 \\
Hooknose & 0.8 & 2.7 \\
Bib & 0.7 & 0.3 \\
Dragonet & 0.7 & 1.5 \\
Whiting & 0.6 & 0.4 \\
Scad & 0.4 & 0.1 \\
Turbot & 0.3 & 0.1 \\
Tub Gurnard & 0.2 & 0.1 \\
Brill & 0.2 & 0.1 \\
Poor Cod & 0.1 & 0.1 \\
Solenette & 0.1 & 0.5 \\
Scaldfish & 0.1 & 0.3 \\
Lemon Sole & 0.0 & 0.0 \\
\hline
\end{tabular}


Table 6.8 Results of discard experiments in the North Sea. Consumption rates (\% of discards consumed by scavenging seabirds) and sample size are given for roundfish, flatfish and offal.

\begin{tabular}{|c|c|c|c|c|c|c|c|c|c|c|}
\hline \multicolumn{2}{|c|}{ roundfish } & \multicolumn{2}{|c|}{ flatfish } & \multicolumn{2}{|c|}{ offal } & \multirow[b]{2}{*}{ area } & \multirow[b]{2}{*}{ time } & \multirow[b]{2}{*}{ season } & \multirow[b]{2}{*}{ year(s) } & \multirow[b]{2}{*}{ source } \\
\hline$\%$ & $\mathrm{n}=$ & $\%$ & $\mathrm{n}=$ & $\%$ & $\mathrm{n}=$ & & & & & \\
\hline 58 & 6423 & 5 & 1182 & & - & around Shetland & day & summer & $1984-85$ & (1) \\
\hline 83 & 208 & 67 & 76 & & - & off SW Norway & day & summer & 1990 & (2) \\
\hline 85 & 430 & 30 & 56 & & - & Helgoland area & day & winter & 1991-1992 & (3) \\
\hline 79 & 909 & 30 & 1259 & 83 & 296 & Helgoland area & day & summer & 1991-1992 & (3) \\
\hline 84 & 13594 & 8 & 397 & & - & North Sea & day & summer & 1992 & (4) \\
\hline 92 & 4997 & 35 & 372 & 100 & 605 & North Sea & day & winter & 1993 & (5) \\
\hline 86 & 7 & 16 & 19 & & - & Skagerrak/Kattegat & day & winter & 1993 & (6) \\
\hline 48 & 52 & 24 & 79 & & - & Skagerrak/Kattegat & night & winter & 1993 & (6) \\
\hline 69 & 258 & 13 & 67 & 74 & 608 & southern North Sea & day & winter & 1992 & (7) \\
\hline 85 & 642 & 34 & 387 & 94 & 642 & west of Helgoland & day & summer & 1993 & (8) \\
\hline 71 & 1101 & 31 & 1044 & 66 & 1217 & southern North Sea & day & summer & 1993 & (9) \\
\hline 76 & 8357 & 22 & 1059 & 94 & 844 & North Sea & day & spring & 1994 & this study \\
\hline 70 & 4407 & 10 & 613 & 94 & 3282 & North Sea & day & summer & 1994 & his study \\
\hline 82 & 4500 & 20 & 363 & 97 & 1068 & North Sea & day & autumn & 1994 & this study \\
\hline
\end{tabular}

(1) Hudson \& Furness 1988, (2) Garthe \& Hüppop 1993, (3) Garthe 1993, (4) Garthe \& Hüppop 1994, (5) Camphuysen et al. 1993 [corrected], (6) Garthe \& Hüppop 1993, (7) Camphuysen 1993c, (8) Camphuysen 1993b, (9) Camphuysen 1994 (includes Camphuysen 1993b).

Table 6.9 Calculation of the number of scavenging seabirds supported by offal and discards in the North Sea

1. Number of scavenging seabirds which can potentially be supported (for assumptions see text).

\begin{tabular}{|c|c|c|c|c|c|}
\hline Discarded type & $\underset{(t)}{\operatorname{mass}}$ & $\begin{array}{c}\text { calorific } \\
\text { value } \\
(\mathrm{kJ} / \mathrm{g})\end{array}$ & $\begin{array}{l}\text { maximum } \\
\text { consumption } \\
\text { rate by } \\
\text { seabirds }\end{array}$ & $\begin{array}{c}\text { mass } \\
\text { potentially } \\
\text { available } \\
\text { (t) }\end{array}$ & $\begin{array}{r}\text { number of } 1000 \mathrm{~g} \\
\text { seabirds } \\
\text { supported } \\
(\mathrm{n})\end{array}$ \\
\hline $\begin{array}{l}\text { Offal } \\
\text { Roundfish } \\
\text { Flatfish } \\
\text { benthic invertebr. }\end{array}$ & $\begin{array}{r}69,200 \\
119,000 \\
197,000 \\
181,200\end{array}$ & $\begin{array}{c}10 \\
5 \\
4 \\
2.5\end{array}$ & $\begin{array}{r}100 \% \\
95 \% \\
60 \% \\
8 \%\end{array}$ & $\begin{array}{r}69,200 \\
113,100 \\
118,200 \\
14,500\end{array}$ & $\begin{array}{r}1,404,000 \\
1,147,000 \\
959,000 \\
74,000\end{array}$ \\
\hline$\Sigma$ & 556,400 & & $57 \%$ & 315,000 & $3,584,000$ \\
\hline
\end{tabular}

II. Amount of discards and offal consumed by scavenging seabirds according to consumption rates obtained by this study.

\begin{tabular}{|c|c|c|c|c|c|}
\hline Discarded type & $\underset{(t)}{\operatorname{mass}}$ & $\begin{array}{c}\text { calorific } \\
\text { value } \\
(\mathrm{kJ} / \mathrm{g})\end{array}$ & $\begin{array}{l}\text { average } \\
\text { consumption } \\
\text { rate by } \\
\text { seabirds }\end{array}$ & $\begin{array}{c}\text { mass } \\
\text { consumed } \\
(\mathrm{t})\end{array}$ & $\begin{array}{r}\text { number of } 1000 \mathrm{~g} \\
\text { seabirds } \\
\text { supported } \\
(\mathrm{n})\end{array}$ \\
\hline $\begin{array}{l}\text { Offal } \\
\text { Roundfish } \\
\text { Flatfish } \\
\text { benthic invertebr. }\end{array}$ & $\begin{array}{r}69,200 \\
119,000 \\
197,000 \\
181,200\end{array}$ & $\begin{array}{c}10 \\
5 \\
4 \\
2.5\end{array}$ & $\begin{array}{r}95 \% \\
80 \% \\
20 \% \\
6 \%\end{array}$ & $\begin{array}{l}65,700 \\
95,200 \\
39,400 \\
10,900\end{array}$ & $\begin{array}{r}1,333,000 \\
966,000 \\
320,000 \\
55,000\end{array}$ \\
\hline$\Sigma$ & 556,400 & & $38 \%$ & 211,200 & $2,674,000$ \\
\hline
\end{tabular}


Table 6.10 Calculation of the amount of discards and offal which could have been consumed by the eight most common scavenging seabirds in the North Sea. This estimate is based on the total number of scavengers calculated to occur in the North Sea (tables 4.1.1-4, 4.2.9, and 4.5.2-9). For this calculation it is assumed that all scavengers have only consumed fishery waste. The proportions between ofal, roundfish, flatfish and benthic invertebrates were derived from the consumption rates found on average over all subregions and seasons: $95 \%, 80 \%, 20 \%, 6 \%$ respectively. Calculations for unidentified gulls were performed assuming a medium body mass of all five gull species listed below.

1. Energy requirements in 1,000,000 kJ per season according to Birt-Friesen et al. (1989). See text for details.

\begin{tabular}{lrrrr}
\hline Species & February & \multicolumn{1}{c}{ May } & August & November \\
\hline Fulmar & 70,300 & 87,600 & 199,600 & 190,500 \\
Gannet & 16,800 & 38,200 & 29,900 & 43,900 \\
Great Skua & 200 & 200 & 4,700 & 600 \\
Common Gull & 7,800 & 100 & 200 & 500 \\
Lesser Bl-b Gull & 300 & 8,200 & 17,400 & 1,300 \\
Herring Gull & 24,900 & 7,500 & 2,200 & 57,200 \\
Great Bl-b Gull & 21,000 & 4,000 & 4,500 & 17,200 \\
Kittiwake & 16,200 & 44,200 & 69,900 & 25,400 \\
unidentified gulls & 1,500 & 1,200 & 100 & 7,800 \\
$\Sigma$ & 159,000 & 191,200 & 328,500 & 344,400
\end{tabular}

II. Amount of fishery waste consumed if all scavengers only take discards and offal.

\begin{tabular}{lccc}
\hline & $\begin{array}{c}\text { mass } \\
\text { consumed } \\
(\mathrm{t})\end{array}$ & $\begin{array}{c}\text { \% of theoretically } \\
\text { available } \\
\text { mass }\end{array}$ & $\begin{array}{c}\text { for comparison } \\
\text { consumption } \\
\text { rate observed (\%) }\end{array}$ \\
\hline offal & $66,600-126,700$ & $96 \%-183 \%$ & $95 \%$ \\
roundfish & $56,100-106,700$ & $47 \%-90 \%$ & $80 \%$ \\
flatfish & $14,000-26,700$ & $7 \%-14 \%$ & $20 \%$ \\
benth. invert. & $4,200-\quad 8,000$ & $2 \%-4 \%$ & $6 \%$ \\
\hline
\end{tabular}

prey categories in the same proportions as found during the sessions of experimental discarding (table 6.10). The consumption rate of offal is higher than our findings, but the consumption rates of roundfish, flatfish and benthic invertebrates matched reasonably well or are slightly lower. This means either that the consumption rates found during this study are not conform those of seabirds in asscociation with commercial fishing vessels, or that discard quantities are smaller than we have estimated or that seabird numbers are higher than we have estimated (cf. Camphuysen 1993b). The calculations of the total numbers of seabirds which are potentially supported by fishery waste are based on the energetic requirements of free-living seabirds at sea, landings statistics coupled with an incomplete knowledge of discarding practices, and consumption rates as found during this study. However, we suspect strongly, along with Hudson \& Furness (1988), that consumption rates generally tend to be lower behind commercial fishing vessels. It should be emphasised here that the consumption rates of seabirds were assessed during daylight sessions of experimental discarding. Discarding in many types of fisheries take also place at night, but our knowledge of the scavenging behaviour of seabirds and possible differences in consumption rates between night and day is 
very incomplete (e.g. Garthe \& Hüppop 1993, Camphuysen 1993b). Further studies, under variable conditions, should be designed in a manner that consumption rates of seabirds in commercial fisheries can be assessed more precisely.

\section{Conclusions}

Estimates of the amount of discards produced in beamtrawl fisheries ranged from 4-10 $\mathrm{kg}$ of fish and $4-11 \mathrm{~kg}$ of benthic invertebrates for each $\mathrm{kg}$ of Sole landed, leading to estimates of 197,000 tonnes of flatfish, 15,000 tonnes of roundfish and 181,000 tonnes of benthic invertebrates discharged per annum. Roundfish trawlers are estimated to produce 85,000 tonnes of discards per annum. Pelagic fisheries are estimated to produce 19,000 tonnes of roundfish per annum. Beamtrawl fisheries produce comparatively large amounts of discards of which a relatively small proportion (roundfish, smaller flatfish, offal) can be utilised by seabirds. Demersal and pelagic fisheries for roundfish produce comparatively small amounts of discards which can all be utilised by scavenging seabirds. Offal is estimated to represent $11 \%$ of the mass of roundfish and $6.5 \%$ of the mass of flatfish. From catch statistics in North Sea fisheries it can be estimated that nearly 70,000 tonnes of offal are produced and discharged per annum. The field metabolic rate (FMR) of seabirds in the North Sea is estimated at $3.8 \mathrm{BMR}$ (basal metabolic rate). With an assimilation efficiency of $80 \%$, the energetic requirements for a hypothetical seabird of $1000 \mathrm{~g}$ can be estimated at $1350 \mathrm{~kJ}$ per day, or 493,000 kJ per annum. The total amount of discards and offal in the North Sea has been estimated as $70,000 \mathrm{t}$ of offal, $120,000 \mathrm{t}$ of roundfish, $200,000 \mathrm{t}$ of flatfish and $180,000 \mathrm{t}$ of benthic invertebrates. Calorific values of discards were estimated at $10 \mathrm{~kJ} / \mathrm{g}$ for offal, 5 $\mathrm{kJ} / \mathrm{g}$ for roundfish, $4 \mathrm{~kJ} / \mathrm{g}$ for flatfish and 2.5 $\mathrm{kJ} / \mathrm{g}$ for benthic invertebrates. Between 2.5 and 3.5 million 'hypothetical $1000 \mathrm{~g}$ seabirds' are potentially supported by fishery waste in the North Sea.

\section{DISCUSSION}

The results of our studies strongly support most earlier findings of high consumption rates of scavenging seabirds at fishing vessels, such as found around Shetland in summer (Hudson \& Furness 1988, 1989), at beamtrawlers and fisheries research vessels in the southeastern North Sea (Camphuysen 1993b, Garthe 1993b, Camphuysen 1994b), and in winter over the North Sea as summarised in Camphuysen et al. (1993). However, although they confirm the high consumption rates of discarded offal and roundfish, and low utilisation of flatfish and benthos, there are some clear patterns now evident across the seasons and across the North Sea. Fulmars are especially important consumers of discards in summer and Kittiwakes become much more evident as consumers of discards and offal in winter. Consumption rates are especially high in winter, and in the northern and western sectors of the North Sea. Competition for resources seems to increase between summer and winter and from south to north. Numbers of scavenging seabirds associating with research vessels reflect these conclusions based on consumption rates. The findings suggest that discards and offal gain importance in seabird diets when natural food resources are less available such as in areas with particularly high densities of seabirds or under adverse conditions.

The behaviour and prey selection of scavenging seabirds have been studied from fisheries research vessels during this project. The fact that the work was carried out from research vessels rather than from fishing vessels was a limitation, but this was offset by the unique opportunity to achieve thorough coverage of the whole North Sea in a short period of time. It should be emphasised that these vessels are imitations of demersal fisheries (using GOV bottom trawl), but that these vessels use nets with relatively small meshes. Compared to beamtrawlers, they catch very little flatfish and benthic invertebrates. Compared to pelagic fisheries, these 
vessels catch very small amounts of Herring and Mackerel. Compared to industrial fisheries, these research vessels catch only small amounts of sandeels. Compared to long-line fisheries, tangle nets and gill nets, these vessels catch proportionally few large fish. Offal is not produced on a regular basis and the discarded fraction from research vessels will have included relatively large numbers of very small fish. Because the research vessels sampled quadrants, and not aimed at getting the largest possible catch as fising vessels tend to do, discarded quantities were also different. Discards were occasionally produced when the ship was stationary, but also when sailing full speed (often around 15 knots). The latter is clearly uncommon in commercial fisheries (except in homeport bound vessels) and therefore experimental discarding was normally finished before the vessel set off to the next station. Although overall consumption rates of scavenging seabirds were quite similar to those found onboard commercial boats (Hudson \& Furness 1988, Berghahn \& Rösner 1992, Camphuysen 1993bc), it is possible that seabirds behaved differently near research vessels than at commercial boats.

Differences in size selection by different species go only a small way to reducing this competition. Many discards are stolen from smaller birds by larger species, resulting in the success rates of the smaller birds tending to be lower than those of the larger species. Age effects appear to be small or difficult to measure due to the high level of variability. The importance of the Kittiwake as a consumer of both items of offal and of small discarded fish has been confirmed, though it is clear that this pattern holds only in winter. Presumably the Kittiwake makes less use of discards in summer at least in part because alternative natural foods are more readily available in summer. This situation appears not to be so marked for the Fulmar, for which offal and discards remain important in summer.
Breeding populations of all seabirds in the North Sea which are known to obtain substantial quantities of fishery waste as scavengers at fishing vessels have strongly increased during most of this century (Fisher 1952, 1966, Harris 1970, Møller 1978, Nelson 1978, Smit \& Wolff 1981, Coulson 1983, Croxall et al. 1984, Becker \& Erdelen 1987, Furness 1987, Spaans \& Noordhuis 1989, Dunnet et al. 1990, Lloyd et al. 1991, Furness 1992). It is obvious that the increased availability of food as a result of increased fishing effort has contributed to these trends, but other factors could have been equally or perhaps even more important (e.g. relaxed persecution, declines in exploitation, increases in stocks of small fish in the North Sea). For several species it could be demonstrated that this source of food is very important, at least during part of the year, particularly when natural sources of food become depleted or otherwise unavailable (Prüter 1986, Furness 1987, Furness 1992, Spaans et al. 1994). However, the relative importance of discards and offal in seabird diets should not be overestimated in the absence of less easily gathered data on natural resources. Gannets from Bass Rock largely ignored fishing vessels and fishing research vessels in May 1994 and foraged instead on herring at unusually large distances away from the colony in association with dolphins (Camphuysen et al. 1995). Large flocks of feeding Kittiwakes have been observed off the east coast of Britain during and immediately after the breeding season (May and August), while relatively few birds could be attracted by fishing vessels. High densities of plankton feeding Fulmars were observed in the northeastern North Sea in May in waters where extensive fisheries took place but where relatively few birds were observed scavenging. Auks were foraging behind fishing vessels after a prolonged period with severe weather in January 1993 (cf. Hillis 1971). These observations support suggestions that discards form only a second choice food, a resource which is mainly exploited if natural food is less readily available. 
Comsumption rates of scavenging seabirds were high for roundfish and offal, and distinctly lower for flatfish and benthic invertebrates. Camphuysen (1993b) found that numbers of seabirds at fishing vessels and consumption rates were higher during the middle of the day than early morning and from late afternoon until sunset. It is important to realise that all these studies were performed during daylight, because the behaviour and numbers of scavenging seabirds around fishing vessels are very difficult to study when it is dark. Discarding - and some fisheries as a whole - does not only take place during the day but also at night and the calculations of total amounts of discards produced from landings statistics did not take into account that a substantial part is discharged in total darkness lover $50 \%$ of the time in winter). Scavengers have been recorded feeding at fishing vessels during the night, but the species composition and numbers are different (Garthe \& Hüppop 1993). Overall consumption rates of scavenging seabirds at night may be lower, but with different dominance hierarchies, consumption rates of individual species may be significantly different from the 'daylight' situation (Garthe \& Hüppop 1993).

Quantities of discards produced in the North Sea may decrease in the future with a probable reduction in fishing effort and increase in mesh sizes (Furness 1992, Anon. 1994b, Hubold 1994). A reduction in the amount of food available to scavengers will increase interspecific competition and affect some species more than others according to their competitive abilities. A reduction in fishing effort will reduce total quantities of discards. This could be expected to lead to a higher frequency of kleptoparasitic interactions and and reduced success rates of species such as Kittiwake, other small gulls and Fulmar, low in the dominance hierarchy. An increase in mesh size, providing counteracting methods are not taken by fishermen (Reeves et al. 1992), should lead to an increase in the sizes of fish caught with fewer small fish to be discarded. Furness (1992) presented calculations that an increase in mesh size from $90 \mathrm{~mm}$ to $120 \mathrm{~mm}$ would lead to a reduction in mass of discarded fish of $52 \%$ for Haddock and $65 \%$ for Whiting. The reduction would mainly be in small sized discards and would therefore most affect the birds which feed on the smallest fish, e.g. Kittiwake, Black-headed gull and Common Gull (Camphuysen et al. 1993, Garthe \& Huppop 1994). As well as affecting some species disproportionately, a reduction in discards would increase intra-specific competition.

Where a reduction in the amounts of discards and offal produced in North Sea fisheries will undoubtedly lead to reductions in the availability of food for individual birds, it is not clear to what extend populations may suffer. For example the Lesser Black-backed Gull breeding on the Dutch Wadden Sea island Terschelling, a bird from which diet studies have shown that discards formed a substantial part of its diet during the breeding season, experienced high breeding success in years that clupeid fish were readily available for the chicks and was otherwise facing structural food shortages leading to poor reproductive output (Spaans et al. 1994). Clupeid fish are not normally available from beamtrawlers, the dominant fishery in these waters, and in years when clupeids were apparently scarce and when the importance of discards in the diet increased, fewer chicks were raised to fledging. Similarly, adult Great Skuas breeding on Shetland depend heavily on discards from whitefish trawlers around these islands (Hudson \& Furness 1988). Great Skuas, facing a shortage of sandeel around Shetland, shifted to discards on a much greater scale than usual, but the breeding results were very low in these years (Hamer et al. 1991). Numbers of Great Skuas in Shetland may be affected by future changes in fishing practices, particularly by any reduction in the discarding practices as a result of mesh size regulations or fishing effort (Furness 1992). Diets of most 
Kittiwakes breeding in Shetland did not shift from sandeel towards discards and these birds simply failed as breeders in a series of consecutive years (Heubeck 1989, Hamer et al. 1993). However, the only 'successful' colony of Kittiwakes in Shetland during the bad sandeel years appeared to mainly feed on offal (Walsh et al. 1991). According to our studies, the distribution of several large Larus-gulls at sea in the southeastern half of the North Sea was clearly influenced by the distribution of fishing fleets (chapters 4.4-5). Vauk \& Jokele (1975), Prüter (1986) and Maul (1994) demonstrated that gulls breeding and wintering on Helgoland make such extensive use of fishery waste that reductions in this resource would most probably lead to reductions in reproductive output. There is mounting evidence that a reduction in fishing effort of the coastal zone off the Dutch Wadden Sea islands have reduced the feeding possibilities for Herring Gulls so that breeding success became very low IVan Klinken 1992, Noordhuis \& Spaans 1992, Camphuysen in press). The overall conclusion from most studies should be that, if the birds could turn to alternative food sources, the effect of a reduction in the amounts of discards on populations would probably be negligible. Otherwise, populations will probably be negatively affected, either as a result of poor reproductive output (reduced breeding success) or of lower survival in winter.

Now that distribution patterns, prey selection, dominance hierarchies and seasonal fluctuations in scavenging seabirds are reasonably well known, future research should perhaps concentrate on commercial fisheries themselves and on seabirds for which it is evident that discards and offal play a crucial role. Lesser Black-backed Gulls in the southern North Sea, the Great Skua on Shetland and Kittiwakes in the German Bight, are the most likely species in the North Sea for which a structural reduction in fishery waste could lead to a significant decline in breeding success and population development. But for wintering Kittiwakes and Fulmars, species of which the populations have increased substantially during this century, the provision of discards and offal in commercial fisheries is probably most important under adverse conditions and in winter. The importance of discards and ofal in their diets should be investigated and studies of their diets in winter are now most urgently required. Estimates of the quantities of discards and offal produced in commercial fisheries are based on a small amount of data and are incomplete. Further studies onboard commercial vessels are therefore recommended, particularly on types which have not been studied so far. Similarly, consumption rates of scavenging seabirds should further be studied from onboard commercial vessels and more effort should be directed to night time conditions. Inshore fisheries, particularly the smaller beamtrawlers and shrimpers in the southeastern North Sea, have not yet received sufficient attention from researchers. Most notably, also in a socio-economic context, should the effects of new systems to discharge discards alive after rapid sorting be evaluated, considering both the implications for scavenging seabirds and for the fish itself.

\section{CONCLUSIONS}

Four surveys were conducted onboard fisheries research vessels engaged in the International Bottom Trawl Survey, in February 1993, May, August, and November 1994. Ornithological observations comprised striptransect counts and stern counts, designed to investigate seasonal patterns in the spatial distribution of scavenging seabirds in the North Sea. Records of feeding behaviour were made to assess consumption rates, prey selection and inter-specific competition of seabirds. Discard practices and the distribution of commercial fishing vessels were studied simultaneously. From the results of these surveys, described in chapters 4.1-4.8 and summarised for each seabird species in chapter 5, the following conclusions were drawn: 
Scavenging seabird species (chapters 4.1-3)

$\rightarrow$ Out of a total of 54 species of seabirds and waterfowl recorded during strip-transect counts, 29 species were attracted to research vessels engaged in fishing activity, including four species of Procellariiformes, the Gannet, two species of cormorants, four species of skuas, 12 species of gulls, five species of terns and two species of auks (chapter 4.3).

$\rightarrow$ Of the 29 species which were attracted during fishing, eight species were common at any one season, including Fulmar Fulmarus glacialis, Gannet Morus bassanus, Great Skua Catharacta skua, Common Gull Larus canus, Lesser Black-backed Gull Larus fuscus, Herring Gull Larus argentatus, Great Black-backed Gull Larus marinus, and Kittiwake Rissa tridactyla (chapters $4.1,4.3$ ).

$\rightarrow$ Total numbers of the eight common scavenging seabirds in the North Sea were estimated on the basis of results of striptransect counts, counts of fishing vessels, and counts of numbers of seabirds associated with commercial fishing vessels, to range from 1.5 million individuals in February to 3.5 million individuals in August (table 4.2.5).

$\rightarrow$ The estimates of total numbers of seabirds (see above) are conservative in comparison with similar estimates derived from the European Seabirds At Sea Database, in which total numbers varied between 3.5 million individuals in May and 6.5 milion individuals in November (table 4.2.5).

$\rightarrow$ It is suggested that inter-observer variability and poor coverage of the coastal zone are key factors behind the conservative estimates of total numbers of seabirds (chapter 4.1), but this need further investigation. The estimates of total numbers in the North Sea are therefore given as a range derived from the above two sources (table 4.2.9):
February
$1.5-4.0$ million
May
2.0 - 3.5 million
$3.5-5.0$ million
August
$3.0-6.5$ million

\section{Seabird distribution (chapters 4.1-3)}

$\rightarrow$ Numbers of Fulmars in the North Sea ranged from $0.7-1.1$ million individuals in February to 1.9 - 3.7 million individuals in August. Fulmars were widespread in each of the surveys, but were relatively scarce in the low salinity waters off the west coast of Denmark, in the German Bight and in the Southern Bight. In the northwestern North Sea, Fulmars were usually numerically dominant, both at sea and in association with fishing research vessels or commercial fishing vessels. Between 70\% (February) and $91 \%$ (May) of all sampled hauls of research vessels attracted Fulmars, with slightly larger numbers in summer than in winter.

$\rightarrow$ Numbers of Gannets in the North Sea varied between 100,000 and 200,000 individuals in each of the surveys, but were probably lowest in February. Gannets were most numerous in the western half of the North Sea and comparatively scarce in the Skagerrak and German Bight at any time of year. Between $41 \%$ (February) and 70\% (November) of the sampled hauls attracted Gannets with little variation in numbers between the four surveys.

$\rightarrow$ Numbers of Great Skuas in the whole North Sea were usually very small. In August, when the species occurred in all subregions in small numbers, total numbers in the North Sea were estimated at 30,000-40,000 individuals. Less than one fifth of the sampled hauls attracted Great Skuas to research vessels, with the exception of August when $40 \%$ of the stern counts included one or more individuals of this species.

$\rightarrow$ Common Gulls were usually found inshore. Substantial numbers were observed only in 
winter in the southeastern half of the study area (Skagerrak, German Bight and Southern Bight). Peak numbers occurred in February, estimated at 100,000-200,000 individuals. Common Gulls were most frequently attracted to fishing research vessels in winter in the southeastern half of the North Sea.

$\rightarrow$ Lesser Black-backed Gulls were summer visitors, being widespread in May and August. Largest numbers were found in the southeastern half of the North Sea. Estimated total numbers in summer varied between $100,000-200,000$ individuals. Numbers of Lesser Black-backed Gulls at the stern during fishing reflected its relative abundance at sea.

$\rightarrow$ Herring Gulls were widespread, occurred in large numbers in winter and were comparatively scarce in summer. Estimates ranged from 0.3-1.0 million individuals in February to $0.5-1.5$ million individuals in November, while less than 300,000 individuals were estimated present in the summer. Over $90 \%$ of the sampled hauls in winter attracted Herring Gulls to the ship and overall numbers were particularly large in these months. Herring Gulls were scarce in August.

$\rightarrow$ Great Black-backed Gulls were commonest in winter; between 100,000 and 400,000 individuals were estimated to occur in the North Sea in this season. Summer estimates were below 100,000 birds. Between $80 \%$ and $90 \%$ of the sampled hauls attracted Great Black-backed Gulls in February and November and overall numbers at the stern were higher in winter than in summer.

$\rightarrow$ The second most numerous scavenging species in the North Sea was the Kittiwake which occurred throughout the year in large numbers. Winter estimates ranged from $0.3-$ 1.1 million individuals in February to 0.4-1.4 million individuals in November, summer estimates ranged from 0.6-0.7 million individuals in May to 0.7-1.1 million individuals in August. Over $95 \%$ of all hauls sampled in winter attracted Kittiwakes to the research vessels and overall numbers were much higher in these months. Relatively small numbers were associated with fishing research vessels in summer, despite the fact that overall numbers at sea were very high in these months.

$\rightarrow$ Generally, the seasonal and spatial variations in relative abundance and species composition of seabirds at sea were reflected in the numbers and species composition of scavenging seabirds attracted to the fishing research vessels. A notable exception was the Kittiwake which appeared to be more readily attracted in winter than in summer whereas numbers at sea peaked in summer.

$\rightarrow$ In most gulls, there was a tendency of proportionally lower numbers of adults at the stern (stern counts) than at sea (transect counts) when overall numbers in the North Sea were largest (Lesser Black-backed Gull in summer, Herring Gull in winter, Kittiwake in summer).

\section{Fishing vessels (chapter 4.4)}

$\rightarrow$ The estimated total number of active fishing vessels in the North Sea varied between 800 and 1800 boats. Numbers of trawlers were significantly higher during the week (Monday-Thursday) than in weekends (Friday-Sunday). Overall numbers were lowest in November (800-900 vessels) and highest in August (1350-1750 vessels) (tables 4.4.3-4).

$\rightarrow$ Of the positively identified fishing vessels, beamtrawlers and shrimpers were the most numerous type $(28 \%)$, followed by stern or otter trawlers (27), set net fishing vessels (or long liners; $11 \%)$, purse seiners $(7 \%)$, pair trawlers $(7 \%)$ and anchor seiners $(2 \%)$ (table 4.4.6).

$\rightarrow$ Beamtrawlers, shrimpers, boats working set nets and anchor seiners were the commonest fishing vessels in the southeastern 
half of the North Sea but were rare in the northwest (figures 4.4.11-14).

$\rightarrow$ Purse seiners, pair trawlers, stern trawlers and otter trawlers were the most common types in the central, northern and northwestern North Sea and these were rare in the German Bight and Southern Bight (figures 4.4.11-14).

Seabirds in association with commercial fishing vessels (chapter 4.5)

$\rightarrow$ Maximum numbers of seabirds in association with commercial fishing vessels ranged from just over 20 Great Skuas to 3500 Fulmars (tables 4.5.2-10).

$\rightarrow$ Species composition of scavenging seabirds associated with fishing research vessels appeared to be more diverse than that around commercial fishing vessels. This was probably due to distant observations underestimating the number of species attracted to fisheries. This suggestion was supported by the fact that the presence (\%) of scavenging seabirds at hauls of research vessels was always higher than that recorded by observers of distant commercial boats (table 4.5.11).

$\rightarrow$ The highest numbers of seabirds associated with commercial fishing vessels were found near otter trawlers and stern trawlers, the commonest type in the northern North Sea. These trawlers were the most numerous type in waters very rich in Fulmars and Kittiwakes, which may partly reflect the relatively large quantities of offal and discards produced by these boats. Fulmars were particularly numerous in association with these fishing vessels (table 4.5.13, chapter 4.8 ).

$\rightarrow$ Relatively small numbers of seabirds were associated with purse seiners, probably reflecting the fact that these vessels usually produce few discards and no offal. Fulmars were the commonest seabirds in associated with purse seiners (table 4.5.13, chapter 4.8).

$\rightarrow$ Relatively small numbers of seabirds were associated with beamtrawlers and anchor seiners. These fishery types occur in the southeastern North Sea, where seabird densities were comparatively low. Larus-gulls were the commonest scavenging seabirds in these waters at these boats and numbers of Fulmars in association with beamtrawlers were comparatively small (table 4.5.13, chapter 4.8 ).

$\rightarrow$ Great Black-backed Gulls, Herring Gulls and Lesser Black-backed Gulls (in summer) were the only species of which the distribution at sea was clearly positively influenced by the presence of fishing vessels. The spatial and temporal variations in the overall North Sea distribution of Fulmar, Gannet, Great Skua, Great Black-backed Gull and Kittiwake could not be explained by differences in fishing vessel abundance (table 4.5.15).

Experiments on discards consumption (chapter 4.6)

$\rightarrow$ Generally, consumption rates of offal and discards were higher in winter (February and November) than in summer (May and August). Consumption rates for offal ranged from $94 \%$ (summer) to $97-100 \%$ (winter), for roundfish from $70-76 \%$ (summer) to 82 $92 \%$ (winter), for flatfish from 10-22\% (summer) to $20-35 \%$ (winter) and for benthic invertebrates from 3-8\% (summer) to $3-17 \%$ (winter). Overall consumption rates were estimated at:

$\begin{array}{lrr}\text { Offal } & 95 \% & \\ \begin{array}{l}\text { Roundfish } \\ \text { Flatfish }\end{array} & 80 \% & \\ \text { Benthic inv. } & 6 \% & 20 \% \\ & & \end{array}$

$\rightarrow$ Numbers of scavenging seabirds and species distribution varied considerably between parts of the North Sea and seasonally. In the northwestern North Sea, Kittiwakes were the 
main consumer of discards in February (taking $54 \%$ of ca. 5400 experimentally discarded items consumed by seabirds) and November $(50 \%, n=5600)$, whereas Fulmars predominated in May (43\%, $n=7300$ ) and August ( $75 \%, n=6300$ ). Larus-gulls (mainly Herring Gulls and Lesser Black-backed Gulls) gained importance in the southeastern North Sea and displaced other seabirds as main consumers in the coastal zone of the German Bight, Southern Bight and Skagerrak.

$\rightarrow$ Fulmars accounted for $96.7 \%$ of 1216 discards recorded as 'pecked' (probably ripped open to consume liver and intestines).

$\rightarrow$ Fulmars and Kittiwakes obtained more offal than expected from the total numbers of seabirds competing. Only when Fulmars and Kittiwakes were not present in large numbers did other species obtain more than trivial amounts of offal (table 4.6.19).

$\rightarrow$ For experimentally discarded gadids (Haddock, Whiting, Cod, Saithe, Norway Pout), feeding success indices (i.e. the percentage of all discarded items that were swallowed by a species divided by the percent of all birds present at the trawl that were this species) of Fulmars (virtually always $<1$ ) and Kittiwakes (usually variable 0.5-1.5) were comparatively low and success indices of Gannets (normally 3-12, exceptionally up to 43) were generally very high. Even although the success index of Fulmars was very low, their numerical abundance resulted in their being the single most important consumer in the northern subregions. Lesser Black-backed Gulls (summer) and Herring Gulls (winter) were the most important consumers of gadids in the southeastern North Sea.

$\rightarrow$ Of experimentally discarded clupeids (Herring, Sprat), Fulmars obtained considerably less than their numerical abundance might predict. Gannets obtained significantly more clupeids than gulls in most seasons and subregions, but particularly in the northern and western parts of the North Sea. Kittiwakes, Lesser Black-backed Gulls and Herring Gulls were the most important consumers of clupeids in the southeastern North Sea.

$\rightarrow$ Generally, in all four surveys and all seven subregions, larger scavenging seabirds tended to consume larger discards than taken by smaller species. The median length of roundfish consumed by seabirds ranged from $14 \mathrm{~cm}$ in Common Gulls to $25 \mathrm{~cm}$ in Gannets and Great Skuas. The median width of flatfish consumed by seabirds ranged from 3.5 $\mathrm{cm}$ in Fulmars and Kittiwakes to $6.5 \mathrm{~cm}$ in Gannets and Great Black-backed Gulls (tables 5.1-2, Appendix A).

$\rightarrow$ Based on the observed consumption rates, the competition for fishery waste increased between summer and winter, and from south to north. Numbers of scavenging seabirds associating with research vessels and commercial fishing vessels reflected this conclusion.

$\rightarrow$ The importance of the Kittiwake as a consumer of both items of offal and of small discarded fish holds only in winter. Presumably Kittiwakes make less use of discards in summer at least in part because there are alternative natural foods more readily available. This situation appears not to be so marked for the Fulmar, for which offal and discards remain important in summer.

\section{Kleptoparasitism among scavenging seabirds} (chapter 4.7)

$\rightarrow$ Differences in size selection of discards by different species had little effect on reducing inter-specific competition. Many discards were stolen from smaller birds by larger species, with the result that success rates of the smaller birds tended to be lower than in non-competitive situations.

$\rightarrow$ Short and small fish were consumed in higher proportions than longer (roundfish) or wider (flatfish) discards. Roundfish shorter 
than $15 \mathrm{~cm}$ were usually swallowed by the first bird to handle the fish, whereas fish larger than $20 \mathrm{~cm}$ were lost in more than one out of four occasions. The same tendency held for flatfish. Offal was hardly ever lost by the first bird handling it.

$\rightarrow$ Although the robbery index (i.e. number of fish stolen by a bird divided by the number of fish stolen from that bird) varied among seasons, regions and prey types, it was very obvious that Gannet, Great Black-backed Gull and Great Skua were consistently the species highest in rank in the dominance hierarchy among scavenging seabirds at the stern during experimental discarding. Fulmar and Kittiwake were most vulnerable to robbery. Feeding success of Lesser Black-backed and Herring Gull, with medium vulnerability to robbery indices, varied more than that of the other species.

$\rightarrow$ Smaller species such as Kittiwakes and Common Gulls usually avoided most fights for discards by operating closer to the ship, acting faster as highly manoeuvrable small gulls and by selecting and immediately swallowing relatively small discards or offal particles.

$\rightarrow$ Great Black-backed Gulls and Great Skuas obtained the largest numbers of discards through kleptoparasitism.

$\rightarrow$ Gannets took comparatively large discards and obtained many fish which had sunk out of reach for the other species. Gannets seldom fed on offal.

North Sea fisheries and discard practices (chapter 4.8)

$\rightarrow$ The great variety of fishing gears used in the North Sea can be categorised as towed gears, surrounding gears, and fixed nets and long-lines. The most prominent types are beamtrawl fisheries (main targets flatfish and shrimp), bottom trawlers (otter and Queen trawls; main targets gadids, flatfish, industrial fisheries), pelagic or midwater trawlers (stern trawlers; main targets Herring, Mackerel and Scad), pair trawlers (main target either demersal, Cod, Haddock and Whiting, or pelagic, Herring), purse seiners (main targets small pelagic fish which live in shoals; Herring, Mackerel, Pilchard), anchor seiners (flatfish, Cod), Scottish seine (demersal roundfish), long-liners (large Cod, Saithe, Ling, Torsk, Skate, Halibut) and gill nets or tangle nets (Monkfish, Cod, Pollack, Hake, Sole, Turbot, Plaice).

$\rightarrow$ Three offshore fisheries produce large amounts of discards and offal: demersal fisheries for gadids by trawl and seine, pelagic fisheries for clupeids and mackerel, and beamtrawl fisheries.

$\rightarrow$ In all commercial fisheries, marketable roundfish and flatfish are normally gutted at sea and the offal is discarded, except in some Norwegian vessels which have found a market for the entrails and livers.

$\rightarrow$ Many fishing vessels sort and gut fish during towing for the next catch, leading to a continues trickle of discards and offal.

$\rightarrow$ Discards in industrial fisheries are small and mainly comprise escapes when the net is brought to the surface or while pumping the catch onboard.

$\rightarrow$ Norwegian fishing vessels are not allowed to discard undersized fish and also have a tendency to keep offal onboard.

$\rightarrow$ Discards of large freezer trawlers vary enormously, from virtually nothing (only escaped fish) to a total catch comprising up to several tens of tonnes of fish at once.

The amount of discards in North Sea fisheries (chapter 6)

$\rightarrow$ Estimates of the amount of discards produced in beamtrawl fisheries ranged from 4$10 \mathrm{~kg}$ of fish and $4-11 \mathrm{~kg}$ of benthic inverte- 
brates for each $\mathrm{kg}$ of Sole landed, leading to estimates of 197,000 tonnes of flatfish, 15,000 tonnes of roundfish and 181,000 tonnes of benthic invertebrates discharged per annum.

$\rightarrow$ Roundfish trawlers are estimated to produce 85,000 tonnes of discards per annum.

$\rightarrow$ Pelagic fisheries are estimated to produce 19,000 tonnes of roundfish per annum.

$\rightarrow$ Beamtrawl fisheries produce comparatively large amounts of discards of which a relatively small proportion (roundfish, smaller flatfish, offal) can be utilised by seabirds. Demersal and pelagic fisheries for roundfish produce comparatively small amounts of discards which can all be utilised by scavenging seabirds.

$\rightarrow$ Offal is estimated to represent $11 \%$ of the mass of roundfish and $6.5 \%$ of the mass of flatfish. From catch statistics in North Sea fisheries it can be estimated that nearly 70,000 tonnes of offal are produced and discharged per annum.

$\rightarrow$ The field metabolic rate (FMR) of seabirds in the North Sea is estimated at 3.8 BMR (basal metabolic rate). With an assimilation efficiency of $80 \%$, the energetic requirements for a hypothetical seabird of $1000 \mathrm{~g}$ can be estimated at $1350 \mathrm{~kJ}$ per day, or 493,000 kJ per annum.

$\rightarrow$ The total amount of discards and offal in the North Sea has been estimated as 70,000 $t$ of offal, $120,000 \mathrm{t}$ of roundfish, 200,000 t of flatfish and 180,000 t of invertebrates.

$\rightarrow$ Calorific values of discards were estimated at $10 \mathrm{~kJ} / \mathrm{g}$ for offal, $5 \mathrm{~kJ} / \mathrm{g}$ for roundfish, 4 $\mathrm{kJ} / \mathrm{g}$ for flatfish and $2.5 \mathrm{~kJ} / \mathrm{g}$ for benthic invertebrates.

$\rightarrow$ Between 2.5 and 3.5 million 'hypothetical $1000 \mathrm{~g}$ seabirds' are potentially supported by fishery waste in the North Sea.
Anticipated effects of measures to reduce discards (chapter 7)

$\rightarrow$ Where severe competition between scavenging seabirds exists, a reduction in amount of discards resulting from fisheries management will lead to smaller species being more frequently outcompeted by larger species. A general reduction in fishing effort (and therefore of catch and discards) will probably lead to more intense competition and thus would there for lead to a decline in foraging success of species with the highest vulnerability' to robbery.

$\rightarrow$ An increase in mesh size should lead to a reduction in the smaller discards and therefore mainly affect the smaller species of scavengers.

$\rightarrow$ Reductions in the amounts of offal discharged at sea would negatively affect Fulmars and Kittiwakes.

$\rightarrow$ The effects of a reduction in discards and offal discharges would be greater under adverse conditions (prolonged storms, winter) than in summer.

$\rightarrow$ The development of commercial fisheries this century has provided an important extra source of food, as a result of which several species have apparently increased in numbers and spread over larger areas. If circumstances arise when discards and offal were no longer produced or discharged, and if these birds could not turn to alternative foods, these populations would be negatively affected.

$\rightarrow$ The results of this study may be used to help predict the possible effects of measures to reduce the amounts of discards directly or to reduce fishing effort for seabirds on a regional scale and on species level. 
Recommendations for future research (chapter 7)

$\rightarrow$ Quantities of discards and offal produced in commercial fisheries should be studied in more detail onboard commercial vessels.

$\rightarrow$ Consumption rates of scavenging seabirds should be studied onboard commercial vessels.

$\rightarrow$ Great Skua (Shetland), Lesser Black-backed Gull (Britain, The Netherlands) and Kittiwake (German Bight) are the only seabirds in the North Sea from which diet studies have shown that discards formed a substantial part of the diet during the breeding season. The importance of discards and offal for these species should be studied in more detail and on a larger scale than previously.

$\rightarrow$ Diets of Kittiwakes and Fulmars wintering in the North Sea should be studied to evaluate the importance of discards and offal for these birds.

$\rightarrow$ Inshore fisheries, particularly the smaller beamtrawlers and shrimpers in the southeastern North Sea, have not yet received sufficient attention from researchers and the effects of new systems to discharge discards alive onboard shrimpers for scavenging seabirds should be evaluated.

\section{EVALUATION OF THE PROJECT}

The project 'Consumption of discards by seabirds in the North Sea' was a follow-up study of 'Seabirds feeding on discards in winter in the North Sea', using the same type of platforms (fishery research vessels), roughly the same field methods, and mainly the same partners (six institutions from 5 countries around the North Sea). Some new procedures of field methods and analysis were introduced, but the project was mainly a repetition and extension of earlier work. Because of the large number of individual observers involved, a training cruise was considered essiential to achieve sufficient standarisation of methods. The interpretation of a written manual will always lead to unexpected deviations of the standard and a joint training is therefore extremely important.

With most partners having been involved in the first project, field work went extremely well. In comparison with February, days were considerably longer in May and August, but most people were able to sample the entire period of daylight with transect counts, trawler counts, stern counts and experimental discarding. Storing all these data also in the computer on that same day was a considerable task for the small teams onboard, but usually the data could be sent off to Texel few days after the cruise. The central database was now better structured, so that complete sets of data from individual research vessels could usually be transformed into the final format in less than two days. Complete sets of the data (from four vessels of a cruise) were returned to the participants after each survey as soon as the last set came in. Unfortunately, there was some delay in data sending in the last survey, so that the project, overall, went 10 days overtime $(<5 \%)$.

The writing of the final report took place in February and March. Several partners drafted chapters which were read by others. E-mail and fax machines proved to be essential to transport data and texts sufficiently rapidly. Some delay was caused by the fact that specific calculations were not performed on one central place, but by each of the partners. Shipping and transformation of datasets of one database system into another, whether or not via E-mail, caused errors. Much time was spent on checking and changing calculations so that the outcome was the same all over. For a possible next project, the advice would be to get calculations and queries from the database done on one central place, or to check the outcomes with eachother before writing the chapter. 
The project was successful because all partners co-operated so well. Timetables for projects such as this are extremely tight, mainly to reduce cost. The implication of such planning is that every tiny bit of unexpected delay can cause serious trouble. It is thanks to the effort of all partners in this project that the delay was so minimal and that a comprehensive review of seasonal fluctuations in the distribution and scavenging behaviour of seabirds, the consumption rates of discards by seabirds and the distribution of fisheries is now available. 


\section{REFERENCES}

ABRAMS R.W. 1983. Pelagic seabirds and trawl-fisheries in the southern Benguela current region. Mar. Ecol. Prog. Ser. 11: 151-156.

ABRAMS R.W. 1985. Pelagic seabird community structu re in the southern Benguela region: changes in response to man's activities? Biol. Conserv. 32: 33-49.

ANDREW N.L. \& PePPERELL J.G. 1992. The by-catch of shrimp trawl fisheries. Oceanogr. Mar. Biol. Ann. Rev. 30: 527-565.

ANONYMOUS 1991. Report of the study group on ecosy stem effects of fishing activities. ICES C.M. 1991/G: 7 , session $Y, 66 p p$.

ANONYMOUS 1993. Report of the Working Group on the assessment of demersal stocks in the North Sea and Skagerrak. ICES, Doc. C.M. 1993/Assess:5

ANONYMOUS 1994a. Report of the Study Group on sea bird/fish interactions. ICES, Doc. C.M. 1994/L:3.

ANONYMOUS 1994b Report of the Working Group on ecosystem effects of fishing activities. ICES Doc. C.M. 1994/ASSESS/ENV: 1.

ANONYMOUS 1995. Report of the Working Group on the assessment of demersal fish stocks in the North Sea and Skagerrak. ICES, Doc. C.M. 1995/Assess

ARBouW G.J. 1980. Enkele gegevens over de voedseloecologie en de broedbiologie van de Stormmeeuw Larus canus L. op Texel. Rep. Neth. Inst. Sea Res., Texel.

ARBOUW G.J. \& SWENNEN C. 1985. Het voedsel van de Stormmeeuw Larus canus op Texel. Limosa 58: 7-15.

ARMSTRONG D.W. \& HALL W.B. 1987. The assessment and management of fish stocks: collection, processing and retrieval of data from catches by Scottish commercial fishing vessels of demersal fish species 1950-1982. In: Bailey R.S. \& Parrish B.B. (eds.). Developments in fisheries research in Scotland. Fishing News Books, Surrey

BEAMAN M.A.S. 1978. The feeding and population ecology of the Great Black-backed Gull in northern Scotland. Ibis 120: 126-127.

BEEK F.A. VAN 1990. Discard sampling programme for the North Sea. Dutch participation. Internal RIVO-report, Demvis 90-303.

BEEK F.A. VAN, LEEUWEN P.I. VAN \& RIJNSDORP A.D. 1989. On the survival of plaice and sole discards in the otter trawl and beamtrawl fisheries in the North Sea. ICES C.M. 1989/G: 46 (Dem. Fish. Comm.).

BEEK F.A. VAN, LEEUWEN P.I. VAN \& RIJNSDORP A.D. 1990. On the survival of plaice and sole discards in the otter trawl and beamtrawl fisheries in the North Sea. Neth. J. Sea Res. 26: 151-160.

BECKER P.H. \& ERDELEN M. 1987. Die Bestandsentwicklung von Brutvogeln der deutschen Nordseeküste seit 1950: Aspekte für den Artenschutz. Ber. Dtsch. Sekt. Int. Rat Vogelschutz 26: 63-73.

BERGHAHN R. 1990. On the potential impact of shrimping on the trophic relationships in the Wadden Sea. In: M. Barnes \& R.N. Gibson (eds): Trophic Relationships in the Marine Environment. Proc. 24th EMBS, Aberdeen University Press, 130-140.

BERGHAHN R. \& RöSNER H.-U. 1992. A method to quanti fy feeding of seabirds on discards from the shrimp fishery in the North Sea. Neth. J. Sea Res. 28: 347350.

BERGHAHN R. WALTEMATH M. \& RIJNSDORP A.D. 1992 Mortality of fish from the by-catch of shrimp vessels in the North Sea. J. Appl. Ichtyol. 8: 293-306.

BERGHAHN R. 1994. Auswirkungen der Garnelenfischere auf Wirbeltiere und Krebse im Wattenmeer. In: Lozán
J.L. Rachor E., Reise K., von Westernhagen H. \& Lenz W. (eds). Warnsignale aus dem Wattenmeer: 248-252. Blackwell Wissenschafts-Verlag, Berlin.

BERGMAN M.J.N., FONDS M., DE GROOT S.J. \& VAN SANT BRINK J.W. in prep. Direct effects of beamtrawl fishery on bottomfauna in the southern North Sea. Manuscript.

BIRT-Friesen V.L., MONTEVECCHI W.A., CAIRNS D.K. \& MACKO S.A. 1989. Activity-specific metabolic rates of free-living Northern Gannets and other seabirds. Ecology 70: 357-367.

BLABER S.J.M. \& WASSENBERG T.J. 1989. Feeding ecolo gy of the piscivorous birds Phalacrocorax varius, $P$. melanoleucos and Sterna bergii in Moreton Bay, Australia: diets and dependence on trawler discards. Mar. Biol. 101: 1-10.

BlokPoEl H., MoRris R.D. \& Tessier G.D. 1984. Field investigations of the biology of Common Terns wintering in Trinidad. J. Field Orn. 55: 424-434.

BLOM W.C. \& HAK W. VAN DE 1993. An inventory of bottomtrawling vessels and gear types in the Netherlands. Draft report Netherlands Institute for Fisheries Research, IJmuiden.

BOER E.J. DE 1984. Visserijmethoden. Het Visserijschap, Rijswijk.

BOER P. 1971. Jagers als aaseters. De Lev. Nat. 74 209-211.

BoswALL J. 1960. Observations on the use by sea-birds of human fishing activities. Brit. Birds 53: 12-215.

BosWALL J. 1977. The use by seabirds of human fishing activities. Brit. Birds 70: 79-81.

BOURNE W.R.P. 1983. Birds, fish and offal in the North Sea. Mar. Poll. Bull. 14: 294-296.

BRINDLEY E. \& NEVO A. DEL 1994. Little Gull Larus minutus. In: Tucker G.M. \& Heath M.F. (eds). Birds in Europe - their conservation status: 284-285. Birdlife Conservation Series No. 3, Birdlife International, Cambridge.

BROOKE M. DE L. \& TASKER M.L. 1994. Manx Shearwater Puffinus puffinus. In: Tucker G.M. \& Heath M.F. (eds). Birds in Europe - their conservations status: 68-69. Birdlife Conservation Series No. 3, Birdlife International, Cambridge.

BROWN R.G.B., BOURNE W.R.P. \& WAHL T.R. 1978. Diving by shearwaters. Condor 80: 123-125.

CAMPHUYSEN C.J. 1990. Fish stocks, fisheries and seabirds in the North Sea. Techn. Rapport Vogelbescherming nr. 5, Vogelbescherming, Zeist.

CAMPHUYSEN C.J. 1993a. Scavenging seabirds behind fishing vessels in the northeast Atlantic, with emphasis on the southern North Sea. NIOZ report 1993-1, BEON report 20, Netherlands Institute for Sea Research, Texel.

CAMPHUYSEN C.J. 1993b. Foerageermogelijkheden voor zeevogels in de boomkorvisserij: een verkennend onderzoek. Sula 7: 81-104.

CAMPHUYSEN C.J. 1993c. Een verkennend onderzoek: De exploitatie van op zee overboord geworpen vis en snijafval door zeevogels. Het Vogeljaar 41: 106-114.

CAMPHUYSEN C.J. 1994a. Flatfish selection by Herring Gulls Larus argentatus and Lesser Black-backed Gulls Larus fuscus scavenging at commercial beamtrawlers in the southern North Sea. Neth. J. Sea Res. 32 91-98.

CAMPHUYSEN C.J. 1994b. Scavenging seabirds at beamtrawlers in the southern North Sea: distribution, relative abundance, behaviour, prey selection, feeding efficiency, kleptoparasitism, and the possible effects of the establishment of 'protected areas'. BEON Report no. 94-14, Netherlands Institute for Sea 
Research, Texel.

CAMPHUYSEN C.J. 1994c. Kittiwakes Rissa tridactyla in the North Sea: pelagic ecology, fisheries relationships and feeding strategies. In: Camphuysen C.J. (ed.). Seabirds at sea in the North Sea: 4-5. Abstracts NOU ESAS2 symposium, Netherlands Institute for Sea Research, Texel.

CAMPHUYSEN C.J. 1995. Grauwe Pijlstormvogel Puffinus griseus en Noordse Pijlstormvogel Puffinus puffinus in de zuidelijke Noordzee: een offshore perspectief. Limosa 68: 1-10.

CAMPHUYSEN C.J. in press. Herring Gull Larus argentatus and Lesser Black-backed Gulls Larus fuscus feeding at trawlers in the breeding season: competitive scavenging versus efficient flying. Ardea.

CAMPHUYSEN $C J$ ENSOR $K$. FURNESS R.W. GARTHE $S$. HÜPPOP O., LeAPER G., OFFringa H. \& TASKer M.L. 1993. Seabirds feeding on discards in winter in the North Sea. Final report to the European Comm., study contr. 92/3505, NIOZ-Rapport 1993-8, Netherl. Inst. for Sea Res., Texel.

CAMPHUYSEN C.J., HeEssen H.J.L. \& WinTER C.J.N. 1995. Distant feeding and associations with cetaceans of Gannets Morus bassanus from the Bass Rock, May 1994. Seabird 17: 36-43.

CAMPHUYSEN C.J. \& LEOPOLD M.F. 1994. Atlas of seabirds in the southern North Sea. IBN Research report 94/6, NIOZ Report 1994-8, Institute for Forestry and Nature Research, Netherlands Institute for Sea Research and Dutch Seabird Group, Texel.

CAMPHUYSEN C.J., Winter C.J.N., Calvo B., EnSOR K., Follestad A., GaRTHe S., SCHÜNemann H. \& SPROTTE B. 1994a. Consumption of discards by seabirds in the North Sea. EC Project BIOECO/93/10, 1st interim report, July 1994, Netherlands Institute for Sea Research, 61pp.

CAMPHUYSEN C.J., Winter C.J.N., Calvo B., EnSOR K. Leaper G., Pollock C., Jachmann F. \& Janssen K. $1994 \mathrm{~b}$. Consumption of discards by seabirds in the North Sea. EC Project BIOECO/93/10, 2nd interim report, October 1994, Netherlands Institute for Sea Research, Texel, $55 \mathrm{pp}$.

CARTER I.C., WILLIAMS J.M., WebB, A. \& TASKER M.L. 1993. Seabird concentrations in the North Sea: an atlas of vulnerability to surface pollutants. Joint $\mathrm{Na}$ ture Conservation Committee, Aberdeen, 39pp.

CORTEN A. 1991. Discard sampling programme for the North Sea. Dutch participation (2nd part). Internal RIVO-report, Pelvis 91-402.

Costopoulous C.G. \& FondS M. 1989. Proximate body composition and energy content of Plaice (Pleuronectes platessa) in relation to the condition factor. Neth. J. Sea Res. 24: 45-55.

COUPERUS B. 1992. Reisverslag van de $\mathrm{SCH} 33$ van 19 . 10 tot 7-11-1992. Unpubl. report Rijksinst. Visserijonderzoek, IJmuiden.

COUPERUS B. 1993. Orca's Orcinus orca en Grienden Globicephala melas bij trawlers ten oosten van Shetland. Sula 7: 41-52.

COUPERUS A.S. 1994. Killer Whales Orcinus orca scavenging on discards of freezer trawlers north east of the Shetland islands. Aquatic Mammals 20: 47-51.

COULSON J.C. 1983. The changing status of the Kittiwake Rissa tridactyla in the British Isles, 1969-1979. Bird Study 30: 9-16.

Coulson J.C., Monaghan P., ButTerfield J.E.L., DUNCAN N., ENSOR K., SHEDDEN C. \& THOMAS C.S. 1984. Scandinavian Herring Gulls wintering in Britain. Orn. Scand. 15: 79-88.

CRAMP S. \& SIMMONS K.E.L. 1977. The Birds of the
Western Palearctic, 1. Oxford Univ. Press, Oxford.

Cramp S. \& Simmons K.E.L. 1983. The Birds of the Western Palearctic, 3. Oxford Univ. Press, Oxford.

Croxall J.P., EVANS P.G.H. \& SCHREIBER R.W. 1984. Status and Conservation of the World's Seabirds. Techn Publ. No. 2, ICBP, Cambridge.

DaAN N., BRomley P.J., Hislop J.R.G. \& Nielsen N.A. 1990. Ecology of North Sea fish. In: Wolf P.de, Lindeboom H.J. \& Laane R.W.P.M. (eds). Proc, int symp. Ecol. North Sea, May 1988. Neth. J. Sea Res. 26: 343-386.

DAAN N. 1976. Report on discards of cod, haddock and whiting in the North Sea by the Dutch fleet 1958-1975. ICES C.M. 1976/F: 8, Dem. Fish Comm.

DAMM U. \& WEBER W. 1990. Analysis of catch rates in experimental fishing on North Sea sole with FRV 'Solea'. Arch. Fisch. wiss. 40: 49-55.

DÄNDLIKER G. \& MÜLHAUSER G. 1988. L'exploitation des dechets de chalutage par les oiseaux de mer au large des Orcades et des Shetland (Nord-Est Atlantique). Nos Oiseaux 39: 257-288.

DUFFY D.C., SIEGFRIED W.R. \& JACKSON S. 1987. Seabirds as consumers in the southern Benguela region. In: A.I.L. Payne, J.A. Gulland, K.H. Brink (eds). The Benguela and Comparable Ecosystems. S. Afr. J. Mar. Sci. 5: 771-790.

DUFFY D.C. \& SCHNEIDER D.C. 1994. Seabird-fishery interactions: a manager's guide. In: Nettleship D.N., Burger J. \& Gochfeld M. (eds). Seabirds on Islands threats, case studies and action plans: 26-38. Birdlife Conservation Series No. 1, Birdlife International, Cambridge.

DUNN E. 1994. Interactions between Fisheries and Marine Birds: Research Recommendations. Royal Society for the Protection of Birds, Sandy, 44pp.

DUNNET G.M., FURNESS R.W., TASKER M.L. \& BECKER P.H. 1990. Seabird ecology in the North Sea. Neth. J. Sea Res. 26: 387-425.

EVANS S.M., HUNTER J.E., Elizal \& WAHJu R.I. 1994 Composition and fate of the catch and bycatch in the Farne Deep (North Sea) Nephrops fishery. ICES J. mar. Sci. 51: 155-168.

EWINS P.J. 1987. Opportunistic feeding of Black Guillemots Cepphus grylle at fishing vessels. Seabird 10: 58-59.

FELTON C. 1969. Black-headed Gulls following boats at night. Brit. Birds 62: 117.

FISHER J. 1952. The Fulmar. Collins New Naturalist Series, Facsimile 1984, Collins, London 496pp.

FISHER J. 1966. The Fulmar population of Britain and Ireland 1959. Bird Study 13: 5-76.

FoNDS M. 1991. Measurements of catch composition and survival of benthic animals in beamtrawl fishery for Sole in the southern North Sea. In: Effects of beamtrawl fishery on the bottom fauna in the North Sea. II. The 1990 studies. BEON-rep. 13: 53-67.

FONDS M. 1994a. Catch composition of 12-m beamtrawl and 4-m beamtrawl for Sole fishing. In: Groot S.J. de \& Lindeboom H.J. (eds). Environmental impact of bottom gears on benthic fauna in relation to natural resources management and protection of the North Sea. EC Research contract MA 2-549, Netherlands Institute for Fisheries Research, IJmuiden and Netherlands Institute for Sea Research, Texel.

FONDS M. 1994b. Mortality of fish and invertebrates in beamtrawl catches and the survival changes of discards. In: Groot S.J. de \& Lindeboom H.J. (eds). Environmental impact of bottom gears on benthic fauna in relation to natural resources management and protection of the North Sea. EC Research contract MA 
2-549, Netherlands Institute for Fisheries Research, IJmuiden \& Netherlands Institute for Sea Research, Texel.

FondS M., Verboom B.L. \& Groeneveld K. 1992. Catch composition and survival of fish and benthic invertebrates in commercial beamtrawls for sole- and plaice fishery in the southern North Ses. In: Anon.: Effects of beamtrawl fishery on the bottom fauna in the North Sea. III. The 1991 studies. BEON-rep. 16 17-22.

FRANEKER J.A. VAN \& WATTEL J. 1982. Geographical variation of the Fulmar Fulmarus glacialis in the North Atlantic. Ardea 70: 31-44.

FURNESS R.W. 1979. Foods of the Great Skuas Catharacta skua at North Atlantic breeding localities. Ibis 121: 86-92.

FURNESS R.W. 1981. Estimating the food requirements of seabird and seal populations and their interactions with commercial fisheries and fish stocks. In: Cooper J. (ed.). Proceedings of the Symposium on Birds of the Sea and Shore, 1979. African Seabird Group, Cape Town, pp 1-13.

FURNESS R.W. 1983.Foula, Shetland, 4. The Birds of Foula. Brathay Centre Expl. Fld. Stud., Old Brathay.

FURNESS R.W. 1987. The Skuas. T. \& A.D. Poyser, Calton.

FURNESS R.W 1989. Changes in diet and breeding ecology of seabirds on Foula, 1971-88. In: Heubeck M. (ed.). Seabirds and sandeels: proceedings of a seminar held in Lerwick, Shetland, 15-16th October 1988. Shetland Bird Club, Lerwick.

FURNESS R.W. 1992. Implications of changes in net mesh size, fishing effort and minimum landing size regulations in the North Sea for seabird populations. Contr. Rep. to JNCC and Scottish Office, Appl. Orn. Unit. Dept. Zool., Univ. Glasgow, Glasgow.

FURNESS R.W. 1993. An assessment of human hazards to seabirds in the North Sea. WWF International Report \& Executive summary, February 1993, London, 86pp.

FURNESS R.W. ENSOR K \& HUDSON A.V. 1992. The use of fishery waste by gull populations around the British Isles. In: Spaans A.L. (ed.). Population dynamics of Lari in relation to food resources. Ardea 80: 105-113.

FURNESS R.W. \& HISLOP J.R.G. 1981. Diets and feeding ecology of Great Skuas during the breeding season in Shetland. J. Zool., Lond. 195: 1-23.

FURNESS R.W. HUDSON A.V. \& ENSOR K. 1988. Interactions between scavenging seabirds and commercial fisheries around the British Isles: 240-268. In: Burger J. (ed.) Seabirds \& Other Marine Vertebrates: Competition. Predation and Other Interactions. Columbia Univ. Press, New York.

GARTHE S. 1992. Quantifizierung von Abfall und Beifang der Fischerei in der südöstlichen Nordsee und deren Nutzung durch Seevögel. Diplomarb. Math.-Naturw. Fakult., Inst. Meeresk., Christian-Albr. University, Kiel, $111 \mathrm{pp}$.

GARTHE S. 1993a. Durchzug und Wintervorkommen der Zwergmöwe (Larus minutus) bei Helgoland in den Jahren 1977 bis 1991. Die Vogelwarte 37: 118-129.

GARTHE S. 1993b. Quantifizierung von Abfall und Beifang der Fischerei in der südöstlichen Nordsee und deren Nutzung durch Seevögel. Hamburger avifaun. Beitr. 25: 125-237.

GARTHE S. \& HüPPOP O. 1993. Gulls and Fulmars following ships and feeding on discards at night. Ornis Svecica 3: 159-161.

GARTHE S. \& HüPPOP O. 1994. Distribution of ship-following seabirds and their utilization of discards in the North Sea in summer. Mar. Ecol. Prog. Ser. 106: 1-9.

GARTHE S. \& DAMM U. in prep. Discards from beamtrawl fisheries in the German Bight. Manuscript.

Gee A. DE, BAARS M.A. \& VeER H.W. VAN DER 1991. De Ecologie van het Friese Front. NIOZ Rapport 1991-2, 96pp, NIOZ Texel.

GISLASON H. 1993. Report of the study group on ecosystem effects of fishing activities. Copenhagen, 7-14 April 1992, ICES C.M. 1992/G: 11, Ref.: Session T.

GLUTZ VON BLOTZHEIM U.N., BAUER K.M. 1982. Handbuch der Vögel Mitteleuropas, 8/l. Akad. Verl., Wiesbaden.

GOLDBACH R. \& HANSEN K. 1979. De Zilvermeeuw. Kosmos Vogelmonografieën, Amsterdam/Antwerpen.

GRAINGER R.J. (ed.) 1992. ICES Fisheries Statistics. Vol. 73. Internat. Counc. Explor. Sea, København.

GROOT S.J. DE \& LINDEBOOM H.J. (EDS) 1995. Environmental impact of bottom gears on benthic fauna in relation to natural resources management and protection of the North Sea. NIOZ-Rapport 1994-11, RIVO-DLO Report C026/94, Netherlands Institute for Sea Research, Texel.

HALL A.L., TASKER M.L. \& WeBB A. 1987. The marine distribution of Sooty Shearwater, Manx Shearwater Storm Petrel and Leach's Petrel in the North Sea. Seabird 10: 60-70.

HAMER K.C., FURNESS R.W. \& CALDOW R.G.W. 1991. The effects of changes in food availability on the breeding ecology of Great Skuas Catharacta skua in Shetland. J. Zool. (London) 223: 175-188.

HAMER K.C., MONAGHAN P., UTTLEY J.D., WALTON P. \& BURNS M.D. 1993. The influence of food supply on the breeding ecology of Kittiwakes Rissa tridactyla in Shetland. Ibis 135: 255-263.

HARRIS M.P. 1970. Rates and causes of increase of some British gull populations. Bird Study 17: 325-335.

HARRIS A.N. \& POINER I.R. 1990. By-catch of the prawn fishery of Torres Strait; composition and partitioning of the discards into components that float or sink. Aust. J. Freshwater Res. 41: 37-52.

HEIDE G. VAN DER 1938. Waarnemingen over het voorkomen van enkele zeevogels bij de Doggersbank in October 1936. Ardea 27: 256-258.

HEUBECK M. (ED.) 1989. Seabirds and sandeels: proceedings of a seminar held in Lerwick, Shetland, 15-16th October 1988. Shetland Bird Club, Lerwick, 81 pp.

HILL B.J. \& WASSENBERG T.J. 1990. Fate of discards from prawn trawlers in Torres Strait. Aust. J. Mar. Freshwat. Res. 41: 53-64.

HILLIS J.P. 1971. Seabirds scavenging at trawlers in Irish waters. Irish Nat. J. 17: 129-132.

HIOM BOLTON M. MONAGHaN P. \& WORRALL D. 1991. Experimental evidence for food limitation of egg production in gulls. Ornis Scand. 22: 94-97.

HOWEL W.H. \& LANGAN R. 1987. Commercial trawler discards of four flounder species in the Gulf of Maine. North Am. J. Fish. Manage. 7: 6-17.

HUBOLD G. 1994 Maßnahmenkatalog für eine ausgewogenere und rationellere Bewirtschaftung der von der deutschen Fischerei genutzten Fischereiressourcen im EG Meer. Inform. Fischwirt. 41: 3-18.

HUDON C. 1990. Distribution of shrimp and fish by-catch assemblages in the Canadian eastern Arctic in relation to water circulation. Can. J. Fish. Aquat. Sci. 47: $1710-1723$

HUDSON A.V. 1986. The biology of seabirds utilising fishery waste in Shetland. Ph. D. thesis, Univ. Glasgow, Scotland.

HUDSON A.V. 1988. Seabirds feeding on fishery waste 
around Shetland. In: Tasker M.L. (ed.). Seabird Food and Feeding Ecology. Proc. 3rd int. Conf. Seabird Group, Cambridge, p26.

HUDSON A.V. 1989. Interspecific and age-related differences in the handling time of discarded fish by scavenging seabirds. Seabird 12: 40-44.

HUDSON A.V. \& FURNESS R.W. 1988. Utilization of dis carded fish by scavenging seabirds behind white fish trawlers in Shetland. J. Zool., Lond. 215: 151-166.

HUDSON A.V. \& FURNESS R.W. 1989. The behaviour of seabirds foraging at fishing boats around Shetland. Ibis 131: 225-237.

HUNT G.L. (ed.) 1993. Draft report of the study group on seabird/fish interactions. ICES C.M. 1993/L: 10, 1-22.

HüPPOP O. \& GARTHE S. 1993. Seabirds and fisheries in the southeastern North Sea. Sula 7: 9-14.

HüPPOP O., GARTHE S., HARTWIG E. \& WALTER U. 1994. Fischerei und Schiffsverkehr: Vorteil oder Problem fü See- und Küstenvögel? In: Lozán J.L., Rachor E., Reise K., von Westernhagen H. \& Lenz W. (eds). Warnsignale aus dem Wattenmeer: 278-285. Blackwell Wissenschafts-Verlag, Berlin.

JEAN Y. 1963. Discards of fish at sea by northern New Brunswick draggers. J. Fish. res. Board Can. 20 497-524.

Jensen H., TASKer M.L., Coull K. \& EMslie D. 1994. A comparison of distribution of seabirds and prey fish stocks in the North Sea and adjacent areas. Final report of EC DG XIV research contract 92/3501. JNCC Report no. 207. Joint Nature Conservation Committee, Peterborough.

JERMYN A.S. \& ROBB A.P. 1981, Review of the Cod Haddock and Whiting discarded in the North Sea by Scottish fishing vessels for the period 1975-1980. ICES C.M. 1981/G: 47, Dem. Fish. Comm.

JERMYN A.S. \& HALL W.B. 1978. Sampling procedures for estimating haddock and whiting discards in the North Sea by Scottish fishing vessels in 1976 and 1977. Cons. int. Explor. Mer Pap. Res. D 9: 1-4.

JESPERSEN P. 1930. Ornithological observations in the North Atlantic Ocean. Ocean. Rep. Dan. 'Dana' Exp. 1920-1922 (7): $1-36$

JøRGENSEN O.M. 1973. Some results of Herring Gull ringing in Denmark, 1958-1969. Dansk Orn. Foren. Tiddskr. 67: 53-63.

JUHL R. \& DRUMMOND S.B. 1977. Shrimp by-catch investigation in the united States of America. A status report. In: Symposium on progress in Marine Research in the Caribbean and Adjacent regions, 12-16 July 1976. Caracus, FAO Fish Rep., No. 200 FIR/k2000, pp 213-220

KEIJL G., ROOMEN M.W.J. VAN \& VELDHUIJZEN VAN ZANTEN H. 1986. Voedselecologie van de Stormmeeuw (Larus canus) te Schoorl 1986: Voedselkeuze en fourageerritme in de periode dat de jongen worden grootgebracht. Inst. lerarenopl., Hogeschool Holland, sektie biologie, Diemen 64pp.

KEIJL G.O. ROOMEN M.W.J. VAN \& VELDHUIJZEN VAN ZANTEN H. 1989. De relatie tussen het gebruik van de zeereep door Stormmeeuwen Larus canus en het voorkomen van vissende meeuwengroepen op zee. Sula 3: 26-30

KLINKEN A. VAN 1992. The impact of additional food provisioning on chick growth and breeding output in the Herring Gull Larus argentatus: a pilot experiment. In: Spaans A.L. (ed.). Population dynamics of Lari in relation to food resources. Ardea 80: 151-155.

LAKE N.C.H. 1984. A study of the discarding of fish at sea by commercial fishing vessels - its impact and implications. Thesis, Plymouth Polytechnic, Plymouth, England.

LAMBERT K. 1975. Schwalbenmöwen -Xema sabini-, Beobachtungen im Südsommer 1972/73 im südafrikanischen Winterquartier. Beitr. Vogelk. 21: 410-415

LAMP F. \& WEBER W. 1984. Further investigations on discarding of cod in the German Bight by fishermen of the Federal Republic of Germany. ICES C.M. 1984/G: $50,1-14$.

LEE A.J. 1980. North Sea: Physical oceanography. In Banner F.T., Collins M.B. \& Massie K.S. (eds). The north-west European shelf seas: the sea bed and the sea in motion, II. Physical and chemical oceanography and physical resources. Elsevier Oceanography Series.

LOCKLEY R.M. \& MARCHANT S. 1951. A midsummer visit to Rockall. Brit. Birds 44: 373-383.

LLOYD C., TASKER M.L. \& PARTRIDGE K. 1991. The Status of Seabirds in Britain and Ireland. T. \& A.D. Poyser, London.

MANIKOWSKI S. 1971. The influence of meteorological factors on the behaviour of sea birds. Acta Zool. Cracoviensia 16: 582-657

MAUL A.M. 1994. Ernährungsweisen und Brutbiologie der Dreizehnmöwe Rissa tridactyla (Linnaeus, 1758) auf Helgoland. Diplomarbeit an der Naturwissenschaftlichen Fakultät der Karl-Franzens-Universität Graz.

MEEK E.R., SIM I.M.W. \& RIBBANDS B. 1994. Breeding skuas in Orkney: the results of the 1992 census. Seabird 16: 34-40.

MEER J. VAN DER \& CAMPHUYSEN C.J. in press Effect of observer differences on abundance estimates of seabirds from ship-based strip transect surveys. Ibis.

MITCHELL R., LANGSLOW D.R., BLAKE B.F., JONES P.H., DIXON T. \& TASKER M.L. 1980. Investigation of the distribution of seabirds at sea: first annual report, November 1979 to November 1980. Nature Conserv. Council, Aberdeen 88pp.

MøLLER A.P. 1978. Magernes Larinae yngleudbredelse, bestandsstørrelse og andringer i Danmark, med supplerende oplysninger om forholdene $\mathrm{i}$ det øvrige Europa. Dansk Orn. Foren. Tidsskr. 72: 15-40.

Møller A.P. 1981. Problems with Danish Herring Gulls Larus argentatus. Proc. 2nd Nordic Congr. Orn. 1979: 127-135

MONAGHAN P. 1993. Lesser Black-backed Gull Larus fuscus. In: Gibbons D.W., reid J.B. \& Chapman R.A. (eds). The New Atlas of Breeding Birds in Britain and Ireland: 1988-1991. T. \& A.D. Poyser, London.

MUNSTERMAN P. 1971. Vogels tijdens de haringvangst. Het Vogeljaar 19: 625-628.

NELSON J.B. 1978. The Gannet. T. \& A.D. Poyser, Berkhamsted.

NELSON J.B. 1980. Seabirds: their biology and ecology. Hamlyn, London/New York.

NoORDHUIS R. 1987. Voedseloecologie van zilver- en kleine mantelmeeuw of Terschelling: een geval van het 'competitive exclusion principle'. Mimeogr. report, Rijksinstituut voor Natuurbeheer, Arnhem.

NOORDHUIS R. \& SPAANS A.L. 1992. Interspecific competition for food between Herring Larus argentatus and Lesser Black-backed Gulls $L$. fuscus in the Dutch Wadden Sea area. In: Spaans A.L. (ed.). Population dynamics of Lari in relation to food resources. Ardea 80: 115-132.

OLIVER P.J. 1983. Use by seabirds of human fishing activities. Brit. Birds 76: 31-32.

Paterson A.M., MARTínez VILALTA A. \& Dies J.I. 1992. Partial breeding failure of Audouin's Gull in two Spanish colonies in 1991. Brit. Birds 85: 97-100. 
PEARSON T.H. 1968. The breeding biology of sea-bird species breeding on the Farne Islands, Northumberland. J. Anim. Ecol. 37: 521-552.

PINGREE R.D. \& GRIFFITHS D.K. 1978. Tidal fronts on the shelf seas around the British Isles. J. Geoph. Res. 83 (C9): 4615-4622.

P ATteeuw M. HAM N.F. VAN DER \& OUdEN J.E. DEN 1994. Zeetrektellingen in Nederland in de jaren tachtig. Sula 8: 1-203

PRENDERGAST H.D.V. 1992. Behaviour of Leach's Petrels at dusk and night around yacht in mid Atlantic. Brit. Birds 85: $557-558$

OLIVER P.J. 1983. Use by seabirds of human fishing activities. Brit. Birds 76: 31-32.

PRÜTER J. 1983. Bestandsentwicklung und Durchzug der Heringsmöwe (Larus fuscus) in der Deutschen Bucht. Seevögel 4: 29-35.

PRÜTER J. 1986. Untersuchungen zum Bestandsaufbau und zur Ökologie der Möwen (Laridae) im Seegebiet der Deutschen Bucht. Unpubl. Ph.D. thesis, 'Vogelwarte Helgoland' \& Tierärztl. Hochschule Hannover, 142pp.

PRÜTER J. 1989. Phänologie und Ernährungsökologie der Dreizehnmöwen (Rissa tridactyla) - Brutpopulation auf Helgoland. Ökol. Vögel 11: 189-200.

PRÜTER J., SAHMOW A. \& VAUK-HENTZELT E. 1988. Unter suchungen zur Ernährung der Silbermöwe (Larus argentatus) auf der Insel Scharhörn (Elbmündung) während der Brutzeit. Seevögel 9(4): 56-58.

RAMM D.C., PENDER P.J., WILLING R.S. \& BUCKWORTH R.C. 1990. Large-scale spatial patterns of abundance within the assemblage of fish caught by prawn trawlers in northern Australian waters. Aust. J. Mar. Freshw. Res. 41: 79-95.

REES E.I.S. 1961. Notes on the food of the Greater Shearwater. Sea Swallow 14: 54-55.

REES E.I.S. 1963. Marine birds in the Gulf of St. Lawrence and Strait of Belle Isle during November. Can. Fld.-Nat. 77: 98-107.

REES E.I.S. 1964. The Sooty Shearwater Procellaria grisea on the Newfoundland Banks. Ibis 106: $118-119$.

REES E.I.S. 1983. Little Auks scavenging at trawler. Brit. Birds 76: 454.

ReEves S.A., ARMstrong D.W., Fryer R.J. \& Coull K.A. 1992. The effect of mesh size, cod-end extension length and cod-end diameter on the selectivity of Scottish trawls and seines. ICES J. Mar. Sc. 49: 279-288.

REINSCH H.H. 1963. Zugbeobachtungen auf der Doggerbank. Orn. Mitt. 15: 131-133.

REINSCH H.H. 1969. Der Basstölpel. Neue Brehm Bücherei 412, Wittenberg Lutherstadt $111 \mathrm{pp}$.

RYAN P.G. \& MOLONEY C.L. 1988. Effect of trawling on bird and seal distributions in the southern Benguela region. Mar. Ecol. Prog. Ser. 45: 1-11.

RYAN P.G. 1991. The impact of the commercial lobster fishery on seabirds at the Tristan da Cunha Islands, South Atlantic Ocean. Biol. Cons. 57: 339-350.

SAHRHAGE D. 1958. Untersuchungen über die Vernichtung untermaßiger Schellfische durch die deutsche Heringsschleppnetzfischerei in der Nordsee. Ber. Dtsch. Wiss. Komm. Meeresforsch. 15: 105-131.

SAHRHAGE D. 1959. Untersuchungen über den Anteil untermaßiger Wittlinge in den Fängen der deutschen Heringsschleppnetzfischerei in der Nordsee. Ber. Dtsch. Wiss. Komm. Meeresforsch. 15: 335-356.

SAILA S.B. 1983. Importance and assessment of discards in commercial fisheries. FAO Fisheries Circular 765: 1-62.
SARA M. 1993. Feeding habits of Cory's Shearwater (Calonectris diomedea) in the Central Mediterranean Sea. In: Aguilar J.S., Monbailliu X. \& Paterson A.M. (eds). Estatus y Conservacion de Aves Marinas: 213-220. Actas del II Symposio MEDMARAVIS, SEO, Madrid.

SAUER J.R., Peterjohn B.G. \& Link W.A. 1994. Observer differences in the North American breeding bird survey. Auk 111: 50-62.

SCHÜZ E. 1933. Von den Wanderungen der Eismeer- und Ostsee-Silbermöwen (Larus a. argentatus). Orn. Fenn. 10(2): 17-19.

Sears J., Ellis P.M., Suddaby D. \& HaRRop H.R. 1995. The status of breeding Arctic Skuas Stercorarius parasiticus and Great Skuas $S$. skua in Shetland in 1992. Seabird 17: 21-31.

SIBLY R.M. \& MACCLEERY R.H. 1982. The distribution between feeding of herring gulls breeding at Walney Island, U.K. J. Anim. Ecol. 52: 51-68.

SIBLY R.M. \& MACCLEERY R.H. 1982. Increase in weight of herring gulls while feeding. J. Anim. Ecol. 52: 35-50.

SMIT C.J. \& WOLFF W.J. 1981. Birds of the Wadden Sea. Report no. 6, Final report of the section Birds of the Wadden Sea Working Group, Balkema, Rotterdam.

SPAANS A.L. 1971. On the feeding ecology of the Herring Gull Larus argentatus Pont. in the northern part of the Netherlands. Ardea 59: 73-188.

SPAANS A.L., BUKACIÑSKA M. \& BUKACIÑSKA D. 1994. The relationship between food supply, reproductive parameters and population dynamics in Dutch Lesser Black-backed Gulls Larus fuscus: a pilot study. IBN-Research report 94/9, Institute for Forestry and Nature Research, Arnhem.

SPAANS A.L. \& NOORDHUIS R. 1989. Voedselconcurrentie tussen Kleine Mantelmeeuwen en Zilvermeeuwen. In: Spaans A.L. (ed.), Wetlands en Watervogels: 35-47. Pudoc, Wageningen.

SPITZER G. 1976. Zur Ernährung gelbfüßiger Silbermöwen (Larus argentatus michahellis) in der Adrie und im Binnenland. Die Vogelwarte 28: 298-306.

StANLEY P.I., BROUGH T., FletCher M.R., HORTON N. \& ROCHARD J.B.A. 1981. The origins of herring gulls wintering in south-east England. Bird Study 28: 123-132

StONE C.J., WebB A. \& CARTER I.C. 1992. Lesser Black-backed Gull distribution at trawlers and food availability in the Celtic Sea, 1991. JNCC Report no. 106, Joint Nature Conservation Committee, Aberdeen.

StONE C.J., WeBb A., Barton C., RatCliffe N., CampHUYSEN C.J., REED T.C., TASKer M.L. \& PIENKOWSKI M.W. 1995. An atlas of seabird distribution in North-west European waters. Joint Nature Conservation Committee, Peterborough.

TASKER M.L., JONES P.H., DIXON T.J. \& BLAKE B.F. 1984. Counting seabirds from ships: a review of methods employed and a suggestion for a standardized approach. Auk 101: 567-577.

TASKER M.L., JONES P.H., BLAKE B.F. \& DIXON T.J. 1985a. The marine distribution of the Gannet in the North Sea. Bird Study 32: 82-90.

TASKER M.L., JONES P.H., BLAKE B.F. \& DIXON T.J. 1985 b. Distribution and feeding habits of the Great Skua Catharacta skua in the North Sea. Seabird 8: 34-44.

TASKER M.L., WebB A., HALL A.J., PIENKOWSKI M.W. \& LANGSLOW D.R. 1987. Seabirds in the North Sea Nature Conserv. Council, Peterborough 336pp.

THOMPSON K.R. 1992. Quantitative analysis of the use 
of discards from squid trawlers by Black-browed Albatrosses Diomedea melanophris in the vicinity of the Falkland Islands. Ibis 134: 11-21.

ThOMSON A.L. 1924. The migrations of the Herring Gull and Lesser Black-backed Gull: results of the marking method. Brit. Birds 18: 34-44.

TIEWS K. 1978a. Non-commercial fish species in the German Bight: records of by-catches of the Brown Shrimp fishery. Rapp. P.-v. Reun. Cons. int. Explor. Mer 172: 259-265.

TIEWS K. 1978b. The German industrial fisheries in the North Sea and their by-catches. Rapp. P.-v. Réun. Cons, int. Explor. Mer 172: 230-238.

TIEWS K. 1983. Über die Veränderungen im Auftreten von Fischen und Krebsen im Beifang der deutschen Garnelenfischerei während der Jahre 1954-1981 Ein Beitrag zur Ökologie des deutschen Wattenmeeres und zum biologischen Monitoring von Ökosystemen im Meer. Arch. Fischereiwiss. 34 (Beiheft 1): 1-156.

TIEWS K. 1984. Beifanguntersuchungen zur Garnalenfischerei signalisieren für die kommende Fangsaison 1984/85 Normalisierung der Kabeljaufischerei in der Deutschen Bucht. Inf. Fischw. 31: 96-98.

TIEWS K. \& WIENBECK H. 1990. Grundlagenmaterial zu 35-Jahres-trend (1954-1988) der Häufigkeit von 25 Fisch- und Krebstierbeständen an der deutschen Nordseeküste. Veröff. Inst. Küsten- und Binnenfisch., Hamburg, Nr. 103/1990, Bundesforsch. Fischerei.

VAUK G. \& JOKELE I. 1975. Vorkommen, Herkunft und Winternahrung Helgoländer Dreizehnmöwen (Rissa tridactyla). Veröff. Inst. Meeresf. Bremerhaven 15: 69-77.

VEEN J.F. DE HUWAE P.H.M. \& LAVALEYE M.S.S. 1975. On discarding in the sole fishery and preliminary observations on survival rates of discarded plaice and sole in 1975. ICES C.M. 1975/F: 28: 1-9.

VERBEEK N.A.M. 1979. Some aspects of the breeding biology and behavior of the Great Black-backed Gull. Wilson Bull. 91: 575-582.

VERBOOM B.L. 1991. BEON Bodemverstoringsonderzoek 1990 - discards. Rapp. MO 91-01, Rijksinst. Viss. Onderz., IJmuiden.

VERNON J.D.R. 1969. Black-headed Gulls following boats at night. Brit. Birds 62: 386-387.

WAHL T.R. \& HEINEMANN D. 1979. Seabirds and fishing vessels: co-occurrence and attractions. Condor 81 : 390-396.

Walsh P.M., Sears J. \& Heubeck M. 1991. Seabird numbers and breeding success in 1990. NCC Chief Sc. Dir. Report No. 1235, Nature Conservancy Council, Aberdeen.

WALTER U. \& BECKER P. 1994. The significance of discards from the Brown Shrimp fisheries for seabirds in the Wadden Sea - preliminary results. Ophelia Suppl. 6: 253-262

WASSENBERG T.J. \& HILL B.J. 1990. Partitioning of material discarded from prawn trawlers in Moreton Bay. Aust. J. Mar. Freshwat. Res. 41: 27-36.

WATSON P.S. 1978. Seabirds at commercial trawlers in the west Irish Sea. Ibis 120: 106-107.

WATSON P.S. 1981. Seabird observations from commercial trawlers in the Irish Sea. Brit.Birds 74: 82-90.

WEBER W. \& LAMP F. 1983. Discarding of cod in the German Bight by fishermen of the Federal Republic of Germany. ICES C.M. 1983/G: 25.

WEIGELT C. 1891. Die Abfälle der Seefischerei. Experimentelle Untersuchungen über deren Natur, Menge,
Verarbeitung und Verwerthung. Mitt. Sekt. Küstenu. Hochseefisch. 1891, Sonderbeilage 2.

WOLF P. DE (ED.) 1990. De Noordzee. Uitgeverij Terra, Zutphen. $200 \mathrm{pp}$.

WUNDERLE J.M. JR. 1992. Age-specific foraging proficiency in birds. Curr. Ornithol. 9: 273-324.

WYNNE-EDWARDS V.C. 1935. The habits and distribution of birds on the North Atlantic. Proc. Boston Soc. Nat. Hist. 40: 233-346. 


\section{Appendix}

Size selection of scavenging seabirds during experimental discarding from research vessels can be derived from tables in this appendix (see chapter 4.6 for further details). Discarded fish of which the fate is unknown were not included, given are numbers of fish per $\mathrm{cm}$ length/width class that either sunk or were consumed by seabirds. Total numbers of experimentally discarded gadids (Haddock, Whiting, Saithe, Cod, Norway pout) or clupeids (Herring and Sprat) per $\mathrm{cm}$ length and of experimentally discarded flatfish per $\mathrm{cm}$ width, which sank or were consumed by seabirds were calculated (tables 1-70) per subregion and season. Median values are marked with an asterisk "*".

Table 1. Consumption of gadids in NW in February.

\begin{tabular}{|c|c|c|c|c|c|c|c|c|}
\hline Fish length & sunk & Gan & GBG & $H G$ & LBG & GSk & Kit & Ful \\
\hline $\begin{array}{l}11 \\
12 \\
13 \\
14 \\
15 \\
16 \\
17 \\
18 \\
19 \\
20 \\
21 \\
22 \\
23 \\
24 \\
25 \\
26 \\
27 \\
28 \\
29 \\
30 \\
31 \\
32 \\
33 \\
34 \\
35 \\
36 \\
37 \\
38 \\
39\end{array}$ & $\begin{array}{r}1 \\
1 \\
1 \\
1 \\
3 \\
1 \\
4 \\
4 \\
7 \\
1 \\
1 \\
\\
\\
2 \\
2 \\
2 \\
5 \\
4 \\
* \\
10 \\
6 \\
6 \\
6 \\
7 \\
1 \\
1 \\
1 \\
2 \\
1 \\
1 \\
3\end{array}$ & $\begin{array}{r}3 \\
\\
3 \\
3 \\
3 \\
15 \\
18 \\
11 \\
6 \\
6 \\
11 \\
8 \\
15 \\
11 \\
12 \\
27 \\
25 \\
42 \\
22 \\
24 \\
34 \\
13 \\
10 \\
10 \\
9 \\
9 \\
9 \\
3 \\
2\end{array}$ & $\begin{array}{r}1 \\
1 \\
\\
\\
2 \\
4 \\
2 \\
1 \\
6 \\
13 \\
11 \\
11 \\
18 \\
13 \\
* 21 \\
16 \\
11 \\
20 \\
12 \\
4 \\
9 \\
3 \\
1\end{array}$ & $\begin{array}{r}6 \\
9 \\
9 \\
4 \\
5 \\
6 \\
2 \\
3 \\
10 \\
* \quad 9 \\
15 \\
18 \\
9 \\
7 \\
4 \\
2 \\
3\end{array}$ & & & $\begin{array}{r}10 \\
8 \\
6 \\
24 \\
35 \\
64 \\
* 60 \\
45 \\
19 \\
14 \\
7 \\
8 \\
10 \\
4\end{array}$ & $\begin{array}{r}2 \\
2 \\
1 \\
1 \\
1 \\
* \quad 2 \\
1 \\
2 \\
3 \\
1\end{array}$ \\
\hline Totals & 76 & 358 & 180 & 125 & 0 & 0 & 314 & 18 \\
\hline
\end{tabular}


Table 2. Consumption of gadids in NW in May.

\begin{tabular}{|c|c|c|c|c|c|c|c|c|}
\hline Fish length & sunk & Gan & GBG & HG & LBG & GSk & Kit & Ful \\
\hline $\begin{array}{l}10 \\
11 \\
12 \\
13 \\
14 \\
15 \\
16 \\
17 \\
18 \\
19 \\
20 \\
21 \\
22 \\
23 \\
24 \\
25 \\
26 \\
27 \\
28 \\
29 \\
30 \\
31 \\
32 \\
33 \\
34 \\
35 \\
36 \\
37 \\
38 \\
39 \\
40 \\
41\end{array}$ & $\begin{array}{r}4 \\
4 \\
24 \\
13 \\
11 \\
23 \\
14 \\
* 16 \\
8 \\
4 \\
8 \\
10 \\
12 \\
16 \\
11 \\
2 \\
3 \\
2 \\
2 \\
3 \\
1 \\
3 \\
2 \\
3 \\
1 \\
2\end{array}$ & $\begin{array}{r}2 \\
3 \\
7 \\
7 \\
9 \\
24 \\
16 \\
10 \\
8 \\
11 \\
15 \\
23 \\
* 20 \\
19 \\
23 \\
14 \\
12 \\
11 \\
8 \\
6 \\
10 \\
6 \\
3 \\
3 \\
2 \\
2 \\
2\end{array}$ & $\begin{array}{r}3 \\
3 \\
1 \\
2 \\
6 \\
2 \\
2 \\
2 \\
3 \\
11 \\
7 \\
* 17 \\
11 \\
8 \\
5 \\
4 \\
5 \\
3 \\
1 \\
2 \\
1 \\
3 \\
1\end{array}$ & $\begin{array}{r}2 \\
2 \\
2 \\
1 \\
* 1 \\
\\
2 \\
2 \\
1 \\
1 \\
1 \\
1 \\
1\end{array}$ & $\begin{array}{r}1 \\
1 \\
3 \\
3 \\
2 \\
3 \\
3 \\
6 \\
1 \\
1 \\
1 \\
* 4 \\
11 \\
3 \\
3\end{array}$ & $\begin{array}{r}2 \\
1 \\
\\
1 \\
* \quad 2 \\
1\end{array}$ & $\begin{array}{r}6 \\
28 \\
38 \\
29 \\
* 30 \\
26 \\
20 \\
22 \\
9 \\
3 \\
3 \\
2\end{array}$ & $\begin{array}{r}16 \\
38 \\
43 \\
35 \\
48 \\
30 \\
* 39 \\
31 \\
20 \\
18 \\
20 \\
30 \\
15 \\
15 \\
15 \\
5 \\
5 \\
7 \\
3 \\
4\end{array}$ \\
\hline Totals & 202 & 273 & 101 & 18 & 45 & 8 & 216 & 443 \\
\hline
\end{tabular}


Table 3. Consumption of gadids in NW in August.

\begin{tabular}{|c|c|c|c|c|c|c|c|c|}
\hline Fish length & sunk & Gan & GBG & HG & LBG & GSk & Kit & Ful \\
\hline 7 & & & & & & & & $\overline{2}$ \\
\hline 8 & 1 & & & & & & & 1 \\
\hline 9 & 1 & & & & & & 1 & $\begin{array}{l}4 \\
5\end{array}$ \\
\hline $\begin{array}{l}10 \\
11\end{array}$ & & & & & & & 1 & $\begin{array}{r}b \\
11\end{array}$ \\
\hline 12 & 1 & & & & & & & 10 \\
\hline 13 & & & & & & 1 & & 13 \\
\hline 14 & 1 & 1 & & & & 1 & 1 & 25 \\
\hline 15 & & 1 & 2 & & & 4 & & 42 \\
\hline 16 & 2 & 2 & 3 & 1 & & 5 & 2 & 44 \\
\hline 17 & & & & 1 & & & $* 3$ & 39 \\
\hline 18 & 2 & 1 & & & & 1 & 1 & 38 \\
\hline 19 & & 1 & & & 1 & 1 & & * 28 \\
\hline 20 & & & & & & 1 & & 37 \\
\hline 21 & 3 & 1 & & & & & & 29 \\
\hline 22 & 3 & 2 & 4 & & & 3 & & 25 \\
\hline 23 & & 1 & & 1 & & 2 & & 26 \\
\hline 24 & 1 & 3 & 4 & & & 8 & & 8 \\
\hline 25 & 5 & 5 & $* 8$ & 1 & 1 & * 11 & & 15 \\
\hline 26 & 3 & 8 & 4 & r & & 3 & & 17 \\
\hline 27 & $* 3$ & 7 & 3 & & & 4 & & 17 \\
\hline 28 & 4 & 7 & 3 & & & 4 & & 18 \\
\hline 29 & 4 & * 13 & 1 & & & & & 7 \\
\hline 30 & 2 & 7 & 1 & & & 4 & & 8 \\
\hline 31 & 5 & 1 & 2 & & & 2 & & 7 \\
\hline 32 & 1 & 8 & 1 & & & & & 6 \\
\hline 33 & 1 & 4 & & & & & & 2 \\
\hline 34 & 1 & 2 & & & & & & 6 \\
\hline 35 & 1 & 2 & & & & & & 5 \\
\hline 36 & & & & & & 1 & & 3 \\
\hline $\begin{array}{l}37 \\
38\end{array}$ & & $\begin{array}{l}1 \\
2\end{array}$ & & & & & & 1 \\
\hline 39 & 2 & & & & & & & 1 \\
\hline 40 & & & & & & & & 2 \\
\hline $\begin{array}{l}42 \\
47\end{array}$ & 1 & & & & & & & $\begin{array}{l}1 \\
1\end{array}$ \\
\hline Totals & 48 & 80 & 36 & 4 & 2 & 56 & 8 & 504 \\
\hline
\end{tabular}


Table 4. Consumption of gadids in NW in November.

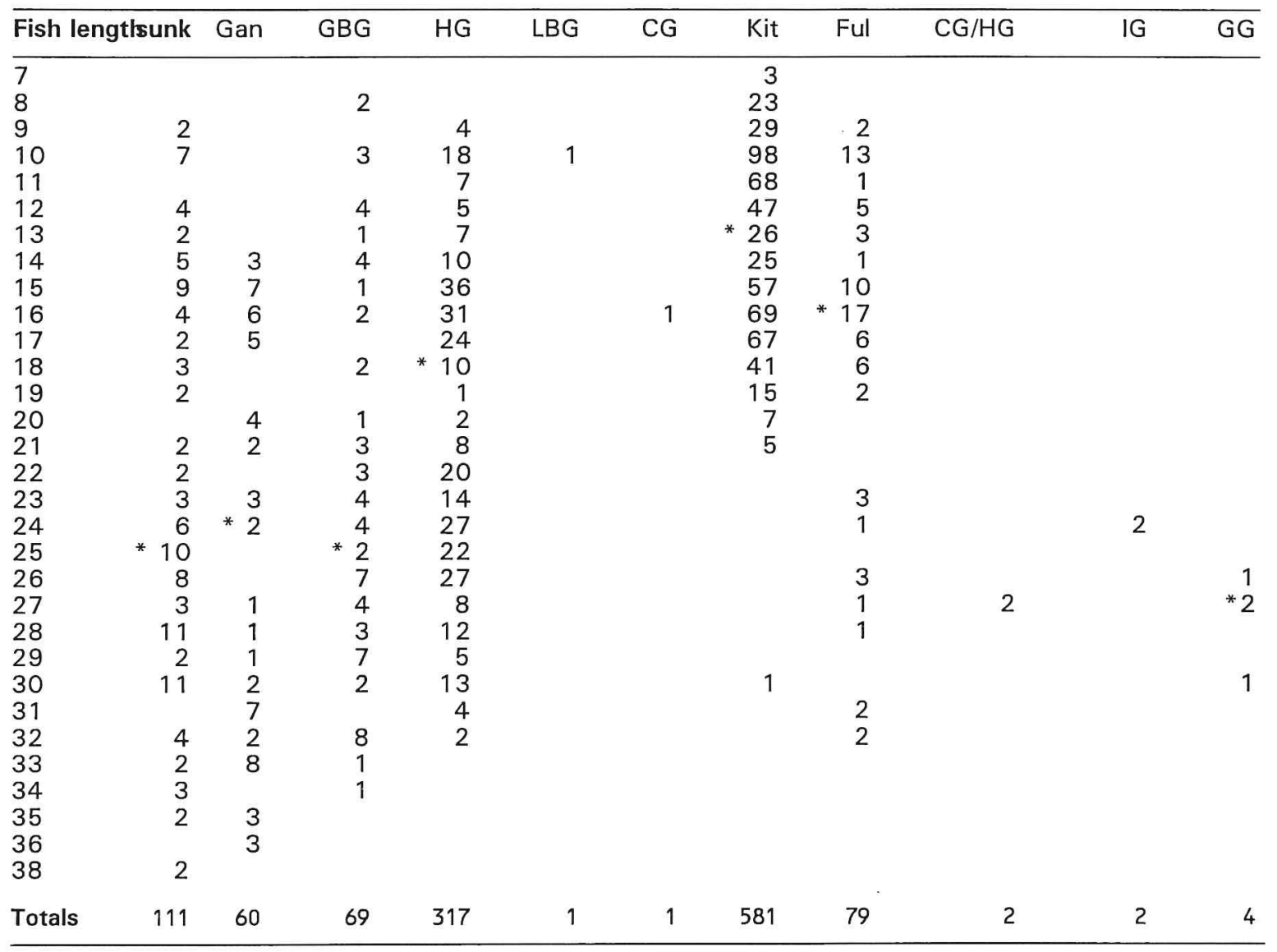

Table 5. Consumption of flatfish by seabirds in NW in May.

\begin{tabular}{|c|c|c|c|c|c|c|c|}
\hline Fish width & sunk & Gan & GBG & $H G$ & LBG & Kit & Ful \\
\hline $\begin{array}{l}1 \\
2\end{array}$ & $\begin{array}{l}2 \\
5\end{array}$ & & & & & & 3 \\
\hline 3 & 21 & 1 & & & & 1 & 8 \\
\hline 4 & 20 & 3 & & & 2 & 3 & * 5 \\
\hline 5 & 38 & * 6 & 1 & & & & 2 \\
\hline 6 & * 33 & 3 & 3 & 1 & & & 2 \\
\hline 7 & 38 & 4 & * 3 & & & & 3 \\
\hline 8 & 12 & 1 & 1 & & & & 2 \\
\hline 9 & 7 & & & & & & 1 \\
\hline 10 & 2 & & & & & & 1 \\
\hline 11 & 2 & & & & & & \\
\hline Totals & 180 & 18 & 8 & 1 & 2 & 4 & 27 \\
\hline
\end{tabular}


Table 6. Consumption of flatfish in NW in August.

\begin{tabular}{|c|c|c|c|c|c|c|}
\hline Fish width & sunk & Gan & GBG & HG & LBG & Ful \\
\hline $\begin{array}{l}2 \\
3\end{array}$ & 2 & & & 1 & & $\begin{array}{l}1 \\
7\end{array}$ \\
\hline $\begin{array}{l}3 \\
4\end{array}$ & $\frac{2}{7}$ & & 2 & 1 & 1 & * 5 \\
\hline 5 & 13 & 2 & * 3 & $* 3$ & 1 & 3 \\
\hline 6 & 11 & $* 2$ & 1 & & & 2 \\
\hline 7 & * 24 & $\overline{1}$ & & & & \\
\hline 8 & 19 & & & & & \\
\hline 9 & 15 & 1 & & & & \\
\hline 10 & 6 & & & & & \\
\hline 11 & 4 & & & & & \\
\hline 13 & 2 & & & & & \\
\hline Totals & 103 & 6 & 6 & 5 & 2 & 18 \\
\hline
\end{tabular}

Table 7. Consumption of flatfish in NW in November.

\begin{tabular}{|c|c|c|c|c|c|}
\hline Fish width & sunk & Gan & GBG & CG & Ful \\
\hline $\begin{array}{l}2 \\
3 \\
4 \\
5 \\
6 \\
7 \\
8 \\
9 \\
11\end{array}$ & $\begin{array}{r}2 \\
21 \\
* 16 \\
7 \\
9 \\
7 \\
2 \\
1 \\
1\end{array}$ & $\begin{array}{l}2 \\
2\end{array}$ & 3 & 1 & $\begin{array}{l}1 \\
1\end{array}$ \\
\hline Totals & 66 & 4 & 3 & 1 & 2 \\
\hline
\end{tabular}

Table 8. Consumption of gadids in NE in February.

\begin{tabular}{|c|c|c|c|c|c|c|c|c|}
\hline Fish length & sunk & Gan & GBG & HG & LBG & CG & Kit & Ful \\
\hline $\begin{array}{l}11 \\
12 \\
13 \\
14 \\
15 \\
16 \\
17 \\
18 \\
19 \\
20 \\
21 \\
22 \\
23 \\
24 \\
25 \\
26 \\
27 \\
28 \\
29 \\
30 \\
31 \\
32 \\
33 \\
34\end{array}$ & $\begin{array}{r}1 \\
2 \\
2 \\
* 3 \\
1 \\
1 \\
5 \\
1\end{array}$ & $\begin{array}{r}2 \\
3 \\
2 \\
4 \\
2 \\
* 7 \\
2 \\
5 \\
6\end{array}$ & $\begin{array}{r}1 \\
2 \\
3 \\
1 \\
1 \\
5 \\
3 \\
* 2 \\
8 \\
2 \\
2 \\
2 \\
1 \\
1\end{array}$ & $\begin{array}{r}2 \\
3 \\
1 \\
5 \\
3 \\
2 \\
* 4 \\
1 \\
2 \\
3 \\
2 \\
2 \\
2 \\
2\end{array}$ & & & $\begin{array}{r}2 \\
3 \\
13 \\
22 \\
32 \\
* 33 \\
29 \\
21 \\
17 \\
4\end{array}$ & $\begin{array}{r} \\
* 1 \\
1 \\
3 \\
1\end{array}$ \\
\hline Totals & 19 & 34 & 31 & 34 & 0 & 0 & 178 & 11 \\
\hline
\end{tabular}


XXIV - APPENDIX

EC DG XIV research project BIOECO/93/10

Table 9. Consumption of gadid in NE in May.

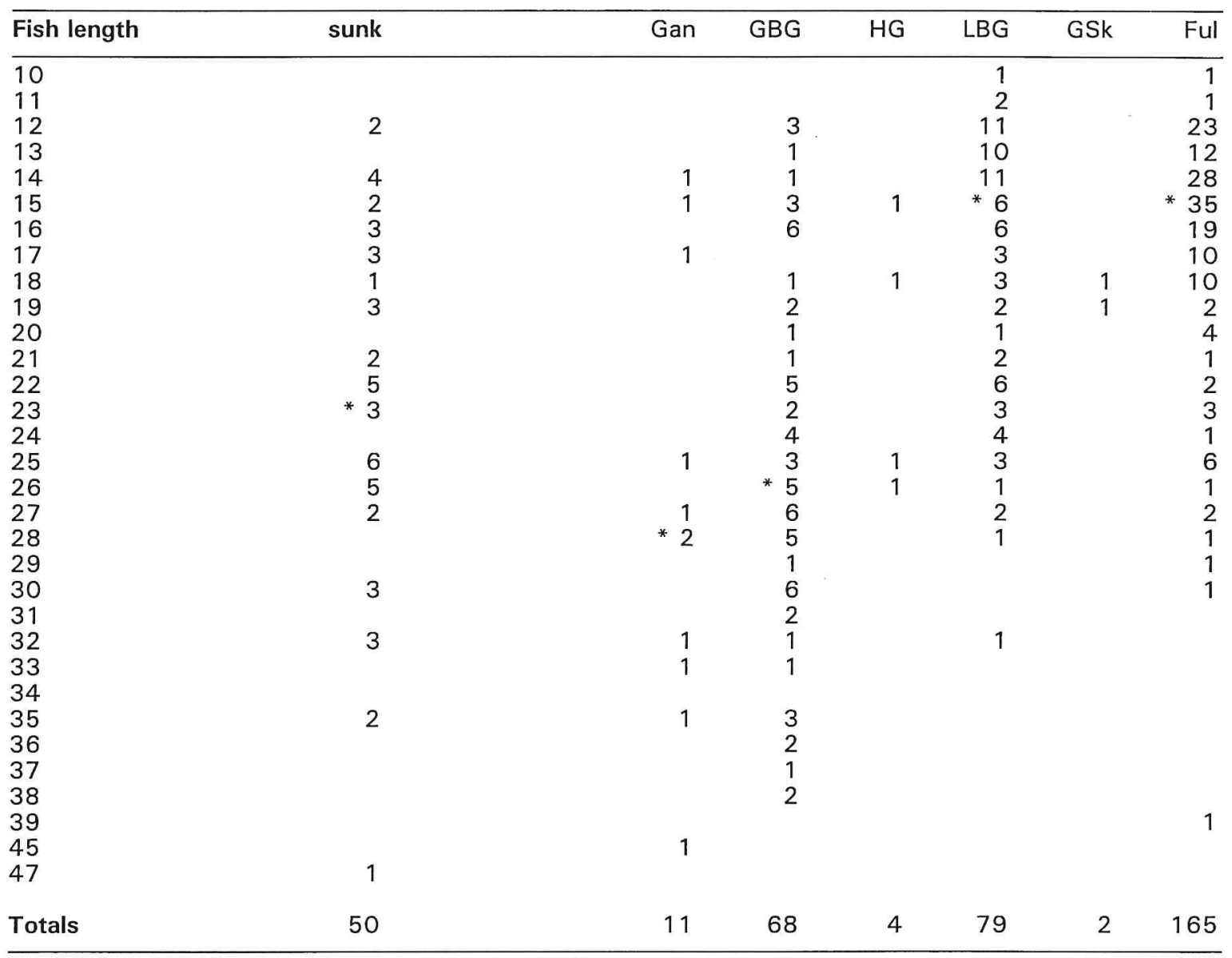


Table 10. Consumption of gadids in NE in August.

\begin{tabular}{|c|c|c|c|c|c|c|c|}
\hline Fish length & sunk & Gan & GBG & LBG & GSk & Kit & Ful \\
\hline $\begin{array}{l}5 \\
6 \\
7 \\
8 \\
9 \\
10 \\
11 \\
12 \\
13 \\
13 \\
14 \\
15 \\
16 \\
17 \\
18 \\
19 \\
20 \\
20 \\
21 \\
22 \\
23 \\
24 \\
24 \\
25 \\
26 \\
27\end{array}$ & $\begin{array}{r}1 \\
2 \\
1 \\
\\
1 \\
3 \\
\\
\\
3 \\
3 \\
3 \\
5 \\
7 \\
9 \\
* 10 \\
2 \\
5 \\
2 \\
3 \\
8 \\
3 \\
2 \\
1 \\
2 \\
2 \\
\\
1\end{array}$ & $\begin{array}{r}2 \\
1 \\
3 \\
3 \\
1 \\
* 2 \\
2 \\
1 \\
1\end{array}$ & 1 & $\begin{array}{r}1 \\
3 \\
4 \\
9 \\
* \quad 9 \\
4 \\
\\
5 \\
2 \\
1 \\
1 \\
1 \\
1\end{array}$ & 1 & $\begin{array}{r}* 2 \\
3 \\
1\end{array}$ & $\begin{array}{r}2 \\
5 \\
5 \\
2 \\
4 \\
11 \\
8 \\
10 \\
16 \\
25 \\
30 \\
20 \\
11 \\
6 \\
15 \\
* 21 \\
20 \\
26 \\
25 \\
25 \\
15 \\
13 \\
20 \\
9 \\
4 \\
5 \\
3 \\
5 \\
2 \\
4 \\
\\
2 \\
\end{array}$ \\
\hline Totals & 81 & 14 & 1 & 46 & 1 & 11 & 369 \\
\hline
\end{tabular}


Table 11. Consumption of gadids in NE in November.

\begin{tabular}{|c|c|c|c|c|c|c|c|}
\hline Fish length & sunk & Gan & GBG & HG & CG & Ful & $\mathrm{CG} / \mathrm{HG}$ \\
\hline 8 & 1 & & 1 & 10 & 15 & 1 & \\
\hline 9 & 2 & & & 4 & 19 & 7 & \\
\hline 10 & & & 1 & 10 & 27 & 14 & \\
\hline 11 & 1 & & 2 & 1 & * 23 & 4 & \\
\hline 12 & 1 & & & 1 & 10 & 1 & \\
\hline 13 & 3 & & & 12 & 6 & 7 & \\
\hline 14 & 2 & & & 21 & 14 & * 5 & \\
\hline 15 & 1 & & 2 & 16 & 22 & & \\
\hline 16 & & & & * 21 & 17 & 7 & \\
\hline 17 & 1 & & & 19 & 4 & 7 & \\
\hline 18 & 3 & & & 16 & 5 & 6 & \\
\hline 19 & & 1 & 2 & 8 & & 5 & \\
\hline 20 & & & 1 & 6 & & 2 & \\
\hline 22 & & & $* 2$ & 12 & & 1 & \\
\hline 23 & 1 & & & 2 & & & \\
\hline 24 & 4 & & & $\overline{7}$ & & & \\
\hline 25 & 3 & 1 & & 8 & 1 & & \\
\hline 26 & $* 5$ & & 2 & 10 & & & 2 \\
\hline 27 & 2 & & 1 & 3 & & & \\
\hline 28 & & 1 & & & & & \\
\hline 29 & 1 & 1 & 1 & 2 & & & \\
\hline 30 & 2 & * 1 & & 1 & & & 2 \\
\hline 31 & 2 & & & & & 1 & \\
\hline 32 & 1 & 1 & 1 & & & & \\
\hline 33 & 2 & & 1 & & & & \\
\hline 34 & 3 & & 3 & & & 3 & \\
\hline 35 & 4 & 1 & & & & & \\
\hline 37 & 1 & & & & & & \\
\hline 39 & & 1 & & & & & \\
\hline 40 & & 1 & & & & & \\
\hline Totals & 46 & 9 & 20 & 190 & 163 & 71 & 4 \\
\hline
\end{tabular}

Table 12. Consumption of flatfish in NE in May.

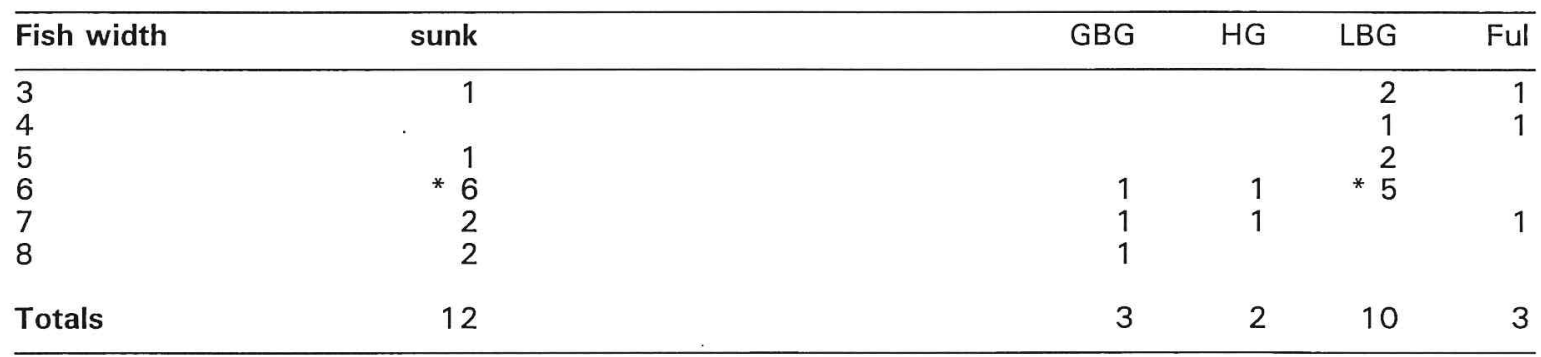


Table 13. Consumption of flatfish in NE in August.

\begin{tabular}{|c|c|c|c|}
\hline Fish width & sunk & LBG & Ful \\
\hline $\begin{array}{l}1 \\
2 \\
3 \\
4 \\
5 \\
6 \\
7 \\
8 \\
9 \\
11\end{array}$ & $\begin{array}{r}1 \\
2 \\
10 \\
* 17 \\
7 \\
2 \\
1 \\
1\end{array}$ & 1 & $\begin{array}{r}1 \\
1 \\
* 4 \\
2 \\
2\end{array}$ \\
\hline Totals & 41 & 1 & 10 \\
\hline
\end{tabular}

Table 14. Consumption of flatfish in NE in November.

\begin{tabular}{|c|c|c|c|c|c|c|}
\hline Fish width & sunk & Gan & GBG & HG & LBG & Ful \\
\hline $\begin{array}{l}2 \\
3 \\
4 \\
5 \\
6 \\
7 \\
8 \\
9 \\
10\end{array}$ & $\begin{array}{r}3 \\
12 \\
* \quad 12 \\
3 \\
5 \\
2 \\
1 \\
2\end{array}$ & 1 & $\begin{array}{r}1 \\
1 \\
* 3\end{array}$ & $\begin{array}{r}3 \\
* \quad 8 \\
3 \\
3\end{array}$ & $\begin{array}{l}1 \\
1\end{array}$ & $\begin{array}{r}2 \\
3 \\
* 3 \\
2\end{array}$ \\
\hline Totals & 40 & 2 & 5 & 17 & 2 & 10 \\
\hline
\end{tabular}

Table 15. Consumption of gadids in CW in February.

\begin{tabular}{|c|c|c|c|c|c|c|c|c|}
\hline Fish length & sunk & Gan & GBG & HG & LBG & CG & Kit & Ful \\
\hline $\begin{array}{l}10 \\
11\end{array}$ & & & & & & & 1 & \\
\hline 12 & & & & & & & 9 & \\
\hline 13 & & & & & & & 8 & \\
\hline 14 & 1 & 1 & & & & & 18 & \\
\hline 15 & 3 & 4 & & 1 & & & 33 & \\
\hline 16 & 2 & 1 & & & & & 21 & \\
\hline 17 & $* 3$ & 6 & & 5 & & & * 63 & \\
\hline 18 & 1 & 4 & & 3 & & & 40 & \\
\hline 19 & 1 & 2 & & 2 & & & 33 & 1 \\
\hline 20 & 4 & 1 & 5 & 5 & & & 12 & \\
\hline 21 & & 6 & & 4 & & & 19 & \\
\hline 22 & & 3 & 2 & * 6 & & & 14 & 1 \\
\hline 23 & & * 5 & 2 & 4 & & & 14 & \\
\hline 24 & & 2 & 2 & 8 & & & 2 & * 2 \\
\hline 25 & & 6 & * 4 & 5 & & & 2 & 1 \\
\hline 26 & & 3 & 2 & 1 & & & & 1 \\
\hline 27 & & 3 & 3 & 1 & & & & \\
\hline 28 & 1 & 3 & 1 & 1 & & & & \\
\hline 29 & & & & 1 & & & & 1 \\
\hline 30 & 1 & 3 & 1 & & & & & \\
\hline 31 & & 3 & & 1 & & & & \\
\hline $\begin{array}{l}32 \\
33\end{array}$ & & 2 & & & & & & \\
\hline $\begin{array}{l}33 \\
34\end{array}$ & & 1 & 1 & & & & & \\
\hline $\begin{array}{l}34 \\
35\end{array}$ & & 1 & & 1 & & & & \\
\hline 36 & & 1 & & & & & & \\
\hline Totals & 17 & 61 & 23 & 49 & 0 & 0 & 289 & 7 \\
\hline
\end{tabular}


Table 16. Consumption of gadids in CW in May.

\begin{tabular}{|c|c|c|c|c|c|c|c|c|}
\hline Fish length & sunk & Gan & GBG & HG & LBG & GSk & Kit & Ful \\
\hline $\begin{array}{l}10 \\
11 \\
12 \\
13 \\
14 \\
15 \\
16 \\
17 \\
18 \\
19 \\
20 \\
21 \\
22 \\
23 \\
24 \\
25 \\
26 \\
27 \\
28 \\
29 \\
30 \\
31 \\
32 \\
33 \\
34 \\
35 \\
36 \\
37 \\
38 \\
39 \\
40 \\
41 \\
45\end{array}$ & $\begin{array}{r}4 \\
4 \\
3 \\
1 \\
1 \\
2 \\
4 \\
1 \\
3 \\
* 5 \\
2 \\
6 \\
2 \\
2 \\
5 \\
1 \\
4 \\
1 \\
2 \\
1 \\
2\end{array}$ & $\begin{array}{r}2 \\
3 \\
1 \\
11 \\
12 \\
20 \\
10 \\
24 \\
20 \\
32 \\
28 \\
* 35 \\
33 \\
25 \\
38 \\
23 \\
18 \\
12 \\
4 \\
11 \\
14 \\
2 \\
6\end{array}$ & $\begin{array}{l}1 \\
1\end{array}$ & 1 & 1 & 1 & $\begin{array}{r}7 \\
13 \\
9 \\
27 \\
* 36 \\
28 \\
22 \\
13 \\
8 \\
3 \\
2 \\
1\end{array}$ & $\begin{array}{r}2 \\
3 \\
7 \\
8 \\
11 \\
17 \\
23 \\
14 \\
20 \\
* 15 \\
26 \\
24 \\
10 \\
21 \\
5 \\
6 \\
4\end{array}$ \\
\hline Totals & 57 & 387 & 4 & 2 & 3 & 1 & 172 & 220 \\
\hline
\end{tabular}


Table 17. Consumption of gadids in CW in August.

\begin{tabular}{|c|c|c|c|c|c|c|c|c|}
\hline Fish length & sunk & Gan & GBG & $\mathrm{HG}$ & LBG & GSk & Kit & Ful \\
\hline 7 & 5 & & & 2 & & & & \\
\hline 8 & 3 & & & 2 & & & & 11 \\
\hline 9 & 10 & & & & & & & 32 \\
\hline 10 & 10 & & 1 & & & 3 & & 63 \\
\hline 11 & & & 1 & 2 & & & & 6 \\
\hline 12 & 8 & & & 5 & & & & 6 \\
\hline $1 \overline{3}$ & 5 & & 6 & 7 & & & & 7 \\
\hline 14 & 5 & 3 & * 4 & 2 & & & 1 & 16 \\
\hline 15 & 1 & 2 & 2 & $* 3$ & 2 & & 3 & 11 \\
\hline 16 & 1 & 6 & 1 & 2 & 2 & & 3 & * 25 \\
\hline 17 & 5 & 1 & & 1 & $* 1$ & & 2 & 16 \\
\hline 18 & 2 & 3 & & 2 & 2 & & $* 3$ & 14 \\
\hline 19 & 3 & 2 & & & & & 3 & 12 \\
\hline 20 & 5 & 5 & & & & & 2 & 9 \\
\hline 21 & 7 & 3 & & 3 & 1 & & 1 & 5 \\
\hline 22 & * 11 & 12 & & 4 & & 1 & 3 & 22 \\
\hline 23 & 10 & 21 & 2 & 4 & & & & 14 \\
\hline 24 & 10 & 12 & 2 & 5 & 1 & & & 16 \\
\hline 25 & 13 & * 14 & & & & 1 & & 9 \\
\hline 26 & 8 & 10 & & 2 & & & 1 & 10 \\
\hline 27 & 3 & 15 & 1 & & & & & 4 \\
\hline 28 & 8 & 16 & 2 & 1 & & & & 5 \\
\hline 29 & 2 & 14 & 1 & & & & & 1 \\
\hline 30 & 2 & 6 & & & & & & 2 \\
\hline 31 & 1 & 5 & & & & & & 2 \\
\hline 32 & 2 & 3 & & & & & & 1 \\
\hline 33 & 3 & 3 & & & & & & 1 \\
\hline 34 & & & & & & & & 1 \\
\hline Totals & 143 & 156 & 23 & 47 & 9 & 5 & 22 & 320 \\
\hline
\end{tabular}


Table 18. Consumption of gadids in CW in November.

\begin{tabular}{|c|c|c|c|c|c|c|}
\hline Fish length & sunk & Gan & GBG & $\mathrm{HG}$ & Kit & Ful \\
\hline $\begin{array}{l}8 \\
9\end{array}$ & & & & & 1 & \\
\hline $\begin{array}{l}9 \\
10\end{array}$ & 3 & & & & $\begin{array}{r}2 \\
26\end{array}$ & $\begin{array}{l}1 \\
5\end{array}$ \\
\hline 11 & 3 & & & & $\begin{array}{l}20 \\
11\end{array}$ & $\begin{array}{r}5 \\
* 4\end{array}$ \\
\hline 12 & 2 & & & & 24 & 2 \\
\hline 13 & & & & 1 & * 12 & 1 \\
\hline 14 & 3 & 2 & & & 9 & \\
\hline 15 & 9 & 2 & & & 17 & \\
\hline 16 & 5 & & & 1 & 9 & \\
\hline 17 & 5 & & & & 9 & 1 \\
\hline 18 & 2 & 5 & & 2 & & \\
\hline 19 & 1 & & 1 & & 3 & \\
\hline 20 & 5 & 6 & & 2 & 2 & 1 \\
\hline 21 & 5 & 6 & & 3 & 2 & 2 \\
\hline 22 & 10 & 8 & 3 & 5 & 4 & \\
\hline 23 & * 8 & 9 & $* 2$ & * 1 & & 1 \\
\hline 24 & 6 & 5 & & 5 & 1 & \\
\hline 25 & 6 & 16 & & 2 & & \\
\hline 26 & 13 & 6 & & 2 & & 1 \\
\hline 27 & 5 & * 13 & 2 & & & \\
\hline 28 & 3 & 10 & & 2 & & \\
\hline 29 & 2 & 18 & & 2 & & \\
\hline 30 & 2 & 12 & & & & \\
\hline 31 & 1 & 10 & & & & \\
\hline 32 & 4 & 14 & & & & \\
\hline 33 & & 3 & & & & \\
\hline 35 & & 2 & & & & \\
\hline 37 & & 2 & & & & \\
\hline 40 & 2 & & & & & \\
\hline Totals & 102 & 149 & 8 & 28 & 132 & 19 \\
\hline
\end{tabular}


Table 19. Consumption of flatfish in CW in May.

\begin{tabular}{|c|c|c|c|c|c|c|}
\hline Fish width & sunk & Gan & GBG & LBG & Kit & Ful \\
\hline $\begin{array}{l}3 \\
4 \\
5 \\
6 \\
7 \\
8 \\
9 \\
10 \\
11\end{array}$ & $\begin{array}{r}1 \\
6 \\
10 \\
* \quad 12 \\
1 \\
2 \\
3 \\
2\end{array}$ & $\begin{array}{r}1 \\
1 \\
5 \\
14 \\
* \quad 20 \\
3 \\
8 \\
1\end{array}$ & 1 & 1 & 1 & $\begin{array}{l}1 \\
1\end{array}$ \\
\hline Totals & 37 & 53 & 1 & 1 & 1 & 3 \\
\hline
\end{tabular}

Table 20. Consumption of flatfish in CW in August.

\begin{tabular}{lrrr}
\hline Fish width & sunk & GBG & Ful \\
\hline 4 & 8 & 1 & 2 \\
5 & 18 & $*$ \\
6 & 13 & & \\
7 & 37 & & \\
8 & 16 & & 1 \\
9 & 15 & & \\
10 & 6 & 1 & 5 \\
11 & 3 & 1 & 1 \\
Totals & 117 & & \\
\hline
\end{tabular}

Table 21. Consumption of flatfish in CW in November.

\begin{tabular}{|c|c|c|c|c|}
\hline Fish width & sunk & HG & Kit & Ful \\
\hline $\begin{array}{l}2 \\
3 \\
5 \\
6 \\
7 \\
8 \\
10 \\
11 \\
13\end{array}$ & $\begin{array}{r}1 \\
6 \\
12 \\
* \quad 13 \\
2 \\
1 \\
1 \\
2\end{array}$ & 2 & $\begin{array}{r}2 \\
* \quad 1 \\
1\end{array}$ & 1 \\
\hline Totals & 38 & 2 & 4 & 1 \\
\hline
\end{tabular}


Table 22. Consumption of gadids in $C$ in February.

\begin{tabular}{|c|c|c|c|c|c|c|c|c|}
\hline Fish length & sunk & Gan & GBG & HG & LBG & CG & Kit & Ful \\
\hline $\begin{array}{l}10 \\
11 \\
12 \\
13 \\
14 \\
15 \\
16 \\
17 \\
18 \\
19 \\
20 \\
21 \\
22 \\
23 \\
24 \\
25 \\
26 \\
27 \\
28 \\
29 \\
30 \\
31 \\
32 \\
33 \\
34 \\
35 \\
36 \\
37 \\
38 \\
39 \\
40\end{array}$ & $\begin{array}{r}1 \\
1 \\
1 \\
1 \\
\\
1 \\
\\
4 \\
2 \\
2 \\
\\
2 \\
2 \\
3 \\
4 \\
* 10 \\
8 \\
5 \\
5 \\
8 \\
1 \\
2 \\
2 \\
\\
1 \\
1\end{array}$ & $\begin{array}{r}1 \\
2 \\
2 \\
3 \\
2 \\
3 \\
* 3 \\
3 \\
7 \\
5 \\
4 \\
2\end{array}$ & $\begin{array}{r}2 \\
1 \\
2 \\
2 \\
2 \\
6 \\
4 \\
* 6 \\
\\
3 \\
\\
6 \\
3 \\
2 \\
1 \\
1\end{array}$ & $\begin{array}{r}1 \\
1 \\
2 \\
3 \\
8 \\
2 \\
9 \\
9 \\
6 \\
9 \\
* \quad 16 \\
17 \\
6 \\
5 \\
7 \\
10 \\
6 \\
1 \\
2 \\
3 \\
\\
1 \\
1\end{array}$ & & & $\begin{array}{r}1 \\
3 \\
11 \\
23 \\
20 \\
39 \\
* 35 \\
24 \\
21 \\
17 \\
12 \\
8 \\
4 \\
\\
2 \\
1 \\
1\end{array}$ & $\begin{array}{r}1 \\
1 \\
2 \\
1 \\
1 \\
1 \\
* \quad 1 \\
2 \\
4\end{array}$ \\
\hline Totals & 67 & 51 & 42 & 126 & 0 & 0 & 222 & 13 \\
\hline
\end{tabular}


Table 23. Consumption of gadids in C in May.

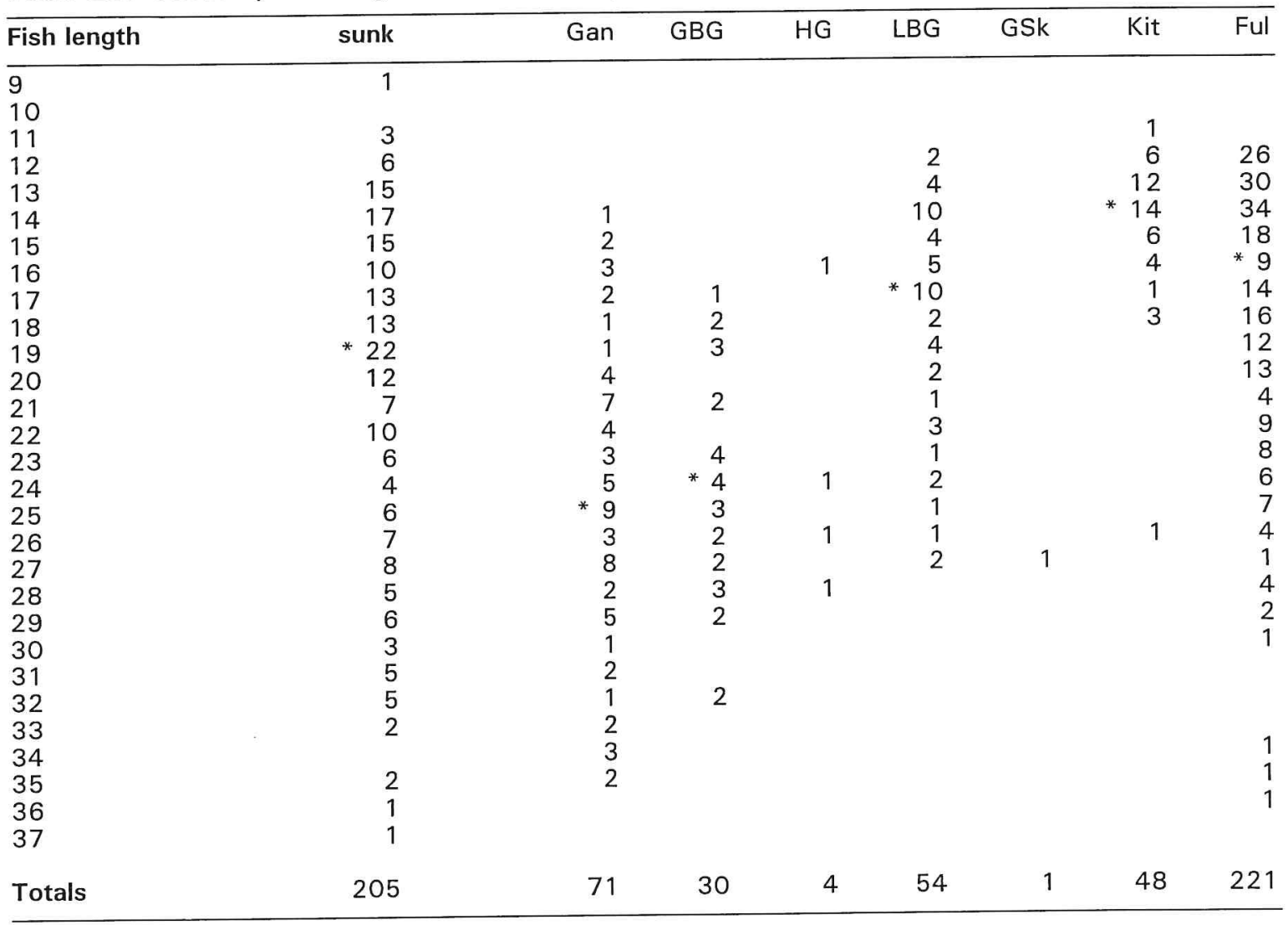


Table 24. Consumption of gadids in C in August.

\begin{tabular}{|c|c|c|c|c|c|c|c|}
\hline Fish length & sunk & Gan & GBG & LBG & GSk & Kit & Ful \\
\hline 6 & & & & & & 1 & \\
\hline 7 & 1 & & & & & 1 & 2 \\
\hline 8 & 2 & & & 1 & & & 9 \\
\hline 9 & 5 & & & & & & 32 \\
\hline 10 & 4 & & & & & & 8 \\
\hline 11 & 1 & & & & & & 8 \\
\hline 12 & 4 & & & 1 & & 1 & 6 \\
\hline 13 & 1 & & & & & & 5 \\
\hline 14 & 3 & & & & & & 2 \\
\hline 15 & 2 & & & & & & 8 \\
\hline 16 & 3 & & & & & 1 & 11 \\
\hline 17 & 2 & & & 1 & & 2 & 13 \\
\hline 18 & 6 & & & 2 & & 1 & 27 \\
\hline 19 & 14 & & & 3 & & $* 2$ & 31 \\
\hline 20 & 24 & 1 & & $* 3$ & & 1 & 54 \\
\hline 21 & 20 & & 1 & 2 & & 3 & * 43 \\
\hline 22 & 22 & & 1 & 2 & 1 & 1 & 32 \\
\hline 23 & * 25 & 1 & & 1 & & & 35 \\
\hline 24 & 20 & 2 & & 2 & & 1 & 42 \\
\hline 25 & 13 & & & & & & 33 \\
\hline 26 & 20 & $* 4$ & & & & & 15 \\
\hline 27 & 8 & 2 & & & & & 13 \\
\hline 28 & 12 & & & & & & 21 \\
\hline 29 & 7 & 1 & & & & & 18 \\
\hline 30 & 12 & 2 & & & & & 16 \\
\hline 31 & 5 & 2 & & & & & 5 \\
\hline 32 & 4 & 1 & & & & & 4 \\
\hline 33 & 3 & 1 & & & & & 2 \\
\hline 34 & 3 & 1 & & & & & 3 \\
\hline 35 & 1 & & & & & & 1 \\
\hline 36 & & & & & & & 3 \\
\hline 37 & 1 & & & & & & 1 \\
\hline Totals & 248 & 18 & 2 & 18 & 1 & 15 & 503 \\
\hline
\end{tabular}


Table 25. Consumption of gadids in $C$ in November.

\begin{tabular}{|c|c|c|c|c|c|c|c|c|}
\hline Fish length & sunk & Gan & GBG & $H G$ & LBG & $C G$ & Kit & Ful \\
\hline $\begin{array}{l}7 \\
8 \\
9 \\
10 \\
11 \\
12 \\
13 \\
14 \\
15 \\
16 \\
17 \\
18 \\
19 \\
20 \\
21 \\
22 \\
23 \\
24 \\
25 \\
26 \\
27 \\
28 \\
29 \\
30 \\
31 \\
32 \\
33 \\
34 \\
37 \\
38\end{array}$ & $\begin{array}{r}1 \\
1 \\
1 \\
5 \\
5 \\
9 \\
4 \\
13 \\
4 \\
4 \\
3 \\
2 \\
2 \\
* 3 \\
5\end{array}$ & $\begin{array}{r}2 \\
6 \\
15 \\
14 \\
11 \\
* \quad 4 \\
8 \\
18 \\
8 \\
10 \\
1 \\
3 \\
2 \\
1 \\
1\end{array}$ & $\begin{array}{r}2 \\
2 \\
2 \\
4 \\
4 \\
5 \\
* 3 \\
4 \\
7 \\
2 \\
1 \\
2\end{array}$ & $\begin{array}{r}1 \\
4 \\
7 \\
18 \\
14 \\
4 \\
* \quad 13 \\
10 \\
10 \\
6 \\
11 \\
5 \\
4 \\
4 \\
2 \\
4\end{array}$ & 1 & 1 & $\begin{array}{r}1 \\
5 \\
22 \\
60 \\
36 \\
29 \\
* 19 \\
22 \\
25 \\
26 \\
19 \\
26 \\
19 \\
10 \\
5\end{array}$ & $\begin{array}{r}2 \\
10 \\
2 \\
2 \\
1 \\
1 \\
* 5\end{array}$ \\
\hline Totals & 110 & 108 & 37 & 120 & 1 & 2 & 326 & 37 \\
\hline
\end{tabular}

Table 26. Consumption of flatfish in $C$ in November.

\begin{tabular}{|c|c|c|c|c|c|c|}
\hline Fish width & sunk & Gan & GBG & LBG & Kit & Ful \\
\hline 3 & 2 & & & & 1 & \\
\hline 4 & 4 & 1 & 1 & & 1 & 1 \\
\hline 5 & 36 & 5 & 1 & & & \\
\hline 6 & 70 & 11 & & 1 & & \\
\hline 7 & * 106 & $* 8$ & * 2 & 2 & & 2 \\
\hline 8 & 23 & 4 & 1 & & & \\
\hline 9 & 27 & 3 & & & & \\
\hline 10 & 11 & 1 & & & & \\
\hline 11 & 3 & 3 & & & & 1 \\
\hline Totals & 282 & 36 & 5 & 3 & 2 & 4 \\
\hline
\end{tabular}


Table 27. Consumption of flatfish in $C$ in November.

\begin{tabular}{|c|c|c|c|c|}
\hline Fish width & sunk & GBG & LBG & Ful \\
\hline $\begin{array}{l}1 \\
2 \\
3 \\
4 \\
5 \\
6 \\
7 \\
8 \\
9 \\
10 \\
11 \\
12\end{array}$ & $\begin{array}{r}1 \\
1 \\
2 \\
14 \\
48 \\
* \quad 55 \\
89 \\
12 \\
6\end{array}$ & 1 & $\begin{array}{l}1 \\
1\end{array}$ & $\begin{array}{r}1 \\
* 2 \\
1\end{array}$ \\
\hline Totals & 235 & 1 & 2 & 5 \\
\hline
\end{tabular}

Table 28. Consumption of flatfish in $C$ in November.

\begin{tabular}{|c|c|c|c|c|}
\hline Fish width & sunk & Gan & HG & Kit \\
\hline $\begin{array}{l}1 \\
2 \\
3 \\
4 \\
5 \\
6 \\
7 \\
8 \\
9 \\
10 \\
11\end{array}$ & $\begin{array}{r}14 \\
20 \\
23 \\
* 20 \\
29 \\
12 \\
6 \\
3 \\
2\end{array}$ & $\begin{array}{l}4 \\
1\end{array}$ & $\begin{array}{r}1 \\
* 2\end{array}$ & $\begin{array}{r}1 \\
2 \\
* 1 \\
1 \\
1 \\
2\end{array}$ \\
\hline Totals & 129 & 5 & 3 & 7 \\
\hline
\end{tabular}

Table 29. Consumption of gadids in CE in February.

\begin{tabular}{|c|c|c|c|c|c|c|c|}
\hline Fish length & sunk & Gan & GBG & $H G$ & LBG & CG & Kit \\
\hline $\begin{array}{l}3 \\
14 \\
15 \\
16 \\
17 \\
18 \\
19 \\
20 \\
21 \\
22 \\
23 \\
24 \\
25 \\
26 \\
27 \\
28 \\
29 \\
30 \\
31\end{array}$ & ${ }^{*} 2$ & & $\begin{array}{r}1 \\
1 \\
* 3\end{array}$ & $\begin{array}{l}1 \\
\\
1 \\
1 \\
1 \\
1 \\
2 \\
1 \\
1 \\
1 \\
1 \\
* 3 \\
1 \\
4 \\
4 \\
1 \\
1\end{array}$ & & 1 & $\begin{array}{r}1 \\
1 \\
1 \\
* 3 \\
3 \\
2\end{array}$ \\
\hline Totals & 4 & & 9 & 19 & & 1 & 11 \\
\hline
\end{tabular}


Table 30. Consumption of gadids in CE in May.

\begin{tabular}{|c|c|c|c|c|c|c|c|c|}
\hline Fish length & sunk & Gan & GBG & HG & LBG & CG & Kit & Ful \\
\hline $\begin{array}{l}10 \\
12\end{array}$ & & & & & 1 & & 1 & \\
\hline 13 & 7 & & & & 1 & & 1 & 1 \\
\hline 14 & 3 & & & & 2 & & 1 & 1 \\
\hline 15 & 6 & & & & 5 & & 3 & 2 \\
\hline 16 & 4 & & & & 7 & & 1 & 3 \\
\hline 17 & 4 & & & & 12 & & * 2 & 2 \\
\hline 18 & * 6 & & & & 13 & 1 & 5 & 4 \\
\hline 19 & 3 & & & 1 & 3 & & 1 & * 1 \\
\hline 20 & 5 & 1 & & 1 & $* 9$ & & 1 & 1 \\
\hline 21 & 5 & & & & 12 & & & 1 \\
\hline 22 & 1 & & & & 4 & & & 1 \\
\hline 23 & 1 & & & & 2 & & & 2 \\
\hline 24 & 4 & & & 1 & 7 & & & 2 \\
\hline 25 & 2 & & & & 7 & & 1 & 1 \\
\hline 26 & 3 & & & 1 & 1 & & & \\
\hline 27 & & & & & 4 & & & 1 \\
\hline $\begin{array}{l}28 \\
29\end{array}$ & & & & & 3 & & & \\
\hline $\begin{array}{l}29 \\
30\end{array}$ & 1 & 1 & 1 & & 4 & & & 2 \\
\hline 31 & & & & & & & & \\
\hline 32 & & & & & & & & \\
\hline 33 & & & & & & & & \\
\hline $\begin{array}{l}34 \\
35\end{array}$ & 1 & & & & & & & \\
\hline 36 & 1 & & & & & & & \\
\hline Totals & 59 & 2 & 1 & 4 & 96 & 1 & 19 & 27 \\
\hline
\end{tabular}


Table 31. Consumption of gadids in CE in August.

\begin{tabular}{|c|c|c|c|c|c|c|c|}
\hline Fish length & sunk & GBG & HG & LBG & CG & Kit & Ful \\
\hline 9 & & & & 1 & & & \\
\hline 10 & 1 & & 1 & 3 & & 3 & \\
\hline 11 & & & & 1 & & 3 & \\
\hline 12 & & & & 7 & & 2 & \\
\hline 13 & & & & 8 & & * 4 & \\
\hline 14 & & & & 3 & & 6 & \\
\hline 15 & 1 & & & & & 1 & \\
\hline 16 & 1 & & & 1 & & 1 & \\
\hline 17 & & & & * 1 & & & \\
\hline 18 & & & & 3 & & & \\
\hline 19 & & & & 2 & & & \\
\hline 20 & & & & 4 & & & \\
\hline 21 & & 2 & & 3 & & & 2 \\
\hline 22 & 4 & & & 3 & 1 & & \\
\hline 23 & 4 & * 1 & & 3 & & & * 1 \\
\hline 24 & * 3 & 1 & & & & & 1 \\
\hline 25 & 3 & & & 3 & & & \\
\hline 26 & 2 & 1 & & & & & 1 \\
\hline 27 & 3 & & & & & & \\
\hline 28 & 1 & & & 1 & & & \\
\hline 29 & & & & 1 & & & \\
\hline 30 & & & & 1 & & & \\
\hline Totals & 23 & 5 & 1 & 49 & 1 & 20 & 5 \\
\hline
\end{tabular}

Table 32. Consumption of gadids in CE in November.

\begin{tabular}{|c|c|c|c|c|c|}
\hline Fish length & sunk & GBG & $\mathrm{HG}$ & Kit & Ful \\
\hline $\begin{array}{l}8 \\
9 \\
10 \\
11 \\
12 \\
13 \\
14 \\
15 \\
16 \\
17 \\
18 \\
19 \\
20 \\
21 \\
22 \\
27 \\
28\end{array}$ & $\begin{array}{r}1 \\
1 \\
\\
2 \\
2 \\
2 \\
3 \\
* \quad 2 \\
1 \\
5\end{array}$ & $\begin{array}{r}3 \\
4 \\
5 \\
1 \\
* \quad 13 \\
4 \\
1 \\
\\
3 \\
1 \\
2\end{array}$ & $\begin{array}{r}5 \\
2 \\
3 \\
6 \\
17 \\
* 15 \\
13 \\
11 \\
4 \\
1\end{array}$ & $\begin{array}{r}2 \\
* 12 \\
4\end{array}$ & $\begin{array}{r}2 \\
* 6 \\
1\end{array}$ \\
\hline Totals & 18 & 26 & 81 & 26 & 9 \\
\hline
\end{tabular}


Table 33. Consumption of flatfish in CE in May.

\begin{tabular}{|c|c|c|c|c|}
\hline Fish length & sunk & GBG & LBG & Ful \\
\hline $\begin{array}{l}1 \\
2 \\
3 \\
4 \\
5 \\
6 \\
7 \\
8 \\
9 \\
10 \\
11 \\
12\end{array}$ & $\begin{array}{r}1 \\
14 \\
38 \\
44 \\
* \quad 88 \\
21 \\
16 \\
11 \\
8 \\
3\end{array}$ & 1 & $\begin{array}{r}1 \\
7 \\
* 6 \\
1 \\
4 \\
1 \\
1\end{array}$ & $\begin{array}{l}1 \\
1\end{array}$ \\
\hline Totals & 244 & 1 & 21 & 2 \\
\hline
\end{tabular}

Table 34. Consumption of flatfish in CE in August.

\begin{tabular}{lrrr}
\hline Fish width & sunk & LBG & Kit \\
\hline 3 & 1 & 2 & 1 \\
4 & 5 & 1 & 1 \\
5 & 4 & 1 & \\
6 & 9 & & \\
7 & 16 & 5 & 1 \\
9 & 4 & 5 & \\
Totals & 4 & 4 & \\
\hline
\end{tabular}

Table 35. Consumption of flatfish in CE in November.

\begin{tabular}{lrr}
\hline Fish width & sunk & HG \\
\hline 3 & 1 & 1 \\
4 & 2 & \\
5 & 3 & \\
6 & 8 & 1 \\
7 & 8 & 2 \\
8 & 3 & 2 \\
Totals & 25 & \\
\hline
\end{tabular}


Table 36. Consumption of gadids in $S$ in February.

\begin{tabular}{|c|c|c|c|c|c|c|c|c|}
\hline Fish length & sunk & Gan & GBG & $H G$ & LBG & CG & Kit & Ful \\
\hline $\begin{array}{l}10 \\
11 \\
12 \\
13 \\
14 \\
15 \\
16 \\
17 \\
18 \\
19 \\
20 \\
21 \\
22 \\
23 \\
24 \\
25 \\
26 \\
27 \\
28 \\
29 \\
30 \\
31 \\
32 \\
33 \\
34 \\
35 \\
36 \\
37 \\
38 \\
39\end{array}$ & $\begin{array}{r}1 \\
1 \\
1 \\
1 \\
* 1 \\
1\end{array}$ & $\begin{array}{r}1 \\
1 \\
* \quad 2 \\
1\end{array}$ & $\begin{array}{r}1 \\
2 \\
7 \\
7 \\
* 8 \\
2 \\
4 \\
2 \\
2 \\
1 \\
1\end{array}$ & $\begin{array}{l}1 \\
1 \\
1 \\
1 \\
4 \\
2 \\
2 \\
1 \\
2 \\
* 5 \\
6 \\
2 \\
2 \\
3 \\
2 \\
1 \\
1\end{array}$ & . & & $\begin{array}{r}2 \\
1 \\
2 \\
5 \\
2 \\
8 \\
* 6 \\
7 \\
2 \\
6 \\
1 \\
1\end{array}$ & 2 \\
\hline Totals & 9 & 8 & 31 & 36 & 3 & 0 & 47 & 3 \\
\hline
\end{tabular}

Table 37. Consumption of gadids in $S$ in May.

\begin{tabular}{|c|c|c|c|c|}
\hline Fish length & sunk & LBG & Kit & Ful \\
\hline $\begin{array}{l}16 \\
17\end{array}$ & 1 & & & 1 \\
\hline 18 & 2 & & 1 & 1 \\
\hline 19 & * 1 & & & \\
\hline 20 & & & & 2 \\
\hline 21 & & & 2 & \\
\hline 22 & 1 & & & * 1 \\
\hline 23 & & & & 2 \\
\hline 24 & & 1 & & 2 \\
\hline 25 & & 1 & & \\
\hline 26 & & & & \\
\hline 27 & 1 & & & \\
\hline Totals & 6 & 2 & 3 & 9 \\
\hline
\end{tabular}


Table 38. Consumption of gadids in S in August.

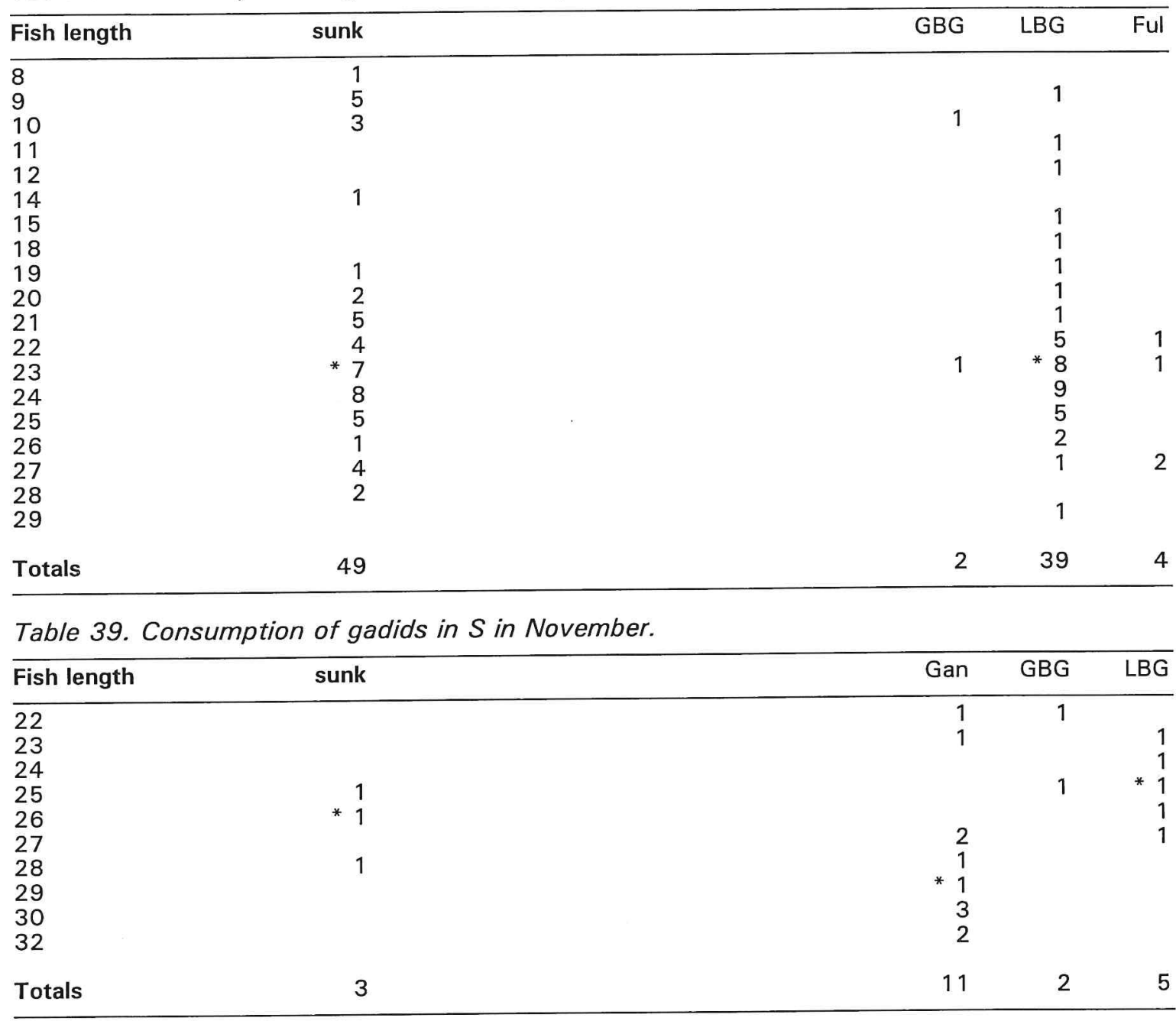

Table 40. Consumption of flatfish in $S$ in August.

\begin{tabular}{lrr}
\hline Fish width & sunk & LBG \\
\hline 5 & 3 & $* 3$ \\
6 & $* 4$ & 1 \\
7 & 1 & \\
8 & 1 & \\
9 & 1 & \\
10 & 10 & 4 \\
\hline
\end{tabular}


Table 41. Consumption of flatfish in $S$ in November.

\begin{tabular}{lr}
\hline Fish length & sunk \\
\hline 4 & 1 \\
5 & 1 \\
6 & 1 \\
8 & 1 \\
9 & $* 3$ \\
13 & 1 \\
Totals & 8 \\
\hline
\end{tabular}

Table 42. Consumption of gadids in Sk in May.

\begin{tabular}{|c|c|c|c|c|c|}
\hline Fish length & sunk & LBG & GBG & $\mathrm{HG}$ & Ful \\
\hline $\begin{array}{l}13 \\
14 \\
15 \\
16 \\
17 \\
18 \\
19 \\
20 \\
21 \\
22 \\
23 \\
24 \\
25 \\
27 \\
29\end{array}$ & $\begin{array}{r}1 \\
* 1\end{array}$ & $\begin{array}{r}2 \\
4 \\
7 \\
2 \\
* 7 \\
2 \\
2 \\
7 \\
3 \\
2 \\
1\end{array}$ & $\begin{array}{l}1 \\
1\end{array}$ & $\begin{array}{r}2 \\
1 \\
1 \\
* \quad 1 \\
1 \\
1 \\
1\end{array}$ & 1 \\
\hline Totals & 4 & 40 & 2 & 9 & 1 \\
\hline
\end{tabular}


Table 43. Consumption of gadids in Sk in November.

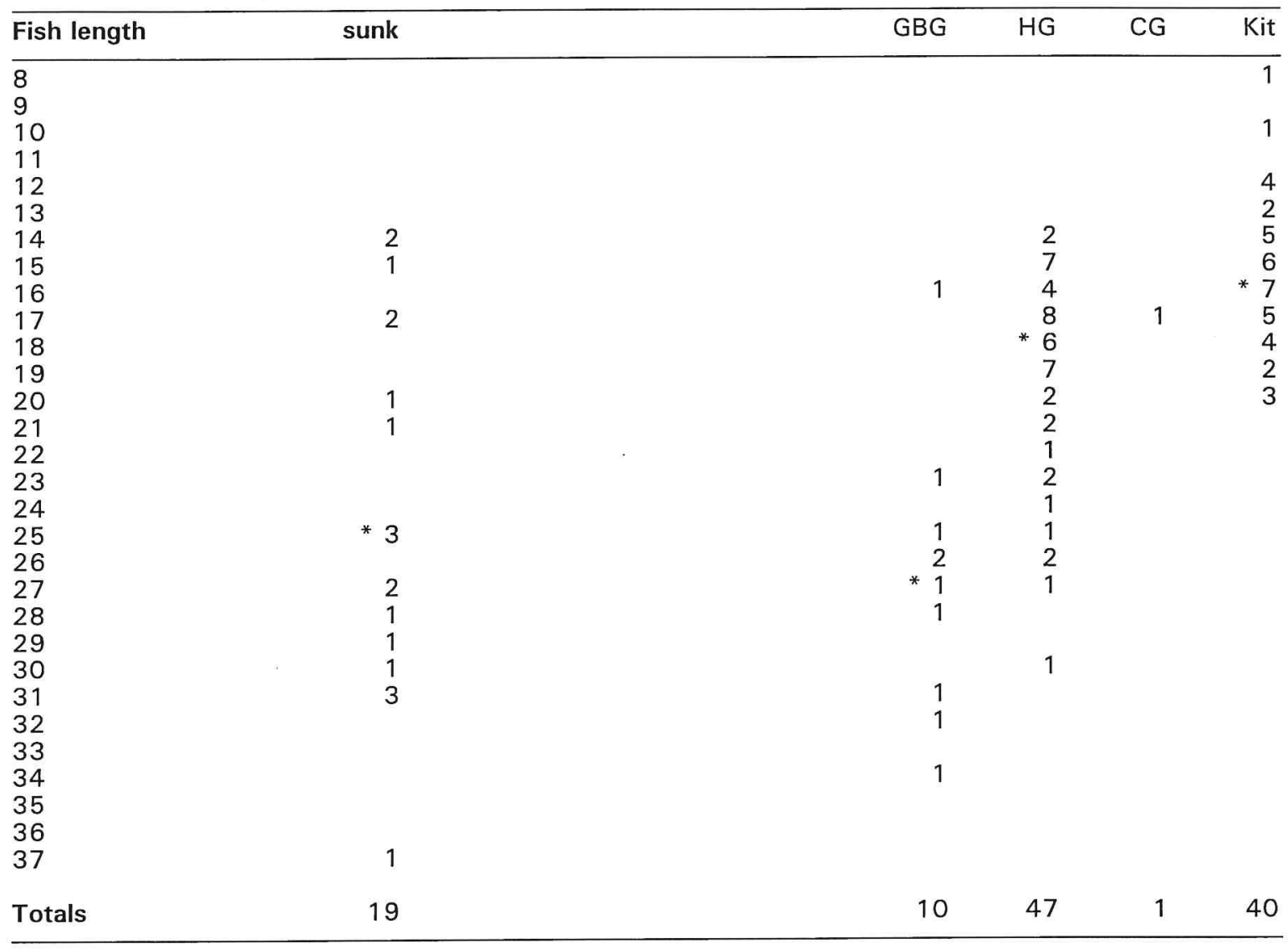

Table 44. Consumption of Flatfish in Sk in November.

\begin{tabular}{lrr}
\hline Fish width & sunk & HG \\
\hline 6 & 2 & 1 \\
7 & 2 & 1 \\
9 & 4 & 2 \\
Totals & 4 & 2 \\
\hline
\end{tabular}


Table 45. Consumption of clupeids in NW in February.

\begin{tabular}{|c|c|c|c|c|c|c|c|c|}
\hline Fish length & sunk & Gan & GBG & $H G$ & LBG & CG & Kit & Ful \\
\hline $\begin{array}{l}10 \\
11 \\
12 \\
13 \\
14 \\
15 \\
16 \\
17 \\
18 \\
19 \\
20 \\
21 \\
22 \\
23 \\
24 \\
25 \\
26 \\
27 \\
28 \\
29 \\
30 \\
31 \\
32 \\
33 \\
34\end{array}$ & $\begin{array}{r}2 \\
* 3\end{array}$ & $\begin{array}{r}1 \\
1 \\
\\
1 \\
2 \\
2 \\
1 \\
2 \\
2 \\
5 \\
* 9 \\
8 \\
1\end{array}$ & 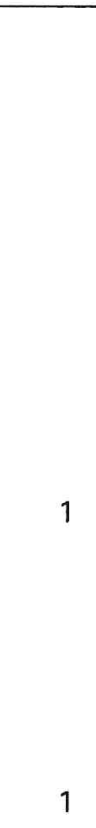 & $\begin{array}{l}1 \\
2 \\
1 \\
1 \\
1\end{array}$ & & & $\begin{array}{r}1 \\
9 \\
* \quad 12 \\
2\end{array}$ & $\begin{array}{r} \\
* 1 \\
1 \\
1 \\
1\end{array}$ \\
\hline Totals & 11 & 33 & 2 & 13 & 0 & 0 & 29 & 5 \\
\hline
\end{tabular}


Table 46. Consumption of clupeids in NW in May.

\begin{tabular}{|c|c|c|c|c|c|c|c|c|}
\hline Fish length & sunk & Gan & GBG & HG & LBG & GSk & Kit & Ful \\
\hline $\begin{array}{l}9 \\
10\end{array}$ & & & & & & & 1 & 1 \\
\hline 11 & 1 & & & & & & 1 & \\
\hline 12 & & & 1 & & & & 3 & 2 \\
\hline 13 & 1 & & 5 & & & & 1 & 1 \\
\hline 14 & & 1 & & & & & 2 & 2 \\
\hline 15 & 1 & 2 & . & & & & 3 & 1 \\
\hline \multicolumn{9}{|l|}{16} \\
\hline 17 & & 3 & & & & & 1 & 3 \\
\hline 18 & & 4 & 1 & & & & * 1 & 6 \\
\hline 19 & 2 & 5 & & & & & 1 & 9 \\
\hline 20 & 1 & 9 & 1 & 1 & & & 2 & 11 \\
\hline 21 & 2 & 11 & 2 & 1 & & 1 & 6 & 13 \\
\hline 22 & 4 & 10 & 19 & * 1 & 10 & & 2 & 29 \\
\hline 23 & $* 7$ & 21. & * 15 & 1 & $* 5$ & & & * 43 \\
\hline 24 & 2 & * 23 & 15 & 1 & 6 & 4 & 1 & 40 \\
\hline 25 & 6 & 28 & 11 & & 1 & $3^{*}$ & & 37 \\
\hline 26 & 1 & 18 & 2 & & & 1 & & 11 \\
\hline 27 & 1 & 4 & & & & 1 & & 2 \\
\hline 28 & 1 & 5 & 1 & & & & & 2 \\
\hline 29 & & 1 & & & & & & \\
\hline Totals & 30 & 145 & 73 & 5 & 22 & 10 & 25 & 213 \\
\hline
\end{tabular}

Table 47. Consumption of clupeids in NW in August.

\begin{tabular}{|c|c|c|c|c|c|c|c|}
\hline Fish length & sunk & Gan & GBG & HG & LBG & GSk & Ful \\
\hline $\begin{array}{l}8 \\
9 \\
10 \\
11 \\
18 \\
19 \\
20 \\
21 \\
22 \\
23 \\
24 \\
25 \\
26 \\
27 \\
28 \\
29 \\
30 \\
31 \\
32 \\
33 \\
34\end{array}$ & $\begin{array}{r}2 \\
* 2 \\
1 \\
1 \\
\\
2\end{array}$ & $\begin{array}{r}1 \\
2 \\
4 \\
3 \\
2 \\
* 4 \\
2 \\
2 \\
2 \\
2 \\
2 \\
1\end{array}$ & $\begin{array}{r}3 \\
* 6 \\
4 \\
2 \\
\\
\\
1 \\
1\end{array}$ & $\begin{array}{r}1 \\
1 \\
* 1 \\
1 \\
2 \\
1\end{array}$ & 1 & $\begin{array}{r}1 \\
1 \\
1 \\
2 \\
1 \\
4 \\
4 \\
15 \\
* \quad 12 \\
7 \\
6 \\
2 \\
1\end{array}$ & $\begin{array}{r}3 \\
3 \\
4 \\
6 \\
1 \\
1 \\
\\
3 \\
3 \\
1 \\
9 \\
17 \\
* \quad 12 \\
14 \\
7 \\
6 \\
8 \\
8 \\
8 \\
3 \\
6 \\
3 \\
1\end{array}$ \\
\hline Totals & 11 & 25 & 17 & 7 & 1 & 53 & 116 \\
\hline
\end{tabular}


Table 48. Consumption of clupeids in NW in November.

\begin{tabular}{|c|c|c|c|c|c|c|c|}
\hline Fish length & sunk & Gan & GBG & HG & Kit & Ful & GG \\
\hline 9 & & & & & 5 & & \\
\hline 10 & & & & 1 & 42 & 2 & \\
\hline 12 & 1 & & & & * 40 & 1 & \\
\hline 13 & & & & & 11 & & \\
\hline 14 & & & & 2 & 15 & & \\
\hline 15 & 1 & & & & 1 & & \\
\hline 17 & & & & 1 & 1 & & \\
\hline 18 & & & 2 & & 2 & & \\
\hline 19 & 1 & & & & & & \\
\hline 21 & $* 1$ & & & & & & \\
\hline 22 & & & & 2 & & & \\
\hline 23 & & & * 1 & 1 & & & \\
\hline 24 & & & & 10 & & & \\
\hline 25 & & & & $* 8$ & & * 1 & 1 \\
\hline 26 & 1 & 4 & & 2 & & & \\
\hline 27 & 1 & 1 & & 3 & & 1 & \\
\hline 28 & 1 & $5 *$ & 1 & 7 & & & \\
\hline 29 & & 2 & & 2 & & & \\
\hline 30 & & 2 & & 6 & & & \\
\hline 31 & & 2 & & & & & \\
\hline 32 & & 1 & & & & & \\
\hline 33 & & & & & & 1 & \\
\hline Totals & 7 & 17 & 4 & 45 & 128 & 6 & 1 \\
\hline
\end{tabular}

Table 49. Consumption of clupeids in NE in February.

\begin{tabular}{|c|c|c|c|c|c|c|c|c|}
\hline Fish length & sunk & Gan & GBG & $\mathrm{HG}$ & LBG & CG & Kit & Ful \\
\hline $\begin{array}{l}14 \\
15 \\
16 \\
17 \\
18 \\
19 \\
20 \\
21 \\
22 \\
23 \\
24 \\
25 \\
26 \\
27 \\
28 \\
29\end{array}$ & $\begin{array}{r}* 3 \\
1\end{array}$ & $\begin{array}{r}1 \\
* 4\end{array}$ & $\begin{array}{r}1 \\
* 2\end{array}$ & $\begin{array}{r}2 \\
2 \\
\\
2 \\
1 \\
2 \\
* 4 \\
2 \\
3 \\
1 \\
1\end{array}$ & & & $\begin{array}{r}1 \\
5 \\
40 \\
* 48 \\
414 \\
7 \\
3 \\
2 \\
2 \\
1\end{array}$ & 1 \\
\hline Totals & 5 & 5 & 3 & 20 & 0 & 0 & 123 & 1 \\
\hline
\end{tabular}


Table 50. Consumption of clupeids in NE in May.

\begin{tabular}{|c|c|c|c|c|c|c|}
\hline Fish length & sunk & Gan & GBG & $H G$ & LBG & Ful \\
\hline $\begin{array}{l}15 \\
16 \\
17 \\
18 \\
19 \\
20 \\
21 \\
22 \\
23 \\
24 \\
25 \\
26 \\
27\end{array}$ & $\begin{array}{r}4 \\
* 3 \\
3 \\
3\end{array}$ & 1 & $\begin{array}{r}1 \\
1 \\
* 2 \\
1 \\
2\end{array}$ & $\begin{array}{r}* 2 \\
1 \\
1\end{array}$ & $\begin{array}{r}2 \\
7 \\
5 \\
* 4 \\
3 \\
3 \\
2 \\
3 \\
1 \\
2 \\
1 \\
1\end{array}$ & $\begin{array}{l}1 \\
1 \\
1\end{array}$ \\
\hline Totals & 14 & 2 & 7 & 5 & 34 & 6 \\
\hline
\end{tabular}

Table 51. Consumption of clupeids in NE in August.

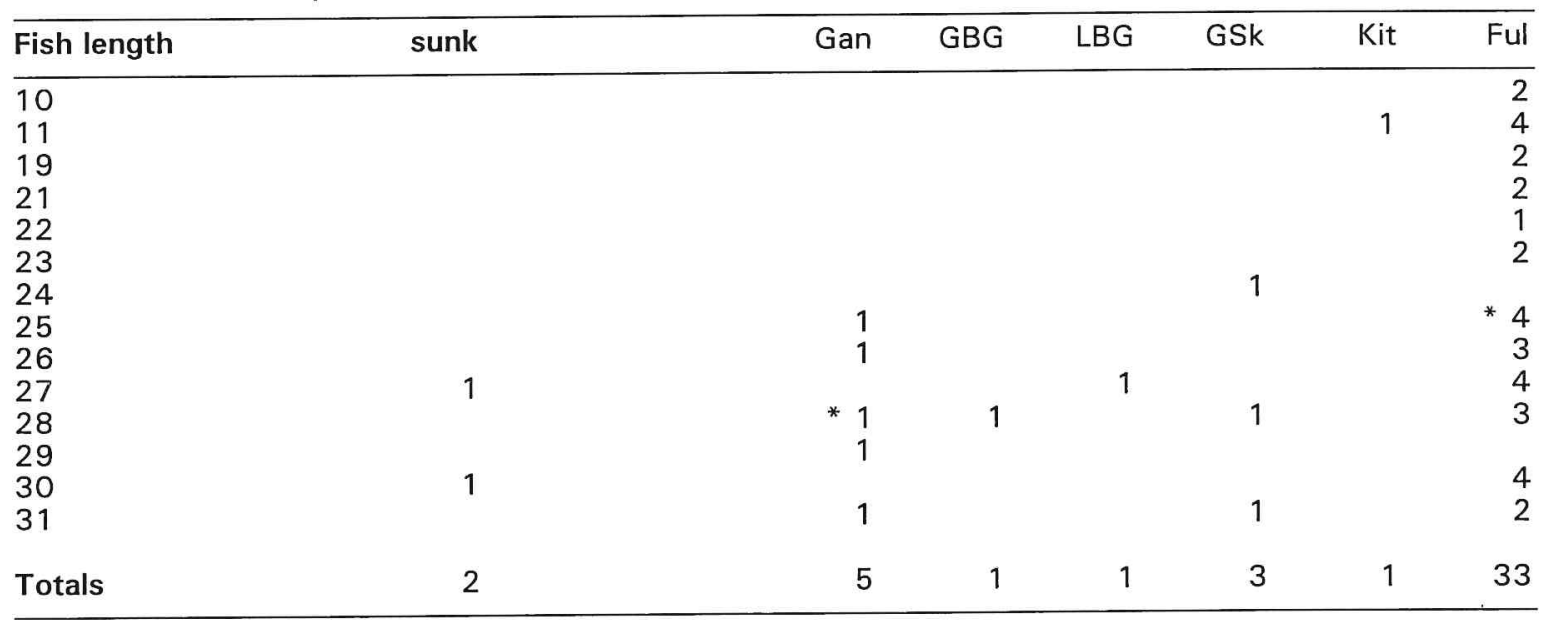

Table 52. Consumption of clupeids in NE in November.

\begin{tabular}{|c|c|c|c|c|c|c|}
\hline Fish length & sunk & Gan & GBG & HG & Kit & Ful \\
\hline $\begin{array}{l}13 \\
20 \\
21 \\
22 \\
23 \\
24 \\
25 \\
26 \\
27 \\
28\end{array}$ & $\begin{array}{r}3 \\
2 \\
1 \\
* 3 \\
4 \\
4\end{array}$ & 1 & $\begin{array}{r}1 \\
1 \\
* 1 \\
1\end{array}$ & $\begin{array}{r}5 \\
3 \\
1 \\
2 \\
* 2 \\
2 \\
3 \\
1 \\
1\end{array}$ & $\begin{array}{l}1 \\
1\end{array}$ & $\begin{array}{l}3 \\
1\end{array}$ \\
\hline Totals & 15 & 1 & 5 & 18 & 2 & 4 \\
\hline
\end{tabular}


Table 53. Consumption of clupeids in CW in February.

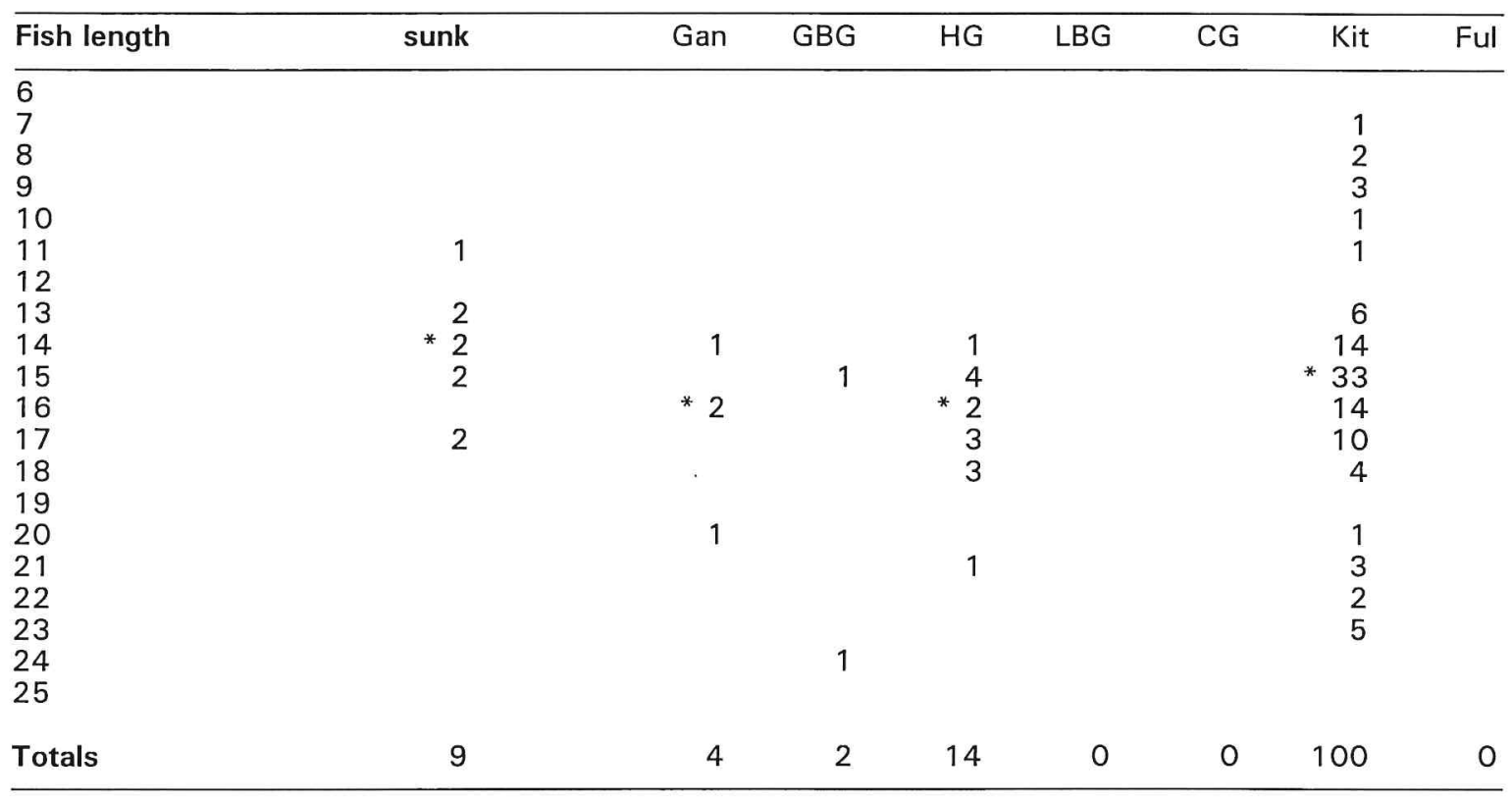

Table 54. Consumption of clupeids in CW in May.

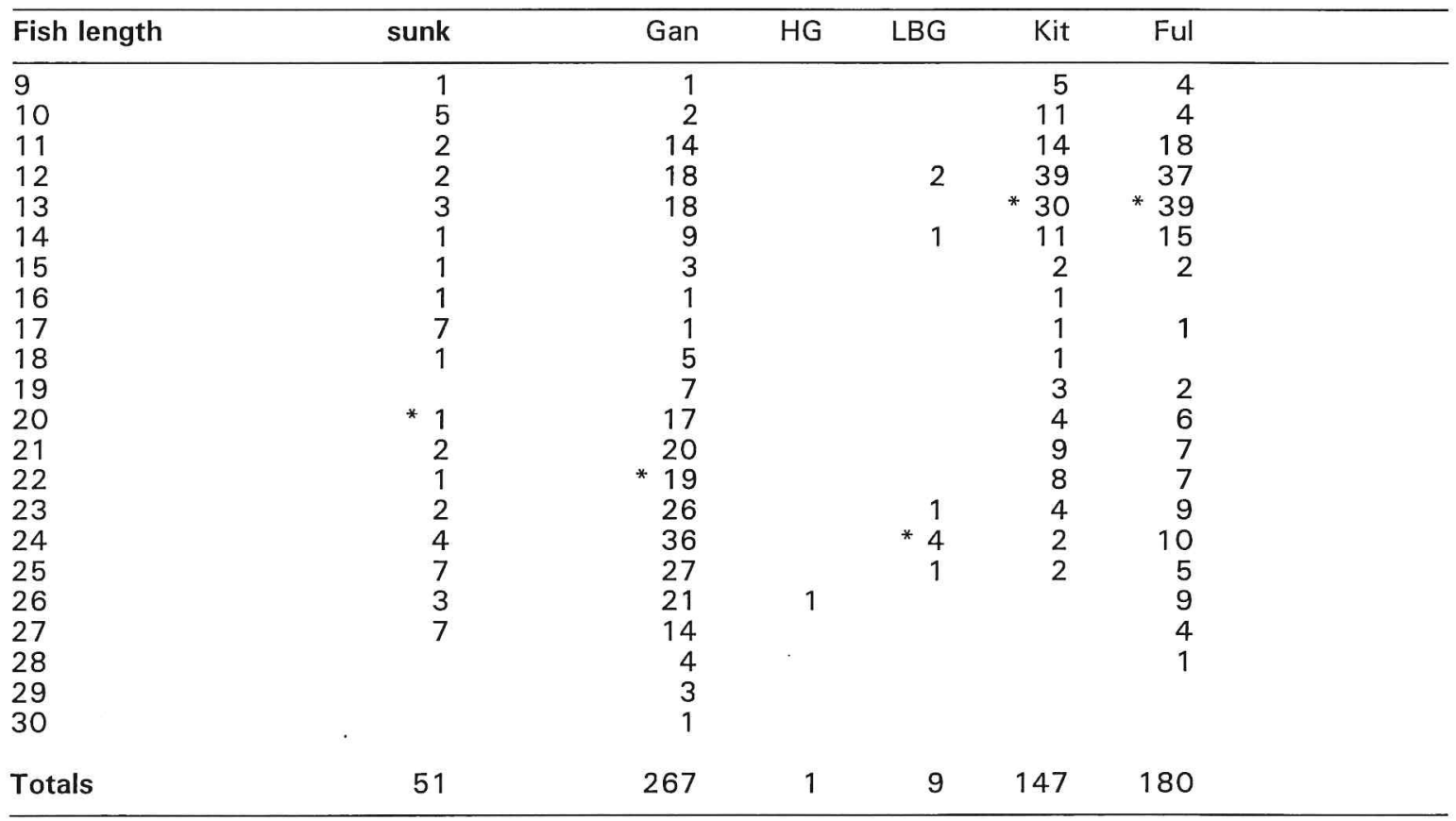


Table 55. Consumption of clupeids in CW in August.

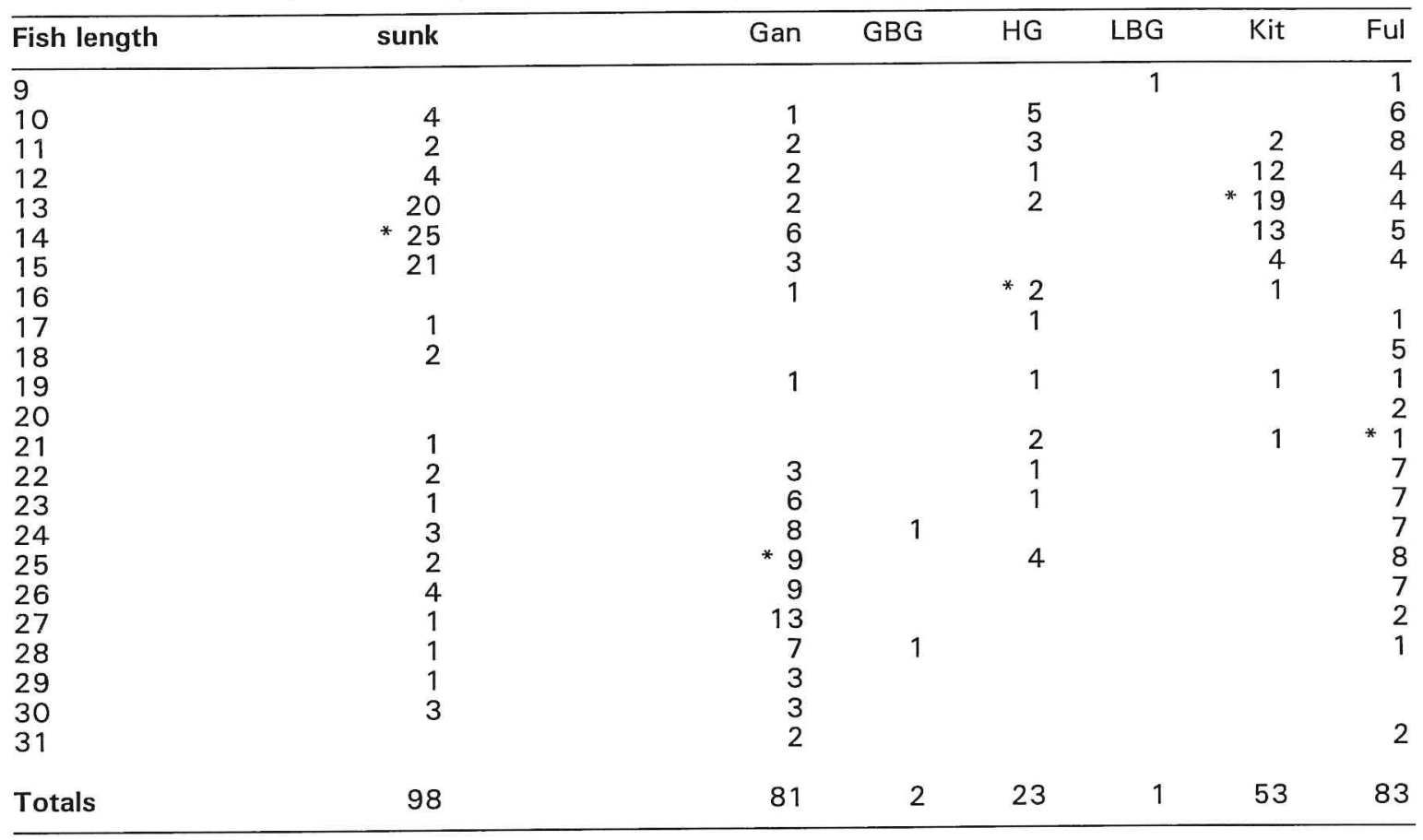

Table 56. Consumption of clupeids in CW in November.

\begin{tabular}{|c|c|c|c|c|c|c|c|}
\hline Fish length & sunk & Gan & GBG & HG & LBG & Kit & Ful \\
\hline $\begin{array}{l}6 \\
10 \\
11 \\
12 \\
13 \\
14 \\
15 \\
16 \\
18 \\
19 \\
20 \\
21 \\
22 \\
23 \\
24 \\
25 \\
26 \\
27 \\
28\end{array}$ & $\begin{array}{r}5 \\
2 \\
* \quad 15 \\
15 \\
7 \\
3 \\
2\end{array}$ & $\begin{array}{r}* 1 \\
2 \\
1 \\
1 \\
2\end{array}$ & $\begin{array}{r}8 \\
* \quad 12\end{array}$ & $\begin{array}{l}1 \\
1\end{array}$ & 1 & $\begin{array}{r}1 \\
2 \\
8 \\
23 \\
* \quad 9 \\
12 \\
18 \\
2 \\
2 \\
2 \\
1 \\
1\end{array}$ & 1 \\
\hline Totals & 63 & 13 & 25 & 2 & 1 & 81 & 2 \\
\hline
\end{tabular}


Table 57. Consumption of clupeids in C in February.

\begin{tabular}{|c|c|c|c|c|c|c|c|c|}
\hline Fish length & sunk & Gan & GBG & $H G$ & LBG & CG & Kit & Ful \\
\hline 5 & & & & & & & 4 & \\
\hline 6 & & & & & & 1 & 17 & \\
\hline 7 & 3 & & & 2 & & & 8 & \\
\hline 8 & 1 & & & 2 & & 1 & 23 & \\
\hline 9 & & & & 3 & & 3 & 39 & \\
\hline 10 & 3 & & & 2 & & * 2 & 66 & \\
\hline 11 & 1 & & 1 & 2 & & $\overline{1}$ & 48 & \\
\hline 12 & 3 & & & 5 & & 1 & 59 & 1 \\
\hline 13 & 1 & & & 6 & & 1 & 84 & \\
\hline 14 & & & & 4 & & & 88 & \\
\hline 15 & 2 & & 2 & 12 & & & * 134 & 1 \\
\hline 16 & & & 1 & 14 & & 2 & 153 & \\
\hline 17 & & & 2 & 9 & & & 73 & \\
\hline 18 & 1 & 1 & 2 & 4 & & & 48 & \\
\hline 19 & 1 & & 3 & $* 9$ & & & 19 & \\
\hline 20 & 1 & & * 3 & 15 & & & 25 & \\
\hline 21 & * 8 & & 2 & 12 & & & 25 & \\
\hline 22 & 5 & & 2 & 20 & & & 19 & \\
\hline 23 & 5 & & 4 & 20 & & & 13 & 2 \\
\hline 24 & 3 & & 2 & 6 & & & 2 & \\
\hline 25 & 1 & & & 1 & & & & \\
\hline 26 & & & & & & & 1 & \\
\hline 27 & & & & & & & & \\
\hline Totals & 39 & 1 & 24 & 148 & 0 & 12 & 948 & 4 \\
\hline
\end{tabular}

Table 58. Consumption of clupeids in C in May.

\begin{tabular}{|c|c|c|c|c|c|c|c|}
\hline Fish length & sunk & Gan & GBG & HG & LBG & Kit & Ful \\
\hline 7 & 1 & & & & & & \\
\hline 8 & 2 & & & & & & 8 \\
\hline 9 & 8 & 1 & & & & 6 & 4 \\
\hline 10 & 12 & 3 & & & 3 & 8 & 1 \\
\hline 11 & 10 & 2 & & & & 32 & 15 \\
\hline 12 & 5 & 2 & & & & * 29 & 34 \\
\hline 13 & 8 & & & & 1 & 7 & 15 \\
\hline 14 & 18 & 1 & & & 4 & 12 & 19 \\
\hline 15 & 15 & 1 & & & 10 & 6 & 31 \\
\hline 16 & * 28 & 5 & 1 & 1 & 11 & 1 & * 28 \\
\hline 17 & 20 & * 4 & & & * 26 & 13 & 26 \\
\hline 18 & 29 & 6 & 1 & & 9 & 8 & 15 \\
\hline 19 & 15 & 1 & 1 & & 3 & 2 & 24 \\
\hline 20 & 8 & & & & 4 & 7 & 14 \\
\hline 21 & 7 & & & & 1 & 2 & 6 \\
\hline 22 & 5 & 1 & & & & & 12 \\
\hline 23 & 7 & 1 & 1 & & & 1 & 9 \\
\hline 24 & & 2 & 1 & & & & 5 \\
\hline 25 & 1 & & 1 & & & 1 & \\
\hline 26 & 2 & 1 & & & & & 2 \\
\hline 27 & 1 & 1 & & & & & 1 \\
\hline \multicolumn{8}{|l|}{28} \\
\hline 29 & & 1 & & & & & 2 \\
\hline Totals & 202 & 33 & 6 & 1 & 72 & 135 & 271 \\
\hline
\end{tabular}


Table 59. Consumption of clupeids in C in August.

\begin{tabular}{|c|c|c|c|c|c|}
\hline Fish length & sunk & Gan & LBG & Kit & Ful \\
\hline $\begin{array}{l}8 \\
9 \\
10 \\
11 \\
12 \\
13 \\
14 \\
15 \\
16 \\
17 \\
18 \\
19 \\
20 \\
21 \\
22 \\
23 \\
24 \\
25 \\
27 \\
30 \\
31\end{array}$ & $\begin{array}{r}4 \\
18 \\
11 \\
9 \\
5 \\
13 \\
* 5 \\
5 \\
16 \\
13 \\
11 \\
6 \\
\\
4 \\
1 \\
1 \\
\\
2\end{array}$ & 1 & $\begin{array}{r}2 \\
* 1\end{array}$ & $\begin{array}{r}1 \\
1 \\
* \quad 22 \\
6\end{array}$ & $\begin{array}{r}4 \\
4 \\
13 \\
14 \\
14 \\
5 \\
6 \\
* \quad 25 \\
20 \\
17 \\
12 \\
5 \\
8 \\
2 \\
2 \\
3 \\
7 \\
1 \\
2\end{array}$ \\
\hline Totals & 125 & 1 & 5 & 33 & 164 \\
\hline
\end{tabular}

Table 60. Consumption of clupeids in $C$ in November.

\begin{tabular}{|c|c|c|c|c|c|c|}
\hline Fish length & sunk & Gan & GBG & $H G$ & Kit & Ful \\
\hline 9 & & 1 & & & 9 & \\
\hline 10 & 6 & & & & 76 & \\
\hline 11 & 12 & 4 & 6 & 6 & 76 & \\
\hline 12 & 37 & 24 & & 4 & * 130 & \\
\hline 13 & 28 & * 15 & & 2 & 78 & 2 \\
\hline 14 & * 65 & 6 & & 3 & 73 & 10 \\
\hline 15 & 7 & 3 & & $* 5$ & 47 & $* 2$ \\
\hline 16 & 5 & 2 & & & 28 & 2 \\
\hline 17 & 5 & 3 & 1 & 6 & 12 & 1 \\
\hline 18 & 4 & 2 & & & 4 & \\
\hline 19 & & & & & 7 & \\
\hline 20 & 3 & & $* 2$ & & 2 & \\
\hline 21 & 2 & & & 1 & 3 & 1 \\
\hline 22 & 1 & 1 & & 2 & & 2 \\
\hline 23 & 1 & 5 & 1 & 3 & 1 & 3 \\
\hline 24 & 4 & 1 & 4 & 2 & & 2 \\
\hline 25 & & 4 & & & & \\
\hline 26 & & 3 & & & & \\
\hline 27 & 2 & 1 & & & & \\
\hline 28 & 1 & 1 & & & & \\
\hline Totals & 183 & 76 & 14 & 34 & 546 & 25 \\
\hline
\end{tabular}


Table 61. Consumption of clupeids in CE in February.

\begin{tabular}{|c|c|c|c|c|c|c|c|c|}
\hline Fish length & sunk & Gan & GBG & HG & LBG & CG & Kit & Ful \\
\hline $\begin{array}{l}5 \\
6 \\
7 \\
8 \\
9 \\
10 \\
11 \\
12 \\
13 \\
14 \\
15 \\
16 \\
17 \\
18 \\
19 \\
20 \\
21 \\
22 \\
23 \\
24 \\
25 \\
26 \\
27 \\
28 \\
29 \\
30\end{array}$ & $\begin{array}{r}1 \\
4 \\
1 \\
* \quad 12 \\
11 \\
1\end{array}$ & & $\begin{array}{r}3 \\
3 \\
3 \\
2 \\
5 \\
4 \\
+3 \\
3 \\
3 \\
4 \\
3 \\
6 \\
1\end{array}$ & $\begin{array}{r}1 \\
2 \\
3 \\
3 \\
2 \\
14 \\
10 \\
* \quad 16 \\
10 \\
10 \\
10 \\
2 \\
\\
3 \\
3 \\
1\end{array}$ & & $\begin{array}{r}1 \\
3 \\
13 \\
* \quad 8 \\
11 \\
7 \\
1\end{array}$ & $\begin{array}{r}11 \\
2 \\
\\
1 \\
7 \\
6 \\
11 \\
15 \\
15 \\
* \quad 19 \\
12 \\
9 \\
6 \\
1 \\
10 \\
7 \\
2 \\
8\end{array}$ & $\begin{array}{r}1 \\
* 1 \\
1 \\
1\end{array}$ \\
\hline Totals & 32 & 0 & 37 & 90 & 48 & 0 & 142 & 3 \\
\hline
\end{tabular}

Table 62. Consumption of clupeids in CE in May.

\begin{tabular}{|c|c|c|c|c|c|c|c|c|c|}
\hline Fish length & sunk & Gan & LG & HG & LBG & CG & Kit & Ful & CT \\
\hline $\begin{array}{l}6 \\
7 \\
8 \\
9 \\
10 \\
11 \\
12 \\
12 \\
13 \\
14 \\
15 \\
16 \\
17 \\
18 \\
19 \\
20 \\
21 \\
22 \\
23 \\
24 \\
25 \\
26 \\
27 \\
28\end{array}$ & $\begin{array}{r}69 \\
95 \\
1 \\
2 \\
4 \\
12 \\
140 \\
* \quad 73 \\
124 \\
109 \\
37 \\
9 \\
2\end{array}$ & $\begin{array}{l}1 \\
1\end{array}$ & 2 & $\begin{array}{l}2 \\
1\end{array}$ & $\begin{array}{r}2 \\
16 \\
15 \\
\\
15 \\
* \quad 22 \\
42 \\
19 \\
8\end{array}$ & 1 & $\begin{array}{r}2 \\
10 \\
6 \\
4 \\
\\
5 \\
13 \\
* 30 \\
10 \\
2 \\
1\end{array}$ & $\begin{array}{r}5 \\
17 \\
* \quad 22 \\
12 \\
3 \\
1\end{array}$ & 12 \\
\hline Totals & 681 & 2 & 2 & 4 & 144 & 1 & 83 & 70 & 12 \\
\hline
\end{tabular}


Table 63. Consumption of clupeids in CE in August.

\begin{tabular}{|c|c|c|c|c|c|}
\hline Fish length & sunk & LBG & $\mathrm{CT}$ & Kit & GSk \\
\hline $\begin{array}{l}8 \\
9 \\
10 \\
11 \\
14 \\
15 \\
16 \\
17 \\
18 \\
19 \\
20 \\
22\end{array}$ & $\begin{array}{l}1 \\
5 \\
1 \\
1 \\
* \\
2 \\
1 \\
1 \\
2 \\
2\end{array}$ & $\begin{array}{r}3 \\
* 9 \\
7\end{array}$ & 1 & $\begin{array}{r}1 \\
12 \\
* \quad 14 \\
5 \\
1\end{array}$ & 1 \\
\hline Totals & 16 & 20 & 1 & 33 & 1 \\
\hline
\end{tabular}

Table 64. Consumption of clupeids in CE in November.

\begin{tabular}{|c|c|c|c|c|}
\hline Fish length & sunk & GBG & $H G$ & Kit \\
\hline $\begin{array}{l}6 \\
9\end{array}$ & $\begin{array}{l}1 \\
2\end{array}$ & & & \\
\hline 10 & 3 & & 9 & 2 \\
\hline 11 & 4 & & 12 & 3 \\
\hline 12 & * 11 & & * 14 & 9 \\
\hline 13 & 2 & 1 & 12 & 1 \\
\hline 14 & 1 & & 5 & * 6 \\
\hline 15 & & & 2 & 4 \\
\hline 16 & 2 & & 2 & 4 \\
\hline 17 & 1 & & 2 & 5 \\
\hline 18 & 1 & & & 3 \\
\hline 19 & 1 & & 2 & 2 \\
\hline 20 & 1 & & 2 & 2 \\
\hline 23 & & & 1 & \\
\hline Totals & 30 & 1 & 63 & 41 \\
\hline
\end{tabular}


Table 65. Consumption of clupeids in S in February.

\begin{tabular}{|c|c|c|c|c|c|c|c|c|}
\hline Fish length & sunk & Gan & GBG & $\mathrm{HG}$ & LBG & CG & Kit & Ful \\
\hline $\begin{array}{l}5 \\
6 \\
7 \\
8 \\
9 \\
10 \\
11 \\
12 \\
13 \\
14 \\
15 \\
16 \\
17 \\
18 \\
19 \\
20 \\
21 \\
22 \\
23 \\
24 \\
25 \\
26 \\
27 \\
28 \\
29 \\
30 \\
31\end{array}$ & $\begin{array}{r}6 \\
16 \\
* 11 \\
9 \\
4 \\
6 \\
2 \\
4\end{array}$ & & $\begin{array}{l}1 \\
1 \\
1 \\
1 \\
1 \\
1\end{array}$ & $\begin{array}{l}1 \\
4 \\
2 \\
2 \\
3 \\
1\end{array}$ & 2 & & $\begin{array}{r}1 \\
1 \\
11 \\
28 \\
36 \\
* 46 \\
43 \\
37 \\
27 \\
1 \\
\\
1\end{array}$ & 1 \\
\hline Totals & 62 & 0 & 6 & 29 & 0 & 2 & 238 & 1 \\
\hline
\end{tabular}

Table 66. Consumption of clupeids in S in May.

\begin{tabular}{lrr}
\hline Fish length & sunk & Kit \\
\hline 8 & 1 & \\
9 & $*$ & \\
10 & 7 & 4 \\
11 & 1 & $* 1$ \\
12 & 2 & 1 \\
13 & & 1 \\
14 & 26 & 1 \\
Totals & & 8 \\
\hline
\end{tabular}


Table 67. Consumption of clupeids in S in August.

\begin{tabular}{lrr}
\hline Fish length & sunk & LBG \\
\hline 10 & 1 & 1 \\
11 & 1 & 1 \\
14 & 5 & 4 \\
16 & $*$ & 4 \\
17 & 1 & 2 \\
18 & 1 & 1 \\
19 & 3 & 1 \\
20 & 1 & 1 \\
21 & 1 & \\
22 & 1 & 1 \\
23 & 1 & \\
25 & 17 & 15 \\
Totals & 17 & \\
\hline
\end{tabular}

Table 68. Consumption of clupeids in $S$ in November.

\begin{tabular}{|c|c|c|c|c|c|}
\hline Fish length & sunk & GBG & $H G$ & LBG & Kit \\
\hline $\begin{array}{l}10 \\
12 \\
14\end{array}$ & 1 & 1 & 1 & & \\
\hline $\begin{array}{l}15 \\
19 \\
20\end{array}$ & $\begin{array}{l}* 1 \\
1 \\
1\end{array}$ & & & & 1 \\
\hline $\begin{array}{l}20 \\
21\end{array}$ & & & * 2 & 1 & \\
\hline 23 & & & 1 & 1 & \\
\hline Totals & 3 & 1 & 4 & 2 & 1 \\
\hline
\end{tabular}

Table 69. Consumption of clupeids in Sk in May.

\begin{tabular}{|c|c|c|c|c|}
\hline Fish length & sunk & LBG & HG & Ful \\
\hline $\begin{array}{l}6 \\
7 \\
8 \\
9 \\
10 \\
12 \\
13 \\
14 \\
15 \\
16 \\
17 \\
18 \\
19 \\
20 \\
21 \\
22 \\
23 \\
25 \\
26\end{array}$ & $\begin{array}{r}5 \\
7 \\
7 \\
1 \\
2 \\
2 \\
\\
\\
4 \\
1 \\
1 \\
1 \\
1\end{array}$ & $\begin{array}{r}1 \\
1 \\
5 \\
1 \\
\\
2 \\
3 \\
7 \\
10 \\
* 21 \\
8 \\
7 \\
3 \\
1 \\
1 \\
1 \\
1 \\
1\end{array}$ & $\begin{array}{r}1 \\
1 \\
3 \\
* \quad 2 \\
3 \\
1 \\
1 \\
1\end{array}$ & $\begin{array}{r}1 \\
* 4 \\
1\end{array}$ \\
\hline Totals & 24 & 73 & 19 & 6 \\
\hline
\end{tabular}


Table 70. Consumption of clupeids in Sk in November.

\begin{tabular}{|c|c|c|c|c|c|}
\hline Fish length & sunk & GBG & HG & $\mathrm{BhG}$ & Kit \\
\hline $\begin{array}{l}10 \\
11 \\
12 \\
13 \\
14 \\
15 \\
16 \\
17 \\
18 \\
19 \\
20 \\
22 \\
23 \\
24 \\
25 \\
26 \\
27 \\
28 \\
31\end{array}$ & & 1 & $\begin{array}{r}1 \\
1 \\
2 \\
2 \\
2 \\
2 \\
1 \\
* \\
2 \\
2 \\
1 \\
1 \\
1 \\
1 \\
2 \\
2 \\
1\end{array}$ & $\begin{array}{l}1 \\
3\end{array}$ & $\begin{array}{r}1 \\
3 \\
\text { * } \\
\\
4\end{array}$ \\
\hline Totals & & 1 & 26 & 4 & 23 \\
\hline
\end{tabular}




\section{CONTENTS}

Abstract

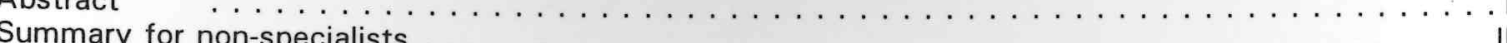

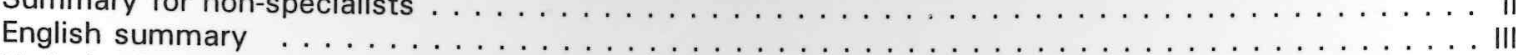

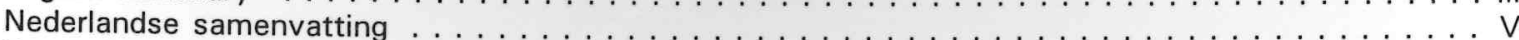

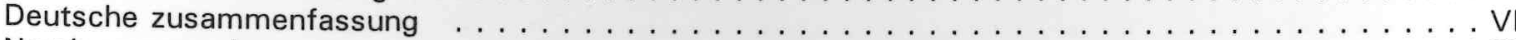

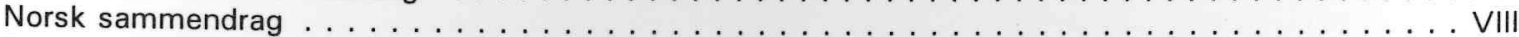

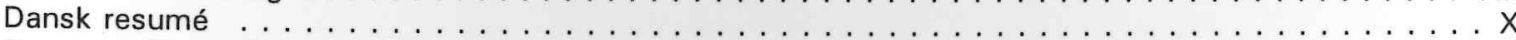

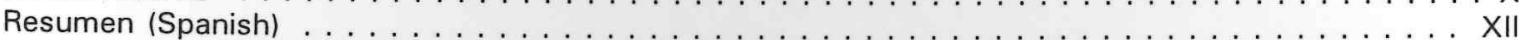

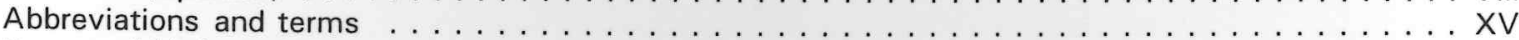

Names of birds and discarded items mentioned in this report . . . . . . . . . . . . . XVI

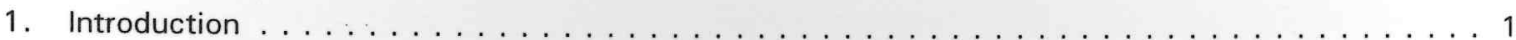

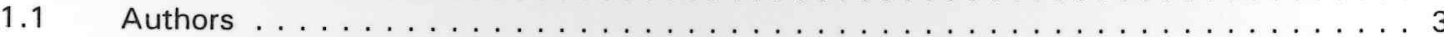

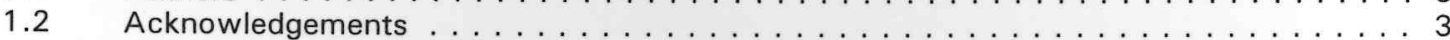

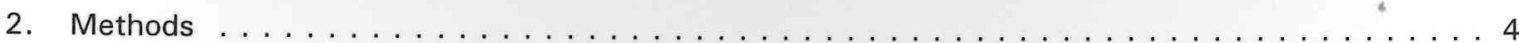

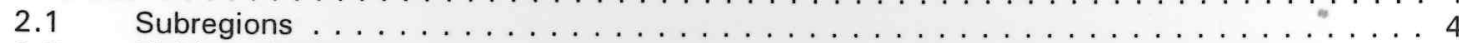

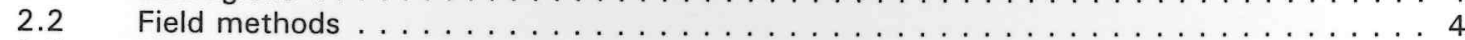

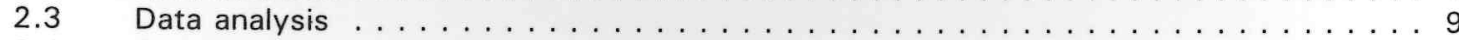

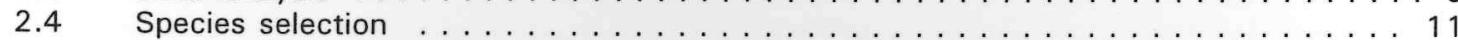

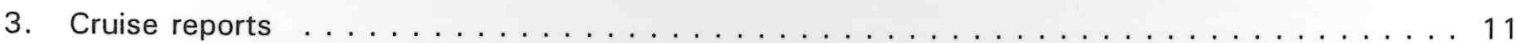

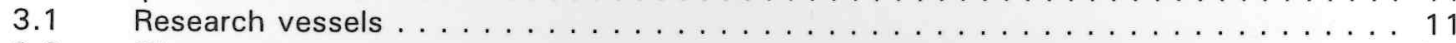

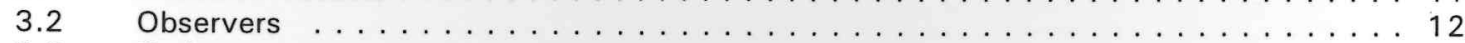

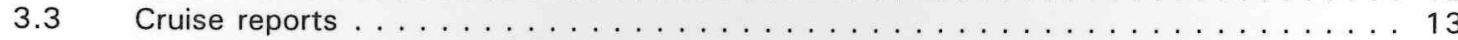

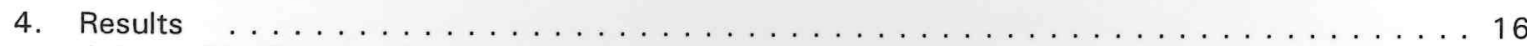

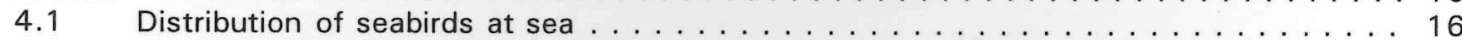

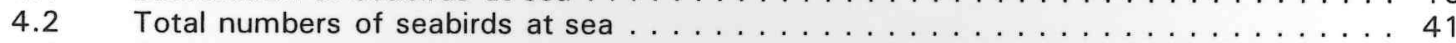

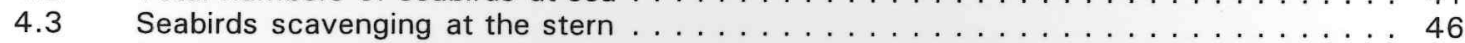

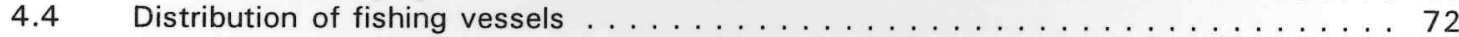

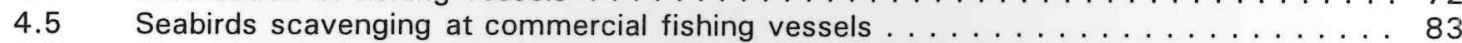

4.6 Discard experiments: consumption rates and feeding efficiency . . . . . . . . . . 95

4.7 Kleptoparasitism among scavenging seabirds $\ldots \ldots \ldots \ldots \ldots \ldots \ldots \ldots \ldots \ldots \ldots$

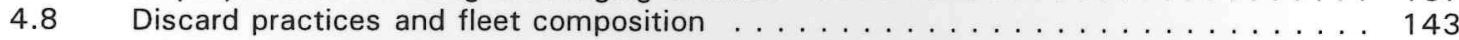

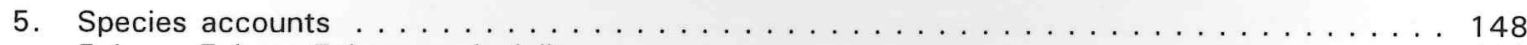

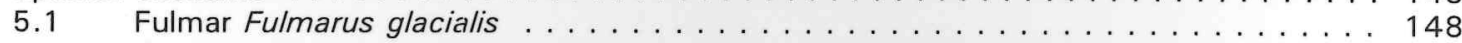

5.2 Gannet Morus bassanus . . . . . . . . . . . . . . . . . . . . . . . . 153

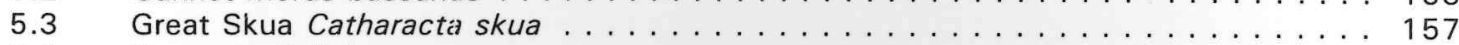

5.4 Common Gull Larus canus . . . . . . . . . . . . . . . . . . . . . . . . . . 158

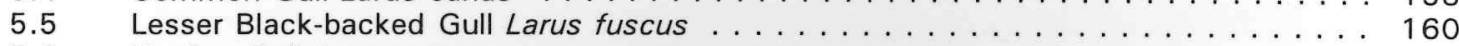

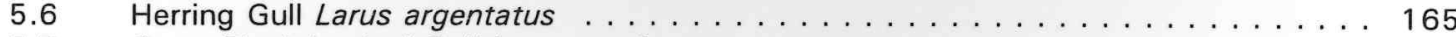

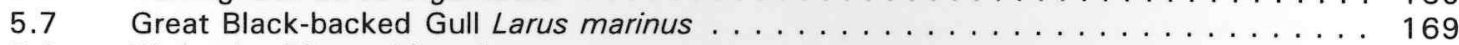

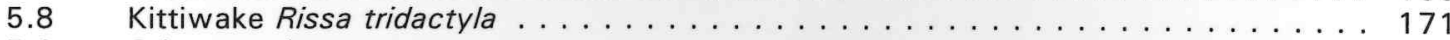

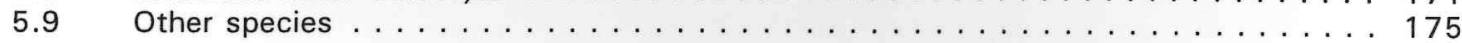

6. The amounts discarded in commercial fisheries and

the number of seabirds potentially supported $\ldots \ldots \ldots \ldots \ldots \ldots \ldots \ldots \ldots \ldots$

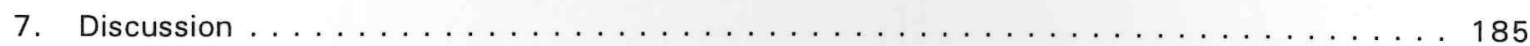

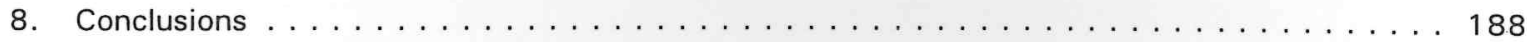

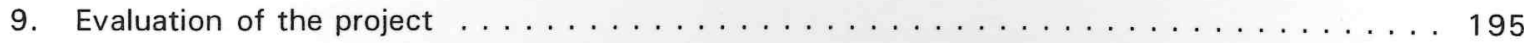

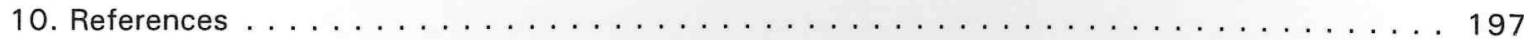

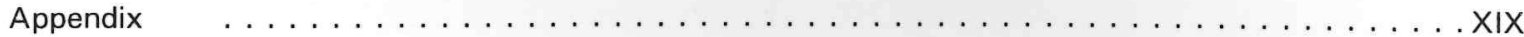

